\title{
CRITERIOS PARA LA RESTAURACIÓN DEL JARDÍN EN EL SIGLO XXI
}

\author{
Julio Lacarra López
}



nacional e internacional.

(c) Julio Lacarra López, 2011

Primera edición, 2011

(c) de la presente edición: Editorial Universitat Politècnica de València www.editorial.upv.es

ISBN: 978-84-694-6204-1

Ref. editorial: 5499

Queda prohibida la reproducción, distribución, comercialización, transformación, y en general, cualquier otra forma de explotación, por cualquier procedimiento, de todo o parte de los contenidos de esta obra sin autorización expresa y por escrito de sus autores. 
A todos los miembros del Departamento de Conservación y Resatauración de Bienes Culturales cuya confianza, amistad y paciencia hicieron posible que este trabajo viera la luz 
ÍNDICE 


\section{ÍNDICE}

\section{B. LA RESTAURACIÓN MONUMENTAL (Y DE JARDINES)}

EN LA EUROPA DEL SIGLO XIX. . . . . . . . . . . . . . 17

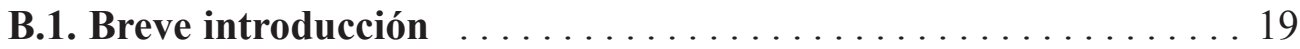

B.2. Diversidad de criterios ante la restauración monumental

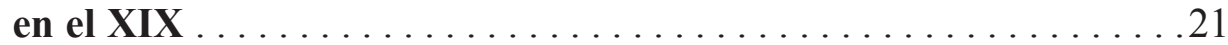

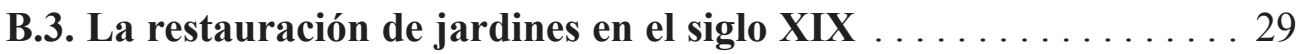

B.3.1. Las restauraciones románticas formales ................. 29

B.3.2. Violetianos en jardinería: el holandés H. Poortman y los franceses Henry y Achille Duchêne . . . . . . . . . . . . . . . . . 30

B.3.3. El caso español: el siglo XIX, un período de agitados cambios . . . . 35

C. EL SIGLO XX. (PRIMERA PARTE) . . . . . . . . . . . . . 39

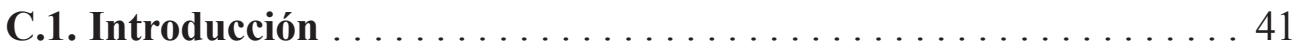

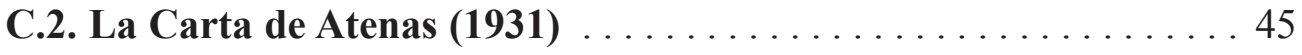

C.2.1. L. Torres Balbás y la restauración en la Segunda República. . . . . . 45

C.2.2. La catalogación del patrimonio verde: Javier de Winthuysen.. . . . . 47

C.2.3. La restauración del Palacete de la Moncloa. . . . . . . . . . . . . . 49

C.2.4. La protección legal del "verde histórico": constitución del Patronato de los Jardines Históricos de España (1934). . . . . . . . . . . . . . 57

C.3. La Guerra Civil de 1936-1939 y la posguerra. Consecuencias sobre los criterios de restauración $\ldots \ldots \ldots \ldots \ldots \ldots 61$

C.3.1. Las restauraciones de J. de Winthuysen en Madrid y Valencia:

- El Jardín de Monforte. . . . . . . . . . . . . . . . . . . . . . . . 63

- La Alameda de Osuna.. . . . . . . . . . . . . . . . . . . . . 69

C.4. La restauración de jardines en España entre 1920 y 1985 según los datos del Archivo de la Dirección General de Bellas Artes: . . 75

- Claustro de la Catedral de Toledo. . . . . . . . . . . . . . . . . 77

- Jardín Botánico de Madrid. . . . . . . . . . . . . . . . . . 81 


\section{C.5. La Segunda Guerra Mundial (1939-1945) y la posguerra.}

Efectos sobre los criterios de restauración. . . . . . . . . . . . . . 95

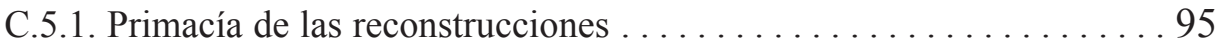

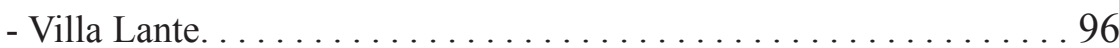

- Museo Willet-Holthuysen. . . . . . . . . . . . . . . . . . 102

- Museo van Loon. . . . . . . . . . . . . . . . . . . . . . . . . . . . . . . . . 104

- Het Loo. . . . . . . . . . . . . . . . . . . . . . . . . . . 106

C.5.2. La Carta de Venecia (1964).................... 120

\section{EL SIGLO XX. (SEGUNDA PARTE).}

\section{LA RESTAURACIÓN DE JARDINES TRAS LA}

CARTA DE FLORENCIA (1981) .................. 123

D.1. La Carta de Florencia y la reacción italiana . . . . . . . . . . . 125

D.2. Restauraciones en Europa tras el documento florentino. . . . . . 129

D.2.1. Italia:

- El Palacio Marigliano de Nápoles. . . . . . . . . . . . . . . . . 129

- Convento de Santa Clara de Nápoles. . . . . . . . . . . . . . 132

D.2.2. Reino Unido: “The Privy Garden” en Hampton Court. 1992-1995. 142

D.2.3. España:

D.2.3.1. Jardines del Patrimonio Nacional: . . . . . . . . . . 157

a) Casita de Abajo o del Príncipe en El Escorial. . . . . . . . 159

b) Casita de Arriba o del Infante. . . . . . . . . . . . . 168

c) Quinta del Duque de Arco en el Pardo........... 178

d) Laberinto del Real Sitio de La Granja. . . . . . . . . . . . . 184

e) Jardín del Rey en el R. S. de Aranjuez. . . . . . . . . . . . 197

D.2.3.2. Otros jardines restaurados en España: . . . . . . . . . . . 204

a) Patio de la Casa de Contratación de Sevilla. . . . . . . . . 204

b) El Capricho o Alameda de Osuna. . . . . . . . . . . . 208

c) Casa del pintor Sorolla en Madrid. . . . . . . . . . . . 217

d) Claustro del Convento de Guadalupe... . . . . . . . . 222

e) El Retiro. ...................... 231 
D.2.3.3. Jardines restaurados en la Comunidad Valenciana: . . . . . 241

a) Jardín Botánico de la Universidad de Valencia. . . . . . . . 241

b) Jardín de Monforte. . . . . . . . . . . . . . . . . . . 271

c) Jardín del Beso de Xàtiva. . . . . . . . . . . . . . . 276

d) Jardín de la Casa de la Cultura González-Quirós de Gandia.......................... 283

\section{E. DISCIPLINAS AUXILIARES Y FUENTES}

DOCUMENTALES DE UTILIDAD PARA LA RESTAURACIÓN DE LOS JARDINES

E.1. La pintura . . . . . . . . . . . . . . . . . . . . 297

E.2. El grabado $\ldots \ldots \ldots \ldots \ldots \ldots \ldots \ldots \ldots \ldots \ldots \ldots \ldots \ldots \ldots \ldots$

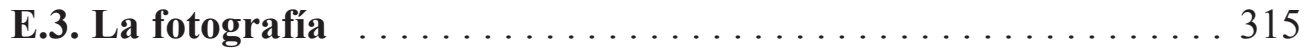

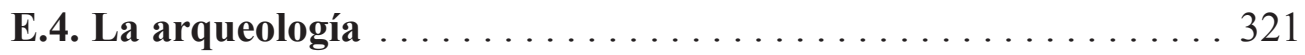

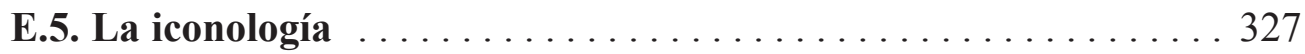

E.6. Fuentes literarias diversas:

E.6.1. Narrativa y poesía. . . . . . . . . . . . . . . . . . 332

E.6.2. Tratados de Agronomía, Agricultura, Botánica y Jardinería. . . . . . 336

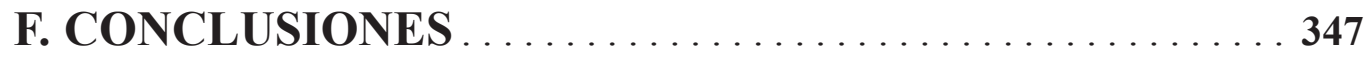

G. BIBLIOGRAFÍA $\ldots \ldots \ldots \ldots \ldots \ldots \ldots \ldots \ldots \ldots \ldots \ldots \ldots$ 
A. INTRODUCCIÓN 


\section{A. INTRODUCCIÓN}

El objetivo que persigue esta tesis es establecer unos criterios de validez universal que permitan afrontar la restauración de cualquier jardín independientemente de su estilo. Aunque tal objetivo parezca un poco pretencioso y hasta incluso haya quien lo considere inadecuado para la restauración del patrimonio monumental (1), el intento de establecer criterios objetivos para afrontar tal actividad en el campo de la jardinería pienso que es un fin valioso y realizable.

Desde el siglo pasado hasta hoy, todos los profesionales de esta actividad estuvieron escindidos en dos posturas opuestas e irreconciliables -restauradores frente a conservadores- ante el hecho de la restauración, $\mathrm{y}$, tras dos siglos de discursos, realizaciones y aportaciones teóricas abundantísimas, sigue siendo aún difícil definir qué es lo que entendemos por tal concepto (2).

El siglo XIX vivió este enfrentamiento de modo radical. La restauración estilística de Viollet-le Duc (1814-1879) verá cuestionada sus principios teóricos por el radicalismo conservacionista de Ruskin (1819-1900). La síntesis entre ambas posturas la realizarán Camilo Boito (1836-1914) y Gustavo Giovannoni (1873-1947) en la teoría que será denominada restauro científico. Tal teoría va a permanecer hasta hoy pero, tras la Segunda Guerra Mundial, surge la denominada restauro crítico. Sus elaboradores serán Renato Bonelli, Roberto Pane y sobre todo Cesare Brandi (1906-1986). El enfrentamiento entre ambas continúa las posturas de debate dialéctico ante el hecho de la restauración del siglo pasado.

Durante el mencionado siglo, la jardinería va a verse apartada de todos los discursos teóricos de la restauración monumental siendo a menudo los jardines formales existentes "restaurados" a la manera inglesa con lo que se produjo la destrucción de importantes joyas jardineras del período barroco y renacentista. Será a final del siglo, cuando empiece a surgir en Holanda y Francia, un movimiento cultural nacionalista que se plasma en la reacción contra la uniformidad y monotonía del jardín paisajísta anglosajón. Este movimiento se personaliza en las obras del arquitecto holandés Hugo Poortman y los franceses Henry y Achille Duchâne. Formado en Francia el primero, "restaurará" Middachten, Weldam y Twickel, volviendo a reconstruir los jardines formales barrocos desaparecidos. Este personaje será el que abra camino a las obras realizadas este siglo en los jardines de los museos Willet-Holthuysen y van Loon de Amsterdam y a la gran reconstrucción de los jardines barrocos del palacio de Het Loo en Apeldoorn.

Después, otros países de Europa seguirán este camino y comenzarán a "restaurar" igualmente los jardines barrocos tras deshacer los paisajistas.

(1) GONZALEZ MORENO-NAVARRO, Antoni. "La restauración objetiva". Resúmenes de la XII Asamblea de ICOMOS. México 1999. Congreso Mundial de la Conservación del Patrimonio Monumental.

(2) GONZALEZ-VARAS, Ignacio. Conservación de bienes culturales. Teoría, historia, principios y normas. Madrid. Manuales Arte Cátedra. 1999. Señala este autor en la página 278: "Nunca como en el momento actual un concepto como el expresado por la palabra "restauración" es interpretado y puesto en práctica según principios y modalidades tan diversas, hasta el punto de resultar imposible proporcionar una definición unívoca." 
Todo lo anterior nos exige una aclaración fundamental en el campo de la restauración del jardín. En ninguna otra área de la restauración de los bienes culturales sigue existiendo actualmente una confusión conceptual que mantenga la tergiversación de los términos de restauración y recreación como en el de la jardinería. Se denomina como restauración a auténticas obras de recreación en unos casos (Het Loo en Holanda, Casa de Lópe de Vega en Madrid, Patio de la Casa de Contratación en Sevilla) o de destrucción en otros (Jardín Botánico de Valencia, Santa Clara de Nápoles, Privy Garden en el Reino Unido) lo que origina confusión frente a las auténticas labores de restauración acometidas como son las realizadas por Javier de Winthuysen en Monforte en los años cuarenta de este siglo o los más recientes trabajos en el Laberinto de la Granja, los Reales Alcázares de Córdoba o los de la Alameda de Osuna y el Jardín Botánico en Madrid.

Tal estado de cosas se debe a que la Jardinería como señalábamos anteriormente se ha visto alejada de la profunda discusión y evolución de las teorías restauradoras habidas en los otros campos de las Bellas Artes en general. Esta actividad artística sigue manteniendo a la hora de restaurar aún aquellos criterios decimonónicos y atávicos que se plasmaron en la reciente Carta de Florencia (1981). Tales criterios, casi superados ampliamente en los demás campos de la restauración de bienes culturales, han permitido la puesta en práctica de repristinos que han conducido a la destrucción de algunos jardines a pesar de la buena voluntad -pensamos- con la que se quisieron restaurar.

En Italia hubo reacción ante las repercusiones posibles que el documento florentino podría tener sobre el ingente patrimonio histórico de jardines conservado en ese país y así se intentó elaborar una Carta de Restauración para los Jardines de Italia llegándose a modificar algunos de los puntos del documento de Florencia y dotarlos el Ministerio con rango de ley, especialmente en lo que respecta a la posibilidad de acometer repristinos en los jardines históricos. Sin embargo, en el resto de los países de Europa, la Carta de Florencia se ha convertido en la norma teórica más extendida para afrontar las restauraciones.

Nosotros, para elaborar el cuerpo teórico de la tesis, cogeremos tanto aspectos de la teoría brandiana -en especial el de la distinción de aspecto y estructura de la materia de la obra de arte- como algunos postulados de la corriente del restauro científico, actualmente denominada "pan-conservacionismo o conservación integral" en lo que respecta a la importancia de conservar la materia del jardín como fuente de información documental.

La metodología partirá del mencionado análisis brandiano sobre la materia de la obra de arte (aspecto y estructura) analizando cómo el predominio del aspecto junto con el desprecio a los componentes de la estructura y la anulación del paso del tiempo sobre los jardines han sido los criterios predominantes en la mayoría de las restauraciones acometidas en Europa en los últimos años.

(3) BRANDI, Cesare. Teoría de la restauración. Alianza Forma. Madrid, 1988. La primera edición italiana es del año 1963.

(4) DEZZI BARDESCHI, Marco. Restauro: punto e da capo. Franco Angeli. Milano, 1991. 
Algunas de ellas serán analizadas más extensamente en la parte práctica del trabajo. La interpretación de los datos de esas restauraciones y las nuevas aportaciones teóricas surgidas tras la Carta de Florencia (1981) en el campo de la restauración de los bienes culturales producirán los enunciados teóricos de la tesis sobre los criterios a tener en cuenta a la hora de efectuar la restauración de esa obra de arte que constituye el jardín.

Pasemos ahora a ver los aspectos de la teoría brandiana de la composición de la materia de la obra de arte aplicada a la Jardinería.

El jardín se constituye en obra de arte cuando el aspecto -en este campo llamado trazado o diseño- lo separa de la naturaleza circundante, siendo la estructura el relleno complemento de aquel primer y fundamental armazón. Consideraremos en este trabajo como estructura la vegetación en primer lugar, y luego, todo tipo de obra presente en ese espacio acotado como son las estatuas, fuentes, estanques y acequias, junto con todo el mobiliario, es decir, la totalidad de los componentes materiales y tangibles del jardín que forman el mismo junto con el diseño.

Sin embargo, es importante señalar que no todo es simplemente aspecto -diseño- o, si se prefiere, mera forma en el jardín. También hay que considerar que los componentes materiales están cargados de profundas connotaciones culturales, históricas y simbólicas en su elección. Veamos un caso. Hay formas que se han mantenido desde hace milenios -el patio en cruz es una de ellas- y sin embargo su sentido y componentes materiales cambian según las necesidades y creencias de los que construyen y habitan ese jardín. Por ser un ejemplo perfecto, veamos su desarrollo formal y pervivencia temporal.

Nacido en el Creciente Fértil, allí será la representación del Cosmos; el mundo clásico lo utilizará sin ese significado simbólico, simplemente como solución práctica al ajardinamiento de los patios rectangulares o cuadrados; el Islam lo convertirá de nuevo en la representación terrena del paraíso prometido al igual que el cristianismo pero con la salvedad de que para esta religión recreará el Edén perdido.

Esta forma - $\mathrm{o}$ aspecto- continúa en el Renacimiento (serán los conocidos como jardines secretos) y en el Barroco, tanto en el mundo cristiano como en el islámico. En éste, se extenderá de Marruecos a la India. Y en el primero, tras su desarrollo en Europa, cruzará el Atlántico y se manifestará desde el sur de los actuales USA hasta la Tierra del Fuego. Sin embargo, esta forma, según ha ido extendiéndose, ha transformado su materia -su estructura- abandonando en unos casos y ganando en otros contenidos simbólicos y culturales. Esta forma en concreto, según se ha desarrollado en el tiempo, ha ido perdiendo su carácter sagrado y simbólico para hacerse más laica y voluptuosa.

Esta transformación conceptual ha ido paralela tanto al abandono de elementos de la estructura como a la adquisición de otros nuevos por fenómenos de simbiosis cultural. 
Ello nos obliga a enfrentarnos ante la restauración de un mismo espacio formal de distinta manera. No será igual recrear un patio en cruz del mundo clásico mediterráneo, lleno de estatuaria religiosa y familiar que uno islámico o cristiano en los que a menudo los mismos elementos vegetales tienen significados culturales y simbólicos completamente diferentes.

Esto conduce a afirmar que en jardinería el aspecto, es, generalmente, lo más fácil de recuperar en la restauración. Con la ayuda de la arqueología, la pintura, el grabado o la fotografía es posible la restauración o recreación bastante fiel del aspecto original.

Sin embargo, la dificultad y el reto en la restauración del jardín reside mayormente en la selección de los elementos que conforman la estructura ya que en esa elección o rechazo de éstos es donde se demuestra la fidelidad a los orígenes, el respeto a la voluntad artística de los creadores de aquel momento y a la misma existencia del monumento a través del tiempo. El reto de todo proceso de restauración está en no traicionar ni enmascarar el paso del tiempo sobre la obra, compatibilizando los usos del jardín con la garantía de su transmisión al futuro.

Todo esto viene a señalar la complejidad que tiene el elemento vegetal en la restauración del jardín y la necesidad de estudiar con detenimiento y rigor la sustitución y los nuevos añadidos en las obras a realizar.

Por último, vamos a señalar los jardines más ampliamente utilizados para este trabajo. Estos -entre otros-son los siguientes:

- Jardines restaurados en España entre 1920-1985 por la Dirección General de Bellas Artes:

— 1982. Toledo. Restauración del jardín del claustro de la Catedral.

—1977-1981. Madrid. Obras de restauración de diversas zonas del Jardín Botánico.

- Las restauraciones de Xavier de Winthuysen:

—El jardín desaparecido del Palacete de la Moncloa

El Jardín de Monforte en Valencia.

El Capricho o Alameda de Osuna en Madrid.

- Jardines restaurados en algunas Comunidades Autónomas tras el traspaso de competencias:

ANDALUCÍA:

Córdoba: Medina Zahara.

— Sevilla: Patio de la Casa de Contratación en los Reales Alcázares.

EXTREMADURA: Claustro del Monasterio de Guadalupe. 
MADRID: Parque del Retiro.

Jardín Botánico.

El Capricho o Alameda de Osuna.

Casa del pintor Sorolla.

- Restauraciones de algunos de los jardines del Patrimonio Nacional:

— Laberinto de el Real Sitio de la Granja de San Ildefonso.

— Jardín del Rey en el Real Sitio de Aranjuez.

—El Escorial. Casitas de Arriba y Abajo.

— El Pardo. Quinta del Duque de Arco.

Algunos jardines restaurados en Europa este siglo:

HOLANDA:

— 1970. Amsterdam. Museo van Loon.

— 1973. Amsterdam. Museo Willet-Holthuysen.

— 1976-1982. Apeldoorn. Jardines del Palacio de Het Loo.

ITALIA:

— Florencia. Jardines de Bóboli.

— Nápoles: Pompeya.

— Palacio Marigliano.

— Claustro de Santa Clara.

— Bagnaia: Villa Lante.

\section{REINO UNIDO:}

— "The Privy Garden" en el Palacio de Hampton Court.

- Algunos jardines de reciente restauración en la Comunidad Valenciana:

VALENCIA:

— Jardín Botánico.

— Jardín del Beso de Xàtiva.

— Jardín de las Marquesas de Gandia. 


\section{B. LA RESTAURACIÓN MONUMENTAL (Y DE JARDINES) EN LA EUROPA DEL SIGLO XIX.}

\section{B.1. Breve introducción}

B.2. Diversidad de criterios ante la restauración monumental en el XIX: la restauración arqueológica, la restauración en estilo y el movimiento anti-restauración de Ruskin, Morris y la S.P.A.B.

\section{B.3. La restauración de jardines en el siglo XIX}

\section{B.3.1. Las restauraciones románticas.}

B.3.2. Violetianos en jardinería: el holandés H. Poortman y los franceses H. y A. Duchêne.

B.3.3. El caso español: el siglo XIX, un período de agitados cambios. 


\section{B.1. Breve introducción}

Es un tópico que causa cansancio a los profesionales del mundo de la restauración el repetir las diversas posturas y criterios que han existido en este campo durante los dos últimos siglos.

Sin embargo, nos es necesario hacer mención brevemente a estas teorías como marco referencial en el que las obras de restauración jardinera se han llevado a cabo.

Las obras bibliográficas recientes de Ignacio González-Varas, María José Martínez Justicia, Isabel Ordieres, Alfonso Muñoz, María Dolores Ruiz de Lacanal y Javier Rivera fundamentalmente, citadas en la bibliografía final, nos han proporcionado los datos para hacer el resumen histórico de la evolución de los criterios y posturas restauradoras desde el principio del siglo XIX hasta hoy.

En lo que respecta a la jardinería, la información disponible es menor y se encuentra más dispersa. Destacan los catálogos de las exposiciones de Javier de Winthuysen del CSIC, la revista del Patrimonio Nacional "Reales Sitios", las actas de los congresos del ICOMOS y los artículos de revistas especializadas. A esto hay que añadir la investigación propia del trabajo de campo.

Todo ello está citado en el apéndice bibliográfico.

Las dos actitudes principales se basan, una, en el respeto más riguroso al monumento que es considerado ante todo un documento, un testimonio (y en caso de los jardines aún más vivo) de la historia a la vez que obra de arte. La otra postura considera al monumento el punto de origen para el desarrollo de un nuevo proyecto creativo, dándole prioritariamente valor a lo estético frente a lo histórico.

En principio, y como punto de partida, los dos planteamientos pueden ser válidos. Lo que habrá que considerar en primer lugar es la metodología seguida y en segundo lugar los resultados finales pues el tema de fondo es la transmisión al futuro de la obra en sus dos vertientes de objeto artístico y documento histórico. Este es el debate que ni resolvió el siglo XIX, ni el XX ni todavía está solucionado de manera unánime en este siglo donde hemos visto por otro lado como se han multiplicado los congresos, simposiums y reuniones con la promulgación de actas, cartas y normas que incluyen todo tipo de documentos y declaraciones. Pero si dejamos al margen los discursos y nos centramos en el análisis de los resultados finales, el que surge ante la obra intervenida, podemos afirmar que la misma dualidad que vivió el XIX perduró en el XX y promete continuar en el XXI.

La jardinería como vamos a ver no estuvo al margen de tales planteamientos.

En el siglo XIX, jardines del Renacimiento y de los períodos barroco y neoclásico (Quinta del Duque de Arco, La Granja de San Ildefonso, Jardín Botánico de Madrid) vieron sus espacios transformados a la inglesa: abandono de los ejes axiales, de las perspectivas en profundidad y de la traza geométrica a favor de lo pin- 
toresco y romántico con caminos sinuosos, efectos sorpresa y predominio de lo curvo en el trazado.

Sin embargo a finales del siglo pasado se da en Holanda una primera reacción ante esta invasión de un paisajismo importado que no era más que un simple formulismo sin los contenidos culturales y simbólicos que acompañaron el surgimiento del jardín paisajista inglés.

El arquitecto Hugo Poortman suprime de varios jardines históricos el diseño a la inglesa y los rehace según los modelos de los trazados barrocos originales o supuestamente originales como ya veremos más adelante. Un seguidor de Viollet y Beltrami en el mundo de la jardinería y que tendrá sus seguidores hasta culminar en el siglo XX con la recreación barroca del Palacio Real de Het Loo en Holanda.

En nuestro país, las grandes convulsiones políticas del siglo pasado vieron la desaparición de más jardines que trabajos de restauración. Por otro lado, y es un elemento significativo, los grandes jardines del entonces patrimonio real se plantaron de ejemplares de coníferas de gran crecimiento para romper las perspectivas barrocas y sin pensarlo crear problemas al resto de la vegetación en el futuro. Es el caso de San Ildefonso de La Granja. En otros casos se alteró su diseño como en el Jardín Botánico de Madrid. O se plantaron nuevos jardines en espacios tan singulares como en el Laberinto de los Reales Alcázares de Sevilla.

Frente a esto, sin embargo, en los grandes conventos, palacios y casones de la nobleza siguió dominando la tradición jardinera hispanomusulmana con lo que el paisajismo tuvo tan poco éxito en estos lugares como el que había tenido la jardinería barroca francesa.

Esto hecho explica el éxito que tuvo el francés Forestier (1861-1930) en nuestro país en los primeros años del siglo XX. Su obra está basada en la creación de jardines inspirados en la tradición mediterránea brillantemente adaptados al clima y a las necesidades de uso de aquellos espacios en ese momento histórico concreto (1). 


\section{B. 2. Diversidad de criterios ante la restauración monumental en el siglo XIX:}

la restauración arqueológica, la restauración en estilo y el movimiento anti-restauración de Ruskin, Morris y la S.P.A.B.

Es sostenido por varios autores que la restauración es tan antigua como la creación de las obras de arte y para ello se basan en los testimonios de reparaciones hechas por faraones y reyes en Mesopotamia y Egipto en monumentos funerarios, religiosos y civiles de sus antecesores. Lo mismo continuó en épocas romana, medieval y renacentista por motivos varios y diversas finalidades que abarcan desde el simple placer estético de reparar estatuas incompletas o bien para fomentar manifestaciones de religiosidad popular (2). Nosotros, sin embargo, nos centraremos en la época contemporánea por cuestiones metodológicas.

El siglo XX dará un paso de gigante al ampliar la consideración de bien cultural a las diversas creaciones del hombre englobando en ese concepto los centros históricos de las ciudades, el patrimonio arqueológico de todo tipo así como los productos de la revolución científico-técnica en toda su inmensa gama que incluye desde edificios a maquinaria o el patrimonio etnográfico universal junto con esa parte olvidada de los pilares de la ciencia que son los fondos documentales y bibliográficos.

Estos logros que han conducido al auge de una profesión -la de restaurador- (3) que se soporta sobre fundamentos científicos y técnicos de vanguardia, son el resultado de más de dos siglos de discusiones y enfrentamientos dialécticos sobre cómo gestionar, conservar y reparar el patrimonio existente entre profesionales, estudiosos, teóricos, historiadores, artistas y críticos del mundo de la restauración.

En lo que todo el mundo coincide es que las primeras normas sobre protección del patrimonio histórico surgen de la Convención francesa en 1794 las cuales trataron de atajar la destrucción de los bienes del patrimonio eclesiástico y del perteneciente a la aristocracia de los excesos de la Revolución al considerar que poseían un interés público y por tanto el estado tenía el deber de conservarlos (4).

Frente a estas normas de protección o salvamento, las actuaciones emblemáticas de restauración/conservación surgen en Roma a comienzos del siglo XIX. Las actuaciones en el Coliseo y en los arcos de Tito y Constantino por Stern y Valadier

(2) El historiador Javier RIVERA cita la restauración de uno de los brazos de las estatuas de Ramsés en Abu Simbel por Seti II, faraón de una dinastía posterior que hizo escribir esta intervención en el monumento. Teoría e Historia de la restauración. Master de Rehabilitación y Restauración del Patrimonio. AA.V. Dirigido por C. Clemente y C. Aymat. También Petra EISELE en Babilonia Ed. EDAF, Madrid,1989 nos cuenta las obras de restauración de antiguos edificios llevadas a cabo por Nabucodonosor en Babilonia.

(3) RUIZ DE LACANAL, Ma Dolores. El conservador-restaurador de bienes culturales. Historia de una profesión. Ed. Síntesis. Madrid, 1999.

(4) No me resisto a no escribir un fragmento del decreto de la Convención Francesa recogido de la obra citada de Javier Rivera por su belleza conceptual y constituir un reflejo de la nueva ideología revolucionaria hacia el patrimonio monumental: "Los ciudadanos no son más que los depositarios de un bien del que la comunidad tiene el derecho a pedirles cuentas. Los bárbaros y los esclavos detestan la ciencia y destruyen las obras de arte, los hombres libres las aman y las conservan." 
van a marcar una trayectoria que en lo fundamental está vigente hasta hoy mismo: consolidación de la ruina y reconstrucción en el estilo del monumento pero diferenciando claramente los materiales nuevos añadidos a la obra en el proceso de la restauración. Esta corriente será conocida como restauración arqueológica.

Por otra parte, cuando Francia asienta su ardor revolucionario y es derrotado el expansionismo napoleónico, vamos a presenciar el resurgir de los nuevos imperios (5). Las nuevas clases dirigentes asimilan los modos de la antigua aristocracia y de esta manera surge el deseo de reparar todos los excesos cometidos contra aquel patrimonio religioso y aristocrático. Es en este contexto donde hay que situar las actuaciones de Viollet-le-Duc (1814-1879) el cual fundó la otra gran corriente de restauración moderna denominada restauración en estilo, de igual duración e importancia que la anterior como veremos posteriormente.

El historiador Arnold Hauser en su obra más conocida (6) nos relata las consecuencias que tuvo la instauración de la Monarquía de Julio (1830-1848) en la vida cotidiana de los franceses y el cambio de gustos ocurrido a partir de los años cincuenta de la nueva clase dominante que se consolida en el Segundo Imperio (18521870). Es citado textualmente el escrito de Hauser como marco histórico en el que la teoría de la restauración en estilo va a surgir y desarrollarse: "En el arte, sobre todo en la arquitectura y en la decoración de interiores, nunca había imperando tanto el mal gusto como ahora. Para los nuevos adinerados, que son lo bastante ricos para querer brillar, pero no lo bastante antiguos para brillar sin ostentación, no hay nada demasiado caro ni pomposo. No hacen distinción alguna en los medios, en la aplicación de materiales verdaderos ni falsos, ni en los estilos que acoplan y mezclan. Renacimiento y barroco son para ellos sólo un medio para un fin, como mármol y ónix, terciopelo y seda, espejo y cristal. Imitan los palacios romanos y los castillos del Loira, los atrios pompeyanos y los salones barrocos, el mobiliario de los ebanistas Luis XV y las tapicerías de las manufacturas Luis XVI. París adquiere un nuevo esplendor, un nuevo aspecto cosmopolita. Pero su grandeza es con frecuencia sólo aparente; el material pretencioso es frecuentemente sólo un sucedáneo; el mármol, sólo escayola; la piedra, sólo mortero. Las magníficas fachadas son sólo imitadas; la rica decoración es inorgánica y amorfa. En la arquitectura hay una nota de falsedad que corresponde al carácter de parvenue de la sociedad dominante. París se convierte otra vez en capital de Europa, pero no en el centro del arte y la cultura como antes, sino en metrópoli del placer, en ciudad de la ópera, de la opereta, del baile de los bulevares, los restaurantes, los grandes almacenes, las exposiciones mundiales $v$ los placeres corrientes $v$ baratos.

(5) Todo el siglo XIX en Francia presenta una gran inestabilidad política. Tras la derrota de Napoleón vemos la restauración de los Borbones Luis XVIII y Carlos X (1815-1830). Luego la Monarquía de Julio de Luis Felipe de Orleáns (1830-1848). Tras éste, la Segunda República de tan sólo tres años de duración (1848-1851) para dar paso al Segundo Imperio (1852-1870) de Napoleón III que durará hasta la guerra francoprusiana y la Comuna de París. El resto de siglo conocerá una relativa estabilidad con la Tercera República.

(6) HAUSER, Arnold. Historia social de la literatura y el arte. Ed. Guadarrama. Madrid, 1962. En el tomo dos hay un capítulo dedicado al Segundo Imperio. Págs 255 y siguientes. 
El Segundo Imperio es el período clásico del eclecticismo, un período sin estilo propio en la arquitectura y en las artes industriales, y sin unidad estilística en la pintura. Surgen nuevos teatros, hoteles, palacios para alquilar, cuarteles, almacenes, mercados; surgen avenidas y paseos de circunvalación. París es casi reconstruido por Haussmann. Sin embargo, todo esto, si se excluyen el principio de espaciosidad y la construcción con hierro, da la impresión de carecer de toda idea original arquitectónica."

Es en este ambiente en el que se restaura Pierrefonds por empeño personal de Napoleón III y no deja de ser sorprendente que en Francia gobierne una monarquía restaurada a la vez que se restauran los monumentos de su pasado medieval. Y en Italia será bajo la mitra del ultraconservador y reaccionario Pío IX (1846-1878) cuando se restauren en estilo numerosas iglesias. En España, las obras más emblemáticas en el siglo XIX de la restauración estilística son la Catedral de León, San Juan de los Reyes en Toledo y San Martín de Frómista y todas se hacen (o comienzan, mejor dicho a hacerse) bajo los gobiernos conservadores del período de la Restauración (7). Esta corriente disminuye de fuerza y queda solapada en el primer tercio del siglo XX para volver a surgir con nuevos bríos en la dictadura franquista.

Quizá sea una coincidencia fortuita que la restauración en estilo coincida con movimientos políticos más conservadores y reaccionarios que las otras posturas existentes en el ámbito de la restauración monumental, posturas más abiertas y menos dogmáticas que se desarrollan en momentos en los que las sociedades cuestionan y rechazan los modelos políticos autoritarios y se dotan de formas de gobierno y gestión más variadas, tolerantes y abiertas a la pluralidad como reflejan los diversos pensamientos políticos y movimientos sociales y culturales.

Aunque es común establecer la antinomia entre Viollet-le-Duc y Ruskin como el comienzo de las críticas a la restauración en estilo, las críticas a la restauración monumental del francés son anteriores y proceden, no del hecho de restaurar, sino del desconocimiento de las arquitecturas medievales por parte de los arquitectos formados en la tradición de la arquitectura clásica, lo que condujo a la destrucción de monumentos restaurados a principios del siglo XIX.

González-Varas (8) señala los desastres que supusieron los trabajos realizados por Cellerier en Saint-Denis en 1805 y después por Debret a partir de 1813 cuya nueva flecha el Ministro de Trabajos Públicos ordenó derribarla en 1846 tras llevar tan sólo una docena de años construida.

Igualmente nefasto para la abadía de Saint-Germain des Près fue la demolición de las torres que flanqueaban el ábside y en Notre Dame de Nantes se llegó incluso a derribar la torre norte para hacerla simétrica con la sur. 
Estos hechos produjeron la reacción de algunos personajes del mundo cultural del momento como es el caso de Ghillhermy y Dridon que plasmaron en los Annales Archeologiques sus críticas a esos dogmatismos constructivos. Igualmente otros personajes importantes del mundo intelectual se sumaron a estas denuncias, destacando Victor Hugo con su famoso escrito en 1825 Guerre aux démolisseurs.

Lo que se criticaba eran las intervenciones para lograr unos resultados que hacían desaparecer la historia del edificio reflejada en su materia y en los diversos añadidos de variados estilos que el edificio había acumulando a lo largo de su historia.

Viollet-le-Duc era historiador de arte, arquitecto y constructor y además estaba al día de los avances científicos y tecnológicos que ocurrían a su alrededor y es necesario decir a su favor que el aportó al mundo arquitectónico de la restauración unos conocimientos profundos y detallados de las técnicas constructivas medievales.

En Inglaterra, donde el estilo gótico no dejó nunca de ser utilizado, vemos que ya desde finales del siglo XVIII se restauran las grandes catedrales medievales (Salisbury, Westminster, Durham, Lichfield, Hereford) destacando la figura de James Wyatt que aplicó los conceptos de unidad de estilo en las obras citadas. A la vez que estas obras se realizaban, surgió una fuerte polémica sobre las mismas siendo un periódico The Gentleman's Magazine el vehículo de difusión de las críticas a las alteraciones y reconstrucciones que estaban ocurriendo en los monumentos. Ya entonces surge aquí el famoso tema de la "autenticidad" de la obra de tanta actualidad.

Esta corriente de reconstrucción-restauración de los monumentos góticos medievales continuó en el siglo XIX aún con más pujanza como muestra la obra de Georges Gilbert Scott que actuó en más de trescientas obras y dio nombre a lo que irónicamente se denomina destructive restorations.

Es en este momento en el que debemos de ubicar la figura de John Ruskin (1819-1900). La restauración para él es uno de los temas que la sociedad utópica que postulaba debía de desarrollar. La supuesta unión existente en el mundo medieval entre arquitectura, religión y sociedad había sido un logro a la que la actual sociedad industrializada y cada vez más laica debía de tender.

El idealiza el mundo medieval frente al industrialismo. De ahí que la conservación de los bienes culturales consiste " no sólo en la tutela de objetos materiales y concretos, sino también en la conservación de las cualidades morales que los objetos encierran como signos y símbolos de la actuación del hombre en la tierra". Para Ruskin el problema de mantener los monumentos y objetos artísticos del pasado va unido a un imperativo de signo ético: estas obras reflejan los valores de una época que es necesario transmitir al futuro.

Y esta transmisión tiene que hacerse con los elementos materiales que los constructores utilizaron en su momento y que son el reflejo de ese mundo moral desaparecido, de una voluntad artística y de unas técnicas concretas. 
Esto conducirá a asumir que la restauración en estilo es imposible ya que es sobre todo un engaño y una falsificación. Sólo la conservación y el mantenimiento son aceptables para no traicionar el legado histórico-artístico. Y cuando llegue el momento en que el tiempo venza la obra, es preferible su muerte a "que ninguna sustitución deshonrosa y falsa venga a privarlo de los honores fúnebres del recuerdo" (9).

Señala González-Varas que muchas de las tesis sostenidas por el inglés han pasado -al menos en teoría- a formar parte del patrimonio universalmente aceptado de la praxis de la conservación moderna. Excepto el de la aceptación de la muerte "natural" del edificio, sus postulados de condena de la restauración en estilo, la defensa de la materia como reflejo de la historia en la obra y la individualidad única del objeto artístico, gozan de amplio respaldo en el mundo de la restauración de bienes culturales.

En la década de los años 50, Ruskin pasó de los discursos teóricos a la práctica en defensa de lo que él juzgaba maltrato del patrimonio. En esos años Giambattista Meduna (1801-1880) comenzó la restauración de la basílica de San Marcos de Venecia y la Ca' d'Oro. Entonces Ruskin publica Las Piedras de Venecia. En la década siguiente los trabajos de restauración se multiplican tras unirse Venecia al gobierno unitario de Italia en 1866. Entonces Ruskin financia y prologa un documento crítico sobre las obras en marcha de un seguidor suyo Alvise Piero Zorzi sobre San Marcos en 1877. Y con su compatriota William Morris (1834-1896) funda en Londres la SPAB (Society for Protection of Ancient Buildings) llamada más tarde Anti-Scrape Society la cual pidió al gobierno italiano la supresión de los trabajos de restauración de San Marcos dirigidos por G. Meduna lo que finalmente consiguió al lograr crear una comisión técnica dirigida por Federico Berchet, antiguo violetiano reconvertido. Dicha comisión primó la conservación sobre las obras nuevas a cargo de Pietro Saccardo.

Este hecho marca un momento histórico. A partir de entonces "conservación” y "restauración" pasan a ser conceptos con nuevos valores. A final de siglo será la obra de Camilo Boito la que sintetizará las corrientes del antirestauro con las de la corriente del restauro archeologico para fundar la postura del restauro científico de actualidad hasta hoy mismo aunque los postulados violetianos no van a desaparecer sino que van a ser revisados. Se evitará la reconstrucción "ideal” y sólo deberá de obrarse tras profundos estudios históricos y documentales para restaurar la obra tal y como verdaderamente la obra fue y no el cómo se pensaba que podía haber sido de las primeras etapas de la restauración en estilo. La figura más importante de esta corriente es Luca Beltrami (1854-1933) que reconstruyó la torre del castillo de los Sforza de Milán entre otras obras. Esta corriente alcanzará su momento de máxima pujanza tras la Segunda Guerra Mundial. 
La otra corriente que Camilo Boito va a tomar para realizar su síntesis es la corriente del restauro archeologico considerada por algunos como la primera teoría científica de la restauración (10).

Como consecuencia del cuidado que los Papas tuvieron sobre el patrimonio clásico a partir del XIX, este movimiento va a restaurar utilizando las piezas originales (asnastilosis) y haciendo incapié en mostrar la diferencia entre lo añadido al monumento y lo original conservado del mismo.

Los personajes que inaguran dicha corriente son Giuseppe Valadier (17621839) y Rafaello Stern (1774-1820) y las obras más emblemáticas son las conocidas intervenciones en el Coliseo de Roma en 1807 y 1827 para consolidar los restos del edificio ante la inminente amenaza de ruina del anillo exterior.

También se actuó en el arco de Tito con una restauración que ha pasado a ser modélica aunque haya habido estudiosos que han sostenido que lo hecho fue el producto de la penuria económica en que se encontraban las arcas vaticanas en esos momentos.

Camilo Boito (Roma, 1836-Milán, 1914) pone los fundamentos de la restauración moderna. El no se resigna a ver la ruina del edificio y tampoco acepta la reconstrucción del mismo ya sea idealizada como postulaba el restauro stilistico ya sea imitada fielmente como sostenía el restauro storico.

El ve el problema de la restauración del edificio en relación directa con el uso final de los edificios reparados. Como metodología utilizará la herencia de Stern y Valadier haciendo que la restauración sea arqueológica y por tanto fiel a la historia a la vez que desarrolla un proyecto moderno sobre la antigua obra con la finalidad de dotar al edificio de utilidad tras la intervención.

Los puntos expresados por C. Boito están ampliamente desarrollados en las obras que se han citado en la introducción de este capítulo.

Haciendo un somero resumen podríamos decir que Boito da importancia al mantenimiento en primer lugar y a la conservación de los distintos añadidos que la historia ha ido posando en la obra. Esto le conduce a considerar el monumento como un documento histórico al que hay que respetar en todo su conjunto y cuando no haya más remedio que efectuar reparaciones sobre él, estas deben de quedar claramente discernibles de la obra antigua a la vez que se le restituye a lo obrado la unidad de comprensión de la obra de arte inalterada.

La teoría de C. Boito y su metodología tuvieron un amplio eco en toda Europa. En primer lugar en Italia donde en 1902 se publicó la ley para la conservación de los monumentos y de los objetos de la antigüedad. En este país su sucesor será Gustavo Giovannoni que llenará con su hacer la primera mitad de ese siglo. En 
Francia será Paul León; en Bélgica La Maine y en España destaca la figura de Leopoldo Torres Balbás que tendrá gran fuerza hasta la Guerra Civil. Pero todo esto lo trataremos en otro apartado. 


\section{B. 3. La restauración de jardines en el XIX.}

\section{B.3.1. Las restauraciones románticas.}

La jardinería va a permanecer al margen de las grandes corrientes de la restauración pues es considerada como un anexo de la arquitectura que adorna el conjunto de las obras arquitectónicas.

Igualmente, la ola que barre Europa procedente del Reino Unido produce el efecto de hacer desaparecer numerosos jardines clásicos y barrocos a favor de las creaciones de efectos pictóricos, sorprendentes y "naturales" del paisajismo anglosajón.

La fuerza que tuvo este movimiento -empezando por el propio Reino Unido- lo podemos ver en el libro de H. Inigo Triggs Formal Gardens in England and Scotland aparecido en 1902 y reeditado por el Antique Collector's Club hace unos años (1988) con fotos actuales de los mismos jardines que la publicación de principios de ese siglo.

En esta obra, Inigo Triggs hace una recopilación de los escasos jardines formales que no sucumbieron a la moda del jardín inglés o de aquellos otros que rehicieron el siglo pasado sus antiguos diseños geométricos a la vez que se lamenta de las pérdidas sufridas. Cita para ello el diario de Celia Fiennes, una dama de la época de los reyes Guillermo y María que por motivos de salud viajó por todo el país dejándonos una descripción bastante completa de los jardines de aquel momento así como del cuidado e interés con que se elaboraban sus diseños y acaba diciendo que dicho diario "también nos permite darnos cuenta, en cierta medida, de cuanto hemos perdido con el vandalismo de la época subsiguiente, la época de "Capability” Brown, Humphry Repton y sus iguales."

El rechazo a los padres fundadores del paisajismo inglés ya había tenido eco en el continente. Lo novedoso y sorprendente es que lo diga un inglés.

Este estado de opinión producirá la actitud de reconstruir los jardines formales clásicos y barrocos eliminando las transformaciones paisajistas de los mismos. 


\section{B.3.2. Violetianos en jardinería: el holandés H. Poortman y los franceses H. y}

A. Duchêne.

En Holanda como señalábamos en la introducción, el arquitecto Hugo Poortman reconstruye o "restaura" o si se quiere mejor recrea varios jardines contiguos a palacios basándose en modelos de la época tomados de grabados, cuadros y tratados de jardinería del momento en cuestión.

La figura de Poortman, de la que no ha sido fácil conseguir datos sobre su obra (11), es un ejemplo de las corrientes violetianas e históricas del XIX que se reflejan en la jardinería.

La obra de este arquitecto holandés tiene el interés de ser el precursor de lo que se realizará más extensamente en el siglo XX culminando con la recreación de los jardines del palacio real de Het Loo en Apeldoorn, residencia histórica de los reyes de Holanda desde el siglo XVII cuyo inmenso parque de trazados paisajistas del XIX vio renacer el jardín barroco próximo al palacio en los años 80 del pasado siglo según modelos conservados en pinturas y grabados de la época. Posteriormente lo trataremos con más detalle en otro capítulo de este trabajo.

Lo novedoso de Hugo Poortman es que actúa a contracorriente deshaciendo las transformaciones paisajísticas de los alemanes J. G. Michael y J. D. Zocher casi recién acabadas pues todos ellos elaboran sus proyectos en la segunda mitad del siglo XIX.

Poortman, formado en Francia, recreó los jardines barrocos de Middachten del siglo XVIII en el 1900; los de Twickel, originales del XVI, reorganizados a la manera barroca por el francés Marot en el XVIII y convertidos al paisajismo en el XIX por Zocher y Petzold y lo mismo hizo con los jardines dieciochescos del castillo de Weldam a los que suprimió su transformación paisajística.

(11) La obra y figura de H. Poortman aparecen citados en el libro de Dusan OGRIN The Wold Heritage of Gardens. Thames and Hudson. Londres, 1993. Pág. 319 y 320. En el resto de bibliografía citada en el apéndice documental no se recoge su trabajo en ninguno de ellos excepto en la obra de C. Thacker History of Garden donde los jardines de Weldam. Twickel y Middachten son citados pero H. Poortman es nombrado una sóla vez en un pie de foto. 


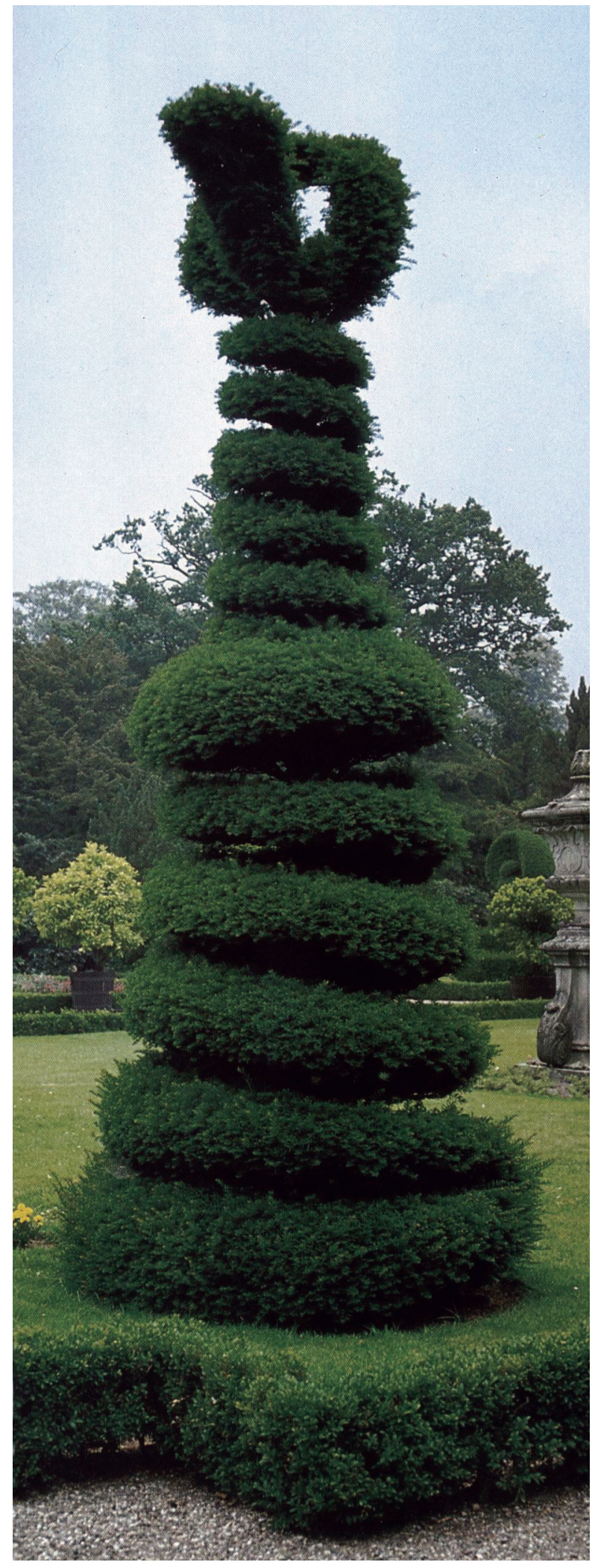

En los jardines de Twickel, recreados por H. Poortman, se han reproducido y se mantienen los excesos de la topiaria barroca. (Foto de la obra citada de Dusan Ogrin) 


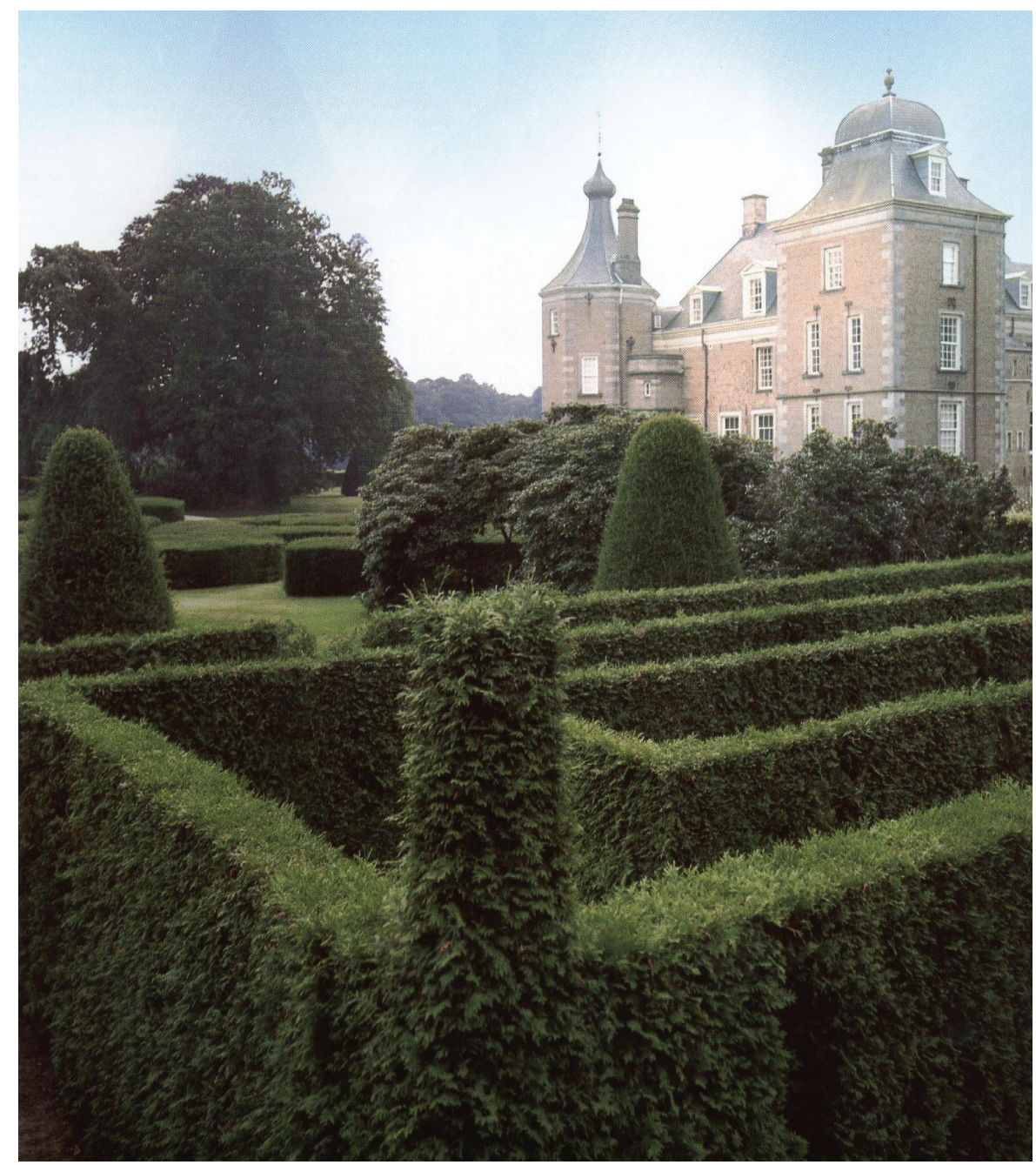

Jardines del castillo de Weldam. Otra de las obras de Poortman consistente en la anulación del jardín paisajista y su recreación a la manera barroca. (Foto tomada del libro de Dusan Ogrin)

En Francia son Henry y Achille Duchêne los responsables de este movimiento. Monique Mosser (12) ha señalado el contexto histórico en el que se desarrolló tal tendencia. Después de la guerra francoprusiana de 1870, en Francia surgió un ambiente de exagerado chovinismo unido a un nacionalismo exacerbado. Muchos pensadores se empeñaron en demostrar que el genio nacional se basaba en una tradición que había alcanzado su cumbre en el Gran Siglo.

En jardinería la obra de Le Nôtre era el gran ejemplo a seguir. En la obra de Lucien Corpechot Les jardins de l'intelligence. Paris et jardins de France (1912) éste señala:

"Si la lengua francesa dejara de ser oída, si nuestra literatura cesara de ser comprendida, si los nombres de Corneille, Bossuet, Racine, Molière, Voltaire, Montesquieu no inspiraran en las mentes un maravilloso frisson... y si el jardín de

(12) MOSSER, Monique y TEYSSOT, Georges. The History of Garden Design. Thames \& Hudson. Londres, 1991. "Henri and Achille Duchêne and the Reinvention of Le Nôtre". Páginas 446-450. 
Le Nôtre no hubiera continuado de ser mientras tanto mantenido, la esencia y la cualidad del espíritu de Francia, la pureza y perfección del poder intelectual de los más grandes genios de nuestro linaje no se revelaría en Versalles en toda su gloria. Esta es la razón de que las terrazas de Versalles sean un lugar idóneo para contemplar el espíritu de Francia. Aqui nuestra historia se revela, se despliega ante nuestros ojos como una clara y lógica campaña. Todos los esfuerzos de nuestra raza en todas las direcciones, todos sus logros y hasta incluso sus faltas encuentran sentido y se acomodan según un plan aparentemente concertado."

Este espíritu fue el que plasmaron los Duchêne. El padre, Henry, comenzó en 1877 sus trabajos. Su hijo Achille (1866-1947) llevaría a los más alejados países del mundo esta actividad reconstructora según los principios del jardín barroco francés. La primera obra de envergadura y que les dio fama fue la reconstrucción de los jardines de Vaux-le-Vicomte para el millonario Alfred Sommier en 1875.

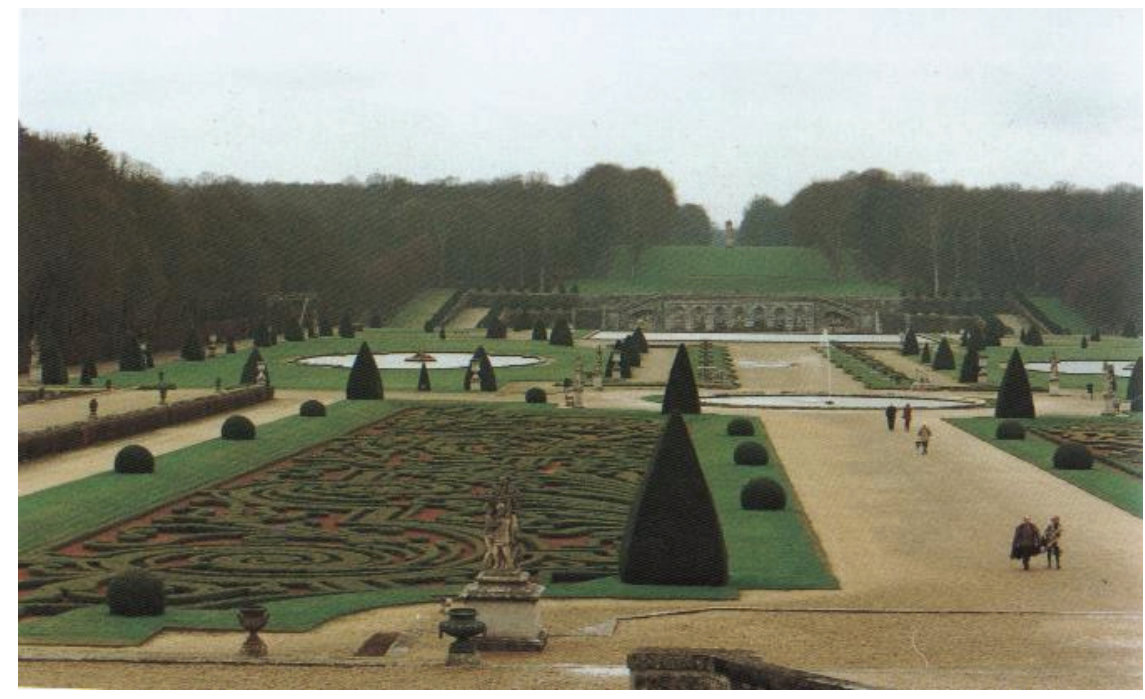

Jardines de Vaux-le-Vicomte. Las fuentes de los laterales de los parterres han sido sustituidas por superficies de césped con arbustos podados en bola. (Foto del libro de Filippo Pizzoni)

Los principios de Le Nôtre se llevaron en este lugar a la práctica con total fidelidad aunque no se pudo reconstruir todo tan fielmente como se deseaba a pesar de la documentación existente. Tal fue el caso de las fuentes laterales de los grandes parterres. Nunca se ha aclarado si fue por falta de agua o por los excesos económicos que exigía tal obra, excesos incluso para un millonario como Sommier. En la reconstrucción del parque de Champs-sur Marne volvieron a demostrar su gran habilidad para reconstruir un nuevo espacio según las fórmulas de la jardinería formal adaptándolas a unas nuevas circunstancias. Esto lo volvieron a demostrar tanto en la recuperación de los viejos jardines (Courances, Baillon, Breteuil, Bizy, Maintenon, Balleroy, Rosny, Langeais o Hautefort) como en la creación de los nuevos en las fincas de los millonarios americanos o en los caserones del París de 
la época (13). Ernest de Ganay, según comenta M. Mosser en su obra citada ha señalado los principios que les sirvieron de inspiración y guía metodológica para enfrentarse a resolver sus trabajos:

"El Pasado no puede ser reconstruido. Si se devuelve a la vida, nunca se puede, a pesar de la ciencia, el buen gusto y los consejos de la experiencia y la elección conseguir exactamente su forma original. Una restauración, y aún más una reconstrucción siempre pueden detectarse. Es por tanto absurdo el intentarlo. Los verdaderos artistas lo saben cuando se les pide que lo hagan. Ellos discretamente interpretan el Pasado. Y la mejor manera de hacerle honores no es buscar reemplazarlo por un Presente que nunca podrá ser su imagen exacta. Por otra parte, lo que debemos de hacer es buscar recrear el ambiente del Pasado.... Si por suerte existe un plano original, constituye una idea para ser interpretada."

Hoy el trabajo de estos autores se ha visto desde un punto de vista más crítico que el que nos transmitieron sus numerosos seguidores e incondicionales clientes. Si bien en algunos casos sus obras fueron notables reconstrucciones de jardines formales, en otros casos no fueron más que invenciones que no tienen nada que ver ni con el entorno arquitectónico donde fueron colocados los jardines ni con el momento histórico en que aquellos fueron edificados pues su jardinería se fue haciendo cada vez más historicista y ecléctica.

De todas formas su herencia será importante en toda la jardinería del pasado siglo XX ya que este modo de hacer será el que triunfe en casi toda Europa después de la II Guerra Mundial y convertida en la corriente "franco-belga" tendrá una influencia decisiva en la elaboración de la Carta de Florencia en 1981.

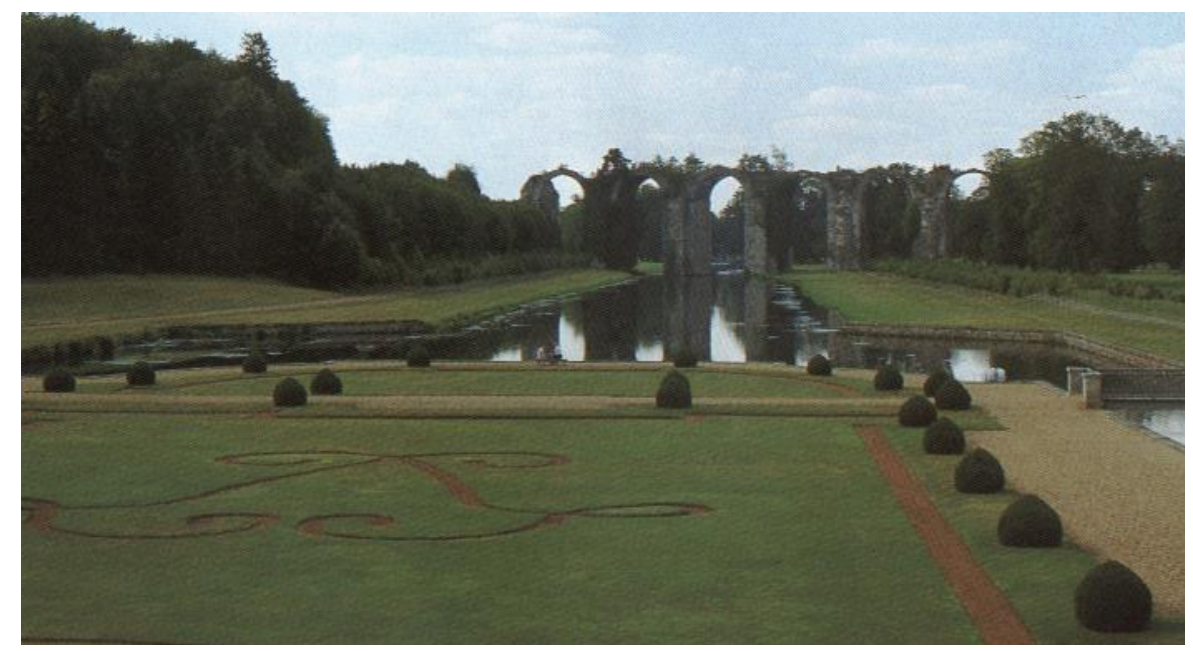

Acueducto del castillo de Maintenon. Esta es una de las reconstrucciones más famosas de los Duchêne.(Foto de la obra de Filippo Pizzoni)

(13) Muchas de las obras de Achille Duchêne están recogidas en el libro-catálogo de la exposición sobre su obra Jardins de Ville Privés 1890-1930 de Jean-Christophe MOLINIER. Ed. Ramsay de Cortanze. París, 1991. 


\section{B. 3. 3. El caso español. El siglo XIX: un siglo de agitados cambios.}

Y mientras eso está pasando en Holanda y Francia, en España, durante la mayor parte del siglo XIX, con sus grandes convulsiones políticas, la jardinería va a encontrar un marco difícil para desarrollarse hasta la restauración de 1872.

Tras la invasión francesa se restauraron algunos jardines como El Retiro de Madrid por empeño de Fernando VII que lo replantó y adornó de construcciones típicas del jardín pintoresco como ermitas, montañas, Casita del pescador, vaquería, etc. Entonces este jardín era aún patrimonio privado del monarca y había resultado especialmente dañado durante la guerra al utilizarlo el ejército francés como cuartel general durante la ocupación de la capital.

El resto de los jardines se replantaron con las mismas trazas que tenían antes de la invasión como es el caso de la Alameda de los Osuna. Solamente a partir de la segunda mitad del siglo veremos que los antiguos jardines formales empiezan a ser reformados con intervenciones paisajistas como es el caso del Jardín Botánico de Madrid del cual tenemos la suerte de disponer de una amplia documentación cartográfica que abarca desde los primeros diseños originales de Sabatini -de carácter barroco y que no se realizaron por no resolver los problemas de la nueva ordenación linneana del mundo vegetal- a los de Tadeo Lope de 1781 (14) y de Manuel Gutiérrez Salamanca de 1786 (15) que muestran los trazados originales del jardín según lo concibió Juan de Villanueva.

Los del siglo XIX son los de Ibáñez de Ibero de 1874 correspondiente al plano de Madrid y el casi idéntico a éste que Miguel Colmeiro publicó en su monografía sobre el Jardín (16) -firmado por Areitio y Larrinaga- con fecha de 1875 los cuales ya muestran los cambios acaecidos en el Jardín el siglo XIX.

Nosotros reproduciremos aquí los de Tadeo Lópe de 1781 (año de la inauguración del Jardín) y el de Areitio y Larrinaga de 1875 ya que estos documentos nos van a permitir apreciar los cambios ocurridos sobre el diseño racional de Villanueva y que reflejan los cambios de mentalidad y estilos de vida y pensamiento que la jardinería recoge de la España del XIX. Dejaremos la reproducción de los otros

(14) AÑON, Carmen; CASTROVIEJO, Santiago; FERNANDEZ ALBA, Antonio. Real Jardín Botánico de Madrid. Pabellón de Invernáculos. En la página 24 Añón señala que el plano de Tadeo Lope habría que considerarlo más bien un proyecto que refleja cosas que nunca llegaron a realizarse que una representación fidedigna del Jardín.

(15) Este plano, que se conserva en el Museo Municipal de Madrid, sigue señalando C. Añón en la obra anteriormente citada, fue encargado por Floridablanca. Es completamente racionalista y si se lleva lo ornamental es renacentista. Su diseño es una figura geométrica claramente definida separada del resto del espacio que abarca el jardín. Para su elaboración se toma de base el empleo de rectángulos de "sección áurea" o "proporción divina". De su desarrollo resulta un triángulo isósceles, eje visual y simétrico que "subraya la importancia del plano superior del jardín. De esta forma, el Jardín está presidido por un triángulo, antiguo símbolo de la ciencia, el conocimiento, la razón. La Trinidad, la armonía y la proporción, simbolismo que subraya la "altura"del terreno" pues la cátedra se podía haber colocado en cualquier otra parte del Jardín pero de esta manera es el centro hacia el que convergen todos los caminos y perspectivas. El edificio así logra desarrollar una doble intención arquitectónica y conceptual ya que este camino ascendente desde la entrada hacia la fuente del conocimiento representa la subida hacia la sabiduría desde los niveles inferiores. Cuando el Jardín se inaugura, sólo existe la entrada de la Puerta del Paseo del Prado. Estas gradas fueron deteriorándose con los años.

(16) COLMEIRO, Miguel. Bosquejo Histórico y Estadístico del Real Jardín Botánico de Madrid. Madrid, 1875. Existe una edición facsímil de las Librerías "París-Valencia" de 1995. 
planos mencionados para el capítulo dedicado a analizar la restauración del Real Jardín en los años ochenta del pasado siglo al igual que el comentario sobre las obras bibliográficas básicas que tratan sobre ese espacio.

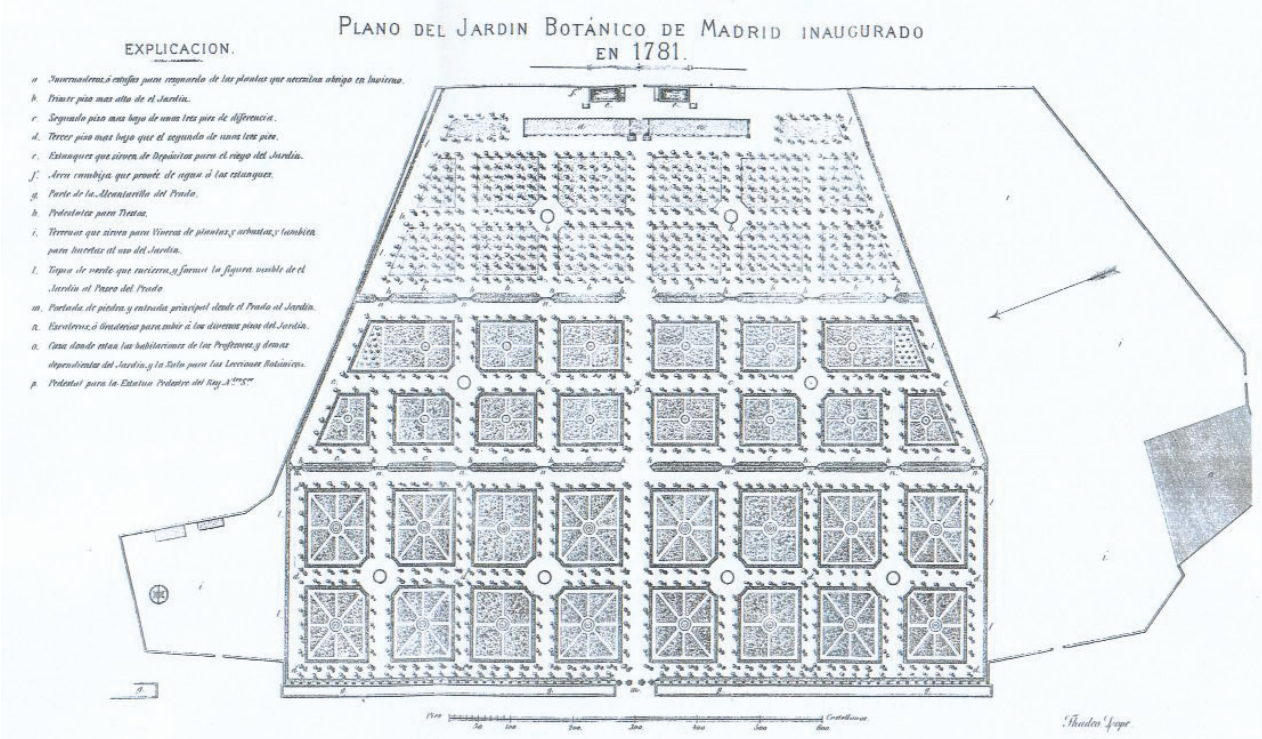

Plano de Tadeo Lope del Jardín del año 1781. (Archivo del Real Jardín Botánico de Madrid).

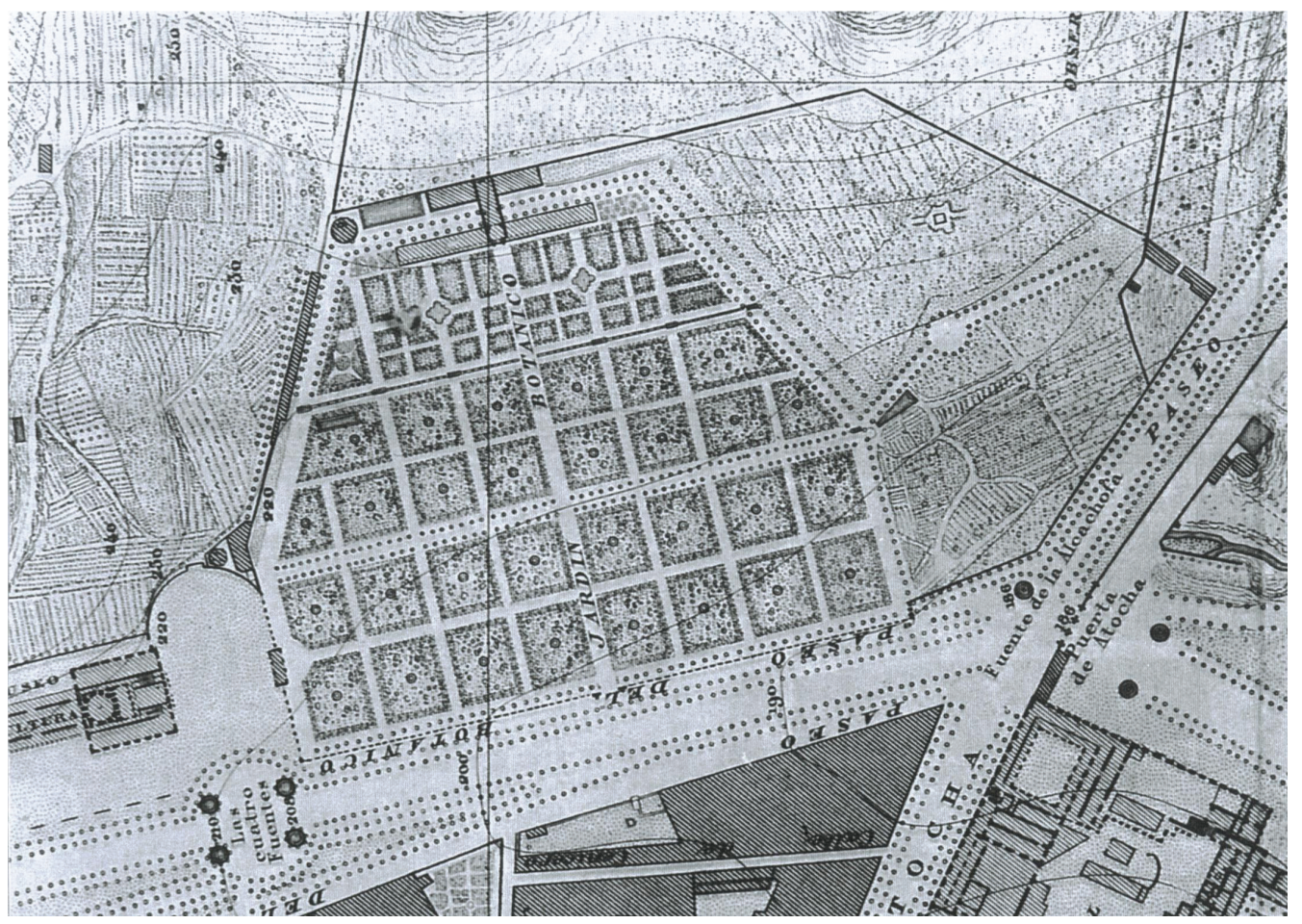

Plano de Madrid de F. Coello de 1848. 


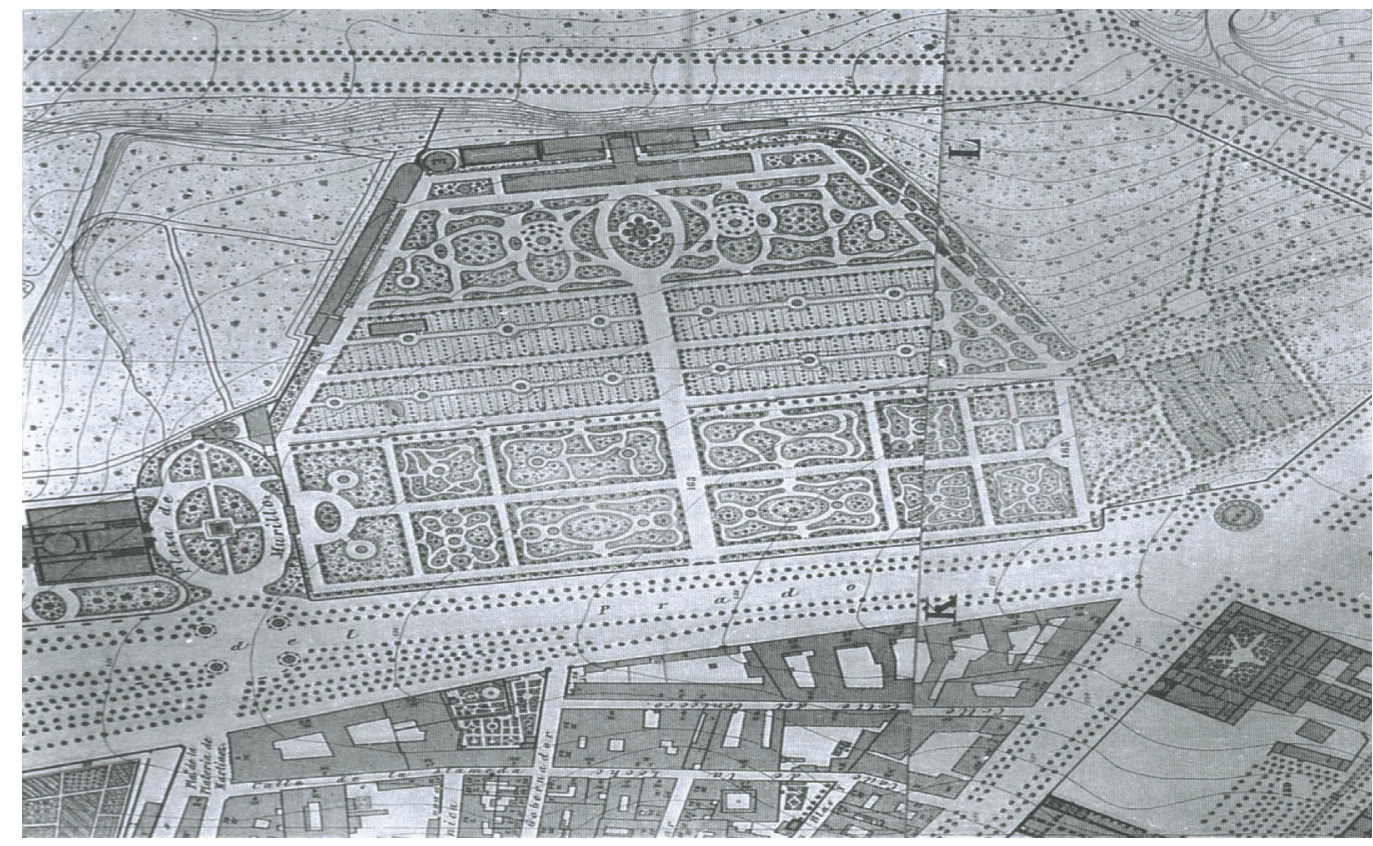

Plano parcelario de Madrid, publicado por el Instituto Geográfico y Estadístico en los años 1872, 1873 y 1874 donde podemos apreciar los cambios ocurridos en el diseño del jardín desde su inauguración.

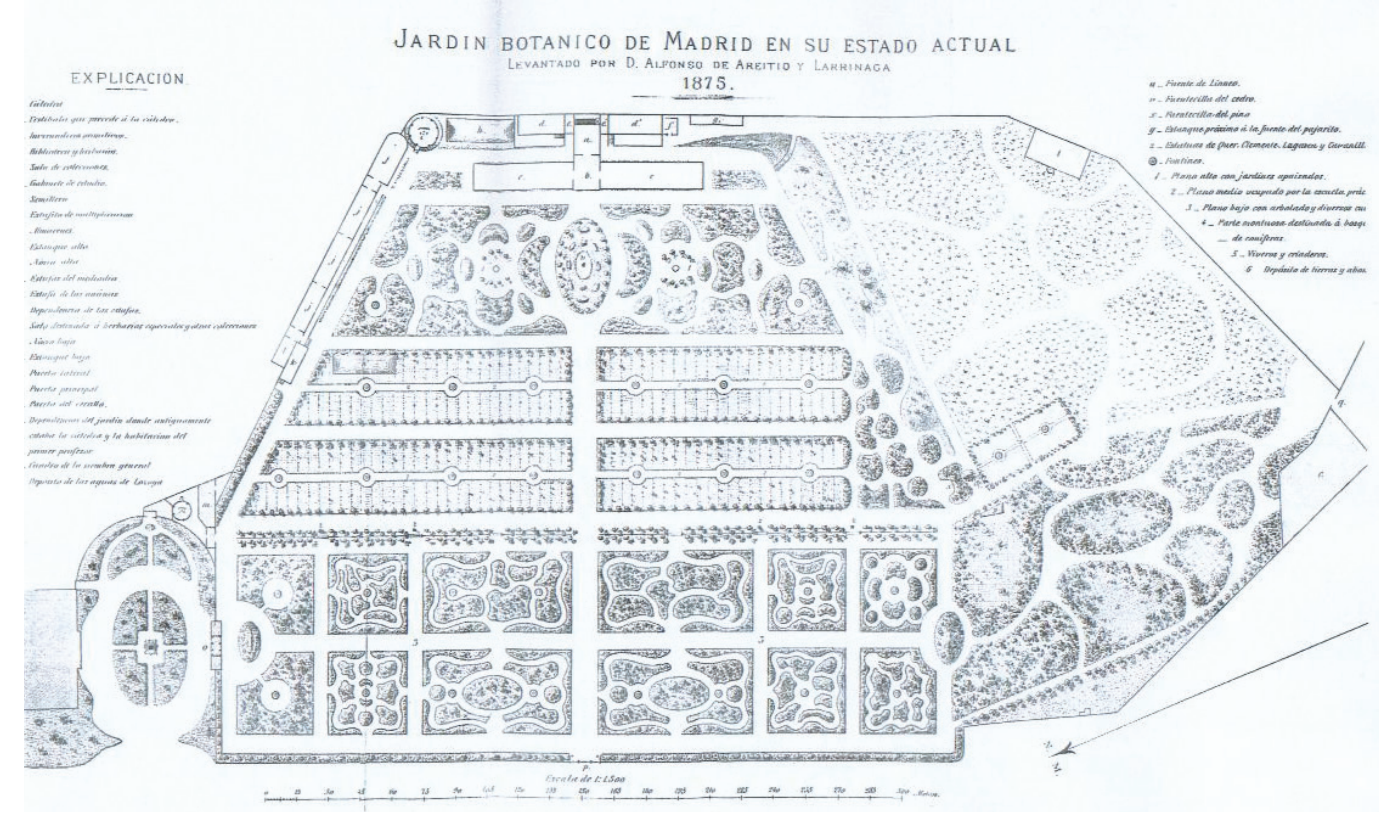

Plano de 1875 de A. de Areitio y Larrinaga publicado por M. Colmeiro.

Debido a las mismas causas que los jardines paisajistas no se desarrollaron ampliamente en nuestro país -eran jardines asociados a la ideología de la Ilustración y ésta no caló demasiado hondo en las capas dirigentes y económicamente fuertes- tampoco hubo por tanto, cambios desde el paisajismo a la recuperación de los diseños formales del clasicismo o del barroco como sucedió en otros países. La gran excepción es el Parque de María Luisa en Sevilla. El Palacio de 


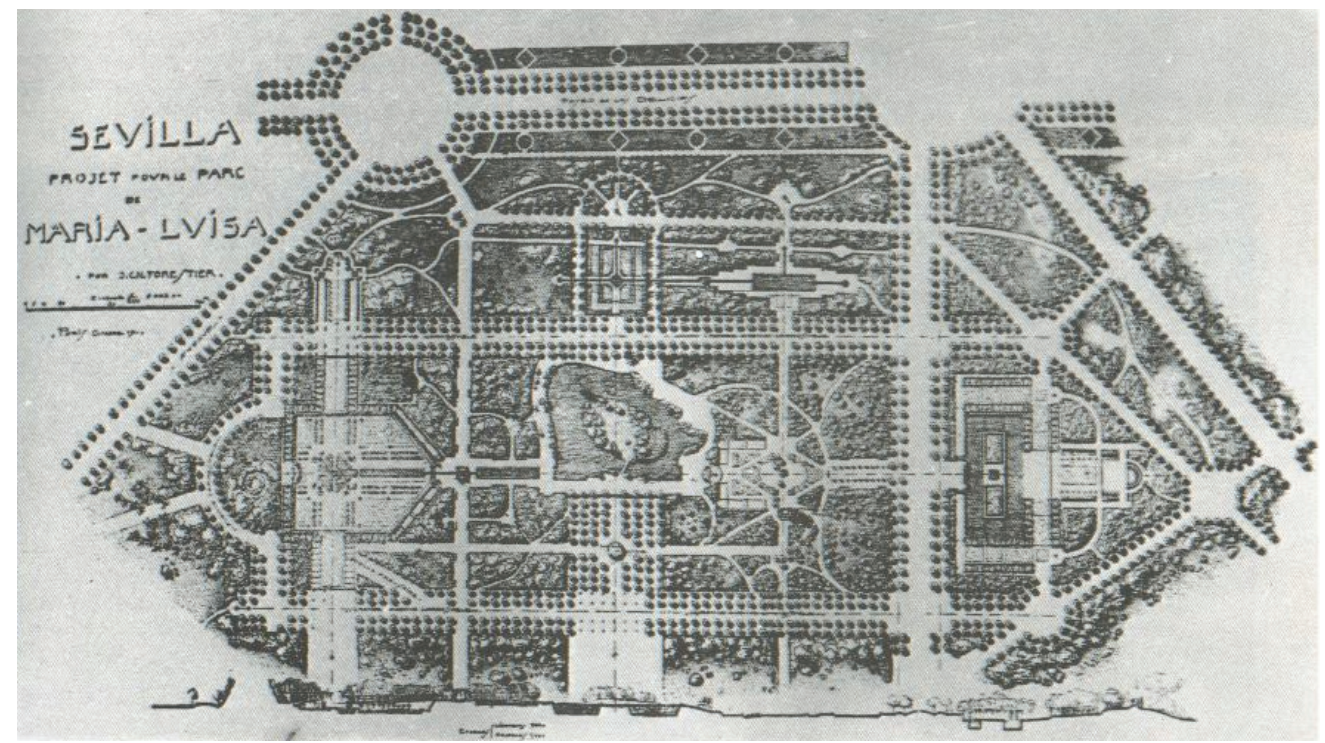

Plano de Forestier para la ordenación del Parque de María Luisa en Sevilla

San Telmo fue adquirido por los duques de Montpensier en 1850. Estos personajes llamaron al jardinero francés Lecolant para que hiciera los jardines quien los diseñó "a la inglesa", es decir, con glorietas unidas por caminos y veredas sinuosas, juegos de agua, kioskos, estatuas, montañas artificiales, estanques con isletas, grutas y albercas (17).

En 1893 la duquesa viuda cede al municipio una gran extensión de los jardines del Palacio. La adaptación de los mismos para uso público la hace el propio arquitecto de la duquesa, Juan Tavera de la Vega.

En 1910, aprovechando los preparativos para la Exposición del 29, se presenta un proyecto de reforma que abarca el Parque, el antiguo huerto de Mariana y el Jardín de Delicias. El proyecto es de J. N. Forestier, defensor de la geometría y la regularidad. Este arquitecto propuso un trazado de grandes ejes según un esquema ortogonal pero respetando el carácter sustentante del arbolado existente del trazado romántico. Con esta intervención se superó la dicotomía entre jardines regulares y jardines pintorescos. En los principales enclaves hizo una aproximación a los jardines de tradición islámica con lo que resolvió el problema de la utilización pública del espacio al mantener lugares de privacidad y encuentros íntimos (supervivencias del trazado romántico) con los de uso multitudinario (espacios geométricos abiertos). 


\section{EL SIGLO XX. (PRIMERA PARTE). LAS CARTAS DE ATENAS Y VENECIA}

\section{1. Introducción}

\section{2. La Carta de Atenas (1931)}

C.2.1. Leopoldo Torres Balbás y la restauración en la Segunda República.

C.2.2. La catalogación del patrimonio verde: Javier de Winthuysen.

C.2.3. La restauración del Palacete de La Moncloa.

C.2.4. La protección legal del "verde histórico": constitución del Patronato de los Jardines Históricos de España (1934).

C. 3. La Guerra Civil (1936-1939) y la posguerra.

Sus consecuencias sobre la restauración.

C.3.1. Las restauraciones de Javier de Winthuysen en Madrid y Valencia.

C. 4. La restauración de jardines en España entre 1920 y 1985 según los datos del Archivo de la Dirección General de Bellas Artes.

C. 5. La Segunda Guerra Mundial (1939-1945) y la posguerra.

Sus efectos sobre los criterios de restauración.

C.5.1. Primacía de las reconstrucciones.

C.5.2. La Carta de Venecia (1964) . 


\section{1. Introducción.}

El siglo XX en Europa va a ver la continuación de las posturas del siglo XIX, matizadas por nuevas aportaciones teóricas que se entremezclan y conviven en paralelo siendo dominantes una u otra según las circunstancias históricas y sociales del momento.

Hasta la Guerra Civil española y la II Guerra Mundial, la corriente dominante es la denominada restauración científica la cual corresponde a las líneas de actuación trazadas por Camilo Boito y que continuadas por Gustavo Giovannoni tendrán su reflejo en la Carta de Atenas de 1931. (Ver Anexo Documental nº 1)

En España, el enfrentamiento entre las dos posturas está presente con gran fuerza en los años veinte. La corriente de restauración en estilo o violetiana la encabeza Vicente Lampérez y Romea (1861-1923) denominándose corriente restauradora.

La otra corriente que se denominará conservadora, la encabezan Leopoldo Torres Balbás (1888-1960) y Jeroni Martorell (1876-1951) y verá su asentamiento en los años de la Segunda República (1931-1936) concretándose legislativamente en la Ley del Patrimonio Histórico de 1933.

En este ambiente se realizará el primer intento de inventariar el patrimonio verde de nuestro país, labor que realizará parcialmente Javier de Winthuysen así como las primeras medidas legislativas para su protección con la creación del Patronato de Jardines Históricos en 1934. Igualmente, Winthuysen acomete la primera restauración de un jardín documentada de la que tenemos noticia (Palacete de la Moncloa) y recrea jardines en edificios históricos como fueron los primeros Paradores de Turismo.

Todas estas actitudes se verán trastocadas tras las guerras Civil y Mundial.

En la posguerra, volverá a ser dominante en toda Europa la restauración en estilo con la reconstrucción de todo el patrimonio dañado fomentándose dicha tendencia por motivaciones politico-simbólicas y de sentimentalismo social. El principal esfuerzo de la restauración monumental en nuestro país se centrará en la reparación del ingente patrimonio eclesiástico dañado en la contienda y en la adaptación de los edificios a las nuevas demandas del incipiente turismo en los 60 y 70 .

La jardinería constituirá un anexo insignificante en toda esta labor restauradora. Los archivos de la Dirección General de Bellas Artes de Alcalá de Henares dan testimonio de esto. (Ver Anexo Documental $n^{\circ} 2$ ). Solamente las escasas restauraciones realizadas por Javier de Winthuysen mantienen un nivel excepcional por su respeto a la obra y la modernidad de sus criterios (Alameda de Osuna, Jardín de Monforte).

Los excesos de la reconstrucción de la posguerra provocarán, en Italia especialmente, una nueva reflexión sobre la actividad restauradora plasmada en la 
Carta de Venecia de 1964 (Ver Anexo Documental n 3) y en las teorías de Cesare Brandi.

Desde esos años, se han celebrado innumerables congresos, convenciones, simposiums, seminarios y publicado numerosas cartas, actas y recomendaciones de toda clase que han contribuido a extender el ámbito de la protección a una más amplia gama de bienes culturales en todo el mundo. Sin embargo, siguen sin existir unidad de criterios. Las dos corrientes decimonónicas siguen presentes plasmadas en dos actitudes irreconciliables: aquellos para los que el monumento debe de ser conservado en su integridad y aquellos otros para los que el monumento es el punto de partida para la realización de un nuevo proyecto. Y esto continúa hasta hoy mismo.

La jardinería en las Cartas de Atenas y Venecia fue levemente mencionada. En la primera de ellas, la de Atenas, dos renglones del artículo VII dicen: "Objeto de estudio pueden ser también las plantaciones y ornamentaciones vegetales adaptadas a ciertos monumentos o grupo de monumentos para conservar el carácter antiguo." Es evidente la subordinación a que queda sometida la jardinería respecto a la arquitectura siendo considerada como parte de la ornamentación de la obra y no obra de arte en sí misma.

En la Carta de Venecia de 1964 se amplía la definición de monumento histórico abarcando "al ambiente urbano o paisajístico". No se vuelve a decir nada más sobre los jardines.

En la Declaración de Amsterdam de 1975 se generaliza la noción de patrimonio arquitectónico ubicándolo dentro de una política global y democrática del medio ambiente.

En dicha declaración se afirma: "Lo que importa proteger hoy son las ciudades históricas. Los barrios urbanos antiguos y las ciudades de tradición, comprendidos los parques y jardines históricos". No se vuelve a citar el verde histórico ya más en este documento en el que se recogen por otra parte las grandes preocupaciones sociales y medioambientales de los centros históricos y se anuncian variadas medidas de toda índole -social, económica, cultural, etc.- para evitar y parar el creciente deterioro de estos lugares.

En la primavera de 1981, el Comité Internacional de Jardines Históricos ICOMOS-IFLA reunido en Florencia, elabora una carta que llama "Carta de Florencia" en honor de la ciudad anfitriona cuyo fin es salvaguardar los jardines históricos. La carta es redactada por el Comité y queda registrada el 15 de diciembre del 81 por el ICOMOS con la pretensión de completar la "Carta de Venecia" en lo que respecta al tema de la jardinería. (Ver Anexo Documental nº 4).

No deja de ser chocante que una Carta que pretende completar la de Venecia, ignore aspectos fundamentales de ésta como la señalización expresa de que el fin de la restauración no es conseguir dotar de unidad de estilo a la obra (Art. 11) y abra las puertas al repristino. 
Dicha Carta fue inmediatamente replicada por un grupo italiano de historiadores y profesionales del mundo de la conservación y la restauración encabezados por Isa Belli Barsali que se opusieron tajantemente al "revival" de las teorías violetianas y consiguieron suprimir los párrafos más polémicos del documento en su versión italiana y constituidos en grupo de estudio obtuvieron que el Ministerio de Bienes Culturales recogiera oficialmente sus reparos a los peligros que podía suponer para el verde histórico el asentamiento de unos principios tan atávicos. Los intentos de Marco Dezzi Bardeschi y Vicenzo Cazzato (Ver Anexo Documental no 5) de promulgar una "Carta italiana degli giardini storici" fueron en esta línea.

Hoy podríamos decir que en la restauración de los jardines coexisten las dos grandes corrientes que escindieron el mundo de la restauración a principios de siglo. Es como si la jardinería llevara más de medio siglo de retraso con respecto a otras disciplinas y así podemos ver que, frente a la actitud minoritaria de conservar el patrimonio verde existente realizando -cuando sea preciso- obras nuevas con mucho tiento y cuidado de respeto a la obra, existen mayoritariamente casos en que aquél es desechado para volver a "recrear" jardines de época según diseños de grabados (Hampton Court) o testimonios literarios (Convento de Santa Clara en Nápoles) olvidando que todo lo presente en el jardín -a veces hasta incluso las más humildes "malas yerbas"- es a menudo el testimonio de una herencia cultural de siglos.

Esta dualidad es la que está presente en el mundo de la restauración de los jardines en estos momentos.

Todo lo anteriormente esbozado es lo que desarrollaremos más ampliamente en los puntos que a continuación siguen. 


\section{C.2. La Carta de Atenas (1931)}

\section{C.2.1. Leopoldo Torres Balbás y la restauración en la Segunda República. La polémica entre conservadores y restauradores.}

Señala Alfonso Muñoz (1) que dicha polémica no hay que enfocarla dentro de dos escuelas enfrentadas puesto que ni tuvieron una metodología única, ni un corpus teórico ni hubo maestros ni discípulos. Este enfrentamiento hay que situarlo en la confrontación entre los seguidores del historicismo ecléctico o academicismo decimonónico en recesión y las nuevas posturas racionalistas emergentes con sus nuevos conceptos de dar valor a la función como eje de la construcción, considerar la realidad social y económica de una manera importante a la hora de afrontar la realización del proyecto y el respeto a la historia de la arquitectura en todas sus manifestaciones.

La polémica como tal estalló en 1919 en el VIII Congreso Nacional de Arquitectos resultando vencedor Leopoldo Torres Balbás cuando abandonó Lampérez y Romea (seguidor de las tesis de Viollet-le-Duc) la reunión tras haber renunciado a la presidencia del mismo para poder participar en los debates.

Este enfrentamiento estaba latente desde principios de siglo pues había profesionales que en aquellos momentos ya se estaban cuestionando todo lo que estaba ocurriendo en el mundo de la restauración monumental. Igualmente, Francisco Giner de los Ríos, desde la Institución Libre de Enseñanza criticó el tipo de restauraciones realizadas por considerarlas dañinas para los monumentos.

Otro personaje clave de ese momento fue el Marqués de Vega Inclán que desde la Comisaría Regia de Turismo demostró que se podía restaurar de otra manera como se pudo ver en la intervención realizada en el Patio de Yeso de los Reales Alcázares de Sevilla. Decisivo fue el apoyo que el Marqués prestó a Leopoldo Torres Balbás en sus actuaciones y también estará detrás de la elección de Javier de Winthuysen para hacer el inventario de los jardines históricos de nuestro país.

Otro tanto ocurría en Cataluña donde las corrientes conservadoras habían penetrado temprano debido a su vigor intelectual y a su proximidad a las corrientes culturales europeas siendo la figura de Jeroni Martorell la que llena estos años.

Tras unos años de divulgación de las teorías "antirrestauradoras" en revistas y conferencias, Leopoldo Torres Balbás las pudo llevar a la práctica en la Alhambra. Posteriormente viajará a Grecia para tomar parte en el congreso donde se elaborará la Carta de Atenas. En ella se plasmarán todos esos principios teóricos en una serie de puntos con la finalidad de que los distintos países participantes pudieran crear un marco legal para afrontar la restauración de los monumentos, siendo el paso previo la catalogación total de los mismos.

(1) MUÑOZ COSME, Alfonso. Teoría e historia de la restauración en España. 1900-1936. "La llegada de la modernidad: Torres Balbás y la escuela conservadora". Págs: 15-31. 
En el tema que nos ocupa -la jardinería- dicha catalogación la emprenderá Javier de Winthuysen y el marco legal en que los principios de la Carta de Atenas se plasman, lo constituirá la Ley del Tesoro Artístico de 1933 sobre Protección del Patrimonio, promulgada en el momento político de la Segunda República y vigente hasta 1985. Los jardines recibirán especial atención con la creación del Patronato de Jardines Históricos de España en 1934 como ya señalábamos anteriormente. En esta Ley de 1933 quedan superadas las polémicas de las primeras décadas del siglo al hacer suyas las autoridades republicanas las tesis conservadoras de Torres Balbás. Otro asunto será la práctica de la restauración tras la Guerra Civil a pesar de la vigencia de dicha ley. 


\section{C.2.2. La catalogación del patrimonio verde: Javier de Winthuysen}

Javier de Winthuysen (1874-1956), sevillano profundo a pesar de su apellido holandés (fue descendiente de holandeses afincados en Andalucía desde el siglo XVIII) llena la primera mitad del siglo XX en el ámbito de la jardinería. Hoy es más conocido casi por esta actividad que por la de pintor (2). Realizó el primer inventario de los jardines históricos de España en unas condiciones muy duras y con escasas economías del cual sólo pudo completar el de la zona centro de la Península. Logró la protección de este sector tan delicado del patrimonio cultural logrando que se crease el Patronato de Jardines Históricos; restauró y recreó jardines con criterios de gran sensatez y modernidad. Igualmente llevó a cabo numerosos proyectos de jardines nuevos tanto para instituciones públicas como para particulares.

Carmen Añón y José Luis Sancho son los responsables de que su figura haya sido conocida para el gran público al elaborar los catálogos de la magnífica exposición del Real Jardín Botánico de Madrid de 1986 que posteriormente viajó a Italia y más tarde, ampliando los aspectos andaluces de esta figura, a Sevilla y Córdoba.

Esta información fue completada con el trabajo que acompaña a la edición facsímil de su obra Jardines Clásicos de España (3) recogida en forma de "notas" en las cuales aparte de completar los datos biográficos de interés, se hace un recorrido por los principales jardines en los que Winthuysen actuó acompañándolo de una completa bibliografía sobre los mismos.

Hace poco, la Fundación Cultural MAPFRE-VIDA (diciembre del 99 y enero del 2000) realizó una exposición de pintores que habían reflejado en sus cuadros el tema de los jardines. Titulada Jardines de España, en el catálogo de la misma Carmen Añón dedica un capítulo a la biografía de Winthuysen no aportando nuevos datos de los ya citados en las anteriores obras.

Nosotros, nos centraremos en el aspecto de Winthuysen restaurador de jardines, dejando de lado los aspectos de pintor, historiador, articulista y jardinero de nuevos proyectos al no ser el objetivo de nuestro trabajo.

El primer trabajo relacionado con el mundo de la restauración del jardín le viene a Winthuysen de la mano de su amigo Lozano a principios de siglo. Este había sido compañero en las clases de aprendizaje de pintura en Sevilla junto con Juan Ramón Jiménez, entre otros.

A Lozano le había encargado el Dr. Carvallo que se ocupara de Villandry, castillo del siglo XVI con un jardín que había que restaurar o mejor dicho recrear según los grabados del libro de Du Cerceau, consiguiéndose una de las más her-

(2) Gracias a la desinteresada donación de su hija Salud podemos ver parte de su obra en el Museo Reina Sofía de Madrid.

(3) WINTHUYSEN, Javier de. Jardines Clásicos de España. Edición facsímil. Editorial Doce Calles. Aranjuez, 1990. La primera y única edición es de 1930. Editorial: Compañía Ibero-Americana de Publicaciones. Madrid. 
mosas recreaciones jardineras del pasado siglo (4). Ambos se pusieron manos a la obra diseñando elementos de adorno como jarrones, vasos, pedestales y obeliscos, ejecutando algunos de ellos con técnicas antiguas. Tras una temporada de trabajar juntos, los celos profesionales de Lozano hicieron que Winthuysen abandonara esta faena y su relación con él.

Winthuysen siguió haciendo jardines y pintando y decidió irse a París para ampliar su formación artística. Allí conocería a personajes claves de la cultura del momento que le serían posteriormente de gran utilidad para ser presentado en círculos culturales donde pudo propagar sus ideas y encontrar apoyo para la realización de las mismas. Entre ellos estaba el Marqués de la Vega Inclán, Comisario Regio de Turismo y responsable de la restauración del Patio de Yeso en los Reales Alcazáres de Sevilla donde fueron empleados criterios respetuosos y modernos con los monumentos como señalamos en páginas anteriores. A su vuelta de París conoce la obra del francés Forestier y los trabajos que estaba haciendo en Sevilla de los que se declara ferviente admirador.

En Madrid, donde se traslada a vivir por los años veinte, Juan Ramón Jiménez le introduce en el ambiente de la Institución Libre de Enseñanza, entidad desde la que se habían criticado las restauraciones en estilo y otros atentados cometidos contra en patrimonio en nombre de la restauración.

El poeta onubense y el pintor Sorolla le recomendaron ante la Junta de Ampliación de Estudios para obtener una beca con la que pudiera realizar el inventario de los principales jardines históricos de España. El resultado fue su libro ya anteriormente mencionado Jardines Clásicos de España que no se publicará hasta diez años después pero en el curso de sus investigaciones, cuando se encontraba en la Biblioteca de El Escorial conoce a Jaoquín Ezquerra. Este, al enterarse de la finalidad de sus trabajos, le presenta en el círculo de la Duquesa de Parcent, lugar de encuentro de políticos y aristócratas aficionados a las Bellas Artes. Allí se decide que Winthuysen restaure los jardines del Palacete de la Moncloa, recientemente cedido por el Estado a la Sociedad de Amigos del Arte. 


\section{C.2.3. La restauración del Palacete de la Moncloa.}

Esta actuación, que él incluirá en su libro en un apartado bajo el título "Resurgimiento del jardín clásico español", nos permite ver los criterios con los que afrontó la restauración así como la situación del jardín antes de su intervención y el proyecto nuevo del mismo. Gracias a las fotos realizadas podemos darnos cuenta de los resultados ya que desgraciadamente, el jardín, al estar en la línea del frente durante la Guerra Civil, fue completamente destruido.

El palacio y la zona de huertas que lo rodeaban perteneció a la famosa Duquesa de Alba. A la muerte de ésta, en 1802, el rey Carlos IV adquirió la propiedad. Se supone que fue en la época de Fernando VII cuando fue realizado el jardín con diseño de parterres irregulares y caminos curvos. Posteriormente, en los años de Amadeo de Saboya, se plantaron coníferas como en el resto de las posesiones de la Corona.

Winthuysen se encontró con grandes ejemplares de wellingtonias, cedros y pinsapos que junto a otros árboles, frondosos arbustos y trepadoras lo cubrían todo en un estado de gran abandono.

Lo primero que Winthuysen hizo fue talar "la maleza que cubría el suelo y tapaba los muros, deiando lo esencial: su arquitectura y los grandes árboles".
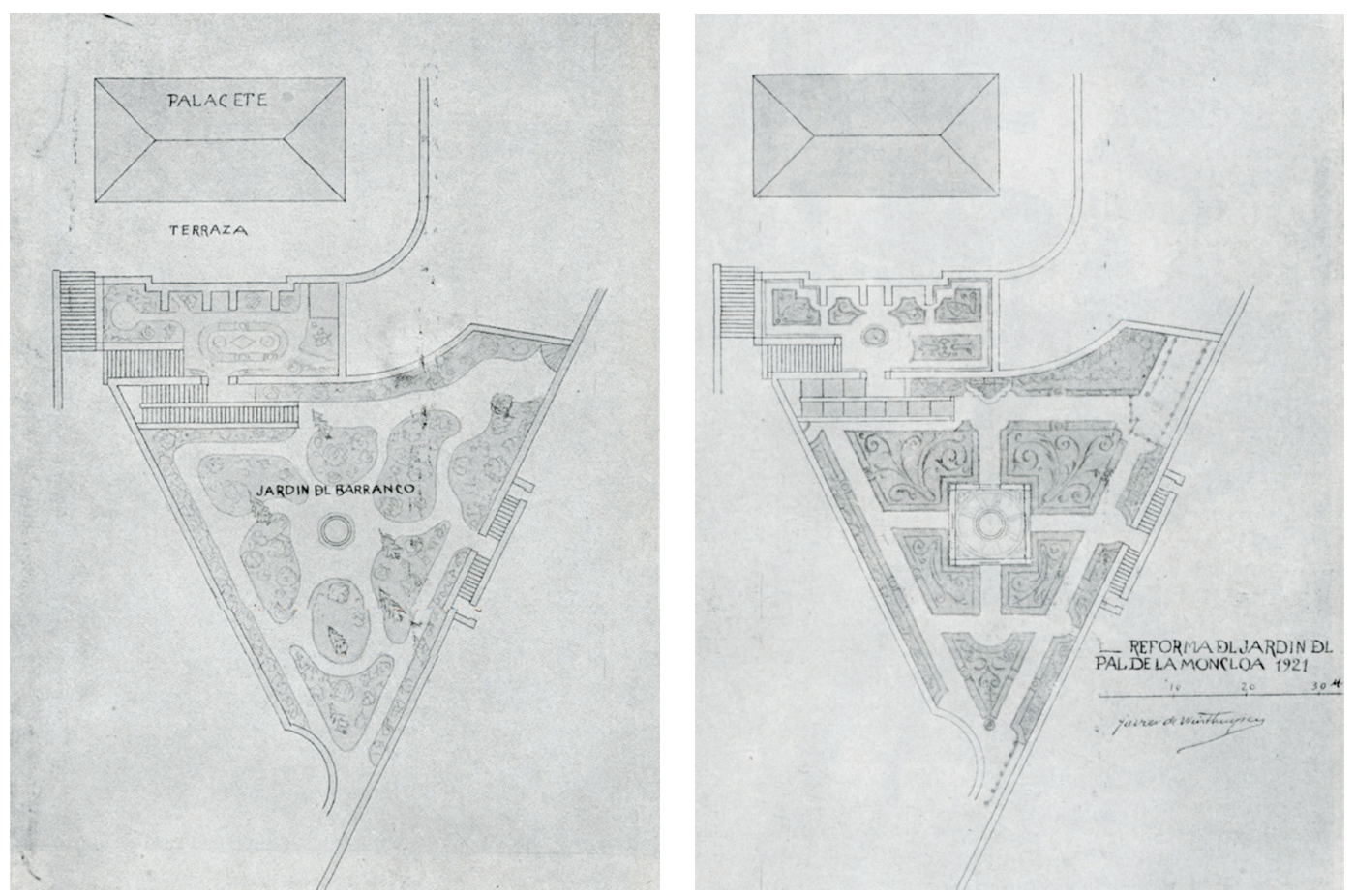

Planos del Jardín de la Moncloa. El de la izquierda es el estado del jardín antes de los trabajos de recreación. El de la derecha refleja el proyecto de Javier de Winthuysen. (Del libro Jardines Clásicos de España) 


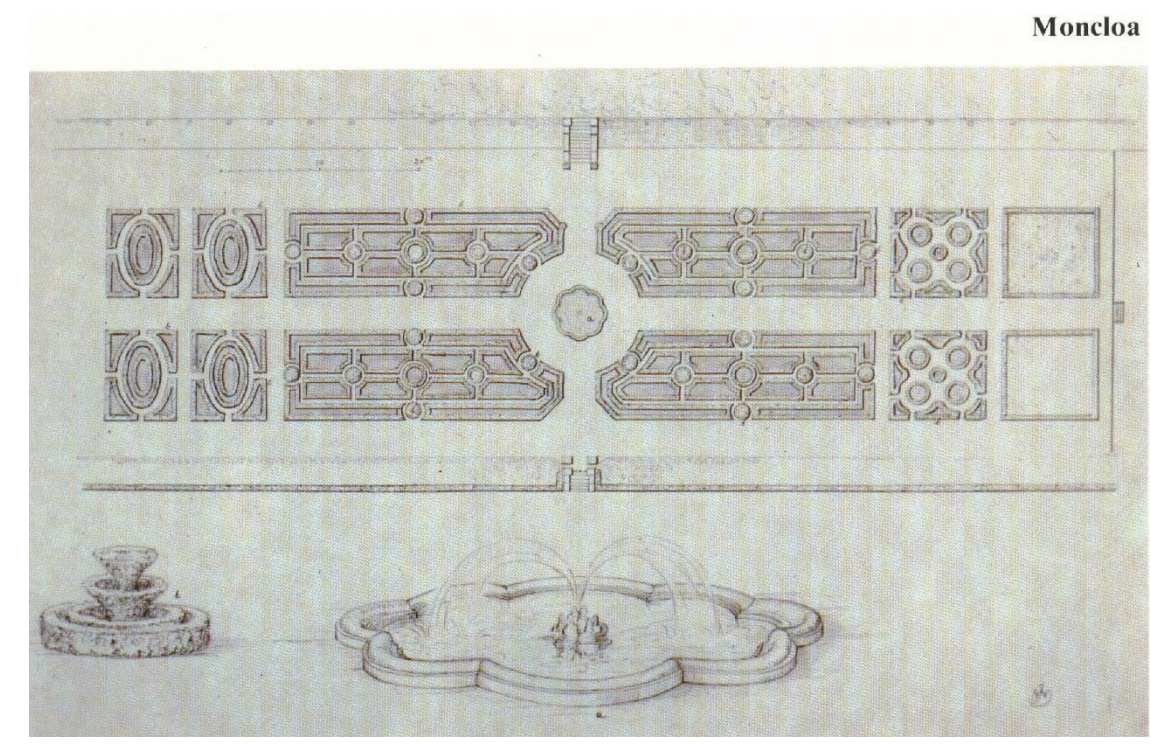

Dibujos de Winthuysen para el jardín del Parterre

En la memoria del proyecto señala que el objetivo de los trabajos no es conseguir un pastiche sino rehacer un jardín según la tradición presente en los grandes jardines de nuestro país para seguir avanzando en esa línea de recuperación de prácticas olvidadas: "Al hacer la reforma del jardín del Barranco no se ha tenido por guía resucitar enteramente lo que por otro lado solamente por conjeturas suponemos." Y posteriormente indica: "Por el contrario, el propósito que nos guía en esta obra es volver al pasado, a un pasado glorioso de buen gusto, y tendiendo un puente sobre la laguna de decadencia que de él nos separa, volver en lo posible a sus bellezas y que éstas nos sirvan de nexo para continuar el camino de la vida".

Para él, la "laguna de decadencia" la constituye el período de aculturación jardinera anglosajona comenzado el siglo XIX y que ha llegado hasta nuestros días.

Tras efectuar la limpieza, aprovecha materiales dispersos por el lugar y construye una fuente. Hace hornacinas para los bustos basadas en las existentes en el Jardín del Rey de Aranjuez, reconstruye las escaleras eliminando las rampas, forra los muros de enverjados con rosales y otras trepadoras y pavimenta con guijarros la glorieta del estanque.

Respecto a la plantación, introduce en el jardín superior parterres de dibujos neoclásicos, mientras que en el inferior, en un rincón donde los árboles existentes no guardaban simetría, introduce parterres de boj con dibujos barrocos.

Y sigue Winthuysen explicando: “Así obligados, se procedió a plantar otros diversos detalles, buscando las soluciones posibles y sin sujetarse a otra norma que a formar una totalidad armónica con el carácter general, cuidando con esmero el aspecto y factura de cada uno de ellos, a fin de que no disonaran de la obra antigua. 

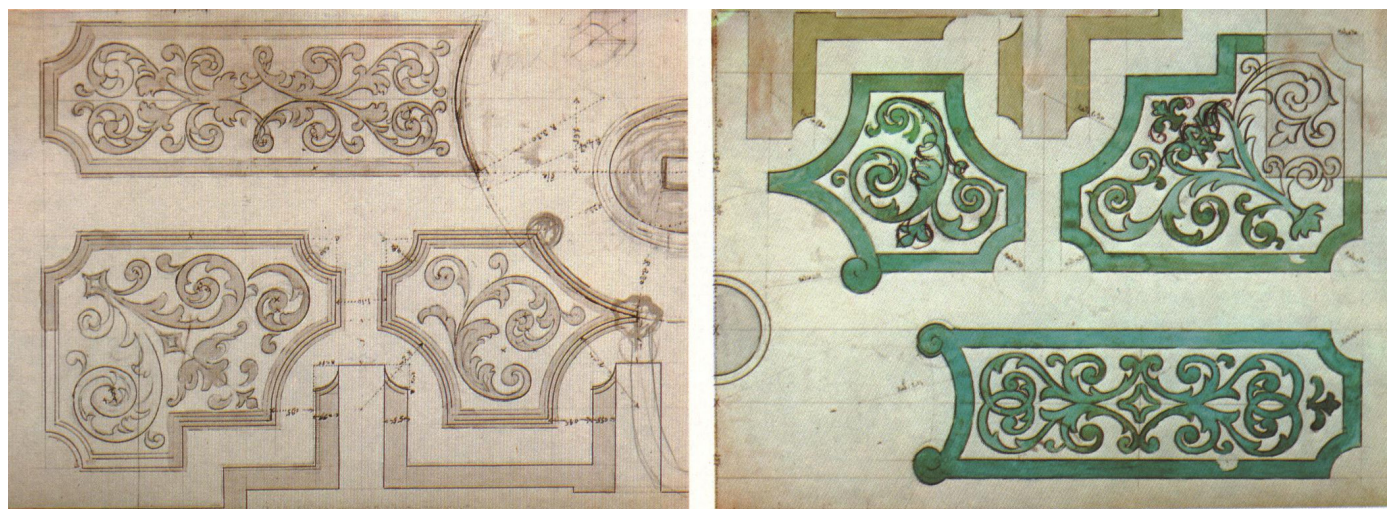

Dibujos de parterres barrocos para el Jardín del Palacete

A poco de estar terminado con su crecimiento y la pátina que pronto adquirió, ha llegado a fundirse, formando un conjunto en que se quedan aliados, desde los viejos muros y obras del XIX hasta lo que se hizo en la actualidad. Por el aspecto que presenta este jardín, sin ser imitación ni copia de ningún otro, sino detalles y soluciones originales, puede figurar entre los clásicos del centro de España como una continuación."

Los criterios seguidos al afrontar la restauración-recreación del Jardín del Barranco en el Palacete de la Moncloa en 1922 los reafirma en 1929 en forma de mensaje de despedida en su libro:

"Hemos querido cerrar el estudio de los Jardines Clásicos de Castilla con este ensayo de resurgimiento, considerando que lo histórico ha de servir de ejemplo y guí, no como traba reaccionaria que ahogue las nuevas importaciones y excluya nuevos horizontes estéticos, sino en lo que la tradición nos muestra como esencia del carácter, poniéndonos de manifiesto lo que es consustancial a él y a la propia naturaleza".

Sus objetivos eran claros: la intervención al recrear o restaurar jardines exigía lograr la conjunción de historia, naturaleza y arte.

Los años veinte son junto con los de divulgación de sus trabajos y pensamiento a través de artículos de periódico y conferencias (famosa fue la del Ateneo en 1922), los de las realizaciones de numerosos proyectos de jardinería de nueva planta para personajes del mundo cultural de la época. Sirvan de ejemplos los realizados para las casas de Salvador de Madariaga y José Ortega y Gasset en Madrid entre otros. 

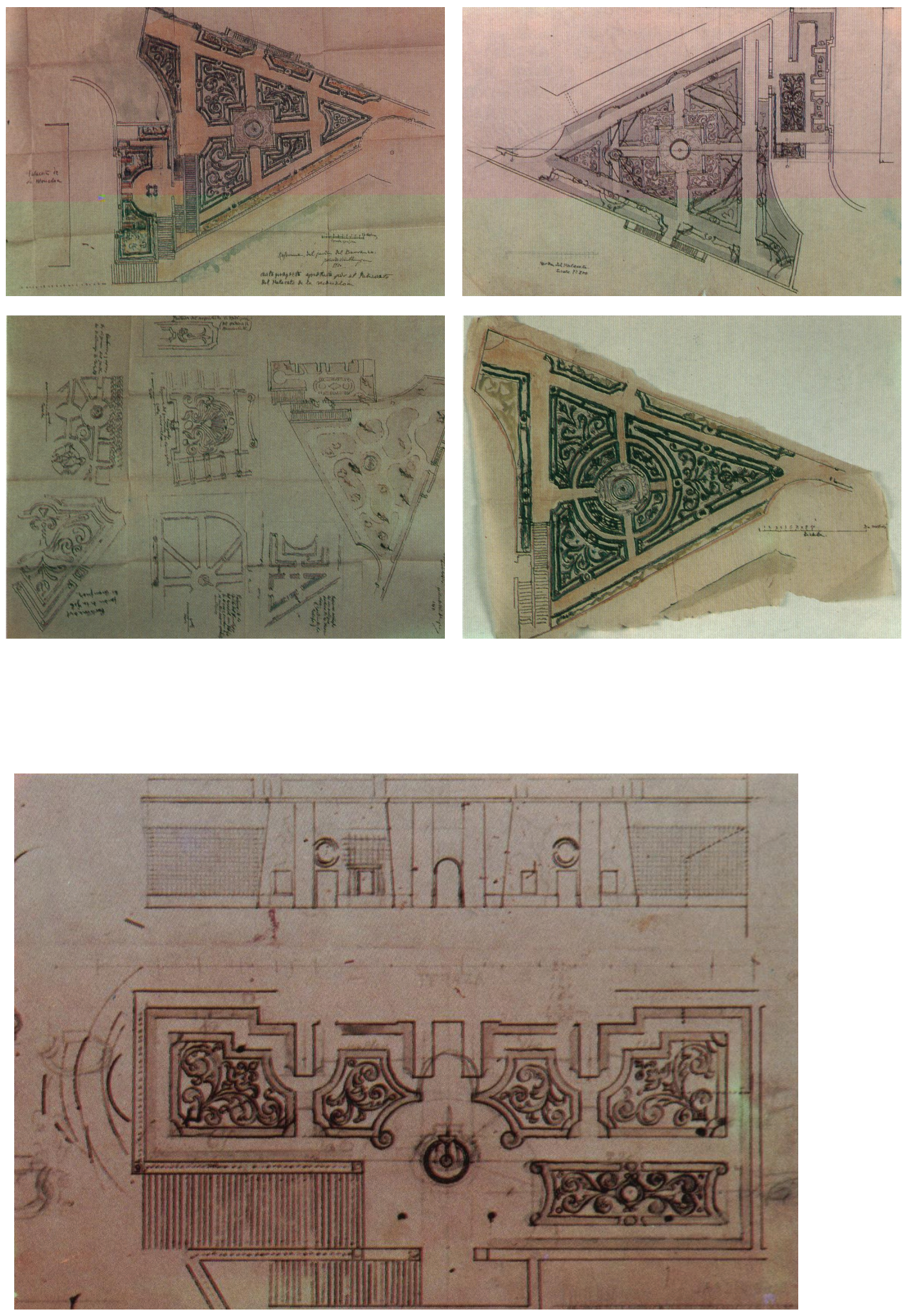

Estudios para el trazado del Jardín del Palacete 


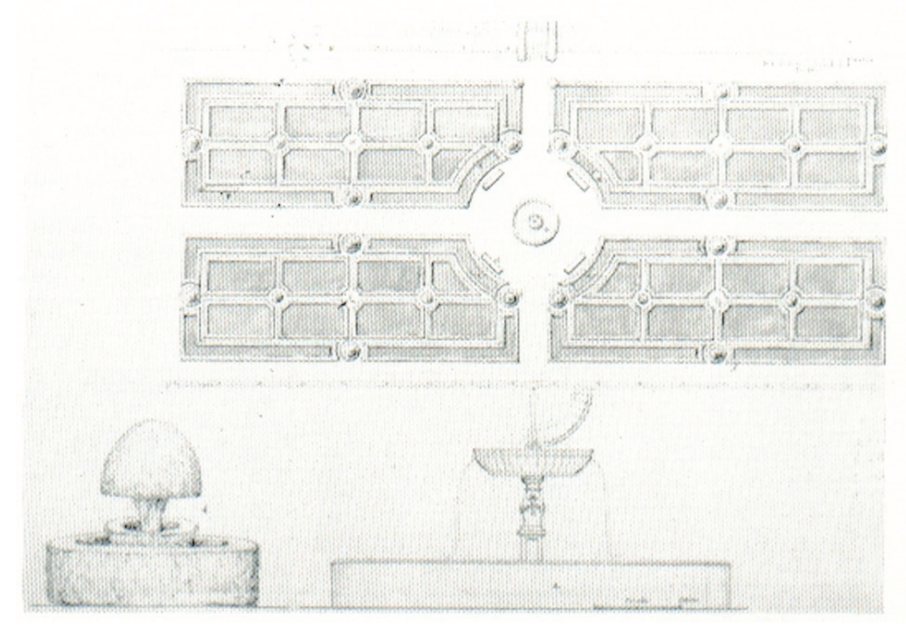

Jardin de la Princesa. Palacete de la Moncloa

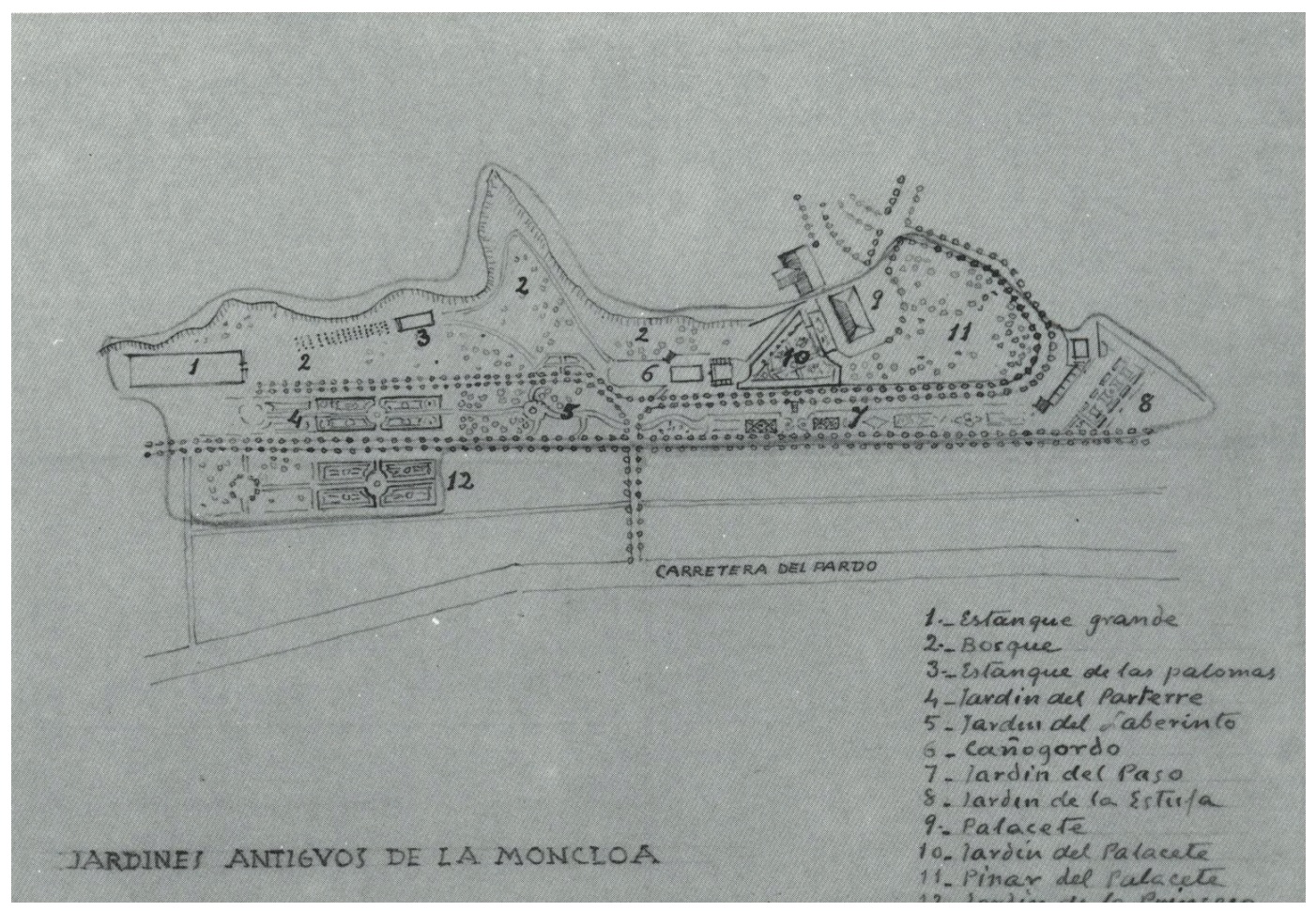

Plano general del Jardín de la Moncloa 


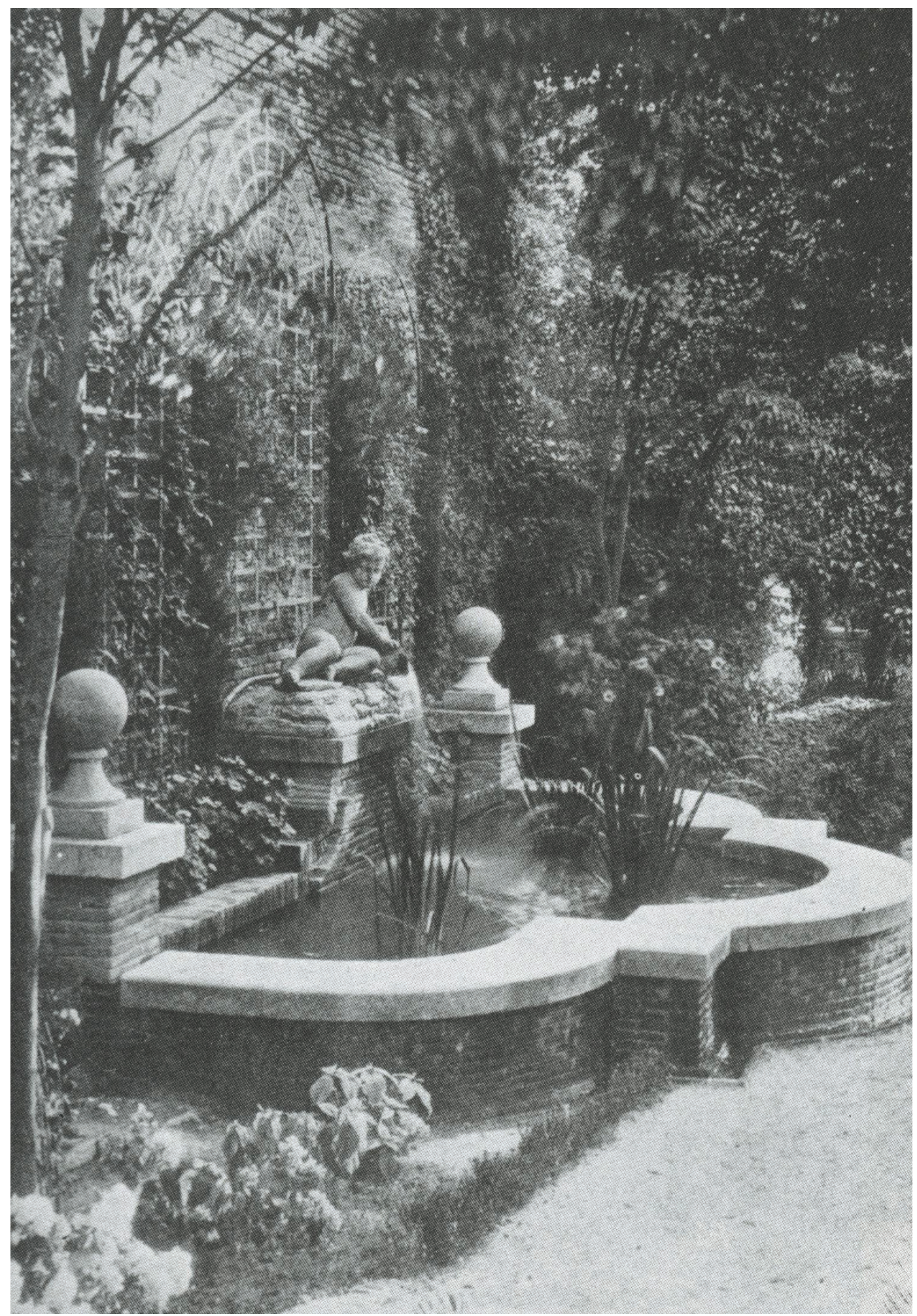

Fuente que construyó Javier deWinthuysen reciclando los diversos elementos repartidos por la superficie del Jardín del Palacete 


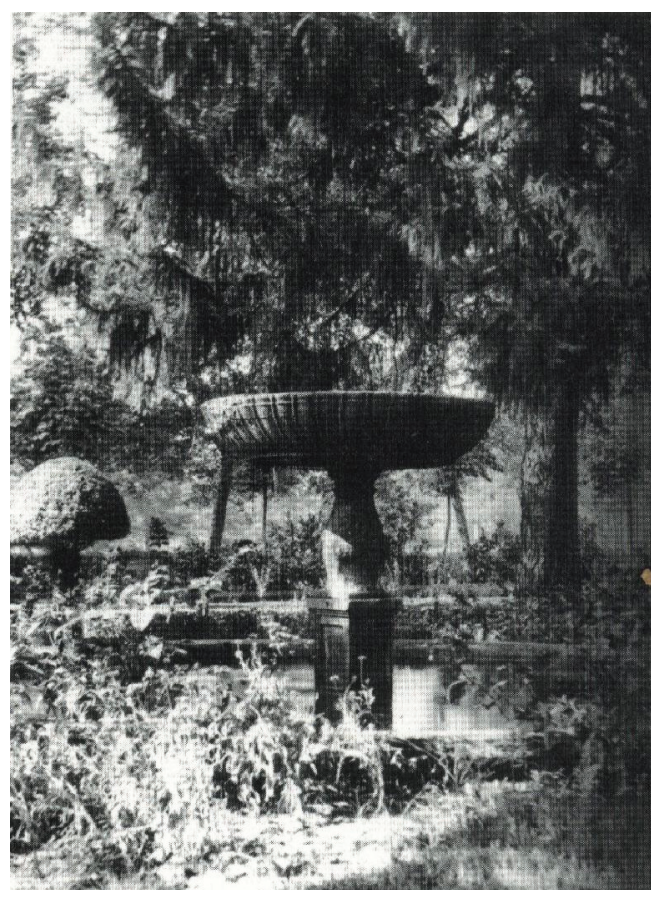

Jardín de la Princesa. Palacete de la Moncloa

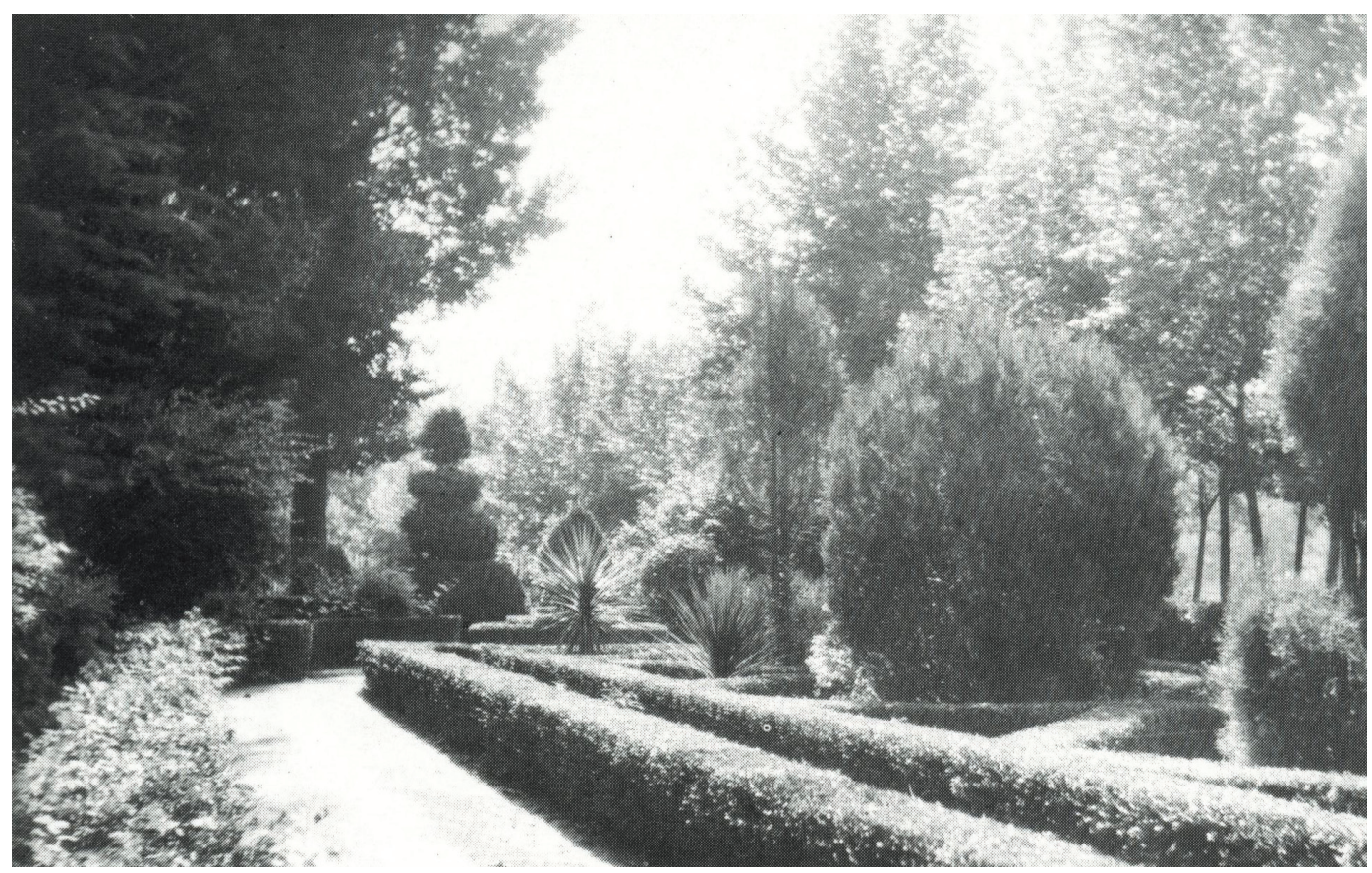

Jardín de la Princesa. Palacete de la Moncloa 


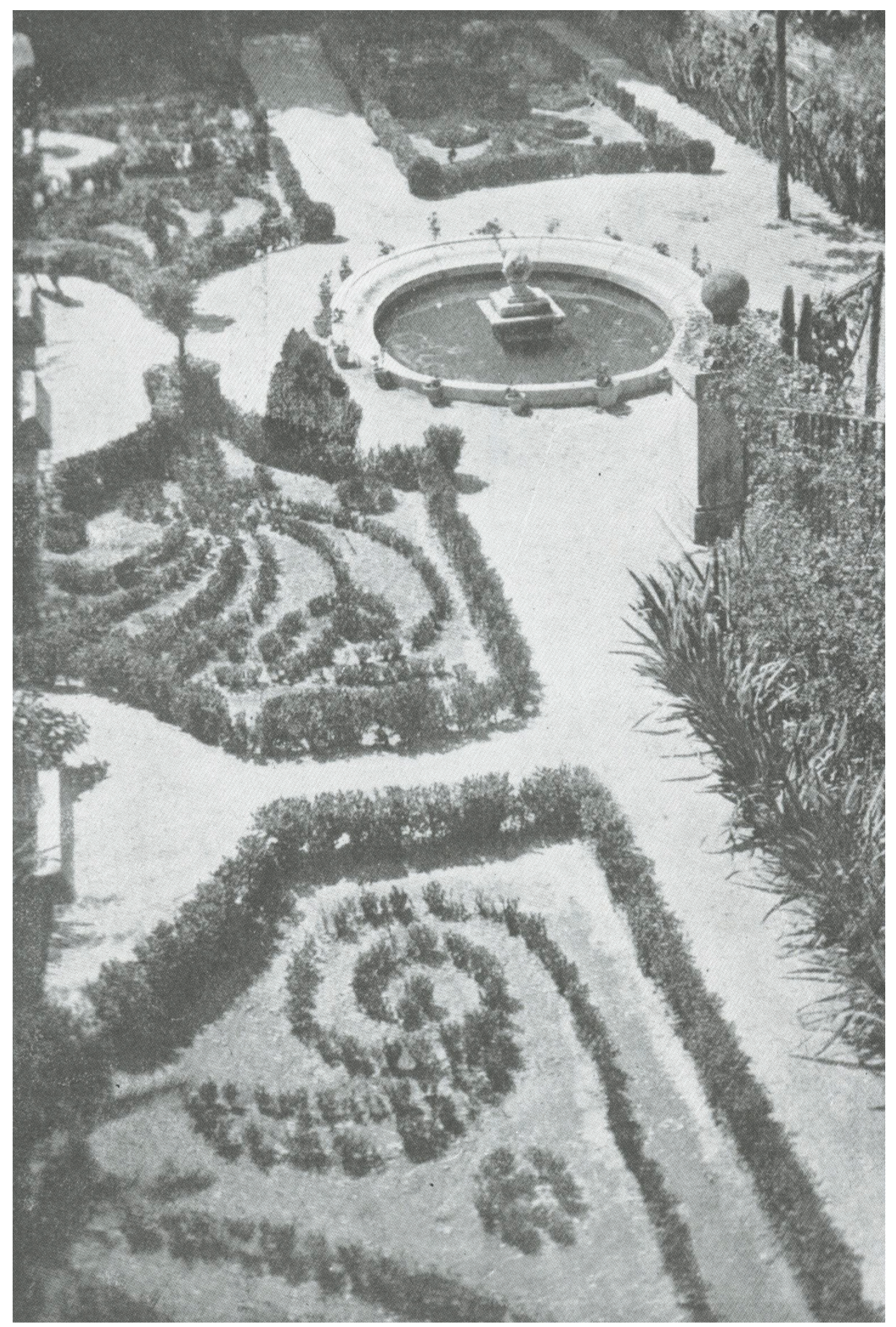

Jardin de la Princesa. Palacete de la Moncloa. (Todas las fotos del jardin proceden del libro Jardines Clásicos de España de Javier de Winthuyen) 


\section{C.2.4. La protección legal del verde histórico: la constitución del Patronato de los Jardines Históricos de España.}

En el año 1934, emanado del espíritu de la Carta de Atenas, se logra dar cuerpo legislativo a la protección del verde histórico de nuestro país a través de la creación de un patronato, siendo Eduardo Chicharro Director General de Bellas Artes. Winthuysen recibe el encargo de la creación del Patronato de Jardines Históricos de España. Y es nombrado Inspector General del mismo. Al principio con sueldo y más tarde éste es suprimido lo cual le dificulta, -aunque no le impide- desarrollar las tareas de protección del verde histórico.

La parte expositiva o memoria del mismo también es suya y precede a su publicación en el número 73 la Gaceta de Madrid. Por el interés que muestra esta exposición como reflejo de sus opiniones sobre la conservación de los jardines, lo reproducimos aquí:

En todas las culturas aparecen los jardines como una de tantas expresiones estéticas. Los países europeos en que existe una tradición de este arte conservan con orgullo sus obras del pasado, que constituyen una de sus principales galas.

Inútil sería encarecer la importancia de los jardines de Italia, Francia, Inglaterra, etcétera, sobre los que existen tal número de publicaciones desde el siglo XVI a la actualidad que sería dificil enumerarlas y enseñanzas especiales que han permitido mantener el concepto de estas obras, conservarlas y continuar este arte.

Otro tanto ocurre en naciones modernas como los Estados Unidos de Norteamérica donde la enseñanza artística de la jardinería tiene gran importancia en las Universidades de Harvard y Syracusa y sus pensionados paisajistas recogen los ejemplos de Europa para sus producciones inspiradas en estas obras clásicas que en todas partes son respetadas y consideradas como monumentos tan importantes como los de otra índole.

Aparte de las consideraciones que van señaladas, concurren en los jardines españoles circunstancias especialísimas que elevan su interés por las Bellas Artes.

España es el único país de Europa que conserva un jardín medieval, en parte tal como fue creado. Desde esta obra hispano-morisca hasta la actualidad, por la sucesión de aportaciones que se han desarrollado, encierra España en el conjunto de sus jardines la historia completa del arte de la jardinería con sus ejemplos hispano-árabe, mudéjar, escurialense, renacimiento, italiano, barroco, clásico francés, neoclásico, romántico y actual resurgimiento neosevillano. Por la particularidad geográfica de España y sus diferentes suelos y climas tenían sus jardines en las distintas regiones matices que vienen a aumentar las riquezas de las modalidades citadas. La modalidad andaluza, fraguada con los diversos estilos durante la historia, ha llegado a constituir el tipo de jardín conocido con el nombre genérico de "Jardín Andaluz" que ha tenido en la modernidad la extensión 
mundial que es sabida, con las obras de Forestier en Sevilla y Barcelona, llevadas también al Protectorado francés de Marruecos y por los paisajistas americanos en las obras de los Estados de California y Florida aprovechando así los extranjeros nuestra tradición, que pudiera ser una expansión para la labor de nuestros artistas, de existir en España una atención para nuestras obras del pasado (únicas) y una enseñanza especial artística de jardinería.

Ninguna de las consideraciones expuestas ha sido bastante para que se haya reconocido hasta ahora toda la importancia de la conservación de estos monumentos. Para nadie es un secreto lo que se ha ido arrancando de los que están reducidos a ruinas aún muy apreciables y el desvirtuamiento que siguen sugiriendo muchos de ellos por abandono, incuria o por reforma improcedente.

Considerando la importancia estética e histórica de estas obras la no menor para el interés social y la trascendencia que para el arte moderno de ellas se derivan, estando todo por hacer en este orden y creyendo de conveniencia nacional el desarrollo de una política de nuestra jardinería, sería necesario proceder a la catalogación de los jardines para fijar la existencia, declarando monumento de interés artístico estas obras, que por sus cualidades especiales de vitalidad y continuado desarrollo no pueden ser consideradas como de otra clase de obras inertes y que necesitan un régimen especial e idóneo para su conservación e inspeccionadas por la Dirección General de Bellas Artes, en armonía con lo que establece el artículo tercero de la Ley de 13 de marzo de 1933.

Por las razones expuestas, a propuesta del Ministro de Instrucción Pública y Bellas Artes y de acuerdo con el Consejo de Ministros,

Vengo a decretar lo siguiente:

Artículo $1 .^{\circ}$ Se crea un Patronato encargado de la conservación y protección de los jardines de España.

Artículo $2{ }^{\circ}$ Corresponde a dicho Patronato no sólo velar por la integridad de los jardines que se declaren de interés artístico, sino proponer e informar sobre los que han de ser objeto de tal declaración y promover y encauzar toda clase de iniciativas que redunden a favor de los monumentos de esta naturaleza.

Artículo 3. ${ }^{\circ}$ El Patronato estará constituido: por un Presidente, que lo será Director general de Bellas Artes; dos Vicepresidentes, uno el Director General de Propiedades y el otro el Presidente del Patronato Nacional de Turismos; seis Vocales, nombrados por el Ministro a propuesta del Director General de Bellas Artes, y un secretario, que lo será el Jefe de la Sección del Tesoro Artístico.

Artículo $4 .^{\circ}$ El Patronato administrará directamente los recursos que se logren, subvenciones, donativos, legados, billetes de entrada, productos de venta de publicaciones, etc. El Presidente ordenará los pagos.

Artículo 5. ${ }^{\circ}$ Por el Ministro de Instrucción Pública y Bellas Artes se dictarán las órdenes oportunas para la ejecución y desarrollo del presente Decreto. 
Dado en Madrid a trece de marzo de mil novecientos treinta y cuatro. Niceto Alcalá-Zamora y Torres. El Ministro de Instrucción Pública y Bellas Artes, Salvador de Madariaga Rojo.

Gaceta de Madrid.-Núm. 73

Los años anteriores a la Guerra Civil son a la par que nuevos proyectos de ajardinamientos para clientes privados los de la recreación de jardines en los Paradores Nacionales de Turismo (Ciudad Rodrigo, Medinaceli, patios de la Santa Cruz y Santa María la Blanca en Toledo), realizando algunos y otros quedándose en proyectos.

Tras la Guerra Civil, el Marqués de Lozoya reorganiza el Patronato de Jardines Artísticos. Winthuysen es nombrado Inspector General y Vocal del mismo, labor de la que se ocupó hasta su muerte en 1956 realizando desde ese puesto las restauraciones del Jardín de Monforte en Valencia y el del Capricho o Alameda de Osuna en Madrid. Estas intervenciones son las que veremos en el capítulo siguiente. 


\section{C.3. La Guerra Civil (1936-1939) y la dictadura franquista. Consecuencias sobre los criterios de restauración.}

El triunfo de la dictadura franquista sobre la II República significó el rechazo total de las posturas conservacionistas. Los seguidores de esta corriente se vieron forzados unos al exilio y otros al silencio y a la marginación tras las limpiezas ideológicas conocidas como "depuración de responsabilidades" de los primeros años cuarenta. Sirva de ejemplo lo sucedido en la restauración de la Catedral de Sigüenza, empezada por Torres Balbás en 1937 y continuada por Antonio Labrada en 1941 debido a un cambio de criterios completamente opuestos a los mantenidos por el primer arquitecto (5).

Esa fue la causa por la cual, la creación de la Dirección General de Arquitectura y Regiones Devastadas, hizo que la competencia sobre restauración del patrimonio saliera del ámbito de actuación de la Dirección General de Bellas Artes.

Esto explica que durante los primeros años de la dictadura el ímpetu restaurador se pusiera en la reconstrucción de aquellos monumentos dotados de un fuerte carácter simbólico para los vencedores de la contienda tales como el Alcázar de Toledo o el Monasterio de Nuestra Señora de la Cabeza en Andújar, casi completamente destruidos en el período bélico.

A la par y hasta casi hasta hoy mismo, la otra gran beneficiada de los esfuerzos restauradores será la Iglesia Católica. Si consultamos la obra aparecida hace unos años sobre el inventario de edificios restaurados en España entre 1920 y 1981 (6) podremos apreciar que la inmensa mayoría de las obras realizadas son en edificios pertenecientes al patrimonio eclesiástico, estando en franca minoría los edificios de carácter civil y propiedad pública del período del que estamos tratando.

En lo que respecta a la restauración en jardinería, debemos decir que el abandono a que se vieron sometidos los grandes jardines históricos les benefició pues por lo menos conservaron sus principales características formales y materiales no sucumbiendo como en numerosos lugares de Europa al imparable influjo de la jardinería anglosajona, hecho en el que tuvo mucho que ver además del ambiente político de carácter conservador de esas décadas la reorganización tras la Guerra Civil del antiguo Patronato de Jardines Históricos por el Marqués de Lozoya el cual encomendó a Winthuysen el cuidado de los mismos nombrándole Inspector General y Vocal de esa entidad.

Desde el Patronato se van a realizar las restauraciones de la Alameda de Osuna en Madrid y del Jardín de Monforte en Valencia -ambos jardines de propiedad privada entonces- como veremos a continuación. Por otro lado, los grandes jardi-

(5) MUÑOZ COSME, Alfonso. «La llegada de la modernidad: Torres Balbás y la "Escuela Conservadora"» en Historia de la restauración en España, 1900-1936.

(6) Fuentes Documentales para el Estudio de la Restauración de Monumentos en España. Ministerio de Cultura. Madrid, 1989. Prólogo de Alfonso Muñoz Cosme e introducción de Soledad Gómez de Olmedo. 
nes del Patrimonio Nacional, como ya señalábamos anteriormente, al verse en gran parte olvidados hasta la década de los ochenta, se conservarán bastante bien al persistir en ellos las maneras tradicionales de mantenimiento: riegos a manta, podas selectivas y escardas manuales, producción propia de flores de temporada, replantaciones con ejemplares de la tradición jardinera local, etc. Con la excepción de que algunos de sus entornos se verán afectados por la expansión y especulación inmobiliarias tan frecuentes en todos los tiempos.

La actividad restauradora en el ámbito de la jardinería, fuera de los grandes jardines históricos, hay que decir que fue insignificante. Volviendo de nuevo a la publicación anteriormente mencionada donde se recogen las obras del período 1920-1981 y centrándonos en lo sucedido entre 1939 y 1975 tenemos que señalar lo siguiente: de un total de 8.524 intervenciones en el patrimonio sólo habrá 3 de restauración de jardines aunque suman 62 las obras de nuevos ajardinamientos alrededor de los monumentos reparados. Y en el período de 1981-1985 serán 3 las obras de restauración dentro de un total de 236 intervenciones (7).

Las dos obras más importantes de restauración realizadas en el inmediato período posterior a la Guerra Civil son las del Jardín de Monforte en Valencia y la Alameda de Osuna en Madrid, las cuales no están recogidas en el inventario anteriormente citado. 


\section{3. 1. Las restauraciones de Javier de Winthuysen en Madrid y Valencia. El Jardín de Monforte (Valencia).}

Como ya señalábamos anteriormente, nada más constituirse el nuevo Patronato de Jardines Históricos en el año 1941, Javier de Winthuysen recibe el encargo de elaborar una memoria sobre la situación del jardín y los trabajos necesarios para su conservación tras su declaración como Monumento Histórico Artístico Nacional por decreto en el BOE de 9 de junio de 1941, decreto que es parcialmente recogido por Sarthou Carreres en su obra sobre los jardines valencianos (8).

Hay que señalar que unos años antes, en 1937, siendo Director General de Bellas Artes Josep Renau, éste le encargó a Winthuysen un informe sobre el estado del jardín y un proyecto de restauración que llevó a cabo Román Peris, jardinero municipal y vinculado a Monforte desde principios de siglo según señala J. Pérez Rojas en el Catálogo de Monumentos y Conjuntos de la Comunidad Valenciana (9). De esta intervención no sabemos muy bien lo que se llegó a realizar por faltarnos documentación. Sin embargo, de la intervención de 1941 -la encargada por el Patronato- poseemos abundante información gráfica y documental.

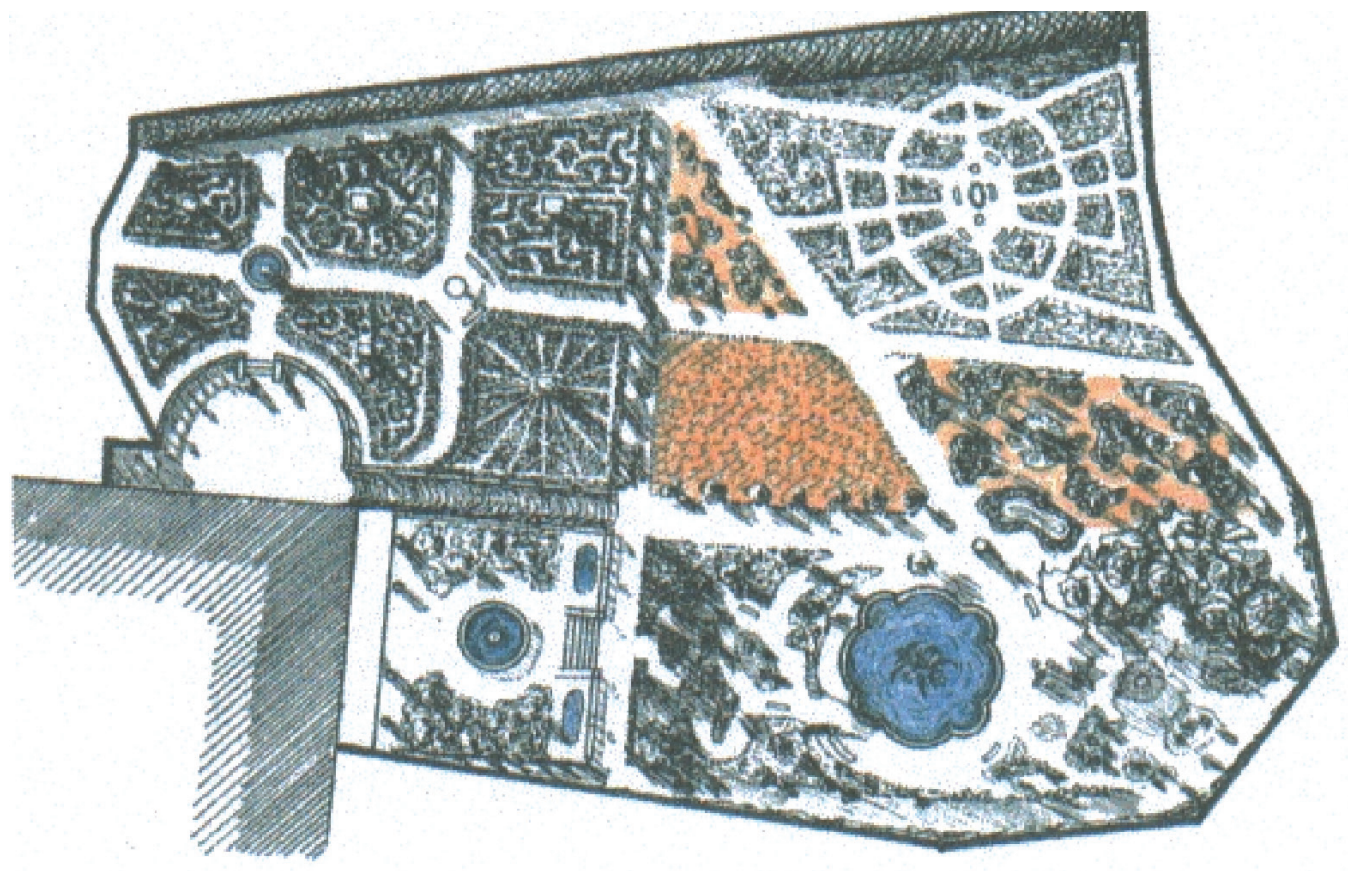

Plano del Jardín de Monforte realizado por Carrascosa Criado, 1932. La zona coloreada en naranja es a la que Winthuysen dedicó mayor esfuerzo.

(8) SARTHOU CARRERES, Carlos. Jardines de España: Valencia. 1948.

(9) V.AA. Catálogo de Monumentos y Conjuntos de la Comunidad Valenciana. Tomos I y II. Consellería de Educación y Ciencia de la Generalitat Valenciana. Valencia, 1983. 
Gracias al plano de Carrascosa Criado (10) de 1932 y al que realizó el propio Winthuysen en 1942 recogido por Santamaría en su monografía sobre el jardín (11) podemos apreciar las intervenciones acaecidas en el trazado -el aspecto según la teoría brandiana- del mismo.

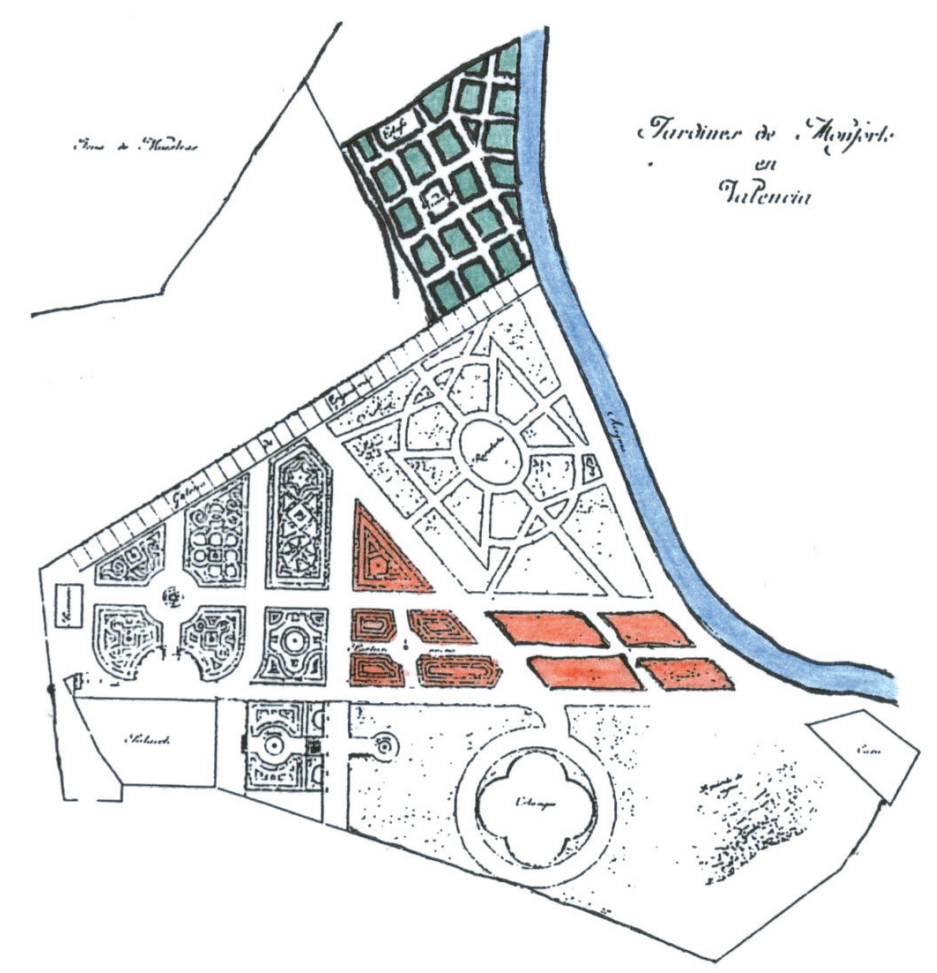

Plano reproducido del libro de Santamaría.

En el plano de 1942 reproducido en esta página, anterior a la intervención de Winthuysen, podemos apreciar la parte de huerta (cuadros coloreados en verde) que fue eliminada del jardín en años posteriores, perdiéndose una de las unidades compositivas características del jardín valenciano. El plano recoge menos detalles que el de Carrascosa en el jardín y algunas de sus partes plantean dudas sobre la autenticidad del plano respecto al jardín real tales como los cuadros coloreados en rojo. La acequia de Mestalla (en azul) aún se ve al descubierto.

(10) CARRASCOSA CRIADO, Josep. Elementos para el estudio histórico de la Jardinería Valenciana. Valencia, 1932.

(11) SANTAMARIA, María Teresa. El Jardín de Monforte. Generalitat Valenciana y Ayuntamiento de Valencia. Valencia, 1993. 


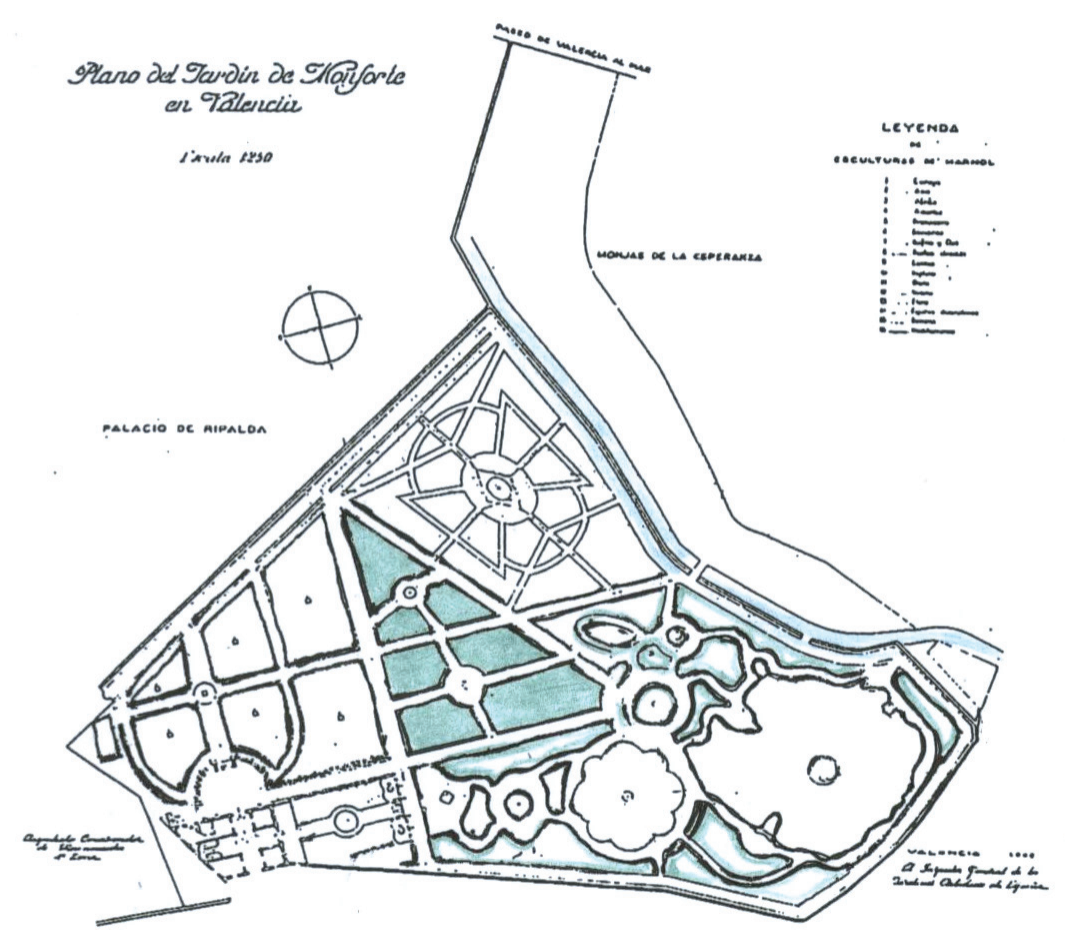

Plano del jardín realizado por Javier de Winthuysen.

En el plano de Winthuysen de 1942 apreciamos la fuerte intervención en dos de los cuadros los cuales rehizo completamente (coloreados en verde). Del mismo modo en la parte del bosque reconstruyó los caminos ondulantes.

Respecto a la materia vegetal o estructura -siguiendo la terminología brandiana- en el Archivo del Real Jardín Botánico de Madrid existe la relación de plantas compradas para este jardín con lo que podemos apreciar los resultados de la intervención así como las pérdidas habidas y el deterioro ocurrido sin que se haya vuelto a intervenir con los criterios de Winthuysen en las posteriores obras.

En la obra de Santamaría y en los catálogos de las exposiciones de Madrid, Roma y Andalucía están recogidas las listas de las plantas utilizadas (12) pero no pueden servirnos como ejemplo a seguir para posteriores restauraciones en su totalidad ya que la elección de algunas especies tales como el árbol del cielo (Ailanthus altissima) o el abedul (Betula verrucosa) se deben o bien al desconocimiento de Winthuysen sobre la climatología y suelos de Valencia o a la falta de variedad donde elegir por la escasez de la posguerra.

(12) Catálogo de la Exposición: Javier de Winthuysen Jardinero. Real Jardín Botánico de Madrid. C.S.I.C. Madrid, 1986. Posteriormente, en 1989, la exposición viajó a Andalucía. Para ello el catálogo fue rehecho ampliando los aspectos andaluces de su obra: Javier de Winthuysen Jardinero. Andalucía. Consejería de Obras Públicas y Transportes de la Junta de Andalucía. Sevilla-Córdoba 1989-1900. En este catálogo, uno de los capítulos de Inmaculada Porras Castillo titulado «Las plantas en los jardines de Winthuysen» expone las especies usadas y los jardines en los que aquellas se emplearon. 
Hoy de lo plantado por Winthuysen permanecen muchos ejemplares. Algunos han alcanzado un desarrollo óptimo creando rincones de gran belleza y valor. Tal vez el más logrado sea el de la plazoleta rodeada de naranjos y mirtos.

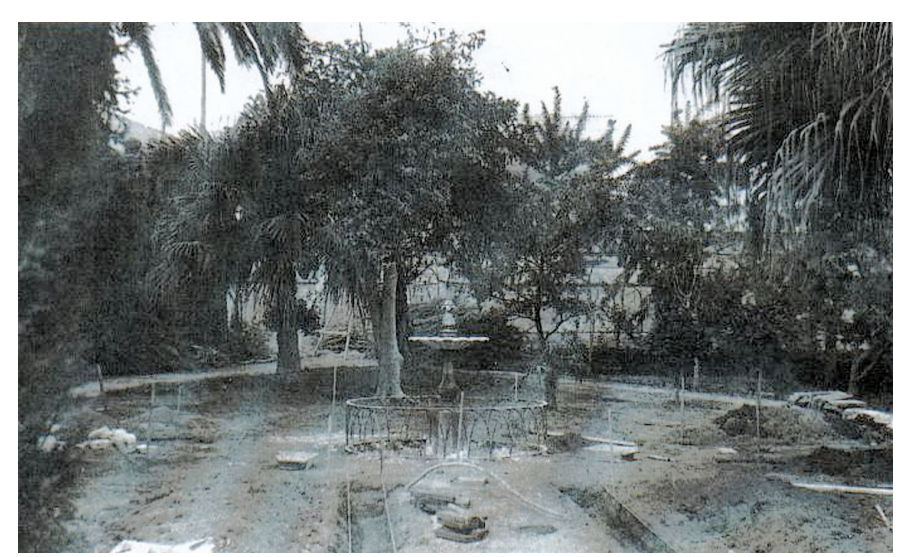

Monforte. La plazoleta de la fuente durante las obras de recuperación por los años 1940. (La foto procede del catálogo de la exposición: Javier de Winthuysen, jardinero)

Otras han desaparecido como los chopos del fondo. La pérdida más lamentable la constituyen los rosales que cubrían la pérgola hoy sustituidos por buganvileas.
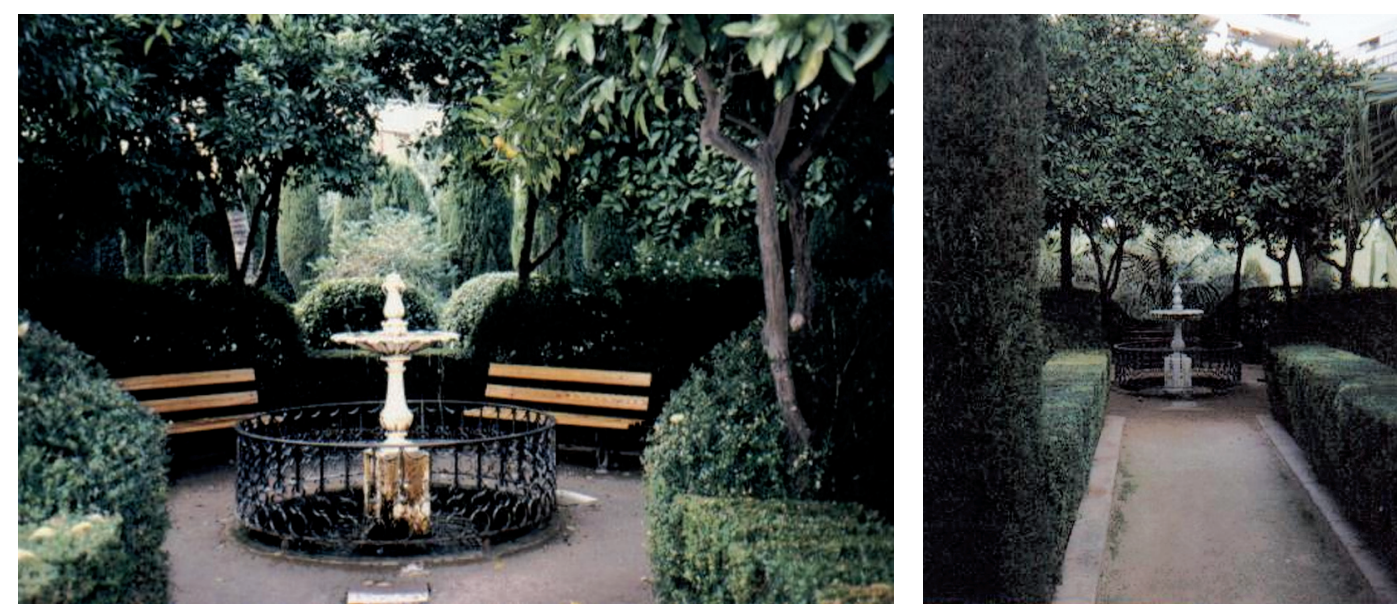

Estas imágenes muestran la misma fuente más de medio siglo después, en el 2000. (Fotos del autor)

Igualmente es de lamentar la sustitución de los originales setos de boj por evónimos tras la riada de 1957 aunque recientemente se han ido plantando arrayanes para cumplir esta función tras pasar el jardín a ser cuidado por la Fundación Municipal de Parques y Jardines Singulares.

En los catálogos de las exposiciones mencionadas, se señala que la intervención se centró en las siguientes partes del jardín: Galería de Trepadoras (plantación, mobiliario y estatuaria); Parterre Viejo (limpieza, desbroce y restauración del 


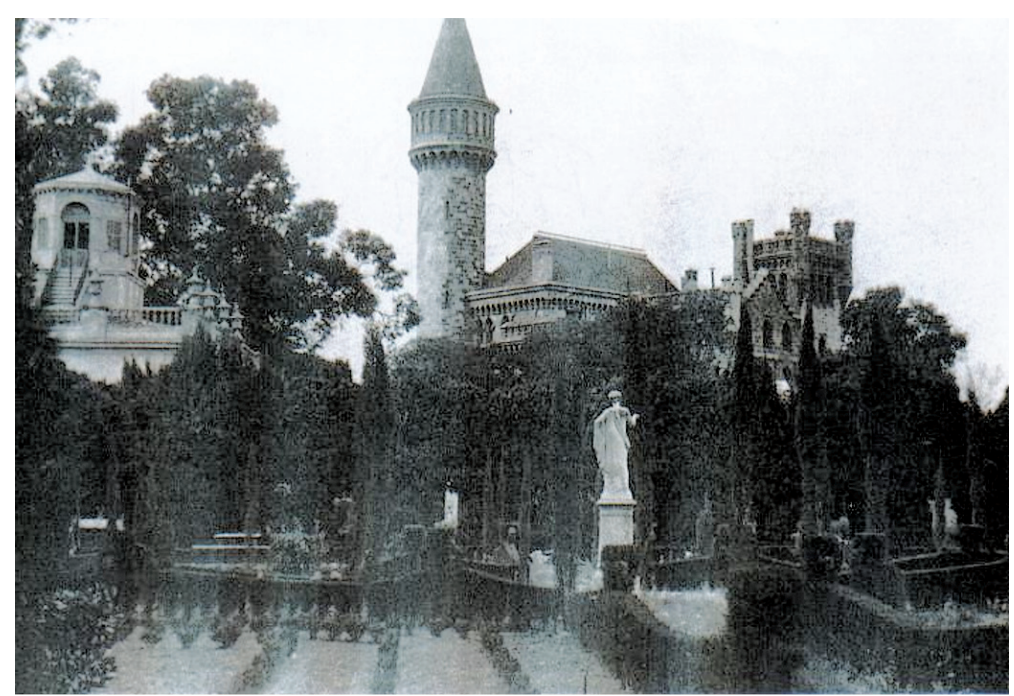

La Plaza de los juegos de agua durante la intervención de Winthuysen. (Foto del catálogo de la exposición anteriormente mencionada)

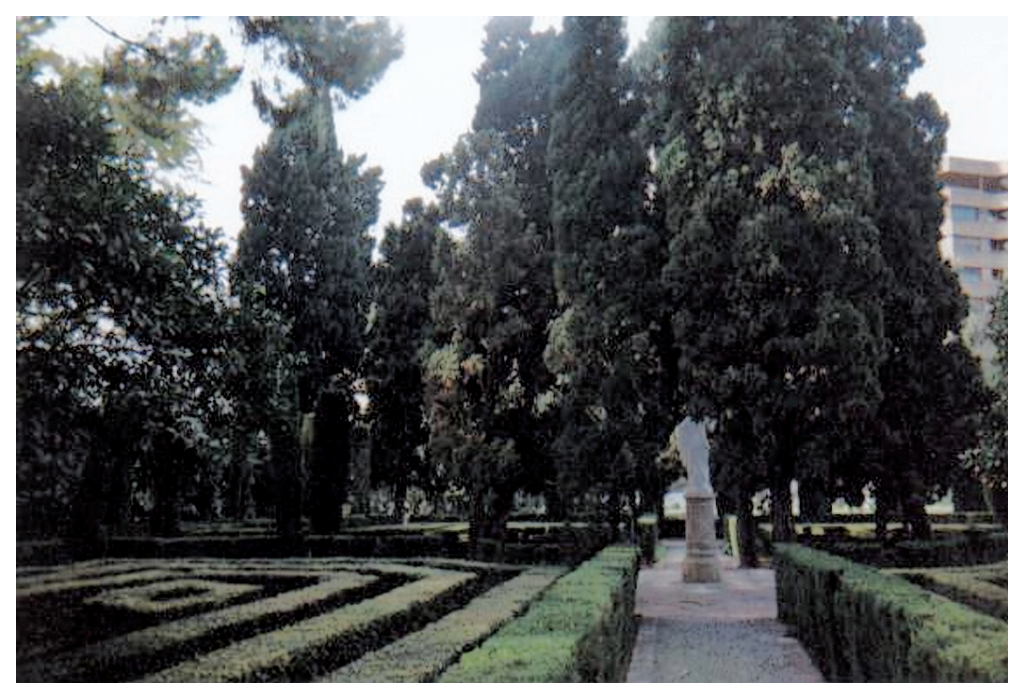

Monforte. La Plaza de los juegos de agua en el 2001. (Foto del autor)

estanque); Atrio o Patio de los Leones (plantación y limpieza); Parterre Nuevo (pavimentación y plantación); Rosaleda (poda y plantación); Patio de los Surtidores (fontanería); Bosque (plantación, albañilería y saneamiento). Además se realizaron otras obras puntuales siendo Alejandro Ferrant el responsable de las intervenciones arquitectónicas.

Los criterios que empleó están señalados en su informe. Tras relatar el estado de abandono del jardín y enumerar las obras necesarias, señala que éstas deben de realizarse siguiendo el criterio de "conservar el poético efecto que en general el jardín presenta, impidiendo al par que se acentúe su ruina y escondiendo en lo posible la mano para que las obras que se realicen no desdigan de las antiguas".

En esta misma línea van unas afirmaciones suyas hechas unos años antes, en plena Guerra Civil que todavía definen más certeramente su pensamiento sobre la 
restauración: “Los jardines históricos de España deben ser más para conservarlos como oro en paño que para ensayar reformas; y las restauraciones sólo son admisibles para reconstituir fielmente lo perdido. Además, sería imposible depurarlos, ya que cada generación ha ido dejando algo en ellos. Así es, que lo más acertado sería respetarlos tal y como han llegado hasta nosotros si son bellos. Y este resultado estético (privativo del jardín) hay que respetarlo sin enmendarlo ni querer competir con él vanamente. Al contrario: escondiendo nuestra mano para que estos jardines aparezcan bellos por sí mismos."(13)

Estas palabras las volveremos a recordar cuando veamos más adelante las intervenciones hechas en el jardín en las décadas de los 70 y 80 tras el cambio de propiedad y pasar el Jardín al Ayuntamiento y realizar esta institución algunas obras un tanto extrañas y sorprendentes.

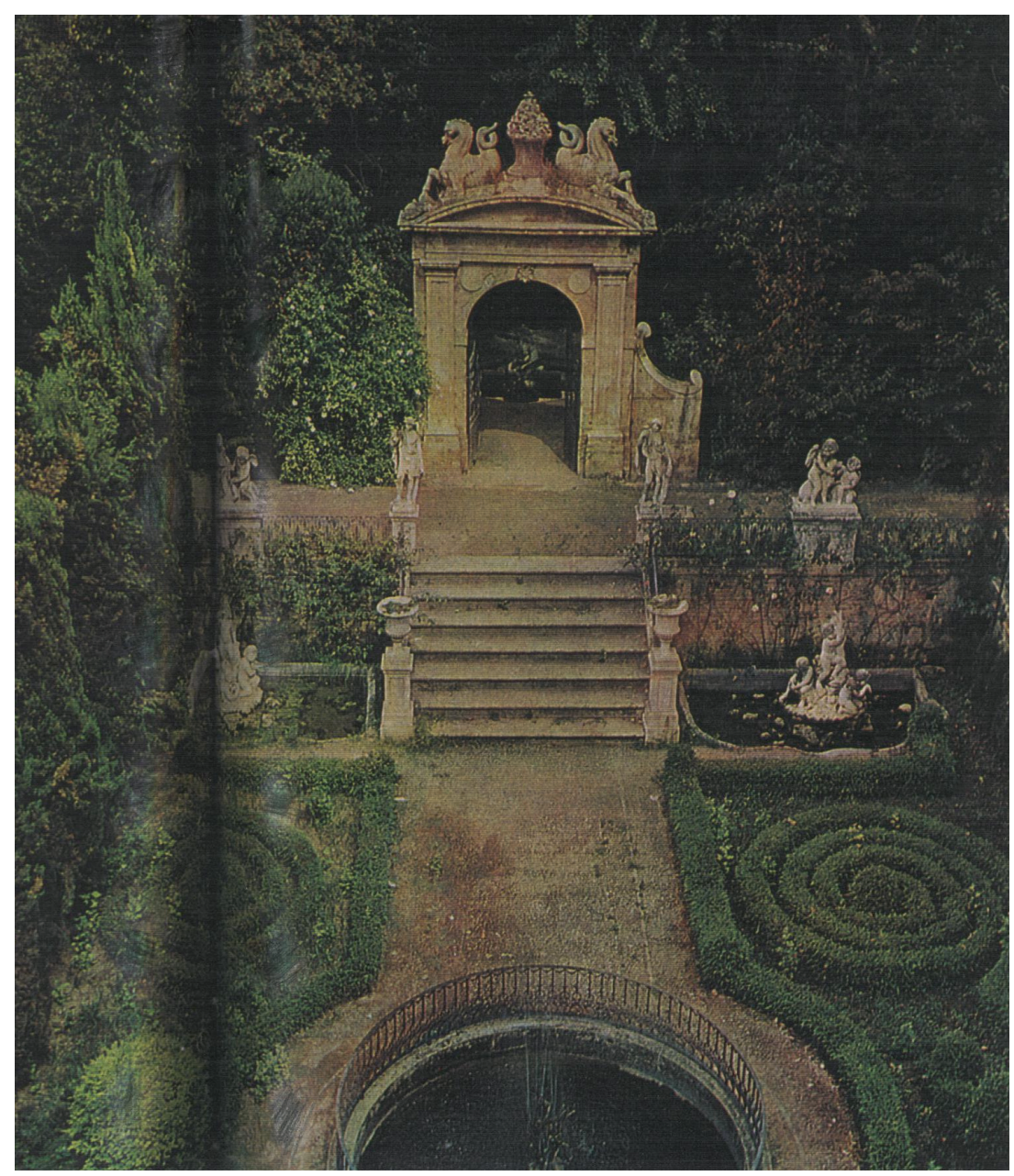

Jardin de Monforte en los años 60. Reportaje del "ABC"

(13) SANTAMARIA, María Teresa. Obra citada. 


\section{La Alameda de Osuna o "El Capricho"}

Comenzaremos a ver la intervención de Winthuysen tras un breve resumen histórico del jardín.

Este lugar tiene su origen en la adquisición de unos terrenos por los Duques de Osuna en 1783 que se dividirán en dos zonas. Una de explotación agrícola según los criterios fisiocráticos tan caros a la Ilustración (de la que la Duquesa fue una de las grandes figuras en España) y la otra parte se dedica a jardín.

Encargó la Duquesa al francés Jean Baptiste Mulot el diseño del mismo quien tenía como referencia profesional su trabajo en el Petit Trianon de Versalles para la reina María Antonieta. Lo continuará Pierre Prevost quien incluso cuidará el jardín durante la invasión francesa.

El jardín tiene tres partes claramente diferenciadas: un eje de entrada al palacio, de estructura formal bordeada con parterres; un jardín en la zona baja del Palacete de carácter íntimo y recoleto que recoge la tradición del "giardino secretto" italiano o si se prefiere la más honda tradición andalusí y finalmente la zona de traza paisajista con sus construcciones varias que son las que le dan gran valor a este espacio y lo convierten en el mejor jardín de su clase en España. Denominado como "jardín inglés", su superficie es la de mayor extensión de la propiedad.

Los elementos constructivos presentes en él corresponden a tres períodos: el primero es el de la recién adquirida posesión (Casa de la Vieja, Templo de Baco, Abejero, Columna de Saturno, Estanque de las Tencas y Embarcadero); el segundo es el que sigue a la Guerra de Independencia (Casino de Baile y Ría) y el tercero, tras la muerte de la Duquesa en el año 1834, recoge las intervenciones de tipo romántico de su nieto D. Pedro de Alcántara y Tellez-Girón (isla con monumento

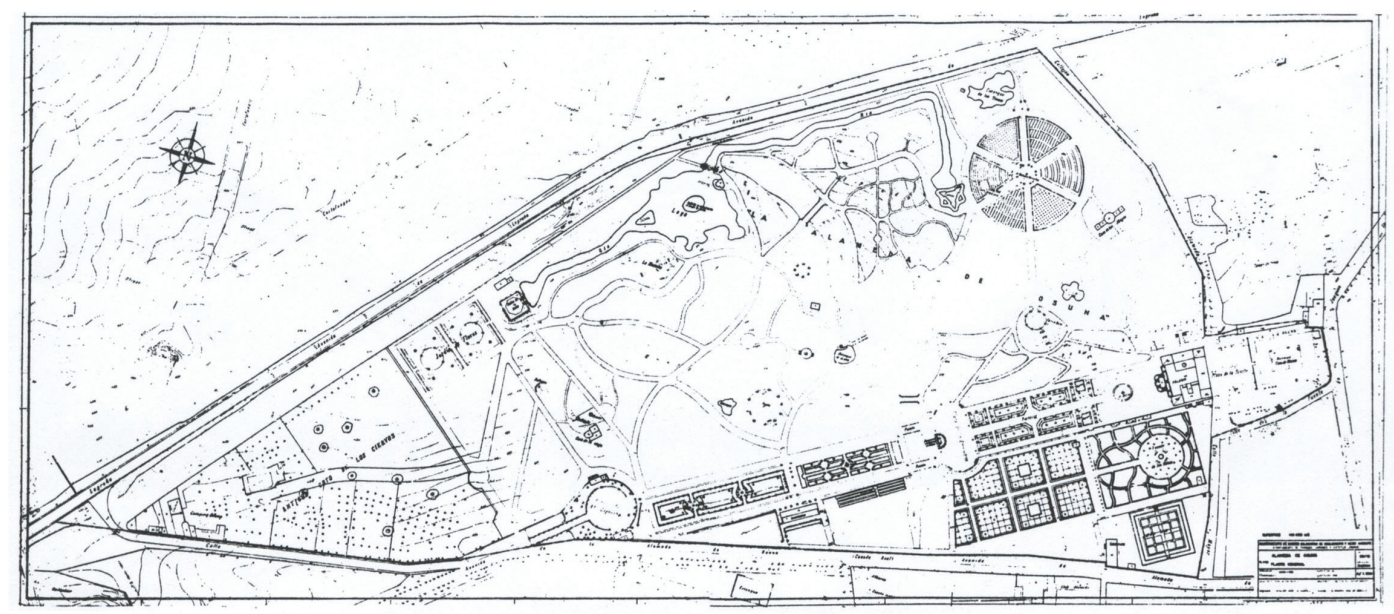

Plano de La Alameda. Catálogo de la exposición: "Jardines Clásicos Madrileños”. Madrid. Museo Municipal. 1981 
funerario al III Duque de Osuna y exedra en homenaje a su abuela -la duquesacomo fundadora del lugar).

En 1882 muere el Duque D. Mariano, hermano de D. Pedro, famoso entre otras muchas cosas por haber fundido en vida la mayor fortuna de España. Tras su muerte, el palacio y los jardines pasan a pública subasta, adquiriéndolos la familia Baüer.

Durante la Guerra Civil, la Alameda se convirtió en el Cuartel General de la Defensa de Madrid y por esta causa se excavaron varios túneles para hacer un refugio antiaéreo los cuales debieron de afectar el sistema hidráulico del jardín basado en la traída de aguas por canales subterráneos a veces desde kilómetros.

El jardín había sido declarado artístico el 20 de Octubre de 1934. Tras la guerra, a Winthuysen se le encarga un informe en el que éste relata su estado de destrucción y saqueo como resultado de la contienda. El Patronato de Jardines Históricos le encarga la restauración del mismo, tarea que realizará entre 1943 y 1952. Los trabajos se centrarán en la exedra, la fuente de los delfines, el parterre y sus estanques.

De la intervención en los parterres conservamos los planos con los diseños de Winthuysen en los que podemos apreciar las transformaciones que realizó. Los parterres, que eran dos espacios rectangulares bastante largos, Winthuysen los compartimenta en cuatro espacios en los cuales, a su vez, traza setos rectilíneos de boj con plantas de flor en su interior siguiendo una vez más la tradición de la jardinería clásica española.

El jardín siguió siendo utilizado en años posteriores a esta intervención y sabemos gracias a lo relatado por la Marquesa de Casa Valdés en su obra (14) sobre los

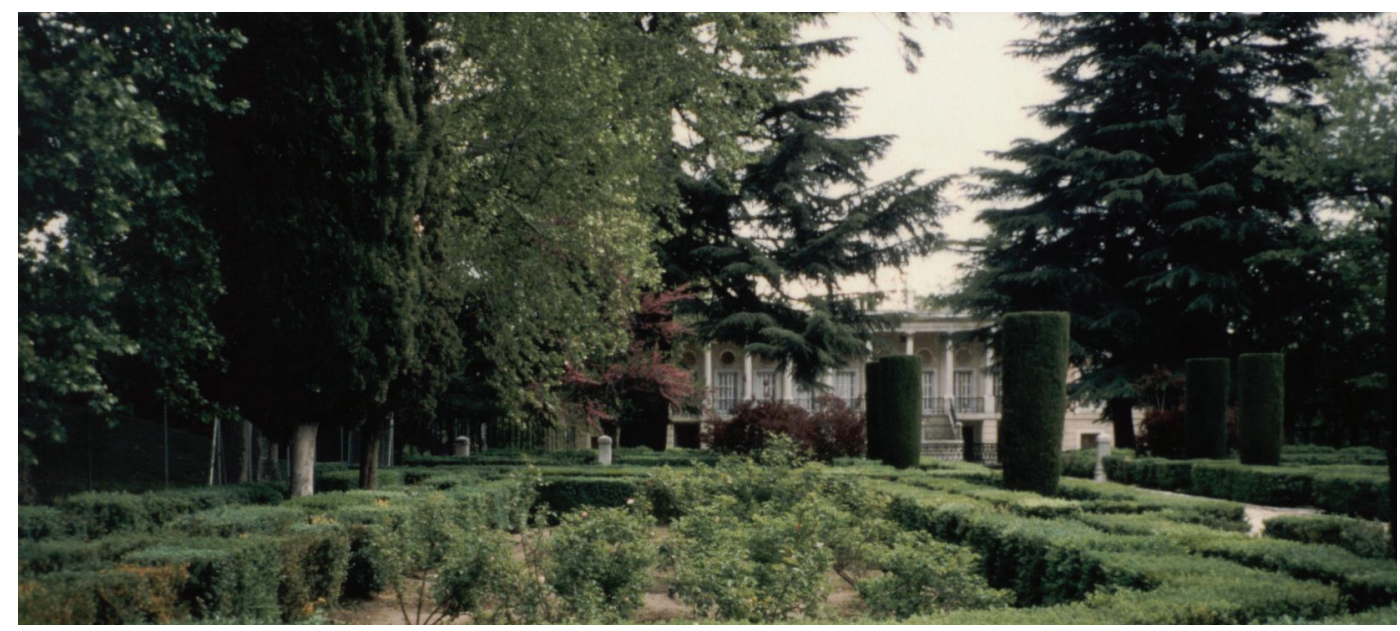

Parterres con rosales. Al fondo el Palacete.(Foto del autor) 
jardines españoles que ella asistió a más de una fiesta, lamentándose de su posterior abandono y de la degradación medioambiental que la zona sufre en los años del desarrollismo.

En la obra de Carmen Añón y sus hijas Ana y Mónica Luengo (15) leemos que tras la intervención de Winthuysen, el jardín sufrió transformaciones más tardías y pone como ejemplo las plantaciones de Arizonica glauca de los parterres.

La restauración llevada a cabo estos años atrás por la Escuela-Taller Alameda de Osuna y que veremos posteriormente con más detalle, ha rehecho los parterres de Winthuysen, plantando rosales en su superficie y dejando las grandes coníferas en el interior de los mismos como criterio de respeto a las actuaciones y aportes del pasado aunque rompan las perspectivas del parterre e imposibiliten la plantación de plantas de flor en su proximidad. Criterio tan discutible como la nueva plantación de cipreses de recorte en la línea del eje del camino central.

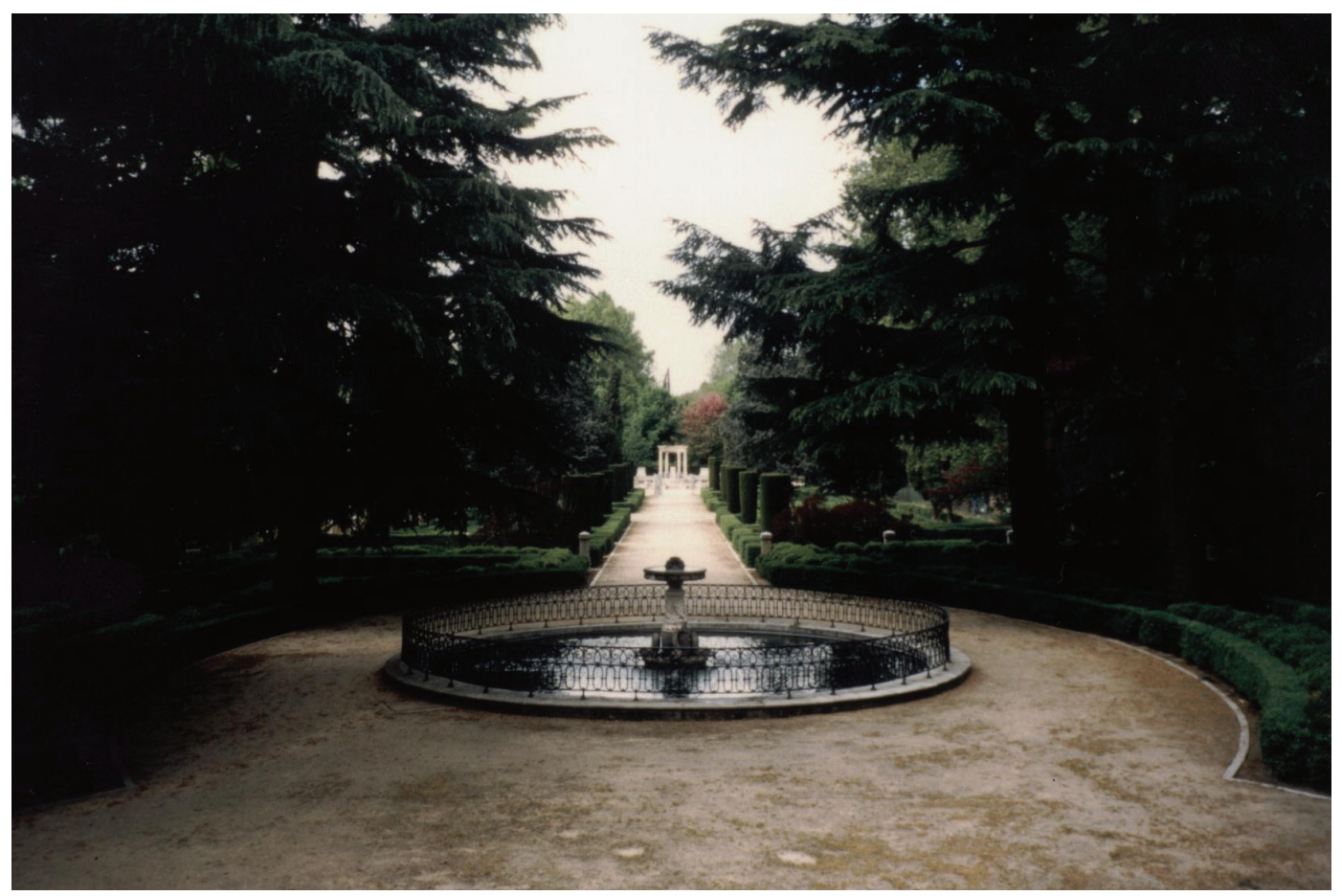

Vista general de los parterres desde el Palacete. Al fondo la exedra. Nótese cómo las grandes coniferas impiden la visión global de los mismos. (Foto del autor) 


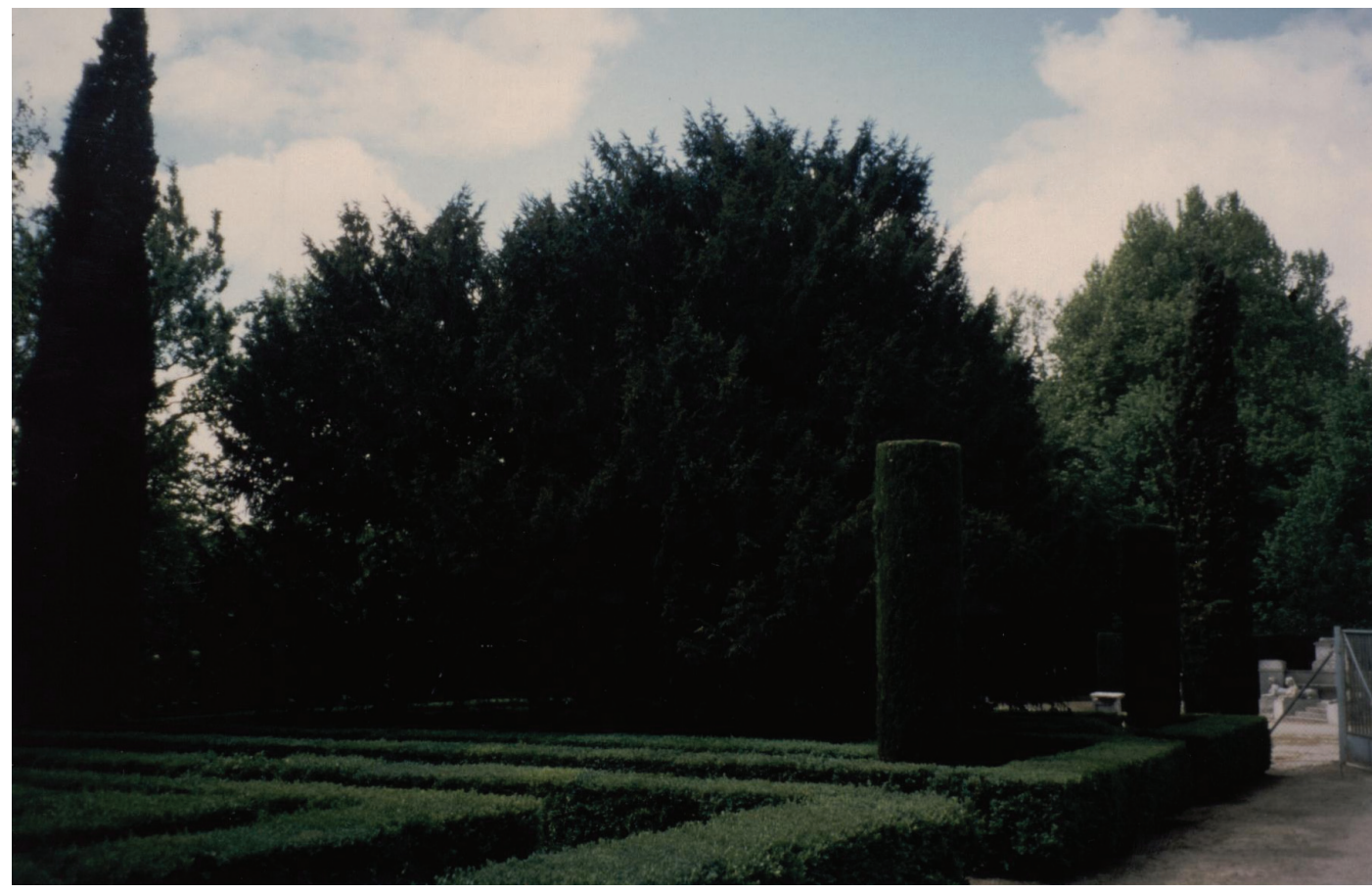

Parterre próximo a la exedra. La gran conífera en el interior del mismo impide que vivan rosales o cualquier otra vivaz.(Foto del autor)

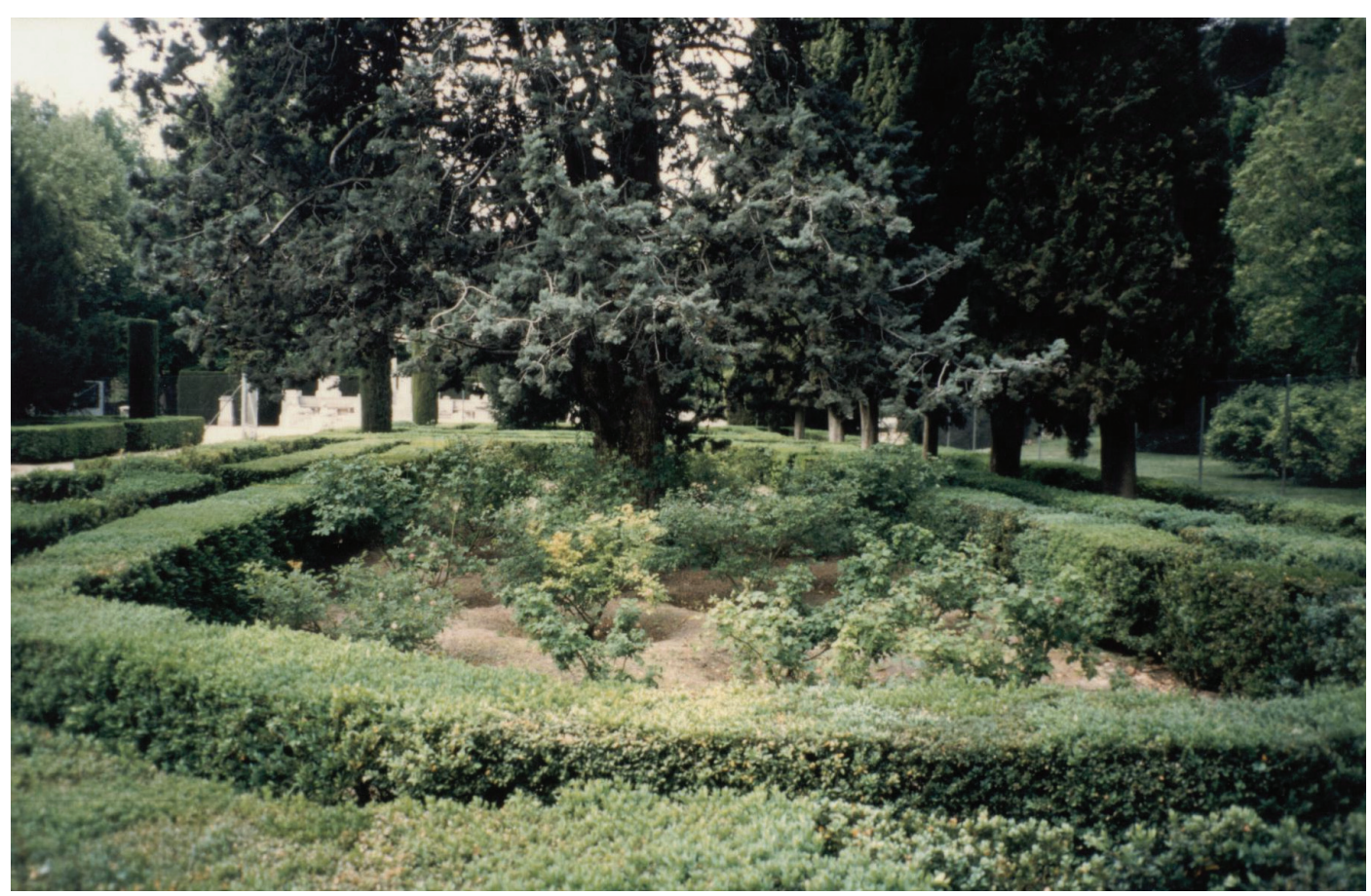

Parterre con gran ejemplar de Arizonica glauca añadido posteriormente a la intervención de Winthuysen.(Foto del autor) 


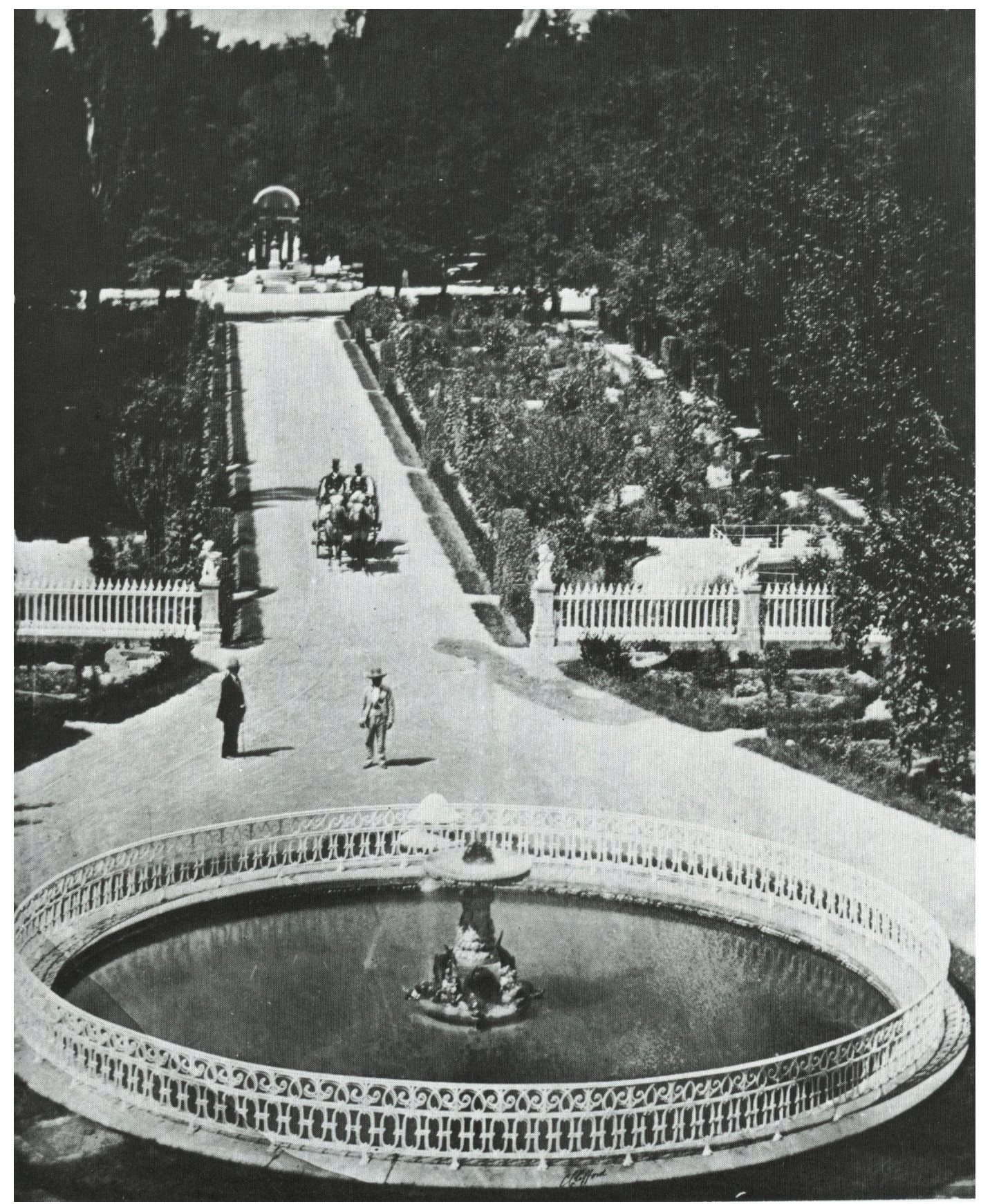

La Alameda en 1856 vista por Clifford. Foto desde el Palacete a la exedra 


\section{C.4. La restauración de jardines en España desde 1920 a 1985 según los datos del Archivo de la Dirección General de Bellas Artes.}

Para elaborar el siguiente capítulo nos hemos basado en las dos principales obras que abarcan la restauración del patrimonio monumental en este siglo: la primera es Fuentes Documentales para el Estudio de la Restauración de Monumentos en España (16) que abarca el período de 1920 a 1985. A esta obra, tenemos que añadir Intervenciones en el Patrimonio Arquitectónico (1980-1985) (17) que completa la anterior. Por otro lado, utilizando las referencias de estas obras, acudimos al Archivo General de la Administración de Alcalá de Henares para consultar los únicos tres proyectos de restauración de jardines habidos en todo ese largo período así como algunas otras intervenciones definidas como nuevos ajardinamientos.

En el primer libro se refleja una época que aparte de las características señaladas en otro capítulo de predominio de lo político sobre lo técnico, "es también el de la consolidación como responsables de la restauración de una minoría de profesionales adscritos a las cátedras de historia de la arquitectura que hicieron de la restauración su feudo particular. En este ambiente los postulados del historicismo y de la restauración estilística se desarrollaron de modo indiscutible”.

La segunda obra recoge las actuaciones realizadas durante el período de las transferencias de competencias sobre restauración monumental a las diversas Comunidades Autónomas.

En ella podemos analizar la política de restauraciones promovida por el Ministerio en aquellos momentos que refleja los nuevos aires de renovación surgidos tras la desaparición de la dictadura y que se puede concretar en los siguientes puntos:

$1^{\circ}$ ) Entendimiento de la restauración desde la Administración como una operación dedicada fundamentalmente a la conservación del patrimonio arquitectónico entendido éste de modo global.

$\left.2^{\circ}\right)$ El entendimiento de la restauración desde la Administración como un servicio público por lo que se primarán las intervenciones en los edificios cuya finalidad sea resolver necesidades de interés social y uso público (museos, bibliotecas, centros culturales, etc.).

$3^{\circ}$ ) El entendimiento de la restauración como un problema puro y exclusivamente de arquitectura. 
Los resultados de esta manera de intervenir en el patrimonio han sido variados y lo que es innegable por otra parte es el aumento de la preocupación y el interés por los temas de la restauración entre el colectivo de profesionales de este campo.

Esta línea de actuación experimental queda cerrada en el año 1985 cuando finaliza el traspaso de las competencias sobre protección y conservación desde la Administración Central a las diversas Comunidades Autónomas abriéndose una nueva etapa. A partir de entonces, cada Comunidad estará encargada de la conservación y protección de su patrimonio con los resultados diversos que hemos ido viendo estos últimos años.

Haremos a continuación un breve resumen de las intervenciones de restauración habidas señalando el número de ellas realizado en los campos de la restauración monumental en general y en el de la jardinería en particular.

De la primera obra señalada, la de Soledad Casas Gómez de Olmedo y Alfonso Muñoz Cosme, éste es un resumen de los datos recogidos. La clasificación sigue el orden de la obra por lo que iremos viendo las obras realizadas por Comunidades Autónomas. En el Anexo Documental $n^{0} 2$ se ofrece una información más completa ya que se recogen con fechas, autores y signaturas todas las obras de nuevos ajardinamientos y las tres únicas restauraciones de jardines del citado período: el claustro de la Catedral de Toledo, el Jardín Botánico de Madrid y la confusión lingüística en torno al claustro de la Iglesia de San Francisco en Lugo.

ANDALUCIA tiene 1.605 obras de restauración realizadas en un período que va desde 1929 hasta 1985. De ellas sólo hay 18 de jardinería, siendo todas ellas nuevos ajardinamientos. En todo el tiempo señalado no se realiza ni una sola obra de restauración a pesar de existir en esa zona los jardines más antiguos de Europa y ser una de las zonas de España con mayor número de ellos.

Hay que señalar igualmente la ambigüedad de la terminología empleada.

Por ejemplo, el arquitecto Prieto Moreno en el Generalife, en los años 1953 y 1955 hace obras de "saneamiento" en los jardines bajos con reposición de paramentos y especies de vegetación y Sierra Delgado, en Sevilla, en la catedral, realiza unas obras de "acomodamiento" del jardín.

Tales obras de "saneamiento" en el Generalife consistieron en la sustitución de tuberías de barro por otras de fibrocemento "que además de mayor seguridad, presentan la ventaja de poder emplear menores secciones para soportar mayor presión" como se señala en la memoria de la obra (18).

Esta intervención obliga a levantar los pavimentos que se encontraban muy deteriorados y se aprovecha la ocasión para rehacerlos, figurando en el pliego de condiciones el siguiente punto: "Para la construcción del pavimento artístico se 
empleará guijo de colores diferentes formando con ellos el dibujo que indique el arquitecto director de las obras.

En la restauración de los pavimentos artísticos existentes se tendrá en cuenta la conservación del dibujo primitivo".

Y añade a continuación: "Complemento de la restauración de tuberías y pavimentos es la reposición de plantas decorativas a base de especies que son allí características como el ciprés, el rosal, el boj, el naranjo y el magnolio" y se finaliza el documento con el presupuesto del dinero necesario para la adquisición de las mismas.

El proyecto sólo incluye un plano de la planta general del Generalife donde está pintado en rojo el patio de la Sultana y la línea de la acequia subterránea paralela a los balsones, quedándonos la duda -según el proyecto- de si la reposición de los elementos vegetales se hace en este patio o en los que están situados juntamente debajo del pabellón citado.

En ARAGON se ejecutan 482 obras entre 1934 y 1985. No hay un solo caso de nuevo ajardinamiento o de restauración.

En ASTURIAS desde 1934 a 1983 se acometen 283 intervenciones. Sólo hay una obra de nuevo ajardinamiento.

En BALEARES se realizan 168 obras entre 1932 y 1983. La única obra de jardinería es el nuevo ajardinamiento de las murallas de Alcúdia.

En CANARIAS hay 52 obras en un período que va desde 1951 a 1984. La única obra en relación a nuestro tema es de Alemany y Orella y se encuentra en el Castillo de Santa Catalina en la Isla de la Palma. Es una intervención nueva del año 1971 la cual es definida como obra de "ambientación exterior y jardinería".

En CANTABRIA se hacen 94 obras desde 1941 a 1983. No hay ninguna que tenga relación con la jardinería.

CASTILLA-LA MANCHA tiene 703 obras realizadas en su patrimonio en un período que abarca desde 1928 a 1986.

Aquí encontramos diez intervenciones de nuevos ajardinamientos y una de restauración propiamente dicha. Se trata del jardín del claustro de la Catedral de Toledo. La dirigió Ignacio de las Casas Gómez en 1982.

\section{Restauración del claustro de la Catedral de Toledo.}

La restauración de este jardín es un ejemplo de metodología proyectual. Independientemente de algunos aspectos criticables del mismo como es el caso del añadido de las nuevas escaleras, el proyecto recoge una memoria de intenciones, documentación histórica sobre el lugar en el que se va a intervenir, planos con la 
vegetación existente antes de la intervención y planos de la vegetación a introducir así como las habituales cláusulas de ejecución para la obra y el presupuesto económico.

Empezaremos por hacer una breve síntesis histórica sobre este espacio recogida de la memoria del proyecto en cuestión.

Su origen se remonta a 1.389. Al principio no tenía vegetación. Posteriormente se eleva el nivel, se llena de tierra y se planta lo que hace pensar que su base es la roca toledana. Al cabo de un cierto tiempo se elimina la vegetación. En un documento posterior del siglo XVI, los canónigos se quejan de que este hecho ha ocasionado que se sienta más calor en verano y más frío en los inviernos. Debido a esto, el cardenal Quiroga encarga en 1581 a Nicolás de Vergara el diseño del jardín y su plantación. Tal diseño es el que ha llegado hasta nuestra época. (Ver planos en Anexo Documental no ${ }^{\circ}$ ).

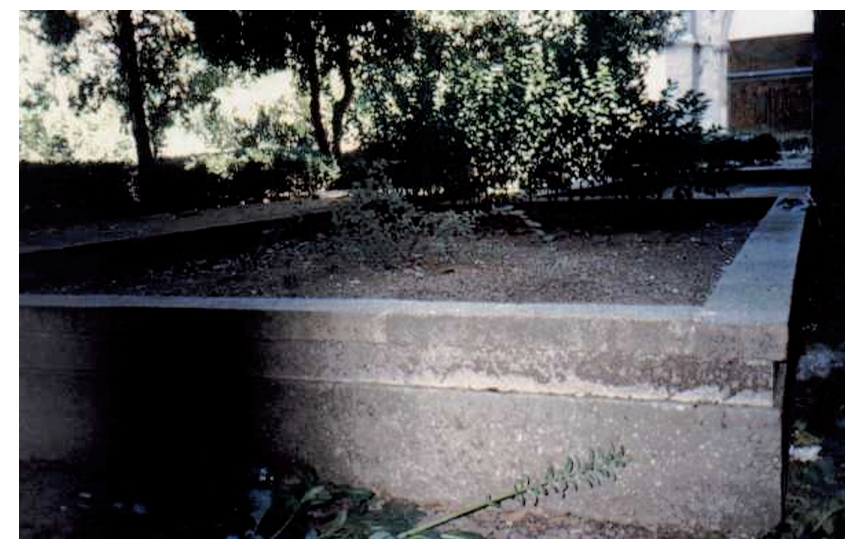

Una de las jardineras de granito elevadas sobre el suelo para contener las tierras que permiten la presencia de las plantas. Diseño de Juan de Vergara de 1581. (Foto del autor)

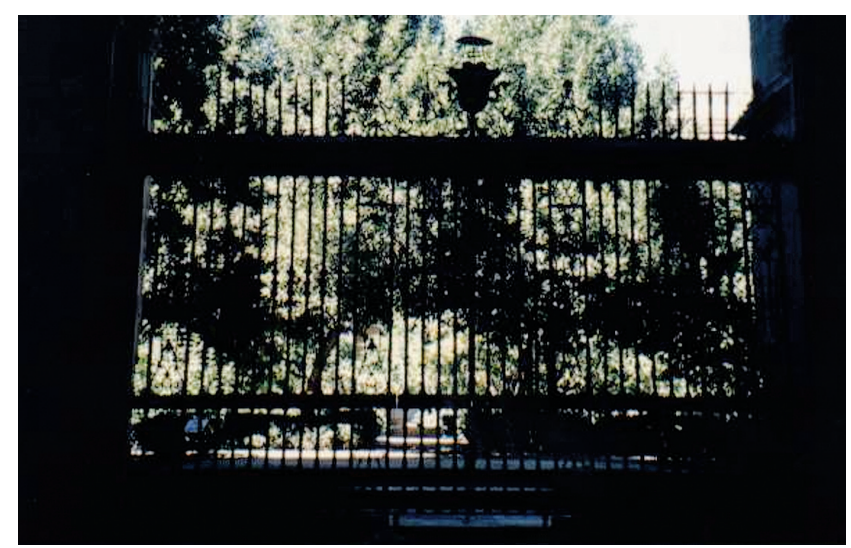

Una de las rejas colocadas en el siglo XVIII para dotar de privacidad al claustro. (Foto del autor) 
En el siglo XVIII se colocan las rejas que aún se conservan con lo que pierde su carácter público y la fuente central es desmontada para colocar un cenador en su lugar.

En el siglo XIX las crónicas hablan de su abundante vegetación.

La última remodelación conocida antes de la restauración actual es la de 1973. Se hacen nuevas plantaciones -ignoramos de qué- sustituyendo a los granados y demás árboles frutales así como a la Broussonetia papyrifera y se transplantan palmeras y cipreses. También sabemos que sus cuadros eran utilizados para cultivar flores que servían para adorno de los altares.
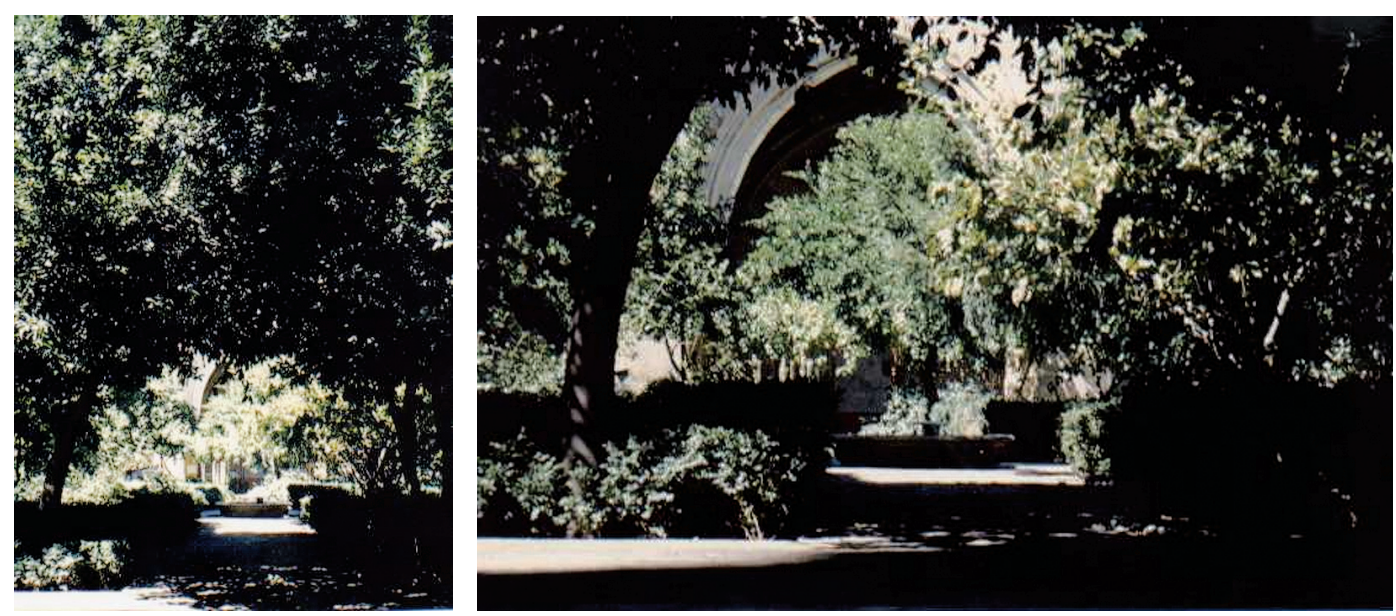

Dos imágenes del claustro donde podemos apreciar la fuente central y la gran densidad de vegetación. Los árboles grandes del primer plano son laureles.(Fotos del autor)

A principios de los ochenta, la situación en la que se encontraba el claustro es la siguiente: el diseño original de cuadros de granito se conservaba bien. Sin embargo, el riego por inundación de los cuadros o "a manta" no se podía realizar pues los canales estaban colmatados.

La relación de plantas existentes en el claustro en ese momento antes de empezar las obras es la siguiente:

Arboles:

Ligustrum ovalifolia (aligustre); Laurus nobilis (laurel); Ficus carica (higuera); Ziziphus jujuba (azufaifo); Citrus aurantium (naranjo amargo); Prunus persica (melocotonero); Acer negundo (arce); Trachycarpus fortunei (palmera de la suerte); Punica granatum (granado); Broussonetia papirifera (moral del papel); Cercis siliquastrum (árbol del amor).

Arbustos:

Aralia variegatus (aralia); Cortaderia argentea (cortaderia); Lippia citrodora (maríaluisa); Mirabilis jalapa (Don Diego de noche); Prunus laurocerasus (laurel-cerezo); Rosa sp. (rosa); Ruscus aculeatus (rusco); Spirea vanhouttei (espirea); Syringa vulgaris (lila); Vitis vinifera (vid). 
La fuente central se hallaba desmontada y no existía ya el antiguo cenador. Se señala igualmente la existencia de dos algibes antiguos fuera de uso.

Los criterios de restauración que se establecen son eclécticos. Por un lado se decide mantener el nivel histórico del jardín solucionando los problemas de humedad a la vez que se quieren guardar los valores del conjunto. Para ello se decide reconstruir la fuente central, conservar el sistema de riego tradicional de los cuadros lo que exigía mantener más elevado el nivel de los caminos que aquéllos. Se recuperan los algibes para el riego con una bomba y el seto perimetral es regado con una tubería enterrada para evitar que el agua dañe la estructura de piedra del claustro. Las plantas son seleccionadas según las zonas sean umbrías o soleadas y disponemos de la relación de las mismas así como de su número. Se señala igualmente la necesidad de incorporar tierra, compost y abonos a los cuadros.

Dicha selección -según el proyecto- es la siguiente:

Arboles:

4 Cupressus sempervirens (ciprés); 4 Taxus baccata (tejo); 18 Punica granatum (granado); 2 Diospyrus caqui (caqui); 1 Citrus sp. (¿naranjo amargo?); 12 Cydonia oblonga (membrillero).

Arbustos, trepadoras y vivaces:

Myrtus communis (mirto, no se indica cantidad); 152 rosales arbustivos; 5 ejemplares de Rosa lutea (rosa fétida); 8 ejemplares de rosales trepadores "Marmaid"; 6 ejemplares de rosal trepador "Iceberg"; 4 rosales trepadores "New Dawn"; 5 Jasminum sp. (jazmín); 12 Lonicera sp. (madreselva); 20 Hedera helix (hiedra); 12 Huttonia sp. (¿Houttunia cordata?); 12 Ranunculus sp.(ranúnculos); 16 Ninphea sp. (nenúfar); 310 ejemplares de Vinca minor (vincapervinca); 170 ejemplares de Viola odorata (violeta); 7 Arbutus unedo (madroño); y 10 Viburnum sp. (durillo).

A la par se pretende hacer una modificación de la estructura del claustro con el añadido de unas nuevas entradas en los laterales; rebaja del muro exterior y supresión del borde ajardinado del claustro para aumentar la visibilidad, aspectos que no llegaron a realizarse según el proyecto, no habiendo podido averiguar las causas de que tales ideas no fuesen llevadas a la práctica (19).

Con la excepción de algunos cambios en el proceso de ejecución como el cambio de arrayán por boj para los setos y la desaparición o no incorporación de algunas especies, el claustro de esta catedral mantiene tanto en su estructura -plantascomo en su aspecto - diseño- la idea del "hortus conclusus" de recinto ajardinado siendo un punto de referencia obligado lo sucedido en su espacio para el resto de los edificios religiosos de nuestro país por la calidad del proyecto, por el resultado de la intervención y por el posterior mantenimiento de la misma. 
En CASTILLA-LEON la suma de restauraciones llega a las 1.772 en un período que abarca desde 1929 a 1985 . Hay nueve intervenciones de nuevos ajardinamientos y ni una de restauración de jardines y eso de que se trata de la Comunidad Autónoma de España que más restauraciones tiene en total.

En CATALUÑA se llevan a cabo 553 obras en el período de 1940 a 1981. Las obras de nuevos ajardinamientos son dos no existiendo ninguna de restauración.

En EXTREMADURA son 484 las intervenciones desde 1941 a 1983. Aquí tenemos tres obras de nuevos ajardinamientos y ninguna de restauración.

La restauración en GALICIA abarca el período 1941-1982 y tenemos la suma total de 1.466 obras realizadas. De nuevos ajardinamientos hay seis y de restauración existe una intervención en el Convento de San Francisco de Lugo en 1957 dirigida por Luis Menéndez Pidal y Francisco Pons Sorolla. La obra está definida como "restauración del jardín".

Consultado el proyecto en el Archivo General de la Administración de Alcalá de Henares (20) vimos que tales obras consistieron en el apuntalamiento de las arquerías del claustro, no existiendo ningún trabajo de jardinería, ni nueva ni de restauración de lo anteriormente existente.

En MADRID, en el período que va desde 1939 a 1985 se ejecutan 315 obras siendo ocho de ellas de nueva jardinería y una de restauración. Entre esas ocho intervenciones destaca la realizada en el patio de la casa de Lope de Vega. Respecto a la de restauración propiamente dicha, ésta es del año 1977 siendo el arquitecto José Ignacio Otamendi. Se define como obras de restauración de diversas zonas del Jardín Botánico. En la obra que seguimos hay una referencia a otros trabajos de restauración también en el Jardín Botánico dirigidos por Antonio Fernández Alba en los años 80 y 81 . Estos consistieron en la recuperación del edificio de los umbráculos de Villanueva, completamente desfigurados tras el levantamiento de un piso sobre ellos por los años treinta del pasado siglo y las posteriores catas, destrozas y final abandono cuando se intentó transformarlo en el Museo de Goya por los años 1970.

En primer lugar veremos el Jardín propiamente dicho y luego trataremos sobre el umbráculo de Villanueva.

\section{Proyecto de 1977 de Otamendi y Silva para la restauración del Jardín Botánico de Madrid.}

Como novedad aparece en este trabajo junto al arquitecto J. Ignacio Otamendi Pineda el arquitecto paisajista recientemente fallecido Leandro Silva Delgado.

Este proyecto, que se encuentra en el Archivo del Real Jardín, realiza un estudio de la situación en que se encuentra el Jardín y algunas de las causas que han motivado su estado de abandono. Tras esto se propone la intervención, explicando los criterios de la misma. Un breve resumen son las siguientes líneas: 
El Jardín en 1977 presentaba un aspecto de difícil lectura debido a la huella de los añadidos habidos en su historia que pasaron desde albergar un zoológico a las fantasías constructivas o "follies" de la segunda mitad del siglo XIX "en que las trazas originales se vieron alteradas por pérgolas, estanques, etc. que desvirtuaban su carácter y hacían difícil su interpretación histórica concreta."

Además existían otras dificultades de orden técnico creadas "por el continuo aporte de tierras y arenas hecho a lo largo de los siglos para paliar el mal sistema de drenaje, que convirtieron los estrictos bancales neoclásicos de Villanueva en masas informes y pintorescas."

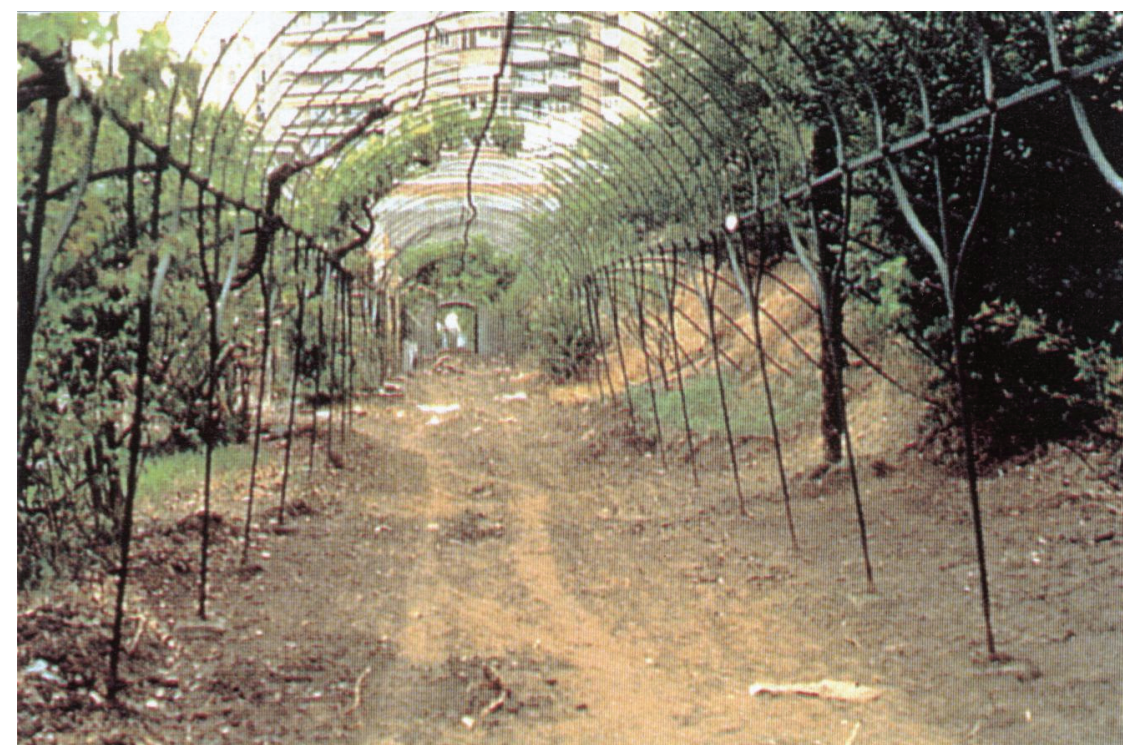

La pérgola de Simón de Rojas Clemente en el año 1977

Todo esto se agravó con el abandono que sufrió el Jardín en los años de la dictadura que llegaron a convertir esos espacios en plantaciones densas y arbitrariamente pobladas sin ningún criterio científico o estético por lo que "se imposibilitaba aún más la lectura ordenada y constructiva del cuerpo histórico del Jardín".

La excepción se conservaba en el plano superior, el de la Flor, que mantenía restos de sus trazados románticos, lo que permitió la restauración de los mismos, completada con los arbustos desperdigados por el Jardín que se concentraron en esta parte con criterios de colección decimonónica.

A lo comentado hay que añadir las intervenciones realizadas en los primeros años 70 por una paisajista británica, Judy Brace, que transformó algunas zonas en verdaderas praderas "a la inglesa" siendo salpicadas por los árboles y arbustos sobrevivientes. En el libro de Pilar Gómez-Centurión sobre el Jardín (21) se

(21) GOMEZ-CENTURION, Pilar. Real Jardín Botánico de Madrid Un Jardín Ilustrado. CSIC. Lunwerg Editores con la colaboración de Caja Madrid. Madrid, 1999. 
comenta esta situación y la polémica que se originó. Cito textualmente: "Se reprochó especialmente a la dirección del Botánico el haber recurrido a la paisajista británica Judy Brace que sin duda actuó con la mejor voluntad pero completamente al margen de la historia del jardín y de la realidad del clima madrileño. Así, los parterres se convirtieron en praderas, los caminos se cubrieron de macadam rojo y se proyectó una gran pérgola de metacrilato que hizo correr ríos de tinta."

Añádase a todo esto, la indignación y el asombro que originó entre amplios colectivos ciudadanos la idea de la Dirección General de Bellas Artes de construir el Museo Goya dentro del Jardín según proyecto de Jaime de la Fuente y Miguel Cuadrado, proyecto que provocó la dimisión del director del centro Francisco Bellot por desacuerdo con el mismo.

La nueva situación social tras la muerte del dictador generó numerosas protestas ciudadanas y un gran debate en la prensa (22) que llevó al entonces nuevo director Salvador Rivas Martínez a encargar un estudio alternativo a Leandro Silva. Este arquitecto, que había trabajado en el estudio de Burle Marx, estudiado paisajismo en Versalles y colaborado con Jacques Sgard en la restauración de algunos jardines en Francia, apostó por conservar el Jardín como monumento histórico a la vez que proponía la recuperación del trazado de Juan de Villanueva como expresión de la mentalidad ilustrada.

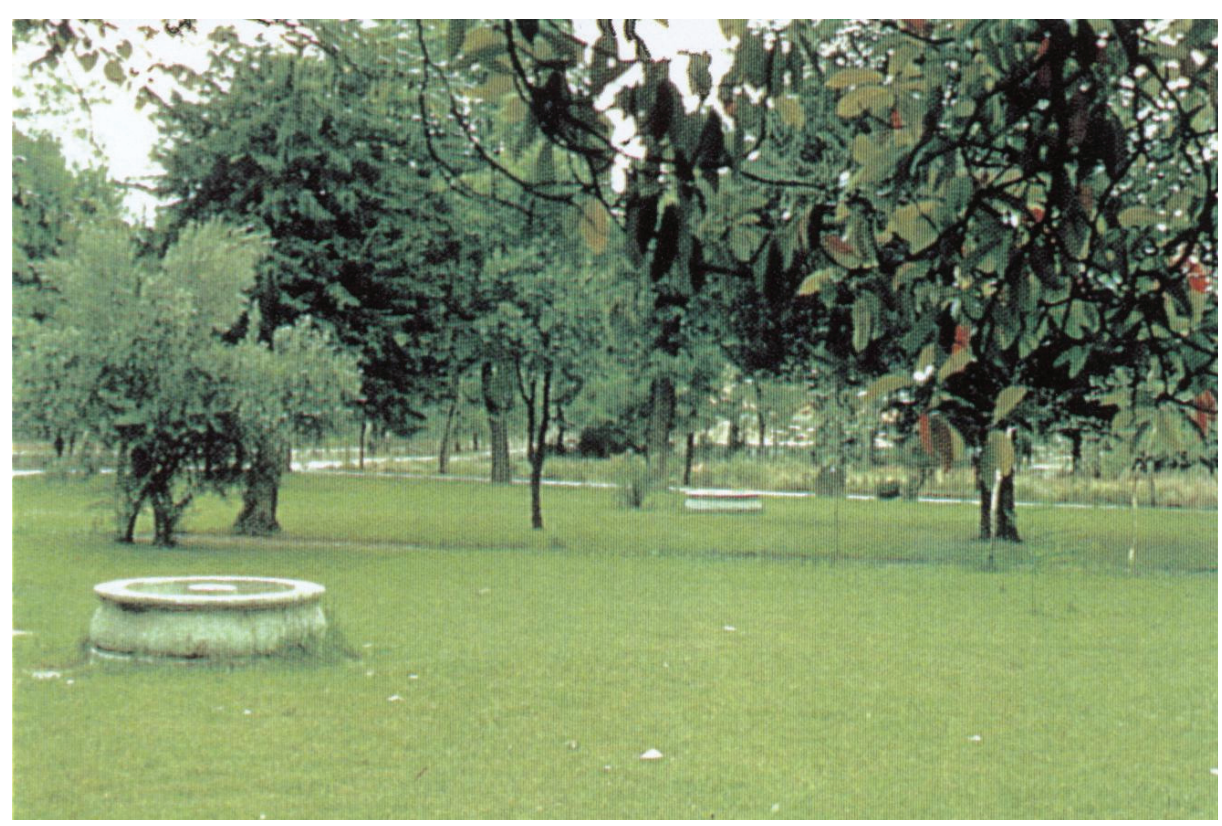

Las praderas de césped introducidas por la paisajista inglesa Judy Brace en los 70. (Foto del libro de Pilar Gómez-Centurión al igual que la anterior de la pérgola)

(21) GOMEZ-CENTURION, Pilar. Real Jardín Botánico de Madrid Un Jardín Ilustrado. CSIC. Lunwerg Editores con la colaboración de Caja Madrid. Madrid, 1999.

(22) AÑON, Carmen; CASTROVIEJO, Santiago; FERNANDEZ ALBA, Antonio. Real Jardín Botánico de Madrid Pabellón de Invernáculos. Real Jardín Botánico de Madrid. CSIC. Madrid, 1983. 
El informe convenció a los responsables de iniciar la recuperación del Jardín descartándose la ubicación del Museo Goya en el interior del mismo.

Tras estos preámbulos, se le encarga a Leandro Silva y a José Ignacio Otamendi el proyecto de restauración del Jardín. Tras la muerte del último arquitecto se incorpora al trabajo Guillermo Sánchez Gil.

Con estos antecedentes, los arquitectos proyectan una restauración cuya finalidad es exaltar el carácter científico del Jardín para lo que se tendrá que recuperar la trama racional del siglo XVIII. A la vez se quiere dejar constancia de la historia de este lugar conservando todos los árboles con los que el romanticismo protestó contra el rígido trazado neoclásico y así los autores señalan que "podían (los árboles) ser considerados en su sitio indefinidamente como elementos de una dialéctica que colaboraría en el enriquecimiento del discurso, poniendo en evidencia el cambio de criterio y el ir y venir en la evolución del gusto." Esta actitud conducirá igualmente a conservar el Plan de la Flor o tercio superior del Jardín con las formas sinuosas e irregulares que el período isabelino le dotó como ya señalábamos anteriormente.

Y por último, un tercer aspecto que se señala en la memoria como objetivo es compatibilizar los usos científicos con los sociales en el disfrute y utilización del Jardín: "En este sentido, pensamos que Madrid merece este jardín histórico artístico restaurado, por razones históricas, estilisticas, sociales y cientificas. Es importante que la capital y el país puedan ofrecer a los españoles y a los visitantes un jardín que constituye la imagen visible de uno de los más laboriosos y secretos

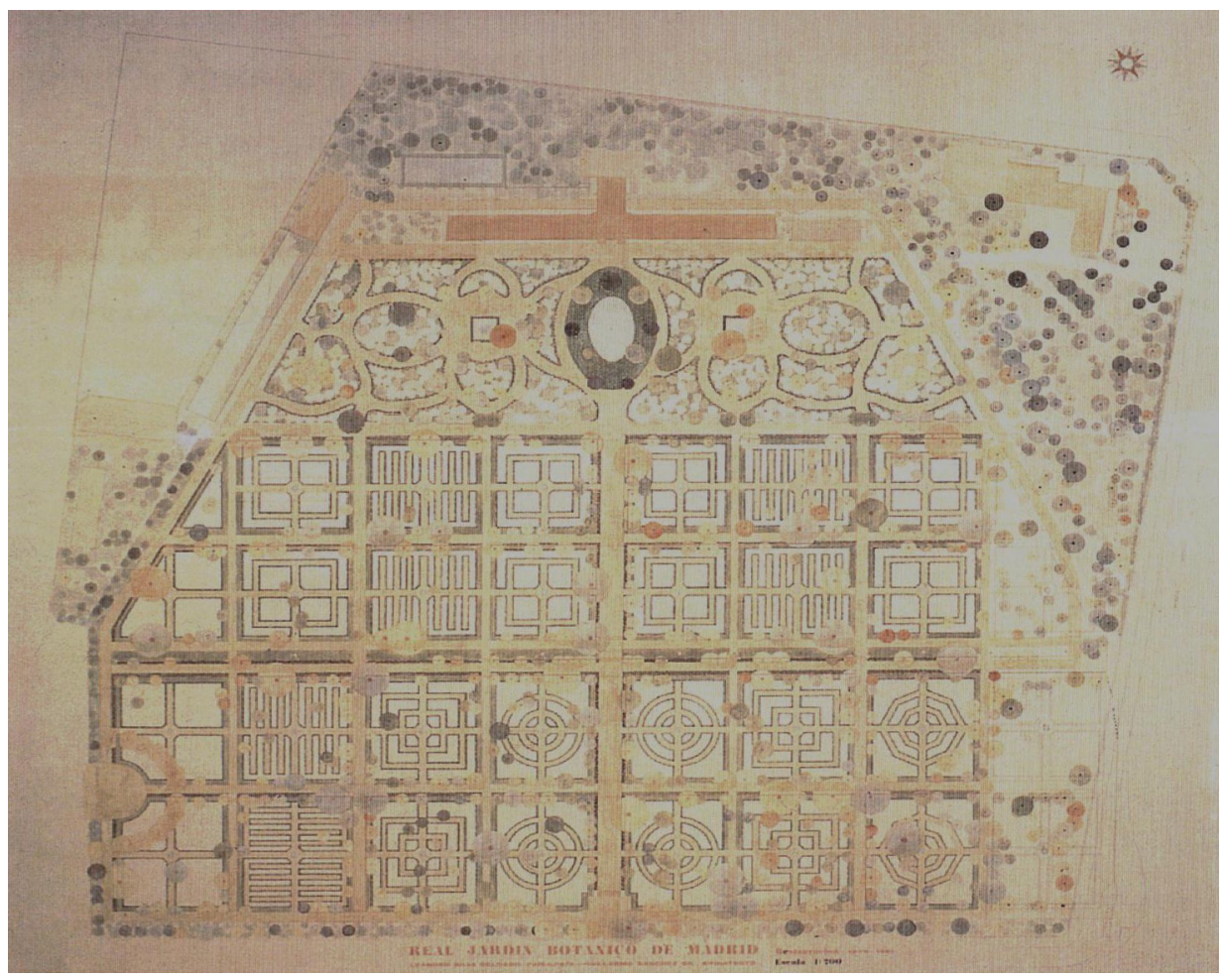

Plano del proyecto para la restauración del Jardin de Leandro Silva y Guillermo Sánchez Gil del año 1978-1981 
esfuerzos de la Ciencia en este país. Es atinado también pensar en la necesidad de crear para un futuro próximo un tipo de jardín botánico de otras características en lo que tiene que ver con su situación y su extensión. Las directivas internacionales en este sentido recomiendan un carácter y una capacidad para la investigación en los nuevos jardines a crear que dificilmente se pueden conciliar con las características y proporciones del resto."

La metodología seguida es igualmente ejemplar para ese momento. Tras establecer los criterios de recuperación del Jardín, se constituyó un equipo interdisciplinar dando gran importancia a los aportes de cada uno de los distintos profesionales que conformaron el equipo: historiadores, historiadores del arte, topógrafos, botánicos, agrónomos, biólogos y demás científicos quienes estudiaron ese espacio, para ir completando los aspectos de la idea proyectual.

Fueron básicos en esta fase del proyecto los planos existentes del Jardín: el de Tadeo Lope de 1781; el de Gutierrez Salamanca de 1876 y el de Alfonso de Areitio y Aguinaga de 1875. (Ver Anexo Documental nº 9).

Tras los trabajos de excavación casi arqueológica con la sorpresa en muchos casos de encontrar nuevos fontines enterrados, la recuperación del trazado racional fue cobrando más y más fuerza así como el mantenimiento de la estructura "apaisada" del Plano de la Flor.

Según se van desarrollando estos trabajos, los responsables del proyecto se ven en la necesidad de hacer un "Reformado del Proyecto de restauración" con fecha de julio de 1979. Ellos lo explican de la siguiente manera: “... el Proyecto de restauración de 1977 creaba una filosofía, daba criterios generales, se organizaba a partir del espíritu del lenguaje neoclásico de Juan de Villanueva. Pero no descendia a detalles de importancia, era imposible en aquellos momentos, como definición de cotas exactas, traslado de la red de riego, concreción de muros de contención, escaleras, etc."

Este reformado define el proyecto anterior bajando a detalles como los movimientos de tierra, terrazas, cotas de altura, muros de contención "e incluso elementos tan secundarios como las arquetas de desagüe, de llaves, y concreta detalles dejados sin definir en el anterior proyecto como son los remates de caminos secundarios, peldaños, plazas de los fontines ..."

Especial importancia se da en este documento al movimiento de tierras pues no sólo se señala lo que debe hacerse a máquina y a mano sino que también se realza lo que implica este movimiento de tierras para la red de riego, la cual es preciso modificar al haberse cambiado las cotas iniciales con las que se trabajaba al principio así como la aparición de fontines y muretes que estaban enterrados.

Los autores explican de la siguiente manera las consecuencias que provocó en el proyecto los nuevos hallazgos: "Por lo tanto nos encontramos con que el movimiento de tierras que exigía la imagen recobrada de las terrazas neoclásicas sobrepasaba en metros cúbicos las cantidades previstas, que aparecieron fontines enterrados, muretes cuya cota inicial (siglo XVIII) se desconocía, etc. Por lo tanto, 
la correcta articulación de todos estos nuevos datos iban exigiendo un sutil cambio de matices en las soluciones a dar, que se iban traduciendo en un ajuste de proyecto y un cambio de presupuesto."

Tras estos considerandos, se ejecutan los siguientes puntos del proyecto:

a) Recuperación del trazado original de Villanueva en las terrazas bajas. Los cuadros se enmarcan con setos de boj, vacíos en su mayor parte, a la espera de su posterior relleno según vayan llegando las plantas de las colecciones botánicas al Jardín.

b) Restauración de la terraza superior o Plan de la Flor según el diseño del romanticismo decimonónico con la incorporación de los arbustos y palmeras de la suerte desperdigados por el Jardín.

c) Recuperación del entorno verde que rodeaba al Jardín sirviéndole de anillo protector del exterior para lo que se transplantarán árboles y arbustos desde las zonas que van a ser obradas a este cinturón perimetral.

d) Recuperación de los fontines.

e) Restauración de la pérgola de parras de Simón de Rojas Clemente.

f) Restauración del invernadero de Graells.

g) Restauración del Pabellón Villanueva. Esta ultima obra se hará en un proyecto aparte siendo el encargado del mismo durante los años 1980 y 1981 el arquitecto Antonio Fernández Alba.

Antes de parar a analizar la intervención en el pabellón, veamos algunas imágenes del Jardín ya restaurado. Unas son al poco de haberse inaugurado. Otras -la mayoría- de unos años más tarde.

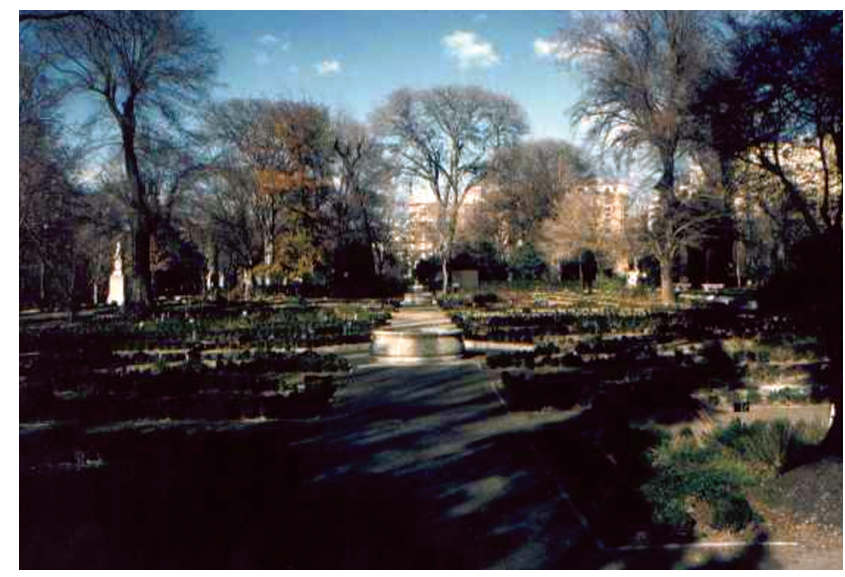

Imágenes del Jardín en 1985, cuatro años después de su inauguración. Los grandes árboles destacan entre los cuadros, vacios o recién plantados. (Foto del autor) 

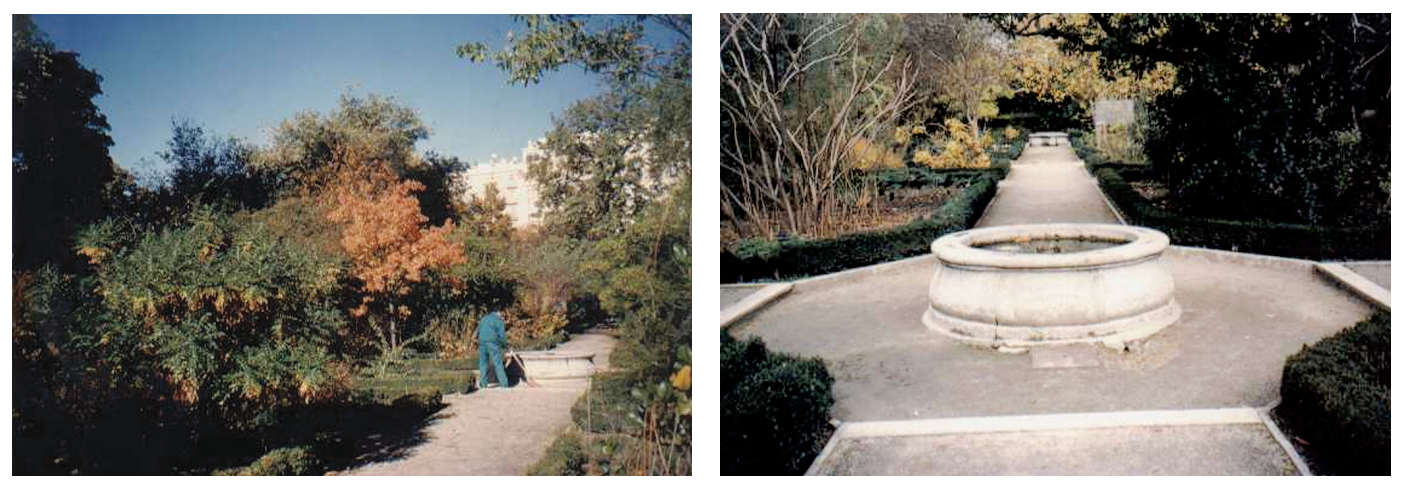

Dos imágenes del Jardín en el año 2000. (Fotos del autor)

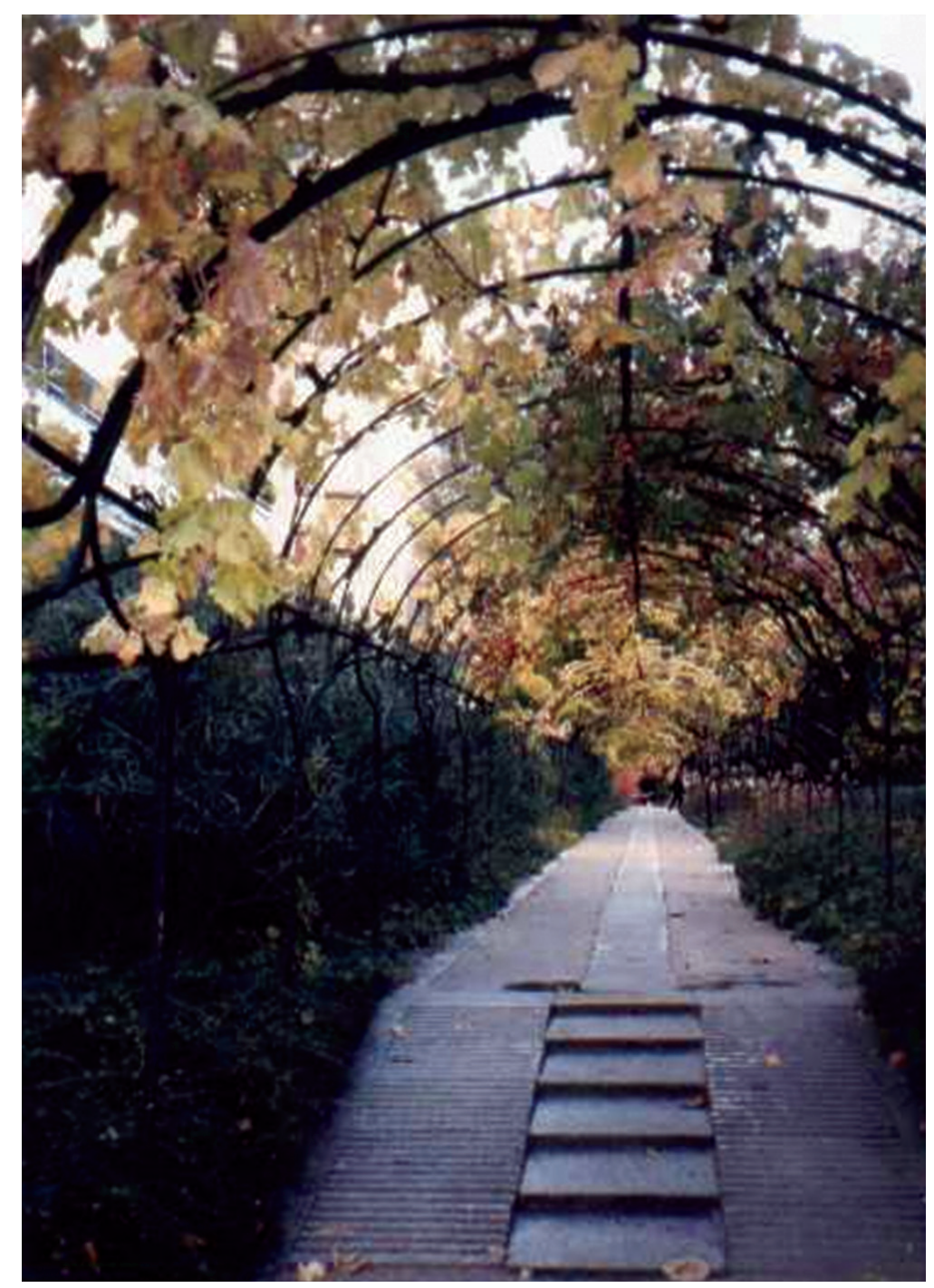

La pérgola de Simón de Rojas Clemente unos años después de su restauración en el otoño del 2000. Compárese con la de la página 82 antes de la intervención. (Foto del autor) 


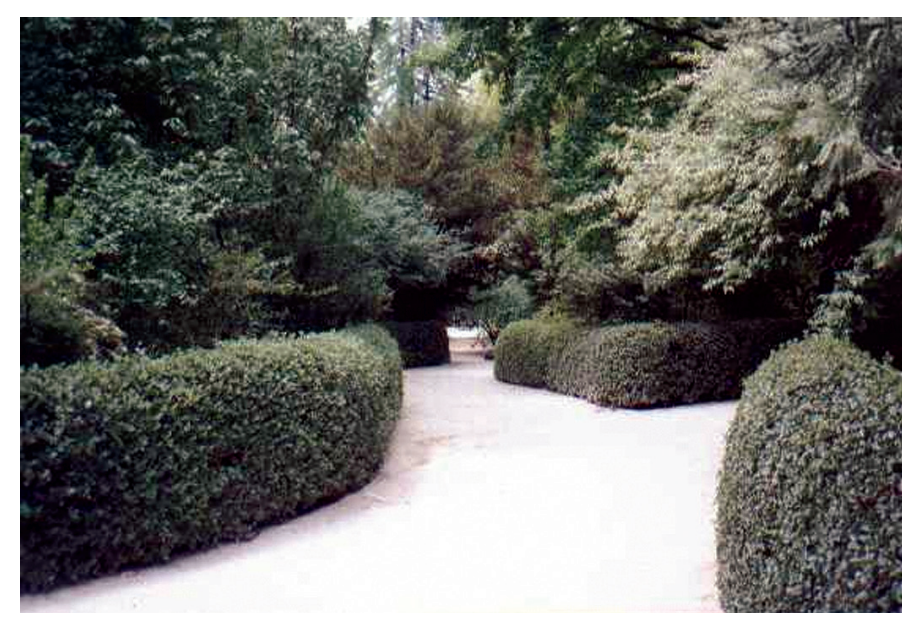

La parte superior o “apaisada”. Abril de 1999.(Foto del autor)

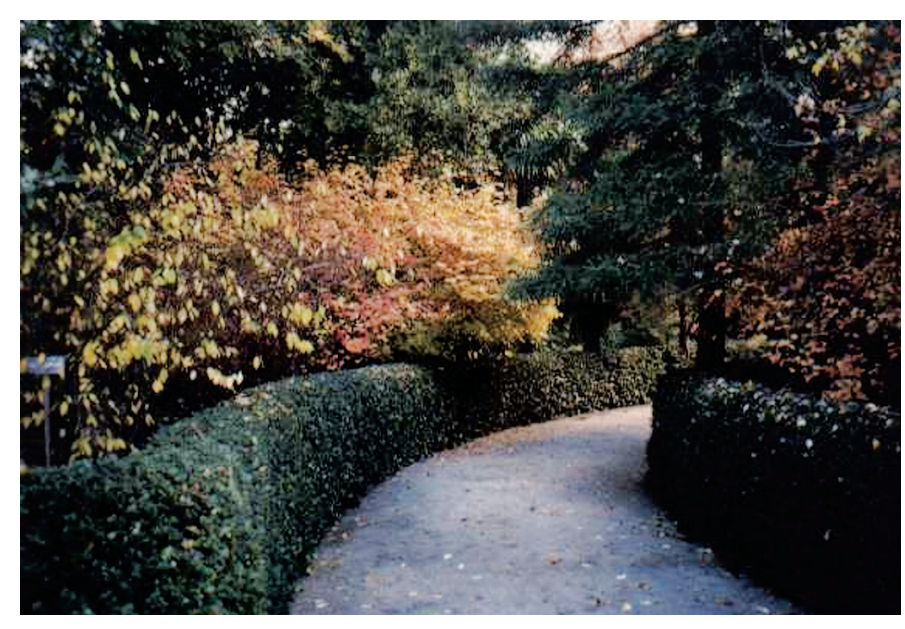

Otro aspecto de la parte superior del Jardín en el otoño del 2000. (Foto del autor)
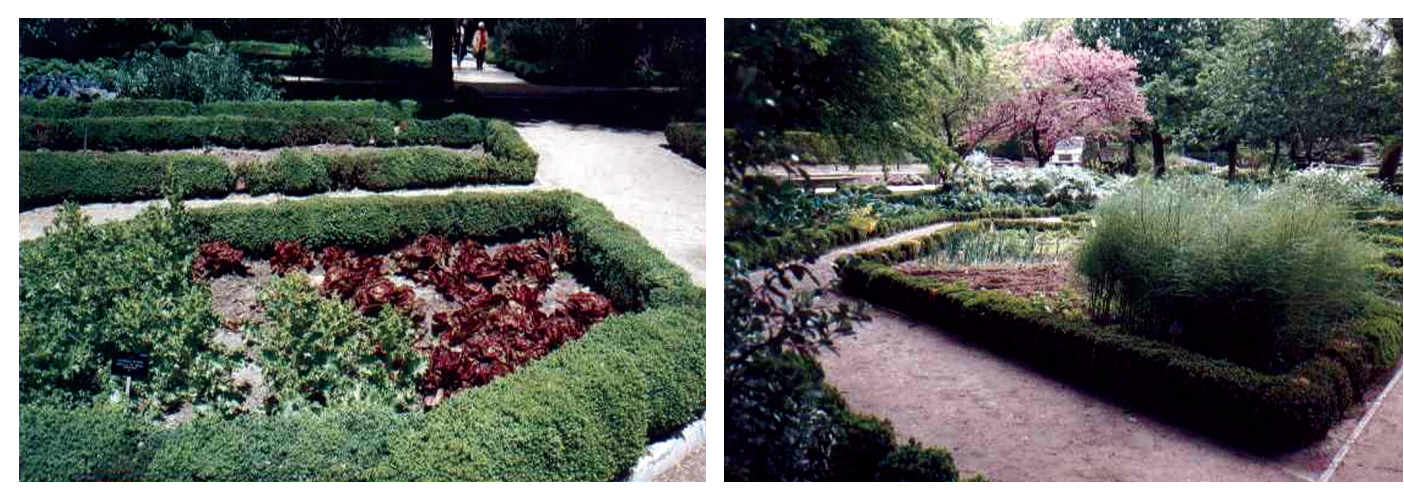

Dos imágenes de la huerta en la primavera de 1999. (Foto del autor) 


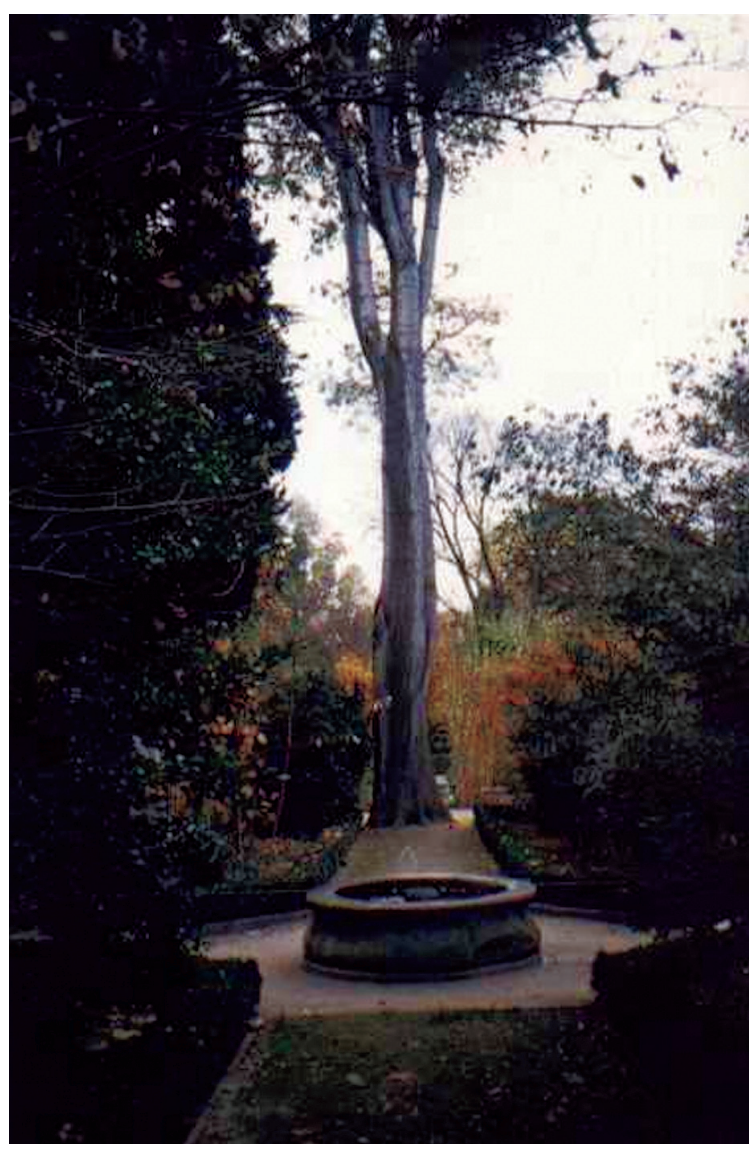

La decisión de conservar los grandes ejemplares existentes en el Jardín, testimonio de la protesta romántica contra el trazado clásico, originó que muchos de ellos al encontrarse en los caminos, rompieran algunas de las perspectivas del nuevo diseño recuperado. La conservación de los mismos es uno de los grandes aciertos conseguidos en la restauración de este Jardín. (Foto del autor)
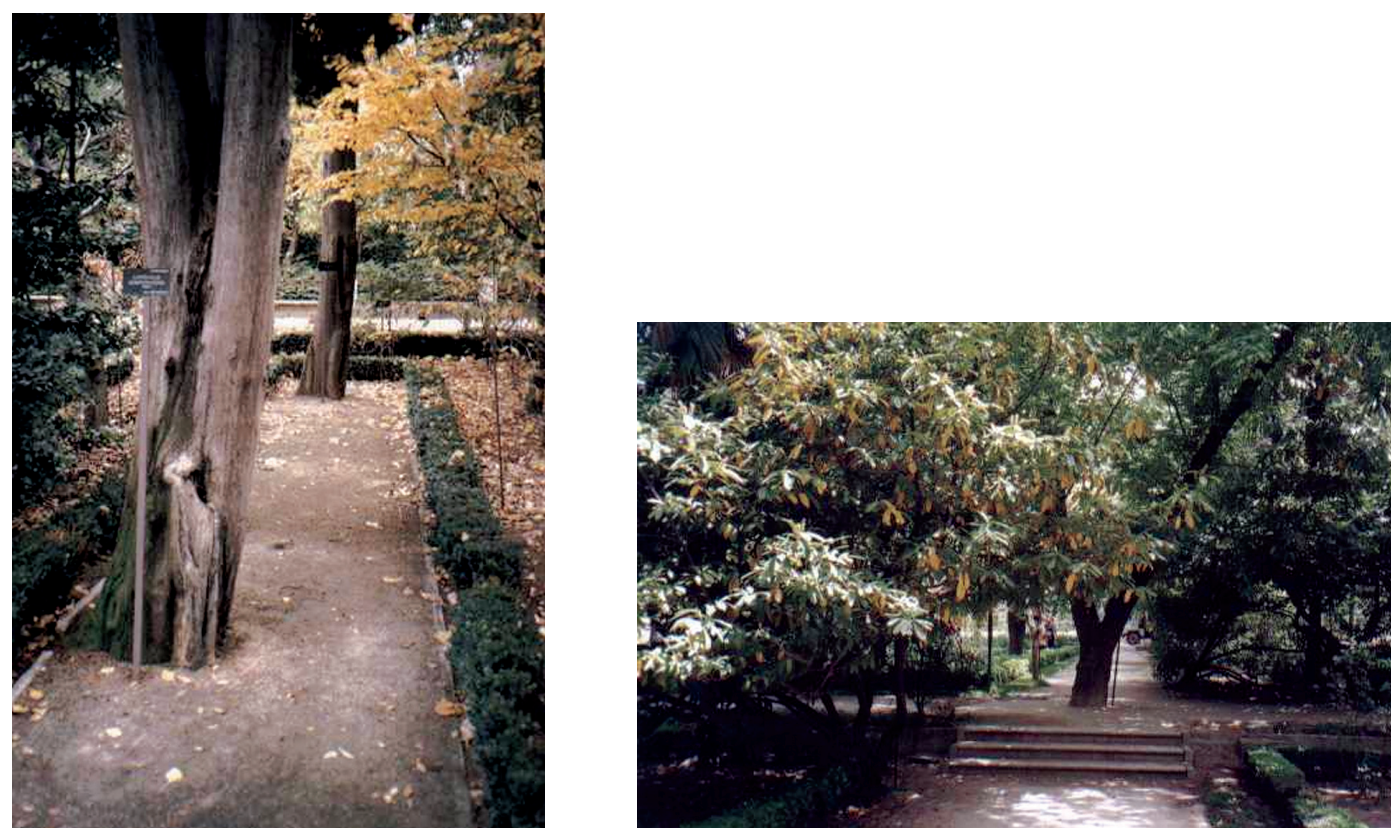

Dos ejemplos más de lo comentado en las líneas de arriba (Fotos del autor) 


\section{Restauración del Pabellón de Umbráculos de Juan de Villanueva.}

La explicación de las intenciones de este proyecto viene detallada en la obra Real Jardín Botánico de Madrid (23) donde se recoge una amplia relación de material fotográfico, planos de la situación del edificio y del nuevo proyecto junto con citas de prensa. En la obra Intervenciones en el Patrimonio Arquitectónico (1980-1985) ya citada anteriormente, se definen los objetivos de la restauración de esta manera: La intervención, realizada en varias fases y dentro de un programa general de restauración del Jardín Botánico, ha consistido fundamentalmente en el derribo de la planta añadida al Pabellón, su restitución a su estado original según los numerosos testimonios históricos analizados, la consolidación y completación de los pabellones posteriores, en estos momentos en ruina, y la ordenación y tratamiento de suelo del espacio existente entre las edificaciones y el muro de cerramiento con la calle Alfonso XII, mediante una plataforma con dos rampas laterales. En el Pabellón se repuso totalmente la carpintería y se realizaron unos nuevos lucernarios sobre la cumbrera de la cubierta.

Si tuviéramos que hacer un balance de la restauración diríamos que es altamente positivo. La contradicción dialéctica que surge en todo proceso restaurador entre la intervención innovadora y el mantenimiento de los testimonios del paso del tiempo se resuelve en este espacio con la conservación de los ejemplares supervi-

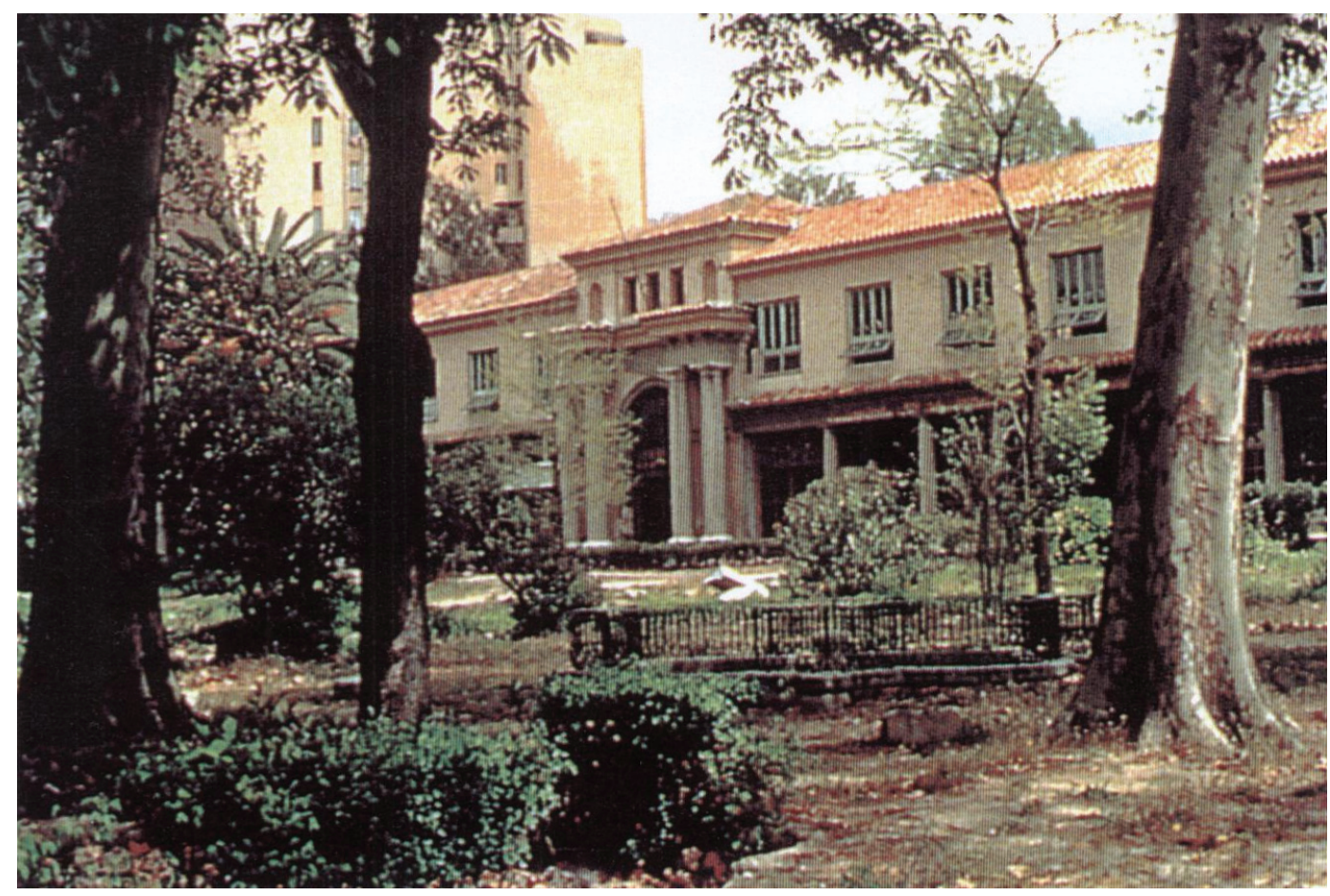

El Pabellón de Villanueva con los añadidos de los años 30 suprimidos en la reciente restauración. (Foto del libro de Pilar Gómez-Centurión)

(23) AÑON, Carmen; CASTROVIEJO, Santiago; FERNANDEZ ALBA, Antonio. Real Jardín Botánico de Madrid. Pabellón de Invernáculos. Noticias de una restitución histórica. CSIC. Madrid, 1983. 

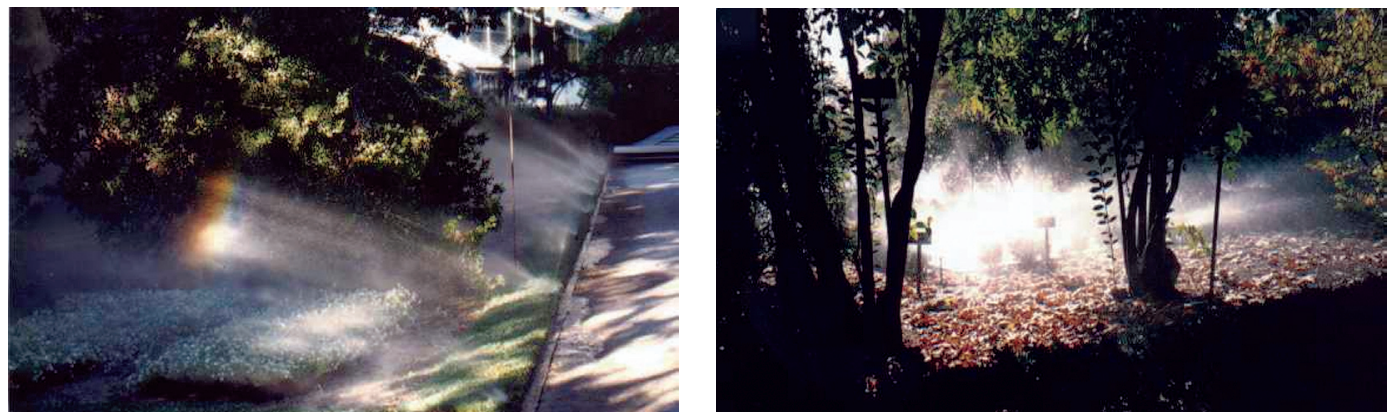

Dos imágenes del nuevo sistema de riego por aspersión existente en el Jardín. Se ha perdido con su instalación una de las estructuras internas del espacio y esto sin entrar a valorar lo nefasto que es para la salud de las plantas ese tipo de riego ya que favorece la proliferación de hongos en nuestro clima. (Fotos del autor)

vientes de la plantación romántica del XIX, los cuales quedan integrados en la nueva trama formal recuperada, con una lectura nueva a pesar de que dichos ejemplares rompen las perspectivas. Igualmente es notable la recuperación de los umbráculos tras la desafortunada intervención de dotarlos con un piso superior en los años treinta del siglo pasado.

Sin embargo, es de lamentar en este proceso, la no recuperación del sistema de riego tradicional -a manta o pie-suprimido en 1976.

Sólo ha sido Ramón Guerra de la Vega en su obra sobre Villanueva (24) quien ha señalado la importancia del sistema de riego para la estructura del jardín. Las nuevas tecnologías han imperado en la reciente etapa tal vez arrastrados o seducidos sus responsables por la demagogia del ahorro de agua en los sistemas de goteo o aspersión como frecuentemente se pondera lo cual, además de no ser cierto, rebaja al Jardín y por extensión a la Jardinería, a la categoría de mera rama de la actividad agrícola y no como muestra del nivel artístico y cultural de una determinada sociedad en un momento histórico concreto.

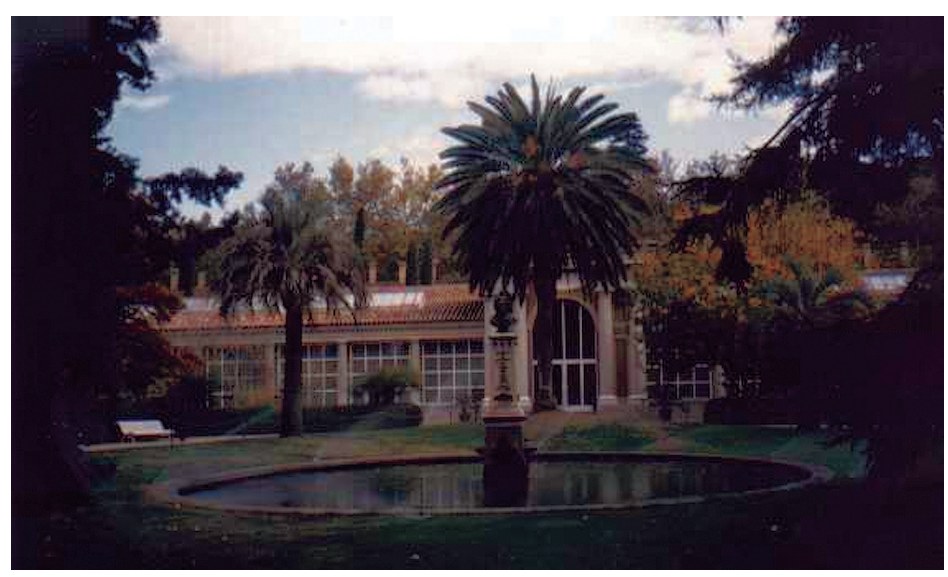

El Pabellón de Villanueva tras las obras realizadas (Foto del autor)

(24) GUERRA DE LA VEGA, Ramón. Juan de Villanueva arquitecto del rey Carlos III. Dos tomos. Edición a cargo del autor. Madrid, 1987. Este autor señala que el sistema de riego -a manta- es la estructura oculta del jardín. (Pág. 166 del $2^{\circ}$ tomo). Igualmente señala que Villanueva habría conocido esta forma de riego en sus viajes a Granada. Sin embargo, todos los Reales Sitios -incluyendo el cercano Retiro- lo empleaban. 
En MURCIA se hacen 139 intervenciones entre 1939 y 1983 no existiendo ninguna en relación con la jardinería.

Lo mismo ocurre en NAVARRA que ejecuta 29 obras en el período 1940-1984 y en LA RIOJA que suma 97 obras entre 1941-1984.

En el PAIS VASCO se cuentan 122 obras desde 1942 a 1981, existiendo solamente una intervención de nuevo ajardinamiento.

En la COMUNIDAD VALENCIANA hay 282 intervenciones citadas desde 1940 a 1984. Sólo existe una cita de jardinería, tratándose de un nuevo ajardinamiento en el exterior del castillo de Montesa. La obra es del año 1960 y puedo asegurar que en 1997 no existían las trazas de tal intervención.

El resumen general dice bastante sobre la actividad de restauración de jardines en nuestro país. En un período temporal que abarca desde 1920 a 1986 se hacen en total 8.556 obras siendo tres las obras de restauración propiamente dichas y 51 las de nuevas recreaciones.

Completa la anterior información una nueva publicación de 1990 del ICRBC que ya hemos citado anteriormente Intervenciones en el Patrimonio Arquitectónico (1980-1985) en el que se da por finalizada la relación de monumentos restaurados desde la Administración Central y que abarca el período de 1980-1985 que es el de las transferencias a las diversas Comunidades Autónomas de las competencias sobre restauración monumental que tenía hasta entonces la Dirección General de Bellas Artes y Archivos.

En esta relación de obras correspondientes a dicho quinquenio se numeran 236. Se citan los monumentos, el tipo de intervención, localidad y provincia así como los arquitectos responsables de cada proyecto.

Las intervenciones se dividen en capítulos: intervenciones estructurales (30); reparaciones y restauraciones en general (72); restituciones y eliminación de elementos degradantes (48); intervenciones superficiales (25); introducción de nuevos usos y remodelaciones (26); ampliaciones de monumentos (9) y acondicionamiento de ruinas y yacimientos arqueológicos (26).

De todas estas intervenciones solamente se citan 4 obras de jardinería. La primera es en el Patio de los Naranjos de la Mezquita de Córdoba (según proyecto de Gabriel Ruiz Cabrero) y consistió en la "liberación de las galerías perimetrales del patio ya que se encontraban cegados sus arcos y en algunos casos con forjados intermedios para conseguir habitaciones dobles, almacenes, altillos, etc.[...] y la restauración completa del piso del jardín tanto en nuevas plantaciones como en el enmorrillado, canales de riego, fuentes, etc., construyendo un banco corrido a todo su largo que suaviza el corte brusco que existía entre el nivel del jardín y el andén de piso de mármol que da acceso a la fachada del patio de la sala de oraciones de la mezquita. "; la segunda es el pabellón Villanueva en el Jardín Botánico de Madrid (proyecto de A. Fernández Alba) que ya vimos al tratar sobre la restau- 
ración del Jardín Botánico de Madrid y que consistió en la eliminación del añadido de los años 30 sobre el Pabellón; la tercera es la reconstrucción del edificio (según proyecto de Ignacio Garate Rojas) y la replantación del bosquete talado en el Cármen de los Mártires por aquellos especuladores inmobiliarios sin escrúpulos allá por los últimos años de la dictadura, y la cuarta es la Iglesia de la Magdalena de Jaén (proyecto de Luis Berges Roldán) cuyo patio árabe ha sido plantado de arrayán y naranjos.

El resto son intervenciones en monumentos muchos de los cuales poseen jardines en sus claustros o patios. El trato recibido por estos espacios se desconoce al no detallarse en las fichas dedicadas a cada monumento en particular pero es de suponer el trato habido en tales espacios si han seguido el ejemplo del claustro de la catedral de Ciudad Rodrigo (Salamanca).

Tal claustro, conocido en mi infancia y juventud por razones familiares, mostraba en su abandono controlado la permanencia de algunas de las especies de la jardinería tradicional: lirios, azucenas, claveles, valerianas, violetas y rosales vivían en aquel espacio hermosísimo hasta que "las obras de restauración (que) consistieron en el enlosado del claustro según las necesidades expresadas por el Deán" hicieron que aquel lugar cambiara radicalmente. Tales obras, calificadas como "intervención superficial" por el autor del proyecto, J. A. Espejel, han transformado de modo sustancial la percepción estética del espacio en cuestión. 


\section{5. La Segunda Guerra Mundial (1939-1945) y la posguerra. Sus efectos sobre los criterios de restauración.}

\section{5.1. Primacía de las reconstrucciones.}

La ingente cantidad de edificios dañados tras la contienda conduce a apartarse de los criterios marcados en Atenas y los principios de la restauración científica o filológica entran en crisis.

En unos casos se va a reconstruir el monumento tal como era recurriendo a los principios de la restauración histórica de Luca Beltrami. Eso es lo ocurrido en el centro de Varsovia, la abadía de Montecasino, el puente de la Trinitá de Florencia o el puente de Bassano, que se reconstruye por tercera vez según el proyecto de Andrea Palladio.

El templo Malatestiano de Rímini cuya fachada de Alberti se desplomó a causa de los bombardeos, es levantada de nuevo. En Nápoles, la iglesia de Santa Clara, edificio gótico revestido de una exuberante decoración barroca, desaparece por efecto de las bombas y su reconstrucción es de tipo estilístico ya que se rehace según las normas de aquel estilo medieval. Y lo sucedido en el Claustro lo veremos en el siguiente capítulo.

En Alemania, muchas zonas completamente destruidas se volvieron a levantar según los criterios del Movimiento Moderno dejando únicamente las ruinas de algunos monumentos como testimonios simbólicos. Tal es el caso de Dresde cuya Frauenkirshe se está reconstruyendo en estos momentos bajo los criterios de la restauración histórica, rodeada de edificios completamente modernos.

En los jardines, sucedió lo mismo. Muchos de los que fueron destruidos se volvieron a plantar con criterios de reconstrucción histórica y es especialmente curioso que muchos de ellos que sufrieron cambios en su diseño en el XIX que los llevó de lo formal a lo paisajista, vuelvan a ser reconstruidos en el estilo barroco o formal de sus orígenes.

En Italia se reconstruyeron los jardines de Villa Lante (Bagnaia) y los de Villa Gamberaia (Florencia), basándose en planos y dibujos de los antiguos diseños. Veamos lo sucedido en estos jardines.

La intervención habida en Villa Lante oscila entre la reconstrucción y la restauración. La importancia otorgada a los elementos de la parte escultórica del jardín condiciona de tal manera el espacio que se consigue anular su percepción global con la ayuda de esos setos que al enmarcar la cadena del agua consiguen desconectar las partes arboladas que en su día eran los laterales del jardín.

Y respecto a las intervenciones ocurridas en las otras terrazas inferiores tampoco tienen nada que ver con un jardín renacentista. Los parterres se han rehecho según modelos de jardinería francesa barroca y se ha olvidado que esos cuadros no fueron concebidos para ser adornados con dibujos de boj y rellenos de piedras 


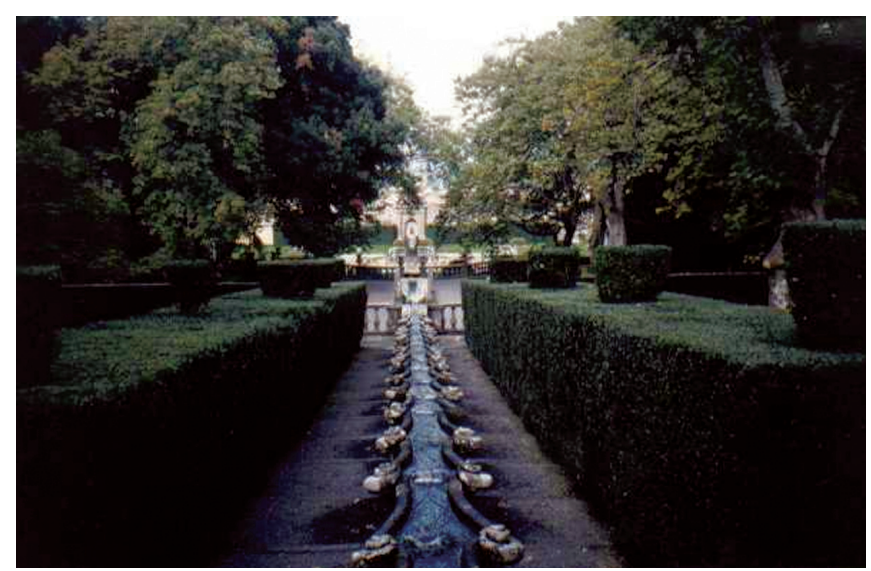

La restauración dio realce al agua y a sus efectos escénicos. Los setos de boj consiguen ese fin pero ocultan los laterales del jardín impidiendo apreciar la amplitud del mismo.(Foto del autor)

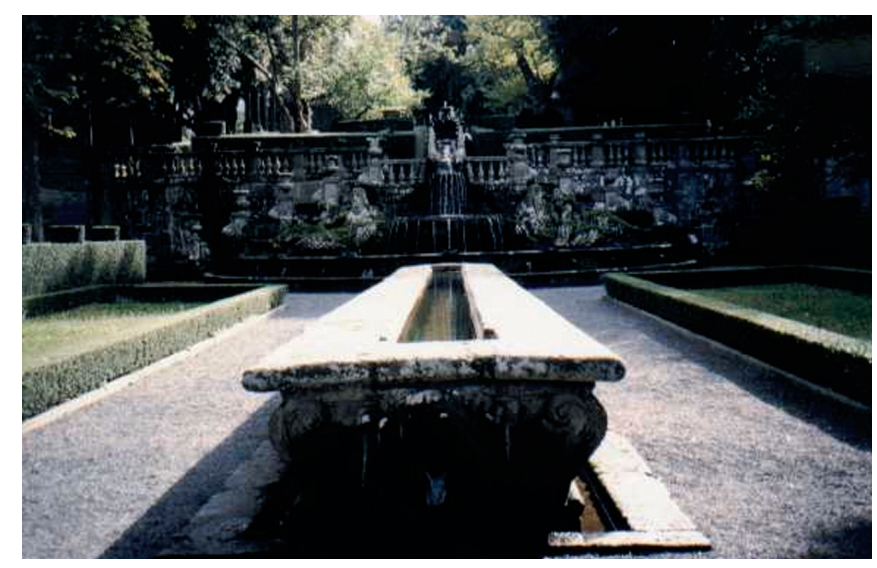

Los parterres laterales que acompañan la gran mesa hoy se ven con césped, sin plantas, una muestra más de la ausencia de jardinería en los principales jardines históricos de Italia. (Foto del autor)

coloreadas sino los espacios más cuidados del jardín en donde toda la riqueza botánica del momento se mostraba en su esplendor.

En la obra de Claudia Lazzaro (25) sobre los jardines italianos del Renacimiento hay un capítulo dedicado a Villa Lante. Gracias a esta obra sabemos que tras el cardenal Gambara perteneció durante tres siglos a la familia Lante della Rovere. En dicho período sufrió algunos cambios. Los más importantes fueron en el siglo XVIII (1656 y 1685) cuando los parterres se modificaron para hacerlos a la francesa. Durante la Segunda Guerra Mundial sufrió bastantes daños y posteriores abandonos. En 1953 es adquirida por la Sociedad Villa Lante. Entonces, bajo la dirección del Dr. Angelo Cantoni comenzó su gran restauración. Según C. Thacker "extensa y fiel" (26). Pero lo sucedido consistió en que se fue "fiel" a los modelos del jardín francés del siglo XVIII en lugar de a los del jardín italiano del XVI. Y

(25) LAZZAR0, Claudia. The Italian Renaissance Garden. Yale Univ. Press. New Haven and London, 1990.

(26) THACKER, Chistopher. The History of Gardens. Groom Helm. London, 1979. 


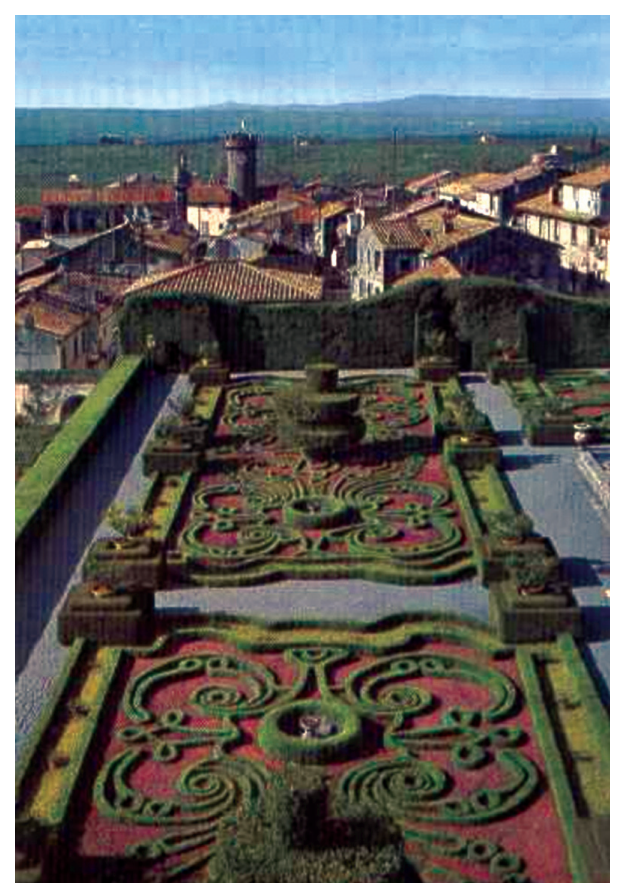

En esta postal de Villa Lante se pueden apreciar los parterres a la francesa recreados en la última intervención

existía además de documentación gráfica de los dos momentos históricos, la relación de las plantas existentes del siglo XVI recogidas en el inventario que cita Claudia Lazzaro.

Dicho inventario está recogido en uno de los apéndices de su obra. El inventario es notarial y está hecho a la muerte del cardenal Gambara en 1587. Contiene una descripción detallada del parque y del jardín por lo que sabemos las especies usadas en los cuadros, setos y existentes en el bosque en aquel momento y, aunque las comparaciones sean odiosas, es lamentable ver la pobreza actual de la vegetación presente en el jardín tras su restauración respecto a la que existía en el XVI dejando, por otro lado, el comentario para otra ocasión sobre la introducción de rododendros y hortensias en este lugar, plantas que no son las apropiadas para un jardín de estas características.

Villa Gamberaia es otro caso distinto al de villa Lante. Consecuencia de ser un centro de mando del ejército nazi en la última guerra, fue intensamente bombardeada quedando convertida en una ruina completa. Su dueña, una alemana, lo regaló al Vaticano y éste lo puso en venta.

Su nuevo propietario, se entregó a realizar una reconstrucción tan primorosa que unos años más tarde, cuando Georgina Masson (27) lo visita, es calificado como el jardín que mejor expresaba el ambiente de la jardinería de la Toscana. 


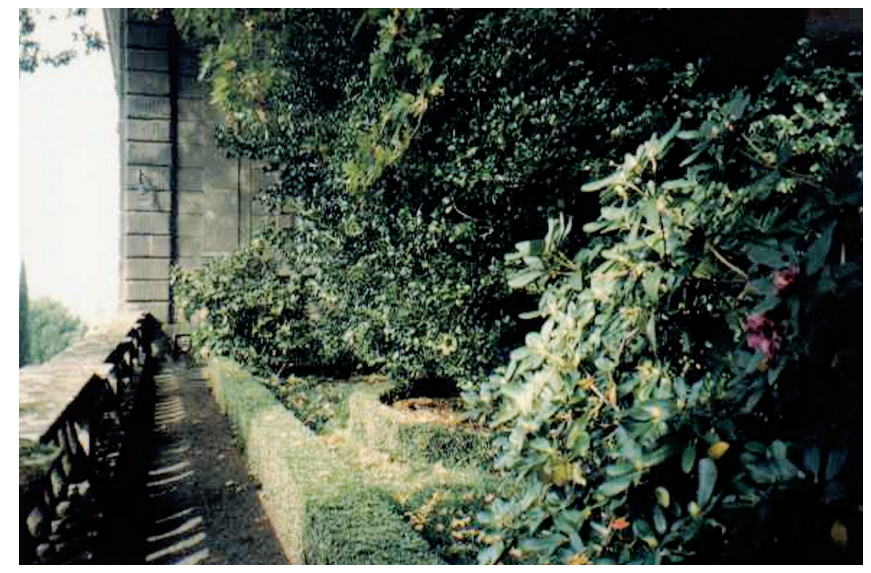

En esta imagen de Villa Lante en el invierno de 1999 podemos ver uno de los parterres con rododendros y camelias, una de las aportaciones más negativas de la última restauración llevada a cabo en la "estructura" del jardín. (Foto del autor)

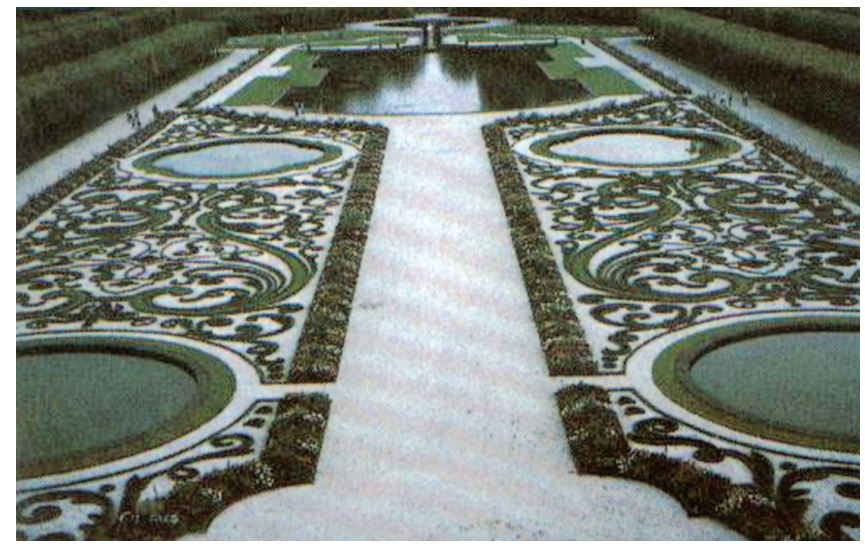

Vista del parterre de Brühl tras las obras de 1983-85. (Foto de W. Hansmann)

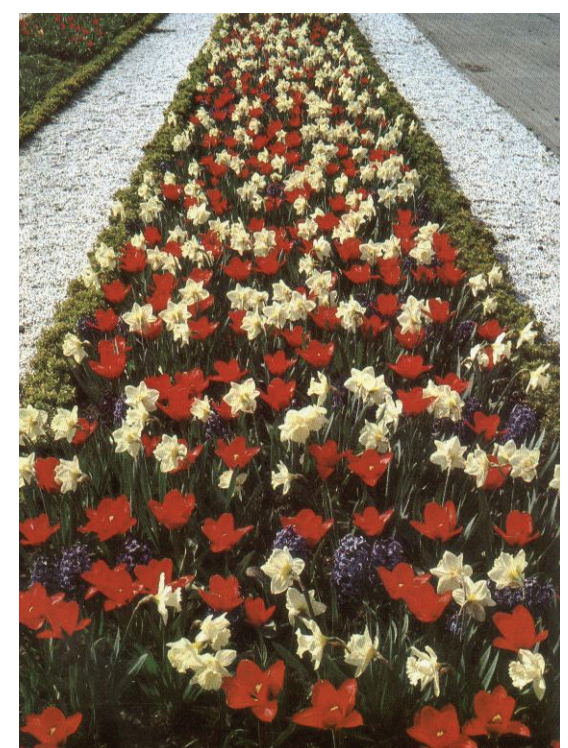

Brühl. Vista de la plantación experimental según esquemas históricos de tulipanes, narcisos y jacintos realizada en 1981. (Foto de W. Hansmann) 
En Alemania, donde la guerra fue especialmente sentida, numerosos jardines resultaron dañados y muchos de ellos incluso completamente destruidos. Algunos de los que fueron reconstruidos tras la contienda son los siguientes:

Jardines de Brühl, situados entre Bonn y Colonia. Sus orígenes son de 1728. Tuvieron trabajos de restauración en los años 1933-37 y de nuevo tras la Segunda Guerra Mundial, constituyendo en estos momentos la mejor representación de los jardines del Barroco tardío que tanta fuerza tuvo en Alemania.

Jardines de Charlottenburg en Berlín. Fueron diseñados por Simón Godeau, uno de los discípulos de Le Nôtre. En el siglo XIX Peter Joseph Lenné rediseñó el jardín a la inglesa. Durante la guerra, el jardín y el castillo fueron arrasados siendo reconstruidos ambos pero se optó por recuperar los diseños barrocos originarios. Los trabajos acabaron en 1968.

Jardines de Herrenhausen en Hanover. Son jardines barrocos construidos en el siglo XVII. Durante la Segunda Guerra Mundial, el castillo y los jardines resultaron profundamente dañados. Se rehicieron para celebrar su tercer centenario en 1966. Son unos jardines cuidadosamente mantenidos. Sin embargo, en lo que coinciden los grandes estudiosos de la jardinería barroca Hennebo (28) y Hansmann (29) es que las reconstrucciones se hicieron al gusto moderno, reinterpretando y no reconstruyendo fielmente los trazados barrocos de Martin Charbonnier. Copiamos el comentario de W. Hansmann sobre la recuperación del jardín. "Por desgracia, en la recomposición y reconstrucción del jardín de 1936 y 1966 no se han observado con rigor las informaciones de las fuentes contemporáneas y así, por ejemplo, el parterre se compone en la actualidad de superficies alfombradas barroquizantes, según concepciones del siglo XIX, y de copias libres de un modelo de Dezallier d'Argenville que halagan, indudablemente, el gusto del público moderno, pero que no permiten reconocer nada de aquella reservada y elegante discreción deseada por la princesa electora"

El jardín de Muskau está situado en la actual frontera polaco-germana del río Neisser. Fue un lugar de fuertes combates en la contienda y la posterior división del mismo entre dos países ha ocasionado que sólo la parte alemana fuese reconstruida tras la Guerra.

Pomeranzengarten en Leonberg, a unos $20 \mathrm{~km}$. de Stuttgart. El castillo es de 1609 con unos jardines en terrazas en una ladera, diseñados a la manera italiana. En el siglo XVIII se abandonaron pero se mantuvo el diseño de los mismos. Los trabajos de restauración, basados en fuentes históricas y excavaciones arqueológi-

(28) HENNEBO, Dieter. "The Grosser Garten at Herrenhausen near Hanover". Páginas 192-194. Editado por Monique Mosser y Georges Teyssot.The History of Garden Design. Thames \& Hudson. Londres, 1991. Este autor señala lo siguiente: "The Grosser Garten at Herrenhausen is one of the few Baroque gardens to have survived in its essentials. However, a comparison with its original form and furnishings, which are recorded in numerous sources, shows that the comprehensive and highly commendable restorations in 1936/7 and 1960-66 did not always follow the historical evidence. This is particularly true of the planting of the Triangeln in the Nouveau Jardin and the structure of the parterres"

(29) HANSMANN, Wilfried. Jardines del Renacimiento y el Barroco. Ed. Nerea, 1989. La versión alemana apareció en 1983. Gartenkunst der Renaissance und des Barock, DuMont Buchverlag, Colonia. 


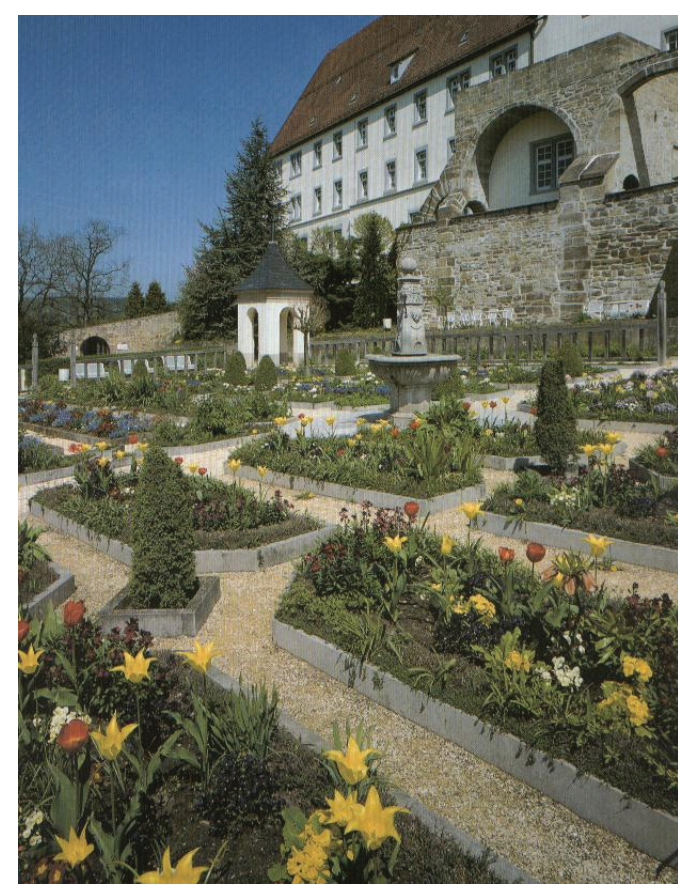

Pomeranzengarten en Leonberg (Stuttgart) considerada una de las reconstrucciones más fieles a la documentación histórica de las realizadas en Alemania.

(Foto de E. Kluckert)

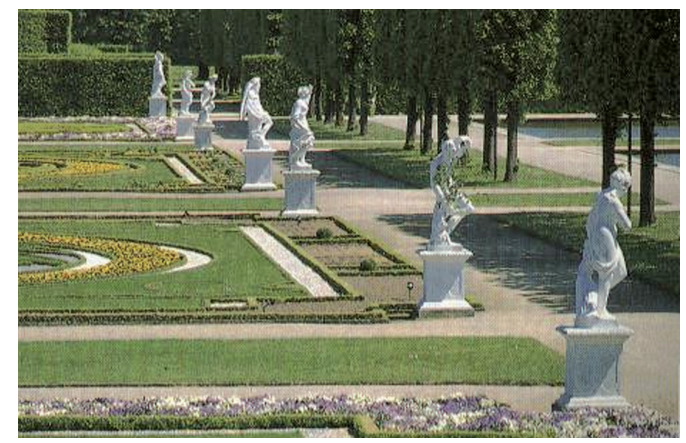

Herrenhausen. Vista de uno de los parterres reconstruidos en la década de 1960. (Foto de Olaf Enge y C. F. Schröer)

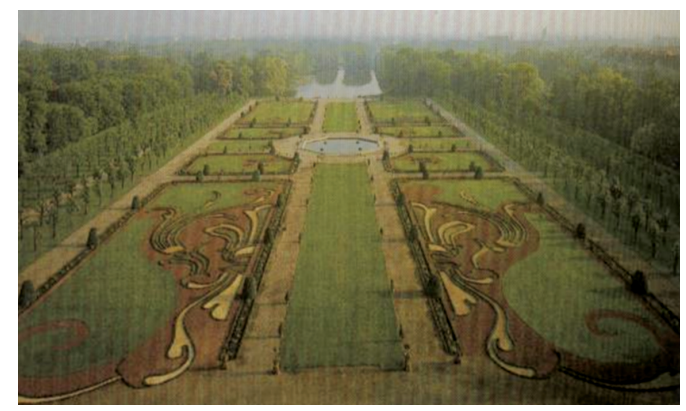

Berlin. Jardines de Charlottenburg. En la reconstrucción de estos jardines se optó por las trazas de Simón Godeau, discípulo de Le Nôtre, descartándose recuperar la posterior intervención de P. J. Lenné.

(Foto de Olaf Enge y C. F. Schröer) 
cas se realizaron entre 1974-1980. La recuperación de tal jardín, especialmente la parte llamada el Jardín de los Naranjos, está considerada "como una reconstrucción ejemplar de un jardín histórico y el mejor ejemplo de la herencia de la arquitectura paisajística alemana."(30)

También se restauraron en ese período los de Schleissheim en Munich; los de Schwetzingen en Baden-Württemberg; los de Zwinger en Dresde; el Hofgarten del Residenz en Würzburg (Baviera) y el Ludwigburg cerca de Stuttgart.

En Polonia, otro de los países cuyo patrimonio fue tan duramente dañado, se ha recuperado el jardín de Wilanów en Varsovia. En este caso es un jardín de origen barroco (1677) que tuvo aportaciones pintorescas y paisajísticas. Los criterios que se siguieron en este lugar fueron los de rehacer cada parte diferente del jardín tal como eran antes de su destrucción.

Otro de los países cuyos jardines sufrieron enormes perdidas fue Rusia, especialmente en la zona cercana a San Petersburgo, la antigua Leningrado de la II Guerra Mundial. La ciudad estaba rodeada de numerosos jardines del mismo período que el de la fundación de la ciudad por el zar Pedro el Grande. Algunos de ellos son los siguientes:

A unos $30 \mathrm{~km}$. al W de San Petersburgo se encuentran los de Peterhof hoy conocidos como Petrodvorets. Resultaron completamente arrasados en la guerra. Hoy están siendo reconstruidos.

Cercanos a los anteriores se hallan los de Oranienbaum, conocidos como Lomonosov desde 1948. Sus orígenes se remontan al comienzo del siglo XVIII. El XIX vio como se realizaban añadidos paisajistas. Durante los años 1975-1976 se rehicieron, recuperando sus trazas formales. Lo mismo ocurrió en los de

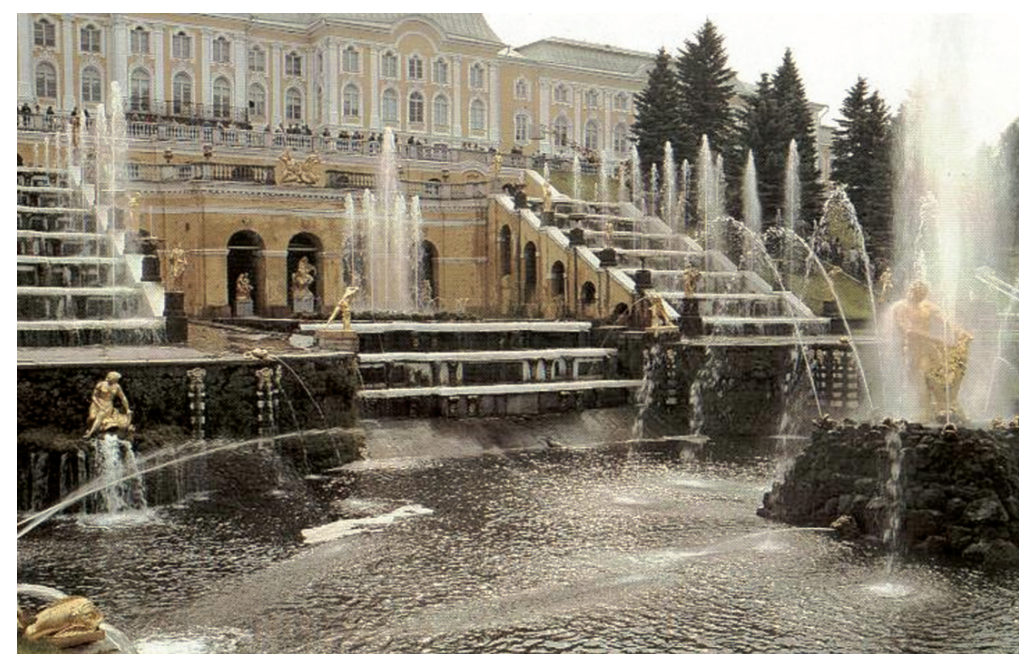

Los jardines de Peterhof fueron completamente reconstruidos tras los daños sufridos en la Segunda Guerra Mundial. (Foto de G. Bazin) 
Tzarkoe, actualmente Pushkin, cuyos diseños formales desaparecieron en el XIX para volver a ser recuperados después de la guerra a base de la documentación existente de la época barroca. Y lo mismo sucedió en Gatchina, esta vez al sur de la ciudad citada, cuyos jardines formales de estilo italiano y holandés resultaron muy dañados, estando en restauración en estos momentos.

Como se ve, todas estas intervenciones pusieron énfasis en la reconstrucción de los diseños formales del período barroco, abandonándose en la mayoría de los casos las opciones de la posible reconstrucción paisajística.

Y de todas formas, como ya señalábamos anteriormente, en ocasiones no se reconstruye con fidelidad histórica a pesar de contar con abundancia de documentación gráfica y escrita sobre los jardines sino que se tiende a reinterpretar los movimientos artísticos del pasado según los prismas y las modas de las tendencias estéticas modernas.

Esta corriente de actuación ante el patrimonio verde es la dominante en la Europa de posguerra y se va a ver continuada hasta hoy mismo tras la proclamación de la Carta de Florencia, aunque deberíamos utilizar el término entronizar para hablar con más propiedad.

Vamos a continuación a ver ahora de tres intervenciones que, aunque se salen del período anteriormente señalado de la estricta posguerra, tienen en común con las anteriormente tratadas el ser reconstrucciones de jardines a partir de referencias literarias o gráficas. Dichas obras se realizaron en Holanda, nos son conocidas de primera mano y una de ellas especialmente, la del Palacio de Het Loo tiene gran importancia pues sirvió de punto de referencia para numerosas obras de reconstrucción a partir de los años ochenta del pasado siglo.

Las dos primeras son reconstrucciones de pequeños jardines en la ciudad de Amsterdam de los años 60 y 70 del pasado siglo. Se trata de los jardines de los Museos Willet-Holthuysen y van Loon, ambos situados en los canales del centro de la ciudad (Herengracht y Keizersgracht).

El primero de ellos, el de Willet-Holthuysen, no tenía jardín. Se reconstruyó en 1973 según los modelos de jardinería francesa imperantes en el siglo XVIII importados por el francés Daniel Marot (1663-1752), un hugonote que encontró refugio en Holanda tras la revocación del Edicto de Nantes.

El diseño está basado en un rectángulo en cuyo exterior existe una platabanda con plantas de flor. Este marco ciñe dibujos geométricos hechos de boj y gravas de colores. Lo que sería un parterre de broderie según la clasificación de A. J. Dezallier d'Argenville (1680-1765) en su obra clásica (31). Las paredes laterales colindantes con los vecinos se plantaron de tilos en espaldera pero la falta de luz produio su muerte existiendo hoy trepadoras de sombra como la hiedra.

(31) DEZALLIER D’ARGENVILLE, Antoine Joseph. La Théorie et la Practique du Jardinage. París, 1760. Hay un resumen en la obra de Wilfried Hansmann Jardines del Renacimiento y del Barroco. Ed. Nerea. Madrid, 1989. 


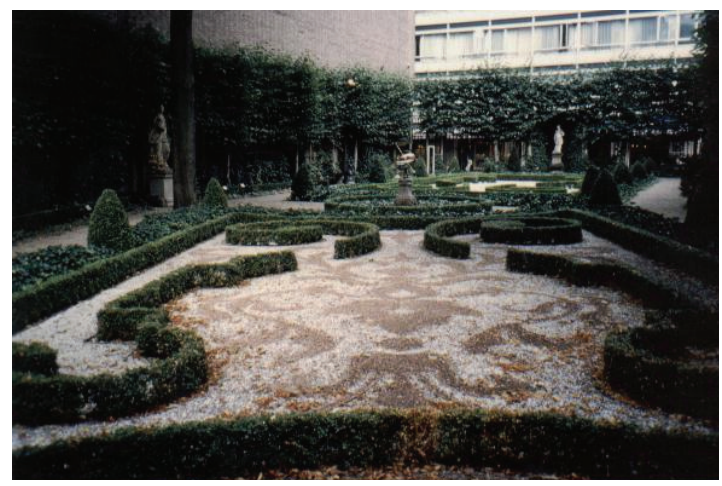

Museo Willet-Holthuysen. Reconstrucción del jardin barroco francés

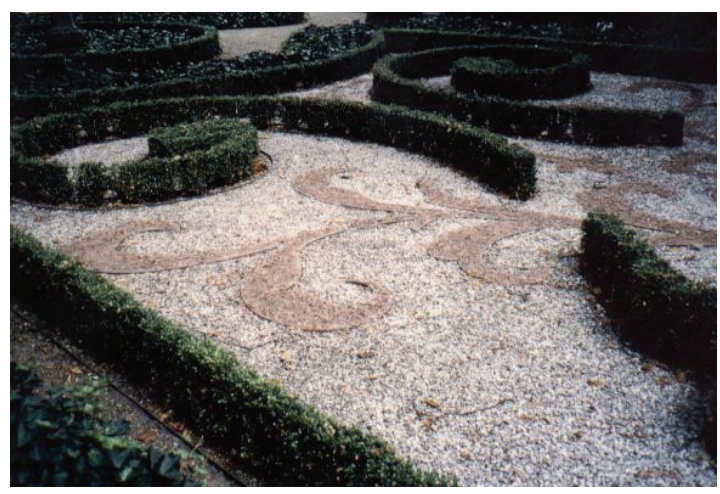

Museo Willet-Holthuysen: Detalle de los dibujos de boj.

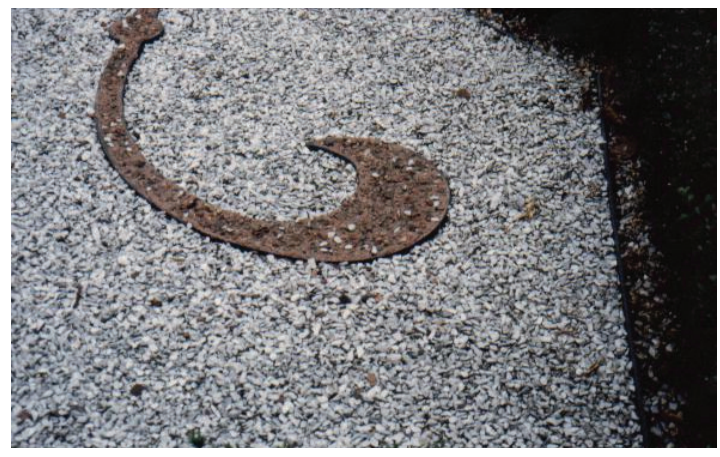

Museo Willet-Holthuysen. Detalle de los dibujos hechos de gravas coloreadas

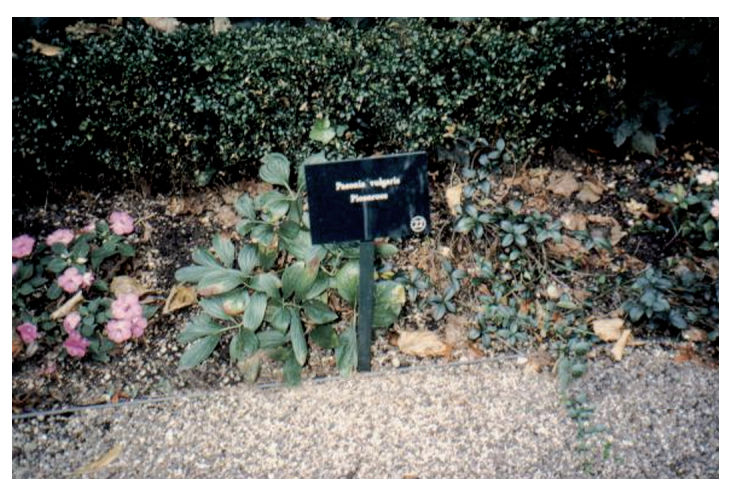

Museo Willet-Holthuysen. Mezcla de plantas utilizada en la recreación sin ningún criterio: al lado de las peonías pueden encontrase alegrías de la casa. (Fotos del autor) 
Las plantas de flor son de dos tipos. Las que corresponden al momento de la recreación del jardín son del período barroco y aún conservan las etiquetas originales de cuando se inauguró el lugar. Algunas de ellas son el hisopo (Hyssopus officinalis); las peonías (Paeonia vulgaris); la saponaria (Saponaria officinalis); la rosa (Rosa officinalis); el díctamo blanco (Dictamus albus); el acanto (Acanthus mollis)y el acebo (Ilex aquifolium).

Posteriormente se recurrió a otro tipo de plantas para dar color a estos parterres entre las que se encuentran algunas completamente fuera del contexto de lo que debe de ser la reconstrucción histórica de un jardín barroco. Algunas de éstas son la alegría de la casa (Impatiens wallerana); la camelia (Camelia sasanqua) y la que más chirría entre todas, la vincapervinca variegata (Vinca minor "argentea variegata").

El otro jardín pertenece al Museo van Loon creado en los años setenta del pasado siglo. El jardín fue diseñado de nuevo inspirándose en los grabados de vista de pájaro del Amsterdam del siglo XVII.

Todo el proyecto de recreación del jardín se encuentra en el archivo de la casamuseo y puede ser consultado por cualquier persona interesada en el tema.

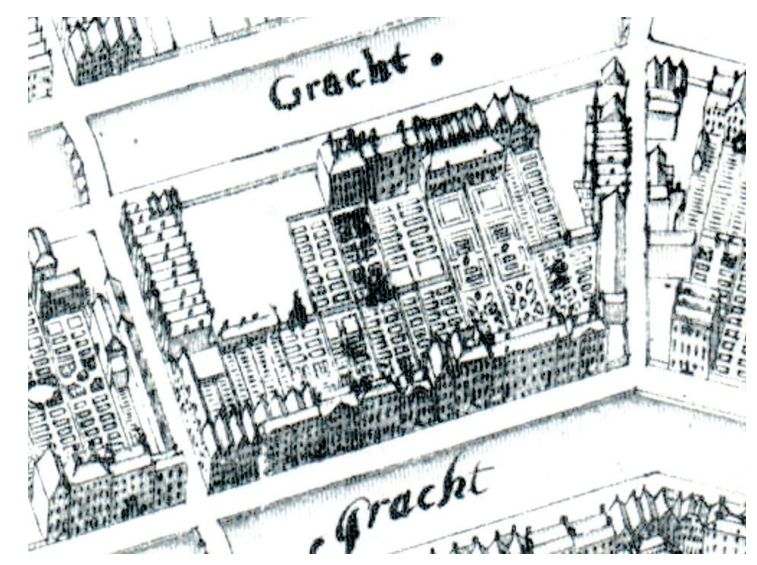

Estos grabados sirvieron de inspiración para la recreación del jardín van Loon

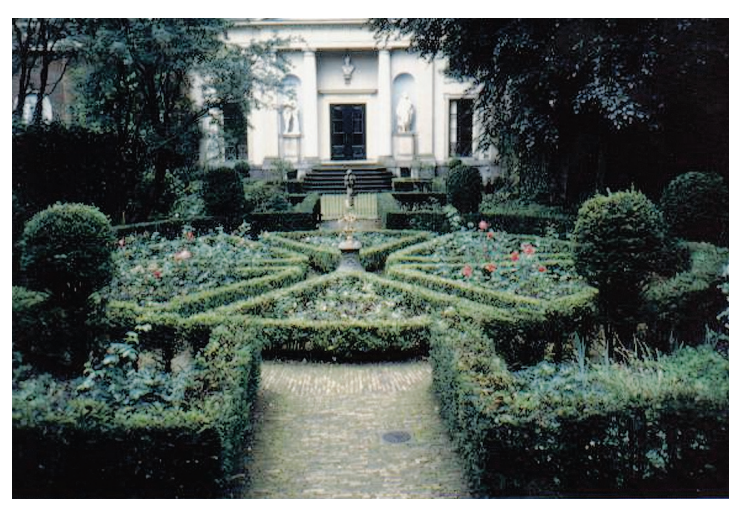

Museo van Loon. El jardín desde la casa con las caballerizas decoradas como templo clásico al fondo. (Foto del autor) 
Es una reconstrucción cuidadosamente hecha, de gran sencillez y elegancia. Se conservó un gran ejemplar de haya existente en el lugar y son notables las tapias de separación de los jardines vecinos recreadas a la antigua usanza.

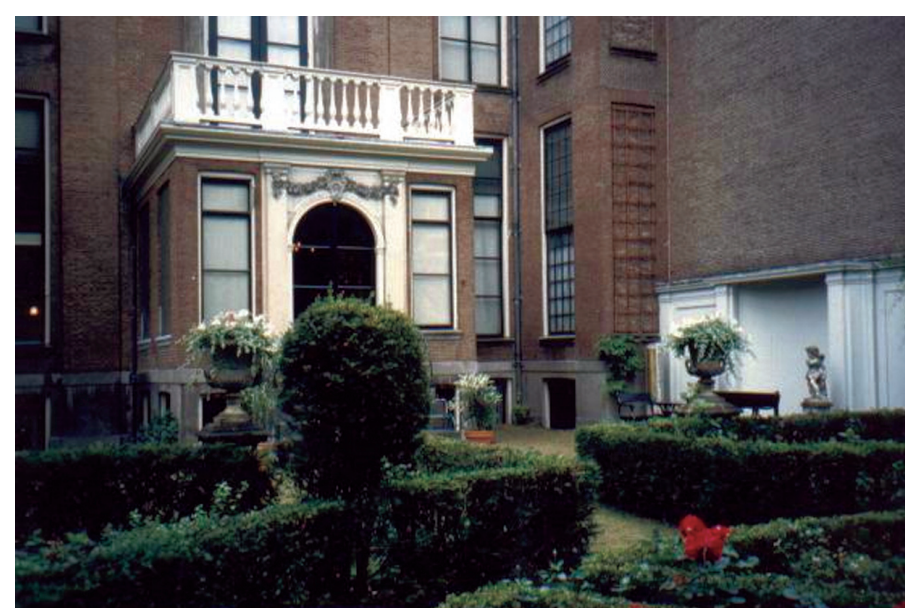

Museo van Loon. El cuarto de estar de la casa desde el jardín.

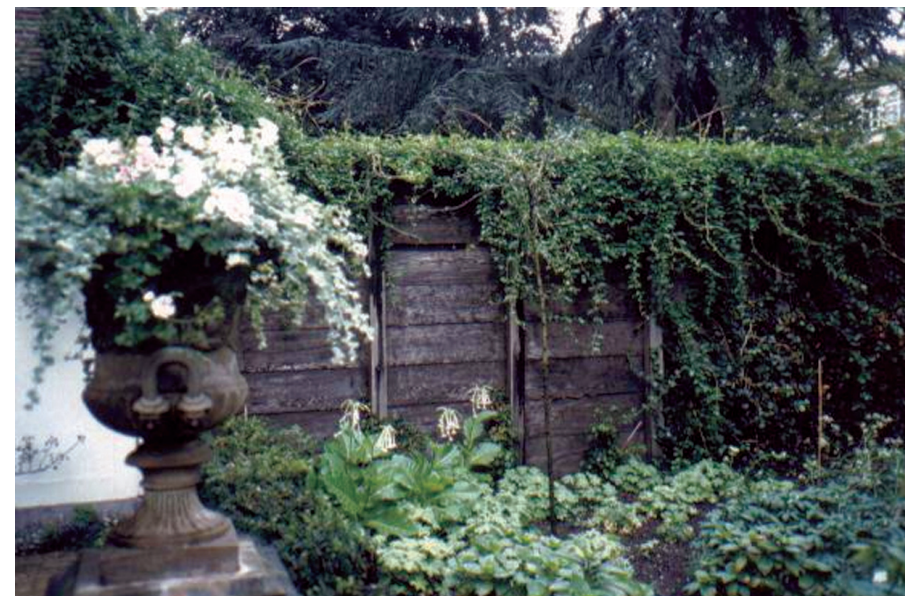

Museo van Loon. Tapias de separación vecinal hechas de tablones de madera.

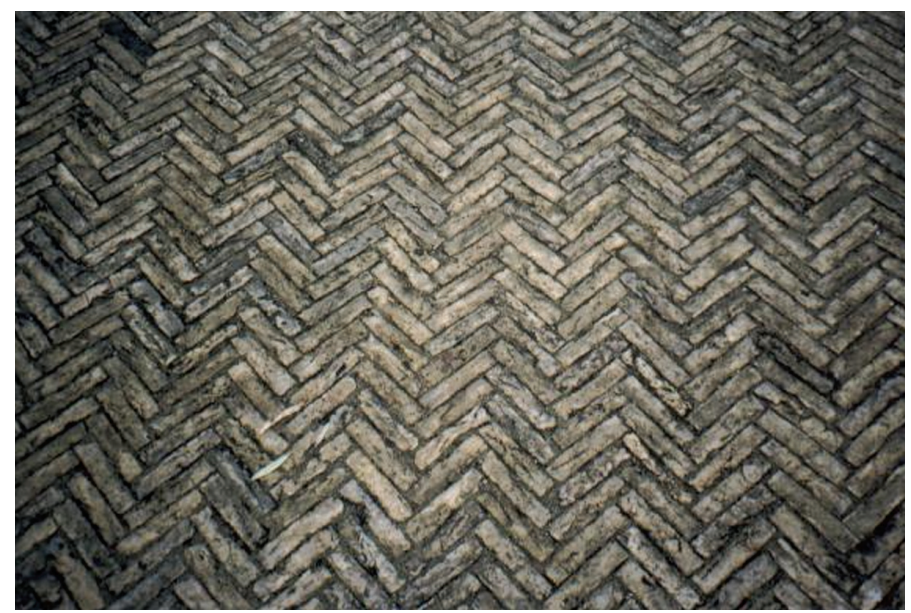

Museo van Loon. Detalle de los suelos del jardín.

(Fotos del autor) 
El otro jardín que trataremos es el de Het Loo. Antes de entrar a analizar su reconstrucción, veremos brevemente algunos datos históricos para conocer las distintas fases que el jardín ha tenido hasta que se llevó a cabo la recreación barroca de hace unos años.

Het Loo está en Apeldoorn, a unos $60 \mathrm{~km}$ al este de Amsterdam y es palacio real. Su construcción es del siglo XVII. Guillermo III (1650-1702) encargó a Jacob Roman (1640-1716) la construcción del edificio y a Daniel Marot (1661-1752) su decoración interior y los jardines. Este último, discípulo de Le Nôtre, era hugonote y tuvo que huir a Holanda tras la revocación del Edicto de Nantes en 1685. Como señalábamos anteriormente estos arquitectos fueron los responsables de unos jardines claramente arquitectónicos, con ejes de simetría bien marcados donde los parterres mostraban dibujos de boj con gran adorno de estatuaria y fuentes.

Rodeando a este jardín formal se extiende un parque de tipo paisajista tras las intervenciones del siglo XIX de $650 \mathrm{Ha}$. Tras este parque existen el bosque y los brezales que alcanzan una superficie de $11.000 \mathrm{Ha}$.

El programa del jardín al parecer, se basaba en la exaltación del agua como origen de la vida. Situado entre los ríos Isel y Rin, ésta se trajo desde kilómetros de distancia a través de cañerías para dar presión a los surtidores de las fuentes más significativas del jardín o bien se almacenaba en grandes estanques para ser posteriormente repartida entre las numerosas fuentes y juegos de agua presentes en el lugar. Los principales elementos arquitectónicos fueron los muros y la potente columnata que cerraba la parte superior del jardín. Estos se piensa que se construyeron más para proteger al lugar de las arenas que el viento portaba que para aislarlo del exterior.

Dentro de esta área vallada se construyeron elementos de diversión y disfrute como laberintos, bosquetes, caminos de formas geométricas, montañas y canales los cuales en algunos tramos hicieron monogramas de los reyes Guillermo y María.

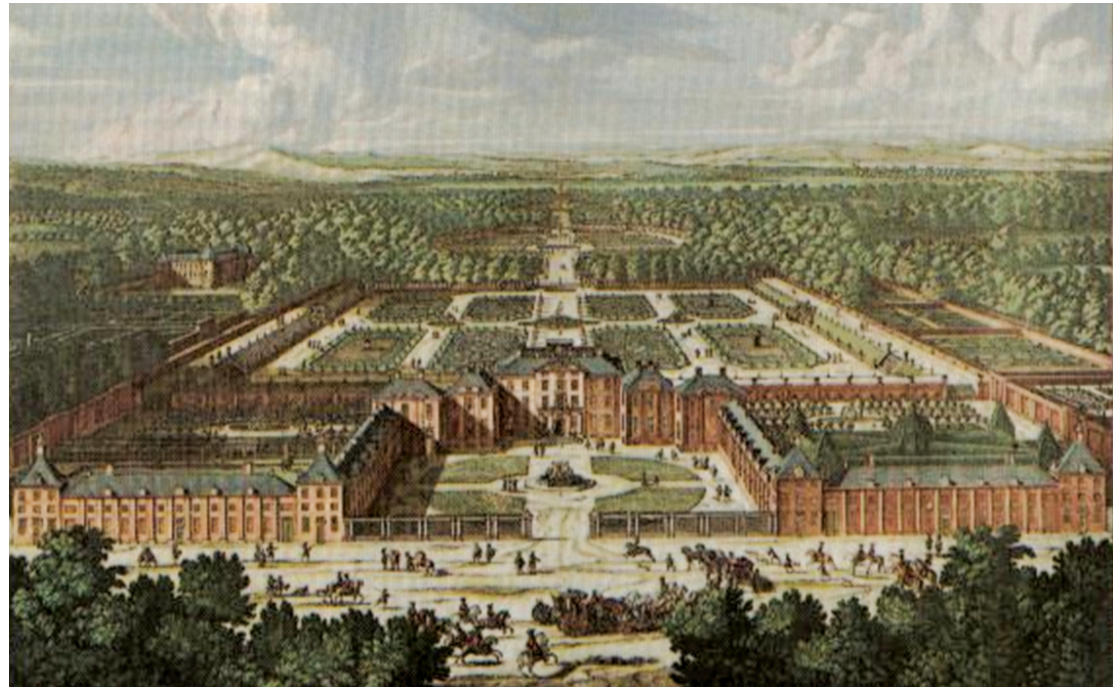

Het Loo hacia 1700 según un grabado coloreado de Petrus Schenk (1660-1719) 
En resumen, un típico jardín barroco francés con los añadidos de plantas curiosas a las que tan aficionados eran los holandeses ya por aquel entonces.

Durante el siglo XVIII el lugar se continuó utilizando como cazadero y residencia veraniega. Guillermo V (1735-1806) hace remodelar el jardín superior al arquitecto Philip W. Schonck (1735-1823) al estilo paisajista. Cuando este príncipe huye del país en 1795 los jardines cayeron en un abandono total.

El palacio cambió de aspecto radicalmente entre 1807-1809 cuando Louis Napoleon (1778-1846), hermano de Napoleón, llegó a ser rey de Holanda en el período que va de 1806 a 1810. Este encargó en su breve reinado al arquitecto Alexandre Dufour (1750-1835) una remodelación del palacio y su entorno en el cual se incluyó el inmenso parque y los jardines. Dicha remodelación fue curiosa.

La parte trasera del palacio -lo que ha sido recuperado hace unos años- fue convertida en una inmensa superficie de césped salpicada de grupos de árboles diferentes. Para lograr la uniformidad de esta gran superficie, las terrazas fueron

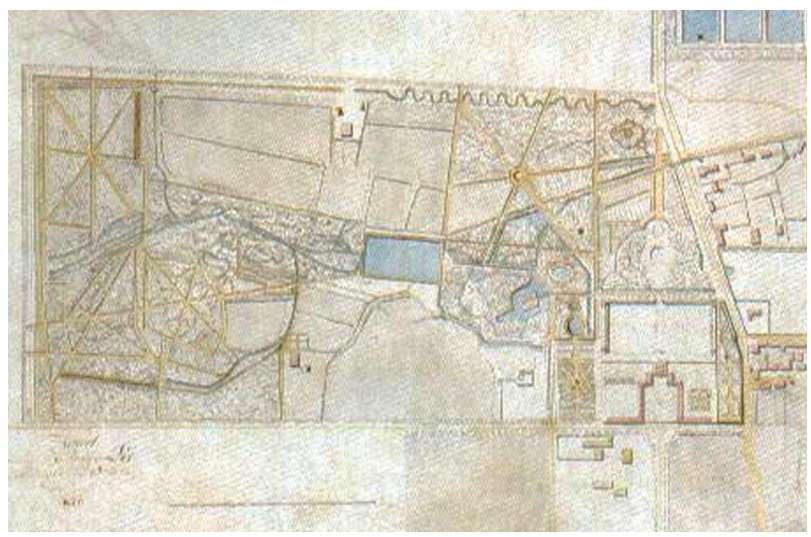

Plano del jardin y el parque en 1806 por Maximiliano J. de Man (1765-1838) antes de su transformación paisajista

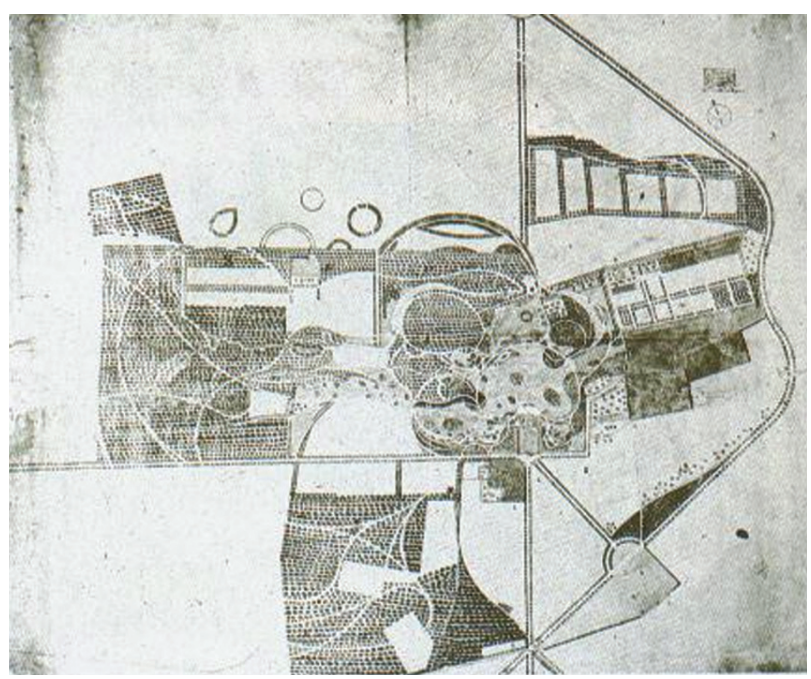

Plano del jardin y el parque tras la intervención paisajística de 1812. Acuarela de P. Broekhoven 
eliminadas y las zonas bajas se rellenaron con tierra hasta alcanzar el nivel requerido. Se llegó hasta rellenar el foso de la vieja fortaleza medieval y toda la gama de artificios hidráulicos desaparecieron. Sin embargo, en la parte frontal del palacio, los diseños barrocos de caminos rectilíneos se mantuvieron.

Tras el hundimiento del imperio napoleónico, los nuevos monarcas no rehicieron el jardín barroco y las intervenciones realizadas fueron en la línea del jardín paisajísta de moda en ese momento. Así Guillermo I vació las peceras para construir dos lagos en cuyas orillas plantó numerosos rododendros. Su nieto Guillermo III, gran amante de las plantas, creó un arboreto pero tampoco recuperó los diseños barrocos.

Durante el siglo XX los diversos monarcas utilizaron Het Loo como residencia de verano o de retiro, manteniendo los jardines y el parque casi en el mismo estado que lo habían recibido.

Es en 1970 cuando se decide convertir el palacio en un museo nacional y en 1974 se establecen los criterios de eliminar los añadidos y transformaciones de los siglos XIX y XX tanto en las edificaciones como en los jardines para lograr la unidad entre la residencia real y su entorno.

Estos trabajos se llevaron a cabo entre 1977 y 1984.

En el congreso del ICOMOS-IFLA (32) de 1975 celebrado en la ciudad de Zeist, Jan van Asbeck ya expone la intención de convertir el palacio y parte del jardín en un museo público dedicado a la Casa de Orange.

Esta intervención llevará a cabo las siguientes medidas con el fin de devolver a Het Loo su anterior magnificencia:

a) Eliminación de los añadidos de principios de siglo que deforman el aspecto exterior del Palacio.

b) Rehacer el jardín formal con el fin de proteger el extenso parque paisajísta que lo rodea.

c) Dividir el parque en tres partes. Estas divisiones se proponen por motivos de seguridad y protección medioambiental. Se lograrán a través de la reconstrucción de los antiguos muros, algunos de cuyos fragmentos aún se conservan.

El primero separará el viejo castillo del siglo XIV o "Viejo Loo" para Su Majestad la Reina Juliana; el segundo aislará la residencia moderna de S. A. R. la Princesa Margarita y el tercero es el que marcará los jardines nuevos y el Museo Nacional del resto del parque. Jan van Asbeck señala que dicho 
cierre redundará en la conservación del parque paisajista. La zona de los jardines formales y del Museo con una superficie de 6,5 Ha representa el 1\% de la superficie total de la posesión. El concentrar los visitantes en esta superficie reducida -entonces eran 3.200 las personas que visitaban diariamente el parque y era el año 1975 esperándose un aumento de 5.000 a 6.000 los visitantes tras las obras- produciría la conservación del medio natural de modo innegable ya que es más fácil absorber los numerosos visitantes en un jardín de tipo formal que en uno de las características anteriormente señaladas.

d) Abatir los árboles viejos con el fin de recuperar la estructura original del edificio.

El argumento que sostiene el cuarto punto no tiene desperdicio. Las palabras textuales, procedentes de la obra citada del ICOMOS-IFLA son las siguientes: "Les groupes d'arbres du parc actuel présentent, sur tout en été, un aspect agréable. Mais à les examiner de plus près, on remarque que certains sont dans un état de vieillissement avancé, ou malades; on voit même des arbres morts et des souches. Le palais blanc et le parc forment une unité. Si l'on veut conserver coûte que coûte les vieux arbres autour du palais, il faut également conserver le parc dans son état actuel, et avec le parc il faudra aussi conserver, en bonne logique, le palais blanc, avec son étage surélevé. Dans ce cas, on préfère conserver une arquitecture remaniée et des déformations (qui altèrent la conposition d'origine) auxquelles les Princes d'Orange n'ont en aucune part. On opte alors pour un musée qui no pourra pas remplir convenablement sa mission -rendre hommage aux Princes d'Orange- parce que le palais n'aura pas retrouvé sa structure d'origine. Toutes ces conséquences trouveraient leur origine dans la valeur trop grande que l'on accorde à des arbres déjà très âgés et qui, de toute façon, ne sont pas éternels."

Tomada la decisión de rehacer el jardín, ésta se basó por un lado en las numerosas fuentes gráficas existentes (pinturas, grabados, dibujos, etc.) y literarias así como en los tratados de jardinería y botánica de la época. Igualmente fue importante la documentación obtenida de las excavaciones arqueológicas realizadas en el jardín.

Respecto a las fuentes gráficas hay que señalar que Het Loo es uno de los jardines de los que más se conservan pinturas y grabados (30). De entre éstos, los de mayor utilidad para los trabajos fueron:

a) El atribuido a Jacob Roman (1640-1716) fechado hacia 1692.

(33) En la obra "The Anglo-Dutch Garden in the Age of William and Mary" en Journal of Garden History, Vol. 8, n² y 3, abril y septiembre de 1988. Editado por John Dixon Hunt y Erik de Jong en la página 147 se hace una relación completa de los artistas que participaron en Het Loo así como la finalidad de estas obras unidas a la concepción de propaganda de la realeza. 
b) El de Romeyn de Hooghe a quien además se debe una breve descripción del lugar y últimamente se le ha atribuido más importancia de la que en un principio parecía en el diseño del jardín.

c) Los de C. Allard (1648-1706) de gran interés por reflejar zonas muy concretas del jardín. Algunos de ellos se han reproducido casi literalmente.

d) Grabados de Daniel Marot.

e) Acuarela de Christiaan Pieter van Standen. Esta obra, fechada hacia comienzos del XVIII, es la que sirvió de modelo para la traza de los actuales parterres.

En la página siguiente veremos un detalle del mismo grabado, el patio de la izquierda o Jardín del Rey y una foto con el resultado de la reciente reconstrucción.

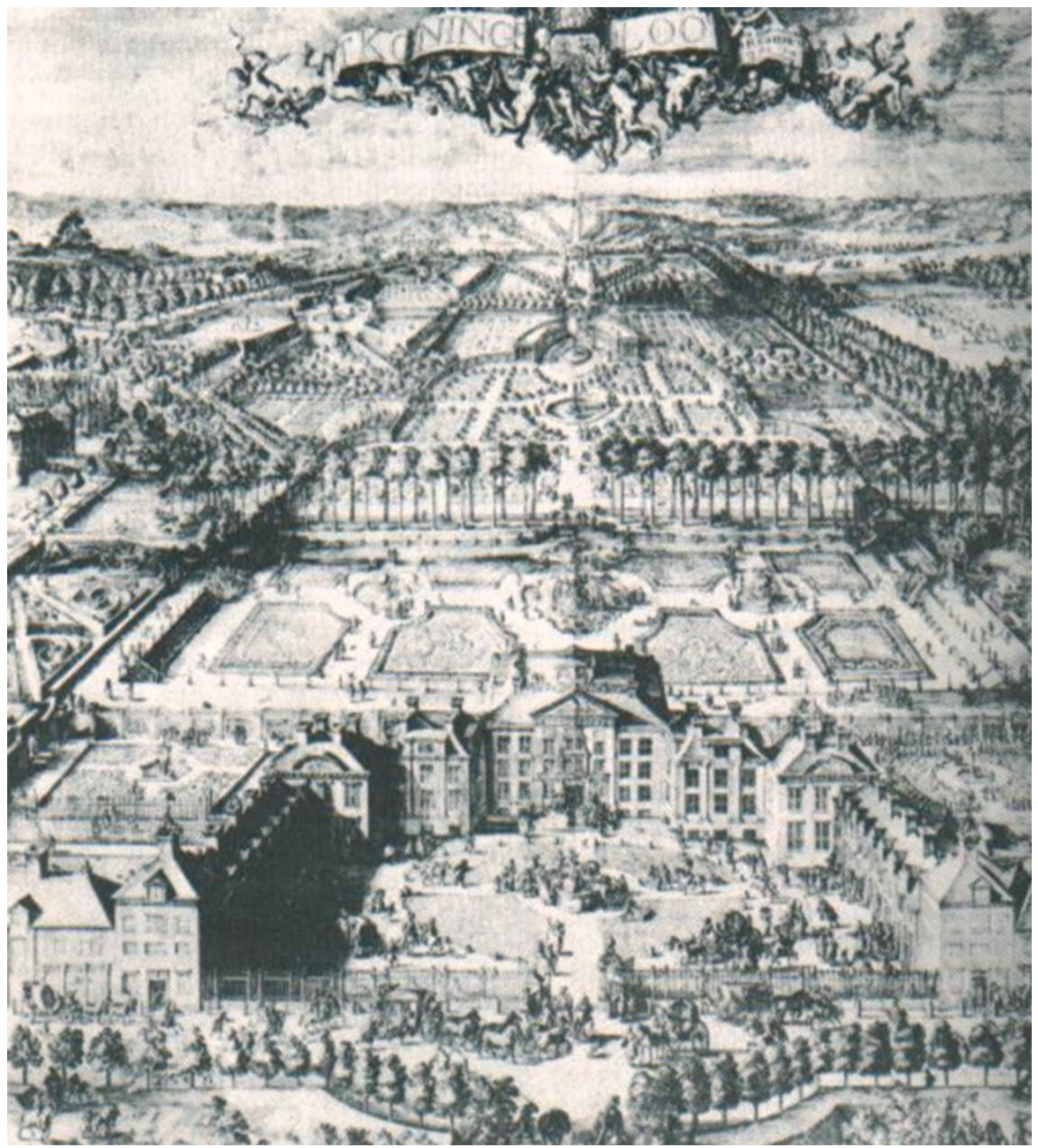

Vista general de Het Loo en el grabado de R. de Hooghe. 


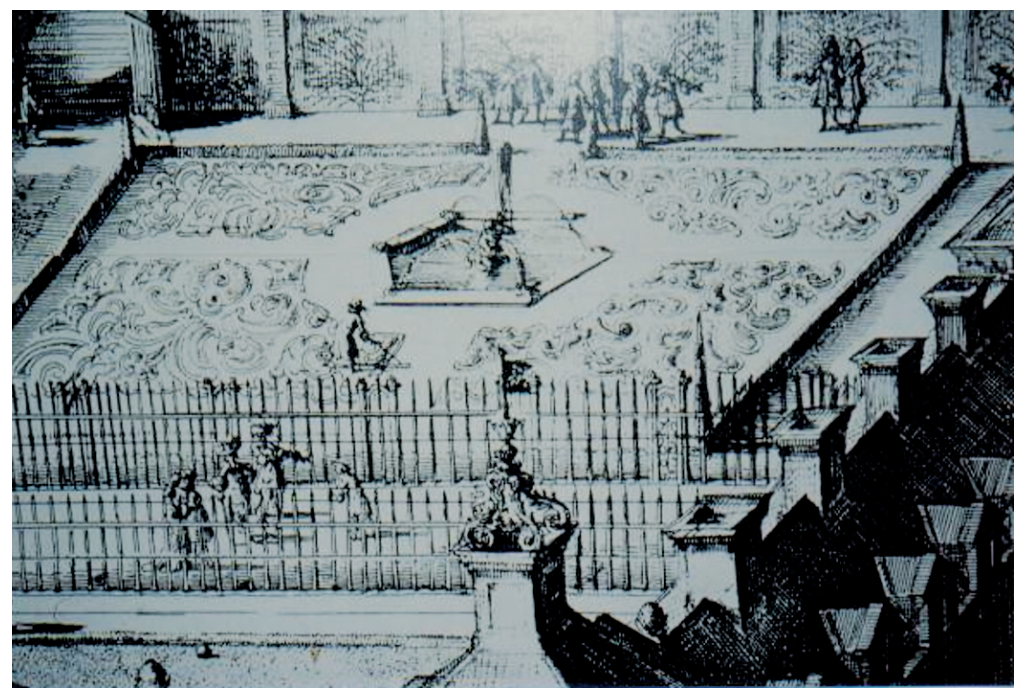

Detalle del grabado anterior donde se aprecian los parterres barrocos del Jardín del Rey

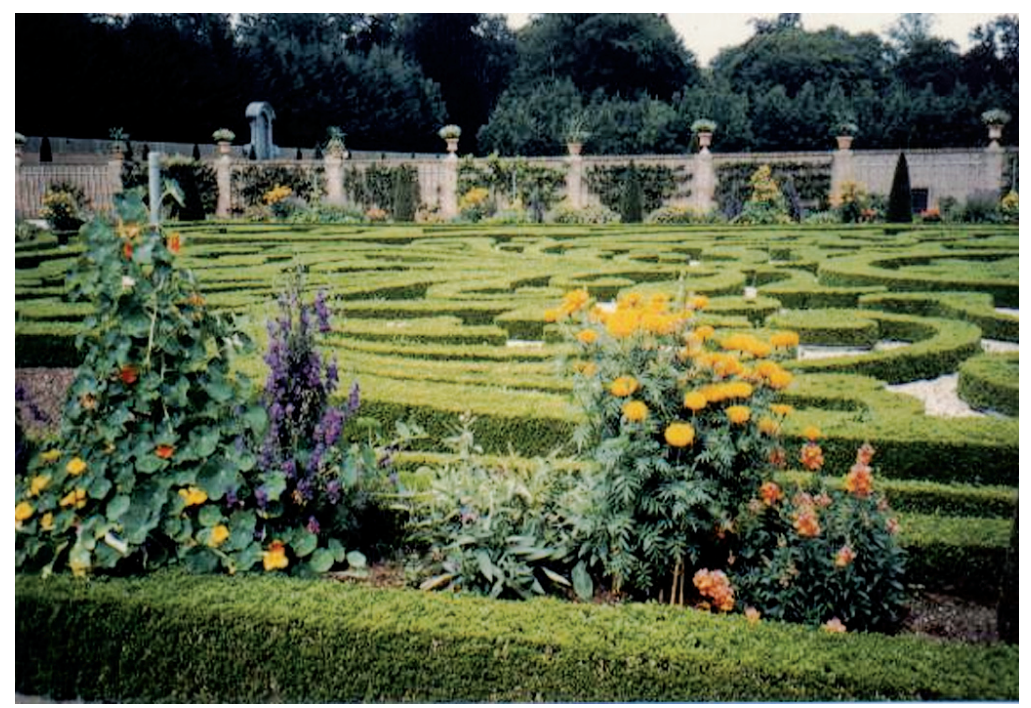

Estado actual del Jardín del Rey. Las plantas están elegidas por el color de sus flores - azul y naranja-colores de la casa de Orange-Nassau. (Foto del autor)

Las referencias literarias son de dos tipos. Unas son descripciones del jardín. Entre éstas destacan las de R. de Hooghe "A short description of the King's Loo" y la del médico antes mencionado Walter Harris quien nos regala una descripción completísima del estado del jardín durante su estancia en el palacio. Esta obra titulada "A Description of the King's Royal Palace and Gardens al Loo. Together with a Short Account of Holland. In Which there are some Observations relating to their Diseases" London. R. Roberts, 1699, fue un encargo de la reina tras su partida de Holanda para hacerse cargo del trono inglés. Su importancia radica en la minuciosidad empleada por el Dr. Harris que llega hasta dar las medidas exactas de los caminos y parterres o relaciones del tipo de materiales empleados en la construcción. Es especialmente amplia la relación de estatuas y fuentes presentes 
en el lugar. Sin embargo, el mundo vegetal lo trata brevemente y apenas superan la docena las plantas por él mencionadas (34).

Las otras referencias son las que comprenden la correspondencia privada de los Reyes así como la relación de los gastos hechos en las diversas posesiones. Estas se encuentran en el Archivo del Consejo de las Posesiones de Nassau y en los Archivos Oficiales y Administrativos de los Principes de Orange. Son citados en la Guía del Palacio y los Jardines como una de las fuentes principales para conocer los detalles del pago a los escultores y demás artistas y las fechas en que aquellos entregaron sus obras. Estas fuentes no se han podido consultar directamente para la redacción de la tesis.

Las otras fuentes escritas que han sido de gran utilidad para la recuperación del jardín son los tratados botánicos y de horticultura de la época. Los principales que aparecen citados en la Guía son: Johannes van der Groen, Hovenier and van Sijn Doorluchtige Hoogheydt, Den Heere Prince van Orangien, Den Nederlandtsen Hovenier, zijnde het I. Deel van het Vermakelyck Landtleven, Amsterdam, 1699; C. van den Passe, Den Blomhof, Utrecht, 1614; H. Cause, De Koninglijcke Hovenier, Amsterdam, 1676; A. Munting, Nauwkeurige Beschrijving der Aardgewassen, Leiden en Utrecht, 1696.

Existe un resumen de estos trabajos en la antología del ICOMOS-IFLA anteriormente citada dedicado a las plantas ornamentales de los siglos XVI y XVII (35).

En el mismo artículo se tratan de los problemas de su uso en la restauración de los jardines históricos así como la dificultad de definir con exactitud algunos de los ejemplares citados en las obras antiguas por la variabilidad de las nomenclaturas utilizadas por los diversos autores hasta la llegada de Linneo. Por su interés, la lista de plantas está disponible en el Apéndice Documental $n^{\circ} 6$ de este trabajo.

Otro de los aspectos de relativa importancia que se tuvo en cuenta en Het Loo fue el uso simbólico de las plantas. En la parte del Jardín del Rey se utilizaron las plantas de color azul y naranja, colores de la Casa de Orange-Nassau. En el Jardín de la Reina se emplearon las plantas consideras "femeninas" por estar de alguna manera relacionas con la iconología mariana tales como las azucenas o las aquilegias.

(34) En el número extraordinario del Journal of Garden History dedicado a la jardinería holandesa e inglesa anteriormente citado, se recoge la descripción del Dr. Harris en el primero de los apéndices. Textualmente dice: "The Beds and Parterres of this and the other Gardens, are not only adorned with Pyramids of Juniper and Box, and with Shrubs of Marshmallows of all colours, but contain variety of Flowers, which successively blow according to the Seasons of the Year. In the Spring there is a variety of the finest Tulips, Hyacinths, Ranunculi, Anemone, Auricula urst, Narcissus, Junci, \&c. In the Summer there are double Poppies of all colours, Gilliflowers, Larks-heels, \&c. In the Autumn, the Sun-flower, Indian Cresses, the Pass-rose, or Stock-rose, Marygolds, \&c. On the walls of these Gardens do grow great variety of most excellent Fruit, as the best Peaches, Apricots, Cherries, Pears, Figs, Plums, Muscat Grapes of all sorts; and their props are every where painted Green."

(35) C. S. OLDENBURGER-EBBERS y J. HENIGER " Ornamental plants in the $16^{\text {th }}$ and $17^{\text {th }}$ Century Gardens" en Tercer Coloquio Internacional sobre la Conservación y restauración de Jardines Históricos. Zeist, 1975. Págs. 107-121. En la obra Jardins et sites historiques. ICOMOS. Fundación Cultural Banesto. Madrid, 1993. 
Tras señalar todos estos puntos que entran en el campo de los criterios metodológicos, pasemos a ver el proceso de reconstrucción.

El director como ya se ha señalado anteriormente fue el barón Jan van Asbeck asesorado por funcionarios del museo y una comisión de expertos de diversos campos. Las bases de actuación se tomaron partiendo de toda la información histórica disponible. Solamente se abandonaron estos principios por razones de naturaleza práctica o financiera.

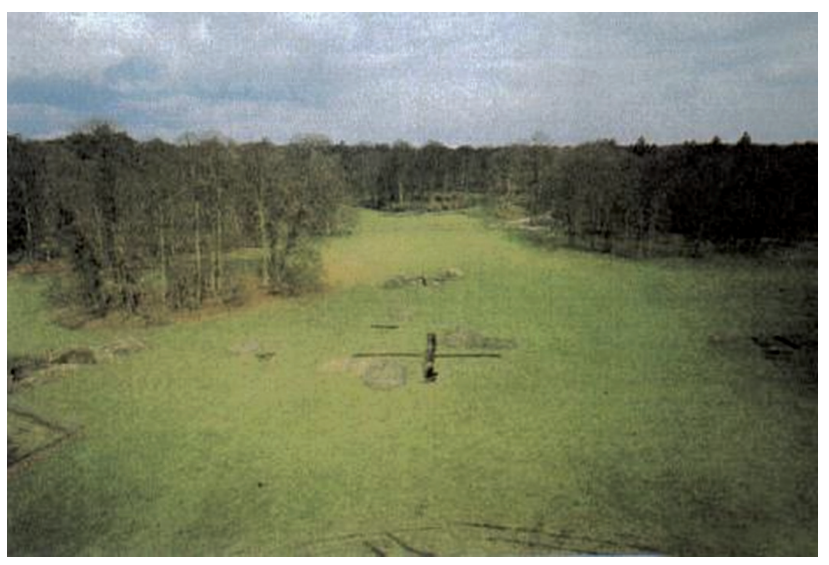

Estado del jardín de Het Loo en 1975 antes de las obras

Lo primero que había que decidir era qué árboles se eliminaban. En la zona más cercana al Palacio, en los jardines bajos o los del Rey y la Reina, se cortaron todos a excepción de un arce en el Jardín del Rey por ser un regalo de la reina Juliana a su madre, la reina Guillermina. Sin embargo, en el jardín superior, sólo se talaron aquellos que molestaban para construir las fuentes, muro y columnata dejando algunos ejemplares magníficos como testimonio de la plantación paisajista de 1780 .

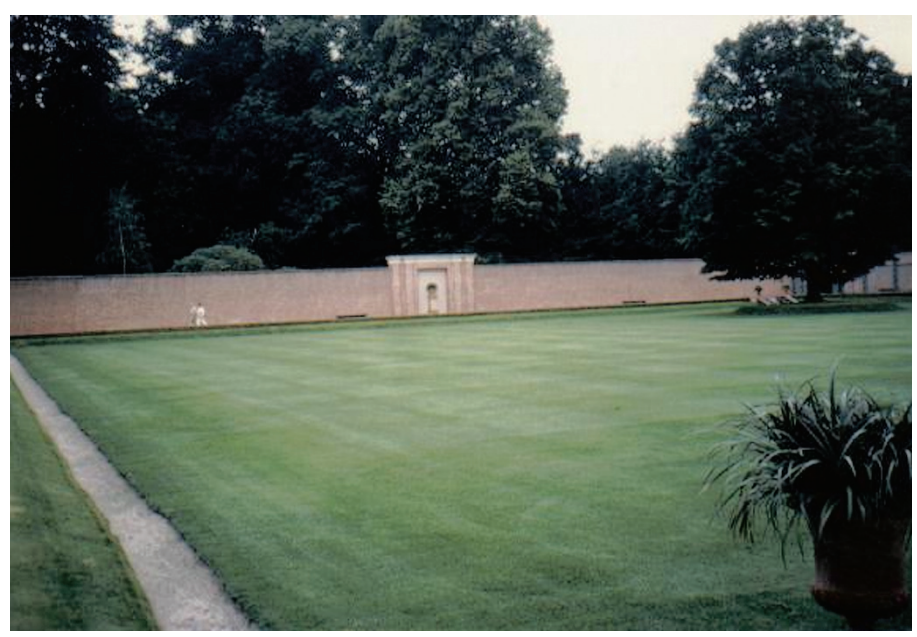

Het Loo. Jardín del Rey. Al fondo de la pradera, a la izquierda, puede verse el arce regalado por la reina Juliana a su madre que se decidió conservar. (Foto del autor) 


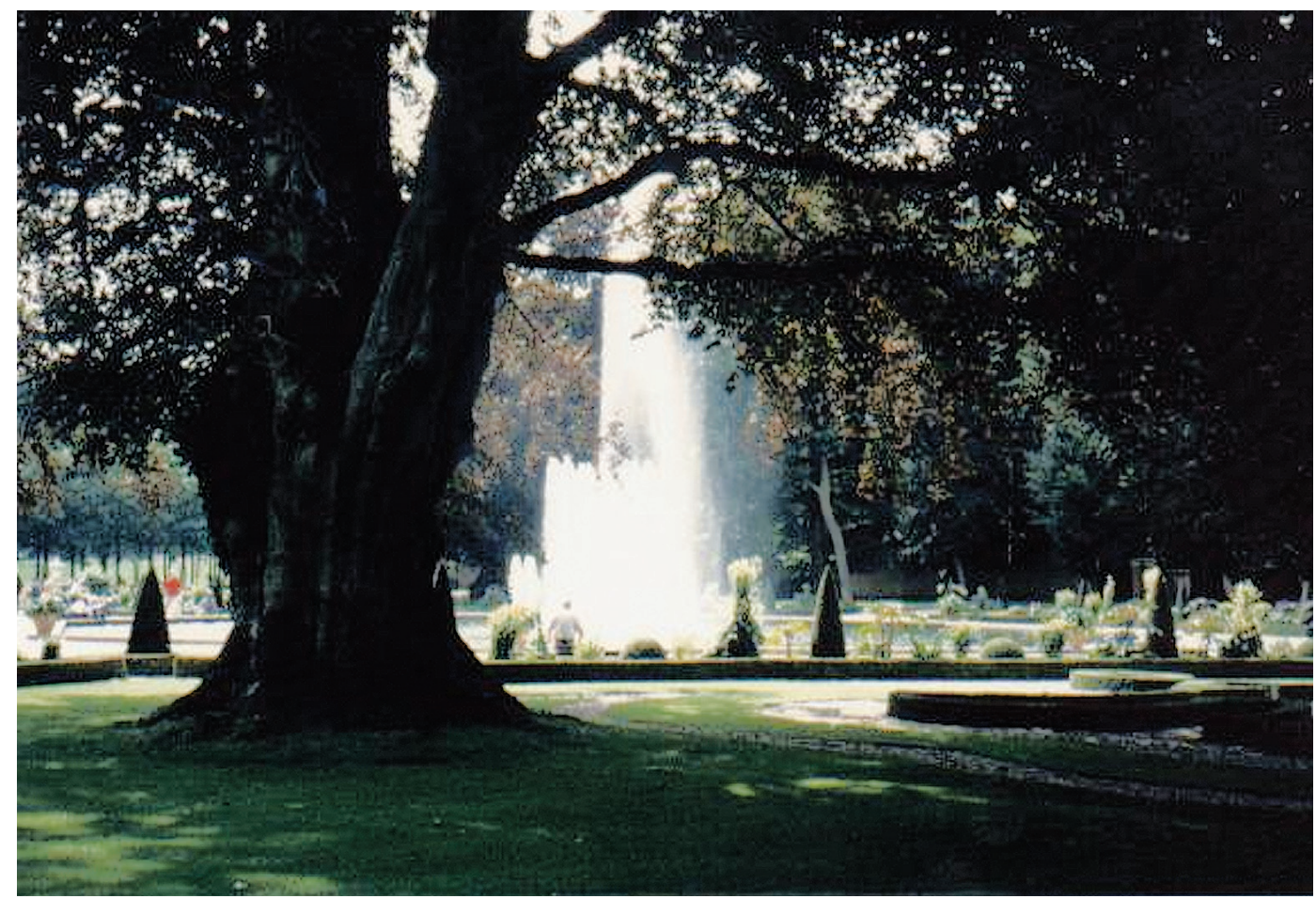

Het Loo. Jardín superior. Uno de los grandes ejemplares de haya roja que se mantuvo tras la recuperación del jardín formal. (Foto del autor)

Tras esto, se empezó a vaciar la superficie de la arena que lo había rellenado el siglo XIX. Al mismo tiempo se levantaron los muros. Estos se hicieron de hormigón para ser posteriormente forrados con ladrillos idénticos a los encontrados de época en el jardín.

Los trabajos arqueológicos realizados a la vez que el vaciado de las arenas fueron mostrando algunos de los componentes del antiguo jardín que yacían enterrados tales como la base de la fuente del Globo Terráqueo o de los canales lo cual permitió por analogía rehacer los elementos perdidos.

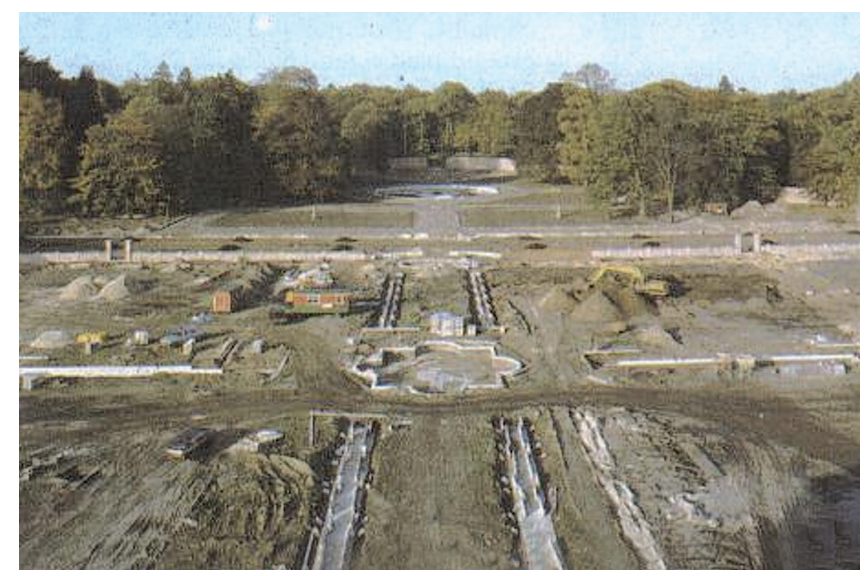

Het Loo. Estado de la excavación del jardín central en 1988 


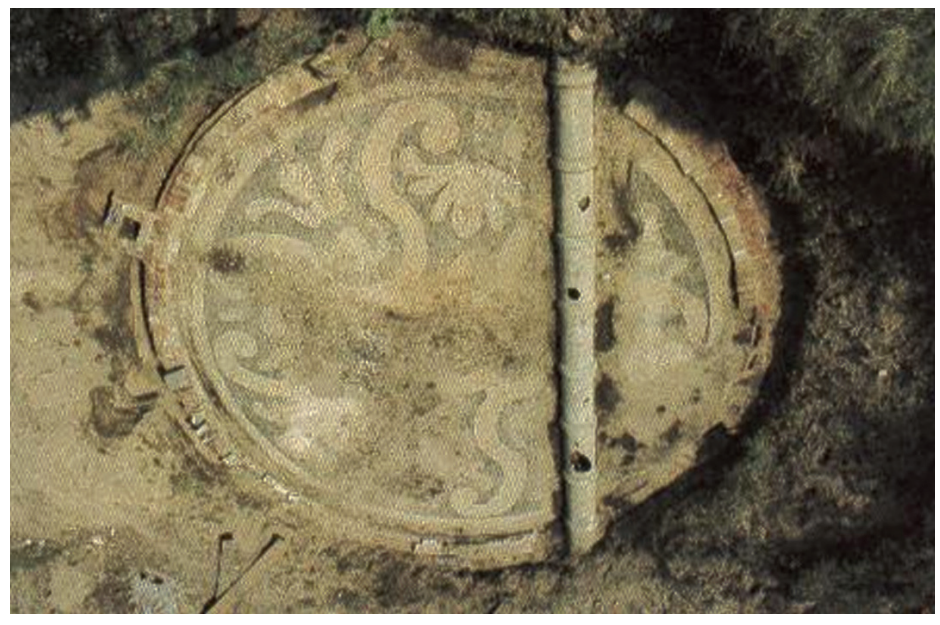

Het Loo. Base de la fuente del Globo Terráqueo y una de las conducciones de agua. Excavaciones del año 1982

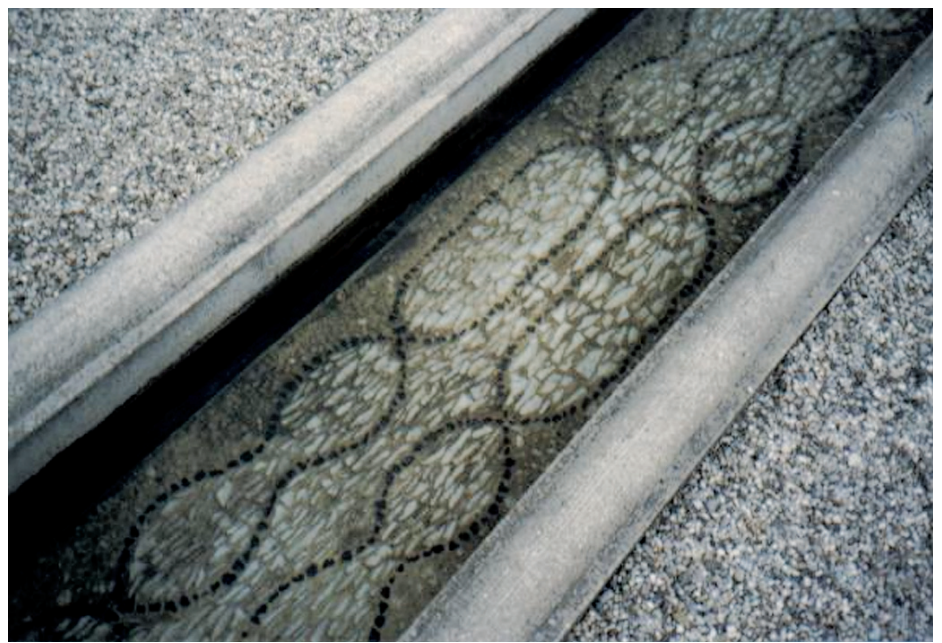

Het Loo. Reconstrucción de los dibujos de los canales de las fuentes a partir de las excavaciones arqueológicas

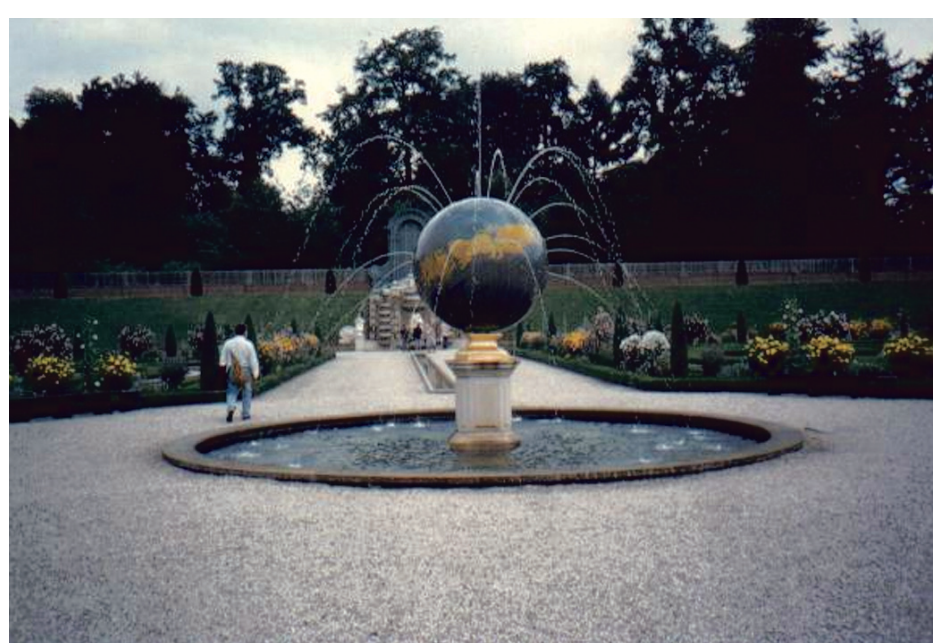

Het Loo. La fuente del Globo Terráqueo tras su reconstrucción en los años 80. (Fotos del autor) 
Una vez limpia la superficie del jardín de toda la arena acumulada, se procedió a la reconstrucción de los parterres siguiendo los diseños de la acuarela de C. P. van Staden reproducida bajo estas líneas. Los dibujos se marcaron con tiras de plástico para facilitar la separación y mantenimiento de las distintas gravas de colores utilizadas en el interior de los mismos y para la vegetación se recurrió a los tratados y fuentes anteriormente citadas.

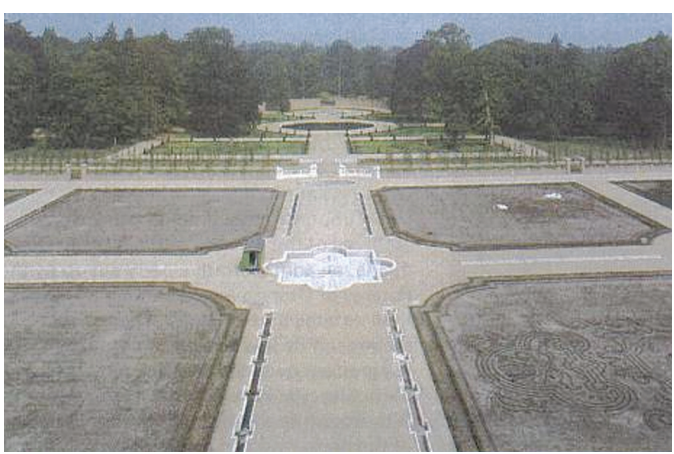

Het Loo. Aspecto del jardín en 1983 cuando se estaban rehaciendo los parterres

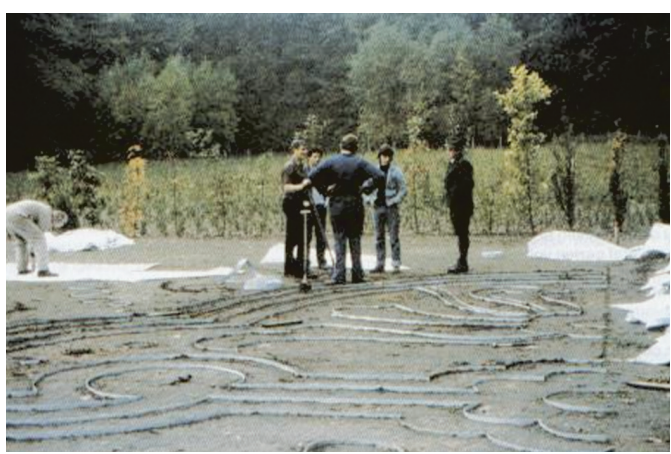

Het Loo. Trazado de los dibujos de los parterres

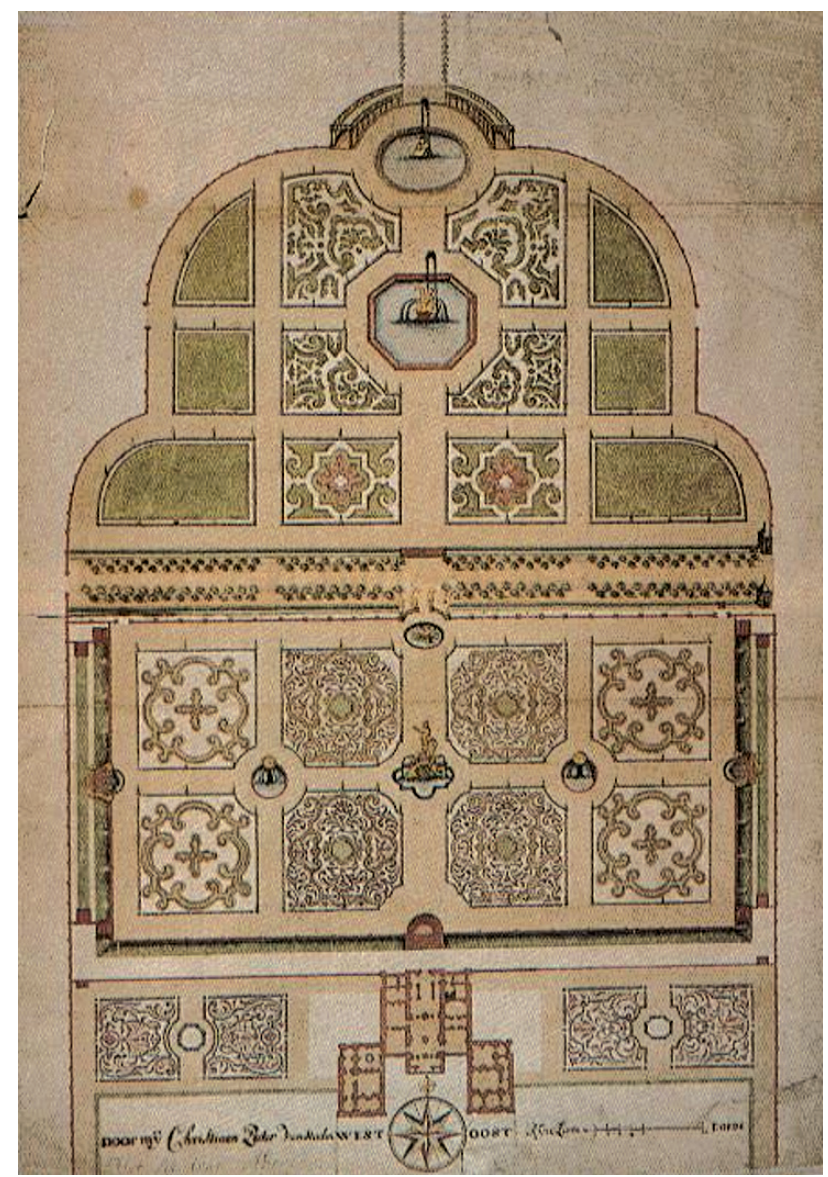

Plano de la planta del jardín de principios del siglo XVIII realizado por Christiaan Pieter van Staden. La minuciosidad empleada en representar los detalles de los dibujos de los parterres constituyó el punto de partida para su posterior reconstrucción 


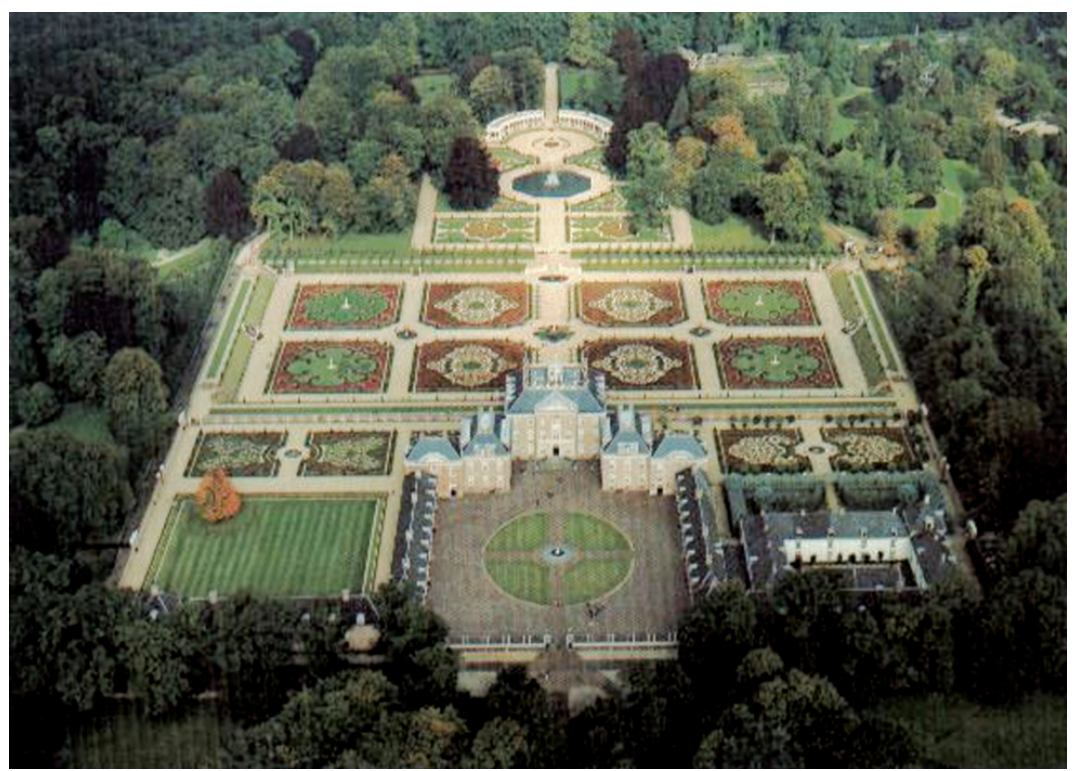

Vista aérea de Het Loo tras la reconstrucción de los jardines formales

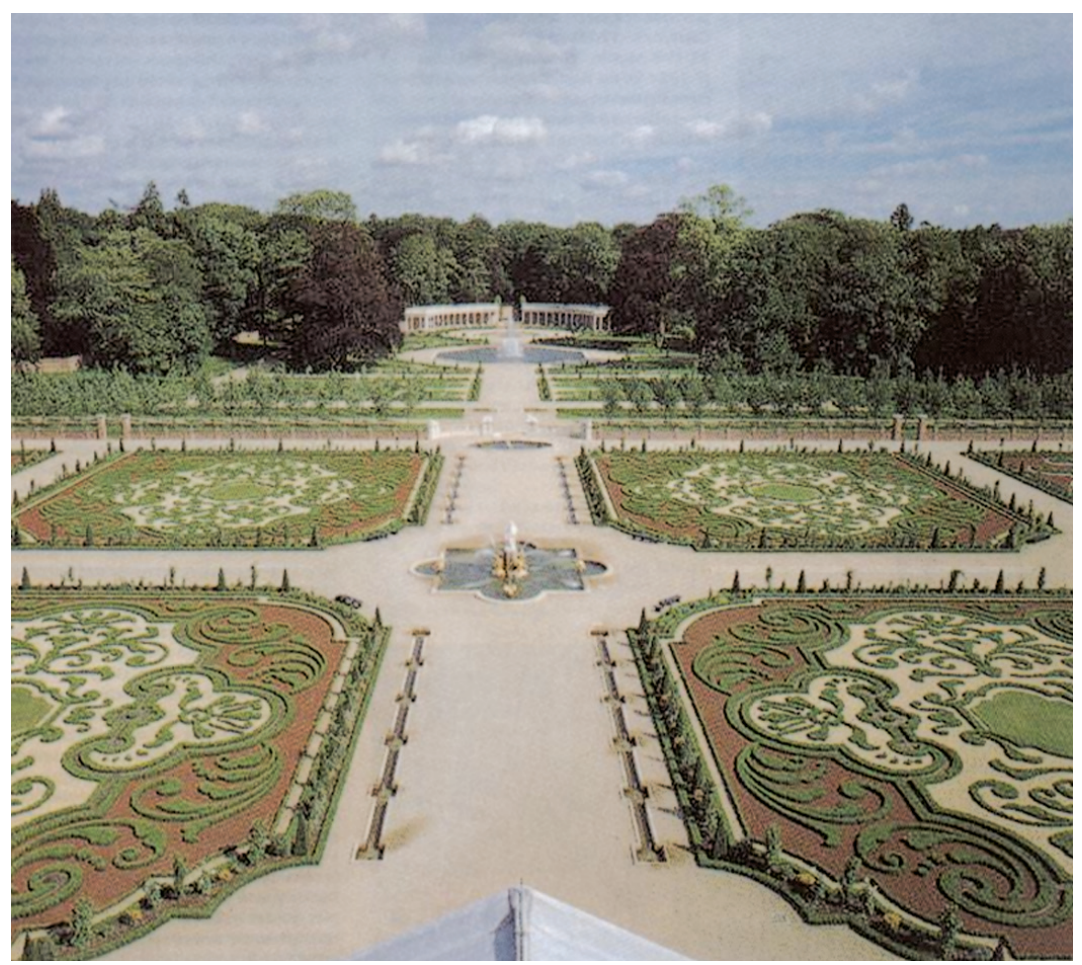

Vista general de los parterres de Het Loo en 1988

Según avanzaban los trabajos se vio la importancia que tenían los elementos arquitectónicos para conseguir recuperar la imagen global del jardín y así la columnata cuya construcción había sido desechada en un principio por motivos económicos pudo ser levantada gracias a la colaboración del mundo empresarial holandés. 


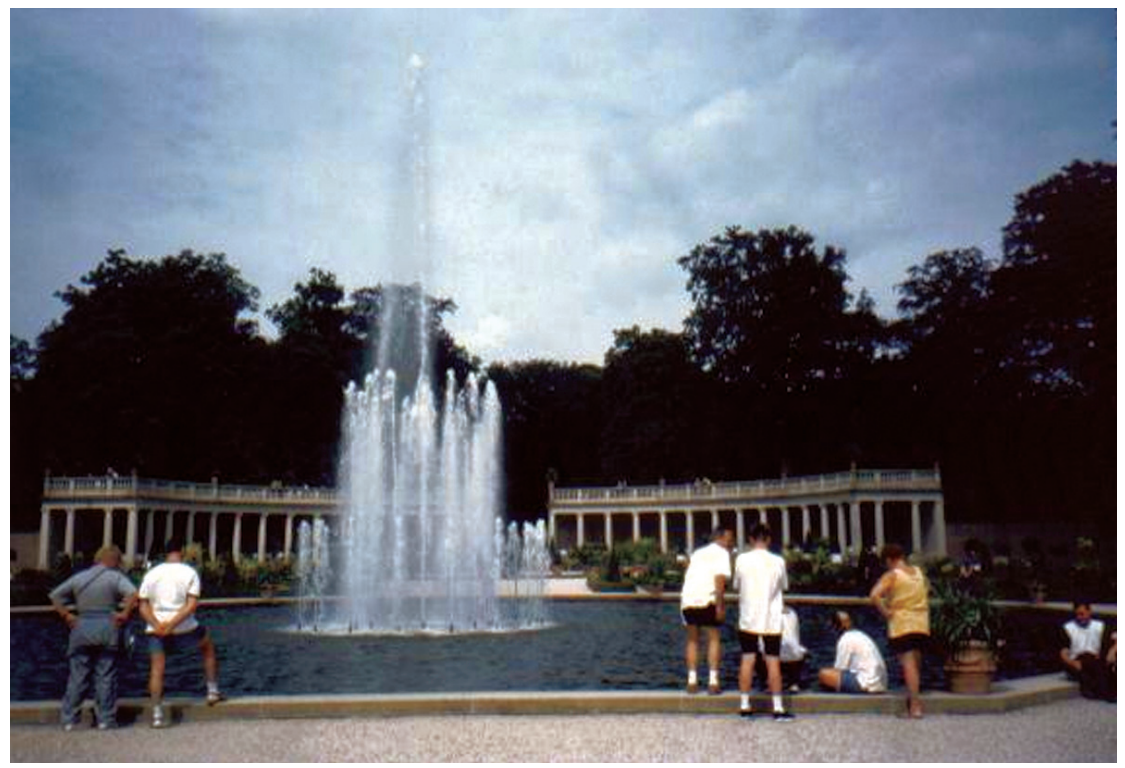

Het Loo. La columnata en el verano del 2000. (Foto del autor)

Construida en piedra artificial al igual que el resto de las fuentes debido a la legislación laboral holandesa que prohibe el trabajo en piedra por sus efectos nocivos para la salud, pudo ser inaugurada en 1984.

Respecto al sistema hidráulico, tuvo que ser descartado la recuperación del original por haber descendido el nivel freático este siglo de manera importante y ser completamente imposible recurrir a la presión para vestir las fuentes. El agua es hoy movida por bombas dentro de un sistema cerrado que permite su constante reutilización

Los elementos de adorno del jardín como bancos, jarrones, macetas, túneles etc. se copiaron en unos casos de los ejemplares conservados y en otros se reprodujeron de los numerosos grabados de la época ya mencionados anteriormente. Y hubo obras que no se pudieron rehacer por su elevadísimo coste como es el caso de los bancos barrocos de madera de los cuales sólo se conserva uno (36).

Los resultados de esta intervención son espectaculares ya que es sin duda una de las grandes obras de reconstrucción de un jardín histórico en Europa, no de restauración pues poco o nada había aquí que restaurar del original jardín barroco. A la vez ha tenido un amplio eco e influencia en el mundo de la restauración y conservación del verde histórico. Tras su inmenso éxito, será el modelo de muchos jardines entre los que destaca por su importancia y envergadura la eliminación del jardín paisajísta en el "Privy Garden" de Hampton Court en el Reino Unido para su posterior reconstrucción según los diseños formales del Barroco. Esto lo veremos en el capítulo siguiente. 
Todas estas reconstrucciones que se realizan hasta hoy mismo están señalando la falta de acuerdos o si se prefiere la profunda crisis existente en el mundo de la restauración entre dejar los monumentos como ruinas o recuperarlos como objetos de arte. Esta crisis de los postulados de la restauración científica la reflejan las declaraciones del mismo Giovannoni cuando señala: "Pero será mejor una restauración científicamente imperfecta, que represente una fich a perdida en la historia de la arquitectura, que la renuncia completa, que privaría a nuestras ciudades de su aspecto característico en sus más significativos monumentos de arte” (37).

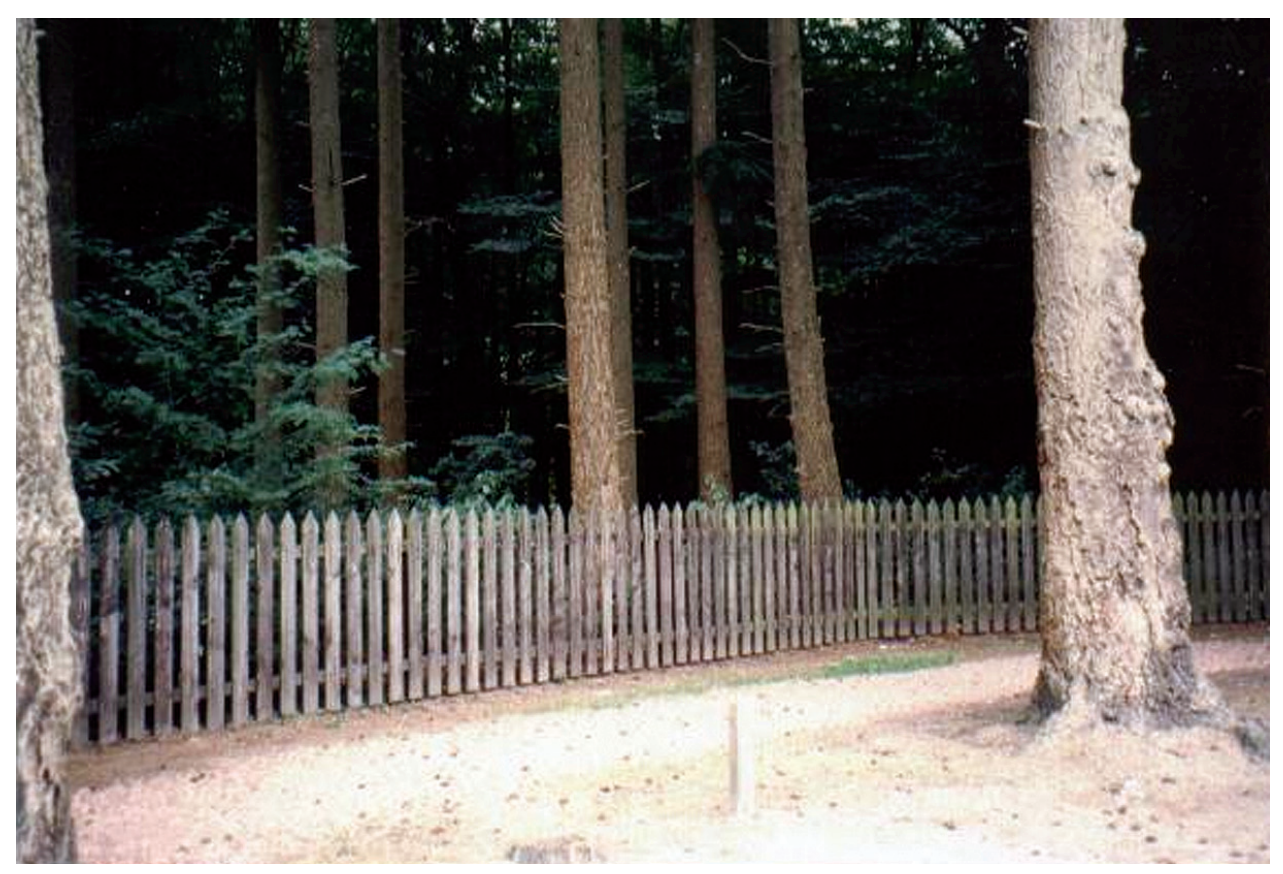

Het Loo. Valla de separación entre el jardín formal y el parque paisajista. (Foto del autor) 


\section{C.5.2. La Carta de Venecia (1964)}

Tras el II Congreso Internacional de Arquitectos y Técnicos de los Monumentos Históricos, celebrado en Venecia en la primavera de 1964, se redacta una nueva carta con fines y miras más amplios que la de Atenas. Se denominó oficialmente Carta Internacional para la Conservación y Restauración de Monumentos y pasa a ser conocida como Carta de Venecia (Ver Anexo Documental no 3).

Surgida en el contexto histórico de la reconstrucción posbélica, después de mirar retrospectivamente las restauraciones llevadas a cabo tras la Segunda Guerra Mundial, tiene como novedades respecto a la de Atenas el ampliar la definición de monumento por un lado y por otro el deseo de que los principios emanados de esta conferencia tengan valor internacional.

En la Carta de Atenas, el monumento era una creación de gran valor artístico e histórico. Aquí se amplía esta consideración al ambiente urbano y ambiental en el que está inmerso ese monumento y se insta a su conservación dándole tanto valor como al monumento en sí siendo considerados como objetos de esta carta sencillas y humildes obras desechadas hasta este momento.

El resto del documento amplía aspectos de la de Atenas, llegando a señalizar expresamente que la restauración debe detenerse donde empiezan las hipótesis (Art. 9) y que el fin de la restauración no es lograr la unidad de estilo del monumento notándose claramente la influencia de G. Giovannoni y C. Brandi en su elaboración.

Respecto al tema de nuestro trabajo -la jardinería- debemos de señalar que nada es expresamente citado en este documento sobre protección o restauración de los jardines excepto la referencia del artículo 1 al ambiente paisajístico cuando se amplía la noción de monumento.

Hay que esperar hasta el año 1972 (que es cuando estas recomendaciones de la Carta de Venecia se hacen normas legales de obligado cumplimiento a través de la Carta del Restauro) para ver en su artículo 2 una mención expresa a la protección de los jardines: "Además de las obras indicadas en el artículo precedente quedan asimilados a éstas, para asegurar su salvaguardia y restauración, los conjuntos de edificios de interés monumental, histórico o ambiental, especialmente los centros históricos, las colecciones artísticas y las decoraciones de interiores conservadas en su disposición tradicional; los jardines y parques que son considerados de especial importancia."

En el artículo 6 se prohiben alteraciones de las condiciones ambientales en las que han llegado a nuestro tiempo las obras de arte entre las cuales vuelve a incluir a los jardines y a los parques.

Vuelven a ser citados los jardines en el Anexo D cuando al tratar de la protección de los centros históricos se hace hincapié en dar tanta importancia a los monu- 
mentos aislados como a las calles en los que éstos se encuentran, a los jardines, a los espacios libres, a los elementos peculiares y al medio natural más cercano.

Unos años después, en la Declaración de Amsterdam de octubre de 1975 del Consejo de Europa se amplían y recogen aspectos de las Cartas anteriores y se da la voz de alarma ante la creciente degradación del patrimonio cultural instando a su protección a los responsables políticos en todos los niveles y así mismo se formulan unas líneas generales de actuación con la finalidad de que cada Estado miembro las aplique en su territorio volviéndose a incluir la protección de los jardines históricos como uno de sus fines. Uno de los párrafos de la Declaración dice: "Nuestra sociedad deberá, en breve plazo, renunciar al patrimonio arquitectónico y a los sitios que constituyen su marco tradicional de vida, si no se pone en marcha con urgencia una nueva política de protección y conservación integrada de ese patrimonio. Lo que importa proteger hoy son, las ciudades históricas, los barrios urbanos antiguos y las ciudades de tradición, comprendidos los parques y jardines históricos. La protección de estos conjuntos arquitectónicos no puede ser concebida más que desde una perspectiva global, teniendo en cuenta todos los edificios que tienen valor cultural, desde los más prestigiosos a los más modestos, sin olvidar los de la época moderna, así como el marco en el que se inscriben. Esta protección global completará la protección puntual de los monumentos y sitios aislados"

Tras este documento será la Carta de Florencia de 1981 la que se ocupará de la conservación y la protección de los jardines en exclusiva. Sin embargo, dicho documento no sólo no logrará conseguir unidad de criterios entre los diversos profesionales y estudiosos del mundo de la conservación y la restauración en lo que respecta a la definición del jardín y a las tareas necesarias de mantenimiento y restauración sino que tras esta reunión volverá la antigua escisión -aún más radicalizada- entre conservadores y restauradores.

Dejaremos para otro capítulo el análisis de esta Carta florentina y las repercusiones que tuvo en el mundo de la conservación y restauración del patrimonio verde histórico. 


\section{EL SIGLO XX (SEGUNDA PARTE). LA RESTAURACION DE JARDINES TRAS LA CARTA DE FLORENCIA (1981)}

\section{D.1. La Carta de Florencia (1981) y la reacción italiana}

\section{D.2. Restauraciones en Europa tras el documento florentino}

D.2.1 Italia:

a) Palacio Marigliano. 1999 (Nápoles)

b) Convento de Santa Clara. 1999 (Nápoles)

D.2.2. Inglaterra: Hampton Court: The Privy Garden.(1992-1995)

D.2.3. España:

D.2.3.1. Jardines del Patrimonio Nacional:

- Casita de Abajo o del Príncipe en El Escorial (Madrid)

- Casita de Arriba o del Infante en El Escorial (Madrid)

c) Quinta del Duque de Arco en el Pardo (Madrid)

d) Laberinto de la Granja (Segovia)

e) Jardín del Rey en Aranjuez (Madrid)

D.2.3.2 Otros jardines de España:

a) Patio de la Casa de Contratación en Sevilla

b) Capricho o Alameda de Osuna (Madrid)

c) Casa del pintor Sorolla (Madrid)

d) Claustro del Convento de Guadalupe (Cáceres)

e) El Retiro (Madrid)

D.2.3.3 Jardines de la Comunidad Valenciana:

a) Jardín Botánico de Valencia

b) Jardín de Monforte (Valencia)

c) Jardín del Beso (Xàtiva)

d) Jardín de la Casa de la Cultura González-Quirós (Gandia) 


\section{D.1. La Carta de Florencia de 1981 y la reacción italiana.}

El año 1981 -fecha de la publicación de la Carta de Florencia- (Ver Anexo Documental $n^{\circ} 4$ ) es una fecha crucial en lo que respecta a la formulación de los criterios de restauración de jardines y su posterior aplicación.

En este documento una vez más se vuelve a mostrar claramente aquella dualidad que escindió y dividió la Europa del XIX a la hora de enfrentarse ante el hecho de la restauración.

Esta Carta representa el triunfo de las teorías de la restauración en estilo con todas sus consecuencias. Si los seguidores de Viollet-le-Duc fueron capaces de derribar edificios para volverlos a rehacer según "la idea original", imaginémonos, lo que en los jardines sucedió y de hecho aún sucede cuando se está trabajando con los elementos componentes de la estructura -las plantas- mucho más perecederos y frágiles que la piedra caliza, los granitos o el mármol, los cuales por otra parte pasan a adquirir mayor relevancia en el jardín que los componentes vegetales a partir del citado documento.

Si bien es cierto que la Carta de Florencia llamó la atención en algunos países de Europa por primera vez sobre la restauración de una parte del patrimonio tan delicada como son los jardines hay que lamentar que su enfoque partió de unas bases erróneas. Previamente a entrar en este punto, debemos de señalar que en España desde los años treinta del siglo pasado se actuó y tomó conciencia sobre la protección de este sector del patrimonio cultural según los principios de la Carta de Atenas, no pudiéndose adelantar más por el desastre que supuso la Guerra Civil como vimos en el capítulo anterior.

Las bases erróneas de las que partió el documento florentino son las de hacer abstracción de la realidad concreta que significa cada jardín en particular con todas las aportaciones y añadidos que la historia ha ido dejando en el lugar. Este punto está explicado ampliamente por Martínez Justicia (1) cuando se refiere a los comentarios de Marco Dezzi Bardeschi (2) en el octavo cumpleaños de la Carta.

Ya durante las jornadas del encuentro florentino, un grupo de estudiosos encabezados por Isa Belli Barsali (3) se opuso a los términos de la Carta tal como estaban siendo redactados. Fue ella quien en el mismo encuentro, hizo una intervención llena de pasión, racionalidad y coraje -como buena italiana- oponiéndose a la sacralización de los principios que se estaban plasmando en la Carta y advir-

(1) MARTINEZ JUSTICIA, María José. Antología de textos de restauración. Universidad de Jaén, 1996.

(2) DEZZI BARDESCHI, Marco. Restauro: punto e da capo. Frammenti per una (impossibile) teoria. Ed. Franco Angeli. Milano, 1991.

(3) BELLI BARSALI, Isa. "Per una Carta dei Giardini Storici” en la obra ya citada del ICOMOS Jardins et Sites historiques, págs. 182-186. 
tiendo del peligro que suponía la aceptación de la misma para la conservación del verde histórico (Ver Anexo Documental no 7).

Isa Belli puso sobre el tapete dos puntos irrenunciables en cualquier gestión del patrimonio de los jardines históricos: el primero era la prioridad en la conservación de todo lo existente y el segundo el considerar el enorme riesgo que suponía para la conservación de este frágil patrimonio cualquier intervención que hiciera desaparecer los vestigios del paso del tiempo que en el jardín se manifestaban de dos maneras. Una consistía en la presencia de las diferentes aportaciones arquitectónicas en el lugar a lo largo de la historia. La otra manifestación era más sutil: como consecuencia de los grandes descubrimientos geográficos fueron llegando a Europa numerosas plantas que han ido marcando de modo decisivo la estructura del jardín, (considerando aquí estructura como sinónimo de componente vegetal).

Isa Belli Barsali insistió en el estudio en concreto de cada jardín, en dar importancia prioritaria antes de cualquier intervención a los análisis arqueológicos, botánicos, topográficos, etc. de los espacios a restaurar siempre con la intención de conservar y señaló que en los casos de jardines desaparecidos en los que el repristino estuviera justificado por la abundancia de información gráfica, estos repristinos deberían de estar precedidos de profundos estudios arqueológicos pues podría suceder que los dibujos y planos existentes y a partir de los cuales se intentara rehacer el espacio no fuesen las reproducciones verídicas del jardín en un momento dado sino meras invenciones del artista y de su fantasía.

A pesar de estas objeciones, la Carta se aprobó, dándose con ella luz verde al repristino en los jardines históricos. Solamente Italia impidió esta práctica añadiendo unas observaciones a la Carta que curiosamente no se traducen ni se dan a conocer en las numerosas publicaciones de libros sobre jardinería que recogen y citan el documento florentino con bastante frecuencia. Con el tiempo, los técnicos italianos consiguieron que sus objeciones al documento adquirieran carácter de ley a través de una normativa publicada por el Ministerio emanada del Comité Italiano para el Estudio y la Conservación de los Jardines Históricos en 1983. Sobre las repercusiones de esta Carta en el mundo de la restauración y de su significado hay que citar las reflexiones ya comentadas de Marco Dezzi Bardeschi sobre este tema y los esfuerzos de Vicenzo Cazzato para establecer una Carta del Restauro para los jardines de Italia (Ver Anexo Documental. nº 5).

A partir de ese momento, con las excepciones de Italia $-y$ ya veremos que no siempre- y algunas intervenciones en los jardines del Patrimonio Nacional en España, la restauración de jardines conocerá una vuelta a las prácticas decimonónicas de la restauración en estilo como ya señalábamos anteriormente.

En este capítulo veremos distintas intervenciones con ejemplos de lo expuesto en los párrafos precedentes. Unas son en Italia (palacio Marigliano y Convento de Santa Clara en Nápoles) e Inglaterra (Privy Garden en Hampton Court) y otras en 
España a las que dedicaremos más extensión al tratarse de intervenciones ocurridas en nuestro territorio: Patio de la Casa de Contratación en Sevilla; Laberinto de la Granja de San Ildefonso en Segovia; El Retiro, la Quinta del Duque de Arco, las Casitas de Arriba y Abajo en El Escorial; El Capricho o Alameda de Osuna; la Casa del pintor Sorolla, finalizando con el Jardín Botánico en Madrid; el Jardín del Rey de Aranjuez; el claustro del Monasterio de Guadalupe en Cáceres y, el Jardín de Monforte, el Jardín del Beso de Xàtiva y el Jardín de la Casa de las Marquesas de Gandia en Valencia. 


\section{D.2. Restauraciones en Europa tras el documento florentino}

\section{D.2.1. Italia.}

\section{a) Palacio Marigliano.}

Tal vez sean estos dos lugares donde mejor queden reflejadas las nuevas tendencias de la restauración jardinera en Italia surgidas tras la Carta de Florencia.

Conocidos en el año 1999, los dos edificios estaban siendo sometidos a importantes intervenciones en ese momento. Veamos primero el palacio Marigliano.

Su origen se remonta al siglo XVI. Se supone que hacia 1513 estaba ya concluido el palacio y disponía entonces ya del jardín, hecho bastante insólito en una ciudad con una altísima densidad de población. En el siglo XVIII sufre el palacio una remodelación a cargo del arquitecto Felice Bottigliero.

En el siglo XX, el palacio pasó a ser propiedad de la Administración que ocupó parte de él para uso de la "Soprintendenza Archivistica" según se recoge en la revista Campania Felix. (4) Cuando nosotros lo visitamos en octubre de 1999 estaba a punto de finalizar una profunda remodelación del edificio con el fin de hacerlo sede de la Scola di Teatro e Cinema. En el folleto publicitario de su primer montaje teatral se dice que la representación es a cargo de dicha escuela cuyo espacio es "el antiguo piso principal del duque Marigliano, con un bellísimo jardín mediterráneo" (5).

Los componentes vegetales de jardín eran plantas frecuentes en la jardinería del XIX pero algunas de un tamaño excepcional. Destacaban entre ellas una gran magnolia (Magnolia grandiflora), dos altísimos palmitos de la suerte (Trachicarpus fortunei), un magnífico ejemplar de palmito (Chamaerops humilis), una camelia (Camelia sp) y una adelfa (Nerium oleander) que habían adquirido un porte arbóreo en busca de la luz, una livistonia (Livistonia chinensis), un cedro (Cedrus libanii) y el rusco (Ruscus aculeatus) utilizado como seto. Pero la reina del jardín era una gigantesca glicinia (Wisteria chinensis) cuyo ramaje ocupaba casi toda la casa saliendo desde uno de los muros junto a la escalera de acceso al giardino segreto.

Tal jardín, presente en todas las guías turísticas de Nápoles como algo insólito, estaba siendo utilizado en ese momento como almacén para los escombros de la obra en curso con lo que parte de la superficie del jardín había resultado destruida. Al mismo tiempo, las plantas presentaban un estado de gran abandono.

Visitado de nuevo dos años después, en septiembre del 2001, pudimos darnos cuenta que la parte que fue utilizada como zona de servicio de las obras había

(4) RUOTOL0, Renato. "Palazzo Marigliano a Napoli” en la revista Campania Felix. Enero de 1998, n²0. Páginas 13-17

(5) Díptico de la programación del año 1999-2000. En Anexo Documental nº 8 
perdido toda la vegetación completamente siendo su superficie cubierta de césped. El resto del jardín se había mantenido y limpiado en su conjunto. En aquel jardín recóndito, rodeado por la densa vegetación del jardín romántico, aún ofrecía más contraste la superficie desnuda del césped cercada por los grandes ejemplares supervivientes. Igualmente triste era comprobar como todos los bustos que adornaban la terraza vecina habían desaparecido en su totalidad.

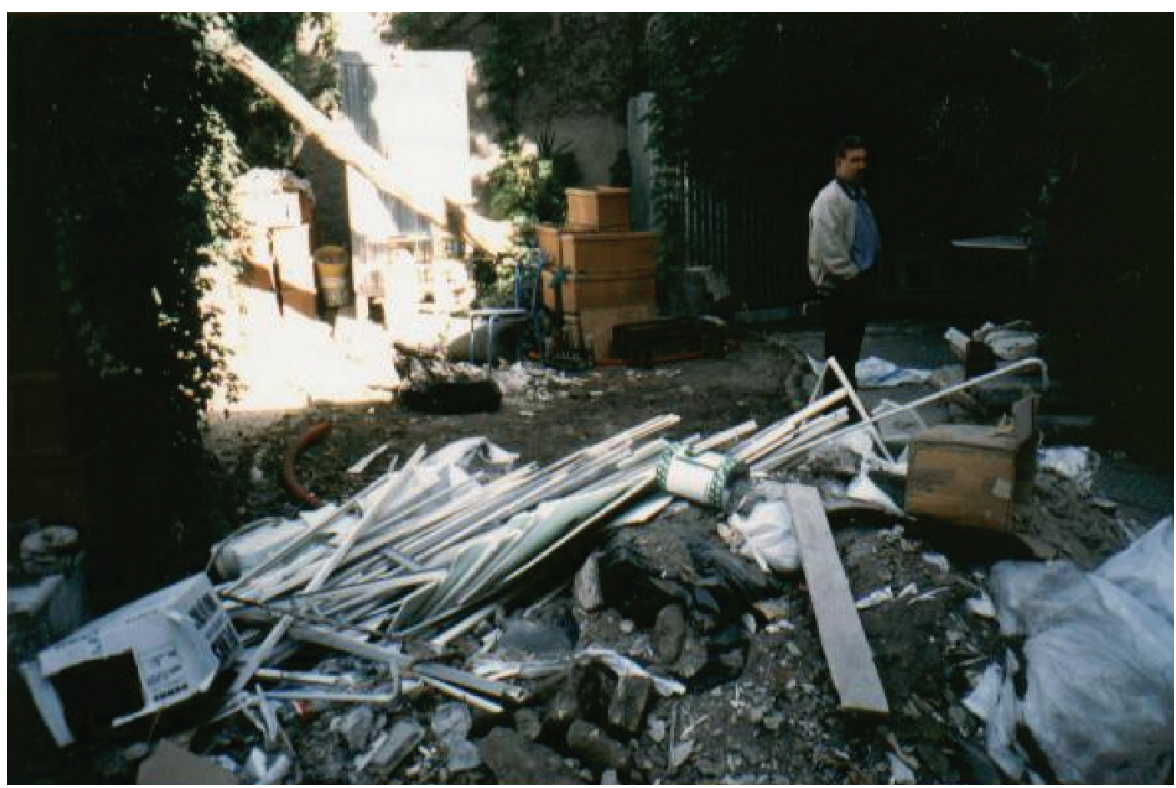

Jardín del palacio Marigliano utilizado como almacén de las obras. (Foto del autor)

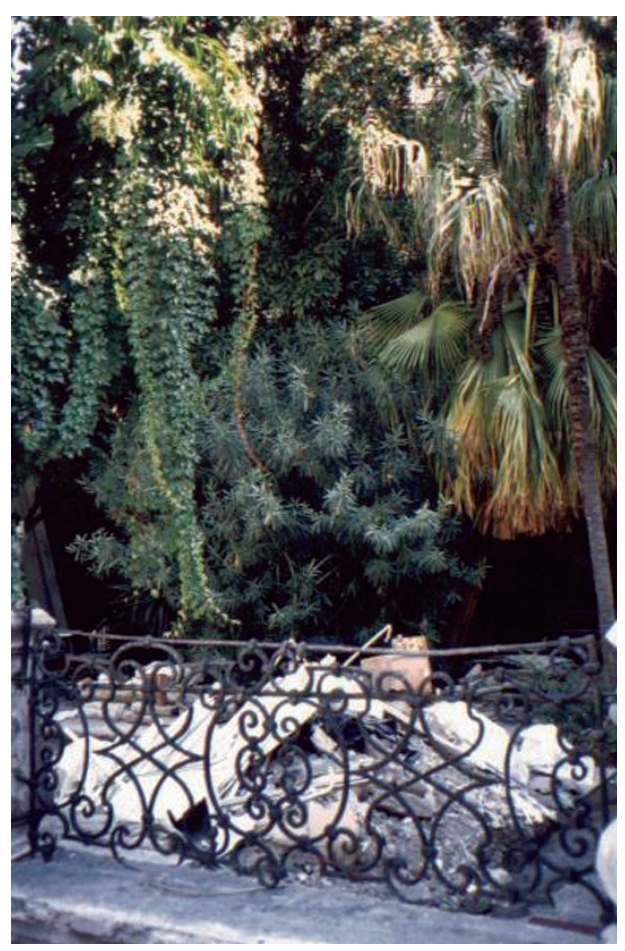

El Jardín secreto del Palacio Marigliano en octubre de 1999. (Foto del autor) 


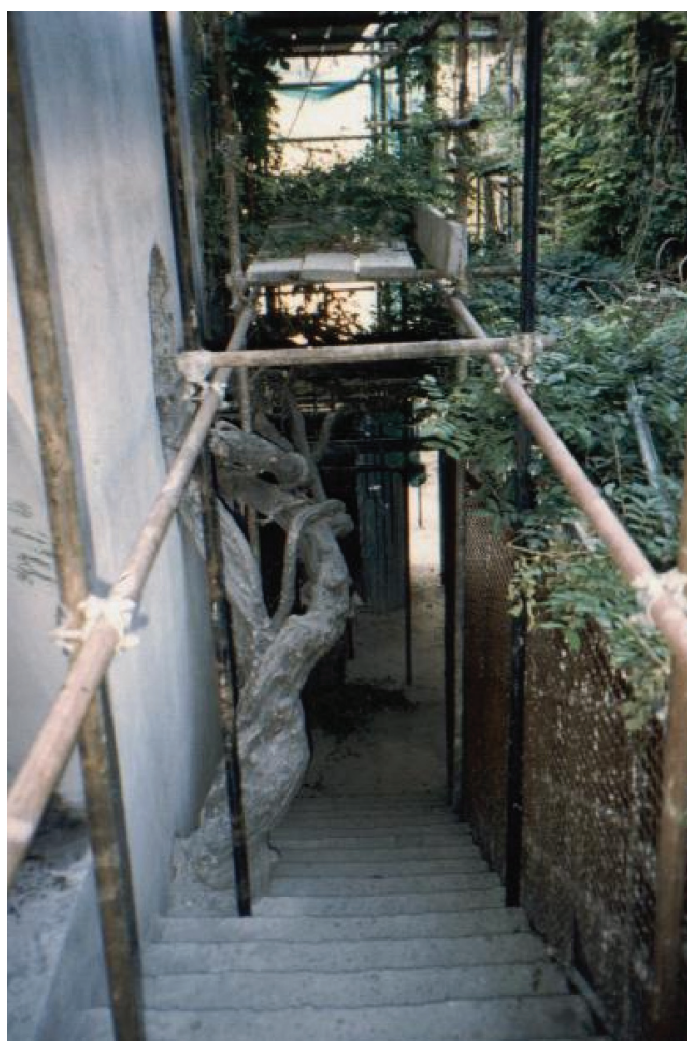

Tronco de la glicinia en las escaleras del jardin. Octubre de 1999. (Foto del autor)

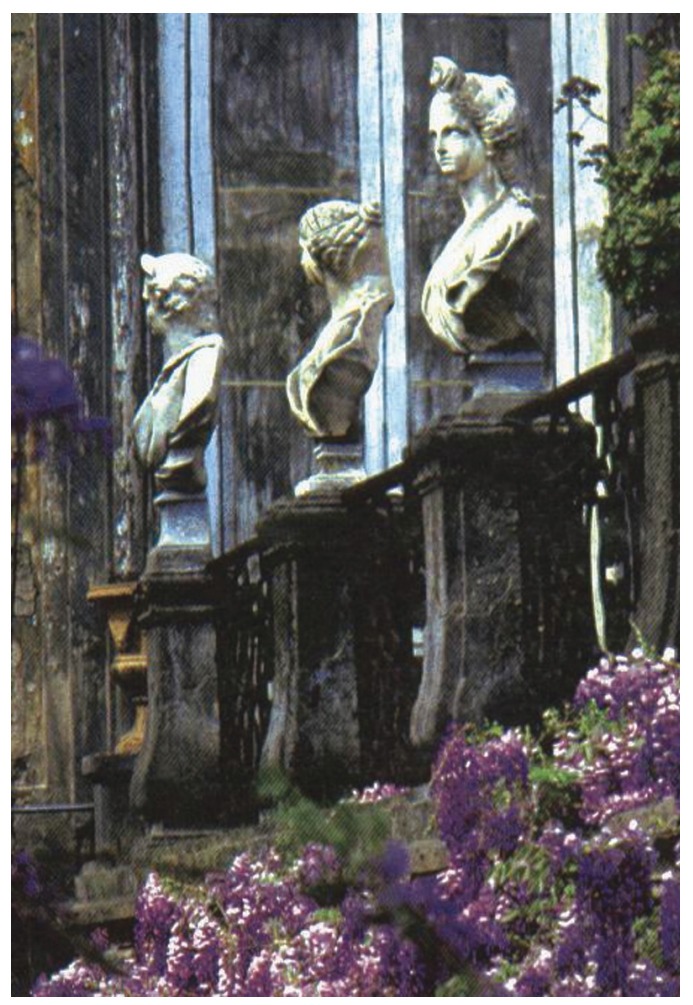

La terraza con los bustos hoy desaparecidos.

(Foto Campania Felix, $n^{\circ} 20$ ) 


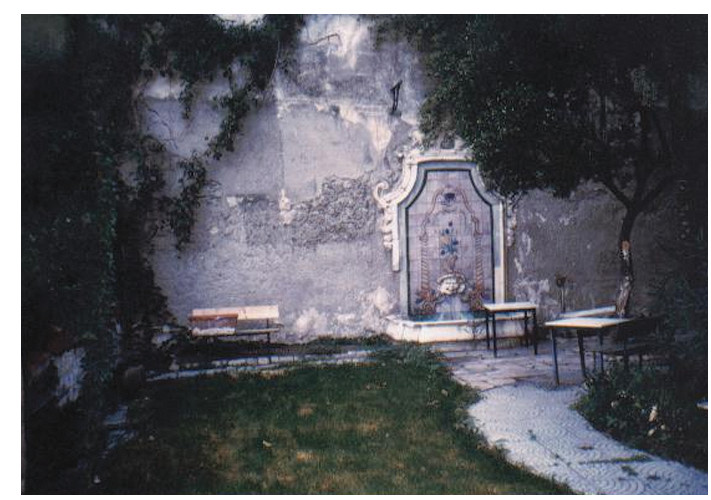

El patio del jardín en el año 2001. El césped ha ocupado el espacio arrasado tras las obras.

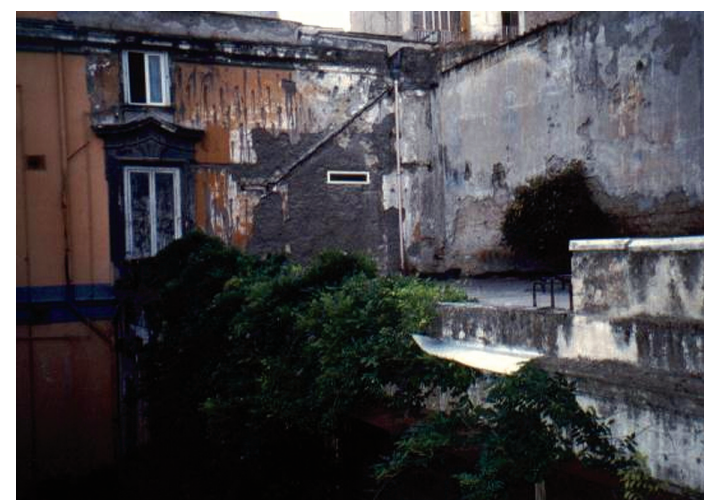

La terraza de los bustos en el verano del 2001. (Fotos del autor)

\section{b) Claustro del Convento de Santa Clara de Nápoles}

El caso anterior tiene el carácter de anécdota de cómo se trabaja generalmente en el mundo de la restauración monumental donde es frecuente la utilización del espacio de los jardines como almacén de los restos de las obras. Sin embargo, el siguiente ejemplo, el claustro del convento de Santa Clara en la misma ciudad que el jardín del palacio Marigliano, tanto por su tamaño como por su importancia histórica y artística, ya no tiene carácter de simple anécdota. El proyecto de restauración de dicho claustro muestra una voluntad clara de recuperar el jardín original. Es decir, es una obra de puro repristino. Por no decir de destrucción/eliminación de los elementos vegetales presentes en el jardín con la finalidad de conservar las columnas recubiertas de azuleios. Algo que hoy nos sigue asombrando.

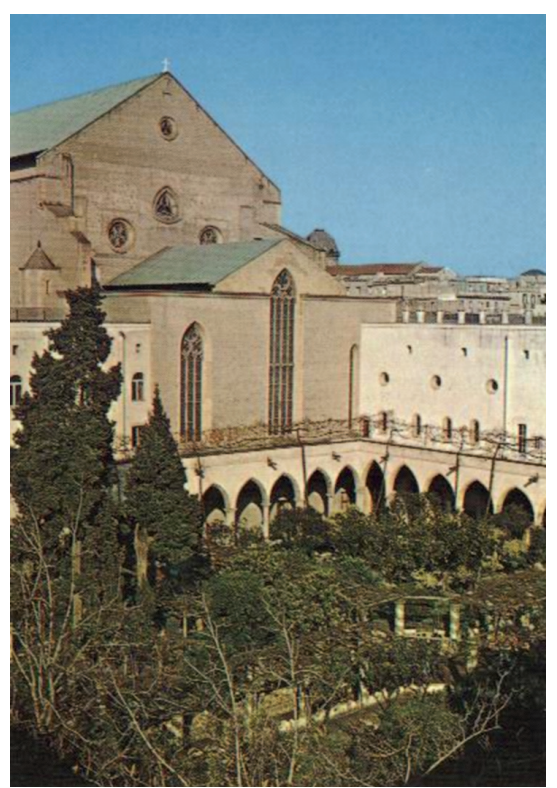

Vista del Claustro. (Tarjeta postal) 
Hagamos brevemente un bosquejo sobre la historia del lugar. El convento se funda en el siglo XIV y se construye en estilo gótico. Unos siglos más tarde, por la mitad del siglo XVIII, la iglesia y el claustro van a conocer una fuerte intervención barroca. El interior de la iglesia se recubre completamente según los cánones artísticos imperantes en ese momento. En el claustro, Domenico Antonio Vaccaro reinterpreta la tradición del jardín litúrgico cristiano creando unos paseos en cruz sombreados con pérgolas cuyas columnas y bancos para el descanso son recubiertos de azulejos y además añade unas fuentes con motivos de la tradición clásica alejadas completamente del espíritu cristiano.

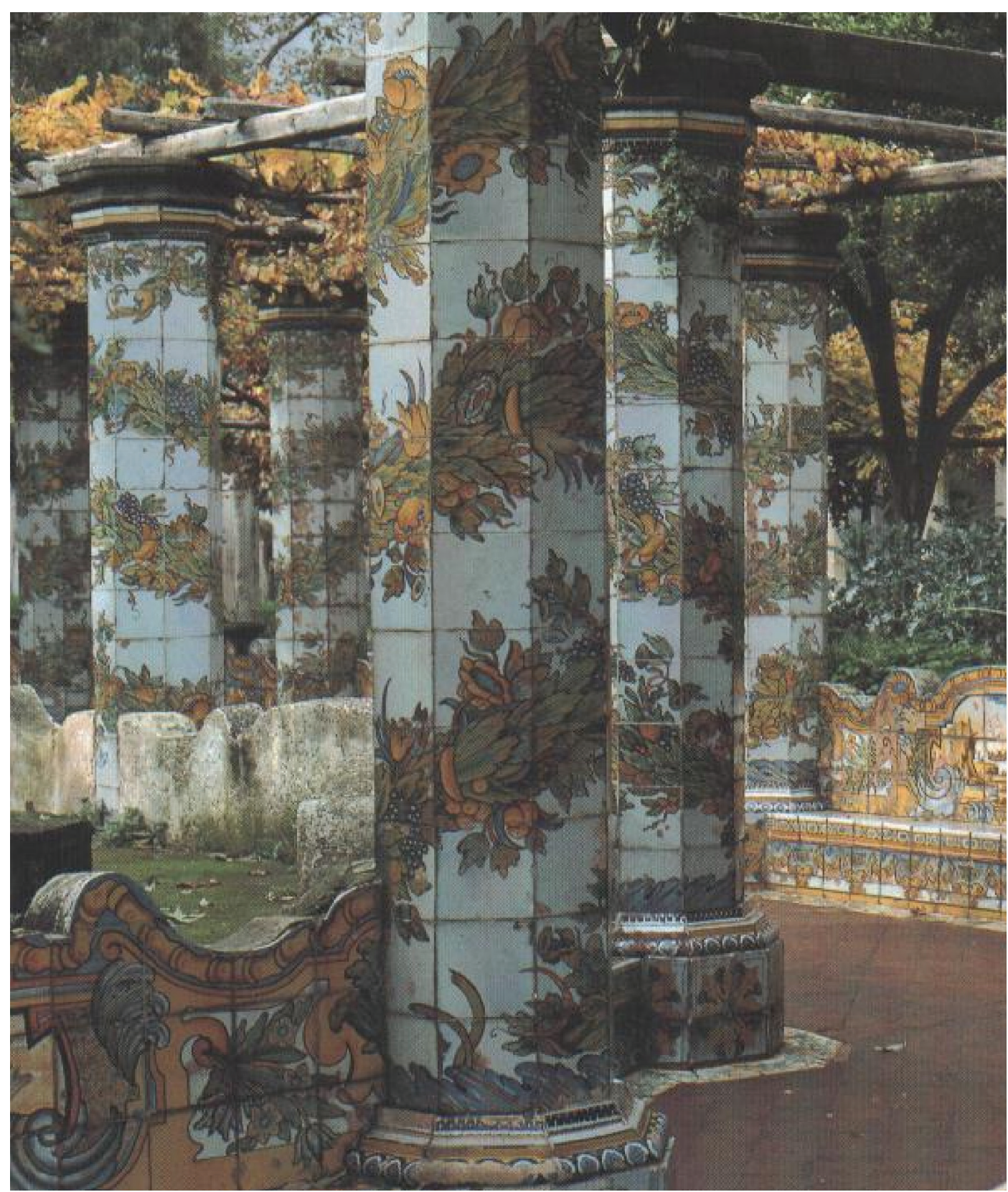

El Claustro antes de la restauración. (Foto de las Guías Artísticas de Electa Napoli) 
Desafortunadamente este jardín y la iglesia van a recibir varias bombas en agosto de 1943. La iglesia ardió durante tres días quedando convertida en un montón de ruinas calcinadas. El claustro también se vio afectado y parte de las columnas de los paseos desaparecieron. Son las que hoy podemos ver reconstruidas con la misma forma que las sobrevivientes a la barbarie pero sin su revestimiento cerámico.

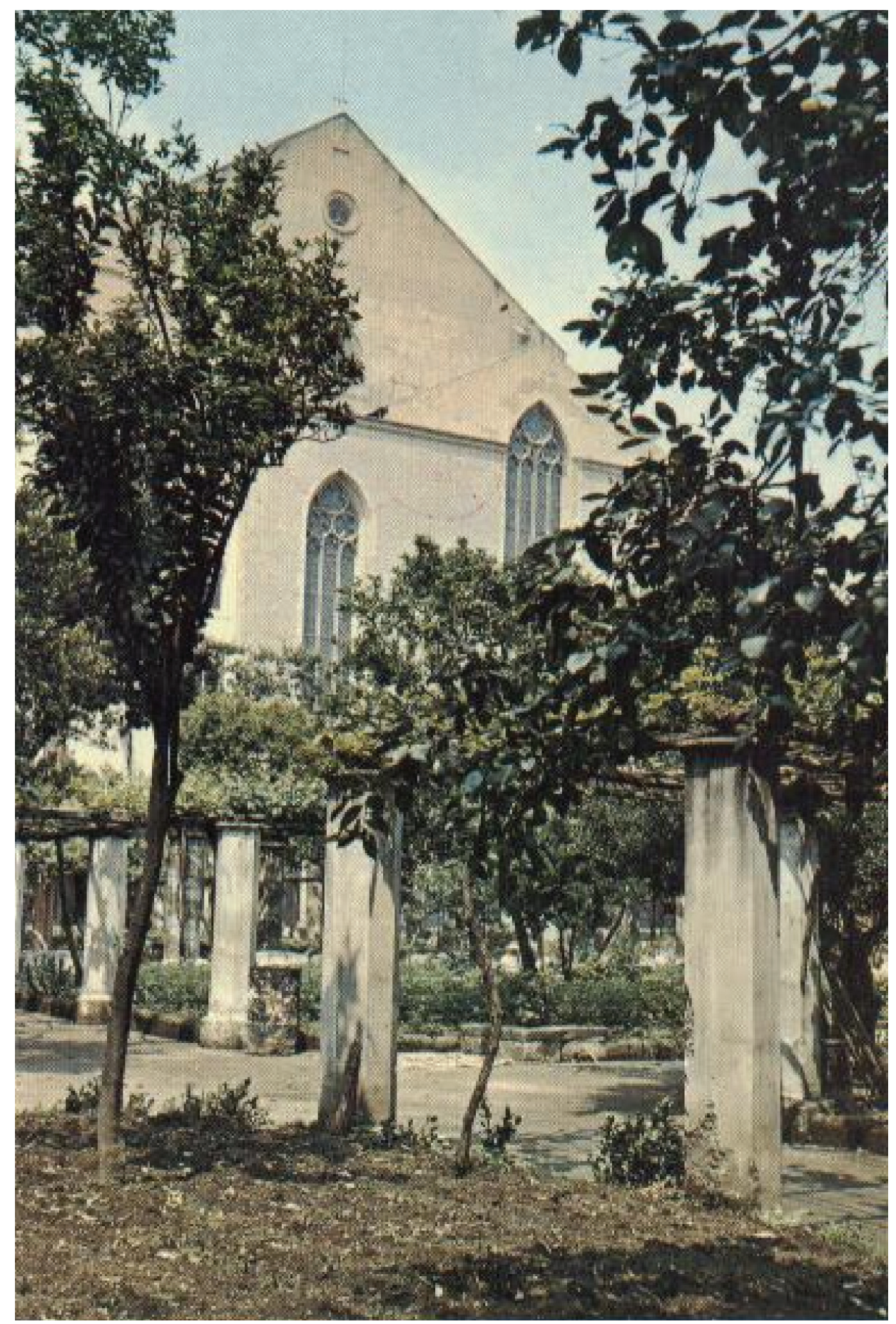

Columnas reconstruidas tras los bombardeos de la segunda Guerra Mundial 


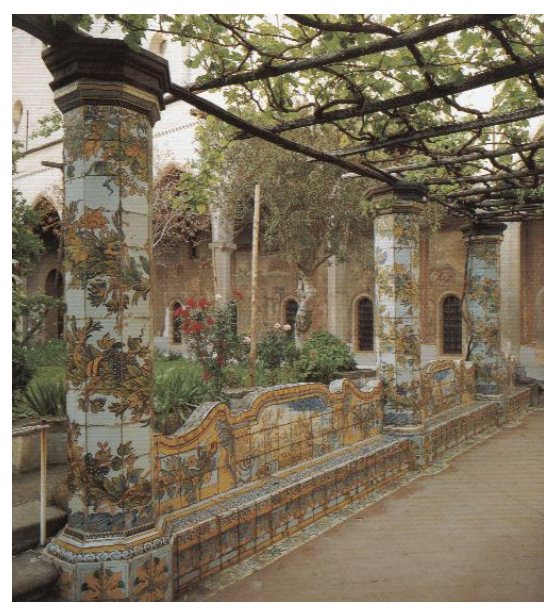

Otra imagen del Claustro antes de su reciente restauración. (Foto procedente de las Guías Turísticas de Electa Napoli)

El claustro mantuvo la tradición de ser un lugar de paseos sombreados gracias a las glicinias y las parras. En el interior de los cuadros se mantuvo y replantó esa mezcla de frutales y ornamentales de la tradición jardinera típica de esos lugares: naranjos, nísperos, granados, olivos, parras, rosales, brugmansias, lirios, palmitos y palmeras, etc.

Cuando conocimos este claustro en el otoño de 1999 estaba siendo acometida su "restauración". Los criterios estaban expuestos en una de las naves del lugar al cual por la peligrosidad de la obra no se permitía la entrada al público y si el público se saltaba estas recomendaciones -nuestro caso- era expulsado amablemente por los vigilantes del lugar.

De lo que pudimos leer, se concluye que partiendo de investigaciones históricas el convento fue utilizado como hospital en la Edad Media. De ahí se deduce que el claustro debía de estar plantado de plantas medicinales. Por tanto, la intervención se centraba en recrear el jardín de aquel momento histórico concreto. Para conseguir este huerto de medicinales era preciso hacer desaparecer todas las plantas presentes en el jardín para conseguir luz, plantas que eran testimonios de una tradición jardinera de siglos, tradición que trató de crear en estos claustros la idea del Paraíso a través de la elección de plantas ornamentales de profundo significado simbólico, intensos aromas, deslumbrante belleza o peculiares y abundantes frutos.

Las fotos tomadas en octubre de 1999, momento en que estaban siendo arrancados los grandes árboles y arbustos presentes en el lugar, son una pequeña muestra de las afirmaciones realizadas en los párrafos anteriores. Y su valor testimonial queda refrendado al no existir ninguna publicación que recoja en extensión el estado del claustro antes de la intervención por lo que tendremos que recurrir a las antiguas tarjetas postales aún en venta en la tienda del convento y a las fotos recogidas en la publicación de Electa Napoli sobre este lugar.

La vuelta al claustro en septiembre del 2001 confirmó nuestros temores de que tal intervención hubiera podido hacer desaparecer casi la totalidad de la vegetación presente en el lugar. Y la realidad aún superó lo previsible. No solamente habían 


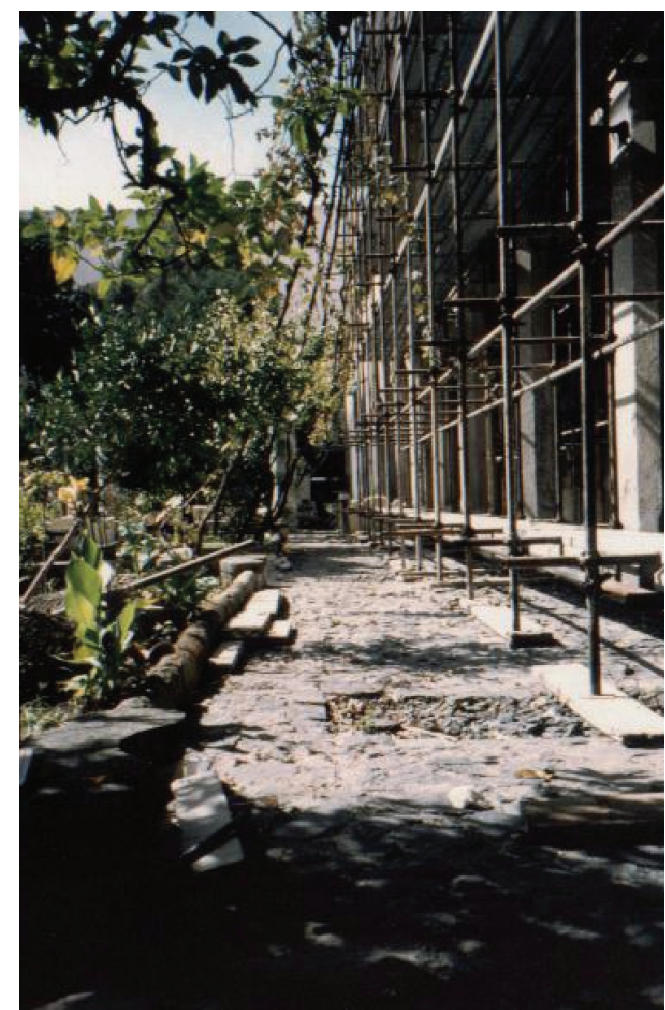

Detalle de la zona del Claustro donde estaba expuesto el proyecto de la restauración en 1999

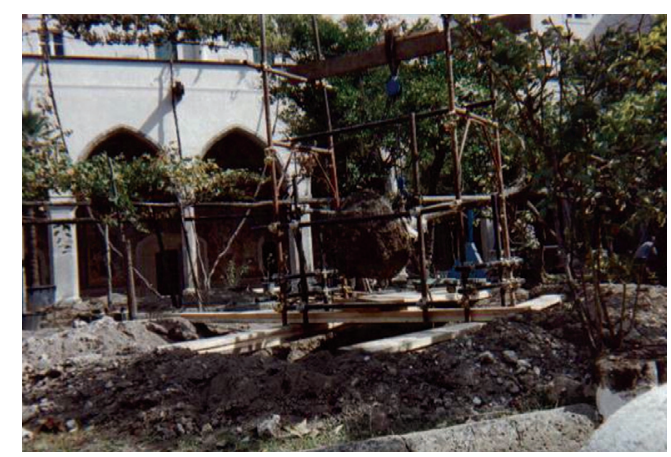

Andamio para el arranque de los grandes ejemplares arbóreos. (Fotos del autor)

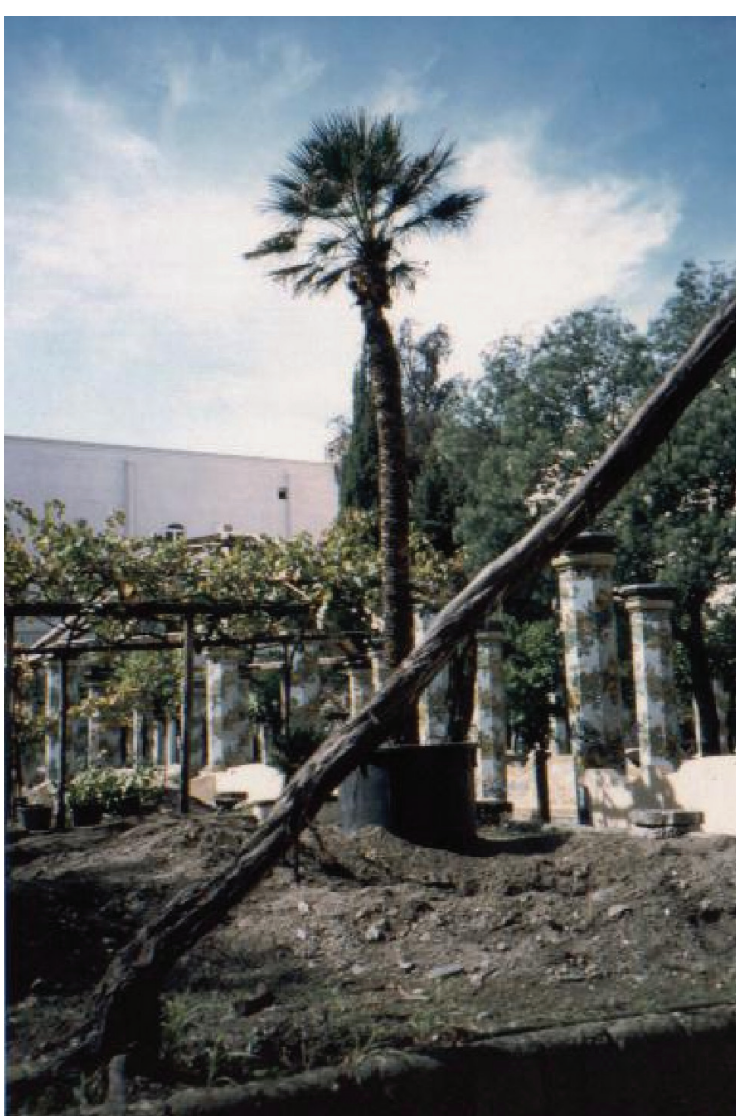

Arranque de un notable ejemplar de palmito (Chamaerops humilis) 


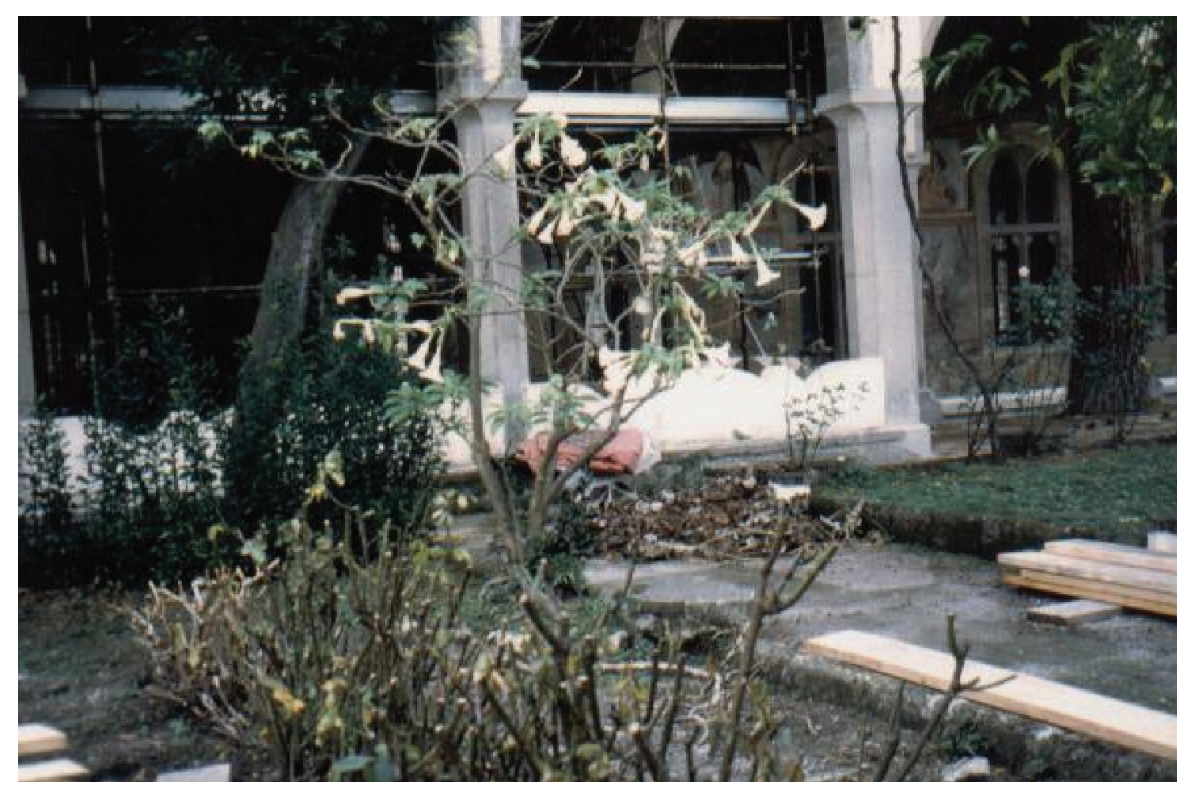

Arranque de rosales y brugmansia arbórea. Otoño de 1999. (Fotos del autor)

desaparecido todos los arbustos, árboles y trepadoras del antiguo jardín, excepto algunos naranjos, sino que incluso las grandes parras que subían hasta la galería superior habían sido igualmente eliminadas. Y el famoso jardín de aromáticas se reducía a dos hileras de plantas en uno de los rincones del patio junto con un pequeño fragmento de huerta en otro rincón.

Unicamente en las columnas reconstruidas tras el bombardeo, las que no conservan el revestimiento cerámico barroco, se permitía crecer a las parras. El resto de las columnas con azulejos mostraban una desnudez total de vegetación con el fin de "protegerlas".

Respecto a la superficie de tierra vegetal, el suelo se veía cubierto completamente de césped habiéndose perdido la rica variedad del pasado. En fin, una intervención que le deja a uno asombrado y que no se llega a entender del todo. Si de

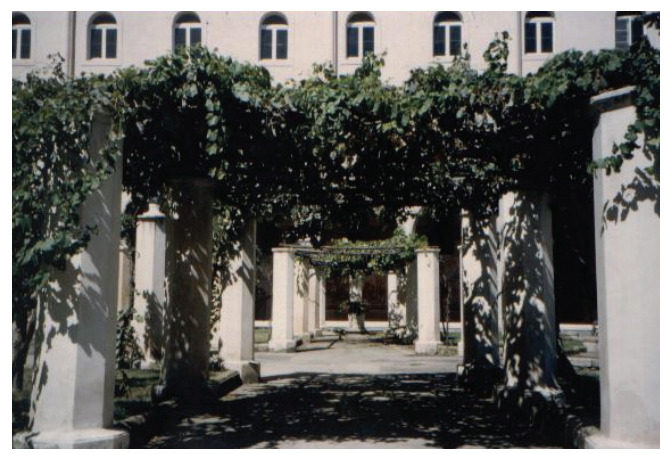

Columnas reconstruidas tras la guerra. Son las únicas que conservan la cubierta vegetal de parras. Verano del 2001. (Foto del autor)

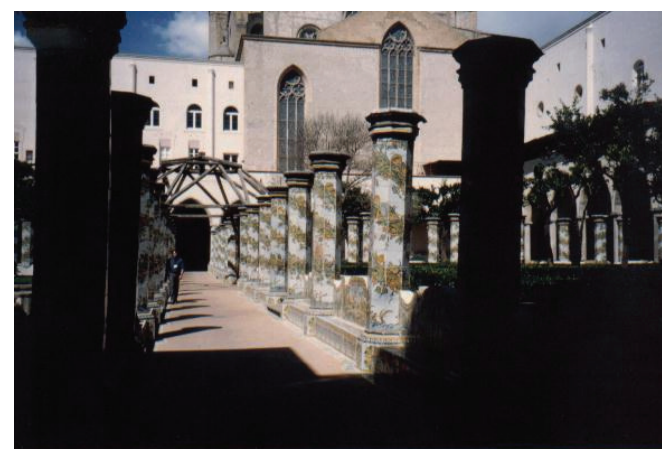

Columnas de azulejos desprovistas de vegetación. Verano del 2001. (Foto del autor) 
lo que se trataba era de proteger las columnas de cerámica, tal vez hubiera sido mejor el haberlas sustituido por reproducciones y proceder a guardarlas en alguna de las salas del museo del convento y dejar al claustro, lugar central de la vida monástica, con su complejo simbolismo religioso de paraíso perdido, que se expresara con toda la belleza que da la armonía entre arquitectura y vegetación, belleza arrebatada al lugar en esta intervención sin sentido que indigna y entristece por lo que supone de pérdida irremediable del acervo botánico de siglos.

Casi podíamos afirmar que las intervenciones llevadas a cabo con esta actuación en octubre de 1999 hicieron tanto daño al claustro como los bombardeos aliados de la última guerra pues ambas acciones suprimieron de manera irrecuperable parte de la historia del monumento.

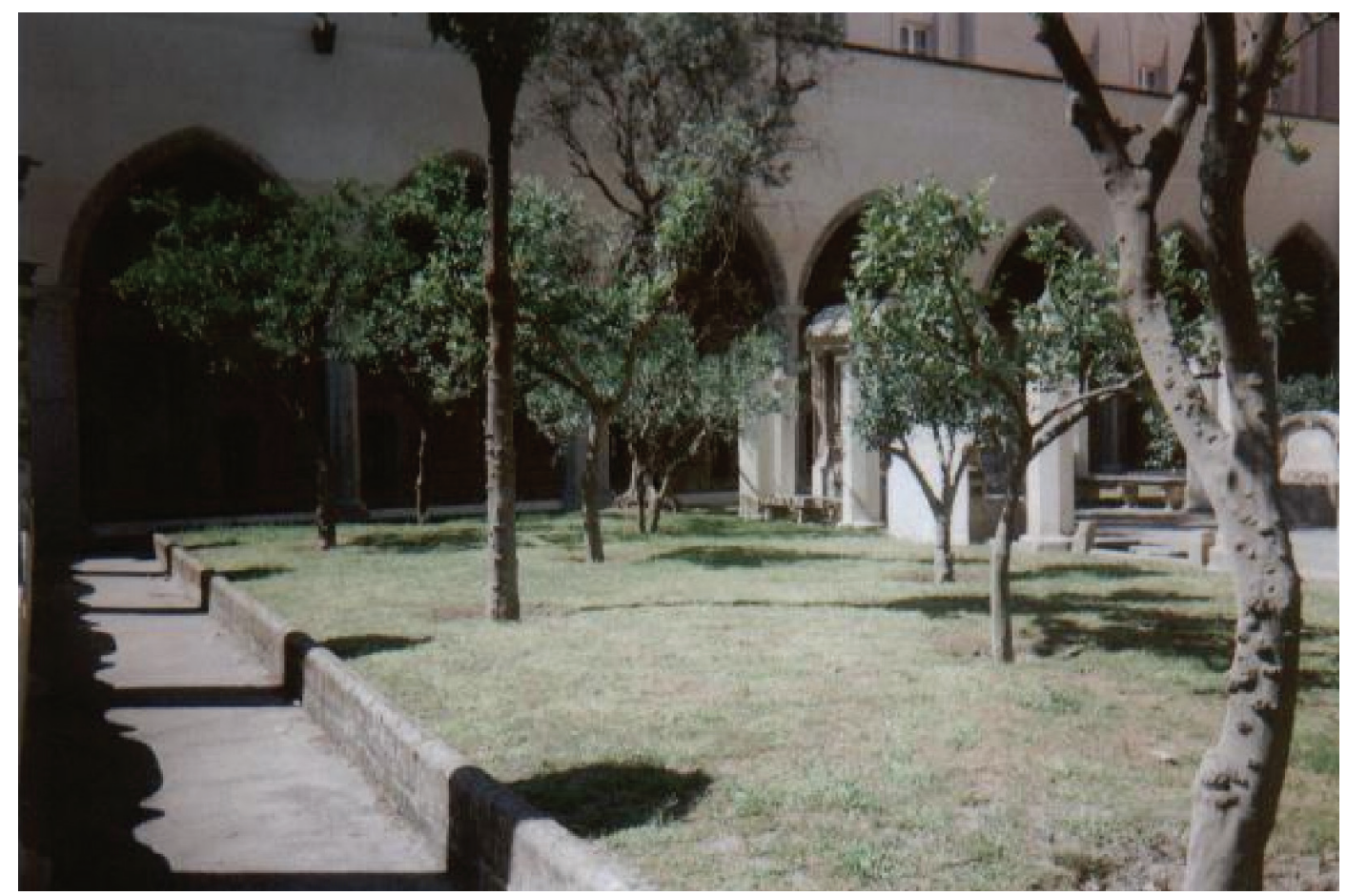

El Claustro tras la restauración en el verano del 2001. (Foto del autor)

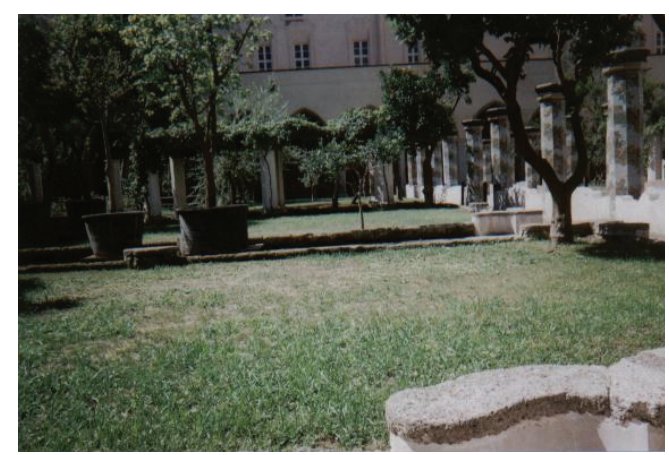

El Claustro en el verano del 2001.

(Foto del autor)

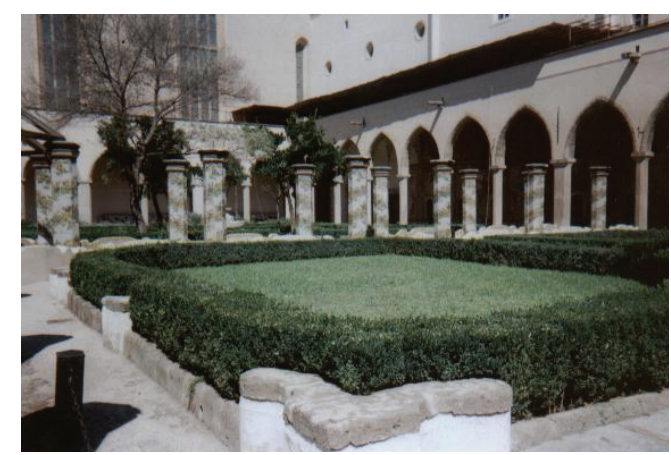

Otra imagen del Claustro en el verano del 2001. (Foto del autor) 

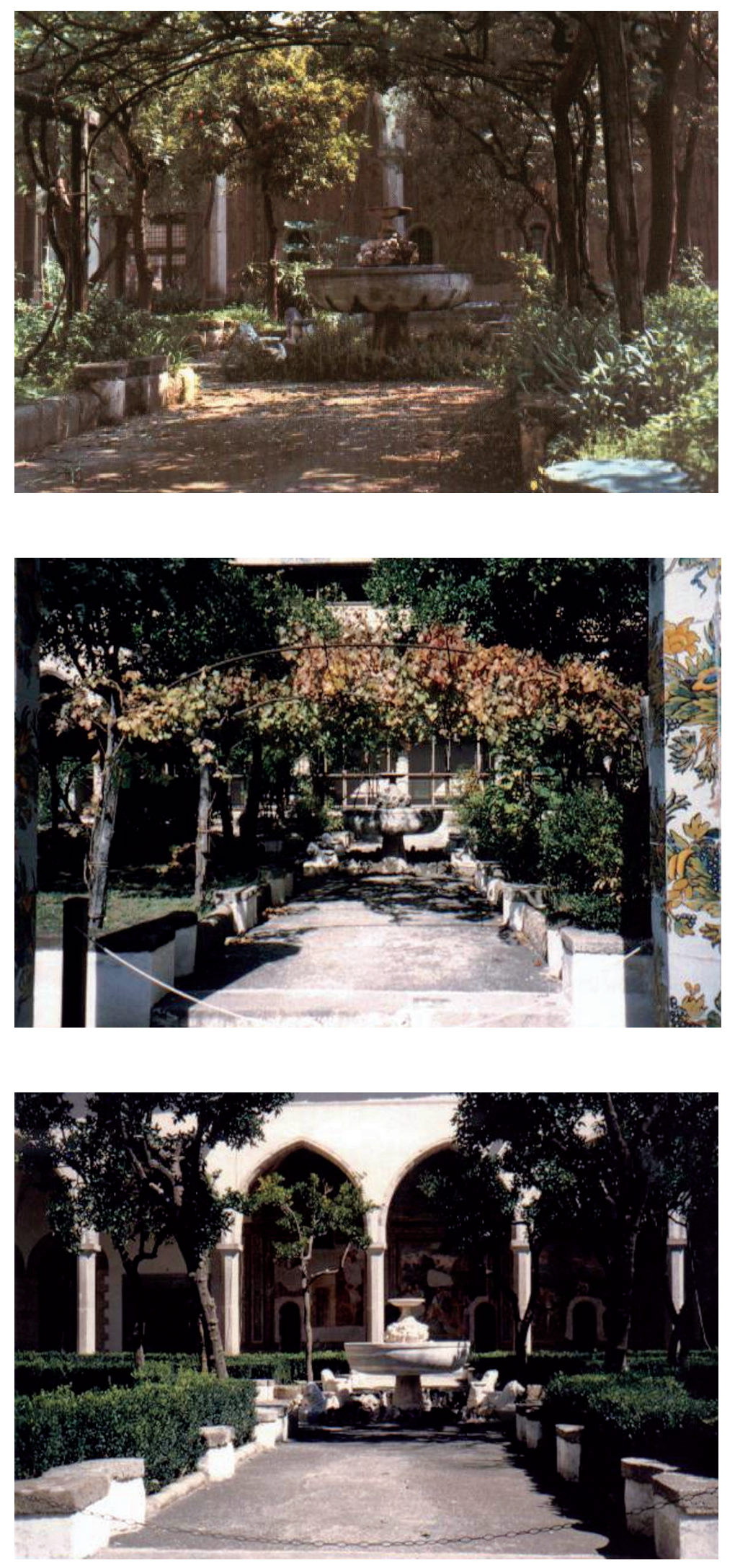

Tres imágenes del mismo lugar. La superior es de una tarjeta antigua. La segunda es del otoño de 1999. La tercera del verano del 2001. (Foto del autor) 

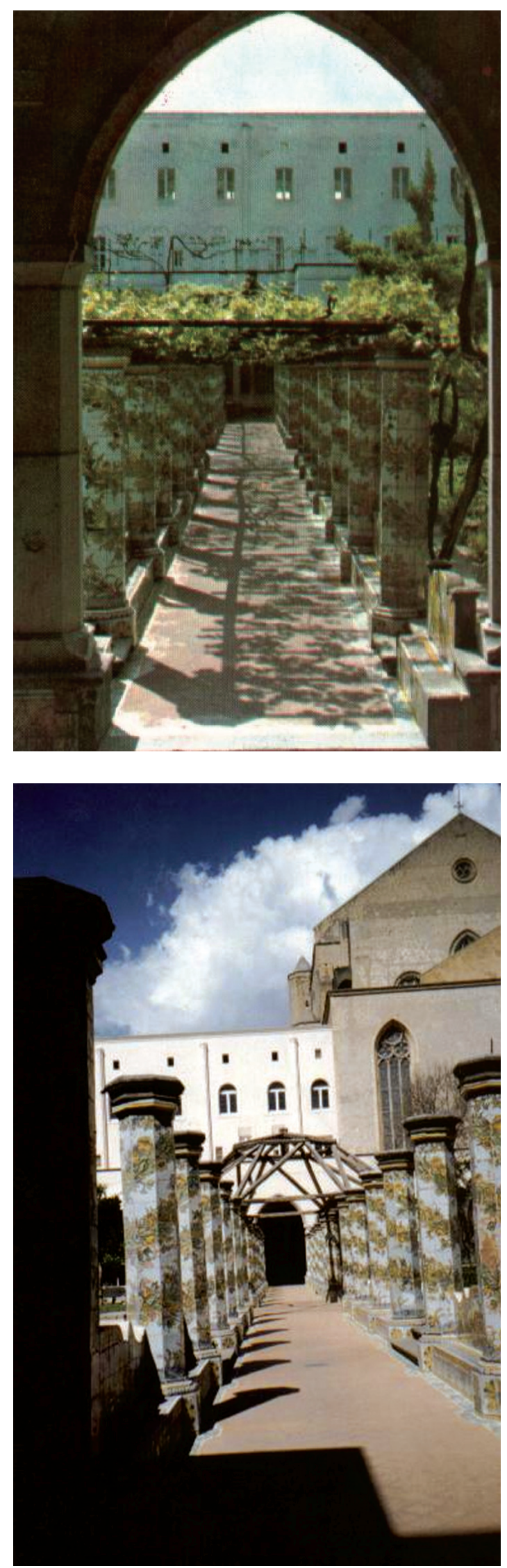

La imagen superior es de una tarjeta antigua. La inferior es del verano del 2001. (Foto del autor) 


\section{Bibliografía sobre el Convento de Santa Clara de Nápoles}

BLAIR MACDOUGALL, Elizabeth. Viaggio nei Giardini di Napoli e di Salerno.Ed. M. T. Train/Scala Books. New York, 1995.

Relación de los principales jardines de la zona del Golfo de Nápoles con fotografías a cargo de Nicolás Sapieha. Hay una introducción general sobre jardines que establece una continua línea desde las creaciones de la antigua Roma hasta los del siglo XIX salvando las diferencias culturales correspondientes. Al Claustro de santa Clara no se le dedica demasiada extensión pero hay fotos en los que se ven las glicinias y las parras sombreando los caminos antes de la intervención del año 2001.

CAMPANELLI, Daniela. Il Monastero di Santa Chiara a cargo de Annachiara Alabiso, Mario de Cunzo, Daniela Giampaola, Adele Pezullo. Editorial Electa Napoli, 1995.

Guía sobre el convento. Contiene algunas fotos antiguas de antes de ser realizada la restauración que nos permiten ver cuanto se perdió en la misma.

MARGIOTTA, Maria Luisa. Il giardino sacro. Chiostri e giardini della Campania. Ed. Electa Napoli, 2000.

Es un paseo por los principales conventos de los alrededores de Nápoles. Podemos ver como aunque las formas en cruz se han conservado, en la mayoría de los mismos las plantas han desaparecido a favor de las praderas de césped. Relación de algunas de las plantas presentes en estos lugares con la simbología religiosa que conllevan. 


\section{D.2.2. Inglaterra}

\section{Hampton Court: The Privy Garden (1992-1995)}

Antes de ver la restauración llevada a cabo en los jardines de Hampton Court, en concreto el denominado Privy Garden, veremos brevemente la historia de este lugar para comprender mejor el contexto histórico en el que el jardín surgió y las circunstancias históricas en que se realizó la restauración.

Hampton Court comienza como residencia real su historia en 1529 tras ser regalado por el cardenal Wolsey a Enrique VIII con el fin de intentar calmar el enfado del rey hacia su persona por el fracaso de sus gestiones para conseguir el divorcio de su esposa Catalina de Aragón del Papa. Enrique VIII se mudó inmediatamente al nuevo palacio y entre 1530 y 1538 construyó el Privy Garden y los espacios que lo rodeaban (la Montaña y la Galería del Agua posteriormente suprimidos como ya veremos) en un intento de dignificar la entrada al palacio desde el río ya que los viajes en barco desde Londres eran bastante corrientes. Gracias a un dibujo de Antonius von Wyngaerde de 1555 y al relato Daniel Jackes nos podemos hacer una idea de lo que el jardín contenía en esos momentos así como en la época de su hija la reina Isabel: gran abundancia de figuras hechas de topiaria en unos espacios de fuerte diseño geométrico característico de los jardines del alto Renacimiento.

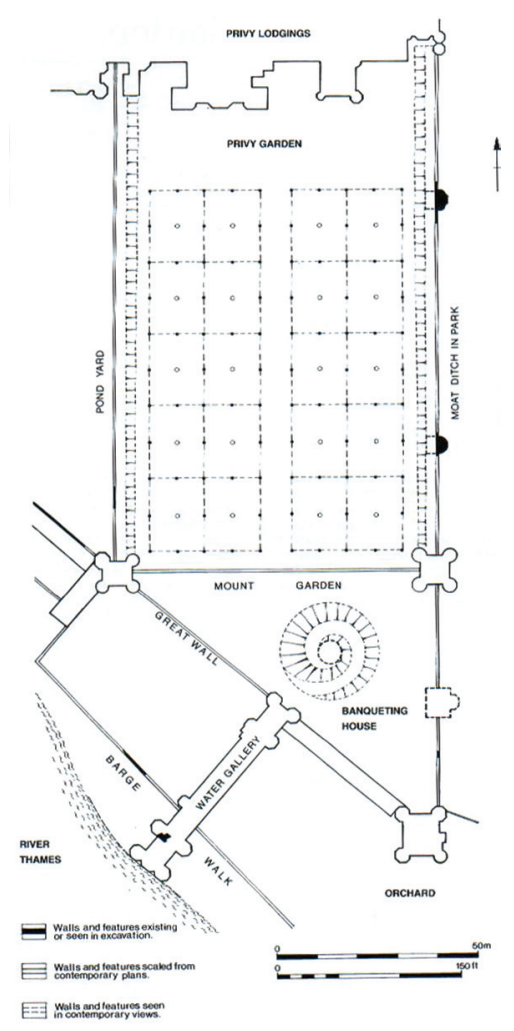

El Privy Garden en la época de Enrique VIII 
La adopción a las formas del Renacimiento pleno realizada por Inigo Jones condujo a la imposición del modelo de patio en cruz (fuente central con cuatro parterres) que perduraría hasta el triunfo de las formas del jardín barroco francés en el siglo XVIII.

Durante la Guerra Civil (década de 1640) el jardín conservó esa forma. Los cuadros estaban plantados con césped y había estatuas que adornaban el espacio. Tras la ejecución del Rey y la declaración de Oliver Cromwell como Lord Protector de la Commonwealth, Hampton Court fue elegido por éste como lugar de estancia y entretenimiento. Numerosas estatuas procedentes de la colección de Carlos I se incorporaron al Jardín y se realizaron mejoras en el lugar.

Con la restauración de Carlos II, Hampton Court conoció una nueva época de esplendor al ser elegido el lugar como residencia de la favorita del monarca. El jardín siguió conservando su forma en cruz.

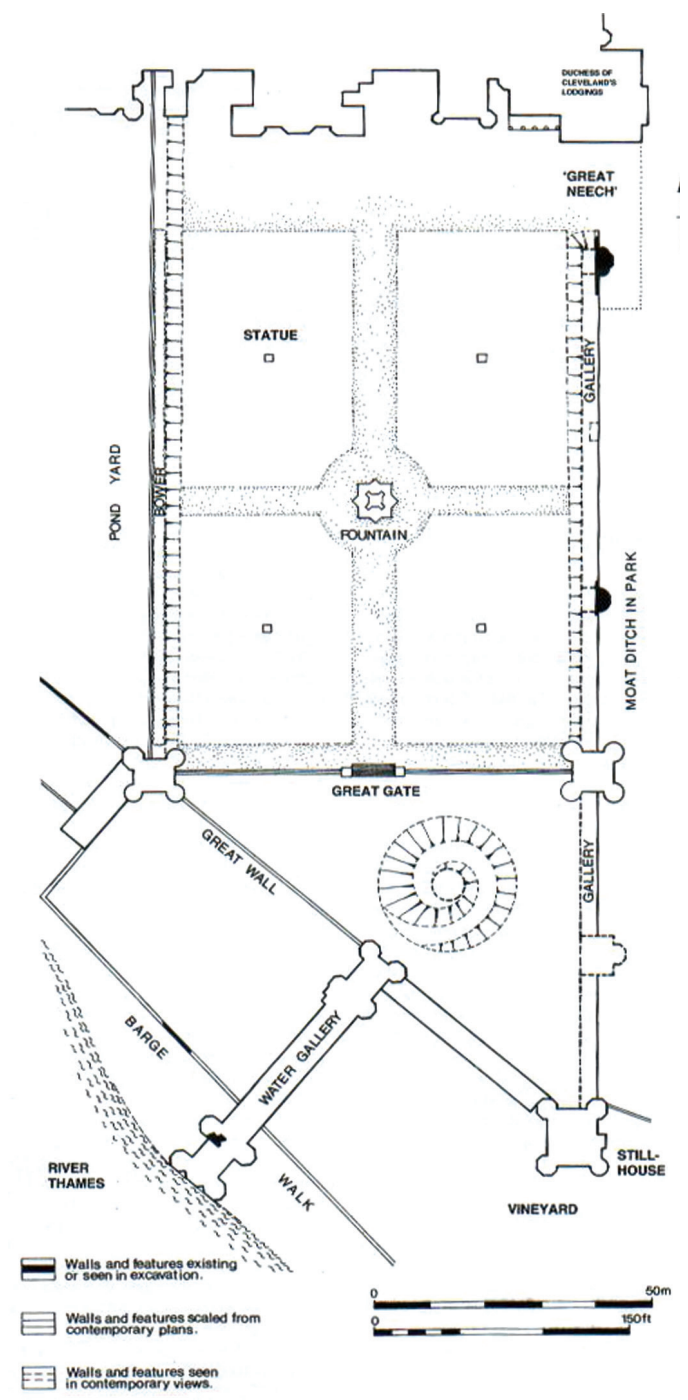

Hampton Court en la época de Oliver Cromwell 
El jardín se mantuvo como lo hemos visto hasta la época de los reyes Guillermo y María. Cuando éstos llegaron a Inglaterra ya tenían experiencia en construir jardines (Het Loo) y además a la reina las plantas le gustaban como lo demostraba toda la colección de exóticas que conservaba en el invernadero del palacio de Hoselaarsdijk y que deseaba trasladar a su nuevo reino.

Los monarcas encargaron a Cristopher Wren los trabajos en el palacio el cual se amplió con la construcción de nuevas habitaciones. En los jardines se decidió construir una orangerie para conservar los cítricos y demás plantas delicadas a la par que se consideró la posibilidad de iniciar su transformación al estilo francés. Los trabajos fueron encargados al francés hugonote Daniel Marot que ya había trabajado para los reyes en otras residencias en Holanda. Para conseguir las perspectivas hacia el Támesis hubo que tirar algunos edificios de la época Tudor así como deshacer la montaña de Enrique VIII. Igualmente se encargó una hermosa verja para separar el jardín del resto de la posesión y así dotarlo de una total privacidad espacial reforzada en lo visual con la plantación de un seto tras la citada verja.

Parece ser que en 1691 ya funcionaba la orangerie y en los cuadros del jardín se realizó un gazon coupé o parterre con dibujos recortados a la espera de acabar las obras del palacio para acometer con profundidad las del jardín.

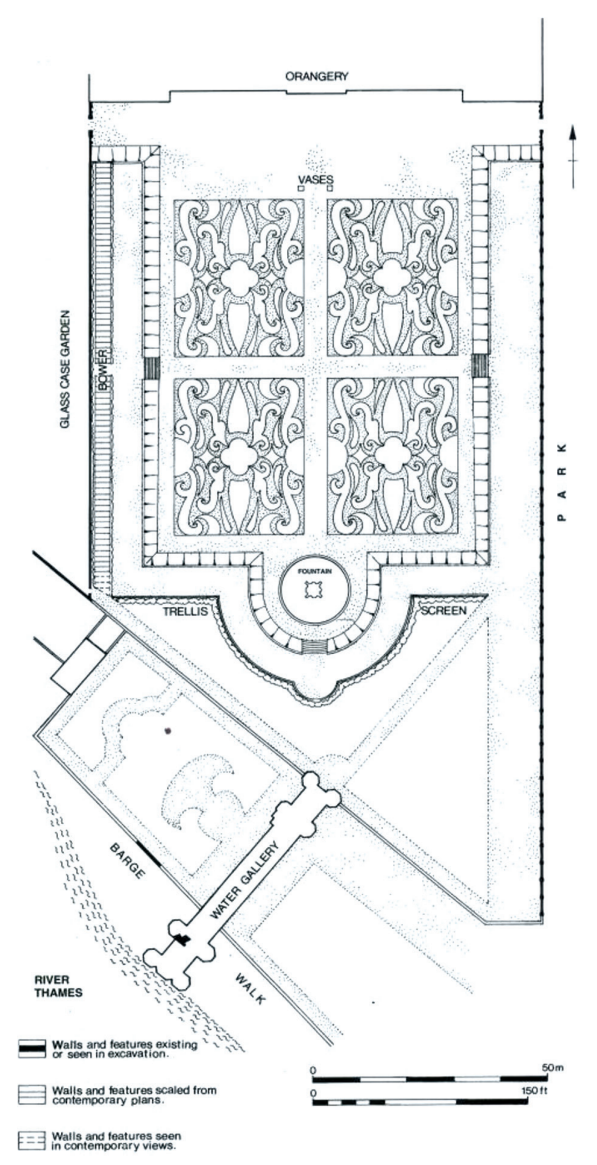

La primera remodelación del jardín por Guillermo y María 
En 1701, ya viudo el rey, decide hacer el jardín definitivo con el fin de lograr una visión del Támesis desde el palacio. Ello implicó un nuevo diseño de los parterres, cambiar las terrazas, nuevas escaleras, fuentes, un nuevo sistema de drenaje, tuberías, etc., Los detalles de toda esta construcción están recogidos en la obra señalada de David Jackes.

Casi acabado el jardín, el rey murió en 1702. Este jardín es el que recuperará la intervención de finales del siglo XX.

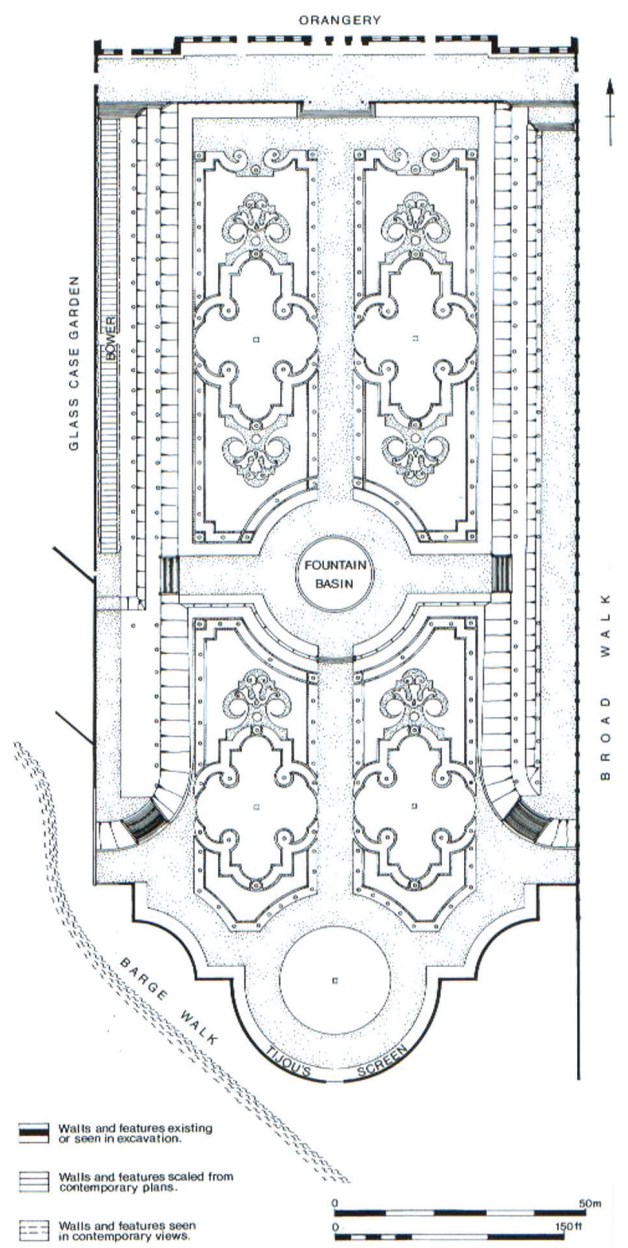

El jardín tras la intervención del rey Guillermo

A la muerte del rey, su cuñada Ana, hermana de María, subió al trono. La vena escocesa se ve que era dominante en ella, por lo que detuvo inmediatamente las obras y entregó el mantenimiento de los jardines a Henry Wise debido a que ofertó a mitad de precio el cuidado de los mismos. Estos se acabaron pero no con los detalles con los que el rey anterior los había pensado. Ya en 1707, los parterres de broderie se suprimieron por su elevado coste de mantenimiento. Se introdujo césped y caminos de grava en vez de los dibujos florales del jardín francés. Y muchos de los encargos de esculturas nunca fueron pagados a los artistas. 
Después de 1737 la Corte nunca volvió a habitar en Hampton Court con lo cual el jardín sufrió abandono. Esto unido a las nuevas corrientes de la jardinería (Lancelot Brown, uno de los padres del jardín inglés, fue Jardinero Real desde 1746 a 1783) propició que los cuadros se convirtieran en habitaciones verdes rodeados de una imponente masa vegetal a la cual se renunció a dar podas de formación como en los tiempos en que imperaban los criterios barrocos.

Podríamos decir para resumir que al final del siglo XVIII el jardín había perdido el aspecto francés de la época de los reyes Guillermo y María.

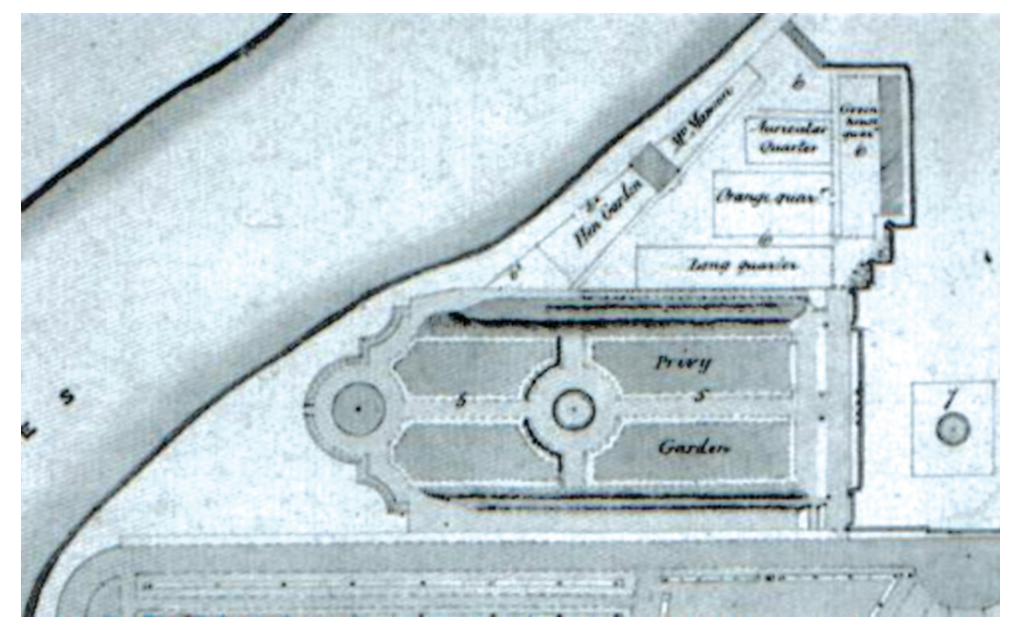

El Jardín Privado entre los años 1783-1806

En 1837 la reina Victoria sube al trono y decide entonces que los jardines se deben de abrir al público en general así como parte de los edificios que de esta manera van adquiriendo poco a poco carácter de museo y perdiendo el aspecto de residencia que refleje la vida cotidiana de los ocupantes. Las facilidades de transporte hicieron que el número de visitantes fuese elevado por lo que los residentes que ocupaban el palacio por concesión real desearon tener espacios privados. Otra vez vuelve el jardín a tener el carácter íntimo frente al resto de la posesión que se ha convertido por las visitas en público.

El jardín va a ser acondicionado según los criterios de jardinería imperantes en ese momento. Arbustos de flor son plantados tales como espireas, budleias, perales japoneses, lilos, durillos, espinos blancos, celindas, etc. junto con perennes y anuales con el fin de conseguir una floración lo más prolongada posible. Una típica representación de lo que se conoce como "estilo mixto".

A partir de 1890 el Jardín vuelve a ser abierto al público. Los testimonios gráficos conservados de este momento muestran un jardín donde abundan los arbustos de flor, árboles variados y herbáceas perennes que ocupan todos los cuadros del jardín con lo que vemos que el estilo mixto perdura hasta finales del siglo XIX. 


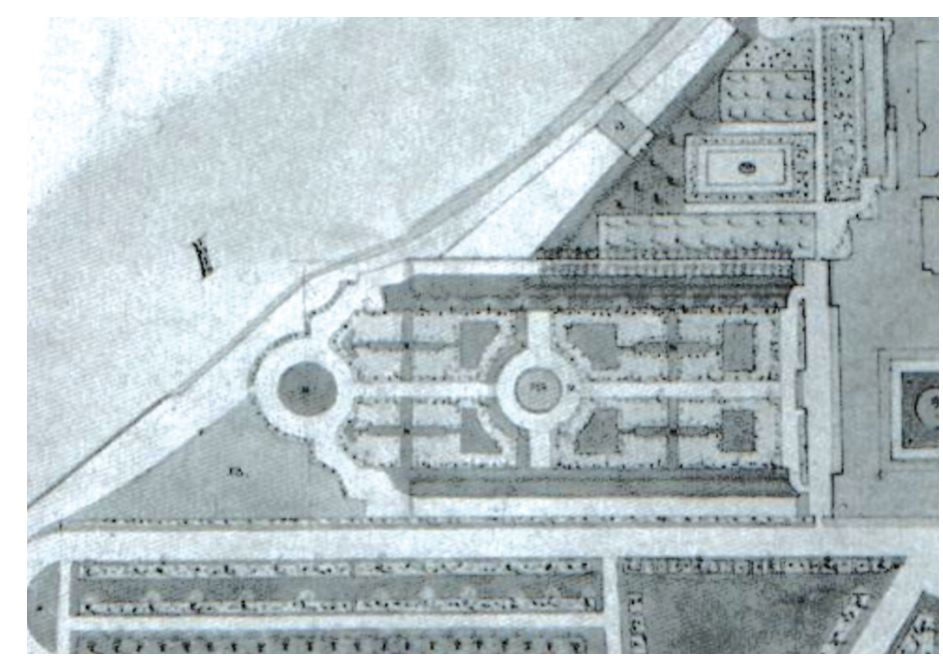

Plano del jardín de Henry Sayer de 1841

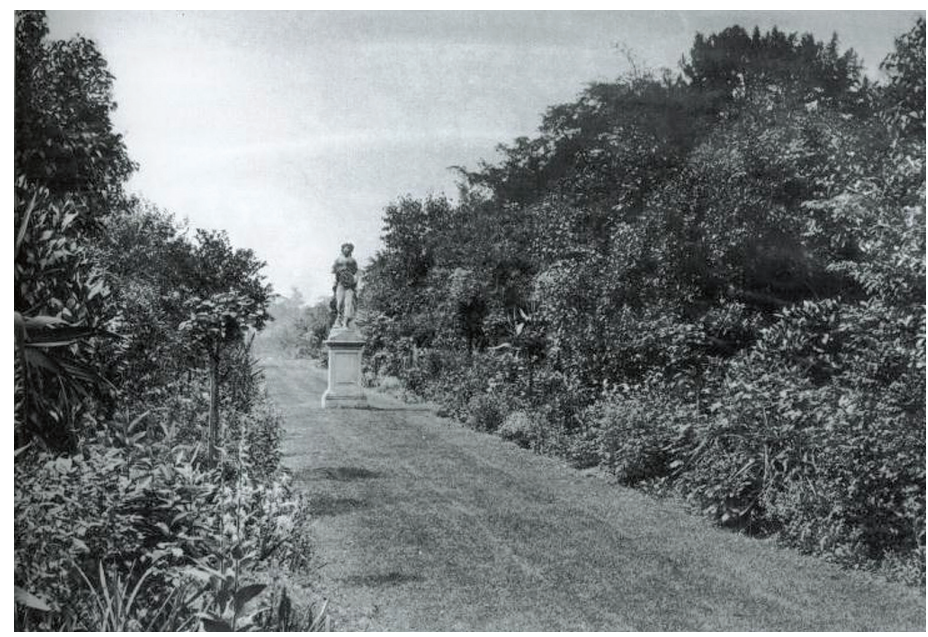

Aspecto del jardín en 1903. Foto procedente del Country Life

En 1986 las construcciones de la época de Guillermo y María arden en su lado sur. Tras seis años de trabajos de restauración se abren de nuevo al público. Estos edificios se ofrecieron a los visitantes no como eran antes del incendio sino como debieron de ser la última vez que los monarcas los habitaron. Esto sirvió para realzar la diferencia entre el nuevo palacio y los jardines existentes los cuales formaban una unidad histórica, social y estética con el edificio. Por tanto, se vio la necesidad de que el jardín hiciera juego con el edificio restaurado y se empezó a pensar en la posibilidad de realizar la restauración integral de los jardines del rey Guillermo.

Lo primero que se hizo fue ver con que información se disponía. Así se encontró en los archivos una relación bastante exhaustiva de las obras realizadas en el jardín entre 1699 y 1702. 
Igualmente los datos topográficos eran buenos como confirmaron las excavaciones arqueológicas. También se disponía de buenas fuentes pictóricas que reflejaban bastante fielmente el estado del jardín en ese momento. Las vistas más importantes eran las del pintor holandés Leonard Knyff (1650-1722), una desde el lado sur y otra desde el lado este. Realizadas a vista de pájaro, se subsanaron sus inconvenientes con el mapa existente en el Museo de Sir John Soane que muestra la traza del jardín hacia los años 1710-1713.

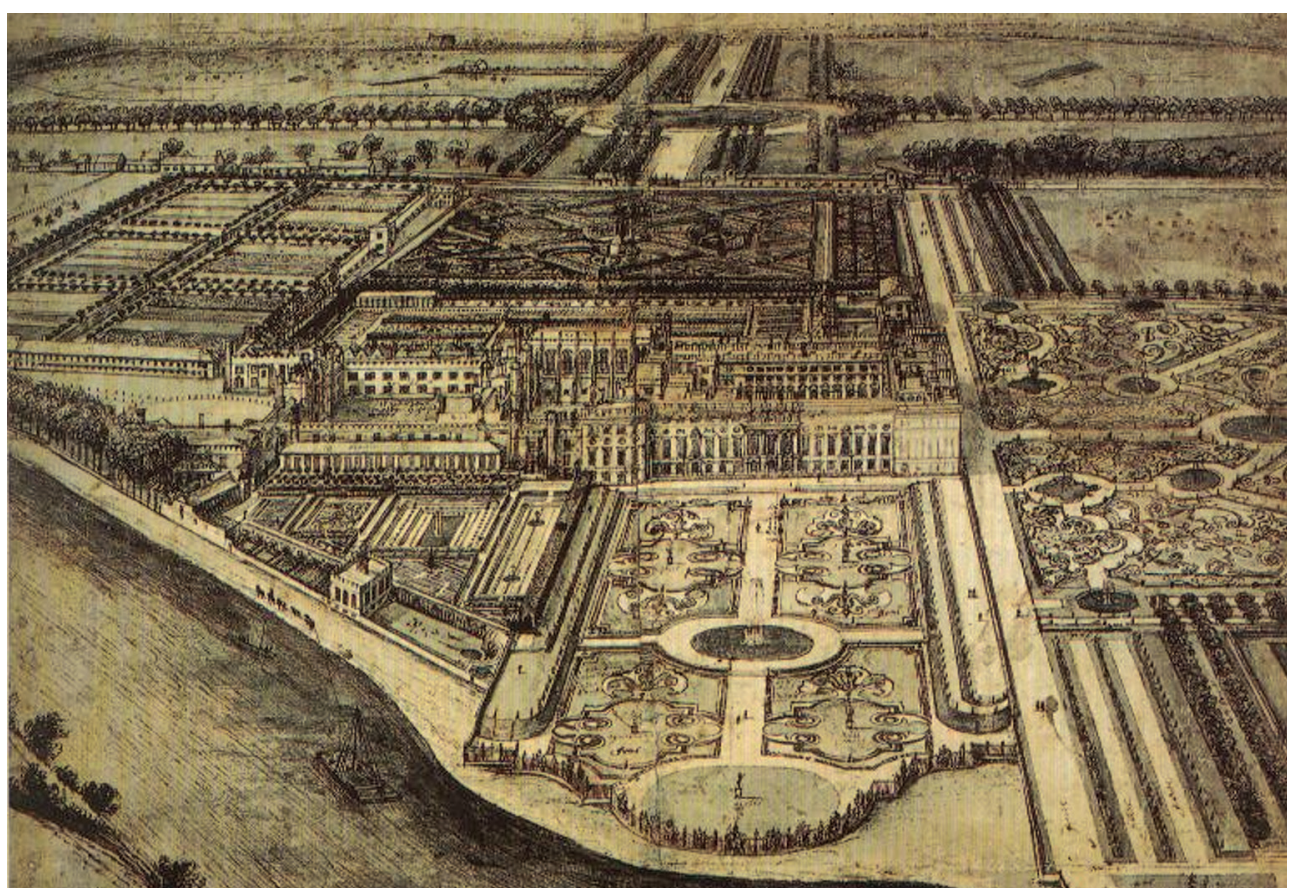

Hampton Court por Leonard Knyff hacia 1702. Museo Británico

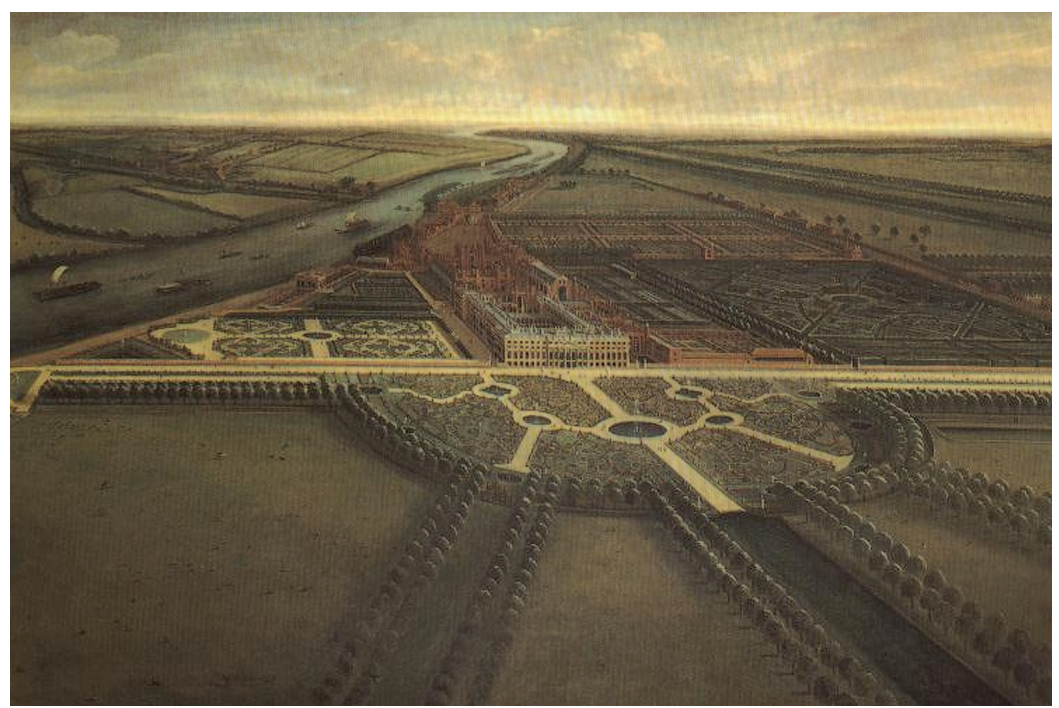

Hampton Court desde el este por Leonard Knyff. Colección de Isabel II 


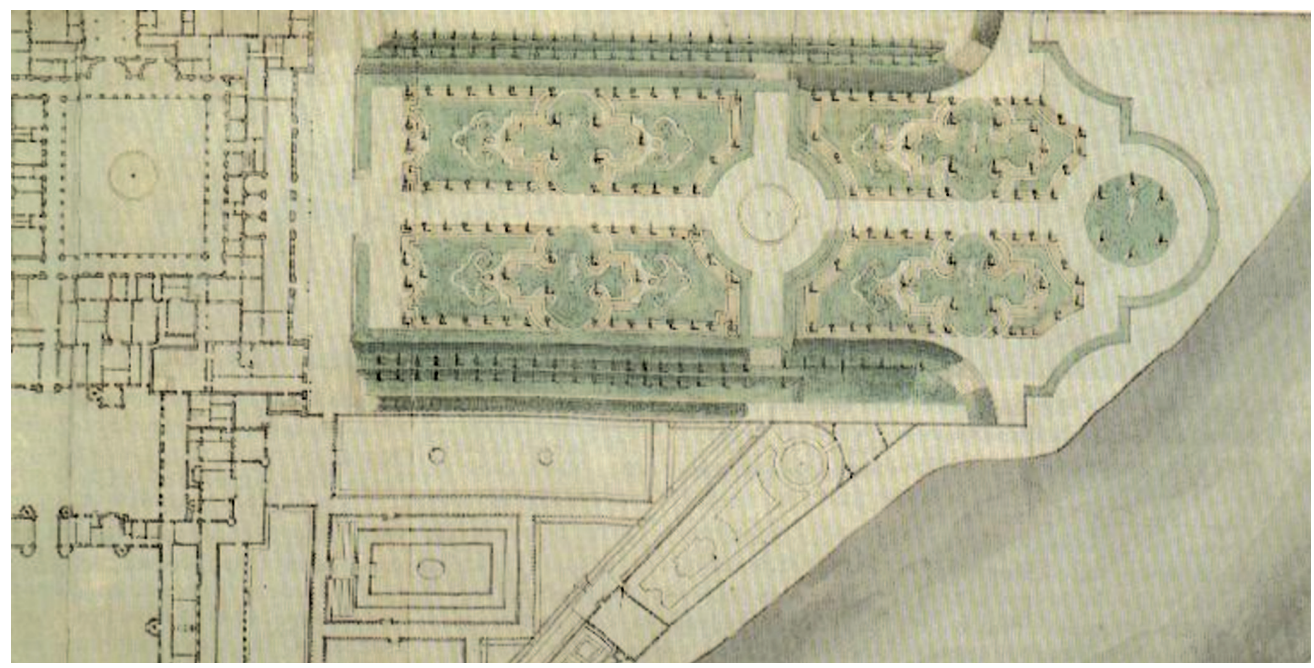

Plano del Jardín Privado hacia 1710-13. Museo de Sir John Soane

Para la elección de las especies vegetales se utilizaron varias fuentes. La primera fue el conjunto de las seis listas de plantas conservadas en el Museo Británico. Aunque cinco de ellas se centran en plantas exóticas de la colección de la reina María presentes en los invernaderos entre 1690 y 1694, hay una sin embargo que data de los años 1700-1701 que recoge la relación de las plantas del jardín.

La segunda fuente es el Herbario Sloane del Museo de Historia Natural. Tal herbario contiene 630 especies de Hampton Court aunque sólo unas cuantas son del Jardín Privado.

La tercera es la obra Opera Omnia Botanica del botánico de la reina Leonard Plukenet (1642-1706) correspondiente a los años 1691-1696 y que aunque contiene 52 especies de Hampton Court, la mayoría constituyen referencias a ejemplares exóticos.

La cuarta y más importante fuente la forman las listas de plantación conservadas en los Archivos Públicos (Public Record Office). Aquí se conservan las listas de compras con las relaciones de arbustos, acebos, tejos y bulbos de primavera adquiridos para el jardín. Aunque todas estas listas eran incompletas, en conjunto constituían una buena base como punto de partida.

A pesar de las transformaciones que el jardín había sufrido en el siglo XIX, aún quedaban en el lugar bastantes elementos del jardín original a la vista como las verjas de hierro, la fuente central, la terraza del lado norte, el reloj de sol y algunos árboles de la plantación de 1702.

El siguiente paso consistió en averiguar los elementos que podían estar enterrados bajo el jardín moderno. Los trabajos arqueológicos hechos en 1992 permitieron ver que a $45 \mathrm{~cm}$ de profundidad se encontraban los restos de la traza de los setos, las bases de las estatuas y hasta los agujeros de los árboles. 
En abril de 1992, justo antes de comenzar los trabajos arqueológicos, se tuvo en cuenta otro aspecto importante: el dar a conocer a la opinión pública lo que se iba a realizar y escuchar las sugerencias o críticas posibles. La experiencia que el English Heritage (Patrimonio Nacional) había tenido en Kenwood y Chiswick, donde hubo una oposición local fuerte en contra de los criterios de restauración empleados (recuperación del jardín original suprimiendo lo existente lo cual produjo el retraso de los trabajos), hizo pensar que era necesario este período de consulta previa ya que se sabía que todo el arbolado existente en Hampton Court así como los arbustos tendrían que desaparecer.

Se publicaron en la prensa los objetivos de la restauración y se hizo una exposición. Miles de personas acudieron a ella, incluidos los representantes de los grupos locales. Las propuestas expuestas recibieron la aprobación de casi todas las personas y organismos consultados.

En el verano de 1992 se decidió acometer la restauración para lo que se estableció un calendario de actuación (comienzo de las obras en el verano del 92 con la finalización de las mismas en el verano del 1995) y fue aprobado un presupuesto (1.200.000 libras).

Al comenzar la restauración se fijó como uno de los objetivos importantes aprovechar todos los elementos existentes del jardín original. En este apartado estaban al menos nueve de los tejos y acebos presentes en el jardín. ¿Qué hacer con ellos? Se consideraron varias opciones. La primera era obtener esquejes de los ejemplares grandes para volver a plantarlos después de la eliminación de los mismos. Otra opción era podarlos drásticamente como se había hecho en Sissinghurst (Kent) y tras la brotada volverlos a formar. Y la última opción era dejarlos como estaban.

La última opción fue desechada ya que el gran tamaño de algunos de los ejemplares (hasta $21 \mathrm{~m}$ los tejos) impedía ver el palacio. La segunda fue igualmente descartada por considerar que el gran tamaño de su tronco así como la potencia de su cepa impedirían el arraigo de los eiemplares más pequeños en su proximidad.

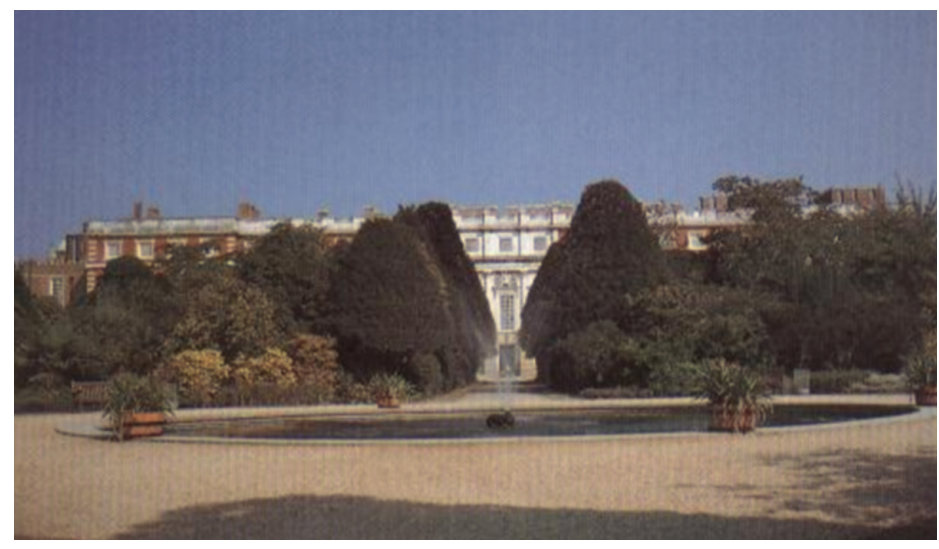

El Jardín Privado en septiembre de 1991. Los grandes ejemplares son los tejos de la plantación original de 1701 del rey Guillermo 
Al final se decidió el arranque de los ejemplares tras haber tomado esquejes de los árboles. Como estos esquejes no estarían listos hasta al menos pasados diez años se optó por comprar 219 tejos holandeses y 96 acebos italianos que serían transplantados después de que transcurrieran los diez años y su lugar ocupado por los ejemplares procedentes de los esquejes obtenidos.

Otros árboles de interés botánico - más que histórico- se transplantaron al Home Park en 1993. La relación de estos ejemplares es la siguiente:

- Parrotia persica

- Gleditsia triacanthos

- Cercis siliquastrum

- Cercis siliquastrum "Alba"

- Cladrastis lutea (dos ejemplares)

- Cladrastis sinensis (cuatro ejemplares)

- Mahonia "Charity"

- Tetradium danielli (dos ejemplares)

- Acer dissectum (palmatum)

- Nothofagus procera (dos ejemplares)

- Celtis occidentalis (dos ejemplares)

- Gymnocladus dioicus (dos ejemplares)

- Acer circinatum

- Arbutus unedo (dos ejemplares)

- Lonicera morrowii (dos ejemplares)

De los 23 ejemplares transplantados vivieron 22. Igualmente hubo que seleccionar el boj para los setos de entre todas las variedades disponibles en el mercado decidiéndose al final por el boi inglés.

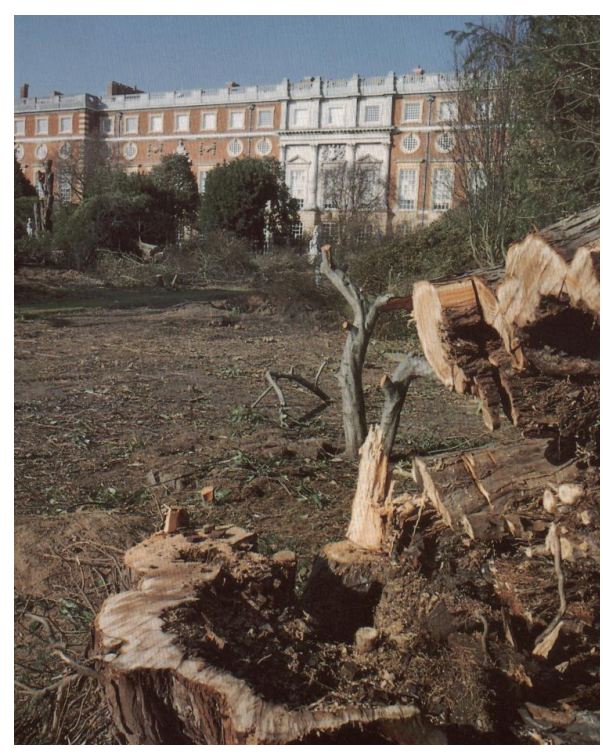

Tala de árboles en el Jardín Privado en 1993. El edificio es ya casi visible. 
Tras esto se acometieron las labores de trazado (el cual se recuperó completamente gracias a los trabajos arqueológicos) y de plantación a base de recurrir además de a las fuentes anteriormente señaladas, a los siguientes libros de jardinería:

- The Retir'd Gard'ner por George London y Henry Wise de 1706

- The Scots Gard'ner por John Reid de 1683

- The Theory and Practice of Gardening por John James de 1712 y 1728

- New Improvements of Planting and Gardening por Richard Bradley en 1726

- New Principles of gardening por Batty Langley.

Todas estas obras fueron de ayuda destacando entre todas la mencionada en primer lugar. Igualmente se tuvieron en cuenta los jardines diseñados por Loudon y Wise como los de Longleat House (Wiltshire), Chatsworth (Derbyshire) y el palacio de Blenheim (Oxfordshire)

Haremos ahora una selección fotográfica de la obra de Thurley que mostrará una secuencia temporal de los diferentes trabajos realizados en el jardín hasta su acabado en 1995.

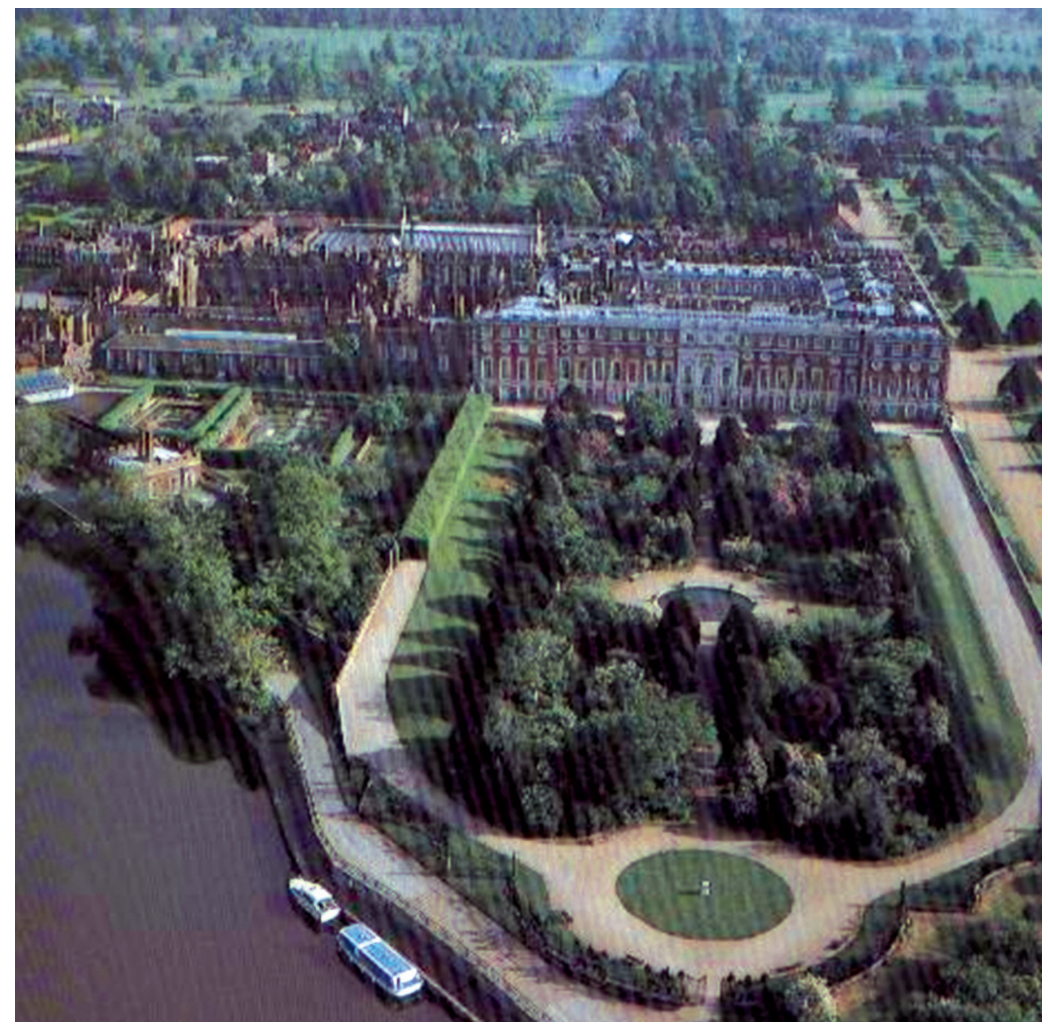

El Jardín Privado de Hampton Court en 1992 antes de la restauración 


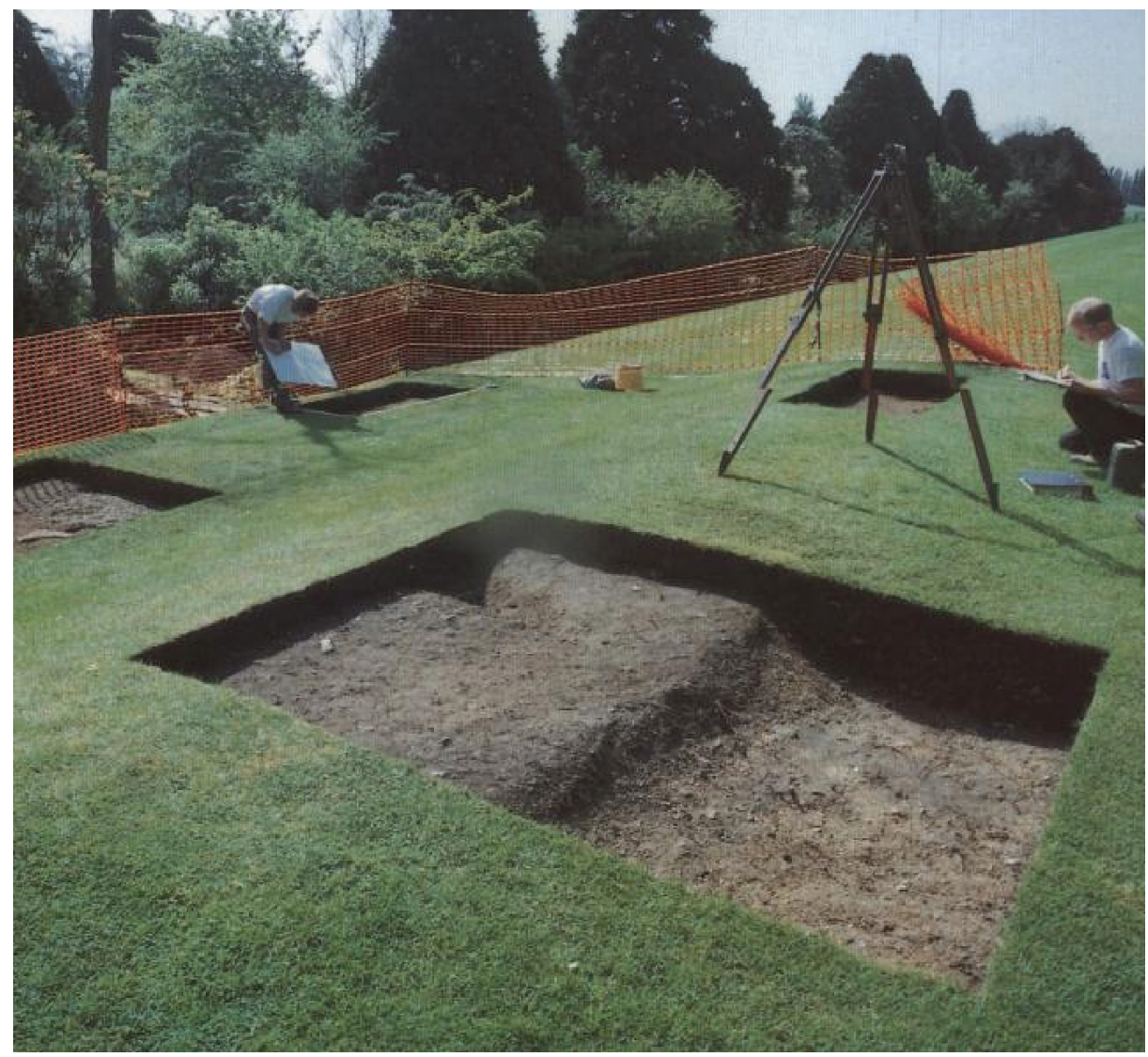

Investigaciones arqueológicas preliminares en mayo de 1992

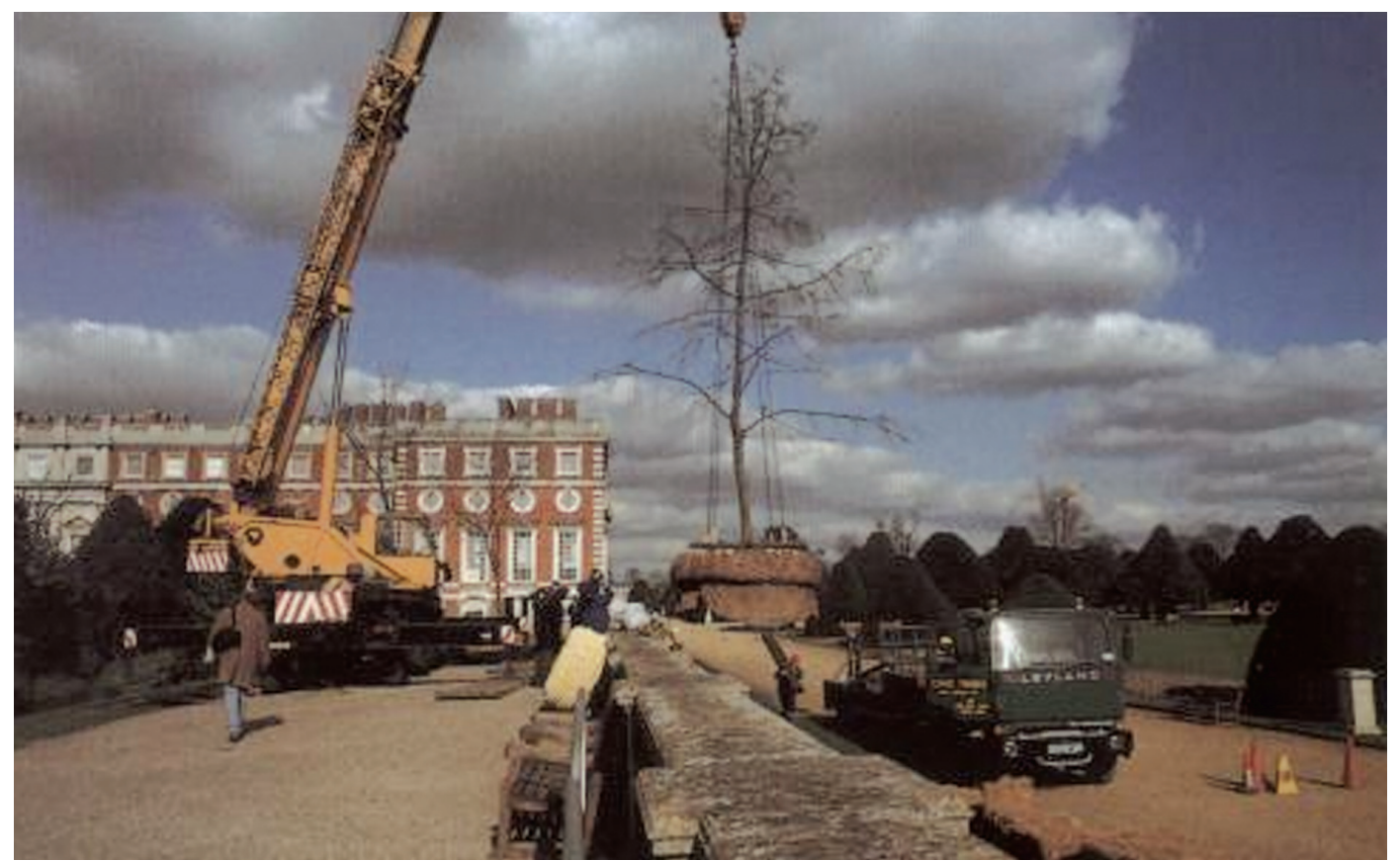

Investigaciones arqueológicas preliminares en mayo de 1992 


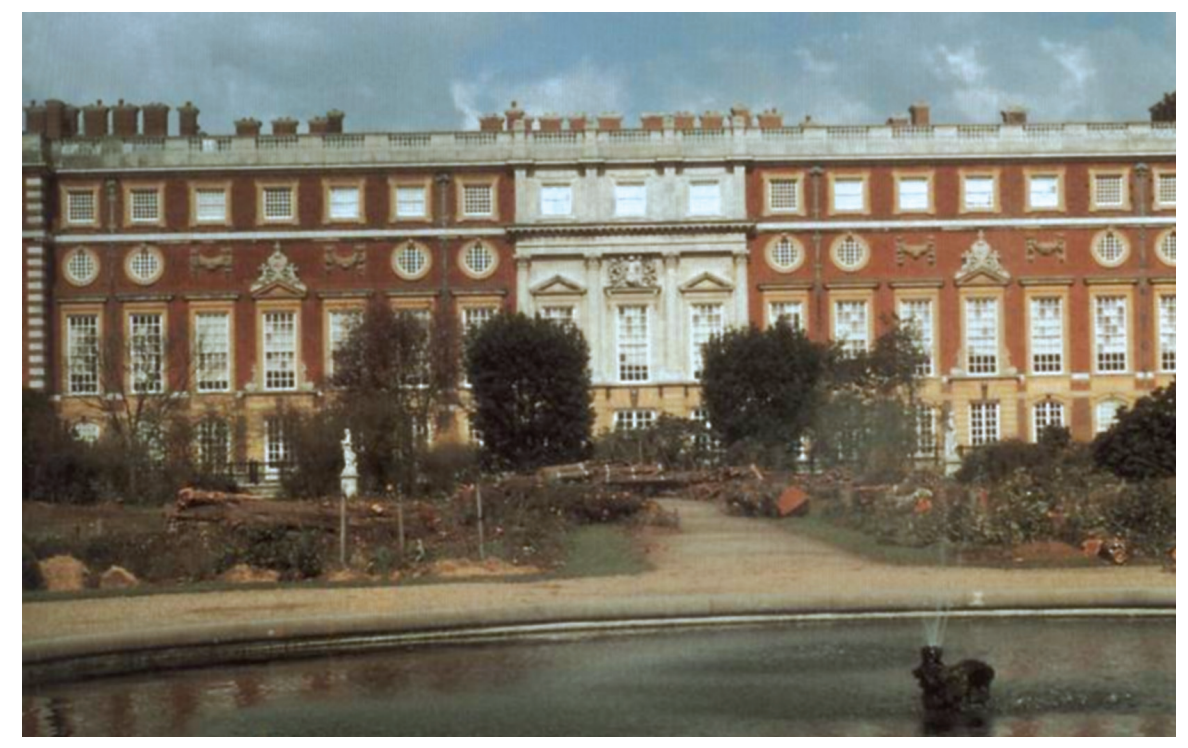

Eliminación de casi todo el arbolado en marzo de 1993. Parte del edificio es ya visible

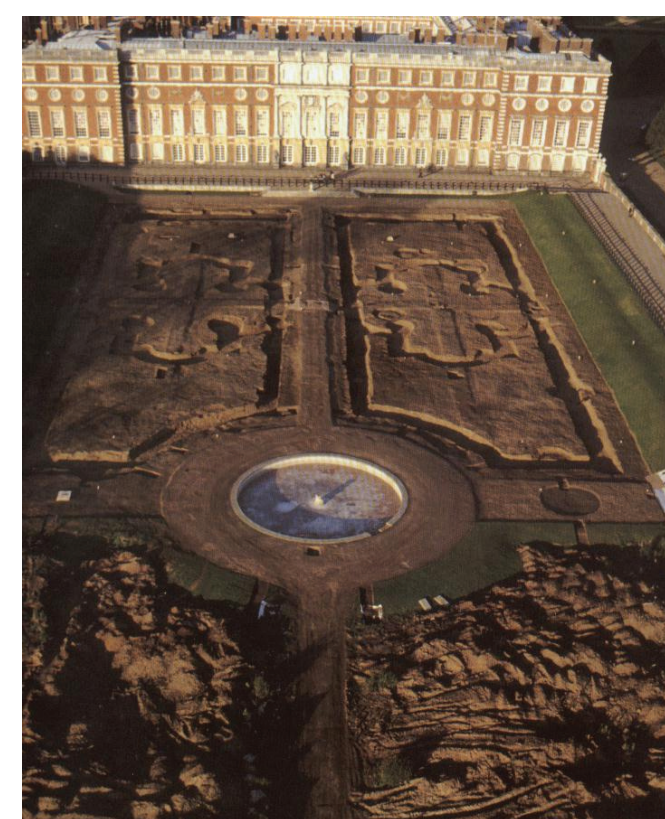

Fin de la primera campaña arqueológica en noviembre de 1993

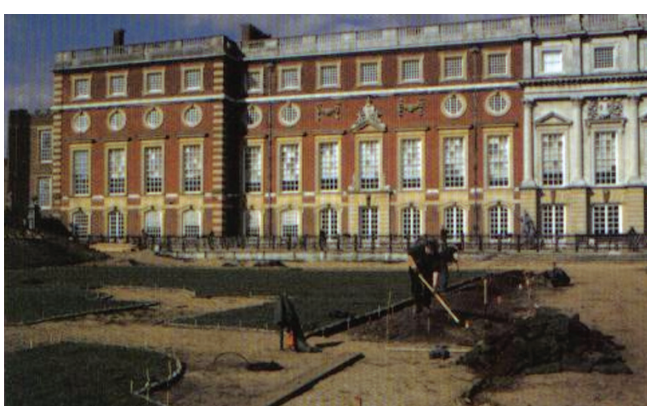

Trabajos de plantación en mayo de 1995

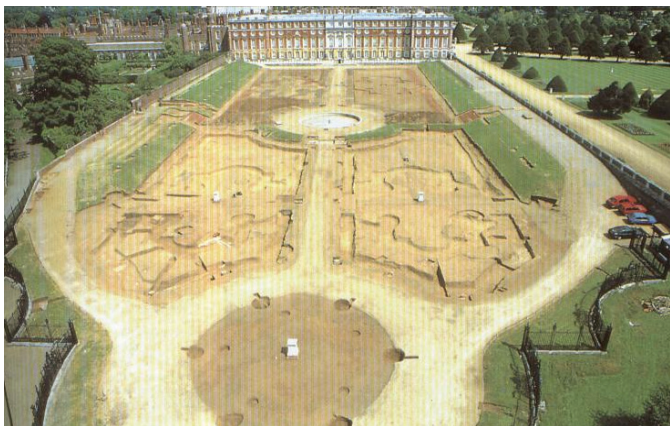

Fin de la segunda campaña arqueológica en junio de 1994

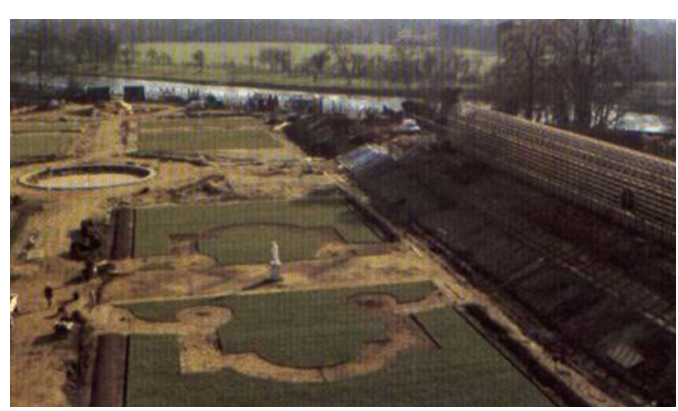

Trabajos de plantación en marzo de 1995 


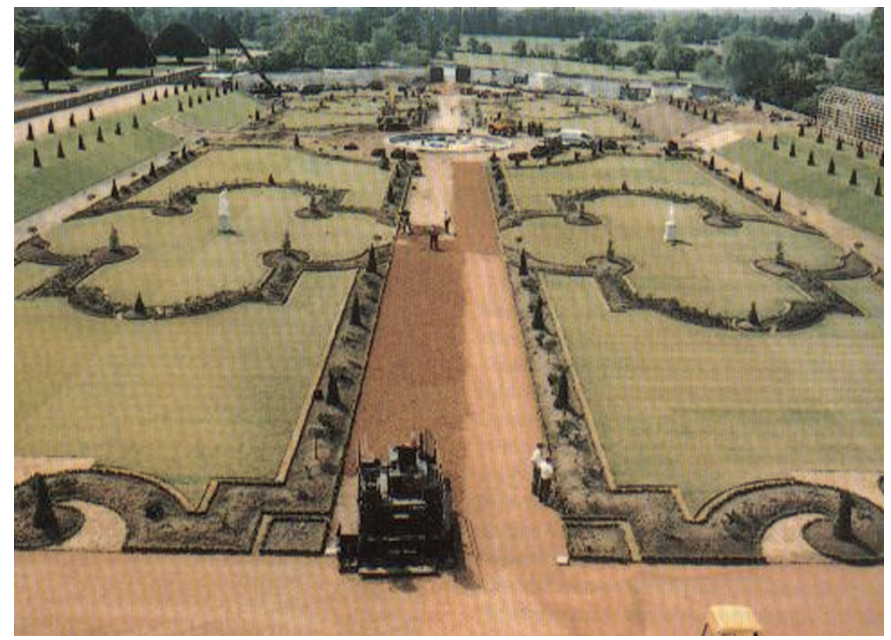

El Jardín Privado al final de su reconstrucción en mayo de 1995

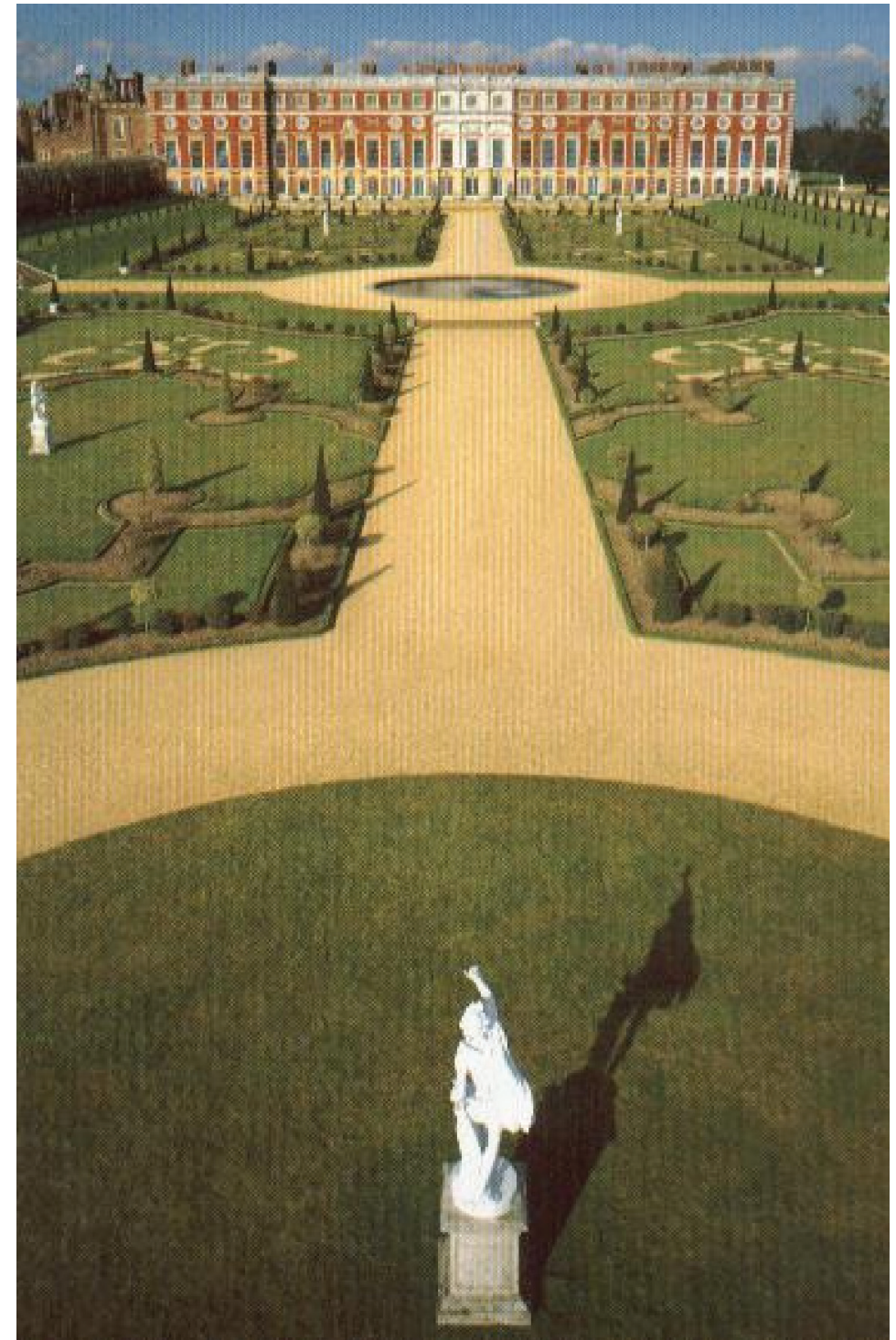

Hampton Court tras su recreación. (Foto procedente de un tríptico publicitario del 2001) 
Como comentario personal hay que decir que todo está bien pero que se llame a las cosas por su nombre. Lo sucedido en Hampton Court no es una restauración -y aquí vuelve a aparecer la antigua confusión lingüística entre restauración y recreación- sino una verdadera recreación (o si se prefiere un repristino) tras la destrucción o aniquilamiento de un auténtico jardín histórico.

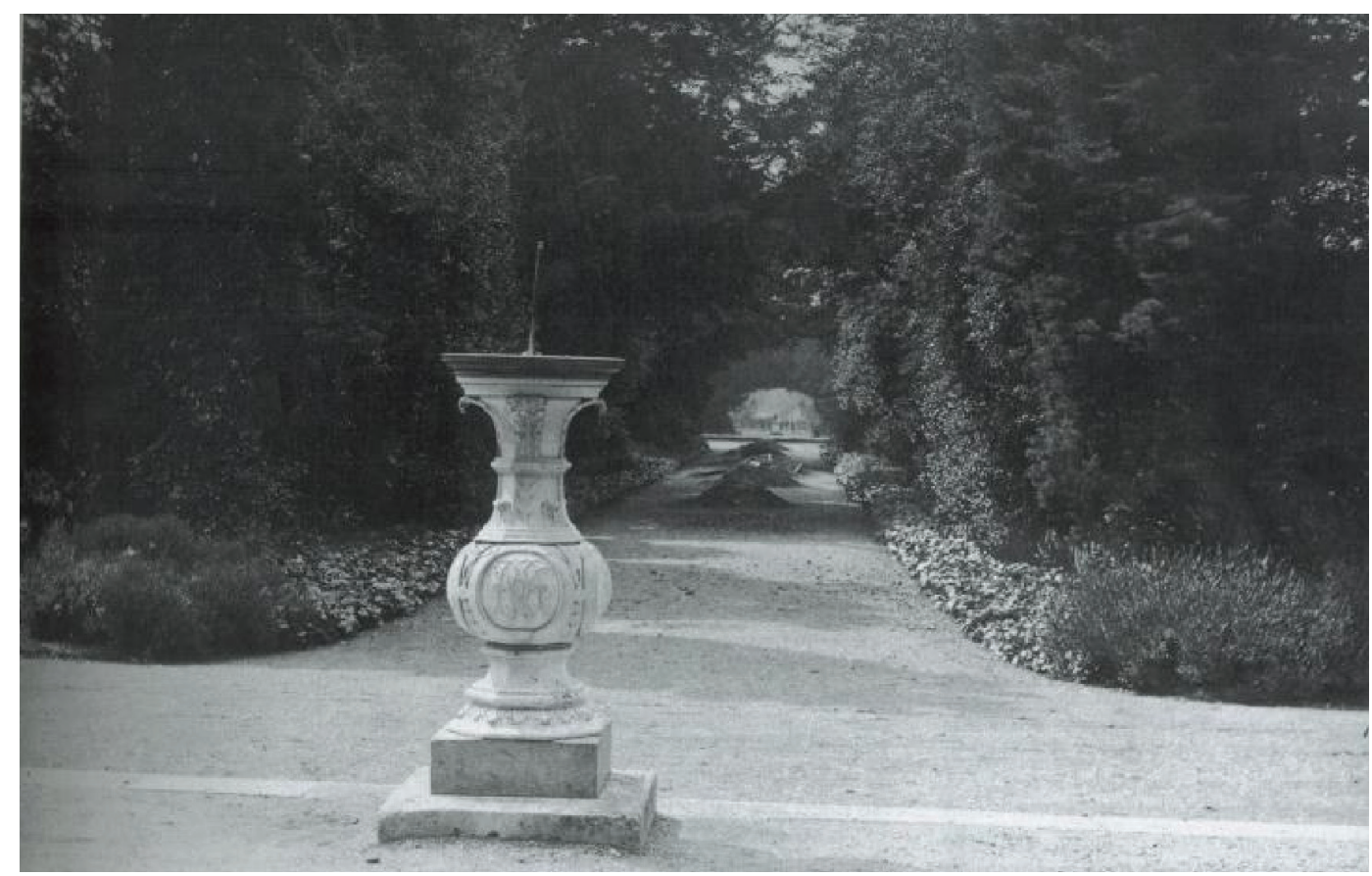

Hampton Court en 1903. Foto procedente del Country Life

\section{Bibliografía sobre Hampton Court}

THURLEY, S. (Editor/Curator) The King's Privy Garden 1689-1995. Apollo Magazine. London, 1995.

En este trabajo se relatan las razones que condujeron a la restauración así como al proceso de la misma. La parte histórica está a cargo de D. Jacques, La investigación botánica es de J. Woudstra y los estudios arqueológicos corren a cargo de B. Dix y S. Parry. Las fotografías y grabados de este capítulo de la tesis están escaneados de esta obra.

WRIGHT, Tom. "Hampton Court Palace, London; Some Historial Aspects, and the Recent Restoration of the Privy Garden" En: Felipe II, el Rey intimo. Jardín y Naturaleza en el siglo XVI. Actas del Congreso celebrado en Aranjuez en 1998 a cargo de la Sociedad Estatal para la Conmemoración de los Centenarios de Felipe II y Carlos V. Páginas 447-466.

Este artículo es un resumen del libro anterior. No aporta ningún nuevo dato de interés. 


\section{D.2.3. España}

\section{D.2.3.1. Jardines del Patrimonio Nacional}

Las intervenciones habidas en los jardines del Patrimonio Nacional son en su mayor parte reflejos del predominio de la corriente conservadora en este ámbito de la Administración hasta los noventa del pasado siglo XX. A principios de los años ochenta, Ramón Andrada en una carta a los lectores de la revista Reales Sitios correspondiente al año 1982 da cuenta de la intención de Patrimonio de comenzar la restauración de los jardines a cargo de esta entidad. Vamos a reproducir unos fragmentos de la misma por reflejar las intenciones y criterios que van a marcar dichas intervenciones: "Muchos de esos jardines fueron declarados de interés histórico-artístico. Por ésta y otras razones, como el estudio comparativo, creemos sin dudas que ningún organismo público o privado tiene bajo su custodia un conjunto tan importante y tan valioso. Y por todo ello, el Patrimonio Nacional conocedor de ese interés y consciente de su responsabilidad-ha empezado una serie de acciones conducentes a la mejora de sus jardines, recuperando para los mismos la esencia de su estado originario: trazado, especies arbóreas y florales, fuentes, estatuas y otros elementos.

Ahora bien, en toda labor de restauración o reconstrucción de la obra de arte -y los jardines son una clara y específica manifestación de la actividad artísticaes imprescindible saber qué hay que hacer y por qué hay que hacerlo. En esta tarea nada debe dejarse a la improvisación o a los criterios personales del que acomete el trabajo. El restaurador ha de actuar siempre con una generosa despersonalización, asumiendo las ideas del creador-fundiéndose, compenetrándose en su pensamiento y en su sensibilidad-para lograr hoy, en lo deteriorado, lo que aquel quiso e hizo. Es decir, en vez de crear un añadido es inexorable recrear para que la obra recupere su esencia primitiva. Pero para que todo este proceso sea así, realizándose con las máximas garantías de fidelidad, es necesario un trabajo previo de documentación, que lleva aparejado el estudio, la investigación y el análisis de la obra objeto de restauración, para determinar con todo rigor la trayectoria válida de actuación. Por último, y para que esa investigación -o cualquier otra, hablando en términos generales- sea posible, es imprescindible, hoy, el impulso y la ayuda, con la correlativa planificación y financiación, de los organismos o entidades culturales bajo cuya tutela se encuentran las obras de arte.

Consecuentemente con estos principios, que considera incontrovertibles, el Patrimonio Nacional ha iniciado esa tarea, amplia y profunda, que tiende a una meta tan deseable como es la minuciosa restauración de los jardines. En este sentido se ha programado una serie de medidas a corto, medio y largo, por estar enlazadas entre sí y ser consecuencia de las anteriores las más alejadas en el tiempo. 
En primer lugar, se ha comenzado -concretamente en el jardín de la Isla, en Aranjuez- una labor consistente en una limpieza general, reposición o plantación de especies degradadas o desaparecidas, arreglo de caminos y reparación de fuentes, estatuas, balaustradas y otros elementos ornamentales. Para esta primera etapa, a corto plazo, se cuenta con los técnicos del Patrimonio y con el aumento en el número de los trabajadores que se dedican a esta faena.

Una segunda fase, consiste en esa tarea de investigación y estudio a que aludíamos anteriormente. Ella permitirá conocer perfectamente el origen, características y trazado exacto de los jardines, en la idea de sus fundadores y creadores. Para esta labor, el Patrimonio Nacional ha establecido acuerdos con especialistas, que son los que llevarán a cabo este trabajo de documentación.

Por último, y dentro de las actuaciones a largo plazo, se encuentran todas aquellas que se pondrán en práctica como consecuencia de los estudios realizados. En consecuencia, y como resultado final que todos deseamos, se conseguirá la mejora de estos espacios artístico-naturales. Porque, repetimos, la operación de la restauración de los jardines del Patrimonio, ha comenzado".

Las actuaciones que vamos a ver son las ocurridas en los jardines de las Casitas de El Escorial, en los de la Quinta del Duque de Arco en el Pardo, en el Jardín del Rey en Aranjuez y en el Laberinto de La Granja de San Ildefonso.

La mayoría de las intervenciones acaecidas en los Reales Sitios son modélicas. Sin embargo, hacia el final de la década de los años noventa del pasado siglo algunas obras realizadas parecen querer reflejar los postulados de la carta florentina como es el caso, por ejemplo, del Jardín del Rey en Aranjuez.

Empezaremos a ver las intervenciones ocurridas en el Patrimonio con las Casitas de El Escorial. Ambas se construyen en la segunda mitad del siglo XVIII en un entorno natural constituido de bosques de robles y fresnos. Sobre las fases de su construcción, su estilo y las influencias clásico-romanas sobre su trazado, en la bibliografía al final del capítulo se da cuenta de las obras que recogen dichas intervenciones.

Lo más importante en lo que respecta a los jardines de las Casitas es señalar la íntima unión de los mismos con el conjunto de las edificaciones que los rodean y su entorno natural. También merece la pena señalarse la conservación del trazado original de sus jardines aunque haya habido posteriormente importantes añadidos de ejemplares de coníferas en el siglo XIX o cuidados sin criterios de ningún tipo como señalara Winthuysen: "Nos quejamos del abandono en que están casi todas las obras de nuestra jardinería clásica; pero, con ser esto muy lamentable, todavía lo es más cuanto están cuidadas por jardineros que ignoran su sentido, pues cuanto más ponen manos en ellas más destrozan el antiguo carácter, llegando a desbaratar en absoluto su esencia, y así vemos en estos dos ejemplares del Escorial que el jardín bien cuidado de la Casita del Príncipe está desvirtuado, mientras que en las ruinas de la Casita de Arriba podemos, al menos, tomar nota de su estructura 
ejemplar, que si estuviera atendida también por un jardinero, ya hubiese desaparecido, puesto que esta clase de obras, para su conservación, habrían de estar bajo una dirección competente que tuviese exacta idea de lo que significan". (6)

\section{a) Casita de Abajo o del Príncipe}

Veremos brevemente un resumen histórico desde sus orígenes hasta hoy para poder apreciar mejor el carácter y los criterios de las intervenciones realizadas contando con la ayuda de los trabajos del historiador del Patrimonio Nacional José Luis Sancho Gaspar y del responsable del patrimonio verde del mismo Santiago Soria.

Este palacete se construye en dos fases. La primera abarca desde 1771 a 1775. El ajardinamiento corre a cargo de Luis Lemmi. Entre 1781 y 1784 se añade el salón grande y la habitación ovalada hacia poniente. Con lo que el jardín crece en esta dirección, creándose el estanque alto y la fuente rústica así como las rampas que suben al plano superior.

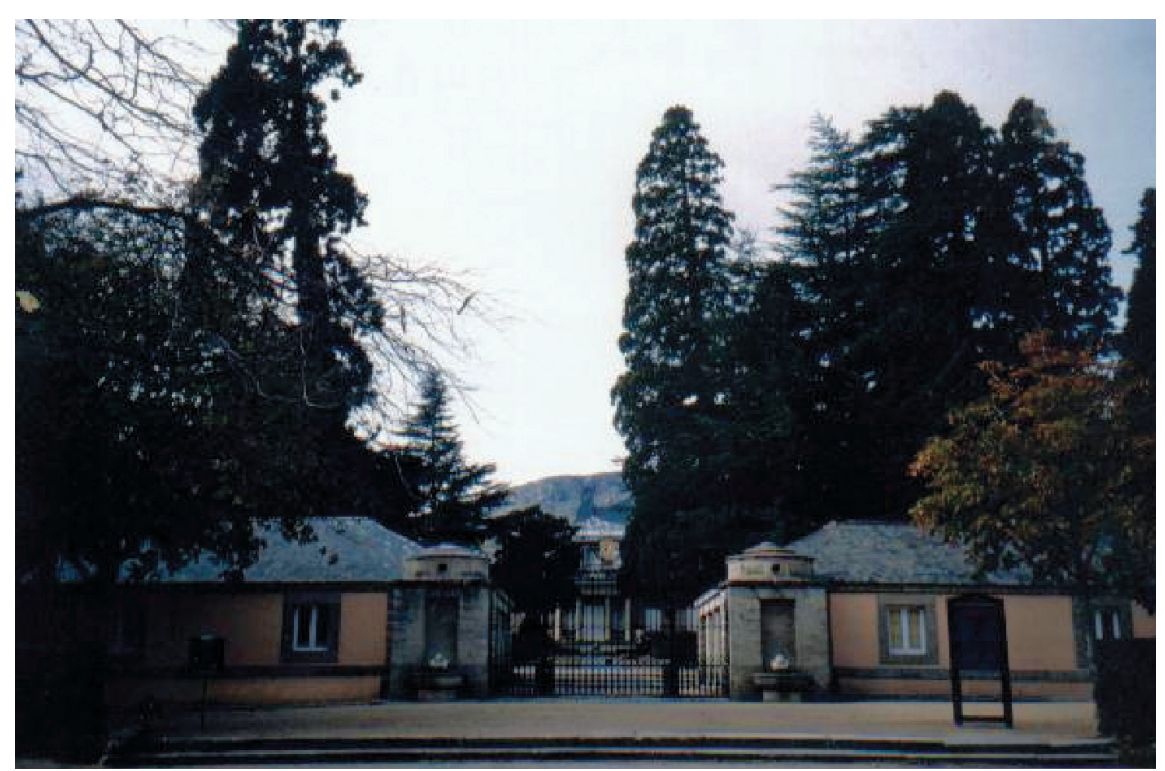

La Casita de Abajo en el 2001. (Foto del autor)

Parece ser que el patio de entrada a la Casita, a oriente, no era originalmente jardín sino una especie de explanada. Ponz relata que el jardín estaba detrás. En la época de Fernando VII ya estaba ajardinado. Debió de hacerse este añadido cuando se elaboró un plan de reconstrucción de los Reales Sitios hondamente dañados tras la Guerra de la Independencia. 
Su hija Isabel II continuó haciendo mejoras y reparaciones. Durante el Sexenio y la Restauración se llevaron a cabo obras importantes. En 1871 se pensó en crear una nueva huerta que cuatro años más tarde se convirtió en vivero. En 1872 se construyó el aún existente invernadero. Desde 1875 a 1878 se hicieron importantes plantaciones tanto en el jardín histórico como en el plantío nuevo. Se arreglaron también las calles y se sustituyeron los ejemplares de arbolado en mal estado por otros procedentes del recién creado vivero.

Coincide toda esta actividad con el traslado de la Escuela Superior de Ingenieros de Montes desde Villaviciosa de Odón a El Escorial en 1870 donde estará hasta 1914.

La presencia de esta institución estará marcada por la plantación en estos lugares de numerosos ejemplares de coníferas como actividades de experimentación tanto en el recinto de las Casitas como en los terrenos cercanos a la población. Tales plantaciones cambiaron el aspecto del lugar pues los jardines de las Casitas no eran jardines umbríos sino "un conjunto ordenadísimo y dentro de él los colores rientes"(7).

Del estado en que se encontraban estos jardines a principios del siglo XX tenemos la suerte de disponer del testimonio de Javier de Winthuysen quien es su obra clásica ya citada anteriormente dice sobre estos jardines: "No conocemos ningún otro jardincito que por su claridad, orden y gracia de sus obras, represente mejor

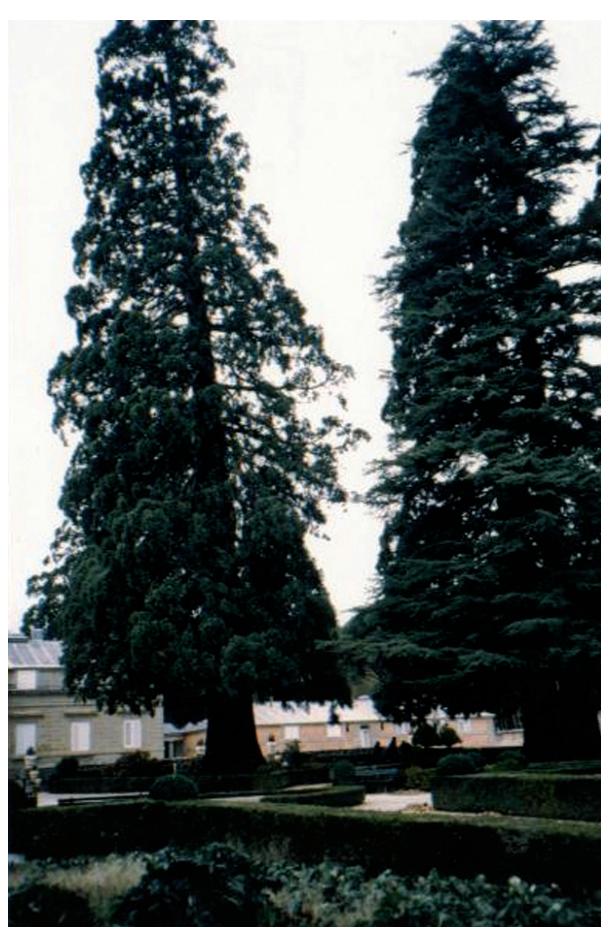

Wellingtonias en el interior de los cuadros de la Casita de Abajo. (Foto del autor) 
la adaptación del neo-clasicismo al gusto español, con la particularidad de no estar bastardeado por obras posteriores; pero tal importancia está incomprendida a tal extremo, que esta linda joya fue cedida para la Escuela de Montes, y se ha destrozado y desatendido lo que debería ser solamente reliquia. Su aspecto ruinoso, acentuado por las oscuras coníferas, sombrías, imprimen ahora tristeza a este lugar"(8).

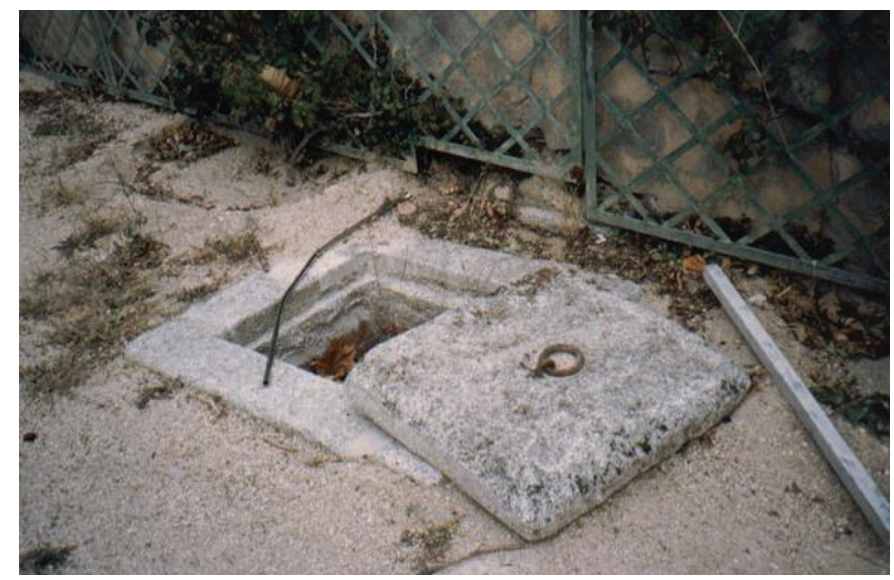

Celosías y nuevo distribuidor de agua hecho con piedra antigua. (Foto del autor)

La reforma más importante llevada cabo en el siglo XX será la realizada por el arquitecto Ramón Andrada. Renovará las cubiertas de los pabellones con estructuras metálicas, se arreglarán las calles del jardín introduciéndose algún elemento pétreo y se rehabilitarán los edificios de la entrada para darles nuevos usos: cafetería, taquillas y servicios. En la Casita se colocarán pavimentos de mármol y nuevas sederías en las habitaciones del piso bajo.

Al principio de la década de los años ochenta del siglo pasado, el Patrimonio reorganiza sus servicios. Uno de ellos tiene como objetivo el mantener y reparar los jardines existentes. Tras una primera fase de inventario, en el año 1985 se pasa a la acción. Es entonces cuando los jardines reciben las atenciones necesarias y cuidados más específicos.

En el conjunto del jardín de la Casita de Abajo se hacen las siguientes faenas:

- Se coloca una celosía a lo largo de todo el interior del muro perimetral, plantándose rosales trepadores.

- Se arreglan todos los paseos.

- Se realiza una nueva red de riego aunque se respetan por su carácter de testimonio histórico las antiguas caceras. 
En las otras zonas del jardín se hace lo siguiente:

\section{En el plano bajo:}

- Se plantan los fallos existentes en los setos de boj y éste es podado para que adquiera una altura uniforme.

- Se colocan losas en el paseo central.

- Se ordenan los arbustos existentes y se plantan otros nuevos como durillos, camelias y celindas.

- Se colocan macetas con naranios formados en bola a lo largo del eje.

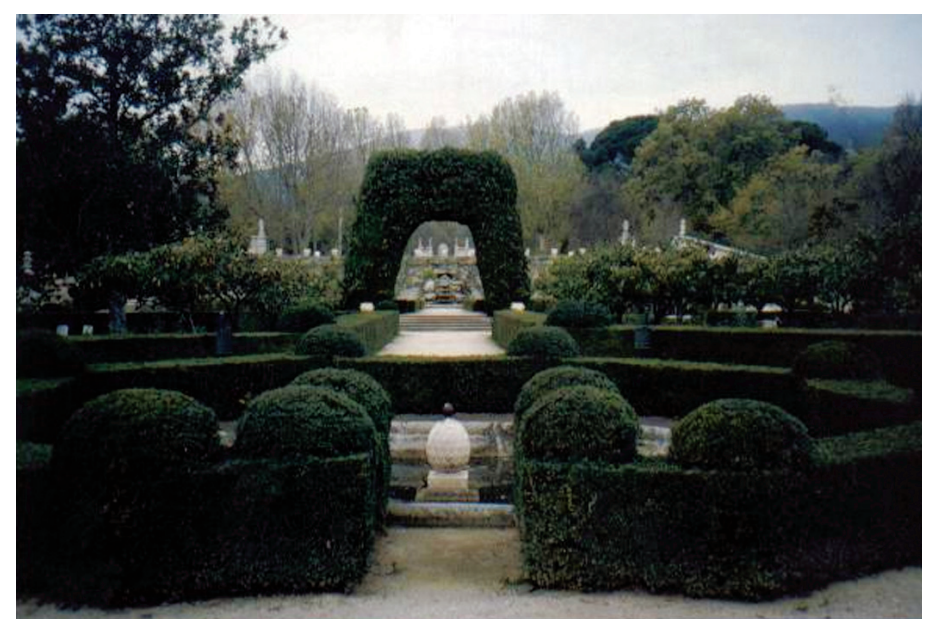

Casita de Abajo. Los setos se han podado redimensionándolos.

El arco se ha mantenido por su carácter testimonial. (Foto del autor)

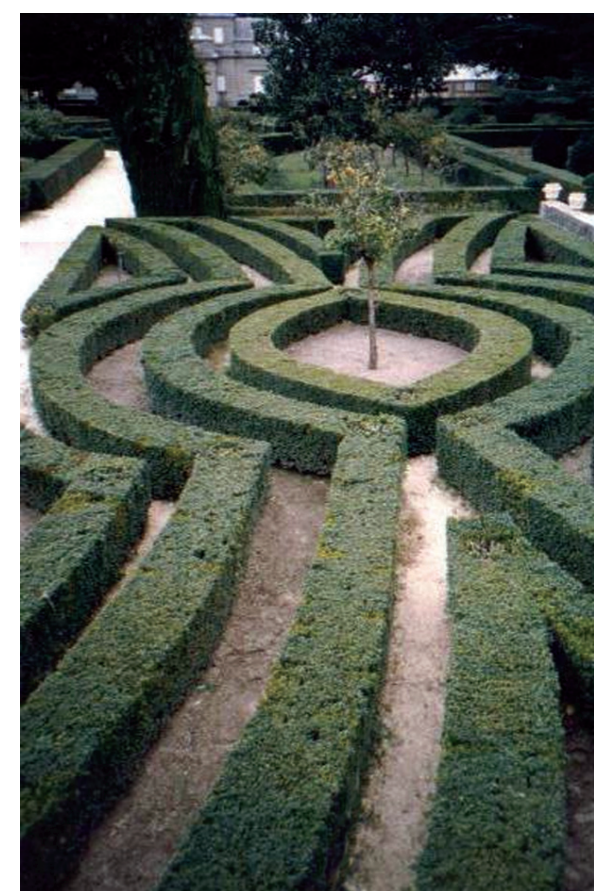

Casita de Abajo. Detalle de los setos del jardín superior. (Foto del autor) 


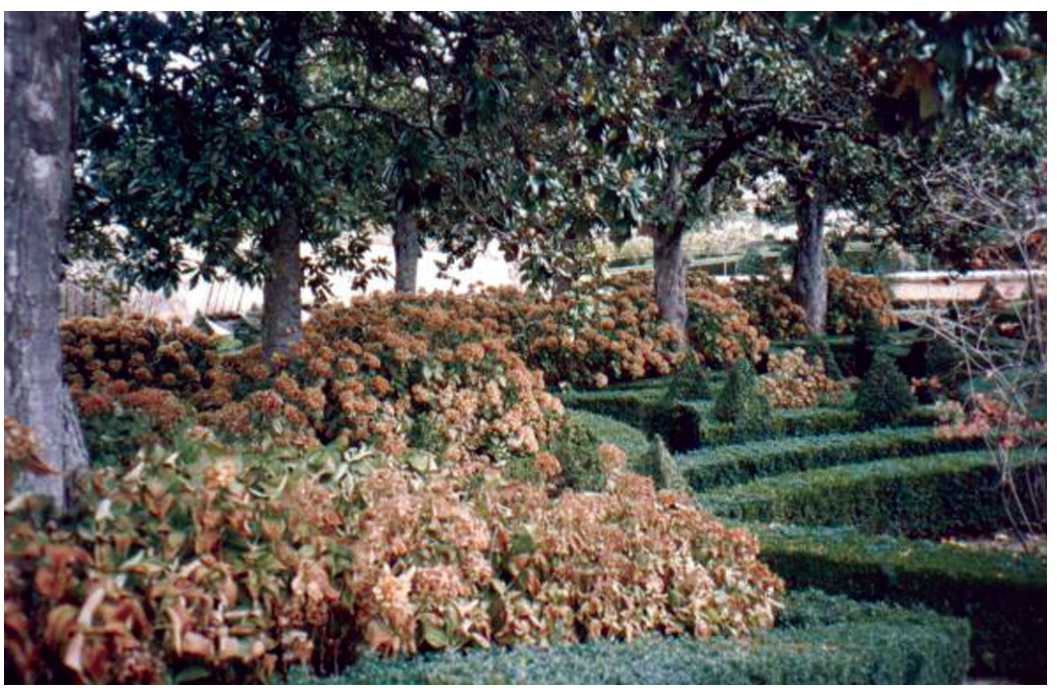

Casita de Arriba. Cuadros rellenados de hortensias. (Foto del autor)

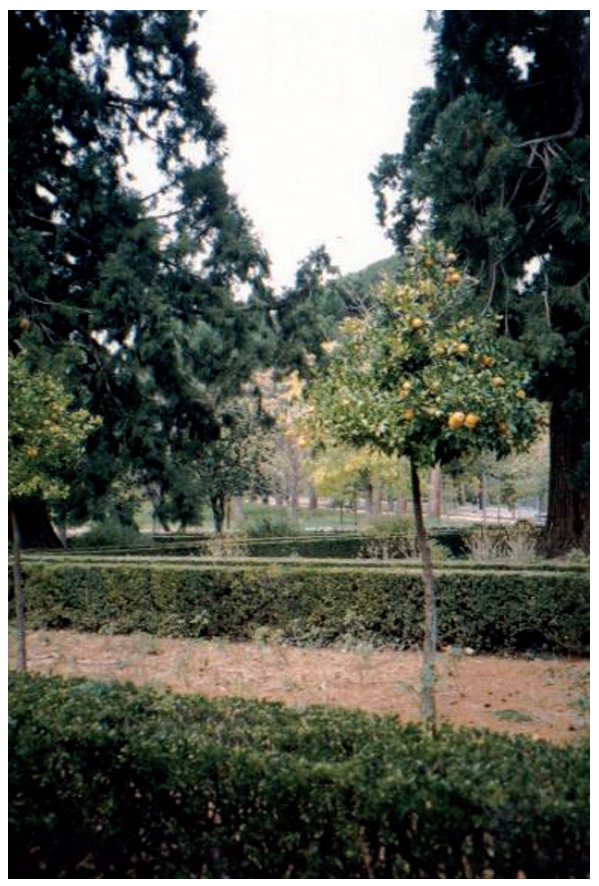

Casita de Abajo. Plantación de naranjos dentro de los cuadros. (Foto del autor)

\section{En el plano medio:}

- Plantación de arbustos de tipo rosales de pie alto, durillos, naranjos en tierra, bergenia, espirea, ciruelos y membrillos.

- Reposición de las marras de boj y redimensionado de los setos.

\section{En el plano alto:}

- Plantación de glicinia en la celosía colocada a lo largo del muro.

- Plantación de rosales de pie alto y naranjos. 


\section{En el plano superior:}

- Plantación de granados y magnolias stellata.

\section{En el jardín de flores:}

- Mantenimiento de las especies existentes, plantando ejemplares de mahonia y hortensia.

- Arreglo de la estufa caliente, haciendo nuevas cerchas y cerramientos pero manteniéndose la estructura original.

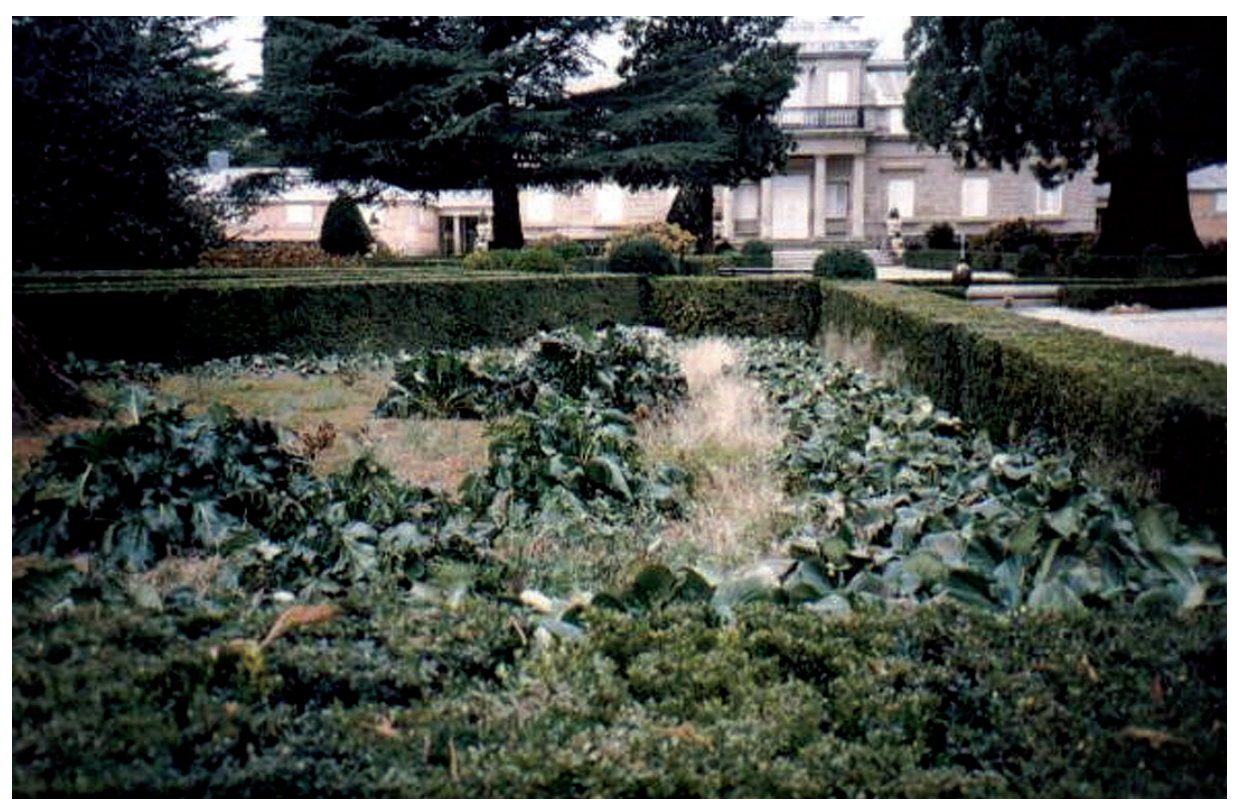

Casita de Abajo. Plantación de bergenias en el interior de los cuadros. (Foto del autor)

\section{Actuaciones en el Parque de la Casita de Abajo:}

El abandono sufrido por estas posesiones se concretó aquí en el arriendo de parte de su superficie para pastos de ganado vacuno en la zona sur, la de las huertas. Por tanto el bosque propiamente dicho no sufrió demasiada presión de estos animales. Por otra parte, la menor presencia de olmos hizo que la grafiosis no dejara grandes claros en el lugar como sucedió en su compañera, la Casita de Arriba, como veremos más adelante.

Lo primero que se hizo antes de cualquier intervención fue la realización de unos estudios cartográficos basados en dos vuelos fotogramétricos en dos temporadas diferentes del año: uno en primavera y el otro en otoño, ambos en el año 1983. En el número 120 de la revista del Patrimonio Nacional Reales Sitios, el ingeniero Angel Muñoz describe detalladamente las técnicas empleadas, la metodología seguida y su finalidad. 


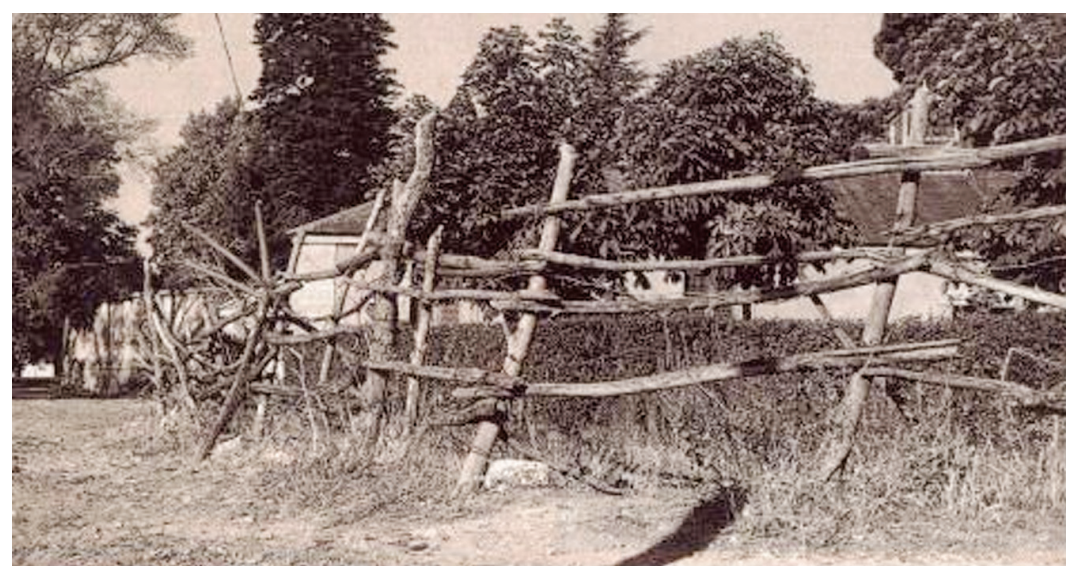

Casita de Abajo. Cerca para las vacas junto a la misma. (Foto de Reales Sitios)

Las tareas llevadas a cabo consistieron en lo siguiente:

- Limpieza del arbolado muerto y cuidados culturales de los ejemplares vivos. Vamos a reproducir los ejemplares tratados como testimonio de las especies presentes en el lugar en ese momento como referencia histórica:

Fresno (Fraxinus angustifolius) . . . . . . . . . 280 unidades

Encina (Quercus ilex) ................. 133 ",

Acer moscón (Acer campestris) .......... 142 ",

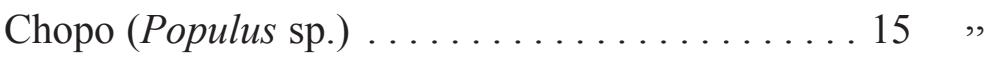

Rebollo (Quercus pyrenaica). . . . . . . . . . 275 ",

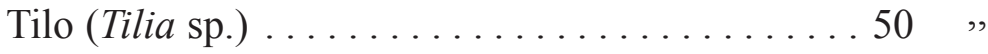

Madroño (Arbutus unedo) . . ..........6 ",

Castaño de Indias (Aesculus hippocastanum) . . . 15 ",

Arbol del amor (Cercis siliquastrum) . . . . . . . 6 ",

Pino piñonero (Pinus pinea) . . . . . . . . . 379 ",

Plátano de sombra (Platanus x hispanica) . . . . 866 "

Nogal (Juglans regia) . . . . . . . . . . . . . 90 ",

Acacia de tres púas (Gleditzia triacanthos) . . . . 99 "

Pinsapo (Abies pinsapo) .............. 6 ",

- Reparación de las alineaciones formadas principalmente por pinos piñoneros (Pinus pinea), plátano de sombra (Platanus hispanica) y nogales (Juglans regia).

- Conservación por su carácter histórico del sistema de riego y dotación de "nuevas infraestructuras" con los más modernos sistemas para conjugar economía y efectividad.

- Reparación de los caminos y viales.

- Reparación de la valla perimetral. 
- Plantación de nuevos ejemplares de árboles (997 unidades) y arbustos (8.643 unidades).

Los árboles plantados son los siguientes:

Aliso (Alnus glutinosa) . . . . . . . . . . . 44 unidades

Abedul (Betula pendula) . . . . . . . . . . . 20 "

Carpe (Carpinus betulus) . . . . . . . . . 140 "

Castaño de Indias (Aesculus hippocastanum) . . 139 "

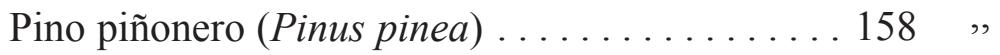

Tilo (Tilia sp.) .................. 120 "

Plátano de sombra (Platanus x hispanica) . . . 266 ",

Nogal (Juglans regia) . . . . . . . . . . . 51 "

Acacia de tres púas (Gleditzia triacanthos) . . . . 18 "

Morera (Morus sp.) . . . . . . . . . . . . . . . 29 ",

Liquidambar (Liquidambar styraciflua) . . . . . . 10 "

Ginkgo (Ginkgo biloba) . . . . . . . . . . . . 3 ",

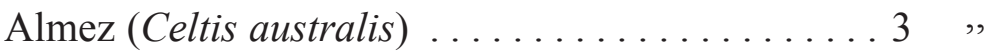

Los arbustos de nueva plantación son de las siguientes especies: rododendros, romeros, lavandas, cotoneaster, piracantas, espireas, majuelos, rosales, mahonias y azaleas.

- Recuperación de las praderas de césped (1.289 m2) en la zona de acceso con especies nobles como Lolium perenne, Agrostis tenuis, Poa praetensis y Festuca rubra stolonifera.

- Finalmente la antigua huerta se transformó en un vivero de especies autóctonas con la finalidad de recuperar el bosque de La Herrería. A mediados de los años 90 el bosque estaba recuperado en un $40 \%$ aproximadamente.

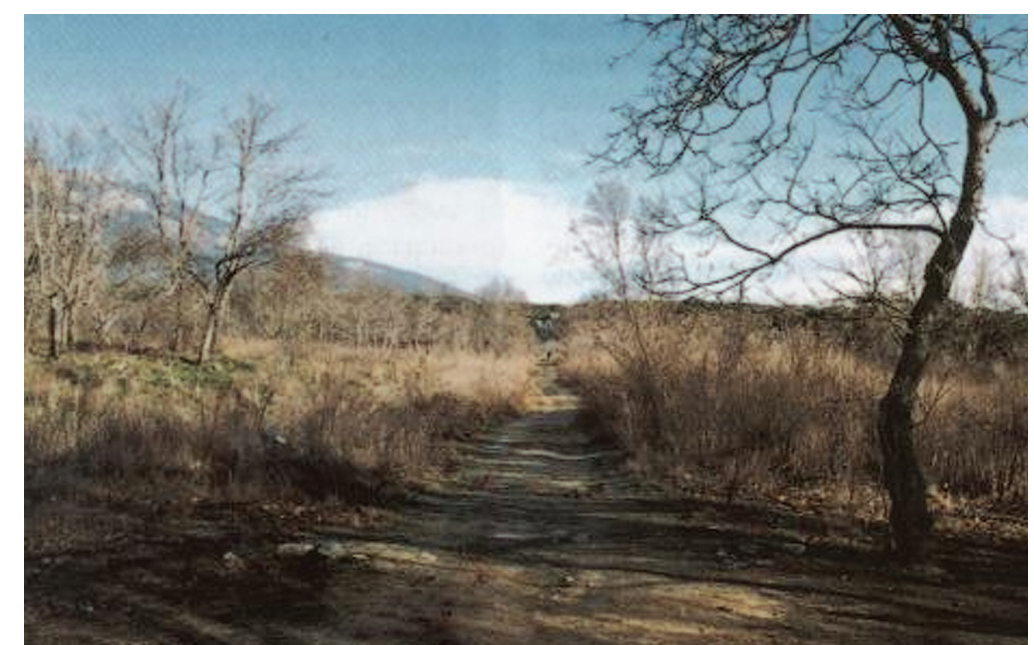

Parque de la Casita de Abajo antes de la restauración. (Foto de Reales Sitios) 


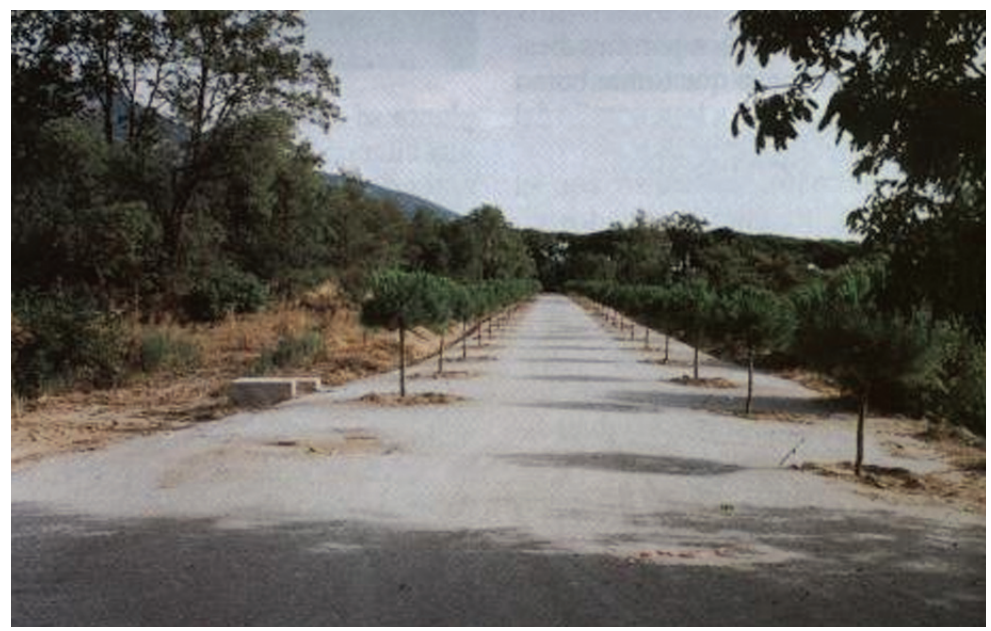

Camino del parque de la Casita de Abajo recién plantado. (Foto proveniente de la revista Reales Sitios)

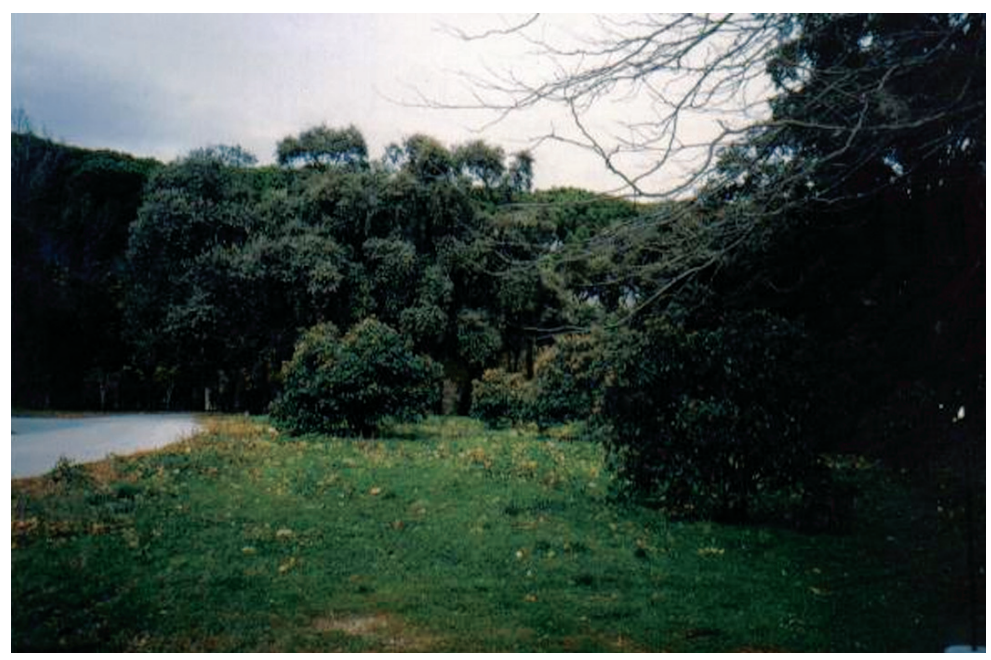

Parque de la Casita de Abajo en el 2001. (Foto del autor)

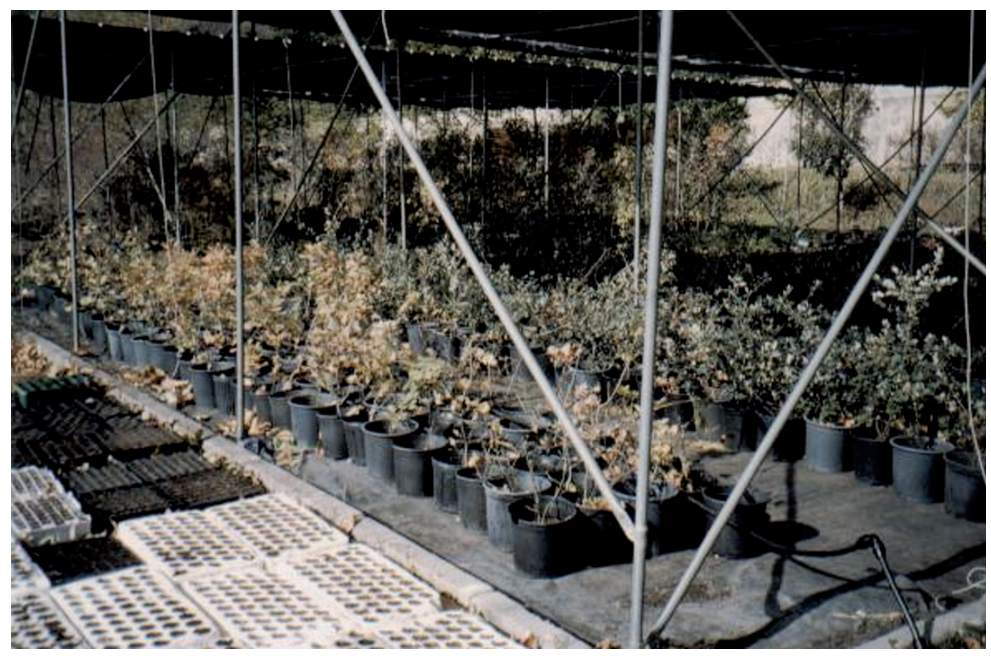

Vivero de especies autóctonas para la repoblación del parque de la Casita de Abajo en el otoño del 2001. (Foto del autor) 


\section{b) Casita de Arriba o del Infante}

Se construyó toda de una vez entre 1771 y 1773 con lo que se logró un resultado de gran coherencia entre edificio y jardín.

Las obras del jardín las dirigió Luis Lemmi, el mismo que había hecho los jardines de la Casita de Abajo.

El historiador del Patrimonio José Luis Sancho ha analizado los cambios ocurridos durante el siglo XIX en la edificación que la privaron de los elementos constructivos proyectados por Villanueva para reforzar la intimidad del lugar. En el jardín fue la tercera esposa del rey Fernando VII, María Josefa Amalia de Sajonia quien hizo importantes transformaciones: amplió su superficie con terrenos del bosque; en el parterre alto, en torno a la fuente, mandó hacer una bóveda con jazmín y plantó gran cantidad de nomeolvides, su planta favorita, así como varias calles con cipreses en el parque que acababan en recoletos cenadores de la misma especie botánica alguno de los cuales ha llegado hasta nuestros días.

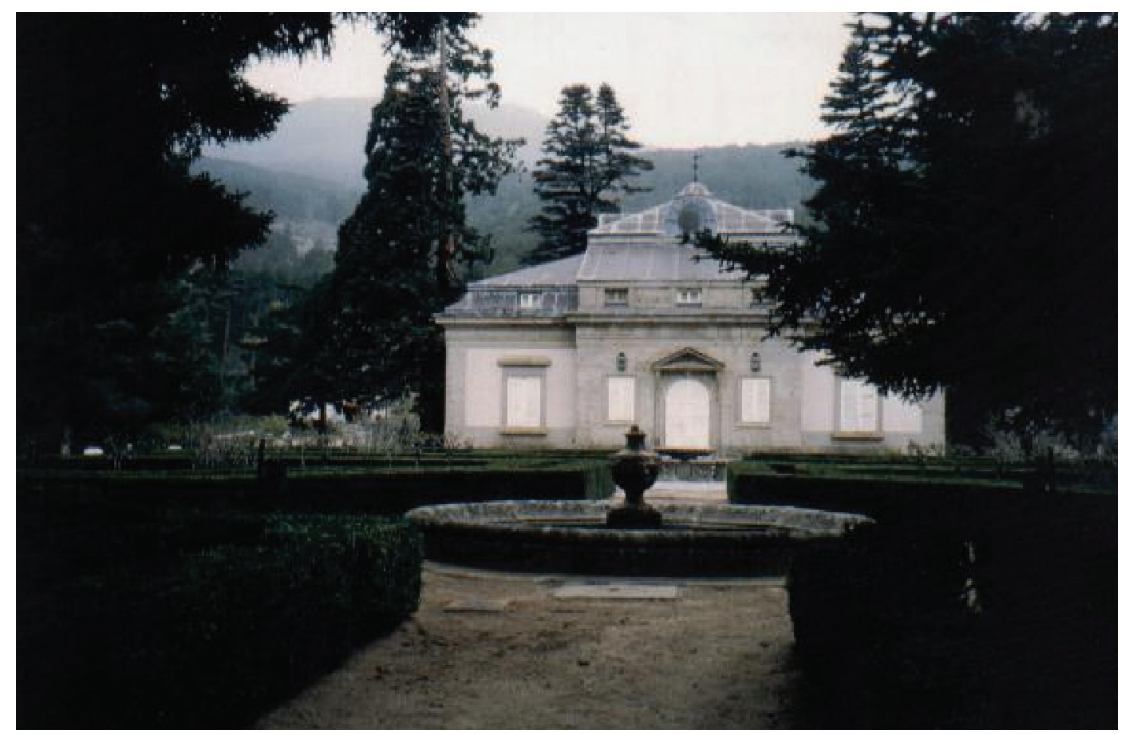

Casita de Arriba en el otoño del 2001. (Foto del autor)

También empiezan a ser utilizados aligustres para los setos en esta época abandonándose el boj. La presencia de la Escuela de Ingenieros de Montes en esta Casita se hizo sentir de manera más profunda que en la de Abajo. Alquilada en 1878 por la Escuela fue utilizada como "campo de prácticas" por los ingenieros intentando Patrimonio que fuese detenido el avanzado estado de abandono y deterioro en que se encontraba. Por un informe del Administrador de la posesión de aquel entonces (1876) nos podemos hacer una idea de su estado: "En el jardín del Infante se advierte más el abandono en que han estado aquellas posesiones, pues sólo tiene algunos cuadros con plantío de monte, y el resto sin cultivo, llenas de brozas sus calles y paseos, habiendo desaparecido la mayor parte del arbolado frutal y lo poco existente en muy mal estado, así como la verja que cierra el par- 
terre se encuentra rota por varios puntos. La presa del infante para riego de dicho jardin no tiene agua alguna” (9).

La decadencia del jardín intentó ser paliada por el Patrimonio llevando a cabo algunas plantaciones desde 1875 a 1878 tales como la del camino que va del Monasterio a la Casita que se plantó con chopos y arces. El último año de este período se realizó un importante plantío con las siguientes especies: de frutales se plantaron 153 perales, 382 manzanos; 208 ciruelos; 75 melocotoneros; 31 albaricoques; 14 nogales y 6 nísperos. De árboles de sombra 30 castaños de Indias; 96 acacias; 40 fresnos; 50 almeces; 28 álamos; 4 tilos; 46 sóforas y 6 hayas. Y finalmente de arbustos se introdujeron 6 sinforinas; 10 adelfas; 684 evónimos; 600 frambuesos y 320 cipreses en seto.

Sigue contándonos José Luis Sancho lo que le sucedió a la Casita a partir de que los ingenieros la ocuparon. Estos se hicieron cargo de los cuidados e "innovaciones" hasta su traslado a Madrid en 1914. Entre estas innovaciones destaca la pérdida de los setos de boj y la decoración de la rotonda central de la Casita con muestras y trofeos de caza. Por los años veinte tenemos la descripción de su estado debido a los trabajos de Javier de Winthuysen ya descritos cuando tratábamos la Casita del Príncipe. En 1930 un incendio destruyó parte de la cubierta. En 1947 es restaurada por Fernando Chueca y será ocupada en 1960 por Don Juan Carlos de Borbón.

Los jardines han recuperado su esplendor gracias a la labor de cuidado y conservación llevada a cabo de forma paralela a las restauraciones de la Casita, y desarrollada luego con mayor fuerza a partir de 1982, tanto en el jardín formal de Villanueva como en el parque o jardín fernandino, bajo la dirección del ingeniero técnico forestal D. Angel Muñoz.

Las actuaciones más importantes realizadas en el jardín pueden ser catalogadas de esta manera:

- Mejora de las infraestructuras: dotación de riego con la instalación de una red perimetral ya que antiguamente sólo existían dos bocas y dada la inutilización de la presa del Infante el agua es necesaria obtenerla mediante el bombeo de la misma desde el estanque.

- Saneamiento de las fuentes.

- Arreglo de la balaustrada.

- Reposición de bancos de granito.

- Saneamiento integral de todo el arbolado.

- Instalación en el cedro del primer pararrayos de coníferas en Europa.

- Reposición de las marras de boj en todos los dibujos interiores que llegó hasta un $90 \%$ y exteriores de los cuadros de boi del jardín formal.

(9) SANCHO GASPAR, José Luis. "El Casino del Infante y la Casita del Príncipe en El Escorial" en Jardines y Paisajes en el Arte y en la Historia. Curso de verano 93-94 de El Escorial. Dirección: C. Añón. Ed. Complutense. 
- Poda de formación de los setos que se han dejado en $70 \mathrm{~cm}$ de alto por $60 \mathrm{de}$ ancho para los perimetrales dejando calles de $50 \mathrm{~cm}$; a los interiores se les dio 45 de altura por 30 de ancho.

- Recebo de las calles.

- Instalación de jarrones copiados de dos modelos de la Casita de Abajo, llevados a cabo en 1986 por la empresa Cerámica Guadarte de Sevilla.

- Ordenación del interior de los arbustos del interior de los cuadros con plantas procedentes de Italia y Holanda. Las especies en cuestión son madroños, rosales de porte llorón, acebos de porte piramidal y espireas. El principio se trajo boj pero para los últimos trabajos la producción del vivero de Aranjuez hizo innecesaria esta importación.

- Adorno de las terrazas en torno a la Casita con naranjos en bola para el verano y laureles para el invierno.

- Instalación de un riego por goteo para el mantenimiento del seto de boj en la terraza sur.

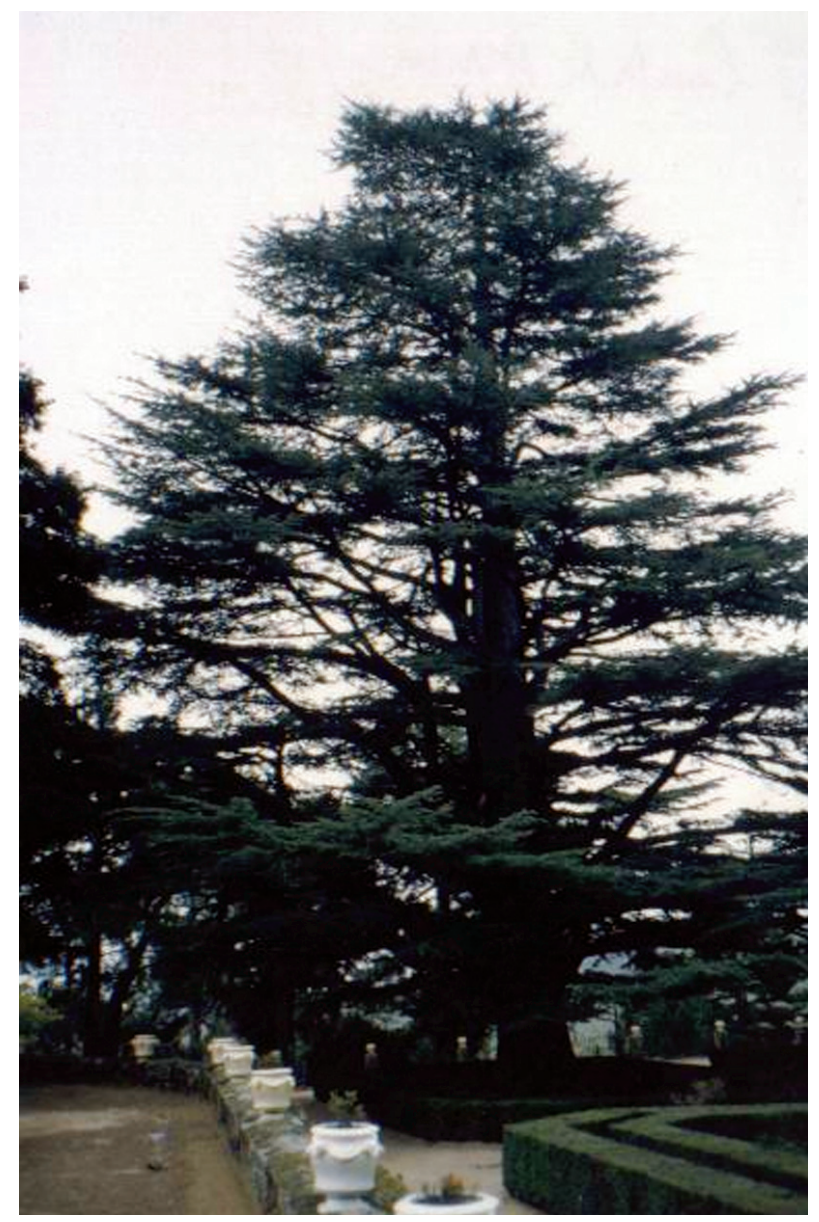

Casita de Arriba. Ejemplar extraordinario de cedro del Libano en el cual se ha instalado un pararrayos para su protección. (Foto del autor) 


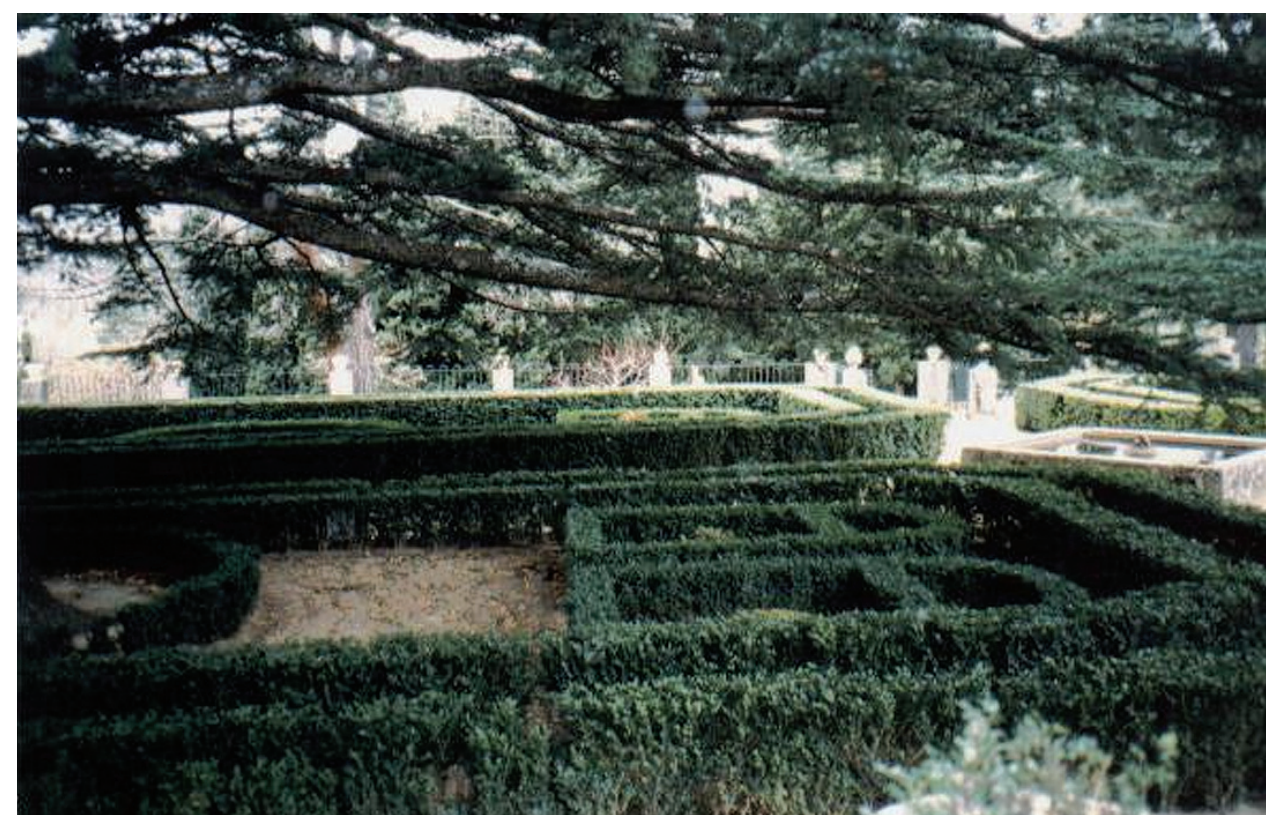

Casita de Arriba. Bajo el ejemplar de cedro del Líbano se han rehecho recientemente los dibujos con boj según lo recoge Winthuysen. (Foto del autor)

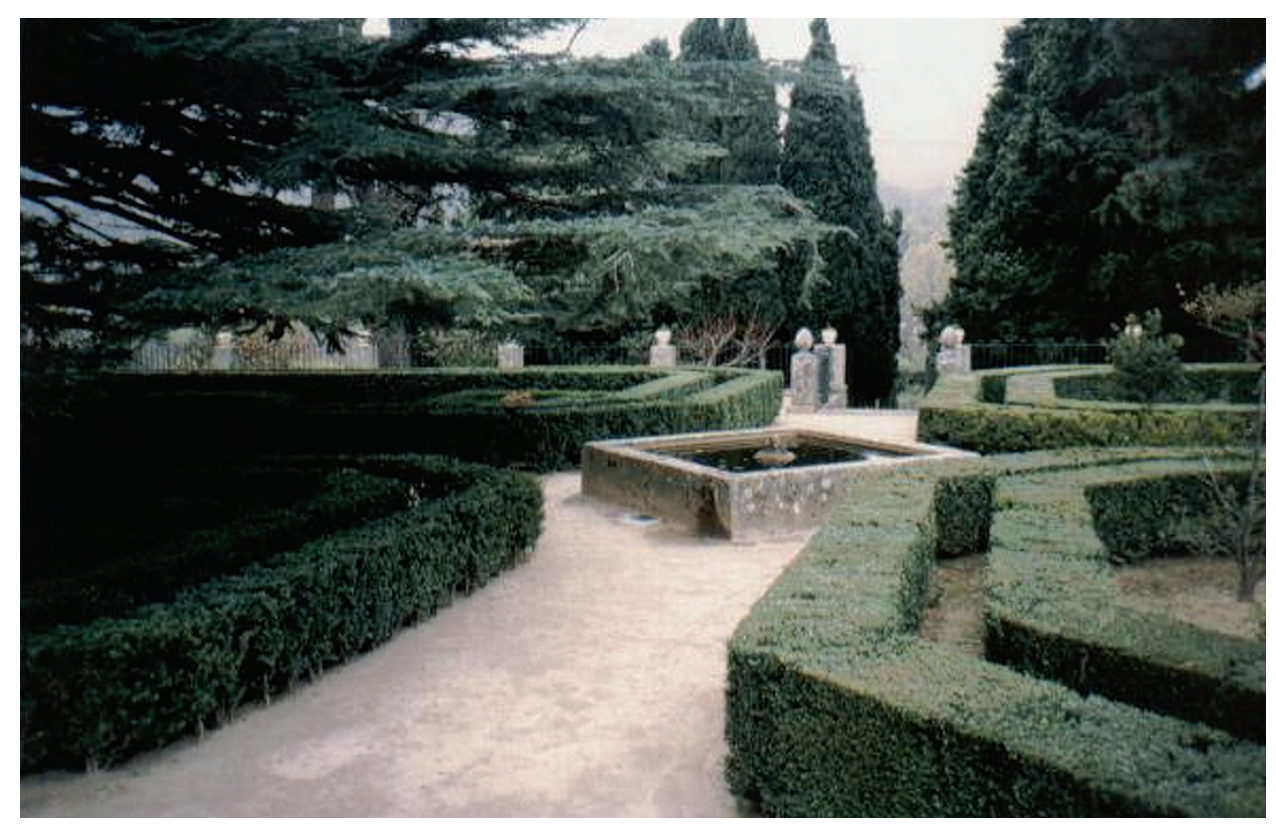

Casita de Arriba. Setos recuperados tras la reciente intervención. (Foto del autor) 


\section{Parque de la Casita de Arriba.}

El estado de abandono señalado por Javier de Winthuysen aún vería un incremento importante en el conjunto. En 1960, 16.000 m2 del Parque de la Herrería son transformados en un campo de golf lo que imposibilitará la recuperación del conjunto de la finca. Además, el parque es arrendado para pasto de ganado ovino con lo que a principio de los años 1980 su aspecto era el de una olmeda totalmente abandonada ya que este ganado había consumido casi todos los arbustos y herbáceas presentes en el lugar excepto el arbolado. En 1983 a esta degradación se añade la aparición de la grafiosis del olmo la cual en tres años causó la muerte a 450 ejemplares dándole al parque un aspecto desolador.

Las alineaciones y cenadores de cipreses estaban perdidas en su mayoría y afectadas del hongo Coryneum cardinale no reflejando el espíritu de su creadora ya que además a la pérdida de los diseños originales hay que añadir la introducción de grandes ejemplares aislados de pinos, de gran interés botánico algunos de ellos al tratarse de ejemplares de especies plantados por vez primera en nuestro país pero que no respetan para nada el diseño del jardín histórico. Otra más de las herencias de la etapa de la Escuela de Ingenieros de Montes tras su paso por El Escorial.

Los ejemplares arbustivos y subarbustivos habían desaparecido en su totalidad, haciendo imposible su recuperación por la presencia de la vegetación introducida en épocas posteriores y que estaba viva.

Los sistemas de riego tradicionales a base de caceras se habían perdido completamente en todos los diseños sucesivos del parque por lo que hubo que hacer una nueva red hidráulica.

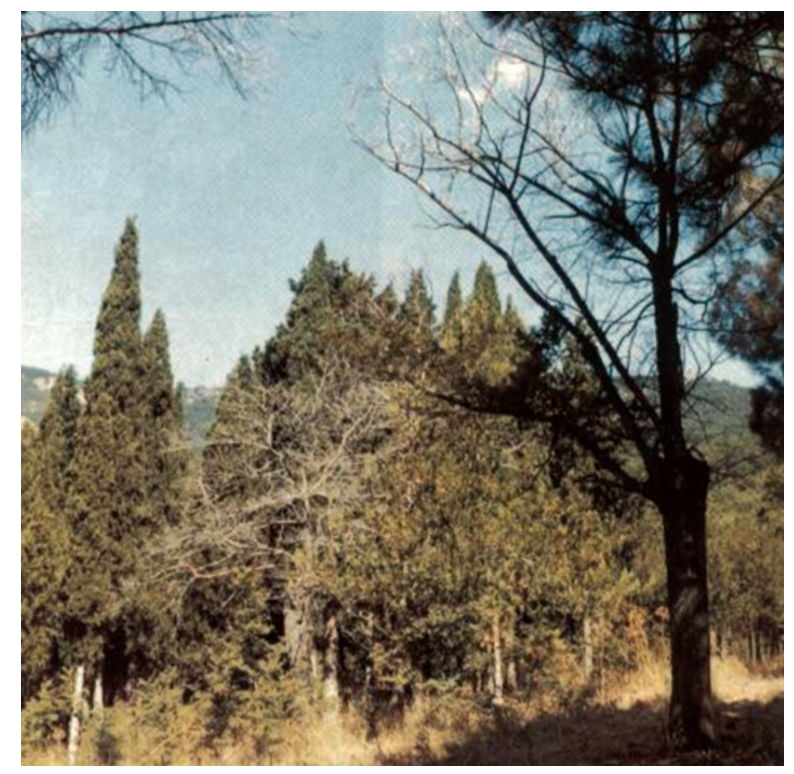

Parque de la Casita de Arriba antes de la intervención. (Foto de la Revista Reales Sitios) 
Ante este estado de abandono y casi destrucción del lugar, los objetivos que se plantean no son la recuperación integral -algo imposible de lograr- sino la conservación de lo existente. Citemos las palabras textuales de Angel Muñoz Rodríguez: "Ante esta situación caótica y siendo imposible la recuperación del trazado original, tanto por la pérdida de parte de su superficie como por el desconocimiento de la vegetación existente en su primer diseño, se optó por recuperar el recorrido del que aún quedaban trazas, posiblemente correspondiente a la época de la reina María Josefa Amalia de Sajonia”(10).

La primera fase consistió en la eliminación de todos los olmos muertos. Al quedar ampliamente deforestado (especialmente el cuadrante noroeste) se procedió a la plantación de frutales de porte medio-bajo (perales, manzanos y moreras) con el fin de que cubrieran la zona a la vez de que no impidieran la vista del Monasterio. Esta plantación se hace con carácter de provisionalidad. En las demás áreas se ha mantenido la vegetación existente, transplantando cuando era necesario por razones de recuperación de los trazados y efectuando tratamientos fitosanitarios y culturales al resto de la vegetación.

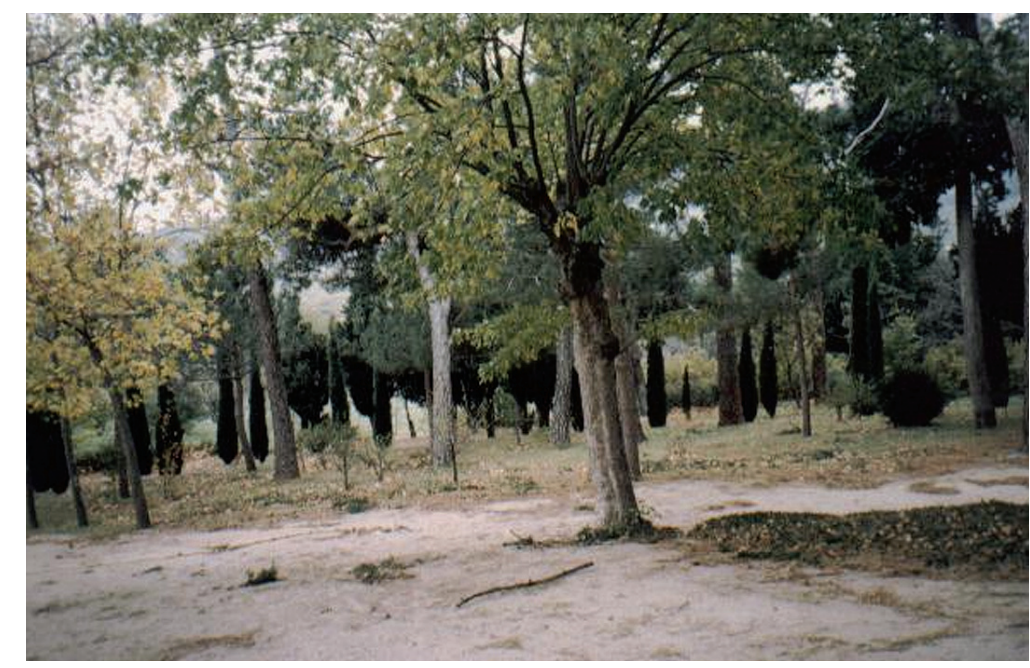

Parque de la Casita de Arriba. Al fondo se ven las nuevas plantaciones de cipreses. (Foto del autor)

A los plátanos se les intentó formar nuevamente y eliminar sus enfermedades. Respecto a los fresnos que presentaban un aspecto envejecido, se incidió en su conservación y saneamiento al igual que con el resto de las demás frondosas.

Los cipreses fueron saneados y perfilados con el fin de devolverles sus portes originales. Las restantes coníferas (época de la Escuela de Montes) han sido conservadas por su belleza, rareza, interés botánico y pedagógico. Algunas de ellas son los primeros ejemplares de su especie introducidos en España -como antes señalábamos- por lo que se han saneado y conservado por su interés histórico aunque no corresponden a la estructura del diseño original. 
La escasa vegetación arbustiva superviviente al ganado la constituían pequeñas matas de majuelo (Crataegus monogyna), boj (Buxus sempervirens), lilos (Syringa vulgaris), rosal silvestre (Rosa canina) y rusco (Ruscus aculeatus) así como algunos arbustos rupícolas como sauces (Salix caprea) y avellano (Corylus avellana) que formaban un bosque de galería sobre el Arroyo del Infante. Su distribución aleatoria hizo obligado su transplante para adecuarlas al diseño elegido.

Tras los cuidados a la vegetación empezó la segunda fase dedicada al agua. Se hizo una red perimetral de la que salen ramales a los bosques y caminos. El agua parte de la presa de Batán, propiedad del Patrimonio y se almacena en dos estanques: uno en la parte posterior del jardín formal con una capacidad de $1500 \mathrm{~m}^{3} \mathrm{y}$ otro en la zona de los invernaderos y estufines con capacidad para $150 \mathrm{~m}^{3}$. Desde el estanque grande el agua es bombeada a la red de riego. Se ha optado por los sistemas de goteo y microdifusión para ahorrar agua.

Los caminos y viales han sido rehechos la mitad de ellos. Unos con base de zahorra y cemento al $4 \%$ con terminación con arena de jabre compactado. El resto han sido nivelados y recebados con el mismo tipo de áridos.

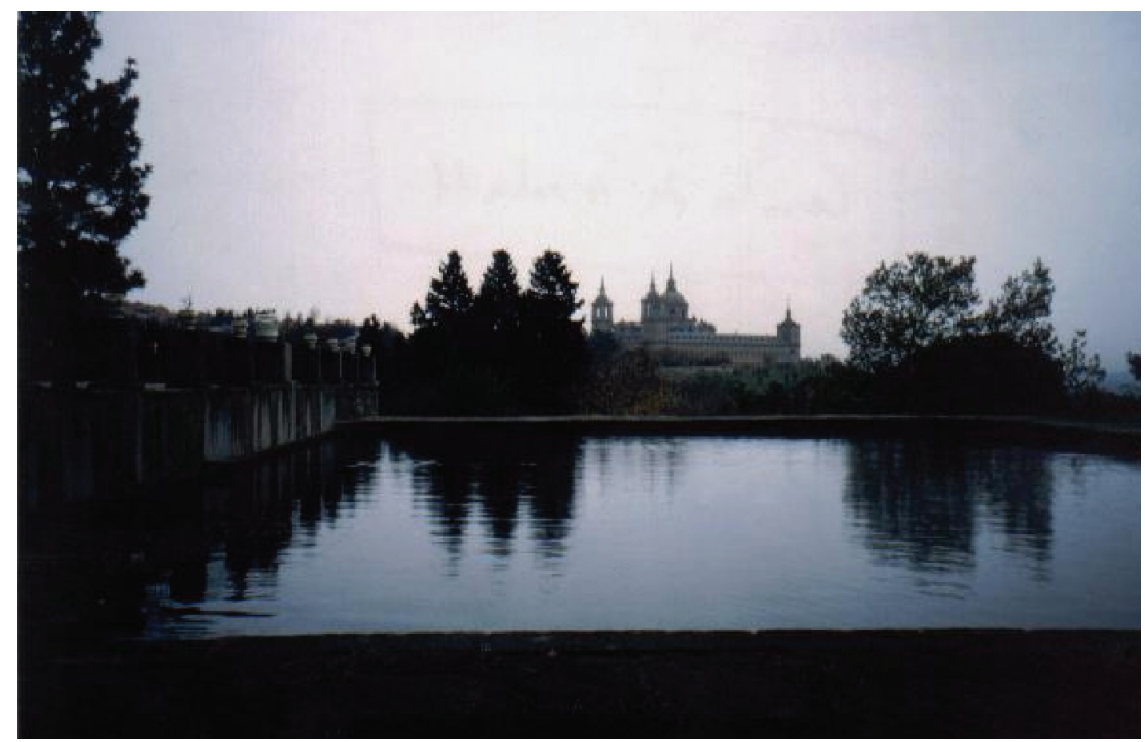

Balsón del estanque de la Casita de Arriba tras su recuperación.(Foto del autor)

La tercera fase ha consistido en la recuperación de las alineaciones arbóreas y cenadores de cipreses.

El número total de árboles ha sido de 225 unidades correspondiendo a las siguientes especies:

Ciprés (Cupressus sempervirens) . . . . . . . 992 unidades,

Plátano (Platanus hispanica hybrida) . . . . . . . 86 ",

Catalpa (Catalpa bignoniodes) . . . . . . . 47 "

Morera (Morus nigra) . . . . . . . . . . . . . 19 "

Tilo (Tilia platyphyllos).............. 11 " 
Los arbustos dispuestos en estas alineaciones, celosías y muros han sido 325 unidades cuyas especies son las siguientes:

Boj (Buxus sempervirens) . . . . . . . . . . . . . . 225 unidades,

Rosal trepador (variedad Roundelay rojo sangre) . . . . 28 "

Rosal trepador, (variedad Roundelay rojo aterciopelado) 24 "

Rosal standard de pie . . . . . . . . . . . . . 7 "

Jazmín (Jasminum officinalis) . ............44 "

El suelo fue abonado y en los casos en que había que estimular el enraizamiento se añadieron fitohormonas a los agujeros de la plantación.

La última fase consistió en la recuperación de los bosquetes, la gran mayoría de ellos en forma de triángulos cuyos lados y bases quedan delimitados por las plantaciones lineales antes mencionadas.

Dichos bosquetes están diseñados como asociaciones artificiales que cubren con gran espesura todos los pisos de vegetación para ser contemplados como un todo desde las terrazas del jardín, sirviendo de transición hacia el bosque natural. La superficie recuperada de estos bosquetes llega al 40\% del total. Igualmente antes de la plantación se abonó y enriqueció el suelo con nutrientes de lenta liberación.

Se han empleado un total de 176 árboles de las siguientes especies:

Morera pendula (Morus nigra pendula) . . . . . . . 27 unidades,

Morera (Morus nigra) . . . . . . . . . . . . 78 "

Tejo (Taxus baccata) ................. 3 "

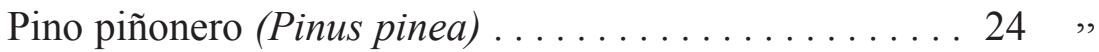

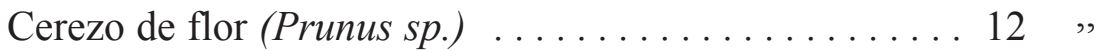

Peral (Pirus communis) . . . . . . . . . . . . . 32 ",

De arbustos y herbáceas se plantaron 32.672 unidades que corresponden a las siguientes especies:

Cotoneaster (Cotoneaster horizontalis) . . . . . . . 1.585 unidades

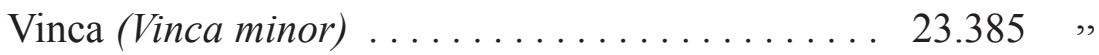

Romero (Rosmarinus officinalis) . . . . . . . . . 114 "

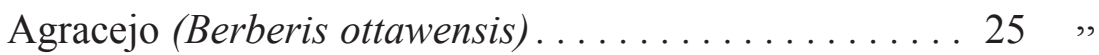

Acebo (Ilex aquifolium). . . . . . . . . . . . . . 6 "

Majuelo (Crataegus monogyna) .............4 42 "

Serbal (Sorbus aucuparia). . . . . . . . . . . . . . 12 "

Lauroceraso (Prunus laurocerasus) . . . . . . . . . . 29 "

Lavanda (Lavandula officinalis) . . . . . . . . . . 3.550 "

Lilo (Syringa vulgaris) . . . . . . . . . . . . . . . 17 , 
Espirea (Spiraea arguta) ......................

Hipérico (Hypericum calycinum) ............... 3.310 ,

Cineraria (Cineraria maritima) ..................178, ,

Pitosporo (Pitosporum tobira).................150,

Verónica (Veronica traversii)..................165 ,

Lirio (Iris Jane Phillips) ....................100 ,

La parte oeste del parque se habilitó como área de viveros y huerta de frutales plantándose manzanos de flor (Malus floribunda).

En el muro de cerramiento que va paralelo a la carretera de Robledo de Chavela se ha instalado una celosía por su parte interna. Tiene dos funciones: una estética y otra servir de soporte a la rosaleda que se ha plantado. Los rosales han sido 28 unidades de la variedad Roundelay rojo sangre y 24 de la variedad Roundelay rojo aterciopelado.

Toda esta extensa relación de las plantas empleadas en la restauración de este lugar se recopilan como ejemplo -en general bastante afortunado con la excepción de algunas de ellas- de actuación en un lugar de estas características.

Los criterios empleados parten de la premisa de conservar lo existente de la época de la reina María Josefa Amalia de Sajonia, ante la imposibilidad de recuperar el trazado original tanto por desconocer la vegetación exacta de ese momento como por la imposibilidad de recuperar la superficie del lugar. Si exceptuamos la introducción de algunas plantas demasiado "modernas" como las variedades de lirios y rosales empleados así como la utilización de rododendros, camelias, azaleas, mahonias, hortensias, moreras péndulas y las magnolias "stellata" el resto de los elementos vegetales es respetuoso con la historia y el carácter del lugar. En resumen, una de las mejores intervenciones de recuperación del verde histórico de nuestro país extensible esta afirmación a las dos Casitas por igual.

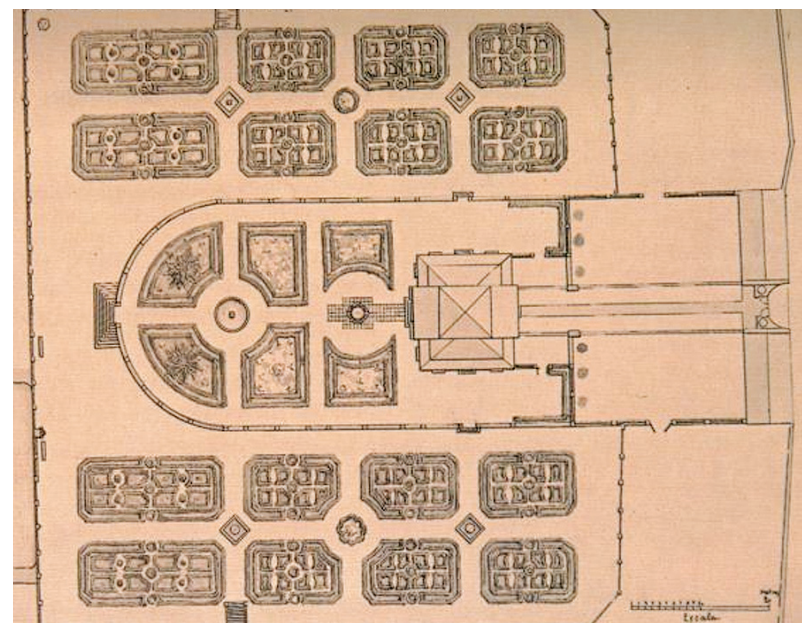

Plano de la Casita de Arriba según J. de Winthuysen 


\section{Bibliografía sobre las Casitas de El Escorial}

AÑON, Carmen; LUENGo, Ana y LUEngo, Mónica. Jardines artísticos de España. Ed. Espasa Calpe. Madrid, 1995.

Tratan de estos jardines en las páginas 33-45. Introducción histórica y breve descripción de los jardines. No hay planos pero si siete fotografías excelentes sobre los dos jardines. Escasos comentarios sobre la vegetación y sobre las vicisitudes ocurridas en el Sitio así como de los procesos de restauración llevados a cabo últimamente en los jardines de las Casitas.

CORRECHER, Consuelo M. "Jardines del Real Monasterio de San Lorenzo de El Escorial” en la revista Reales Sitios, n 78 de 1983 y no 80 de 1984. Esta estudiosa da la relación de plantas existentes en los jardines de la época de Felipe II citadas por el médico Juan Alonso de Almela en 1594. Por ella apreciamos la pobreza actual de las especies presentes en los jardines del Monasterio.

DEL ESTAL, Gabriel. "El Escorial: urbanismo y naturaleza”. En la revista Reales Sitios, no 80 de 1984. Menciona las plantas silvestres y los animales presentes en el entorno del Monasterio.

GUERRA DE LA VEGA, Ramón. Juan de Villanueva, arquitecto del Príncipe de Asturias. Dos tomos. Se tratan estas construcciones en el primer tomo, en las páginas 56-66. Solamente trata de la Casita de Abajo. Análisis arquitectónico de la construcción con las influencias italianas más importantes. Hay fotos y grabados.

MARQUESA DE CASA VALDES. Jardines de España. Ed. Aguilar. Madrid, 1973.

Citados estos jardines en la página 228 brevemente. Los sitúa dentro del neoclasicismo y comenta como su diseño clásico se encuentra estropeado por la plantación de welingtonias.

MUÑOZ RODRIGUEZ, Angel. "La recuperación de los parques de las Casitas de El Escorial" En la revista Reales Sitios, núm. 120, correspondiente el $2^{\circ}$ trimestre de 1994. Páginas 47-55. Hay fotos.

SANCHO GASPAR, José Luis. La Arquitectura de los Reales Sitios. Ed. Patrimonio Nacional. Madrid, 1995.

Trata sobre la construcción de las Casitas, el marco arquitectónico de influencias europeas, las fases, su historia etc. en las páginas 479-489. Hay fotos recientes y planos originales de los dibujos de Javier de Winthuysen sobre los jardines. El texto es casi idéntico a la conferencia de EL Escorial de Carmen Añón del año 93-94.

SANCHO GASPAR, José Luis. "El Casino del Infante y la Casita del Príncipe en El Escorial" Artículo en Jardines y Paisajes en el Arte y en la Historia. Cursos de verano de El Escorial 93-94. Dirigido por Carmen Añón. Editorial Complutense. 1995. Páginas 211-228.

SORIA CARRERAS, Santiago. "La gestión del Patrimonio Nacional en los jardines del Real Sitio de San Lorenzo de El Escorial". Artículo en Jardines y Paisajes en el Arte y en la Historia. Cursos de verano de El Escorial 93-94. Dirigido por Carmen Añón. Editorial Complutense. 1995. Páginas 229-244.

Artículo interesante para nuestros trabajos por la definición de los criterios existentes en ese organismo respecto a la gestión del patrimonio verde.

WINTHUYSEN, Javier de. Jardines clásicos españoles. Edición facsímil Doce Calles. Aranjuez, 1990.

Winthuysen sitúa las Casitas dentro del neoclasicismo en El Escorial. Páginas 106-113. Hay dibujos, fotos y planos levantados por él mismo. Sus comentarios son igualmente importantes sobre el carácter del lugar. Entendió lo que eran estos jardines a pesar de la presencia de las coníferas del siglo XIX y el estado de abandono en que se encontraban los jardines. 


\section{c) Quinta del Duque de Arco en El Pardo}

Antes de ver la restauración de los jardines de la Quinta, haremos un breve resumen de la historia de este lugar.

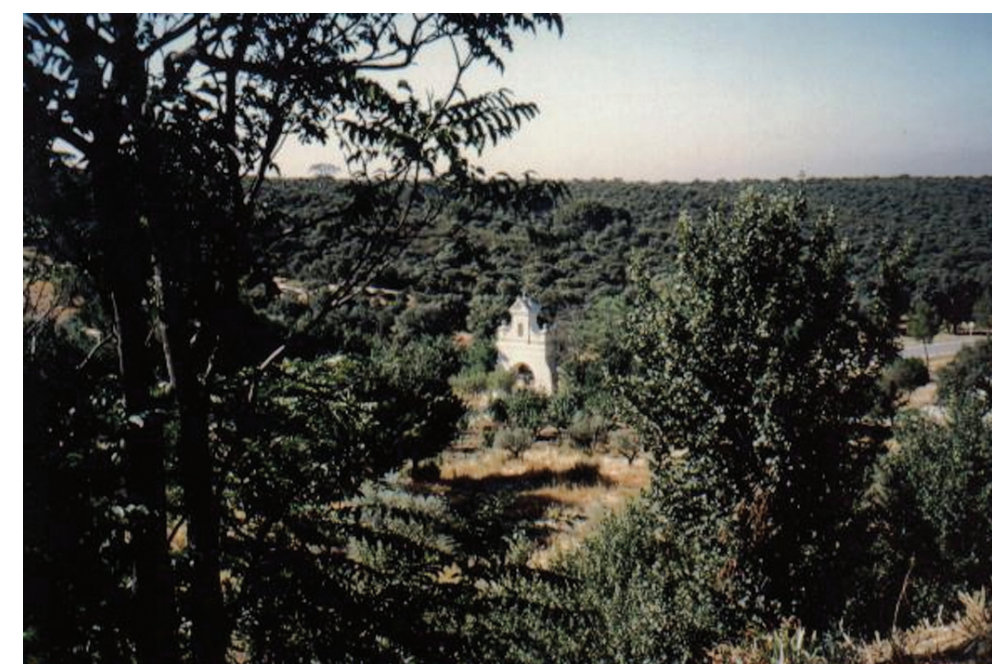

Entrada de la Quinta con el monte del Pardo al fondo. (Foto del autor)

Felipe V, gran aficionado a la caza, se acompañaba de D. Alonso Fernández a quien hizo Caballerizo Mayor y Duque de Arco en 1715. Este adquirió una finca en 1717 colindante con el monte del Pardo. Desde entonces hasta su muerte en 1730, se dedicó a construir y embellecer el lugar. En 1745 su viuda lo cede al monarca. Los estudiosos de la jardinería concedían la autoría del trazado a los franceses Esteban Marchand y Claudio Truchet hasta que las investigaciones del historiador José Luis Sancho (11) confirmaron que la obra era del segundo, hecho venir a España con esta finalidad. Constituye un ejemplo claro de jardín barroco en el que entremezclan las influencias italianas y francesas imperantes en la Europa del momento.

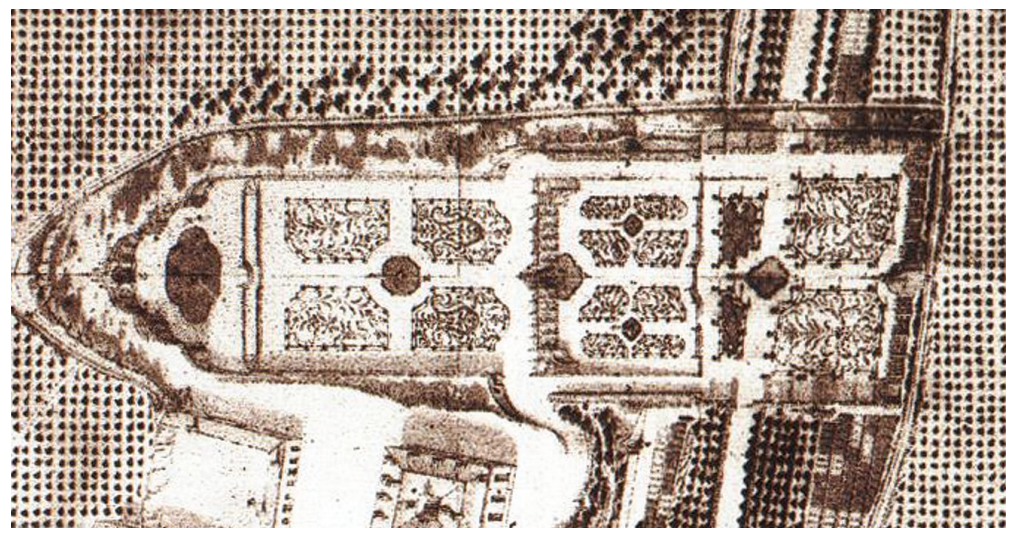

Plano de la Quinta según Francisco Carlier en 1745

(11) SANCHO GASPAR, José Luis. Notas sobre la vida y escritos de Xavier de Winthuysen. Edición facsímil de la obra de Winthuysen Jardines Clásicos de España. Editorial Doce Calles. Aranjuez, 1990. Págs.104-106. 
En 1745, al pasar a la Corona, el rey ordenó levantar planos y realizar un inventario completo del lugar a Francisco Carlier con lo que tenemos la suerte de disponer de una información en la que se recogen todos los elementos del jardín y también de su estado.

Por este inventario sabemos que los setos eran de boj (12), que existían macetones de naranjos, lauros y jazmines formados en espaldera, tiestos de Talavera con claveles y naranjos, césped en alguno de los parterres enmarcados de boj así como frutales, madreselvas, viña virgen y otras plantas junto con numerosas estatuas, jarrones y otros elementos constructivos y decorativos entre los que destacan las fuentes, la gruta, las escaleras y barandas y algunos actualmente perdidos como el cenador.

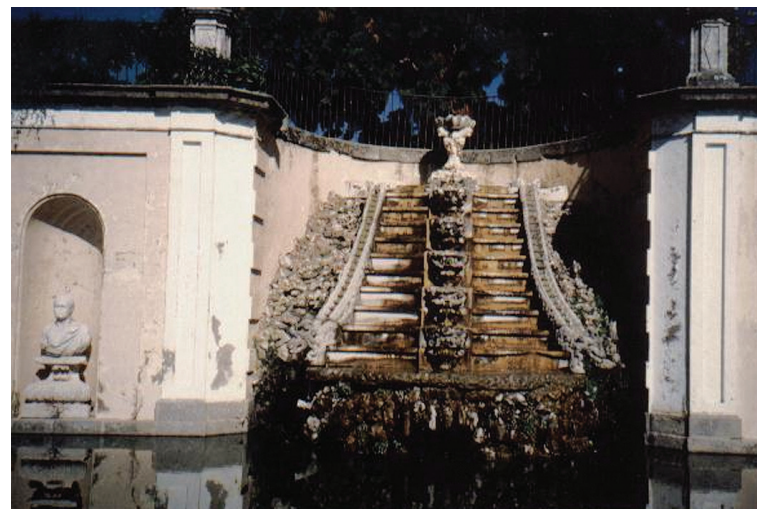

Fuente en escalera de la Quinta. (Foto del autor)

Los comienzos del siglo XIX van a conocer su abandono por las circunstancias políticas de aquel período de nuestra historia. Sabemos por otro inventario de 1840 que se conservaban los setos de boj en cuyo interior estaban plantados rosales. Durante el reinado de Amadeo de Saboya (1871-1873) se plantaron coníferas entre las que destacan las enormes wellingtonias y pinsapos que hoy rompen las perspectivas del trazado original. La decadencia del sitio continúa en años posteriores. En 1880 se desmonta el cenador y no se vuelve a reconstruir en ningún lugar del jardín.

De principios del siglo XX conservamos la descripción y fotos del jardín en la obra tantas veces citada de Winthuysen Jardines clásicos de España quien se lamenta del estado en que se encuentra y de las pérdidas de algunos de los elementos escultóricos del lugar como las estatuas y el cenador ochavado. A pesar de este estado de semiabandono es declarado Monumento Nacional en 1935.Tras la Guerra Civil, el lugar es destinado a Academia de Mandos de la Sección Femenina. El jardín, en muy mal estado, estuvo a punto de ser restaurado por Winthuysen en 1942 pero este proyecto no cuajó como tampoco se llevó a cabo otro proyecto propuesto de índole contraria consistente en la transformación de la mayor parte de su superficie en pistas deportivas.

(12) SANCHO GASPAR, José Luis. La Arquitectura de los Sitios Reales. Ed. Patrimonio Nacional. Madrid, 1995. En esta obra está recogido todo el inventario hecho al pasar la posesión a la Corona en 1745. 


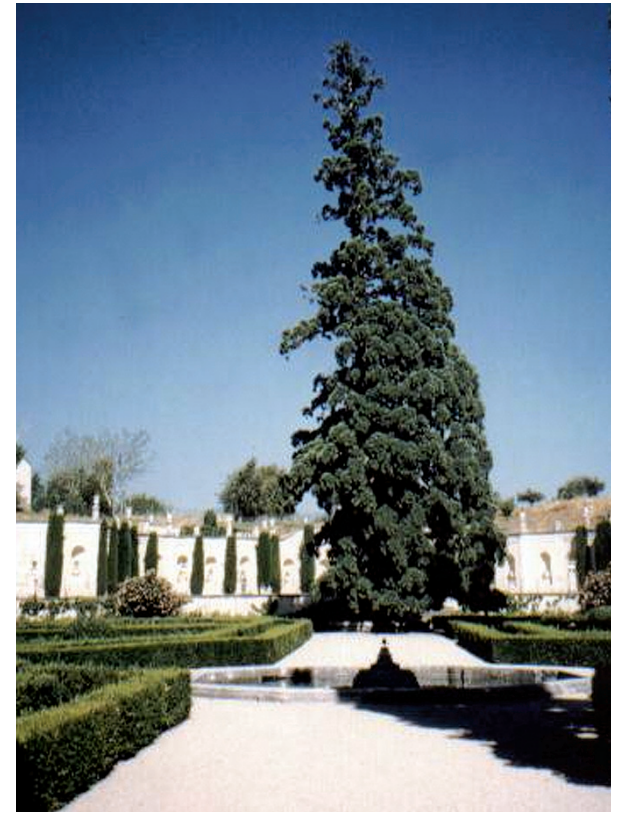

A pesar de romper las perspectivas, los grandes ejemplares del XIX se han respetado.(Foto del autor)

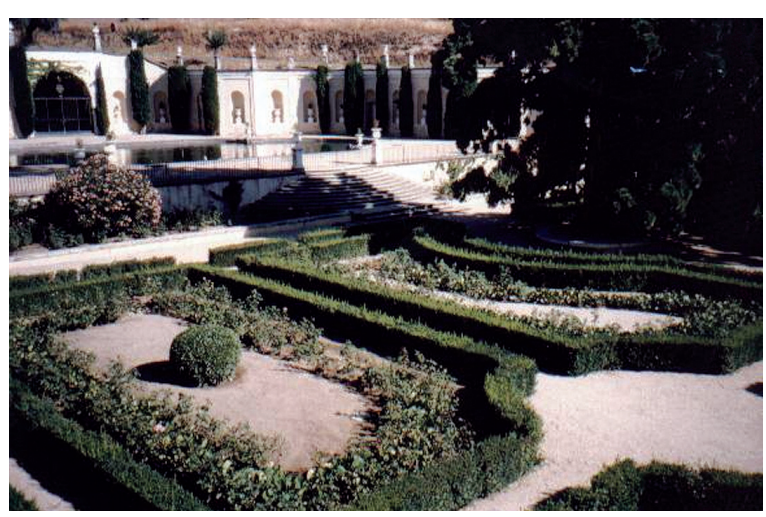

Parterres atribuidos a la Marquesa de Casa Valdés. (Foto del autor)

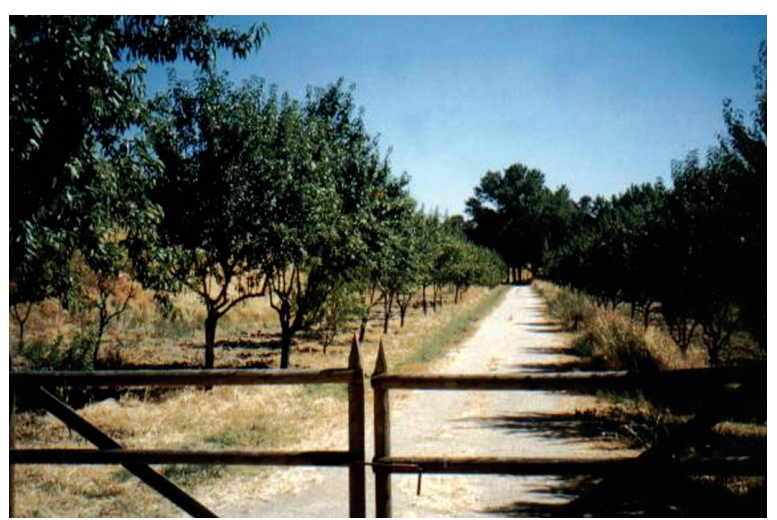

Nueva plantación de frutales en la parte de la vega. (Foto del autor)

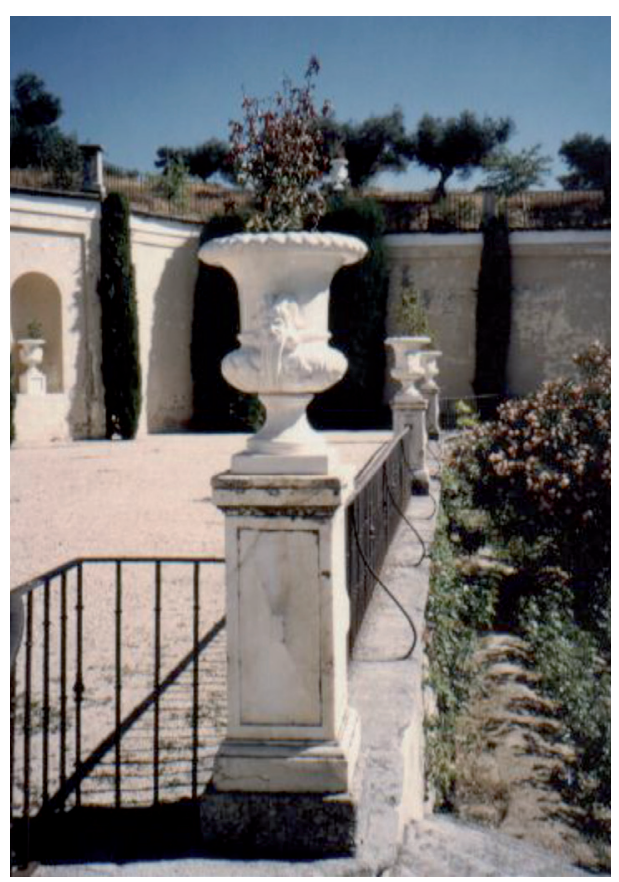

Floreros nuevos sobre las pilastras originales del lugar. Foto del autor) 
Aún llegaría su degradación a un grado mayor cuando en 1970 se arrasa el nivel inferior para permitir que una carretera lo cruzara.

En 1974 la Marquesa de Casa Valdés dirigió la restauración de los tres niveles superiores. Rehace los setos de boj e introduce rosales con lo que consigue que al menos el jardín permanezca.

En 1994 el Servicio de Jardines, Parques y Montes del Patrimonio Nacional realiza una restauración integral del sitio que ha consistido en la plantación de frutales en la vega, en la reposición de las marras de olivos en los campos de cultivo que rodean el lugar y la restauración del jardín en los aspectos de mobiliario, infraestructuras y vegetación.

Dentro de los criterios que imperaban en ese momento en la actividad restauradora del Patrimonio Nacional se conservaron las grandes coníferas de la época de Amadeo de Saboya (pinsapos y wellingtonias). Los setos de boj se rehicieron todos de nuevo y en el interior de los parterres se plantaron de rosales y bergenias. Destaca la reconstrucción del último piso ocupado por la carretera de 1970. Esta ha sido desviada y los cuadros de este plano se han reconstruido por analogía con los de los pisos superiores.

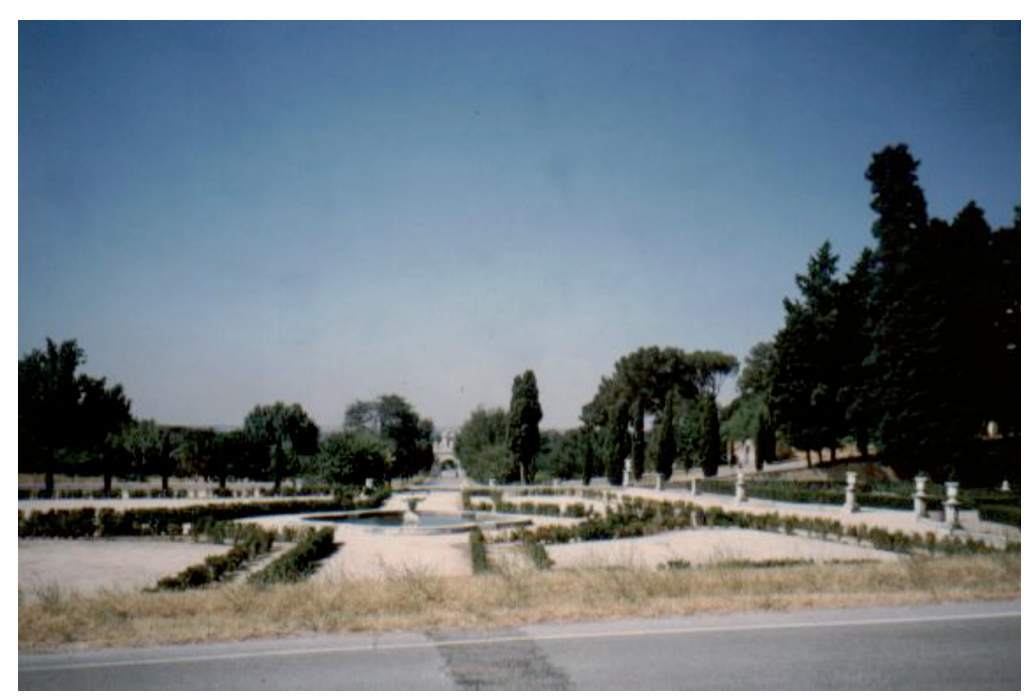

Reconstrucción del nivel inferior del jardín tras desviar la carretera. (Foto del autor)

En su conjunto, las intervenciones llevadas a cabo en este lugar constituyen una restauración/recreación muy sensata. En primer lugar porque se ha respetado el paso del tiempo manifestado en la presencia de las grandes coníferas y en segundo lugar por el esfuerzo realizado en la recuperación del aspecto del antiguo jardín y buena parte de la estructura salvo los cipreses. Sin embargo, los grandes fallos de esta intervención son la ausencia del agua junto a la falta de plantas en muchos de los parterres. 
La pérdida de los antiguos manantiales que abastecían las fuentes no se ha visto compensada con la instalación de un sistema hidráulico de circuito cerrado donde se pueda disfrutar de la visión de la cascada y del resto de los juegos de las fuentes.

Igualmente es de lamentar, a nuestro parecer, el abandono de los riegos tradicionales a manta a favor del sistema de goteo con lo que conlleva de fealdad de los tubos a la vista en todos los cuadros donde aún echamos más en falta la presencia del agua y sus sonidos. También queda un tanto extraño el enlucido de los muros y esa pintura que nos priva de la belleza de la construcción del ladrillo a cara vista que podemos apreciar en las fotos antiguas del lugar.

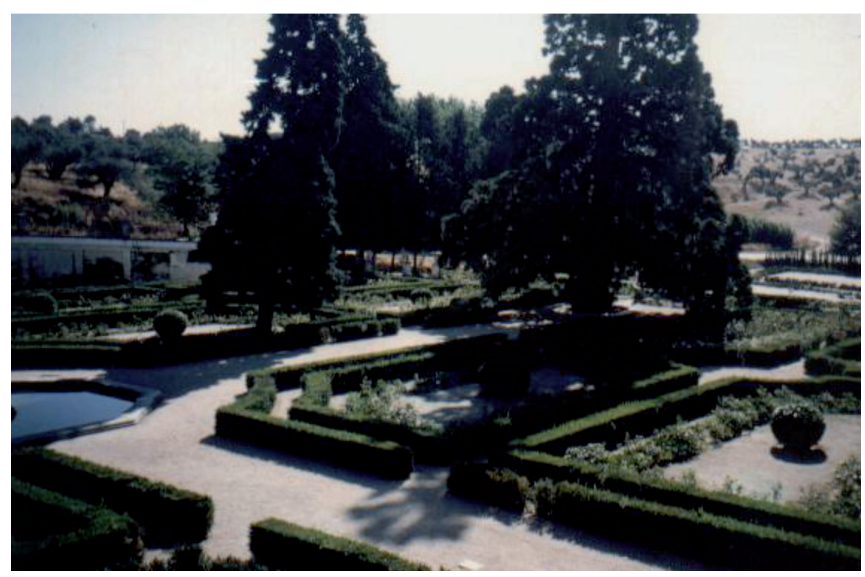

Parte del jardín con las grandes coniferas respetadas.

(Foto del autor)

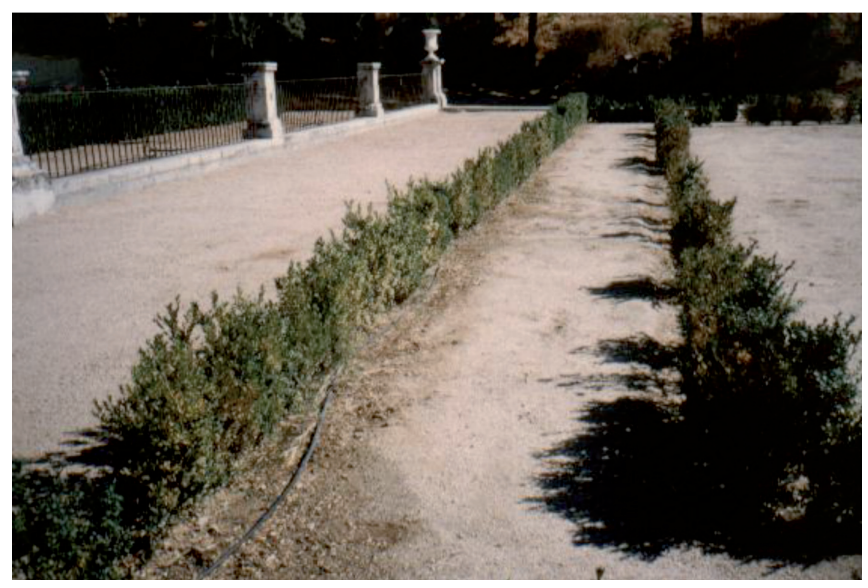

Los nuevos setos de boj son regados a goteo. Terraza inferior. (Foto del autor) 


\section{Bibliografía sobre la Quinta del Duque de Arco}

AÑon, Carmen; LUENGo, Mónica y LUENGO, Ana. Jardines artísticos de España. Ed. Espasa Calpe. Madrid, 1995.

En las páginas 62-67 se describe el lugar con anécdotas biográficas sobre el Duque y los reyes. Descripción del sitio y de su historia sin aportar grandes novedades a lo publicado hasta la fecha. Escasa información sobre el siglo XX y los procesos de restauración ocurridos en el jardín. Buenas fotos del conjunto.

MARQUESA DE CASA VALDES, Ma Teresa de Ozores y Saavedra. Jardines de España. Ed. Aguilar. Madrid, 1973.

El jardín es estudiado en las páginas 134-137. Ofrece las descripciones de Ponz en 1785 y de 1787; la del inventario de 1840 y la de su estado en la década de 1970. Señala que Patrimonio estudia su recuperación. Hay un par de fotos y el plano de Winthuysen.

"Quinta del Duque de Arco" en el catálogo de la exposición Jardines clásicos madrileños a cargo de Carmen Añón. Madrid, 1981. Ayuntamiento de Madrid. Páginas 97 y 98.

Se centra el artículo en la biografía del Duque sin extensas referencias al jardín. Sin embargo, hay un plano nuevo aunque no se puede citar procedencia por el minúsculo tamaño de la letra.

SANCHO, José Luis. En la edición facsímil de la obra de Winthuysen Jardines clásicos de España de 1990 hay unas Notas sobre la vida y escritos de Javier de Winthuysen a cargo de Carmen Añón y José Luis Sancho donde están recogidos los escritos sobre el jardín de la Quinta y su proceso de restauración en las páginas 104-106 según el proyecto de la Marquesa de Casa Valdés.

SANCHO, José Luis. La Arquitectura de los Sitios Reales. Ed. Patrimonio Nacional. Madrid, 1995. En las páginas 225-263 se recoge toda la información existente hasta el momento sobre este lugar. La mejor publicación de todas las existentes hasta la fecha.

TOVAR MARTIN, Virginia. El Pardo. Ed. El Avapiés. Madrid, 1994. Serie: Parques y Jardines de Madrid a cargo de Carmen Añón y Caja Madrid. Páginas 67-104.

Extensa historia del jardín y de los distintos procesos sufridos por obra de sus dueños a lo largo del tiempo hasta nuestros días. Figuran varios planos, fotografías y la cita de su restauración en ese momento. Igualmente figuran los inventarios de 1745 y de 1840.

WINTHUYSEN, Javier de. Jardines Clásicos de España. Compañía Iberoamericana de Publicaciones. Madrid, 1930. Trata sobre el jardín en las páginas 79 y 80 . Hay cuatro fotos del lugar sobre los años 20 del siglo XX y un plano del sitio.

REALES SITIOS, nº 40, 1974 hay tres artículos dedicados a la Quinta. El primero es de Manuel del Río "Obras arquitectónicas en el Palacete de la Quinta de El Pardo"; el segundo es de Angel Oliveras "Restauraciones en el Palacete de la Quinta "y el tercero es del Marqués de Lozoya "Palacete de la Quinta: museo de papeles pintados". Ninguno de los tres desarrolla el tema de la restauración del jardín ni queda confirmado que la Marquesa de Casa-Valdés recibiera el encargo de realizar su restauración. 


\section{c) Laberinto de la Granja de San Ildefonso}

Todas las actuaciones de restauración llevadas a cabo en este lugar se iniciaron tras previos estudios históricos. Realizados los mismos, los trabajos de restauración se centraron en tres aspectos: jardinería, hidráulica y esculturas. Nosotros antes de tratar del Laberinto, veremos los aspectos de la jardinería original del Sitio para poder ubicar en su contexto histórico y cultural ese espacio.

La mayoría de los estudiosos ponen la Granja como ejemplo de la influencia de la jardinería versallesca en nuestro país, cuando más bien el punto de referencia para la Granja es Marly más que Versalles, el palacete construido por Luis XIV como retiro íntimo lejos de la exhibición continua del teatro de la Corte. Igualmente hay que considerar para comprender la creación de estos jardines, la evolución seguida por la escuela de Le Nôtre tras la muerte de éste a principios del XVIII plasmada en la obra de Dezallier d'Argenville La théorie et la practique du jardinage.

Ha sido el historiador del Patrimonio Nacional José Luis Sancho (13) quien ha estudiado la historia de la construcción del jardín, de sus trazas, del espíritu con que se llevó a cabo y de los elementos constitutivos del lugar: bosquetes, fuentes etc. Seguiremos sus pasos para hacer el resumen histórico.

Los autores del proyecto, Carlier, Marchand y Boutelou emplearon en el trazado todas las fórmulas expuestas en la obra de Dezallier d'Argenville. Los planos existentes del jardín del siglo XVIII guardan una estrecha relación con los representados en la obra citada: parterres de broderie, de compartiment, uno de orangerie. Cuatro boulingrins hacían el papel de parterre a l'angloise. Además del laberinto existían otros tipos de bosquetes como el bosquet decouvert et a compartiment, cabinets y salons de verdure. Los anfiteatros, teatros y grandes salas presentes en Versalles faltan, sin embargo, en la Granja.

El tipo más frecuente de bosquete en el jardín segoviano (área de las Ocho Calles) es el bosquet de moyenne futaie a hautes palissades, hoy completamente desaparecido. José Luis Sancho explica el proceso de degradación sufrido por estos bosquetes hasta llegar a su desaparición: "El bosquet deriva de la vegetación natural de Francia, donde las agrupaciones de árboles forman masas cerradas y compactas, sobre todo cuando no son muy grandes, es decir, de mediano porte o moyenne futaie, mientras que los de gran porte o haute futaie, con menos espesura abajo y propios para la caza se atravesaban con grandes calles rectilíneas cruzadas formando estrellas, pero para ser "imitados" en un jardín resultaba necesario formar tal bosque. Ni los pinos, ni mucho menos los rebollos, eran adecuados para formar bosquets de haute futaie, y tanto por ellos como por el espiritu mismo del jardín de propreté se emplearon bosquets de moyenne futaie a hautes palissades. Esta "imitación de la naturaleza” era desde luego, más "natural” en 
Francia, donde la vegetación autóctona formaba sin problemas el "relleno" de los bosquetes. Pero aun alli, se reforzaba el efecto creando muros de vegetación con charmille, es decir carpe o Carpinus betulus, de unos dos metros o poco más de alto, formando muros verdes continuos, que es a lo que se denomina hautes palissades".

Cuando el jardín se creó hubo que desmontar toda la ladera con lo que suponemos que se taló enteramente el bosque existente. Los rebrotes y las nuevas plantaciones crearon un bosque de robles cercado de setos de carpe. Los robles se cortaban de vez en cuando para utilizar sus maderas con lo que la vegetación arbórea del interior de los cuadros se mantenía a una altura media. Posteriormente, el abandono del lugar y las nuevas modas vieron la introducción de coníferas y pinos lo que produjo que los setos de carpe fueran desapareciendo por falta de luz. Esta situación es la que existía en ese lugar en los años noventa del pasado siglo.

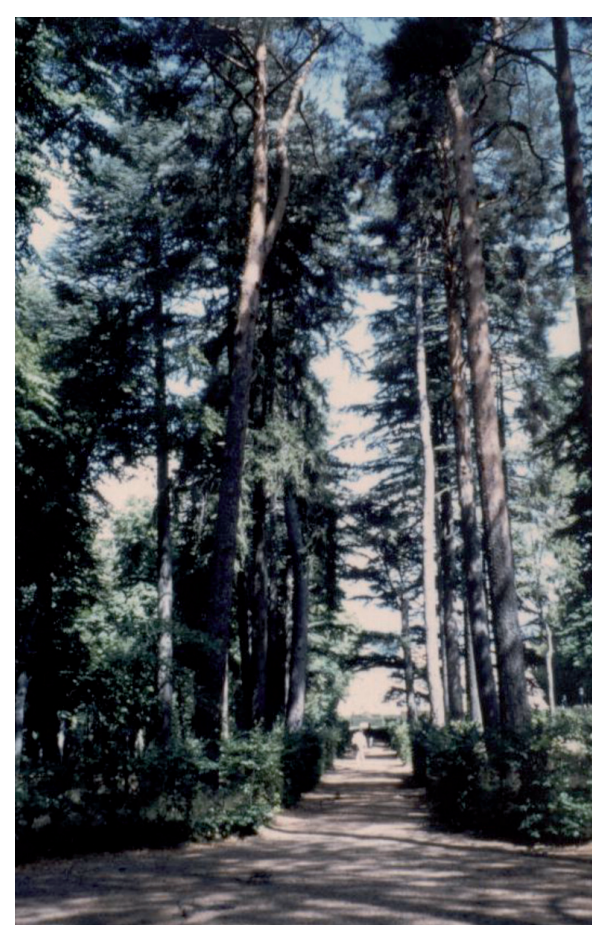

Uno de los cuadros de La Granja (al fondo del parterre de la Fama) ocupados por las coníferas plantadas el siglo XIX. (Foto del autor)

Volvemos a citar a José Luis Sancho para exponer los criterios de intervención que exigió tal situación con el fin de recuperar en lo posible el aspecto que originalmente tenía el jardin de propeté: "Dadas estas premisas, son evidentes las dificultades que se presentan para llevar adelante la actuación global y coherente planteada y deseable. Los parterres, por unas razones o por otras, pueden quedar como están (el de la Fama debe su trazado actual a la época de Carlos IV, y por tanto no parece pertinente restituirlo a su estado original; en el de la Cascada sería posible, pero no así en el de Andrómeda, donde las grandes coníferas indis- 
cretamente plantadas a fines del siglo XIX -y alguna en el XX, para emparejar con las ya existentes-asombran su espacio impidiendo cualquier plantación), pero los bosquetes originan diferentes problemas. Los de diseño más elaborado exigen una actuación drástica, pero sencillamente inevitable, que es su total reposición, eliminando los ejemplares arbóreos inútiles que hoy los forman y replantando ex novo. Tal es el caso de los bosquetes a ambos lados del eje de la cascada principal, y de los de la Selva y del Nocturnal, y dentro de esta categoría hay que considerar como actuación pionera la del bosquete del Laberinto.
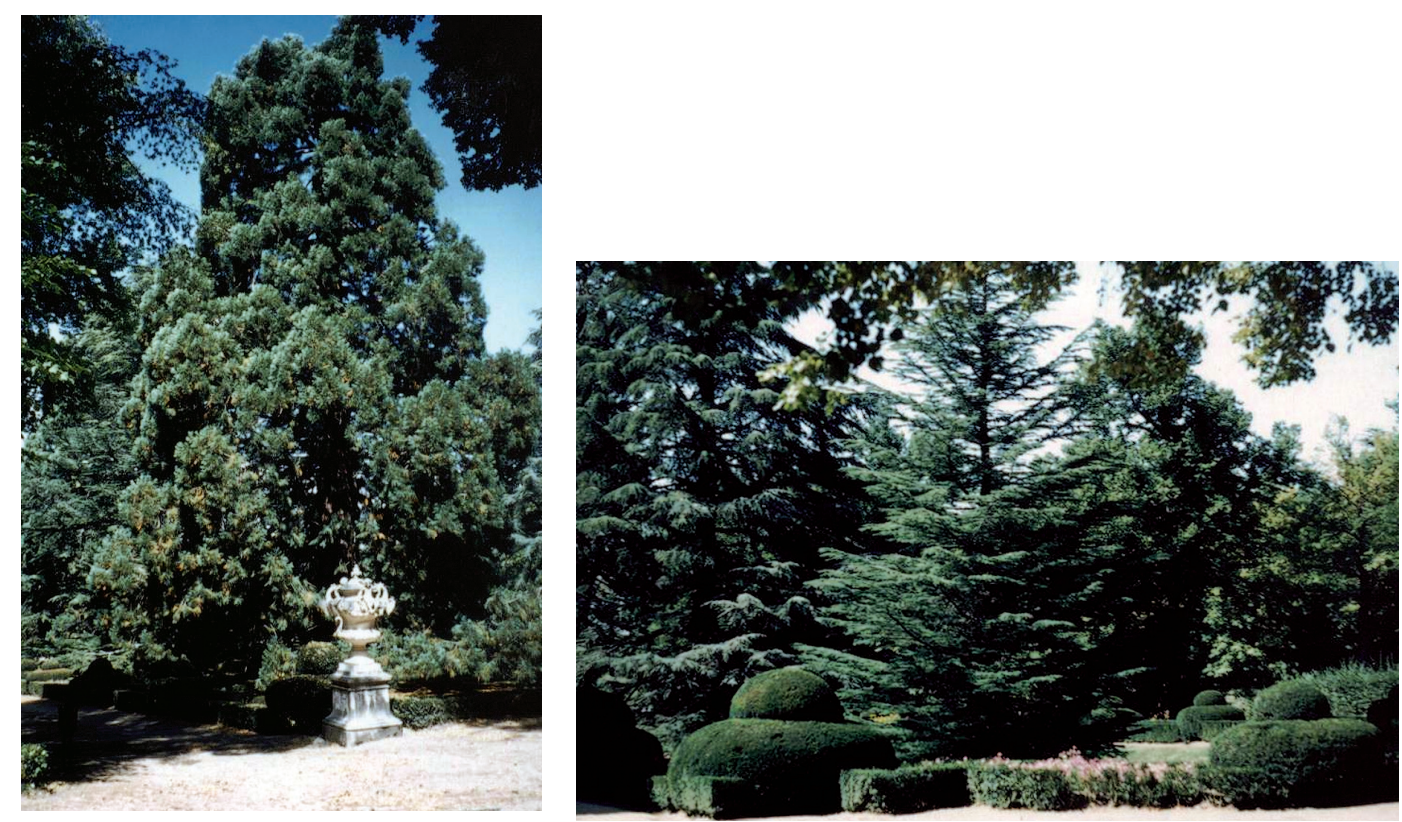

Estas dos imágenes pertenecen al parterre de Andrómeda. Puede apreciarse claramente como las coníferas han ocupado el espacio reservado en sus orígenes a las pequeñas plantas de flor. (Foto del autor)

Paradójicamente, son los bosques de diseño más simple los que presentan más problemas, pues la masa arbórea de su "relleno" ha crecido descontroladamente, alcanzando, por una parte, los robles una altura desmesurada respecto a la que podían llegar a tener en el estado "clásico" del jardín, e introduciéndose por otra parte numerosas coniferas que desfiguran la armonía y el efecto general de las masas. Este crecimiento del fourré ahoga el desarrollo de los árboles de sombra plantados en las calles lineales, condenados así al raquitismo y a la muerte, e impide el desarrollo de las paredes de seto vivo de carpe, como puede apreciarse en las fotografías sobre el estado actual del jardín, especialmente en las del área de las Ocho Calles. El objeto del plan decenal de bosquetes es reorientar esta situación e un modo suave y progresivo. Tal vez, sin embargo, esto no baste y, comprobada la necesidad de actuar con valor y energía, creo que en este punto la actual restauración de los jardines de Versalles es un modelo ejemplar para la que estamos planteando en San Ildefonso". 
Todos estos considerandos se van a ver plasmados en la restauración del Laberinto como veremos a continuación.

La importancia del Laberinto radica en que es un ejemplo de pervivencia a lo largo del tiempo tanto de un trazado de origen puramente barroco como de gran parte de su masa vegetal por lo que las posturas radicales expresadas en los párrafos anteriores volviendo a rehacer desde cero el interior de los bosquetes no fueron aquí necesarias. A pesar de todo, en los citados parterres como el de Andrómeda se ha considerado dejarlos como están y así las grandes coníferas que los rellenan no han sido eliminadas.

El diseño de este lugar está copiado literalmente del laberinto del libro citado anteriormente de Dezallier d'Argenville La théorie et la practique du jardinage de 1713.

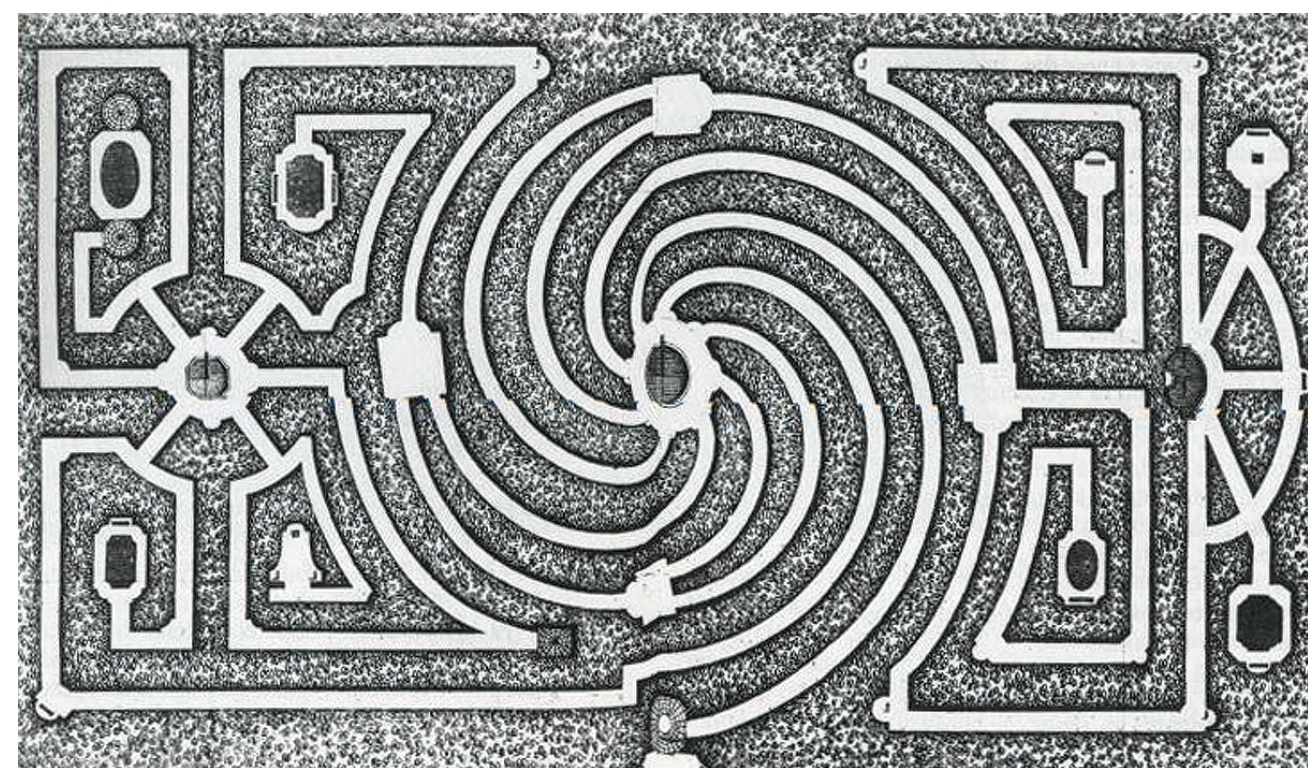

Modelo de laberinto del libro La théorie et la practique du jardinage de Dezallier d'Argenville

Los principales estudiosos de la jardinería de este Real Sitio coinciden en señalar su ubicación dentro de las corrientes posteriores surgidas en la jardinería europea tras la muerte de Le Nôtre. La Marquesa de Casa Valdés atribuye su construcción a Marchad con la colaboración de Esteban Boutelou para la vegetación, alrededor del año 1725 (14).

La conservación de su diseño la podemos seguir a través de toda la documentación gráfica existente que disponemos. El primer plano de San Ildefonso que tenemos es el de Méndez de Rao de 1740. Aquí el jardín está casi completamente acabado y tiene la importancia de plasmar los trazados de bosquetes y parterres de 
todo el lugar en ese momento ya que hoy muchos de ellos han desaparecido por las causas que hemos visto en las líneas anteriores.

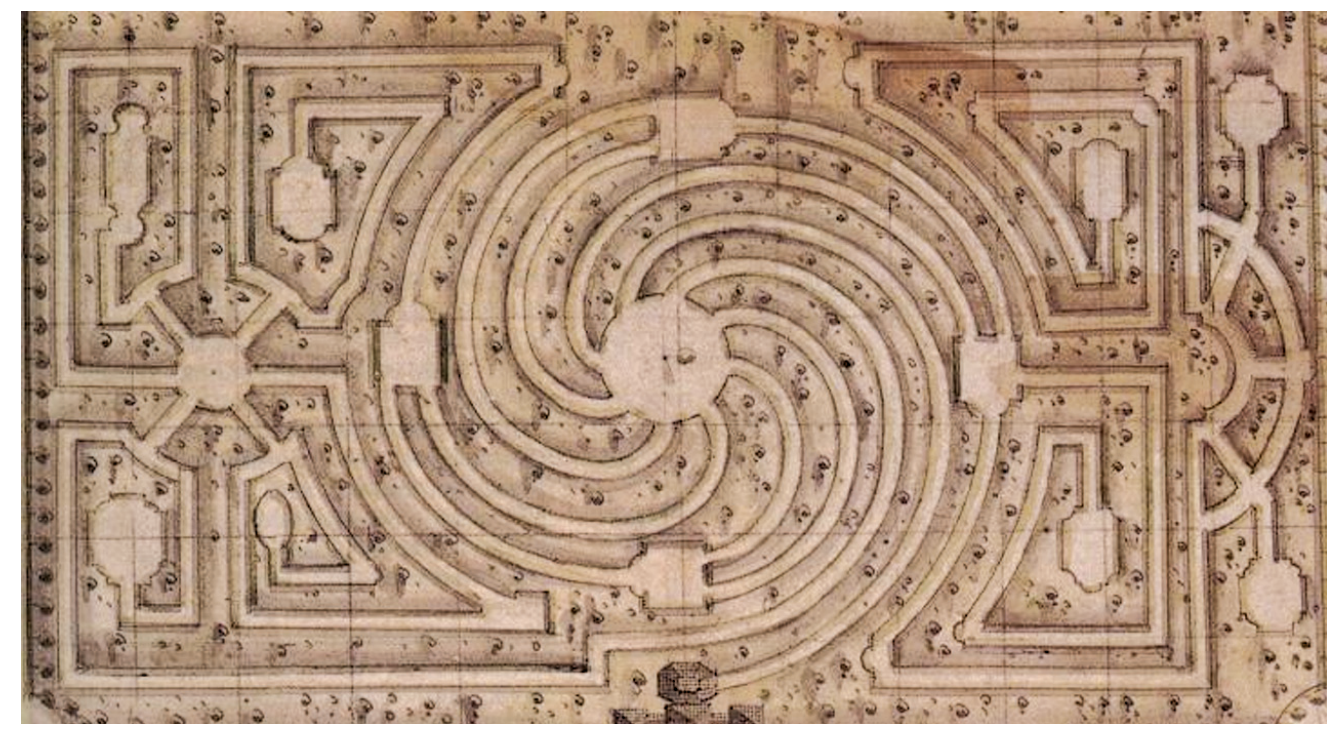

Plano del Laberinto de la Granja procedente del plano de Méndez del Rao.1740. Servicio Geográfico del Ejército. Madrid

En los otros planos del XVIII conservados, tanto el anónimo de la Biblioteca Nacional de París (hacia 1740-1760) como el "Plano General de San Ildefonso Reinado de Carlos III" fechado alrededor de 1788, podemos apreciar que se sigue conservando su traza.

Durante el siglo XIX se realizan varios planos del Real Sitio y en ellos vemos que se sigue manteniendo el trazado del siglo anterior:

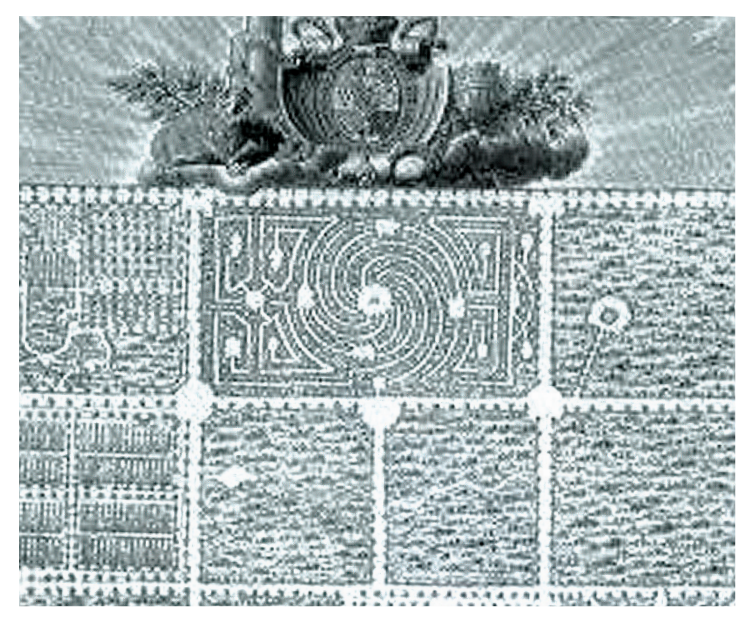

Plano de la Granja de José Ribelles de 1830 


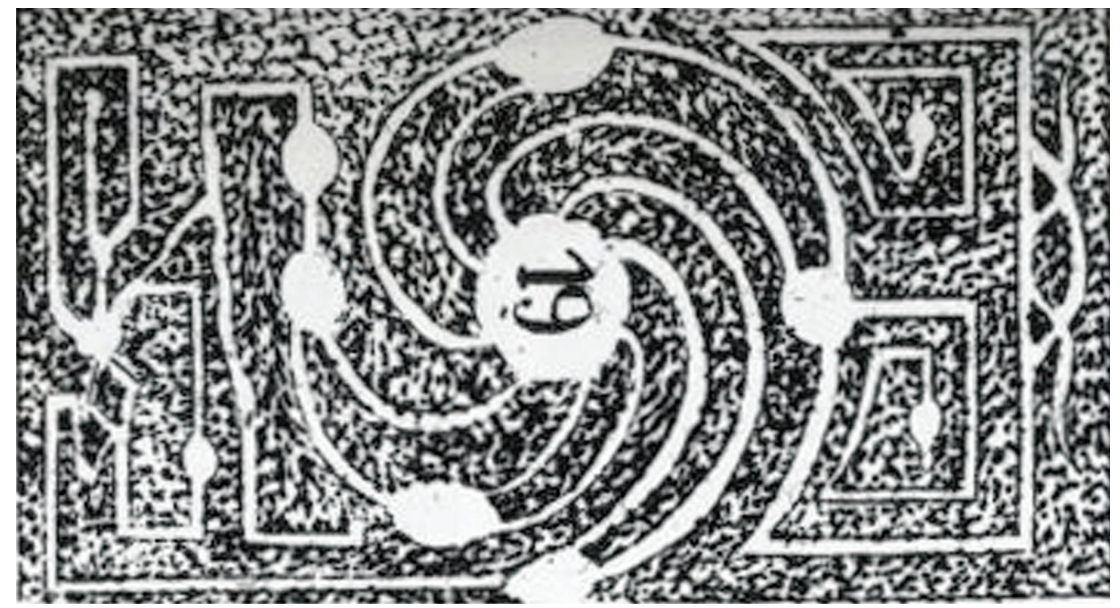

Plano de la Granja del presbitero Tomás Munico de 1851

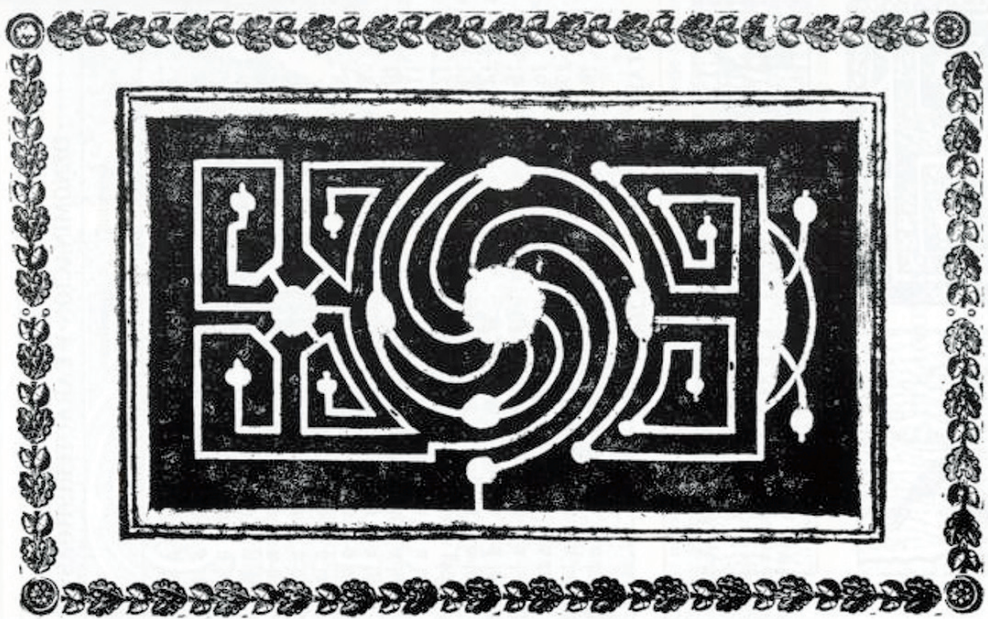

Plano del Laberinto procedente de la Guía del Real Sitio de Martín Sedeño de 1854

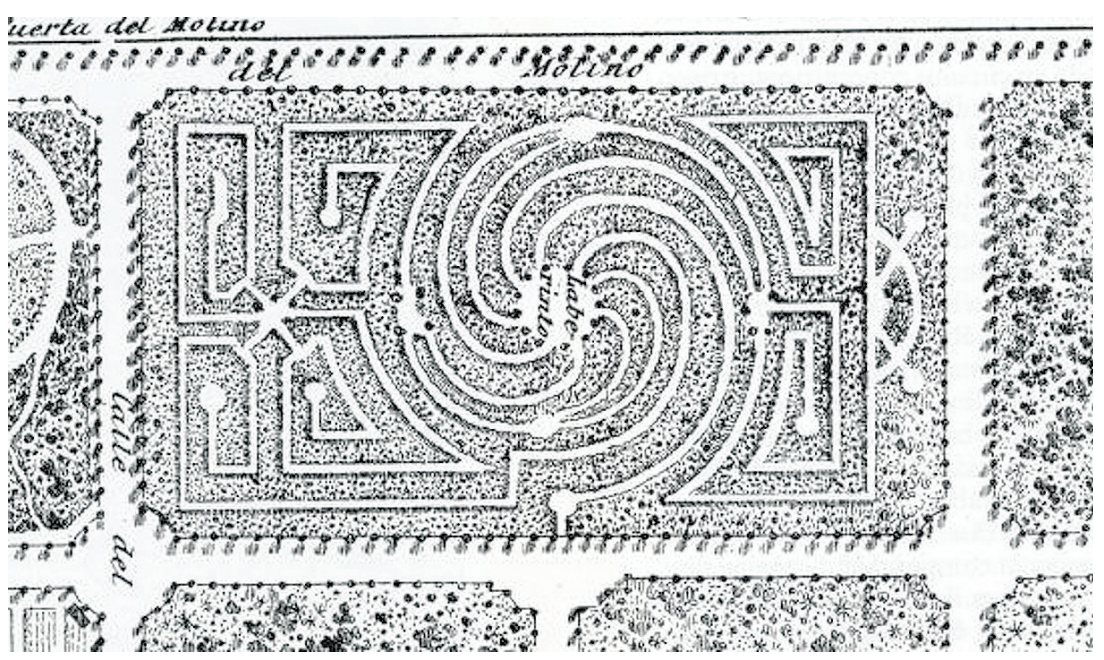

El Laberinto según la Guía de Breñosa y Castellarnau en 1884 
Respecto a la composición vegetal original de este espacio es difícil saberlo con certeza pues la mayoría de los autores de los siglos XVIII y XIX confunden el haya (Fagus sylvatica) con el carpe (Carpinus betulus) llamado haya francesa. Las descripciones son confusas según nos cuenta Juan Fernando Carrascal Vazquez: "Fagoaga señala las paredes formadas por haya, y los interiores cubiertos de álamos, castaños de Indias y otros, sin ningún frutal”. Breñosa, excelente botánico, indica que en la entrada se encuentran unas hermosas hayas, "especie no común en este Real Parque", y que "los pies de carpe que forman el seto son en su mayor parte viejos" por lo que posiblemente, como en otras zonas del Jardín, se encontraban las dos especies mezcladas.

Durante la primera mitad del siglo XIX se conservó bastante bien. En los escritos de Fagoaga y Sedeño de 1840 y 1854 leemos que una persona se podía perder realmente en el lugar. Sin embargo en la Guía de Breñosa y Castellarnau de 1884, ambos autores se lamentan del estado en que se encuentra ya que "no ofrece atractivo alguno, pues los pies de carpe que forman el seto son en su mayor parte viejos y poco poblados de ramas, y pobres los macizos intermedios, lo que hace que las veredas no queden bastante aisladas, y por lo tanto, no ofrece dificultad alguna entrar en su centro y salir luego" y eso como señala Carrascal Vázquez que en 1875 se habían sustituido las piezas de pino de Valsaín que ayudaban a reforzar los setos impidiendo el paso de un camino a otro.

En 1885 se interviene reponiendo setos de carpe. Vuelve a ser restaurado profundamente en 1905, año en que se replantan carpes y se arreglan las caceras de riego.

Todo ese tiempo, el Laberinto estuvo dentro de las zonas consideradas "partidas reservadas" del Jardín, es decir, cerradas al público en general y sólo se podía acceder a ellas con una autorización para su visita. Eran igualmente "zonas reservadas" la zona de huerta y la de producción de flores. En 1940, tras la Guerra Civil, se abre al público con lo que empieza una rápida degradación plasmada en la desaparición de la vegetación que formaba las paredes del Laberinto. Los visitantes, al perderse y cansarse de buscar la salida que no encuentran, rompen las vallas hechas de pino de Valsaín y vegetación para buscar la salida rápidamente.

Juan Fernando Carrascal nos cuenta la importancia que para el Patrimonio revestía este lugar y los criterios que se emplearon: "La recuperación de esta zona fue una de las actuaciones prioritarias decididas desde la creación del Servicio de Jardines, Parques y Montes, tanto por ser un elemento original del Jardín, singular y altamente valorado, como por las escasísimas variaciones que había sufrido en su trazado y espíritu desde el origen, si se exceptúa el mal estado de sus estratos vegetales, y en especial el sub-arbóreo, que se correspondería con las paredes laterales de impermeabilización vial y visual entre los diversos caminos.

El criterio elegido se basó en respetar al máximo la vegetación que de manera natural o cultural se hallaba asentada en el momento del inicio de las obras, siempre que permitiera la recreación de las pantallas vegetales, la creación de una 
nueva "espesura" en los bosquetes que individualizara los caminos, la recuperación del sistema tradicional de riego adaptado a las nuevas circunstancias de la zona visitable y la estabilización de los caminos, para hacerlos transitables la mayor parte del año, causando el menor impacto visual posible.

La reparación para reforzar la división entre los caminos a base de "latas" de pino de los montes de Valsaín se sustituyó por alambrada metálica, de mucho menor impacto visual y mayor duración y fácil arreglo y/o sustitución. En resumen, se optó por un criterio de restauración integral, dentro de la escasa información existente, respetando las posibles adiciones botánicas que no interfirieran en la obra, como un valor añadido, y adaptando los sistemas de infraestructuras a las actuales tecnologías cuando no suponen un fuerte impacto visual o contrario al fin perseguido"(15).

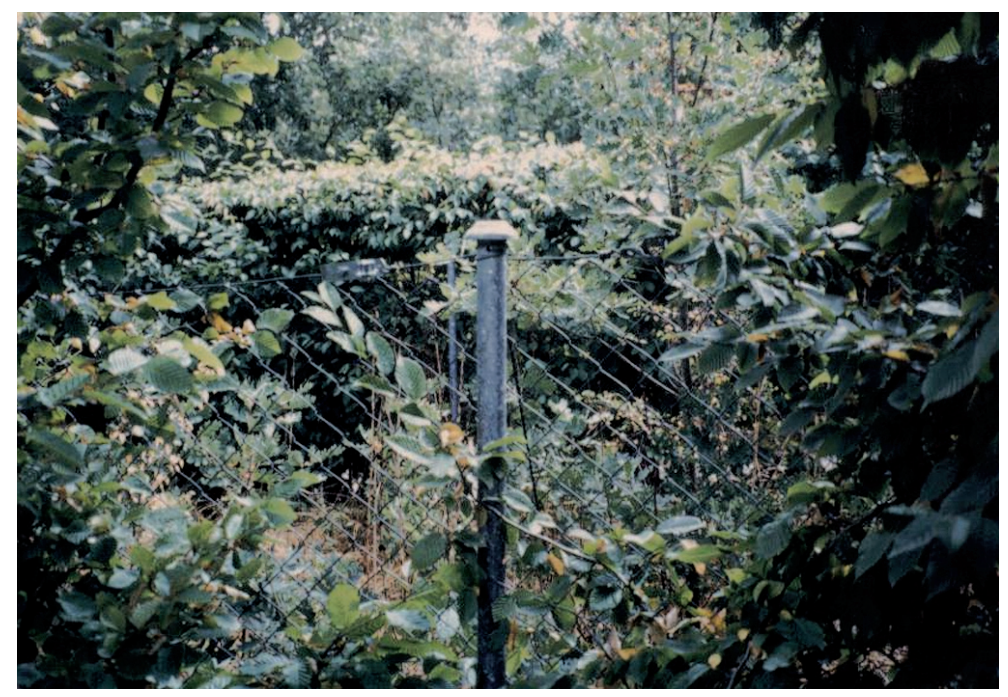

Los nuevos cerramientos del laberinto. (Foto del autor)

Tras establecer los criterios que hemos comentado, se fijó un calendario de actuaciones que tiene la asombrosa virtud de establecer un período de diez años (1984-1993) para las obras, algo novedoso e insólito en la actuación de recuperación del patrimonio verde en nuestro país.

Los trabajos, por orden cronológico de actuación, fueron los siguientes:

$1^{\circ}$ Recepado de algunos ejemplares de Quercus pyrenaica con el fin de seleccionar posteriormente los pies rebrotados para evitar que su sombra impidiera el desarrollo de plantas arbustivas que constituirían los futuros setos. Estas labores se iniciaron en 1985 y concluyeron en 1989.

(15) CARRASCAL VAZQUEZ, Juan Fernando. "La restauración integral del Laberinto del Real Sitio de la Granja de San Ildefonso" en Reales Sitios, $\mathrm{n}^{\circ} 120$ ( $2^{\circ}$ trimestre 1994$)$, páginas 63-70. 
Por otro lado es importante considerar la riqueza botánica de este bosquete del Jardín que con menos de un 2 por 100 de la superficie total, contiene cerca de un 25 por 100 de los árboles y arbustos presentes en el lugar. Algunos de los primeros son:

- Castaño de Indias (Aesculus hippocastanum)

- Tilo de hoja pequeña (Tilia cordata)

- Tilo de hoja grande (Tilia platyphyllos)

- Tilo (Tilia $x$ vulgaris)

- Arce campestre (Acer campestre)

- Carpe (Carpinus betulus)

- Majuelo (Crataegus monogyna)

- Haya (Fagus sylvatica)

- Rebollo (Quercus pyrenaica)

- Arce (Acer platanoides)

- Abeto de Navidad (Picea abies)

- Abedul (Betula pendula)

- Pino de Valsaín (Pinus sylvestris)

- Falsa acacia (Robina pseudoacacia)

- Serbal (Sorbus latifolia)

- Serbal (Sorbus terminalis)

- Ciprés de Lawson (Cupressocyparis lawsoniana)

- Fresno (Fraxinus excelsior)

- Fresno de hoja estrecha (Fraxinus angustifolia)

- Cerezo silvestre (Prunus avium)

- Cerezo silvestre (Prunus padus)

- Alamo temblón (Populus tremula)

- Respecto a los arbustos, podemos citar los siguientes:

- Dafne (Daphne laureola)

- Morrionera (Viburnum lantana)

- Escoba negra (Cytisus scoparius)

- Rosal silvestre (Rosa sp.)

- Zarzamora (Rubus sp.)

- Frambuesa (Ribes rubrum)

- Aligustre (Ligustrum vulgare)

- Majuelo (Crataegus monogyna)

- Bonetero (Evonimus europaeus)

- Madreselva (Lonicera peryclimenum)

- Carpe (Carpinus betulus)

- Lilo (Syringa vulgaris)

- Madreselva (Lonicera japonica)

- Avellano (Corylus avellana)

- Celinda (Philadelphus coronarius)

- Sauce bardeguera (Salix atrocinerea)

- Hiedra (Hedera helix) 
Los setos del Laberinto estaban constituidos principalmente por carpe y haya aunque se entremezclaban arces, lilos, hiedras, aligustres y otras especies que fueron respetadas ya que ayudaban a formar la pantalla. Su interior hoy se ve ocupado por los rebrotes de los robles y otros árboles junto a los arbustos mencionados anteriormente, todos ellos respetados por los jardineros ya que contribuyen a formar la masa verde. Todos estos ejemplares se conservaron dentro de lo posible a pesar de que en algunos lugares hubo que podar para volver a recuperar los perfiles del trazado original perdidos durante los años de abandono.

$2^{\mathbf{0}}$ Reposición de todos los setos de carpe mediante nuevos ejemplares traídos de Holanda y conservación de los ejemplares antiguos. Igualmente se recuperó el antiguo sistema de riego basado en caceras de tejas árabes con el fin de no perder nada de agua por filtraciones o desvíos no deseados. Estos trabajos se realizaron desde 1987 a 1990.

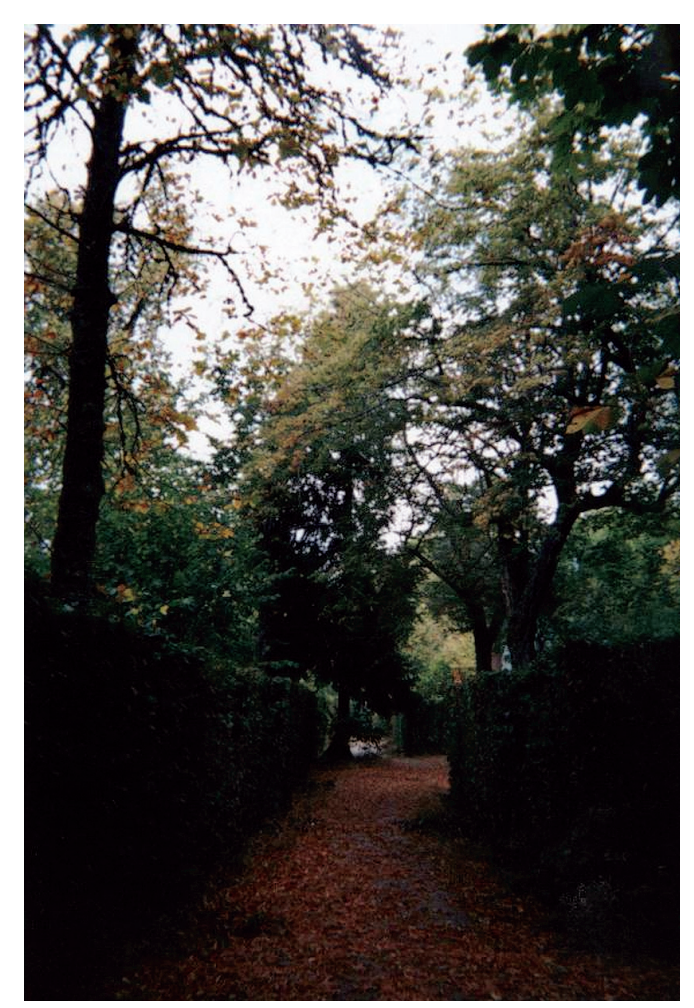

El Laberinto en 1999. Se puede observar como parte de la vegetación arbórea se ha respetado. (Foto del autor)

$\mathbf{3}^{\mathbf{0}}$ Entre 1988 y 1990 se protegieron las plantaciones con una red de acero galvanizado y postes del mismo material. En esta red se dejaron puertas con el fin de que los visitantes perdidos pudieran salir rápidamente sin agobios ni destrucción de las nuevas plantaciones.

$4^{\mathbf{0}}$ Resalveo de los brotes de los rebollos a una media de 100 ejemplares por Ha. Intención de repetir este resaveo cada diez años para conseguir los fines anteriormente explicados. 
$5^{\mathbf{0}}$ Estabilización de los paseos y glorietas con la técnica de la grava-cemento con la finalidad de evitar los estancamientos del agua de lluvias, las invasiones de malas hierbas así como las huellas de la maquinaria de mantenimiento. Estos trabajos se realizaron entre 1991 y 1993.

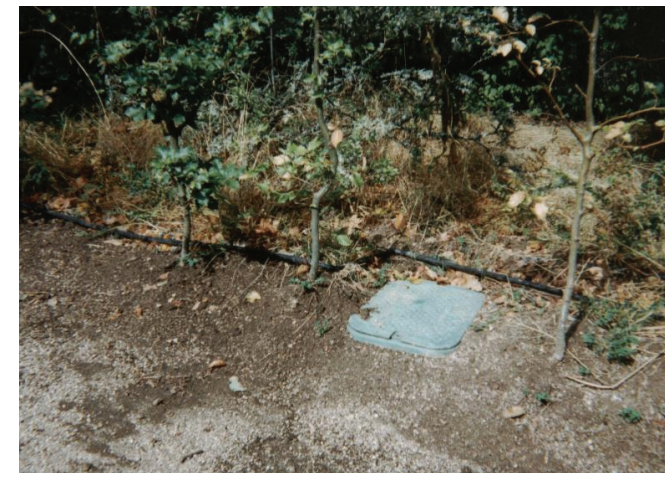

Plantación de nuevos setos de carpe regados a goteo. Una de las innovaciones de la reciente intervención. (Foto del autor)

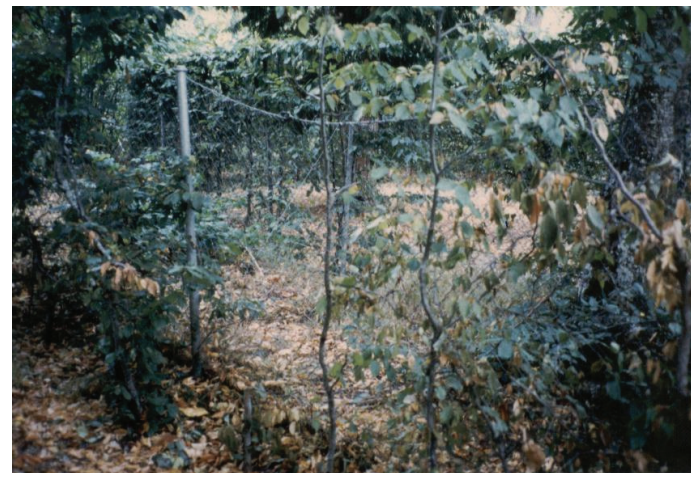

Red de acero galvanizado utilizada para proteger las nuevas plantaciones. La instalación de puertas en ella permite salir del Laberinto sin destrozar la vegetación. (Foto del autor)

Finalmente se renovó la traída de las aguas desde el depósito de las Llagas, se perfilaron los setos, se abonó y podó la vegetación existente. Después de todos estos trabajos, Juan Fernando Carrascal dice en 1994 que lo único que queda es esperar que el paso del tiempo dé a la restauración realizada el carácter de integral. Tras la visita realizada en el verano de 1999 al Real Sitio, podemos decir que los objetivos han sido felizmente logrados. Las obras realizadas en este Laberinto constituyen uno de los mejores ejemplos de restauración del patrimonio verde en nuestro país y en Europa en lo que respecta a la metodología seguida, recursos empleados, planificación temporal de los trabajos y resultados conseguidos.

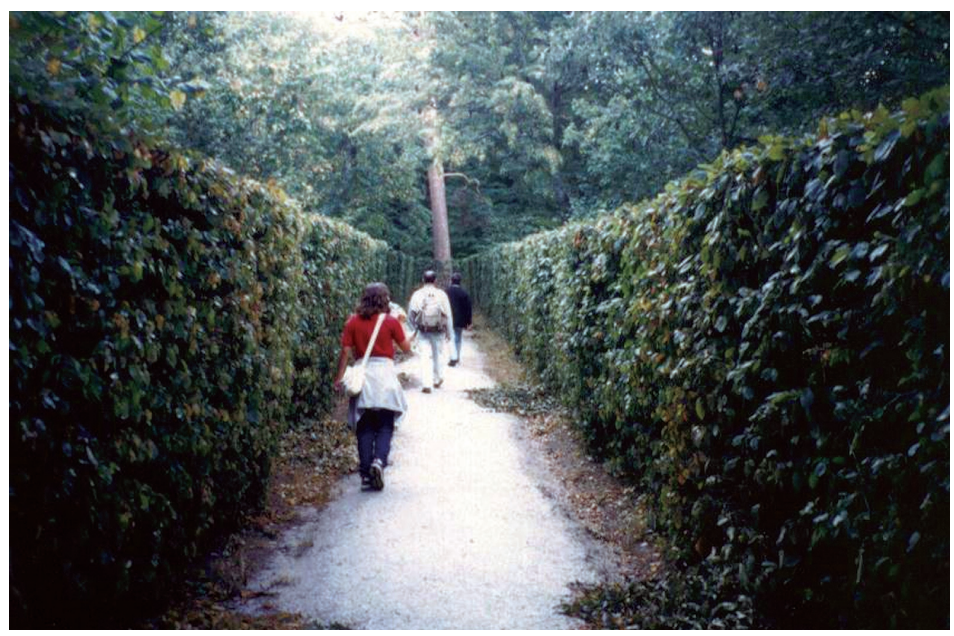

El Laberinto en 1999. (Foto del autor) 
A finales de los años 90 del pasado siglo, coincidiendo con el tercer aniversario de la llegada al trono de España de los Borbones, el palacio y los jardines de La Granja fueron sometidos a una profunda restauración (más el palacio que los jardines) con el fin de recuperar su "aspecto original". Más de 1.500 millones de pesetas procedentes del Fondo Europeo de Desarrollo Regional (Feder) administrado por Patrimonio Nacional, se emplearon en dichos propósitos. Suena un poco a la vuelta de los antiguos criterios de restauración en ese vaivén que es la historia de esa disciplina en nuestro país. En un artículo de prensa se informa de tales intentos y criticas, especialmente en una columna de Pedro Altares de octubre del 2000 (16) donde acaba diciendo: "La restauración -que está teniendo un gran éxito de público - nos ha devuelto un palacio del siglo XVIII y nos ha cercenado unas estancias que antes rezumaban vida. El palacio de La Granja es ahora un museo de época que tendrá su continuación, al parecer, en otro que albergará sus famosos tapices. Ha prevalecido el concepto de decorado frente al de la recuperación de la Historia. Todo un símbolo de los tiempos".

\section{Bibliografía sobre La Granja y el Laberinto.}

AÑon, Carmen, LUengo, Mónica y LUENGo, Ana. Jardines artísticos de España. Ed. Espasa-Calpe. Madrid, 1995.

Tratan del Laberinto en la página 103 afirmando que fue realizado por Marchand sobre planos de Le Blond.

CARRASCAL VAZQUEZ, Juan Fernando. "La restauración integral del Laberinto del Real Sitio de La Granja de San Ildefonso". Revista Reales Sitios, $\mathrm{n}^{\circ}$. 120, (2 ${ }^{\circ}$ trimestre del año 1994). Páginas 63-70.

Es el mejor trabajo sobre la restauración llevada a cabo en el Laberinto. Hace referencias a su estado anterior. Incluye relación de especies botánicas y las fases de actuación de la intervención. También hay una estupenda antología gráfica con las representaciones del Laberinto en los mapas de los siglos XVIII y XIX. Reproduce igualmente el laberinto de la obra de Dezallier d'Argenville. Las imágenes del laberinto están copiadas de él.

DE LA MOREnA VALEnZUELA, Isabel. "Plantas de los jardines de La Granja de San Ildefonso en el siglo XVIII" en Reales Sitios n 146 de 2000 y 149 de 2001. Se da la relación de las plantas ornamentales y de huerta utilizadas en este período según los datos procedentes de los fondos documentales del Archivo General de Palacio.

MARQUESA DE CASA VALDES. Jardines de España. Ed. Aguilar. Madrid, 1973.

Páginas 162-165. Buen estudio histórico sobre la formación del lugar y detallada descripción de sus elementos. El Laberinto lo atribuye a Esteban Marchand según planos existentes en el Archivo General de Palacio (A.G.P.)

A pesar del tradicional marcado carácter francés del diseño es la primera estudiosa que señala las reminiscencias árabes presentes en el jardín: entrada lateral, canalillos para el riego y gran almacén de agua en la parte superior del jardín. Se reproduce el plano de J. de Winthuysen.

(16) "El País". 1de 0ctubre de 2000. 
SANCHO, José Luis. La Arquitectura de los Sitios Reales. Ed. Patrimonio Nacional. Madrid, 1995.

Dedica a La Granja el capítulo V entero, páginas 491-568. Los jardines están tratados desde la 495 a la 521. Trata la formación del jardín, sus autores, el proceso temporal, los jardineros, los autores de la obra y fuentes. El contexto histórico posterior a Versalles plasmado en la obra de Dezallier d'Argenville. Es el mejor trabajo en conjunto hasta el momento. Sobre el Laberinto nos habla en la página 515: "Junto a él, ocupando doble espacio que los demás, (se refiere a los cuadros-bosquetes)se encuentra el más elaborado de todos los bosquetes del jardín, el laberinto, copiado del que publica Dezallier d'Argenville. Según Casa Valdés este laberinto se debe a Marchand, quien trabajó en él durante el mes de enero de 1725, sin duda con la colaboración de Boutelou, por lo que a las plantaciones se refiere. Tanto este sector como el resto de las partidas reservadas sólo eran visitables mediante autorización". No vuelve a nombrarlo más.

SANCHO, José Luis. "Los jardines de La Granja de San Ildefonso. En torno a la restauración de un jardín formal”. Revista Reales Sitios. Núm. 120, $2^{\circ}$ trimestre de 1994. Páginas 17-28. El artículo es casi idéntico al de la obra anteriormente citada. Lo novedoso y más interesante es la referencia a la obra de Dezallier d'Argenville como fuente que inspiró el diseño de gran parte de los elementos del jardín y por tanto la considera una herramienta útil para posteriores restauraciones.

WINTHUYSEN, Javier de. Jardines clásicos españoles. Edición facsímil de Editorial Doce Calles. Aranjuez, 1990.

Páginas 83-88. La Granja la sitúa dentro del apartado del clasicismo francés. No nombra para nada el Laberinto ni hay fotos. Sin embargo hay un plano realizado por él en el que se ve como el Laberinto ha mantenido la forma de los siglos anteriores.

En Las "Notas sobre la vida y escritos de Xavier de Winthuysen" de Carmen Añón y José Luis Sancho, en la página 107, éste último relata las intervenciones más recientes de restauración, especialmente las del Laberinto. Da una bibliografía buena y sitúa La Granja en otro contexto histórico y cultural que va más allá de la simple imitación del jardín clásico francés. 


\section{e) Jardín del Rey en Aranjuez}

El Jardín del Rey en sus orígenes fue un perfecto ejemplo de "jardín cerrado" o "giardino segreto" en donde se mezclaban las herencias musulmanas de la jardinería española con las aportaciones del Renacimiento italiano que se manifestaba en la presencia - a veces exagerada - de estatuaria mitológica con significados alegóricos. Su autor fue Juan Bautista de Toledo y su ejecutor Juan de Herrera acabándose alrededor de 1580 .

El jardín estaba físicamente cerrado del exterior por un muro que sería derribado por los Borbones en el siglo XVIII para incorporar dicho jardín al parterre nuevo frente al Palacio.

Su traza consistía en un rectángulo con parterres cuadrados alrededor de una fuente central. Los caminos eran de ladrillo y en los muros que daban a Oriente se construyeron nueve pequeñas habitaciones para servir de refugio y contemplación retirada del lugar. Igualmente existía una galería descubierta enfrente que disponía de una terraza la cual se cerró en el XVIII para hacer habitaciones eliminándose la posibilidad de disfrutar de las vistas elevadas y sombreadas del jardín desde ese lado.

Felipe IV, nieto del creador del jardín, recién ascendido al trono hace modificaciones en este lugar y lo transforma en una exaltación alegórica de la dinastía reinante. Hace cerrar las cuevecitas y transformarlas en hornacinas donde coloca estatuas de sus antepasados así como bustos y medallones de los emperadores romanos de origen hispano con lo que se simulaba establecer una línea de continuidad desde los césares de la antigüedad hasta los actuales monarcas. En su centro estaba la estatua de Felipe II flanqueada por los relieves de sus padres, el emperador Carlos V y la reina Isabel de Portugal.

Los suelos sencillos de ladrillo macizo del jardín desaparecieron y se empedraron con losas de Colmenar y cuadros con dibujos hechos de guijos.

El lugar permaneció así hasta la llegada de los Borbones. El 1733 se ordena derribar el muro que lo separaba del resto de la posesión con lo que pierde su

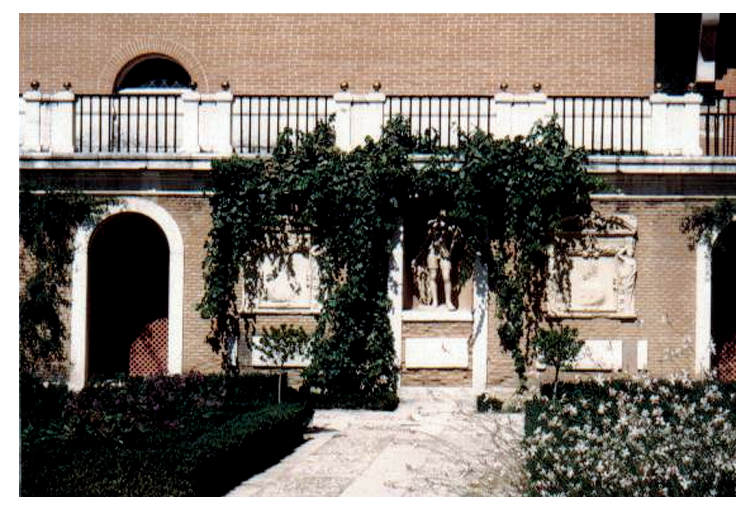

Jardin del Rey. Estado actual.. (Foto del autor) 
carácter de jardín privado. Fernando VI manda luego construir una tribuna que servía de palco regio para los festejos con lo que el jardín vuelve a quedar cerrado. Carlos III hace derribarla con lo que el espacio queda integrado en el gran parterre frente al Palacio.

En 1872 se plantea la reforma de este espacio según la moda de aquel momento. Al tener que terraplenar para hacer el nuevo trazado consistente en isletas de vegetación y caminos sinuosos se decidió nivelar el jardín del Rey para que estuvieran los dos espacios igualados. El resultado fue que sus caminos enlosados desaparecieron enterrados bajo una capa de más de medio metro de tierra.

A principios del siglo XX se construye en el otro lado del palacio el jardín paralelo al nuestro, el de la Reina con lo que se "añadió a ambos jardines un toque de uniformidad - que no de rigor-al colocar en sus respectivos centros sendas fuentes de planta mixtilínea y aspecto dieciochesco en piedra de Colmenar, de tal modo que fueron juzgadas auténticas por Winthuysen"(17). La fuente original de jaspe verde fue desplazada y almacenada hasta su reposición en la reciente restauración.

Esta restauración, calificada como crítica, (18) fue proyectada por Lucía Serredi con asesoramiento de Carmen Añón. Se llevó a cabo en 1985 y consistió en lo siguiente: tras la aparición de la mencionada fuente de jaspe verde y las catas arqueológicas hechas dos años antes que mostraron los restos de los caminos originales del jardín de Felipe IV, se optó por la reconstrucción del jardín del siglo XVII pero descartándose la recuperación de todo el discurso político-simbólico ya que la mayoría de los elementos de la estatuaria estaban dispersos en distintas colecciones y lugares. Tras arrancar los setos existentes reflejados en el cuadro de Winthuysen y en la obra de la Marquesa de Casa Valdés se procedió a la recuperación de todos los elementos del empedrado original con la reposición de las partes nuevas sentando el guijo sobre simple arena provocando que el jardín no pudiera ser de uso público al quedar su entrada restringida a visitantes autorizados.

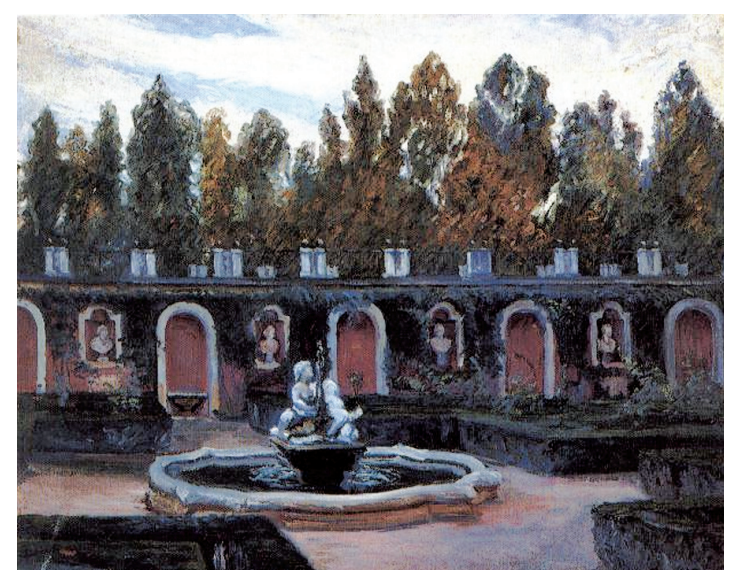

Parterre de Aranjuez. 1916. Javier de Winthuysen. Colección particular

(17) SANCHO GASPAR, José Luis. La Arquitectura de los Sitios Reales. Pág. 314.

(18) SANCHO GASPAR, José Luis. Obra citada. Pág. 314. 


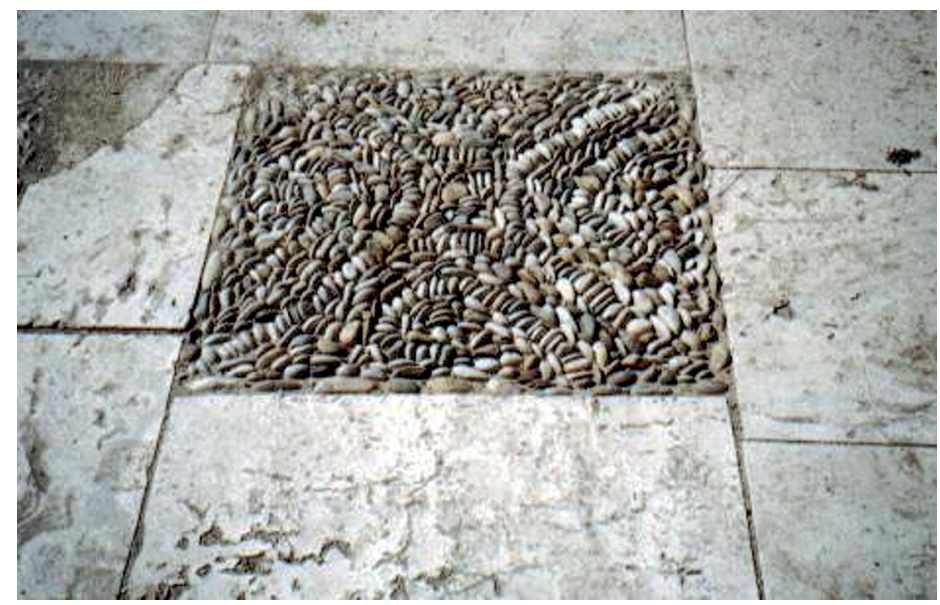

Detalle del suelo del jardín tras la restauración. (Foto del autor)

Para los dibujos de boj -no de murta (19) que fue la planta utilizada en el jardín de los Austrias- se eligieron trazados del siglo XV procedentes de los libros de la época rechazando los dibujos barrocos de época borbónica.

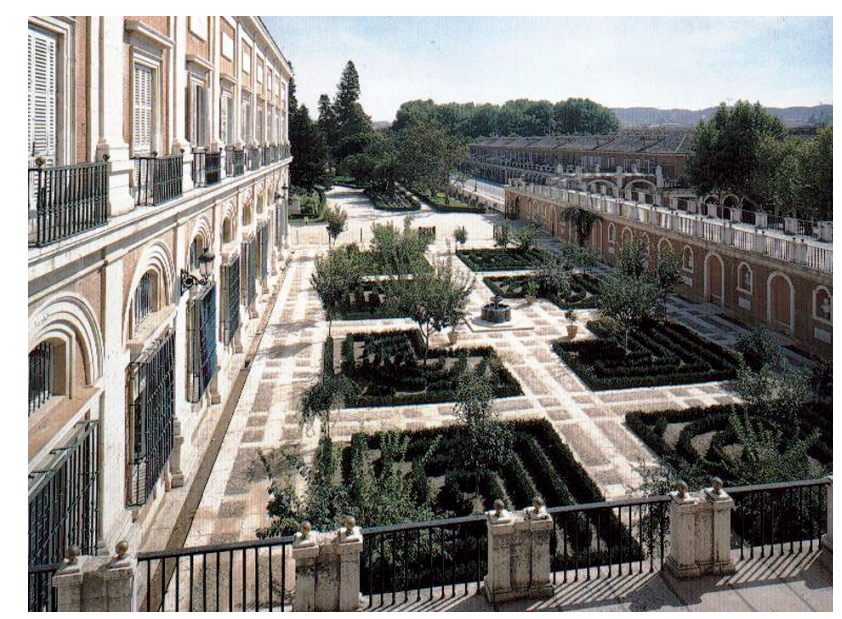

Aspecto del jardín al poco tiempo de su restauración. (Foto del libro de Sancho Gaspar)

Pero dejemos que sea la misma autora la que nos explique los motivos de esta elección: "El trazado del parterre emana de la reelectura de los cuadros definidos por el diseño del pavimento (...) desde las premisas renacentistas hispánicas de la figura única, para lo que además de situar unas pequeñas verjas de madera a la entrada de los caminos según conocido patrón de compartimentación o interdependencia de espacios, se dispone de un seto exterior o perimetral de la misma altura, $60 \mathrm{~cm}$, en contraste con los 40 correspondientes a los dibujos geométricos 
interiores, no inspirados en Serlio, pese a que así lo estime una crítica benévola sino surgidos de una aséptica voluntad de abstracción, reacia a eventuales subsunciones historicistas"(20).

Respecto a los criterios seguidos para la elección de la vegetación la misma autora comenta: "Contrariamente, se ha creído lícito valerse de las especies botánicas más documentadas en Aranjuez tanto para reintroducir en los setos de boj recortado los frutales enanos inseparables de este espécimen de jardín y, con abundancia de flores, el no menos típico golpe flamenco de color, como para reproducir las asimismo peculiares enredaderas de las paredes, todo ello acoplado a una red de riego tradicional "a manta" o "por su propio pie" pero accionada automáticamente"(21).

El 27 de julio del 2000 acudí a visitar el lugar, fecha en que me fue concedida la autorización para ello. Pude contemplar el riego de los cuadros del jardín. En exceso para mi opinión. El boj se había desarrollado bien. Sien embargo los frutales enanos habían desaparecido todos debido -según pienso - a los excesivos riegos y sólo quedaban algunos madroños en las esquinas pero en macetas.

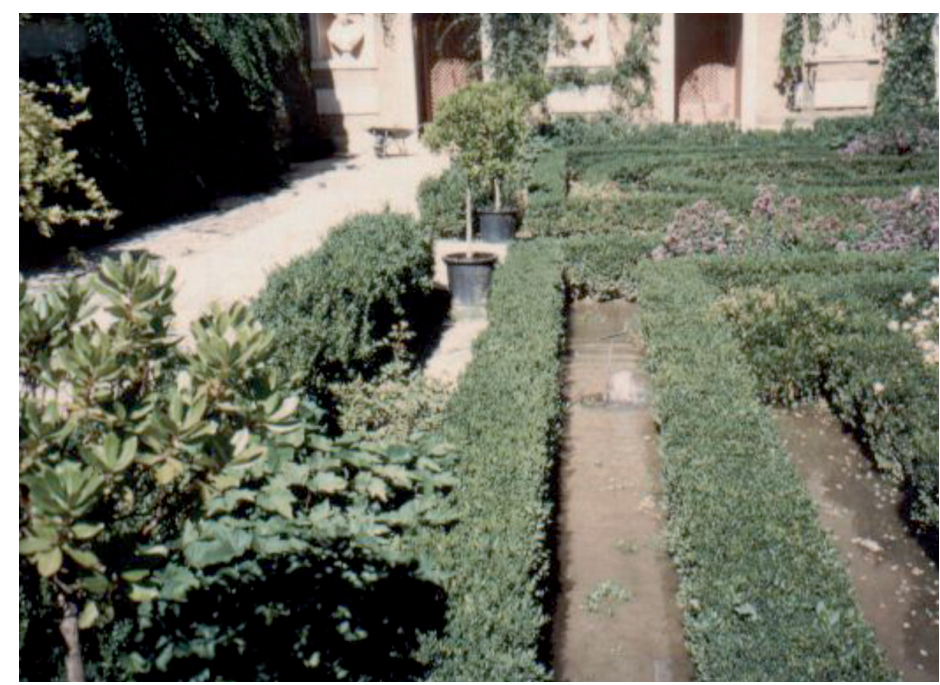

El Jardín del Rey en julio de 2000. Nótese el riego a manta y los madroños en maceta en las esquinas de los cuadros. (Foto del autor)

Las herbáceas que llenaban los espacios entre los dibujos de boj eran las siguientes: orégano de flor morada, verónicas, rosalitos enanos, margaritas amarillas, verbenas (Verbena rigida) y campanulas (Campanula porcharskyana) de los Balcanes y la Gaura lindheimeri. Había amplias zonas que no tenían nada de vegetación.

(20) SOTO, José Luis y SERREDI, Lucia. Felipe II. El rey íntimo. Jardín y naturaleza en el reinado de Felipe II. Sociedad Estatal para la Conmemoración de los Centenarios de Carlos V y Felipe II. Aranjuez. 1998.

(21) SOTO, José Luis y SERREDI, Lucia. Obra citada. 


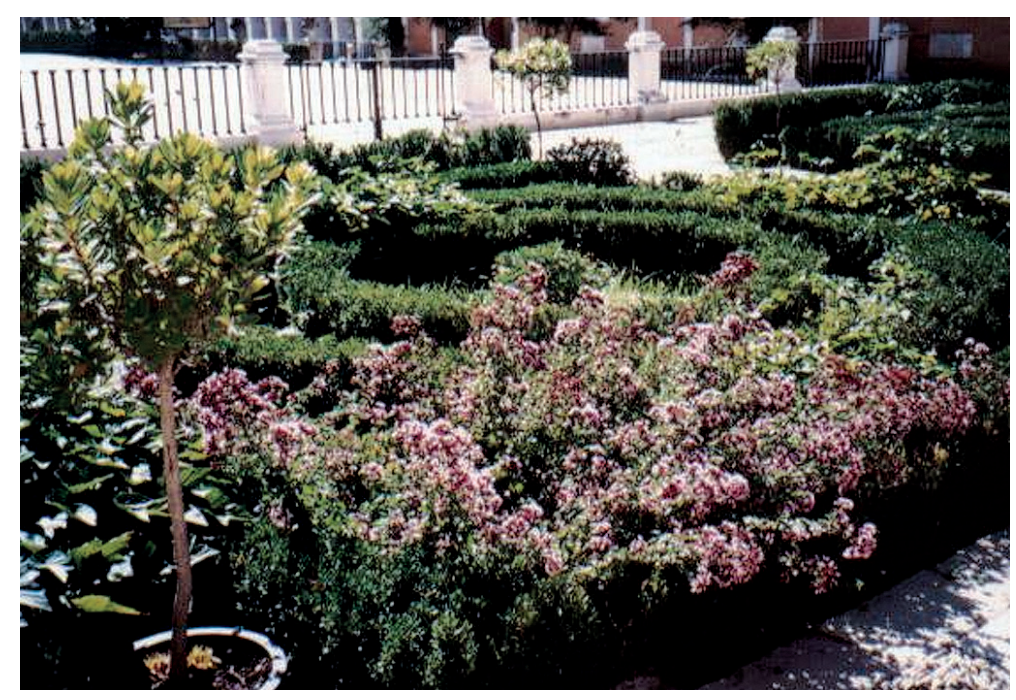

Flores en el interior de los cuadros. (Foto del autor)

En las paredes, las trepadoras eran las siguientes: un viejo rosal banksii, el jazmín estrellado o Rhynchospermum jasminoides, la glicinia, el jazmín amarillo (Jasminum primolinum o J. mesneyi) y una hermosa parra donde está la copia de la estatua de Leoni de Felipe II.

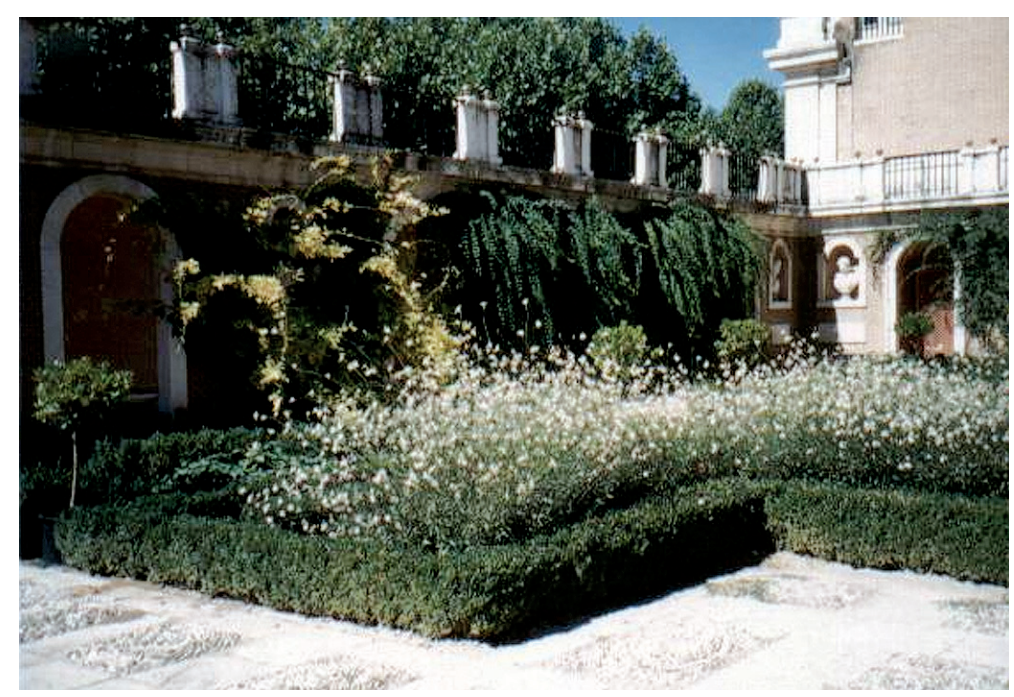

Rincón del jardín con las trepadoras en la pared. La floración del interior de los cuadros corresponde a la Gaura lindheimeri. (Foto del autor)

Se podría repetir lo mismo que hemos visto en otras intervenciones recientes. Exquisito cuidado en la recuperación del aspecto con excelentes resultados pero un leve descuido en la elección de los elementos vegetales constituyentes de la estructura. Y como en tantas otras veces la ambigüedad terminológica sobre el trabajo llevado a cabo. ¿Cómo definir el trabajo realizado? ¿Es restauración, rehabilitación, recuperación, reconstrucción? 


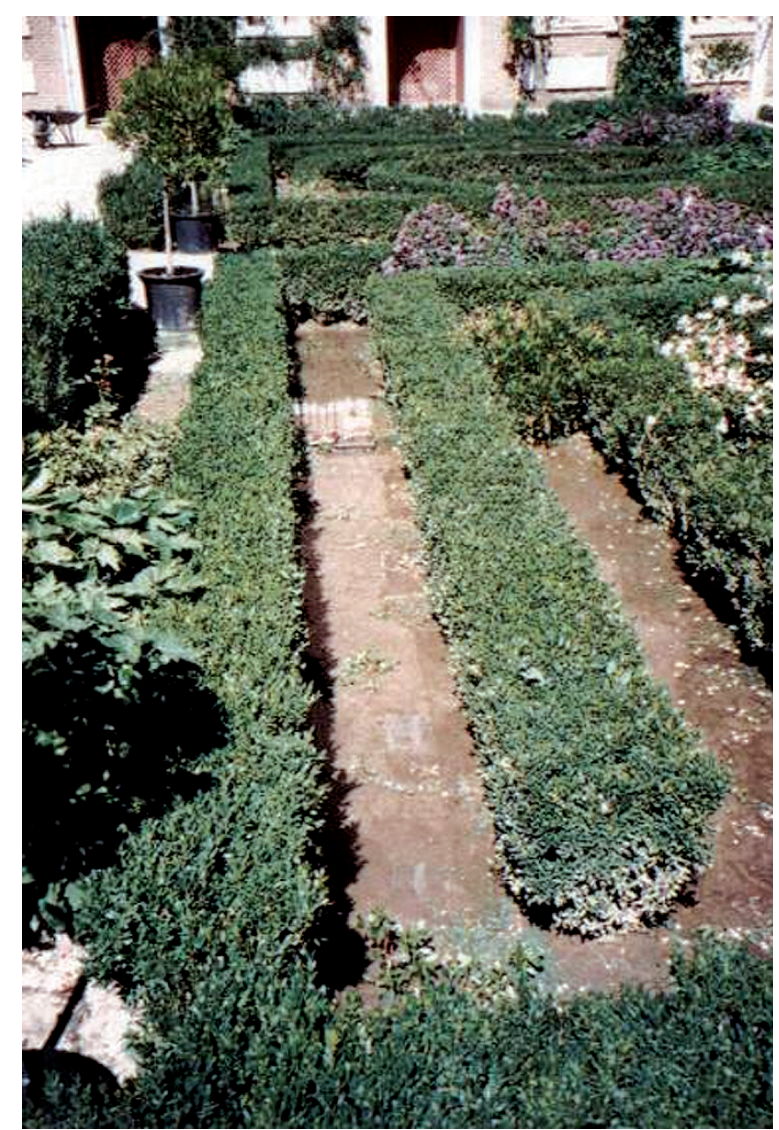

Aspecto del jardín donde puede apreciarse la falta de vegetación en el interior de los dibujos de boj. Sin embargo, se ha mantenido el riego a manta. (Foto del autor)

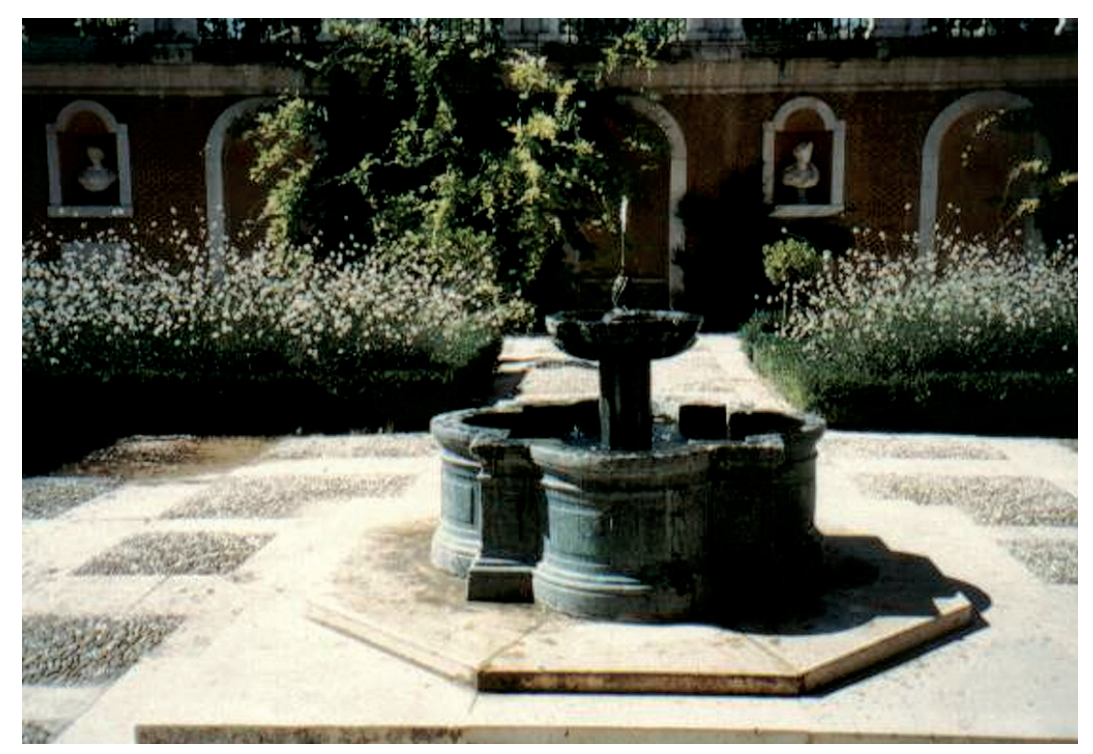

Otro aspecto del jardín con la fuente de jaspe original recuperada. Nótese como las trepadoras ocultan elementos significativos de la arquitectura. (Foto del autor) 


\section{Bibliografía sobre el Jardín del Rey de Aranjuez}

AÑON, Carmen, LUENGo, Mónica y LUENGO, Ana. Jardines artísticos de España. Ed. Espasa Calpe. Madrid, 1995.

Se trata de Aranjuez en las páginas 37-57. Se habla del Jardín del Rey en las páginas 43 y 44. Se cita a Ponz "para jardín de él, el que se llama de las estatuas, de murta y flores, con una fuente en el centro". Es curiosa la referencia a la murta utilizada como seto en lugar del actual boj, planta favorita de los Borbones.

MARQUESA DE CASA VALDES. Jardines de España. Ed. Aguilar, 1973.

Trata de los cambios ocurridos en el parterre de Aranjuez en las páginas 237-238 al describir Aranjuez en el siglo XIX. No cita el Jardín del Rey.

En las páginas 119-127 donde se estudia Aranjuez bajo los Austrias cita abundancia de plantas por referencias literarias. Hay foto en la página 121 de nuestro jardín. Describe al jardín de la Isla y no dice nada del del Rey. Igualmente lo ignora cuando describe Aranjuez con los Borbones en las páginas 141-150.

SANCHO GASPAR, José Luis. La Arquitectura de los Sitios Reales. Ed. Patrimonio Nacional. Madrid, 1995.

Trabajo ya comentado anteriormente. El mejor hasta la fecha. Recoge todas las intervenciones habidas en el lugar en las páginas 311-314. Hay fotos del jardín recién restaurado.

SANCHO, José Luis y SERRADI, Lucía. "El Jardín de las estatuas” en Felipe II. El Rey íntimo. Jardín y naturaleza en el siglo XVI. Catálogo de la exposición celebrada en Aranjuez en 1998. Sociedad Estatal para la Conmemoración de los Centenarios de Felipe II y Carlos V. Páginas 218-228. Resumen histórico del jardín y explicación de las razones que llevaron a la restauración de este jardín. Contiene igualmente fotos del mismo donde puede observarse la evolución reciente del jardín con una notable disminución de los frutales a la vez que el aumento de las herbáceas de flor.

SANCHO, José Luis. “El Jardín del Rey en el Palacio de Aranjuez” en Jardín y Naturaleza en el reinado de Felipe II. Edición a cargo de Carmen Añón y José Luis Sancho. Sociedad Estatal para la Conmemoración de los Centenarios de Felipe II y Carlos V. 1998. Páginas 505-511. Es una repetición de los artículos anteriores que tratan el tema.

WINTHUYSEN, Javier de. Jardines Clásicos de España. Facsímil de Doce Calles/CSIC. Aranjuez, 1990.

No dice nada sobre este jardín. Sin embargo, hay tres fotos. Una de la antigua fuente, otra de un plano del jardín y la tercera de la estatua del rey Felipe II. Todas están englobadas en "Jardín de la Isla" y hace referencia a la influencia herreriana en el muro como en la del plano que la define como "plano del rincón herreriano del parterre". 


\section{D.2.3.2. Otros jardines restaurados en España}

\section{a) Los jardines del Patio de la Casa de Contratación en Sevilla}

Si nos atenemos a la división que Cesare Brandi aplica a la composición de la materia de la obra de arte (aspecto y estructura), este espacio es un ejemplo claro de reconstrucción arqueológica de un patio almohade (el aspecto brandiano) realizado con criterios modernos y resultados espectaculares. Sin embargo, en lo que respecta a la recuperación de la estructura -nos referimos a las plantas y al agua- el resultado es decepcionante. Veamos porqué decimos todo esto.

Empezaremos por los antecedentes históricos del jardín. El primero que intuyó que las ruinas pertenecían a un jardín fue el Marqués de Vega Inclán tras realizar unas catas a principios del siglo XX. Pero no sería hasta 1973, tras la excavación de Rafael Manzano cuando se demostró que en realidad eran dos jardines superpuestos, uno de época taifa sobre el que posteriormente se levantó el almohade que ahora vemos aunque quedan trazas del primer jardín a la vista.

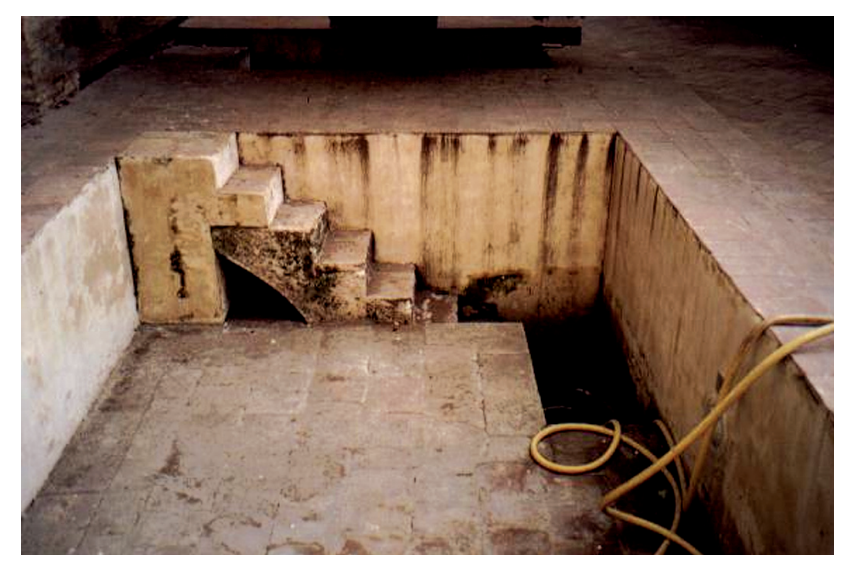

Patio de La Casa de la Contratación. Detalle del jardín taifa (inferior) y del almohade (superior). (Foto del autor)

El hallazgo de los dos jardines complicó la excavación y su restauración y aún tuvo que ver como los cambios políticos de la transición la retrasaron. Durante varios años estuvo la obra parada hasta que la Junta de Andalucía volvió a iniciar las obras dirigidas esta vez por Manuel Virgil. La aparición de pinturas murales dentro de las albercas obligó a abrir otro frente de conservación ya que algunas de ellas hubo que separarlas de los muros para su protección y otras se quedaron en su lugar originario impidiendo de esta manera el posterior uso hidráulico de las albercas.

Los criterios que se emplearon en esta recreación/restauración se basaron en la "anastylosis", es decir, la reconstrucción de los elementos originales encontrados 
con añadidos de piezas nuevas iguales a las originales pero diferenciables de las antiguas a simple vista.

Así se levantaron el testero sur, las cintas de azulejos a lo largo de los caminos y albercas, las arcadas almohades y las solerías de los pasillos y estancias. La zona norte se rehizo de nuevo enteramente para ser ocupada por las oficinas de la Consellería.

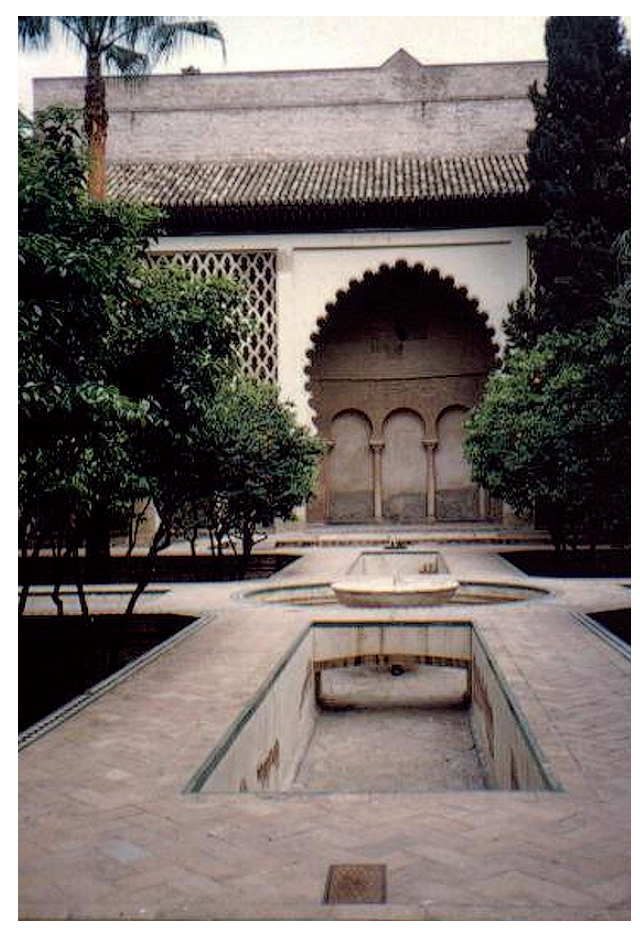

Parte sur del patio reconstruida por "anastylosis". (Foto del autor)

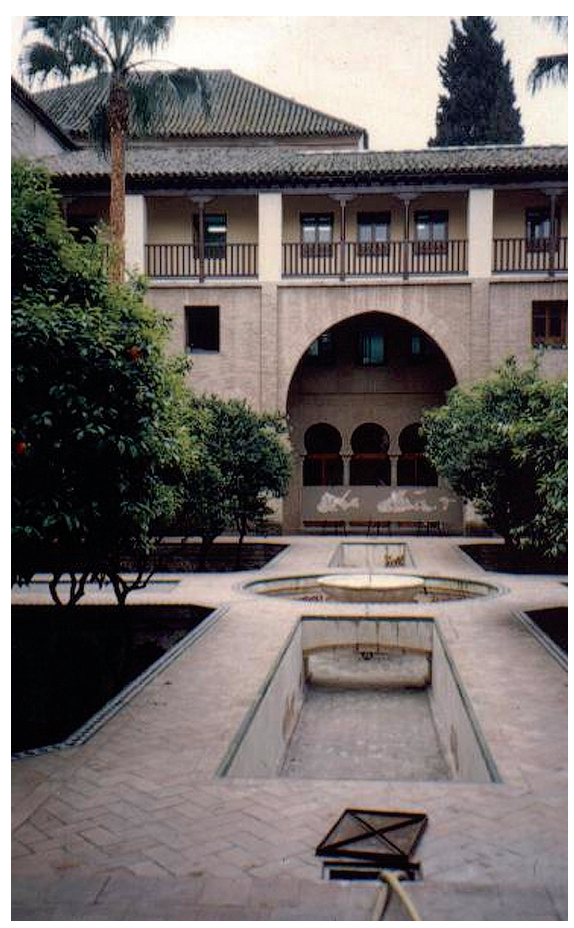

Cara norte del patio reconstruida para oficinas de la Junta. (Foto del autor)

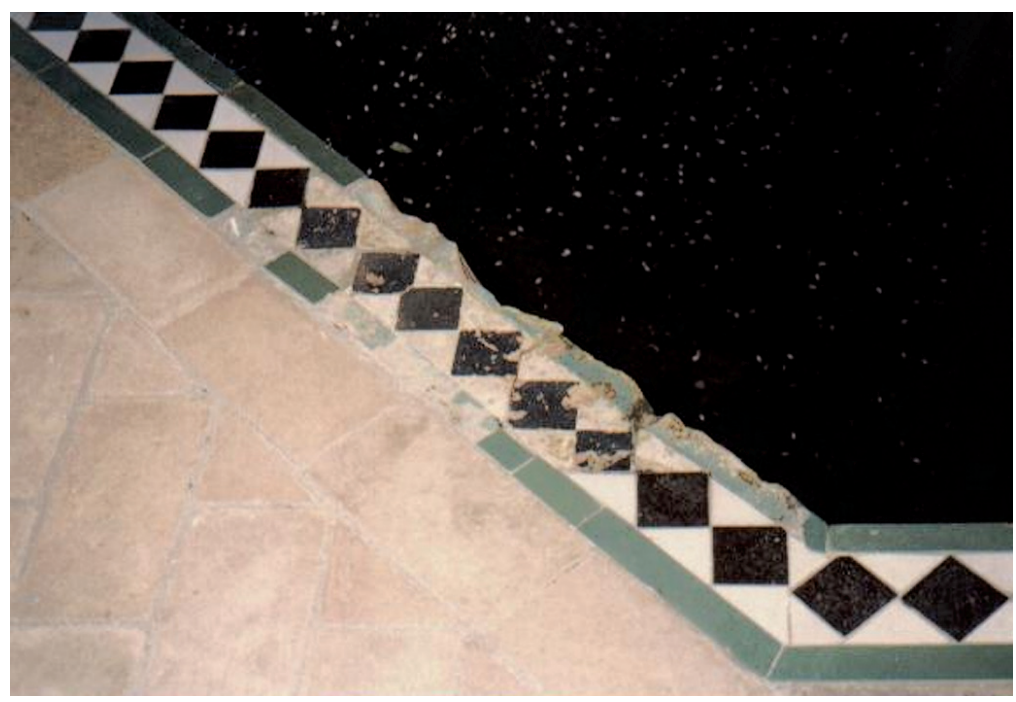

Detalle de las cenefas reconstruidas a partir de los fragmentos antiguos encontrados en las excavaciones (centro de la imagen). (Foto del autor) 
Cuando las obras estuvieron terminadas le llegó el turno a la reconstrucción del jardín. Textualmente citamos a Manuel Virgil: (22) "Desgraciadamente, no pudo llegarse a ninguna conclusión fidedigna acerca de la jardinería original a pesar de los estudios de polen que se manejaban. No obstante, los naranjos que actualmente delimitan los cuadros del jardín ofrecen una imagen que es posible no diste mucho de la que debió de tener en sus mejores días el jardín almohade".

Cuesta de entender que si se hace uso de la analogía para reconstruir los elementos de la obra arquitectónica a partir de los fragmentos encontrados, no se haga uso de la misma herramienta para reponer los elementos vegetales del jardín así como del resto de los componentes que facilitan su visita, estancia o disfrute de una manera relajada: pensamos en las barandillas que se echan en falta en los caminos y que dificultan el paseo por la gran altura existente, barandillas que por otro lado están presentes en todos los jardines del Marruecos de hoy con características tales a las del jardín que nos ocupa. De igual manera hubiese estado acertado el traslado de todas las pinturas de las albercas -no sólo de una parte de ellasa otro lugar para facilitar su conservación para que éstas puedan cumplir sus funciones tanto prácticas en lo que se refiere al riego como sensoriales al mostrar las superficies del agua en las balsas y su sonido.

Respecto a la vegetación es probable que hubiera naranjos amargos (Citrus aurantium), cidros (Citrus medica) y limoneros (Citrus limon). Pero lo que no hubo a ciencia cierta fue palmeras americanas como las washingtonias así como la triste desnudez de los actuales parterres vacíos bajo los naranjos y las palmeras citadas.

Si se ha tomado la línea arqueológica para la reconstrucción de los edificios también se podría haber recurrido a los tratados andalusíes de agronomía donde están recogidas las plantas más frecuentes utilizadas en la jardinería de aquel
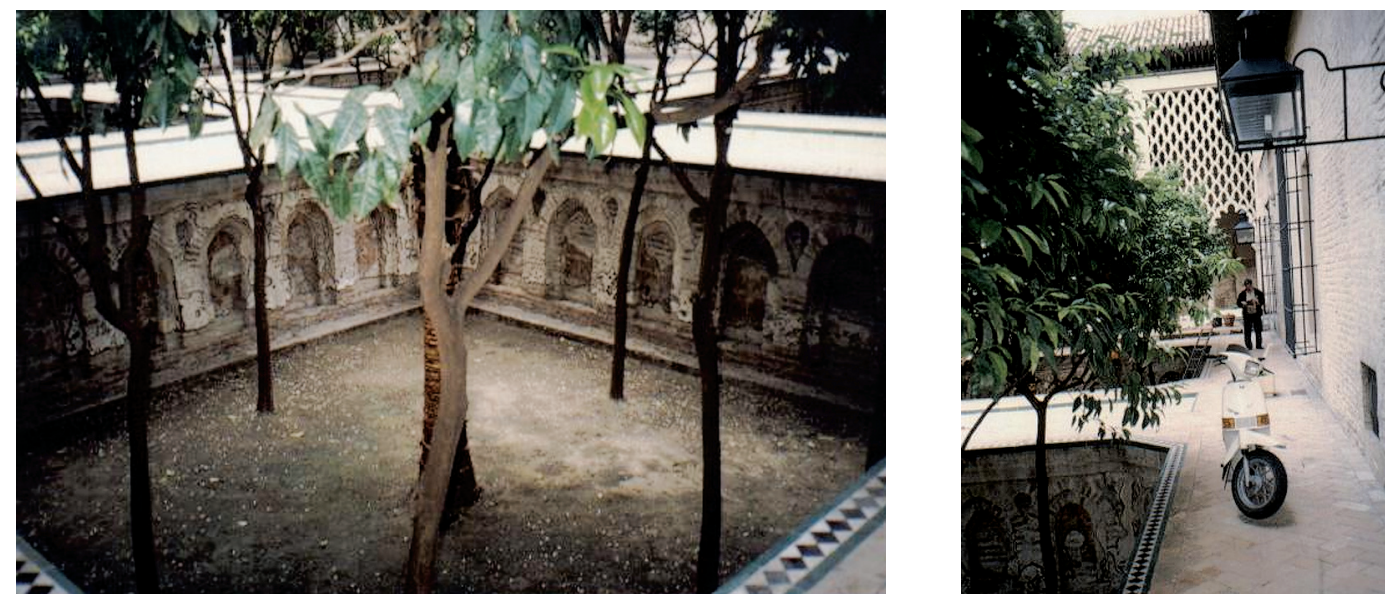

Cuadro del patio con la vegetación actual. (Foto del autor) 
momento o bien, recogiendo la tradición del jardín sevillano, con la simple eliminación de las aportaciones americanas y africanas de los siglos XIX y XX, se habría dotado al patio de un aspecto de oasis de verdor, de recreación del paraíso que hoy, desgraciadamente, echamos en falta. Son tan fuertes los elementos arquitectónicos en el conjunto del patio que anulan la escasa vegetación existente.

Y como punto final y anecdótico, agregar que es difícil de entender que en una obra restaurada con dinero público como es ésta no esté permitido hacer fotografías libremente, mientras que es usada de aparcamiento particular para motos.

\section{Bibliografía sobre el jardín musulmán de la Casa de Contratación de Sevilla}

MARQUESA DE CASA VALDES. Jardines de España. Ed. Aguilar. Madrid, 1973.

Se trata el alcázar en las páginas 57-65. Nombra el jardín de la Casa de Contratación en la pág. 58 y dice que se está excavando. Textualmente afirma: "En él tenemos un perfecto reflejo occidental de la imagen del Paraíso persa".

SANCHO GASPAR, José Luis. La Arquitectura de los Sitios Reales. Ed. Patrimonio Nacional. Madrid, 1995.

Trata sobre los Reales Alcázares en las páginas 621-626. Estupendo resumen histórico. Plano del siglo XVIII de Sebatián van der Borcht. Hay un apartado de jardines pero no se trata el jardín de la Casa de Contratación. Es de gran interés.

VIGIL ESCALERA, Manuel y ABAD GUTIERREZ, Juan. El jardín musulmán de la antigua Casa de Contratación de Sevilla: intervención arquitectónica y recuperación de las pinturas murales. Ed. Junta de Andalucía. Consellería de Obras Públicas y Transportes. Sevilla, $2^{\text {a }}$ edición, 1999. La $1^{\text {a }}$ edición es de 1992.

Trabajo fundamental para conocer todo el proceso de la excavación, restauración y reconstrucción del conjunto del patio de la actual Consellería. Contiene planos y fotos del proceso así como de las pinturas murales encontradas.

VIGIL ESCALERA, Manuel. Tríptico titulado "El Jardín musulmán de la antigua Casa de Contratación” Ed. Junta de Andalucía. Consellería de Obras Públicas y Transportes. Sevilla, 1998.

Resumen del anterior trabajo con fotos. 


\section{b) "El Capricho" o Alameda de Osuna}

Vimos en las páginas anteriores los trabajos que realizó Javier de Winthuysen tras la Guerra Civil para recuperar la Alameda de los daños sufridos en ese período. El estuvo trabajando en el jardín hasta el año 1952. Lo que a continuación sucedió nos lo va a resumir la Marquesa de Casa Valdés con su elegante manera de decir las cosas: "Sufrió también la finca de la Alameda las consecuencias de la guerra. Durante largos años fue propiedad de los señores de Bauer, en cuyas manos recobró parte de su antiguo esplendor y aún conocimos bailes y fiestas.

Hoy día este palacete está encajonado entre el aeropuerto de Barajas y un viaducto; algunos de sus templetes y estatuas han desaparecido y las urbanizaciones y los edificios de esta populosa barriada de Madrid han afeado mucho su emplazamiento.

El jardín atraviesa en la actualidad el más triste abandono aunque, adquirida recientemente esta finca por otros dueños, existen proyectos para su restauración; confiemos que guarden el espíritu primitivo del jardín, que, además, es Monumento Nacional"(23).

Tras el período comentado por la Marquesa, la finca tuvo una rápida degradación. Cambió de dueños varias veces. Alguno de los cuales intentó hacer un lujoso hotel acompañándolo con alguna atrevida operación de especulación inmobiliaria junto a los terrenos que la rodean. En 1974 finalmente, la adquirió el Ayuntamiento de Madrid haciéndola pública en el año 1978. Tras varias polémicas sobre su uso se decidió acometer su restauración. Para ello se creó una Escuela Taller financiada conjuntamente por el Ayuntamiento, el INEM y el Fondo Social Europeo. La dirección de los trabajos estaba a cargo de una comisión de asesoramiento compuesta por diversos profesionales (24). Según el historiador del Patrimonio Nacional José Luis Sancho se decidió acometer una "restauración crítica" (25).

Los criterios de restauración seguidos están recogidos en la publicación que las entidades promotoras anteriormente mencionadas realizaron (26).

Esta publicación comienza haciendo una definición de lo que se entiende por jardín y su importancia cultural señalando la diferencia entre jardín artístico y zona verde. Tras estos primeros considerandos entra de lleno en el tema que nos preocupa de la restauración. Citaremos textualmente estos párrafos por su interés: " $L a$ restauración jardinística debe seguir los mismos criterios básicos que rigen para la restauración del monumento arquitectónico (La Alameda fue declarado jardín artístico-histórico en 20 de Octubre de 1934), manteniendo la imagen que de él ha

(23) MARQUESA DE CASA VALDES. Jardines de España. Ed. Aguilar. Madrid, 1973. Páginas 231-232.

(24) En la comisión figuraban Carmen Añón, Pedro Navascués, Salvador Pérez y Santiago Amón.

(25) SANCHO GASPAR, José Luis. Notas sobre la vida y escritos de Xavier de Winthuysen. Obra citada anteriormente. Página 119.

(26) Escuela Taller Alameda de Osuna a cargo del Ayuntamiento de Madrid, INEM y Fondo Social Europeo. Madrid, 1986. 
llegado hasta nosotros, por constituir esta presencia la suma de los hechos históricos, de las aportaciones estéticas y de la labor creadora del tiempo.

El jardín será analíticamente estudiado en todos sus componentes (arquitectónicos, vegetales, históricos, topográficos, ambientales, etc.) con la colaboración de todos los especialistas que la comisión juzgue pertinentes".

Más adelante se señala "Se respetarán todos los estilos acumulados a lo largo de diferentes épocas, suprimiendo exclusivamente las actuaciones que hayan significado una incongruencia histórica o una evidente degradación estética. En los casos que sean necesarias nuevas intervenciones deberán basarse en claras referencias históricas y estéticas respecto a los elementos aún existentes".

Sin embargo, todas las intenciones expresadas anteriormente quedan en suspenso cuando se recurre a la metafísica para justificar abstracciones alejadas de la obra concreta que la historia nos ha legado en ese espacio. Volvemos a citar literalmente y tenemos nuestras dudas de que los criterios expresados en los párrafos anteriores estén ni siquiera acordes con los establecidos en la Carta de Florencia: "No olvidaremos que el "alma del jardín", la cita "entre un algo escondido y lo aparente", la extrema sensibilidad del viejo jardin, entre cuyos caminos se ha dormido el tiempo, esté siempre presente. Intentar recuperar "la razón de ser" del jardín, su propia personalidad, sin dejar por ello de mantener una rigurosidad histórica pero sensible será premisa básica de todas las actuaciones. Estos criterios generales de restauración están por otra parte acordes con los establecidos en la reciente Carta de Florencia de 1981 que recoge los principios fundamentales de la rehabilitación de jardines artístico-históricos".

Pasemos a analizar la restauración llevada a cabo. En lo que respecta a los elementos arquitectónicos ( templete, abejero, casino de baile) debemos decir que han sido restaurados con gran esmero y sensatez.

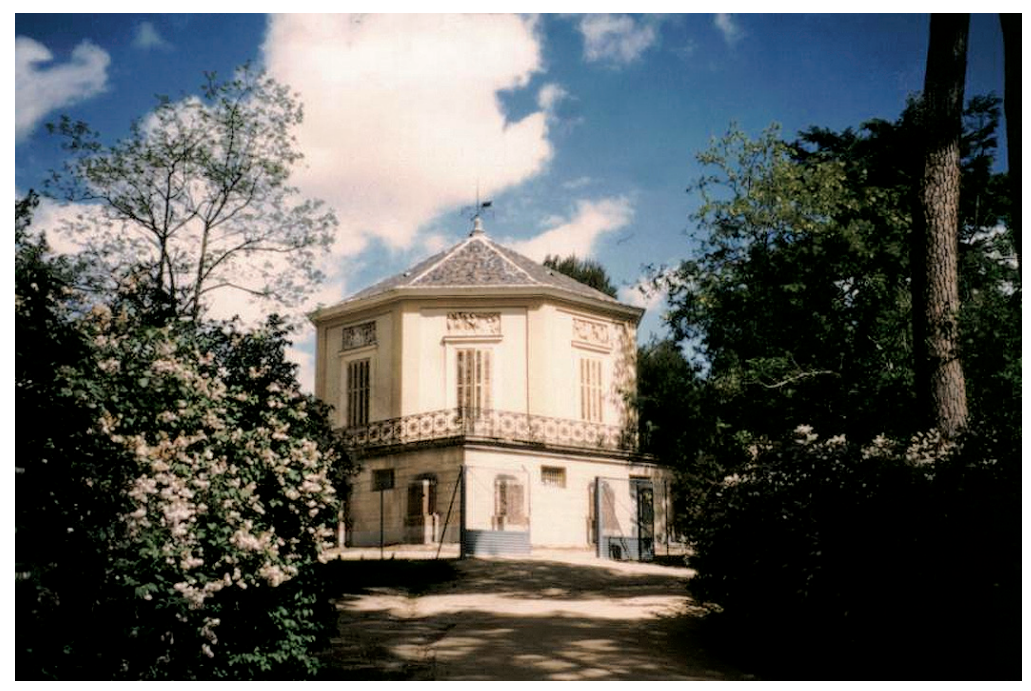

El Casino de Baile. (Foto del autor) 
Respecto a la vegetación, debemos señalar varios aspectos. Uno positivo pues se ha respetado el paso del tiempo que se manifiesta en la conservación de la presencia de las diferentes especies vegetales añadidas a lo largo de historia de este jardín. Sin embargo en lo que atañe a las intervenciones nuevas hay que hacer notar algunas observaciones.

Hay zonas que se han recuperado de una manera muy acertada recurriendo a la analogía como es el caso de las nuevas plantaciones de lilos en la zona de la rueda del tiempo. Sin embargo, la elección de laureles en vez de boj o tejo para la reconstrucción del laberinto debido al criterio de su rápido crecimiento nos parece lamentable como quedó demostrado en el fuerte invierno del 1998-99 cuando el frío de Madrid quemó gran número de ejemplares. Igualmente son sorprendentes los aña-

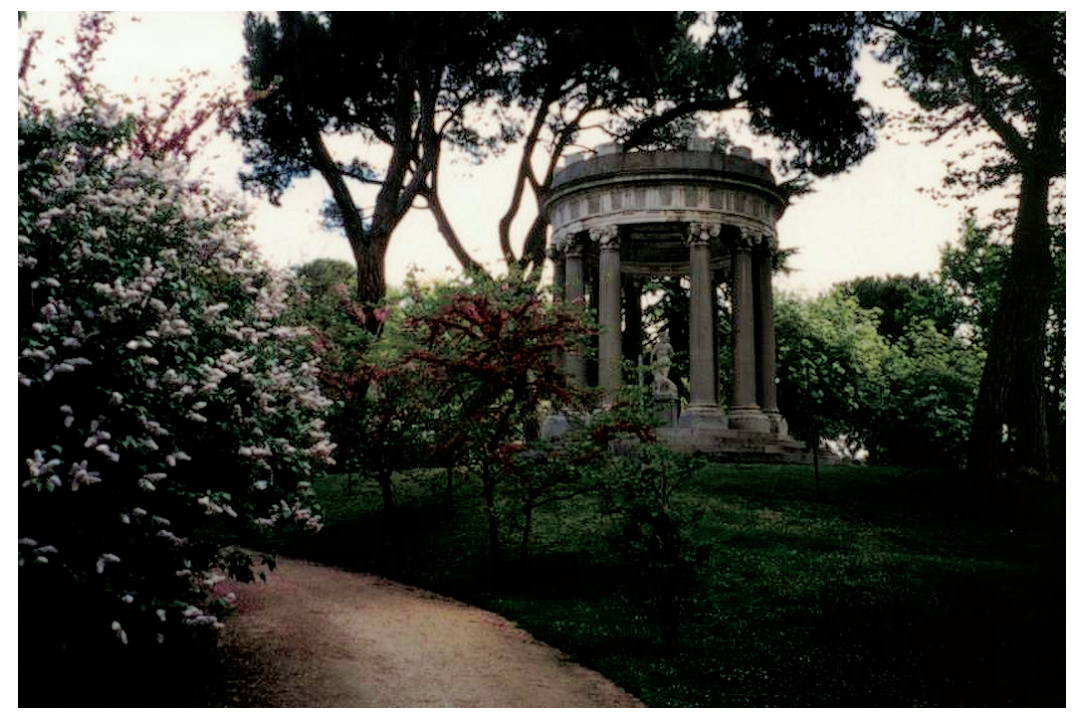

Templete de Venus. (Foto del autor)

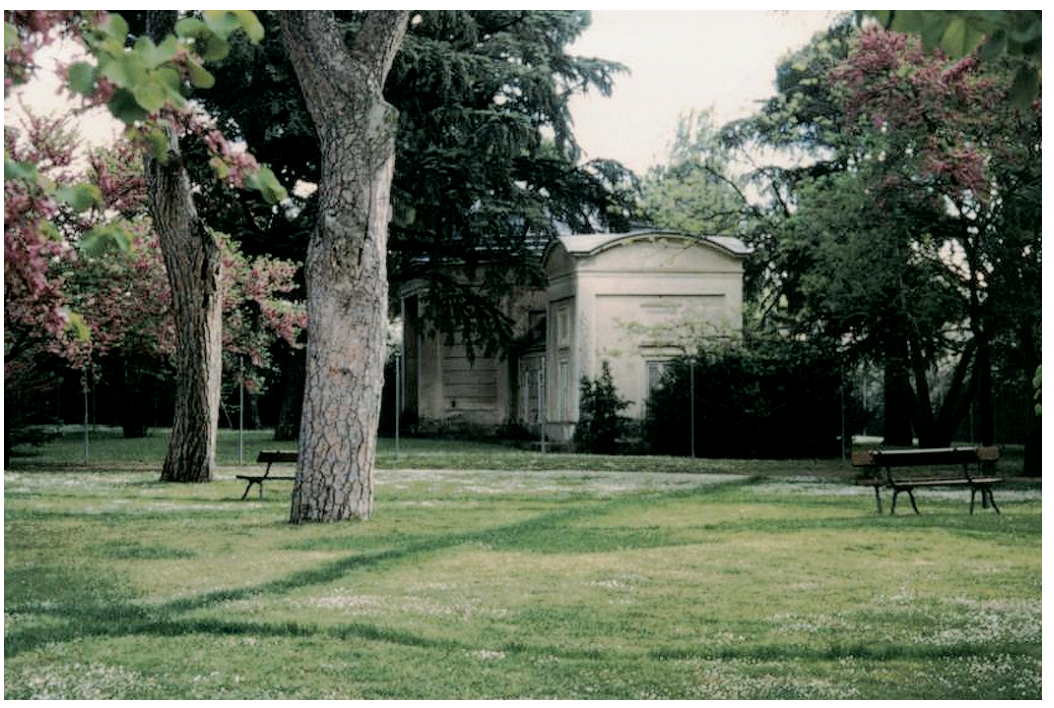

El Abejero. (Foto del autor) 


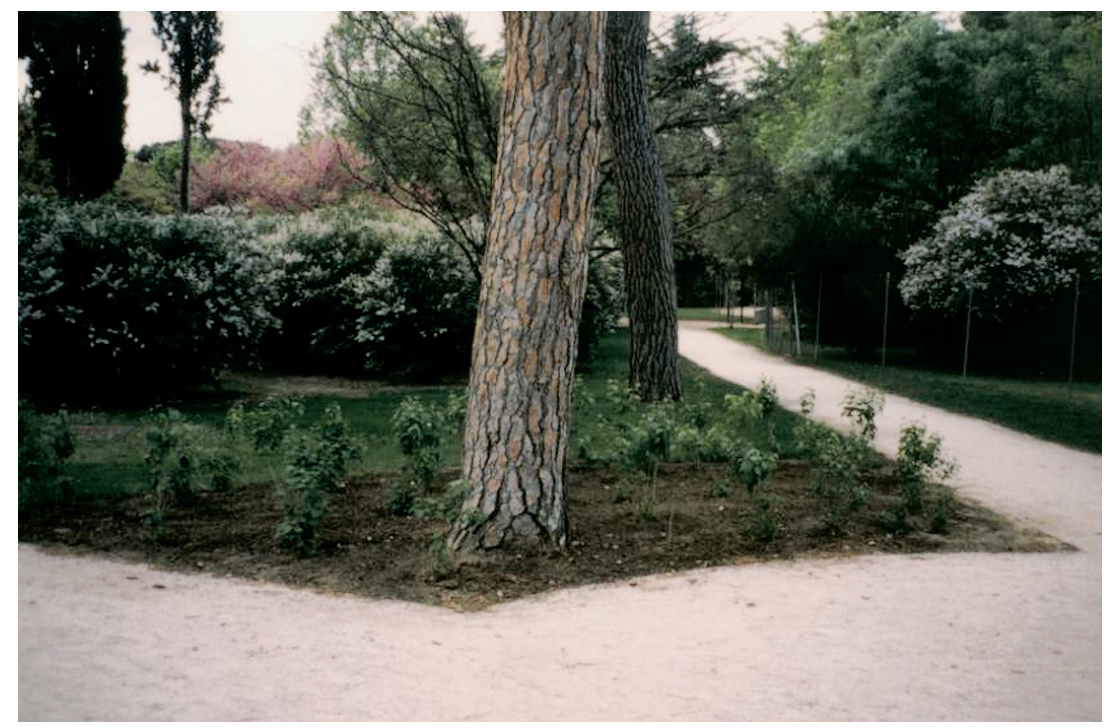

Nueva plantación de lilas en la rueda de Saturno según criterios analógicos con los otros espacios del lugar. (Foto del autor)

didos de muros de ciprés recortado como fondo de la exedra separándola del resto del paisaje naturalista circundante así como los recientes cilindros de ciprés en el parterre de la entrada a la vez que se ha optado por mantener la presencia de las grandes coníferas que aparte de ahogar la vegetación de los parterres impide la visión en profundidad de este espacio. E igualmente fuera de todo orden nos parece la reciente introducción de pérgolas de rosales ocupando los paseos de la parte baja del jardín.

Otro de los puntos negativos de esta restauración es la renuncia a la recuperación del antiguo sistema de riego a manta del que se conservan aún numerosos vestigios como las preciosas acequias de granito con sus partidores por toda la zona del bosque de lilas aunque hay que decir a favor de esta intervención que la gran ría que regulaba todo el sistema de aguas se ha recuperado incluyendo la cascada del monumento al tercer duque en la isleta. Pero para el riego general del jardín se ha optado por la instalación de aspersores con lo que se ha creado un paisaje de praderas de césped bajo los grandes ejemplares arbóreos y arbustivos, un poco chocante con la imagen tradicional e histórica del lugar (y eso en el caso de que nos atuviéramos a la Carta de Florencia) el cual consistía en un bosque ordenado y con unos criterios muy claramente establecidos en lo que competía a la elección de las especies como nos muestran las antiguas fotografías y los ejemplares de la vegetación sobrevivientes, imagen bastante alejada de las extensiones de praderas verdes que dominan el espacio en la actualidad. Conclusión: un ejemplo más de lo peligrosa que puede resultar la carta florentina para la pervivencia de los jardines históricos cuando su aplicación se basa en criterios subjetivos para la creación, recreación, rehabilitación o mantenimiento de los mismos. 


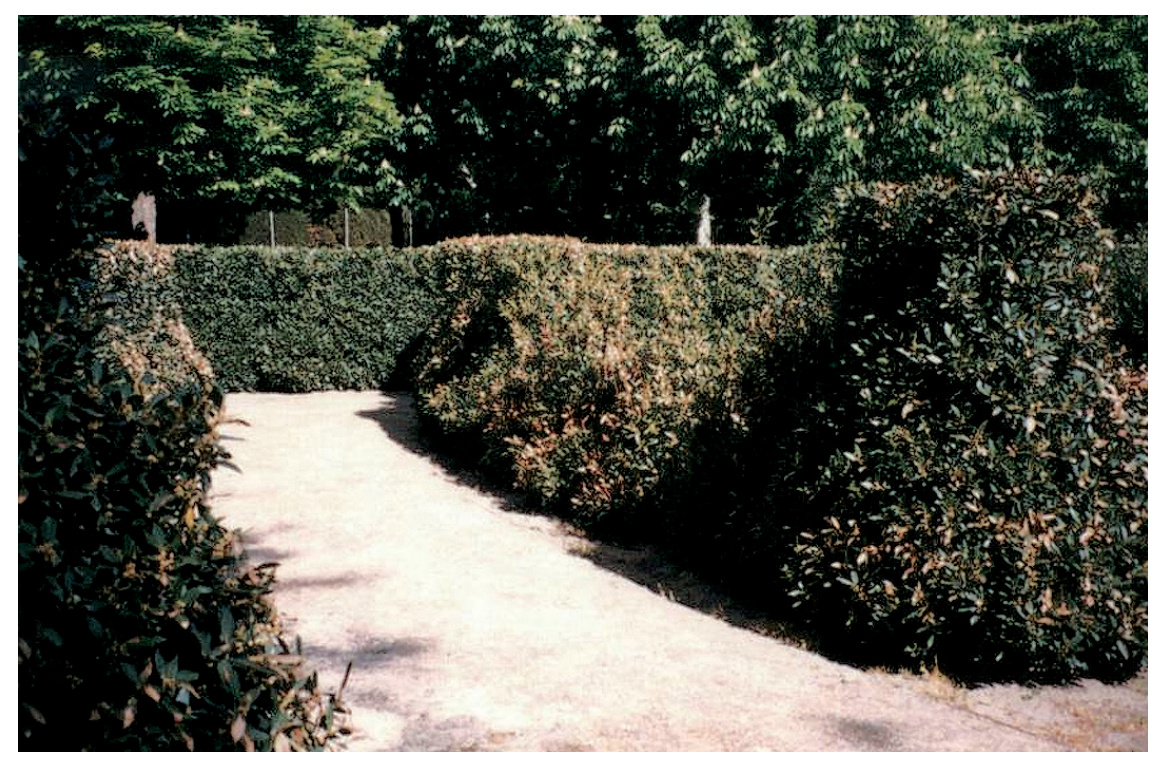

Laberinto. Se puede apreciar como los laureles se han quemado por el frío. La elección de esta planta por su rápido crecimiento constituyó un error de reconstrucción de la estructura del jardín. (Foto del autor)

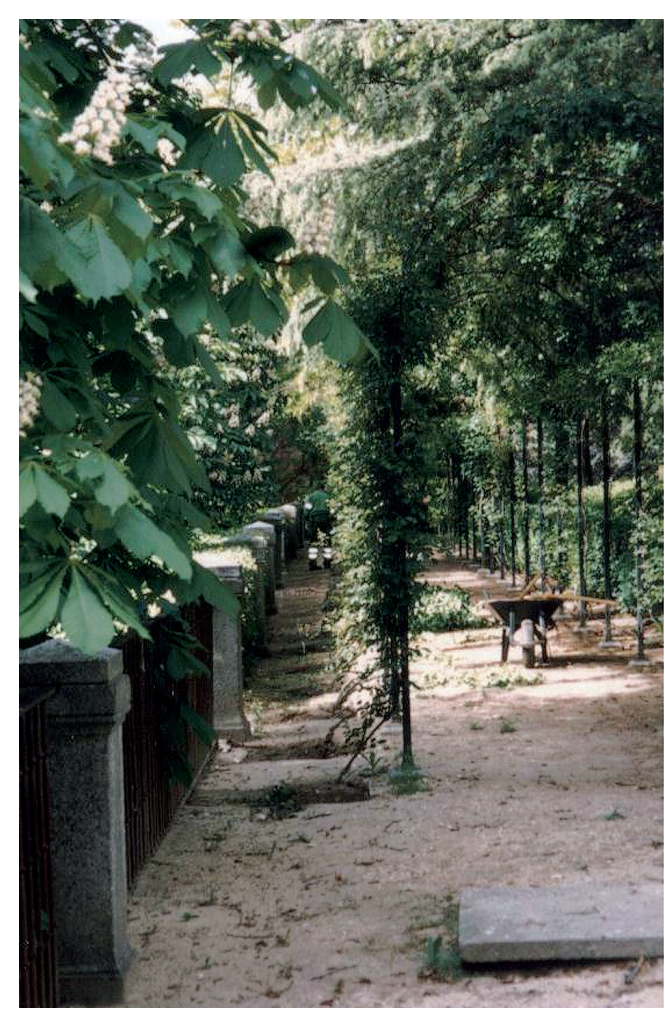

Otra sorprendente y reciente intervención ha sido la instalación de esta rosaleda en uno de los caminos que miran a la fuente de las ranas. (Foto del autor)

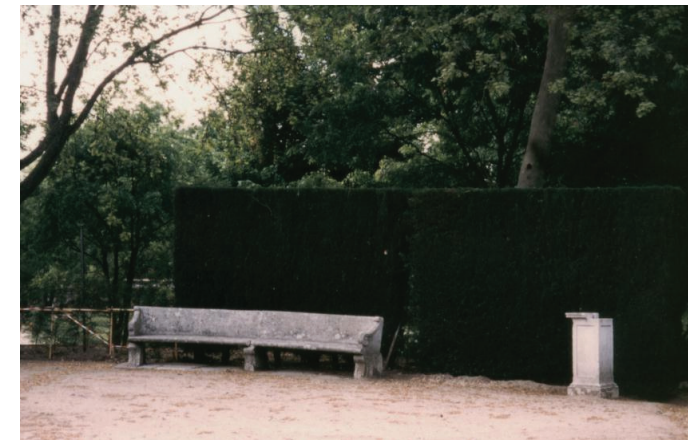

Pantalla reciente de cipreses en la glorieta de la Exedra la cual rompe la visión en profundidad del jardín. (Foto del autor) 


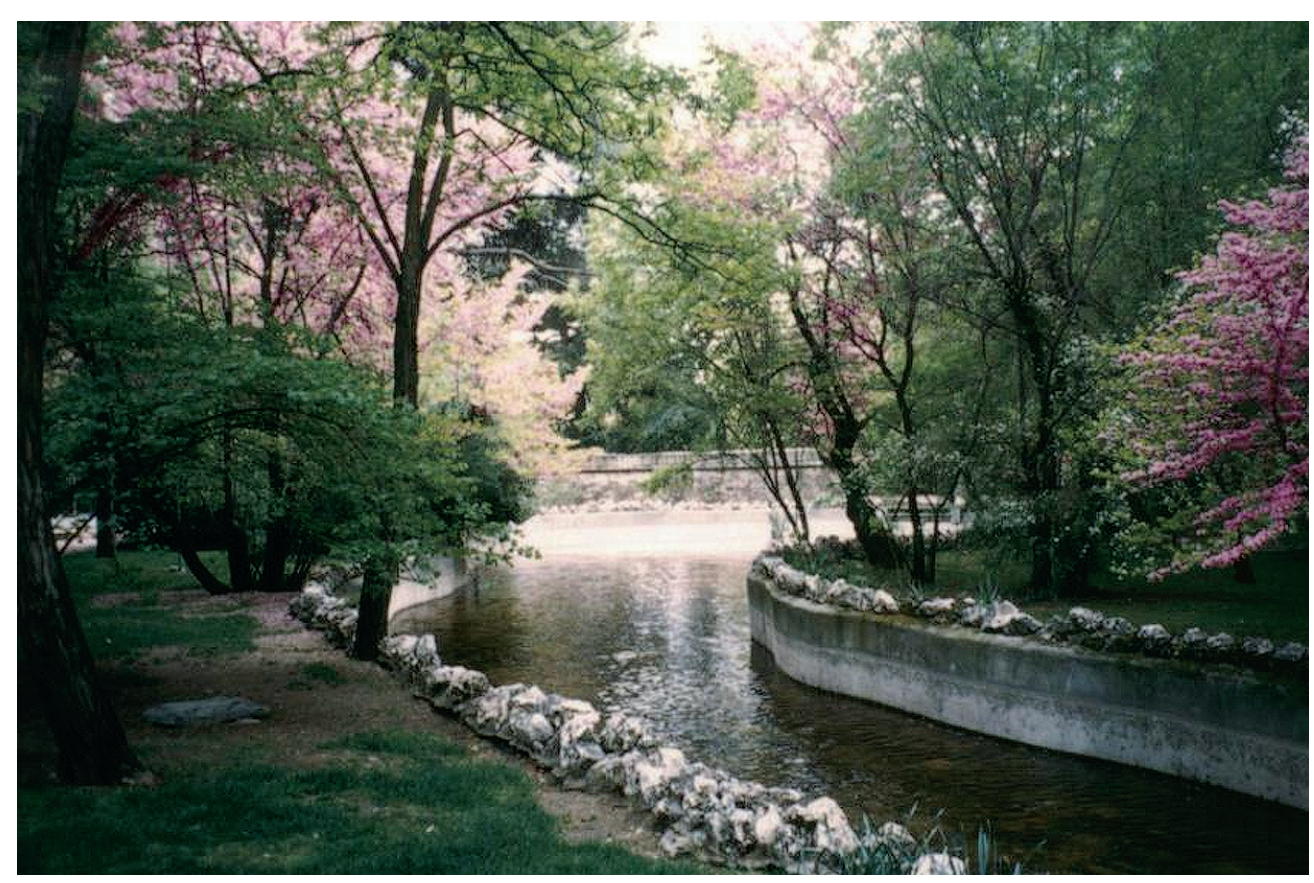

En la parte superior del jardín se ha recuperado la Ría aunque no llega el agua a alcanzar el antiguo nivel. Esta intervención constituye uno de los grandes aciertos en la recuperación del conjunto.(Foto del autor)

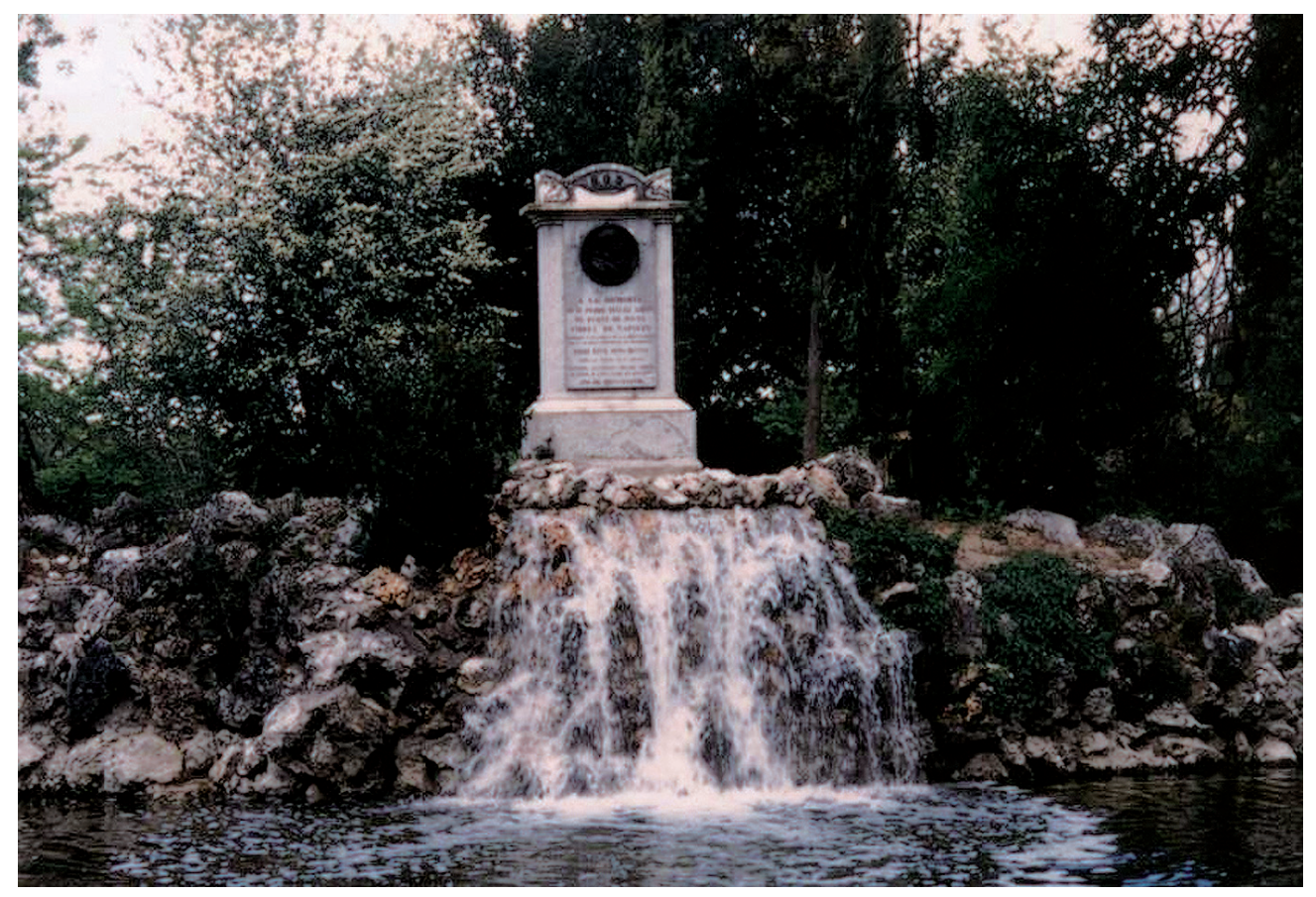

Monumento al III Duque de Osuna en la isleta de la Ría. La recuperación de esta obra de carácter romántico así como del entorno que la rodea es otro de los grandes logros de la restauración del jardín (Foto del autor) 


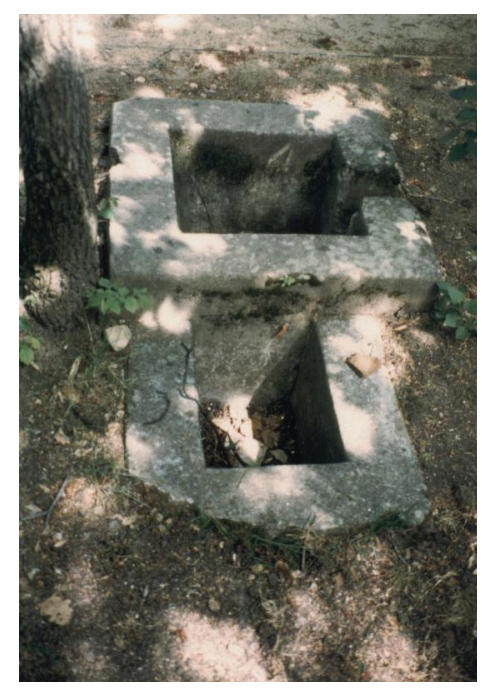

Uno de los aspectos lamentables de la intervención ha sido la renuncia a la recuperación del antiguo sistema de riego a manta. Aún quedan desperdigadas por el jardín bocas y fragmentos de acequias realizadas en granito como la que muestra la foto, hoy reducidas a meros elementos testimoniales.(Foto del autor)

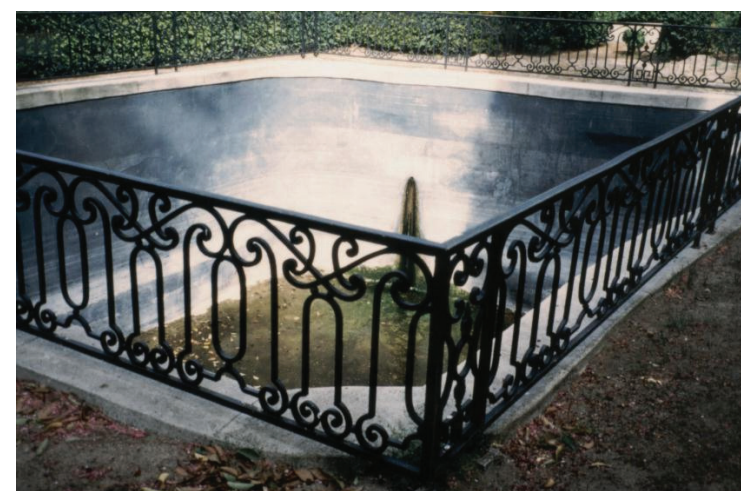

Uno de los grandes balsones para el almacenaje de agua que permanece seco en la actualidad. (Foto del autor)

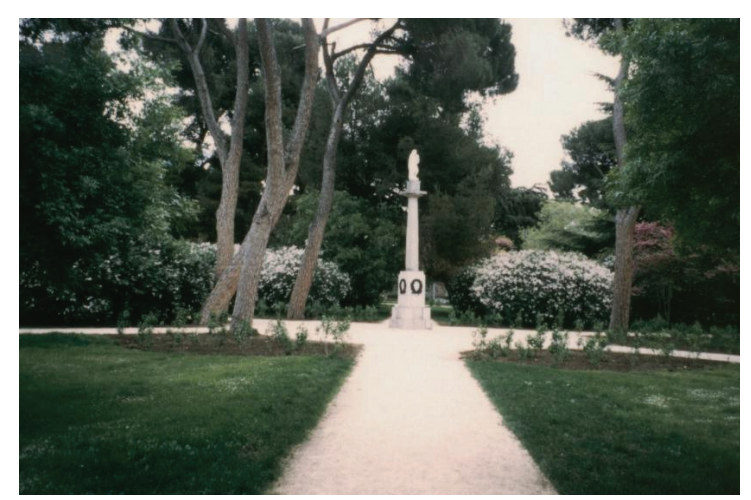

Otro de los fallos de la reciente intervención es el abuso de las extensiones de césped frente a la recuperación de los elementos vegetales del antiguo jardín, conocidos por los restos de las plantas aún sobrevivientes en el lugar o por otro tipo de referencias ya sean fotográficas o literarias.(Foto del autor) 


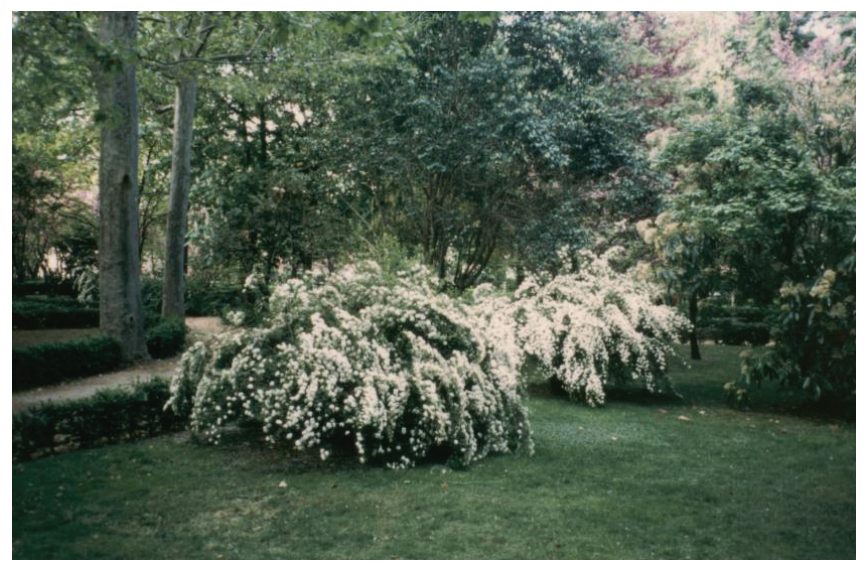

Espireas en flor en uno de los cuadros que se ha cubierto de césped. Estos antiguos arbustos, típicos de la jardinería del XIX, nos están demostrando alternativas distintas de ajardinamiento diferentes a la pradera inglesa.(Foto del autor)

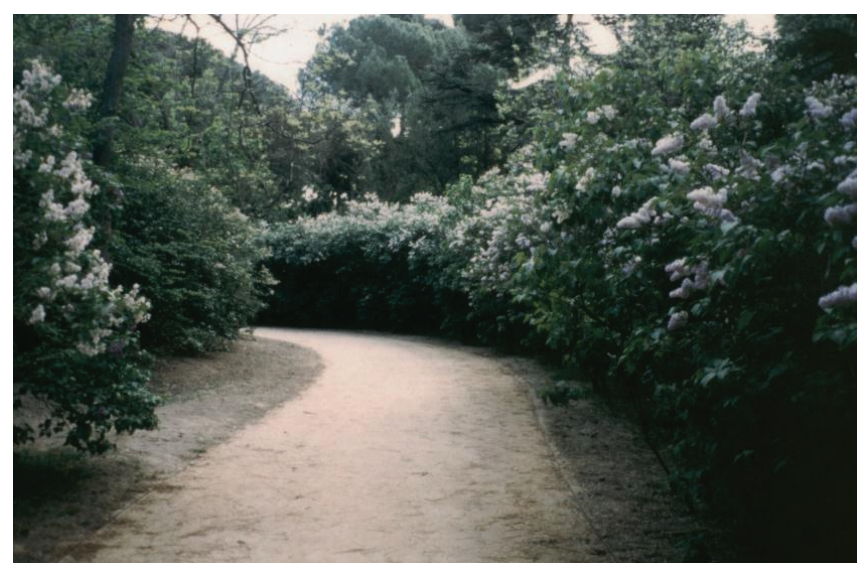

Uno de los paseos del jardín donde podemos apreciar la gran presencia de lilas, arbustos originarios de la creación del jardín. Esta zona se conserva sin haberse realizado ninguna intervención restauradora. Foto del autor)

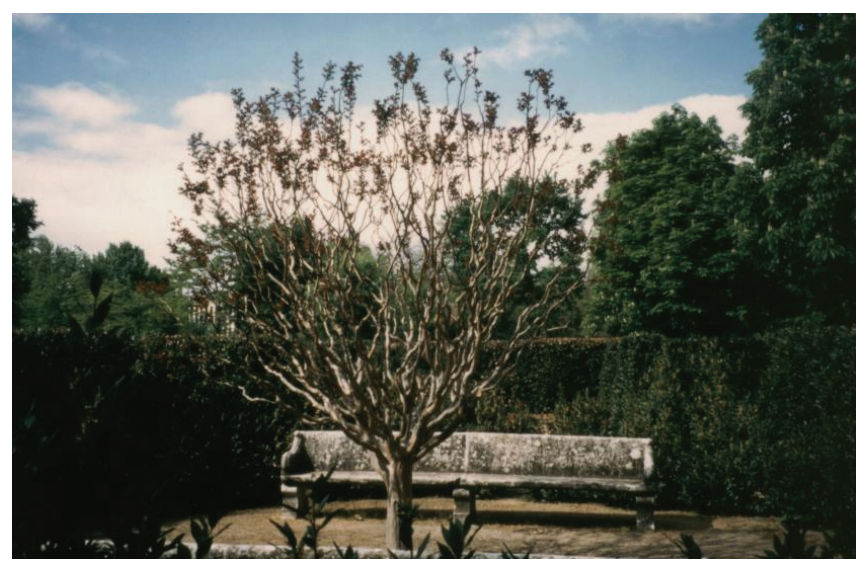

En el centro del Laberinto se encuentra plantado un sorprendente árbol de Júpiter (Lagerstroemia indica) en vez del esperado árbol del amor (Cercis siliquastrum) que dotaría de simbolismo el acceso a este lugar tras el tortuoso recorrido. Aunque sea anecdótico, volvemos a insistir en la importancia de los elementos de la estructura en las intervenciones de restauración.(Foto del autor) 


\section{Bibliografía sobre "El Capricho o Alameda de Osuna}

AAVV. "Lista histórica de plantas, por géneros, encontradas en el jardín El Capricho durante el periodo 1798-1871”. VII Master en Jardinería y Paisajismo. Universidad Politécnica de Madrid. Marzo de 1998.

La lista recoge la presencia de unas 200 especies sin ubicarlas físicamente en el recinto del jardín.

AÑON, Carmen. El Capricho de la Alameda de Osuna Ed. Avapiés. Madrid, 1994.

La autora hace una historia del lugar y de los componentes arquitectónicos presentes en el mismo echándose en falta una relación extensa de los componentes vegetales del jardín.

AÑON, Carmen, LUENGo, Mónica y LUENGO, Ana. Jardines artísticos de España. Ed. Espasa Calpe. Madrid, 1995.

Se trata el jardín en las páginas 146-159. Buenas fotos. El texto da excesiva información sobre datos familiares y anecdóticos de los Osuna dejando en segundo lugar la descripción del jardín y del proceso de su reciente restauración.

ESCUELA-TALLER ALAMEDA DE OSUNA. A cargo del Ayuntamiento de Madrid, el INEM y el Fondo Social Europeo. Madrid, 1987.

En este cuaderno están recogidas las intenciones y se exponen los criterios de restauración empleados en el jardín.

MARQUESA DE CASA VALDES. Jardines de España. Ed. Aguilar. Madrid, 1973.

Páginas 231-232. Sitúa el jardín dentro del neoclasicismo español. Citamos en este capítulo las observaciones sobre su estado.

SARTHOU CARRERES, Carlos. Palacios monumentales y palacios reales de España. Semana Gráfica. Valencia, 1953.

En las páginas 48-53 trata sobre los edificios de la Alameda y no se extiende sobre el jardín porque están tratados en otra obra de este mismo autor que no hemos podido consultar: Jardines artísticos y parques reales de España.

SOTO CABA, Victoria. Muestra los jardines del XIX en "Jardines de la Ilustración” en la obra de Adrian VON BUTLAR de la editorial Nerea, Madrid, 1993 Jardines del clasicismo y el romanticismo. Aquí se hace referencia a la importancia que tuvo este jardín como ejemplo testimonial casi único de aquel momento histórico de la Ilustración en nuestro país (págs. 304-307).

WINTHUYSEN, Javier de. Jardines clásicos de España. Edición facsímil de Doce Calles, Aranjuez, 1990.

El jardín es tratado brevemente. Sólo una página pero se inserta una foto en la que podemos ver la exedra completa.

En las "Notas sobre la vida y obra de Xavier de Winthuysen" de Carmen Añón y José Luis Sancho (págs. 119-120) se amplía la bibliografía sobre el jardín y se señala la polémica que acompañó los primeros proyectos de recuperación de La Alameda. 


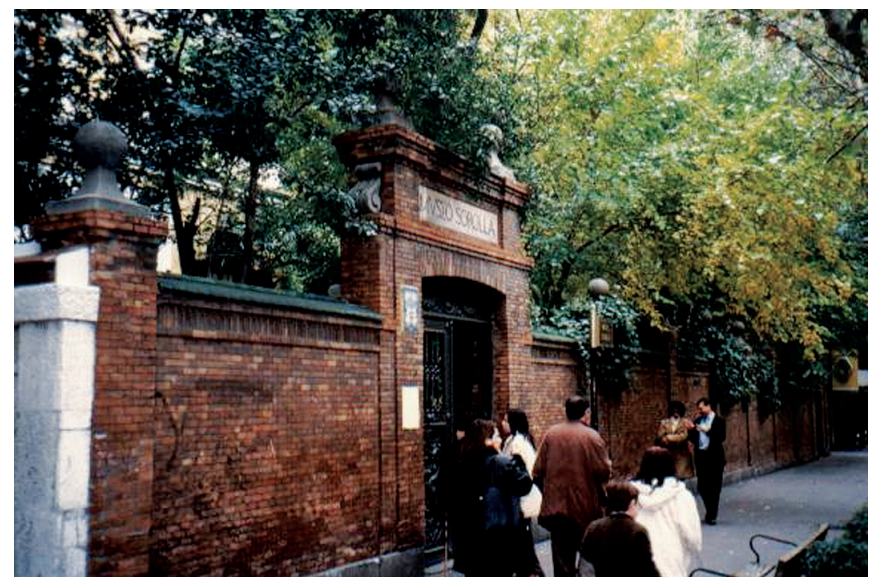

La Casa-Museo desde el exterior. (Foto del autor)

La casa del pintor Sorolla, en la actualidad transformada en museo de su obra desde el año 1931, es uno de los escasos ejemplos supervivientes de las construcciones típicas en esa zona de principios del siglo XX. Junto con la cercana sede del British Council son los únicos chalets rodeados de jardines que aún permanecen de aquel momento en el barrio.

Hoy, el jardín de la Casa-Museo del pintor es umbrío debido a dos causas. Una, la de estar cercada de grandes fincas y otra, al crecimiento natural de los numerosos árboles plantados, algunos de ellos por el mismo pintor.

El tener documentada la fecha de construcción de las obras de la casa (1910-12) así como el disponer de abundante material gráfico -tanto fotográfico como pictórico- la convierte en un buen ejemplo de la rápida transformación de la materia vegetal frente a la buena conservación de los elementos arquitectónicos (27).

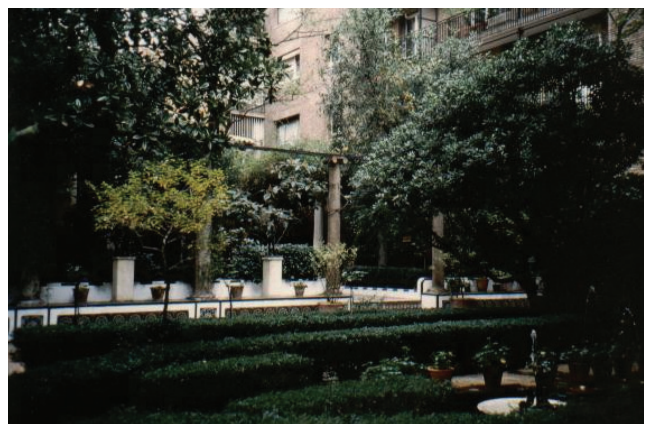

El jardín de la Casa-Museo rodeado de altas fincas. (Foto del autor)

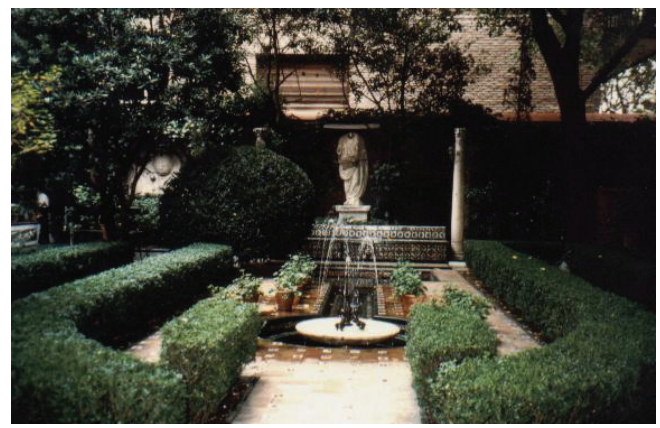

El jardín de la casa Sorolla. (Foto del autor)

(27) Existe una guía titulada "Museo Sorolla" publicada por el Ministerio de Educación y Cultura en 1999 con textos de Florencio de Santa-Ana. Aquí podemos ver en detalle las diferentes fases de construcción de la casa y su posterior conversión en museo. 
Sorolla creó unos jardines de tradición andalusí, inspirados directamente en los que había visto en su tierra natal y en sus viajes, especialmente Andalucía y Granada en particular. De paso utilizó este espacio como lugar donde almacenar toda la colección de estatuas, fuentes y azulejos que iba recogiendo en sus viajes.

En los orígenes del jardín, los parterres se cercaron con setos de arrayán traído expresamente de Granada, de los que aún subsisten algunos transformados en ejemplares casi arbóreos. Estos cuadros se llenaron de plantas de flor -lilas, rosales, claveles y geranios- como podemos ver en sus cuadros. Se levantó igualmente una gran pérgola y se crearon lugares variados de estancia para los que se construyeron numerosos bancos con las cerámicas que el pintor iba coleccionando.

El cambio de un jardín soleado a uno de umbría ha repercutido en la eliminación de aquellas especies de la primera fase del jardín amantes de la luz. Y es en la adaptación a esta nueva situación donde vemos que junto a algunos aciertos se han cometido también errores en la reciente intervención del año 1987 (28). Como aciertos están la sustitución del arrayán por boj en algunos de los setos de los parterres del jardín así como el mantenimiento de los arbustos de gran tamaño y porte desgarbado pertenecientes a la primera plantación. Destacan entre ellos algunos

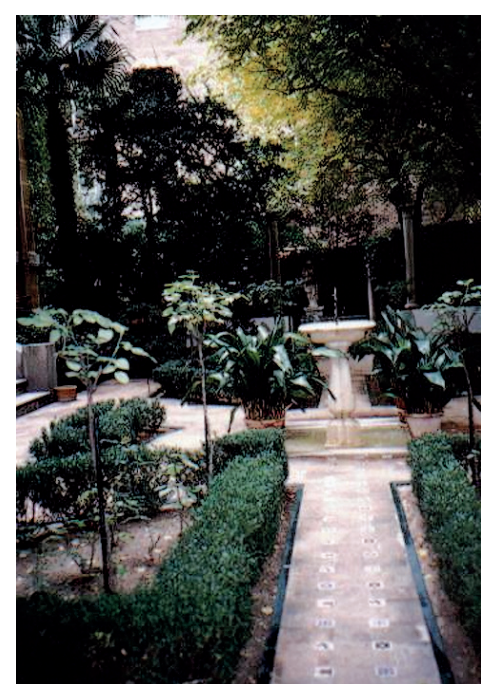

Jardin de la entrada con boj en sustitución de arrayán. (Foto del autor)

(28) Las obras de restauración comenzaron en 1987. Tomaremos las palabras de la guía de Florencio de Santa-Ana para ubicar esta intervención: "Este espacio es una creación más de Sorolla y debe considerarse como una sala más de su Museo. Ferviente admirador de la jardinería andaluza, que representa en numerosos lienzos, intenta reconstruir algunos de sus rincones en su propia vivienda y hace traer planteles de Granada y de Valencia, algunos de ellos desde la Alhambra como los mirtos -o arrayanes- que todavía se conservan. Antes de acometer su plantación dibuja y diseña las distintas partes del jardín, conservando el Museo Sorolla una buena colección de bosquejos que algún día habrá que exponer al público. Muchos de los elementos que lo enriquecen tienen la misma procedencia: pilas de sus fuentes, columnas, capiteles, restos arqueológicos, esculturas, etc., que comparten los honores con azulejería antigua y moderna de Triana, de Manises o de Alcora. Desgraciadamente su plantación no es la misma que en vida de Sorolla, ya que las condiciones lumínicas que hoy tiene el edificio no permiten plantaciones similares a cuando estaba integrado en un entorno de bajas edificaciones, aunque se ha intentado desde su restauración recuperar las primitivas especies vegetales que lo adornaban" 
mirtos de interés histórico por haber sido plantados por el mismo Sorolla, un gran evónimo en la fuente del "riad" que se ha mantenido a pesar de romper la perspectiva, una gran adelfa que languidece por falta de luz y algunos árboles frutales desperdigados por el lugar plantados igualmente por nuestro pintor a pesar de que ocupan los caminos.

Los errores se concretan en la utilización en algunas zonas del jardín del uso de un árbol -el aligustre- (Ligustrum japonicum) como seto y en la excesiva presencia de rododendros, azaleas y camelias introducidas recientemente para llenar los cuadros umbríos, especies que al ser ajenas a la tradición jardinera andalusí quedan un tanto chocantes en este espacio de la casa del pintor.

Tratándose de un jardín de tradición hispanomusulmana, existen numerosas plantas de uso frecuente en los patios de sombra del Levante y zona sur de la península que resolverían este problema independientemente de la diferencia de climas. A excepción del acanto echamos en falta los ruscos, (Ruscus aculeatus), el laurel de Alejandría (Ruscus hypoglossum) del que sobrevive todavía una maceta en la casa, las bergenias (Bergenia cordifolia), violetas (Viola odorata), azucenas del Brasil (Crinum sp.), peonías (Paeonia lactiflora), aquilegias (Aquilegia vulgaris), etc., todas ellas plantas más acordes con el carácter del jardín de un lugar como éste.

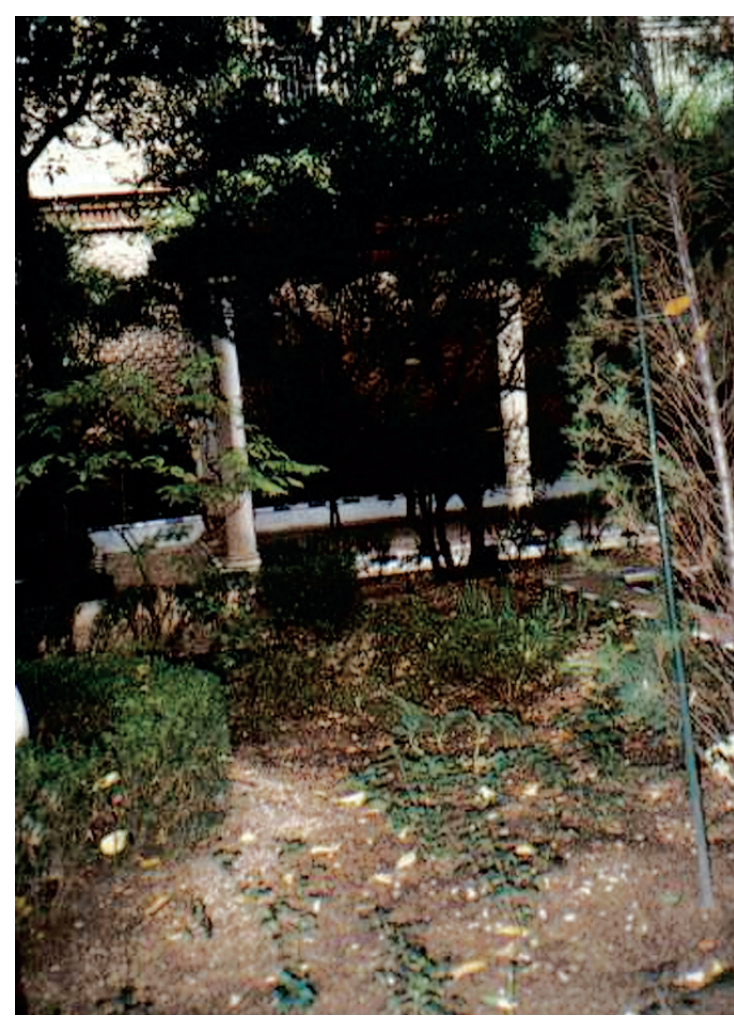

Interior de los cuadros del jardín. (Foto del autor)

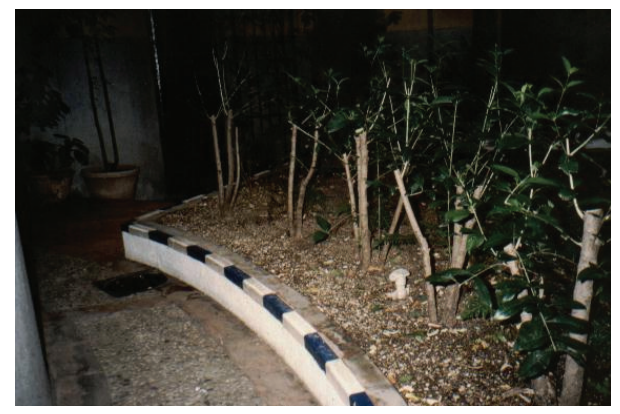

Seto de aligustre (Ligustrum japonica) árbol utilizado como seto bajo.

(Foto del autor) 


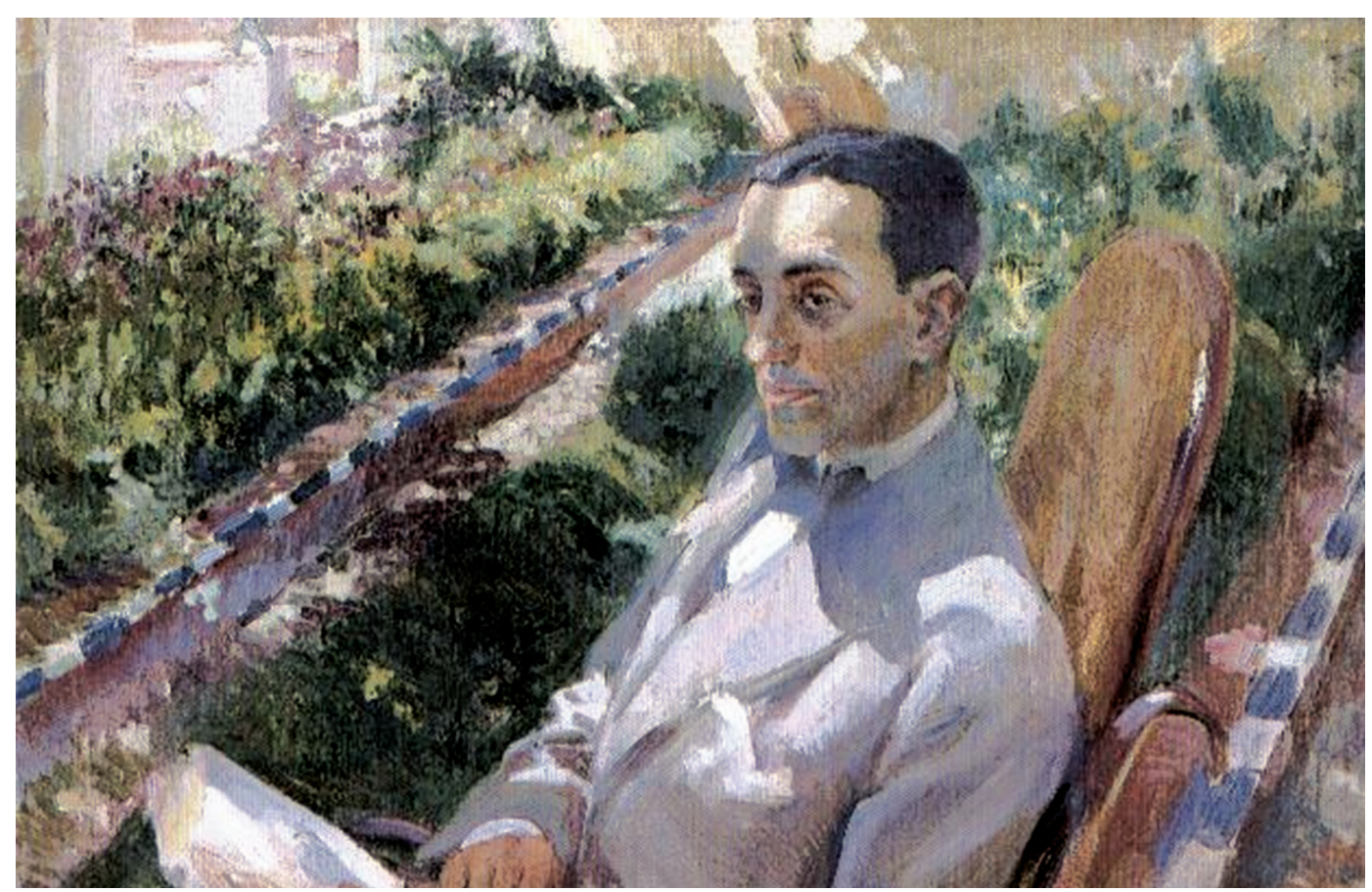

Joaquín Sorolla. Retrato de Ramón Pérez de Ayala. Galería Rafael Pérez Hernando

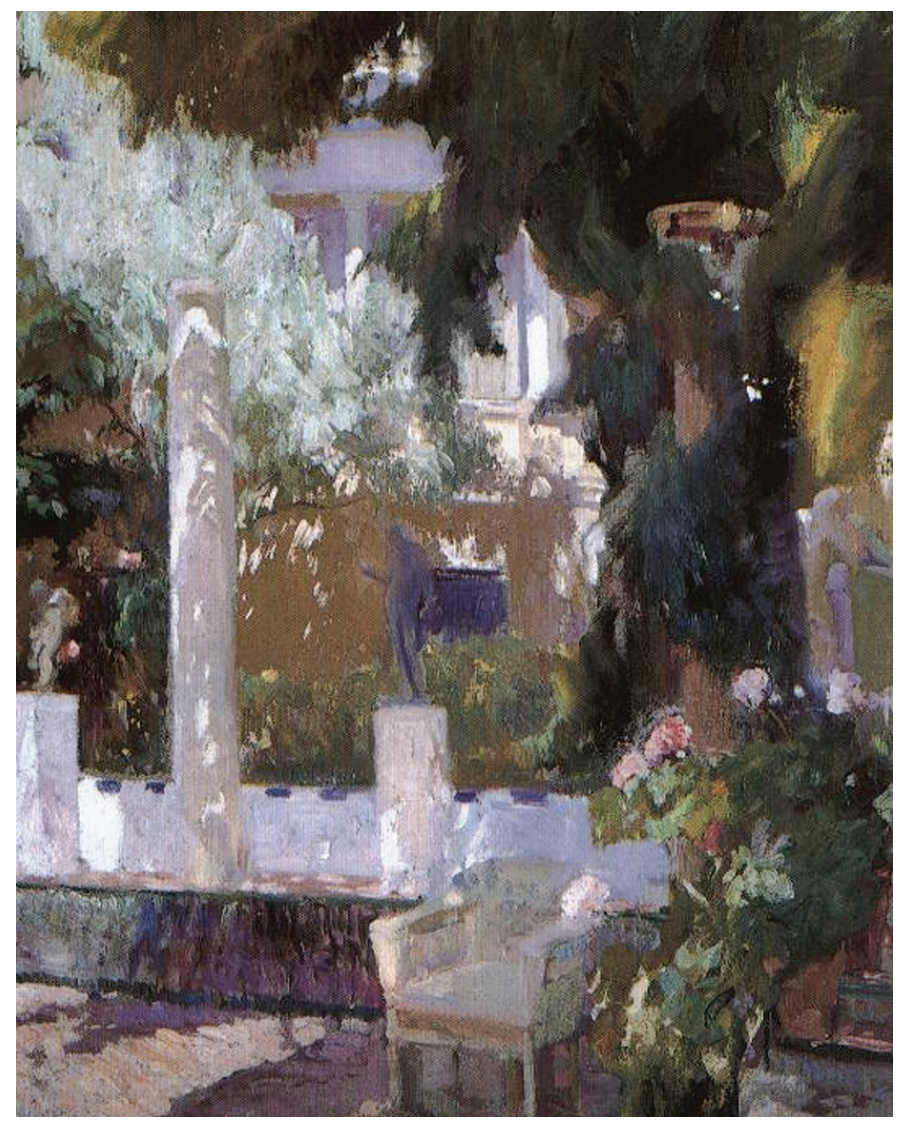

Joaquín Sorolla. Jardín de la casa Sorolla. Museo Sorolla 


\section{Bibliografía sobre la Casa-Museo del pintor Sorolla}

SANTA-ANA Y ALVAREZ-OSORIO, Florencio de. Guía del Museo Sorolla. Ministerio de Educación y Cultura. Madrid, 1999.

SANTA-ANA Y ALVAREZ-OSSORIO, Florencio de. "Sorolla y el jardín de su casa madrileña" en Jardines de España. Catálogo de la exposición de igual nombre a cargo de Lily Lítvak para la Fundación MAPFRE VIDA XII de 1999 a I de 2000. Páginas 71-89.

Se relata la formación del jardín, con referencias bibliográficas al pintor así como la abundante obra pictórica que Sorolla realizó sobre el lugar, las influencias andaluzas y los proyectos previos conservados todos en la Casa-Museo. Hay asimismo reproducciones de cuadros sobre el mismo.

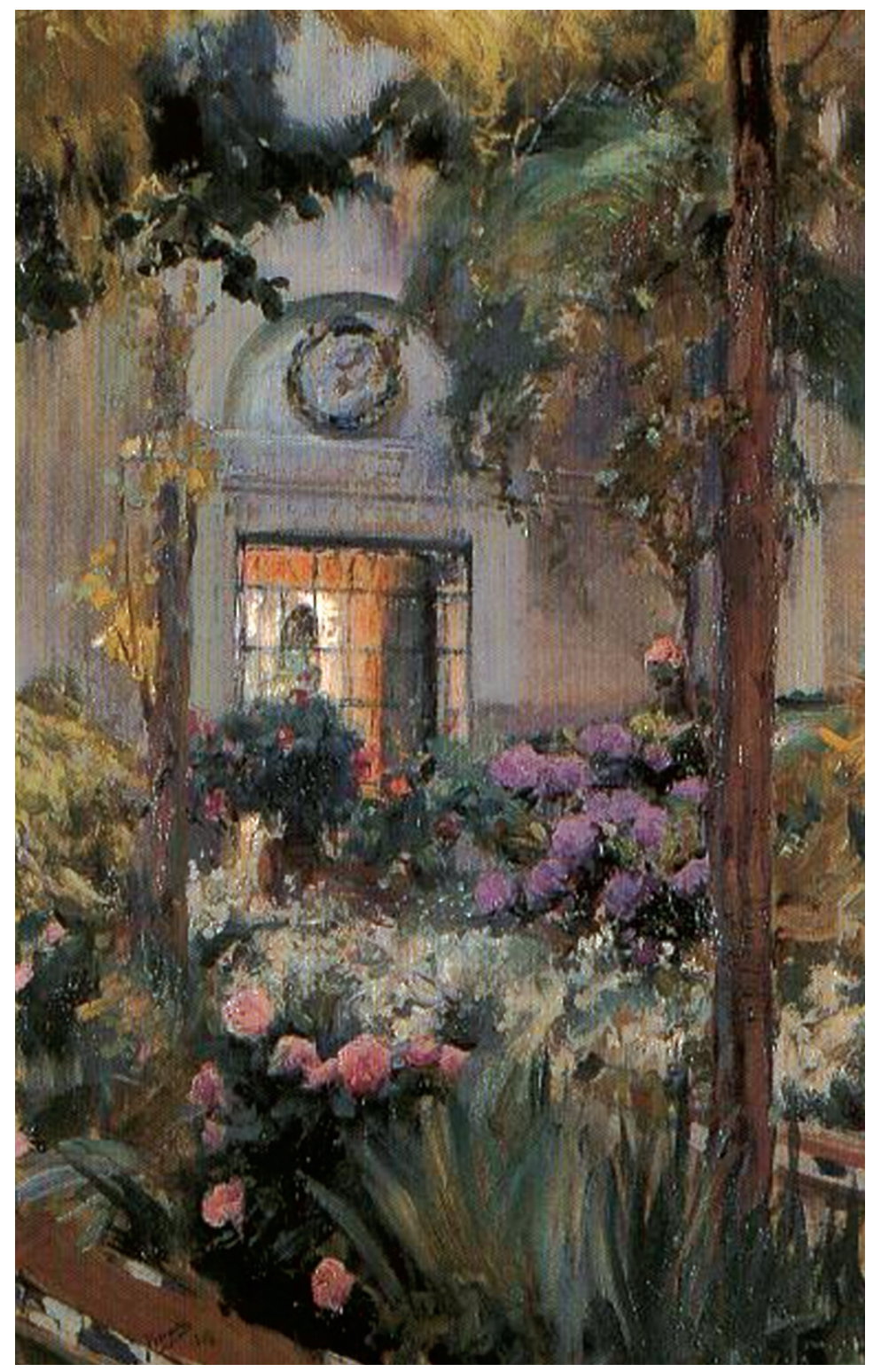

Joaquín Sorolla. El jardín de la casa Sorolla. Ayuntamiento de Valencia. Museo de la Ciudad 


\section{d) Jardín del claustro del Monasterio de Guadalupe}

La intervención en este espacio, definida como rehabilitación por sus autoras, (29) tuvo lugar entre 1988 y 1991. Lo sucedido aquí es un claro ejemplo de restauración según los postulados de la Carta de Florencia.

Veremos, como hemos hecho en los ejemplos anteriores, una breve historia del lugar con la documentación gráfica existente previa a la restauración o rehabilitación así como un resumen de la memoria justificativa que condujo a esta intervención.

El monasterio se funda en el siglo XIV. Fue apoyado desde siempre por los monarcas tanto por ser avanzadilla en los primeros tiempos de la Reconquista como en tiempos posteriores al constituirse en punto importante de la retaguardia en la contienda. A esto se unió el que el lugar se convirtió en un punto estratégico de las rutas de la Mesta con lo que el monasterio llegó a ser un centro de inmensa riqueza, cultura y poder.

Como señala Carlos Callejo (30) la necesidad de mano de obra para la fiebre constructiva entre los siglos XIII y XIV que ocurrió en España hizo venir albañiles tanto del norte de Europa (Flandes y Francia) como del sur, lo que produjo que acudieran grupos de alarifes musulmanes desde al-Andalus, algo corriente en la época como lo atestiguan las obras de éstos en lugares tan al norte como el monasterio de las Huelgas de Burgos. Estas circunstancias dieron como resultado la construcción de este hermoso claustro mudéjar para un convento cristiano.

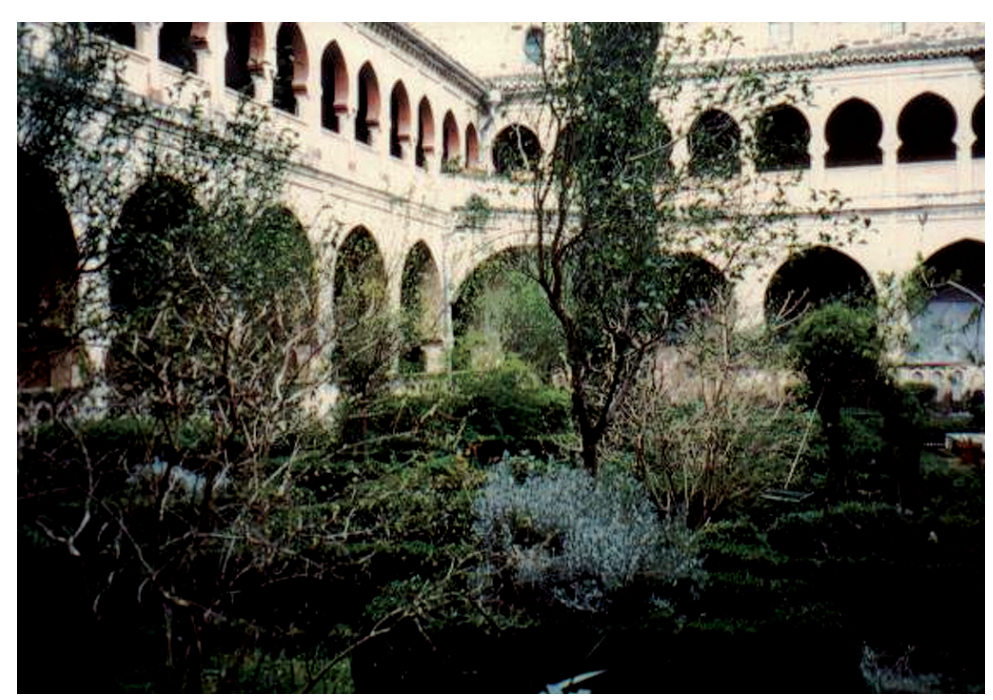

Claustro de Guadalupe tras la reciente intervención. (Foto del autor)

(29) AÑON, Carmen, LUENGO, Mónica y LUENGO, Ana. Jardines artísticos de España. Ed. Espasa Calpe. Madrid, 1995.

(30) CALLEJO, Carlos. El Monasterio de Guadalupe. Libro XXI de la edición Los Monumentos cardinales de España. Editorial Plusultra. Madrid, 1951. 
En su centro se ubicó un pabellón -o templete- del que surgían las aguas para el riego a través de numerosos juegos hidráulicos hoy perdidos y conocidos por los relatos de los viajeros de la época. La traza del jardín era en forma de cruz, con cuatro caminos que llevaban al pabellón desde las galerías perimetrales.

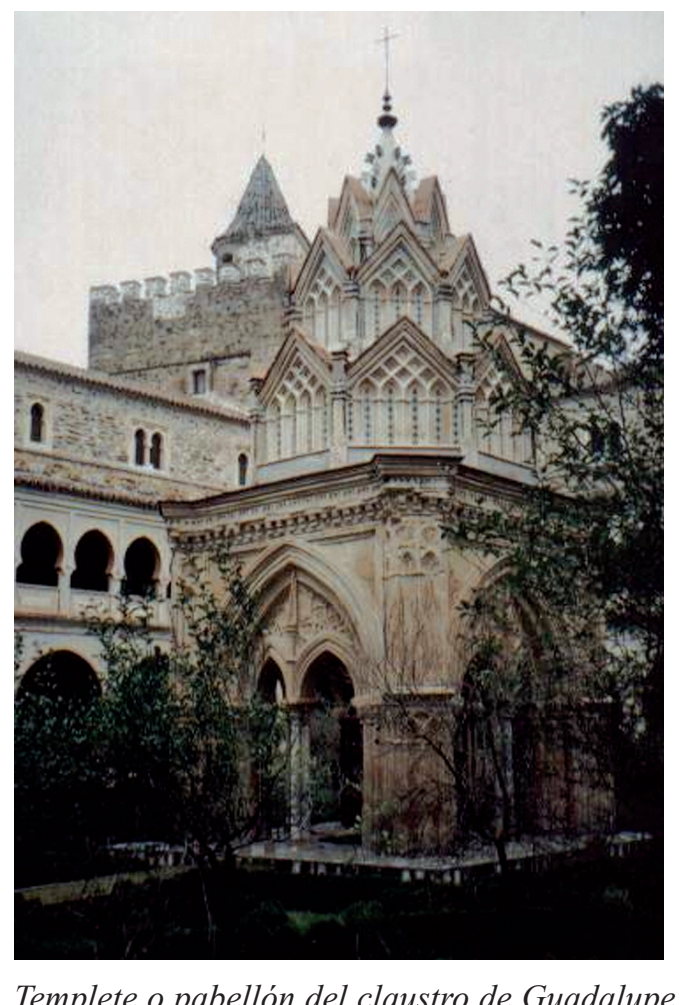

El terreno del jardín propiamente dicho estaba a un nivel más bajo que los caminos para facilitar el riego a manta.

El monasterio siempre fue muy visitado. Jerónimo Münzer en el siglo XV relata que existían infinidad de juegos de agua tanto en el templete como en las otras fuentes del claustro y nombra la existencia de naranjos entre la vegetación. Esta abundancia de agua está confirmada en el Libro de los caños del agua, manuscrito del siglo XV conservado a través de una copia de principios del XX.

A pesar de los avatares de los siglos XIX y XX (invasión francesa, desamortización y Guerra Civil) el claustro siguió siendo un vergel como lo confirman los testimonios fotográficos que han llegado hasta nosotros. Uno de ellos, del que reproducimos la foto pertenece a la obra Monasterios monumentales de España de Carlos Sarthou Carreres del año 1951 en la que podemos ver la frondosidad de la vegetación en ese espacio. Existe otra cita anterior que corresponde al tomo IV del Ars Hispaniae a cargo de Leopoldo Torres Balbás dedicado al arte musulmán. En las páginas 299 y 301 hay reproducciones del claustro acompañadas del comentario de D. Leopoldo: "El patio es hoy un espléndido vergel cuya vegetación amenaza con ocultar casi totalmente a la arquitectura". 


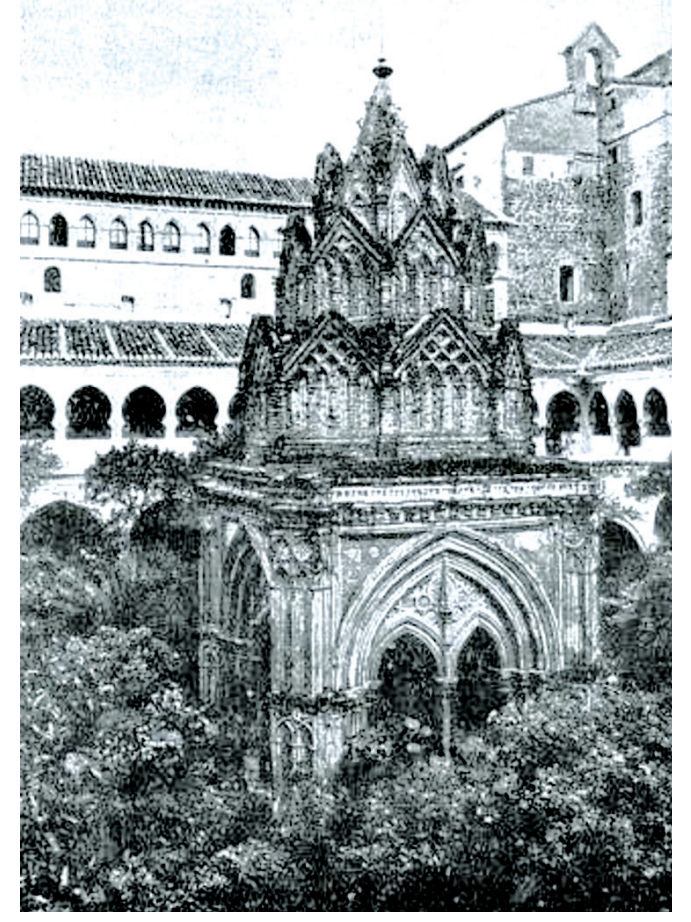

El claustro en el libro de Carlos Sarthou Carreres

No sabemos exactamente cuando se plantaron los setos de boj perimetrales a los caminos y que podemos ver en las postales anteriores a la restauración y que fueron eliminados al realizar la misma como muestra la foto bajo estas líneas.

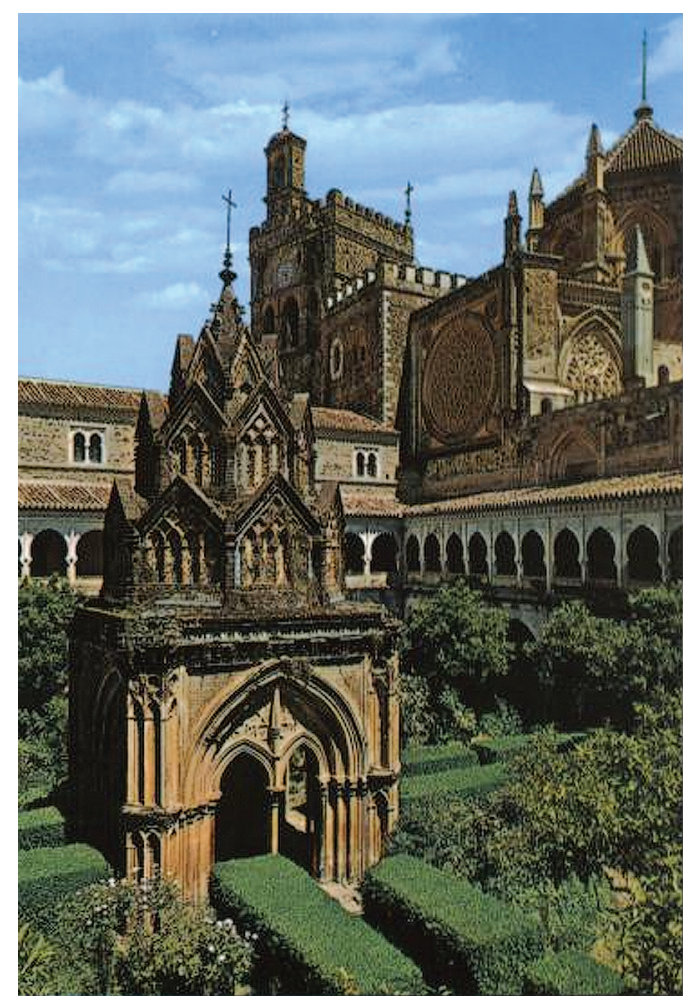

El claustro en el libro de Carlos Sarthou Carreres 
Las causas de la reciente intervención en el claustro son las siguientes: a finales de los años ochenta del pasado siglo, España compró a Estados Unidos unos cuantos aviones de combate. En el contrato de compra-venta se señalaba que el vendedor sufragaría alguna obra de restauración del patrimonio histórico español. Le tocó en suerte a Guadalupe el honor de ser elegido. En la obra de Carmen Añón y las Luengo de Espasa Calpe citada anteriormente se dice que fue el World Monument Fund quien impulsó la restauración del claustro mudéjar entre 1988 y 1991 siendo dirigida por el IRCBC (Instituto de Conservación y Restauración de Bienes Culturales) y la Consejería de Cultura de la Junta de Extremadura (31).

Vamos a ver a continuación los estudios previos que se realizaron, sus conclusiones y los criterios elegidos por sus autoras para lo que tendremos que ir a la revista del Patrimonio Nacional Reales Sitios (32) donde se explican estos puntos. Vamos a citar textualmente las palabras de Carmen Añón del apartado que dedica en esta publicación a explicar los criterios de intervención: "Se ha seguido una estricta y severa metodología antes de formular los criterios definitivos que configuran nuestra actuación. Una rigurosa investigación histórica, recurriendo a las fuentes y archivos originales encomendada al profesor don Antonio Ruiz, especialista en arquitectura de la Orden de los Jerónimos, ha sido nuestro primer punto de partida, complementada por una exhaustiva búsqueda en el propio Monasterio de todas aquellas fuentes que podían proporcionarnos alguna información: biblioteca, museos, arquitectura, escultura, etc., han sido cuidadosamente estudiadas con objeto de extraer datos que pudieran ser útiles y fiables para la rehabilitación del jardin.

En los trabajos de campo se ha analizado con minuciosidad el estado del jardín en el momento de empezar las obras, inventariando y catalogando todas las especies botánicas y levantando con todo detalle los planos necesarios para establecer su configuración.

La escasez de datos que, a pesar de todos los estudios, se habian conseguido, nos llevó a aconsejar una investigación metódica y detallada, realizando los necesarios estudios arqueológicos. No se ha añadido ningún dato importante respecto al jardin original.

No se ha tratado de hacer una rehabilitación integral o parcial del Claustro, por carecer, como ya hemos manifestado, de los restos que nos pudieran servir de guía, o en su lugar de planos o documentos gráficos que suplieran esta carencia. De acuerdo con el espíritu de la Carta de Florencia (ICOMOS, Florencia, 1981) sobre restauración de los iardines históricos, la estructura del Claustro, la fuerza

(31) AÑóN, Carmen. <<Rehabilitación de los Jardines del Claustro Mudéjar del Real Monasterio de Nuestra Señora de Guadalupe $>>$ en Reales Sitios, núm. 123 correspondiente al primer trimestre de 1995. En la primera nota de este artículo se señala que "la investigación para el proyecto de la restauración del Claustro la realizó D. José Antonio Ruíz-Hernando, catedrático de la Escuela de Arquitectura de Madrid. El arquitecto encargado de la restauración de la arquitectura del Claustro fue don Ignacio Gaiate, designado por don Dionisio Hernández Gil, directos del Instituto de Conservación y Restauración de Bienes Culturales. El proyecto y la restauración del jardín fueron realizados por doña Carmen Añón y doña Laura Martínez."

(32) AÑON, Carmen. Obra citada. 
de sus elementos arquitectónicos, las pequeñas indicaciones escritas nos aconsejaron hacer una rehabilitación de características ambientales, acorde con el origen del Claustro, para resaltar y subrayar la belleza del conjunto".

En el apartado siguiente titulado "el espíritu del claustro" se deducen conclusiones a pesar de la falta de pruebas. Veamos lo que se afirma. "Si intentamos llegar al alma dormida del jardín, la cita "entre un algo escondido y lo aparente", no vemos este espacio como lo que clásicamente se ha dado en llamar un jardín hispano-árabe. Es un jardín donde tal vez trabajasen jardineros moriscos y donde su influencia es sin duda notoria, pero ante todo es el jardín de un monasterio cristiano y uno de los lugares más notables y más representativos de todo el conjunto". Tras eliminar que pudiese ser huerta de producción o de medicinales se llega a la conclusión siguiente: "Estamos ante un gran Claustro mariano en loor de la Virgen María, hortus conclusus, fuente sellada, rosa mystica, turris eburnea... bajo cuya protección y amparo está colocado todo el Monasterio".

Como vemos las conclusiones obtenidas de esa "estricta y severa metodología" conducen a la autora a la afirmación de que "no es un jardín hispano-árabe sino el lugar donde tal vez trabajaran jardineros moriscos y sobre todo el jardín de un monasterio cristiano dedicado a María como lo demuestra la presencia de lirios y azucenas y sobre todo el Ave María repetido en las lacerías del templete.

Aquella dualidad que escindía y dividía el alma de la cristiandad de la península ibérica entre las construcciones sensuales del sur, musulmanas, y las procedentes del norte cristiano, en pugna constante durante toda la Alta Edad Media no pueden ser ignoradas como se hace en los estudios previos. La incomunicación cultural entre las diferentes culturas no sólo no existió sino que se dio todo lo contrario, una fluidez constante y duradera que es la que explica fenómenos como el de Guadalupe, no considerados fundamentales por las autoras de la restauración.

Respecto a la vegetación existente en el Claustro en la obra de Añón y las hermanas Luengo se afirma: "La plantación variada y desordenada que presentaba no correspondía a la concepción original del jardín, cuya lectura estaba completamente distorsionada por el crecimiento incontrolado de los setos de boj que contravenía su concepción espacial al ocultar gran parte del templete desde la galería. Todo ello condujo a realizar una restauración de características ambientales, manteniendo en lo posible la fuerza de sus elementos arquitectónicos, el sistema de riego y su propia estructura".

La restauración comenzó quitando tierra para lograr rebajar el nivel del terreno, elevado por los distintos aportes de los frailes a través del tiempo. Ello supuso la eliminación de la mayor parte de la vegetación existente. En una esquina permanece un pitosporo como testigo de la anterior plantación y del nivel del suelo. Las restantes se eliminaron con el objetivo de dar realce a la obra arquitectónica del templete. A éste además, se le rodea de un canal perimetral nuevo y los caminos que conducían al mismo desde las galerías son cubiertos de baldosas, haciéndose desaparecer los setos de boj viejo como ya comentábamos anteriormente y plantándose de manera incomprensible nuevos setos de boj. 
Tras estas operaciones de limpieza y nivelación del terreno se realizan las nuevas plantaciones de los cuadros. Para evitar la plantación "variada y desordenada" ya que no correspondía a la concepción original del jardín, se recurre a utilizar lacerías - diseño obtenido inspirándose en las lacerías del templete- para hacer una plantación uniforme mientras que fuera de los dibujos la plantación es a voleo. Se alejan los ejemplares altos -granados, árboles del amor y naranjos- del templete para no perturbar su visión y se plantan cerca de las galerías.

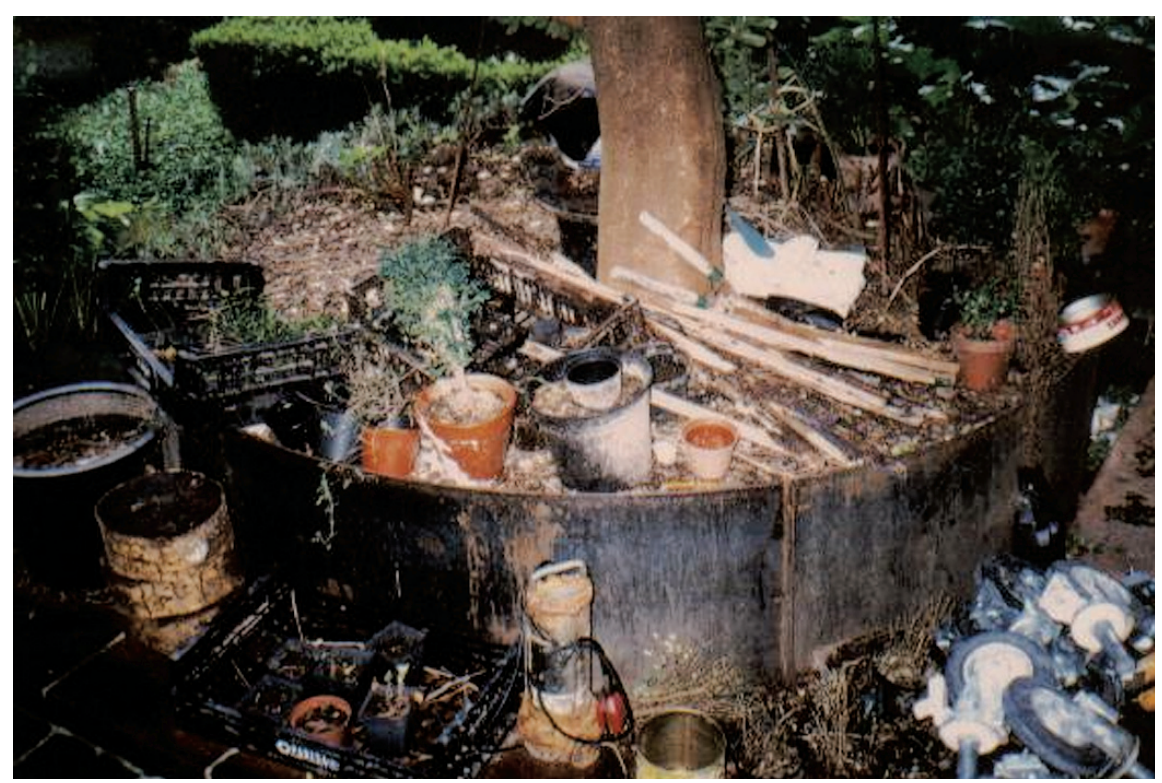

Tronco de evónimo con el cinturón de hierro que muestra el antiguo nivel del jardín (Foto del autor)

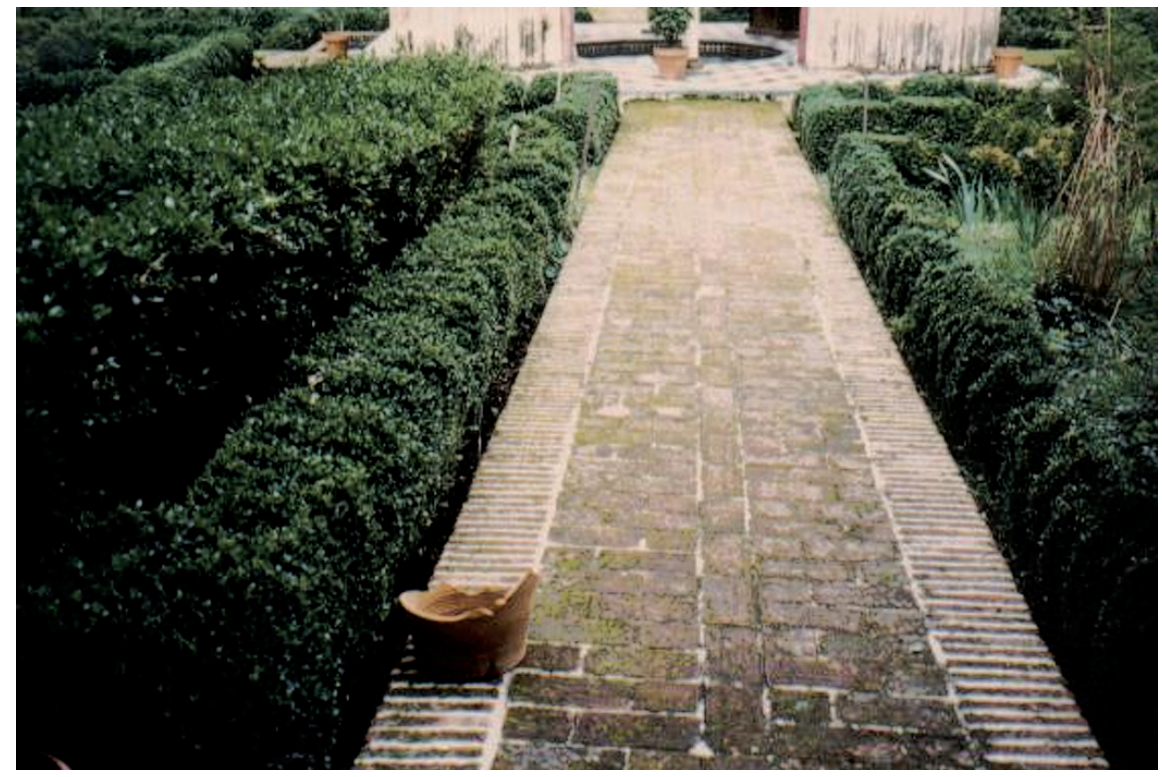

Los caminos embaldosados y los nuevos setos de boj de la reciente intervención. (Foto del autor) 
Las plantas utilizadas han sido seleccionadas tras un cuidadoso estudio histórico y simbólico. Las plantas tienen que ver todas con la Virgen María aunque algunas de ellas tengan su simbología un poco forzada ya que las referencias son sacadas de los autores de la Antigüedad Clásica y de las interpretaciones que los teólogos medievales hicieron de ellas. Más sentido tienen las obtenidas de las representaciones de los libros corporales existentes en el Monasterio. Estas son: ciprés, lirio, boj, clavellina, rosa, nardo, granado, vid, amapola, peonía, violeta, laurel, jazmín, iris, naranjo y mirto.

Lo que más sorprende de toda esta restauración es el empeño en negar la herencia hispanomusulmana en la vegetación utilizada en el claustro así como los modos de plantar y regar. Se afirma que mudéjar es la arquitectura pero no el resto de los elementos componentes del jardín. Este sinsentido que sirve de base al proceso de restauración ha conducido con el apoyo teórico de la Carta de Florencia y subvencionado por las industrias del armamento americanas a la destrucción de una de las joyas jardineras de los monasterios españoles que si bien no era bien original, mostraba la jardinería del siglo XIX anterior a la aculturación anglosajona.

Aquí, tras ver lo sucedió en esta intervención, nos viene a la memoria las palabras del Marqués de Lozoya (33) que no podemos dejar de citar: "En toda Europa hay claustros pero sólo en España guardan el sabor moruno de los jardines mediterráneos".

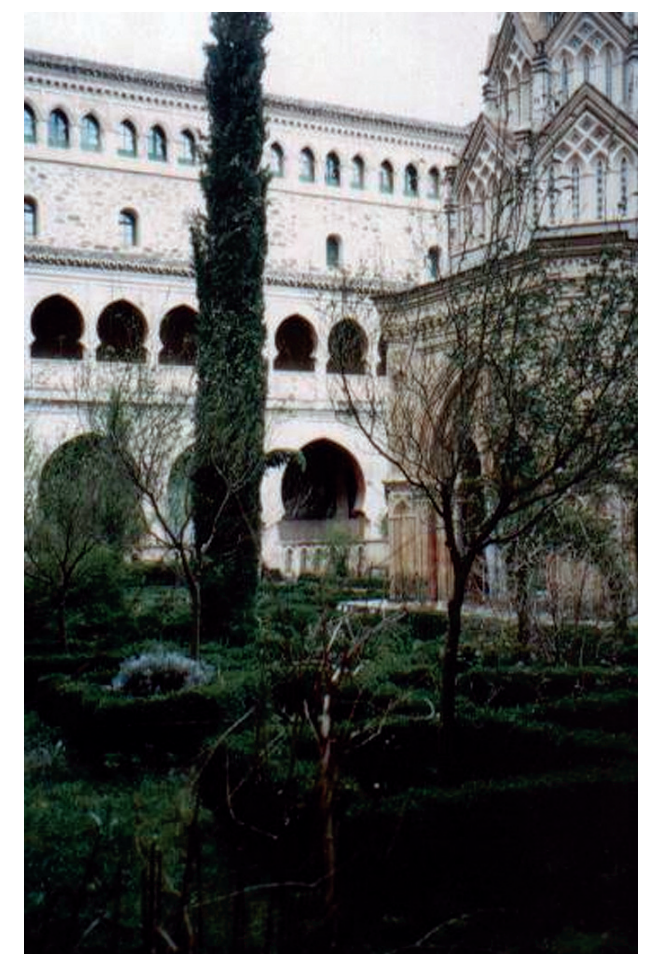

Otro aspecto del claustro de Guadalupe. (Foto del autor) 


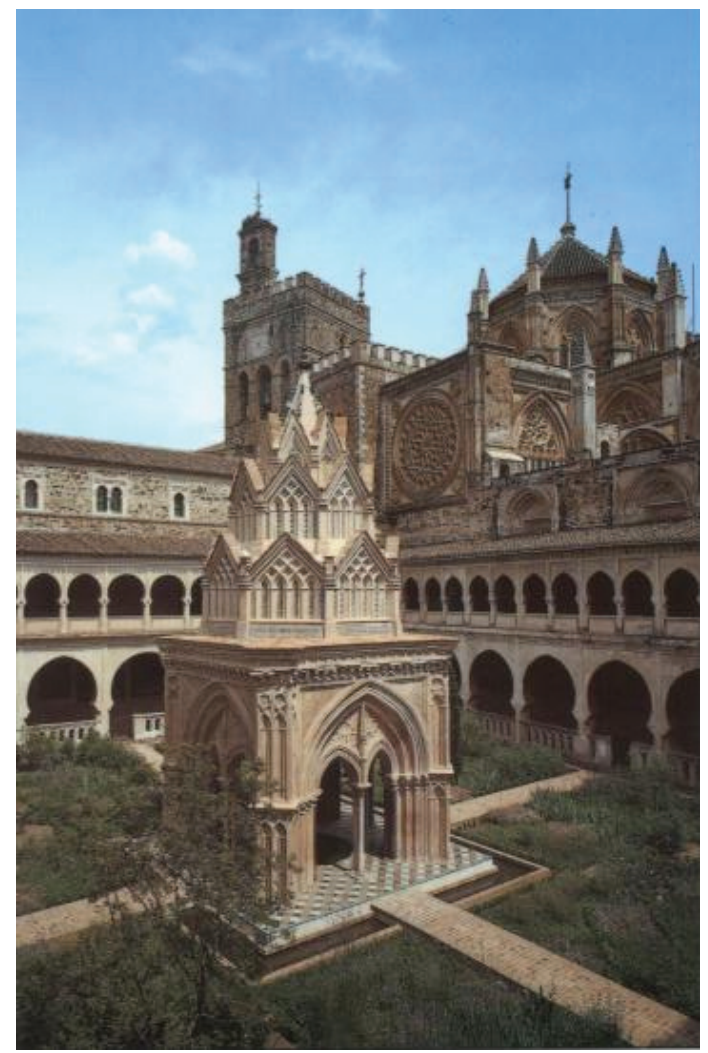

Vista del jardín del claustro tras la intervención en una tarjeta postal

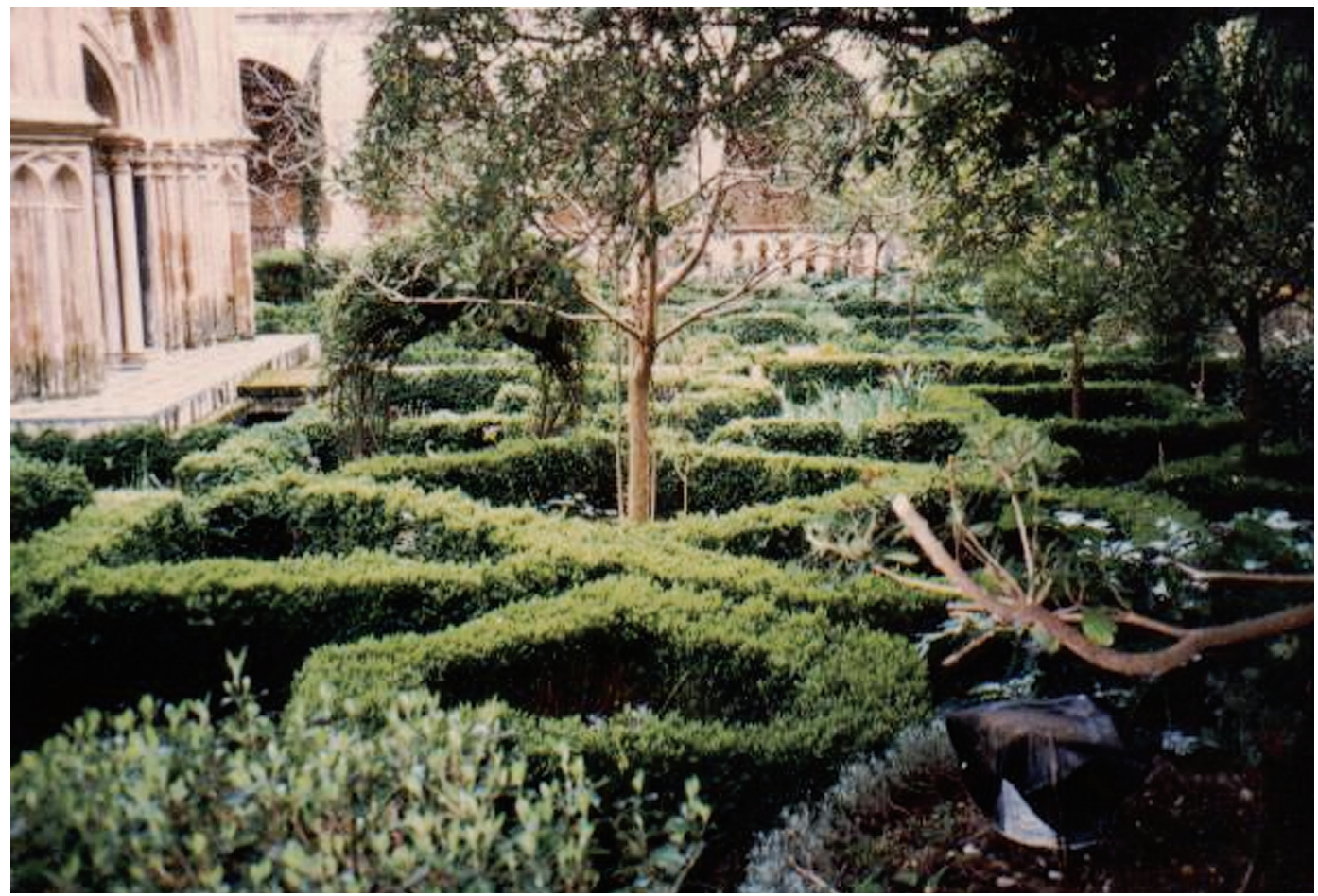

Lacerías del claustro de la reciente intervención. (Foto del autor) 


\section{Bibliografía sobre el claustro del Monasterio de Guadalupe}

ALVAREZ, Arturo. Guadalupe. Ed. Studium. Madrid, 1964.

El autor es uno de los frailes del monasterio. Historia del lugar con referencias a su larga existencia y numerosas anécdotas. Hay fotos anteriores a la restauración donde se ve cómo era el claustro y la vegetación que contenía en aquel momento. También hay un grabado de Laborde de principios del XIX donde se muestra la desnudez del lugar reproducido bajo estas líneas. Es interesante señalar que el monasterio estuvo sin frailes desde 1835 a 1905, período en el que fue hasta cuartel bebiendo las caballerías en la fuente del claustro de donde podemos deducir que el jardín que se restauró debió de plantarse a principios del siglo XX.

AÑON, Carmen. "Rehabilitación de los jardines del claustro mudéjar del Real Monasterio de Nuestra Señora de Guadalupe" en la revista Reales Sitios, núm. 123, primer trimestre de 1995. Páginas 17-32.

Repasa los orígenes de los claustros cristianos con innumerables referencias a los santos de la Iglesia. Desecha idea de orígenes hispanomulmanes de jardinería. Claustro cristiano. Simbología de las plantas. De todo esto deduce criterios a establecer para la rehabilitación.

AÑON, Carmen. "El Claustro: jardín místico-litúrgico" en El lenguaje oculto del jardín: jardín y metáfora, a cargo de Carmen Añón en Cursos de verano de El Escorial en 1995. Editorial Complutense. Madrid, 1996.

Es una repetición casi idéntica al artículo citado anteriormente de la revista Reales Sitios.

AÑon, Carmen, LUEngo, Mónica y LUENGo Ana. Jardines artísticos de España. Ed. Espasa Calpe. Madrid, 1995. Páginas 124-129.

Resumen de los artículos anteriores con buenas fotos del claustro.

CALLEJO, Carlos. El Monasterio de Guadalupe, libro XXI de la colección Los monumentos cardinales de España. Ed. Plus-Ultra. Madrid, 1958.

MARQUESA DE CASA VALDES. Jardines de España. Ed. Aguilar. Madrid, 1973. Páginas 82-83. Cita la Marquesa unas líneas de otra obra del Marqués de Lozoya, la Historia del arte hispánico de 1931 de la editorial Salvat que reproducimos por su interés:"Lo más característico de Guadalupe es el gran claustro en el que se adaptan con singular y bello efecto las formas almohades a la disposición monástica. En el ángulo noroeste hay, como en los claustros del Císter, un templete para el lavabo con pavimentación de alicatado. Lo más interesante es el edículo central, construido hacia 1405, en el que los monjes quisieron imitar, con ladrillos revocados de cal, una construcción gótica de piedra. El mudejarismo aparecía en los lazos moriscos y en los azulejos azules y verdes de las albanegas, y es hoy día más patente al haber quedado al descubierto el ladrillo en toda la parte superior”.

SARTHOU CARRERES, Carlos. Monasterios monumentales de España. Valencia, 1951.

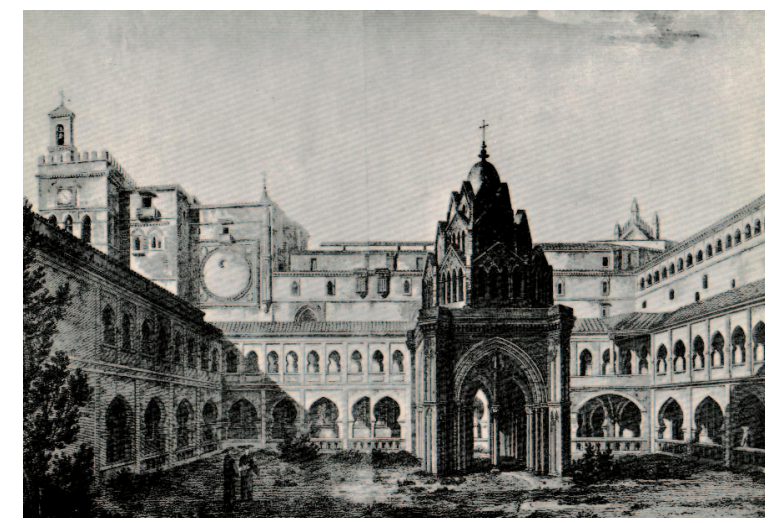




\section{e) Los Jardines del Buen Retiro en Madrid}

Como hemos hecho en anteriores capítulos, antes de ocuparnos del plan de rehabilitación llevado a cabo por el Ayuntamiento de la ciudad de Madrid en este jardín por ser su propietario, pasaremos a realizar un breve bosquejo de la historia del lugar para facilitar la comprensión de las argumentaciones que serán expuestas en contra del citado plan.

El jardín -como se ha estudiado recientemente (34)- fue edificado por el Conde-Duque de Olivares con la finalidad de entretener y alejar de los asuntos del gobierno al rey Felipe IV en las décadas de 1630-40.

El trazado fue obra de los italianos Crescenzi y Cosme Lotti, éste último colaborador de Bernardo Buontalenti en los jardines Bóboli de Florencia. Los jardineros acudieron de Aranjuez y Sevilla así como de Génova y los Países Bajos. Sin embargo, los jardines muestran la falta de un proyecto global debido a la manera improvisada en que se fueron construyendo a base de ir añadiendo partes nuevas a lo ya realizado. Los estudiosos norteamericanos citados señalan que " pese a estos retoques de influencia extranjera, en comparación con los modelos italianos el parque del Retiro resultaba deshilvanado en su composición y organización. La falta de unidad y de coherencia era fruto del azaroso crecimiento del solar, pues continuamente se iban adquiriendo nuevos terrenos en los que se erigian nuevas construcciones"(35).

La otra estudiosa del recinto, Carmen Ariza (36) sigue este argumento cuando señala la falta de un eje dominante o una idea proyectual que ordene todo el conjunto por lo que "todo ello producía un recorrido laberíntico". Hecho explicado, como anteriormente señalábamos, por la forma en que son adquiridos los terrenos poco a poco lo que condiciona la construcción, siempre acometida a base de sucesivas ampliaciones. Los mapas de Pedro Texeira de Madrid de 1656 y la pintura de Jusepe Leonardo del Retiro en 1636-37 conservada en el Palacio de Oriente nos permiten apreciar estas afirmaciones. Solamente las zonas más cercanas al palacio muestran jardines formales así como la parte del Jardín Ochavado dotado de un diseño de plaza central de la que partían ocho caminos cubiertos de celosías con trepadoras que conducían a las diferentes zonas del jardín. El resto del jardín estaba formado, según señala Carmen Ariza (37) “por diferentes recuadros yuxtapuestos, formados por simples alineaciones de árboles, entre los que abundaban los frutales (avellanos, cerezos, guindos, membrillos, ciruelos, perales, manzanos, naranjos de Valencia, almendros de Andalucia, entre otros muchos) y los de sombra (moreras, álamos, laurel, además de otros)".

(34) BROWN, Jonathan y ELLIOTT, John. H. Un palacio para el Rey. El Buen Retiro y la corte de Felipe IV. Ed. Alianza Forma. Madrid, 1981.

(35) BROWN, Jonathan y ELLIOTT, John H. Obra citada, página 80.

(36) ARIZA MUÑOZ, Carmen. Los Jardines del Buen Retiro, dos tomos. Ed. Lunwerg. Madrid, 1990.

(37) ARIZA MUÑOZ, Carmen. Obra citada. Página 45. 
Con la llegada de la nueva monarquía de los Borbones de la mano de Felipe V, el Retiro va a conocer la desaparición del Jardín Ochavado, siendo sustituido por el parterre, único jardín francés del recinto que nos ha llegado casi como fue realizado ya que tan sólo conoció una reforma el siglo XIX. Será otro rey Borbón, esta vez Carlos III, quien realizará reformas importantes como las rejas que todavía existen de la calle Alcalá y otras construcciones desaparecidas de tipo práctico como la Real Fábrica de Porcelana.

Durante la invasión francesa, el Retiro fue elegido por las tropas invasoras como el cuartel general de la capital de España con lo cual es fácil imaginarse cómo quedó tras este período: completamente destrozado. Fernando VII lo reparó y dedicó importantes sumas a esta causa vendiéndose el hielo y las leñas de la poda para obtener fondos para su mantenimiento y ayudar a sufragar los gastos de las reparaciones. El jardín que había sido abierto al público algunos días durante el reinado de Carlos III con la condición de mantener unas estrictas normas de decencia y urbanidad siguió conservando esta costumbre. No obstante, el Rey mantuvo para uso privado algunas partes conocidas como "el Reservado". En este lugar, construyó edificaciones disparatadas conocidas como "follies" o caprichos de las que aún se conservan algunas de ellas como la montaña de los gatos, la casita del pescador o la vaquería transformada esta última en sala de fiestas o algunas de mayor utilidad como el Real Gabinete Topográfico cuyo director León Gil de Palacio realizaría la maqueta del Real Sitio en 1830 que todavía podemos apreciar en el Museo Municipal de Madrid.

Por los planos existentes, vemos que la reconstrucción de la zona del reservado así como la del resto de lugares reconstruidos durante este período se trazaron según las nuevas corrientes de la jardinería paisajista basadas en el diseño de caminos sinuosos dentro de un conjunto ordenado por grandes trazados geométricos en los que todavía se mantenían zonas de huertas.

Igualmente se plantaron gran variedad de árboles: catalpas, falsas acacias, gleditzias, chopos, plátanos de Indias y frutales seguramente para contrarrestar el

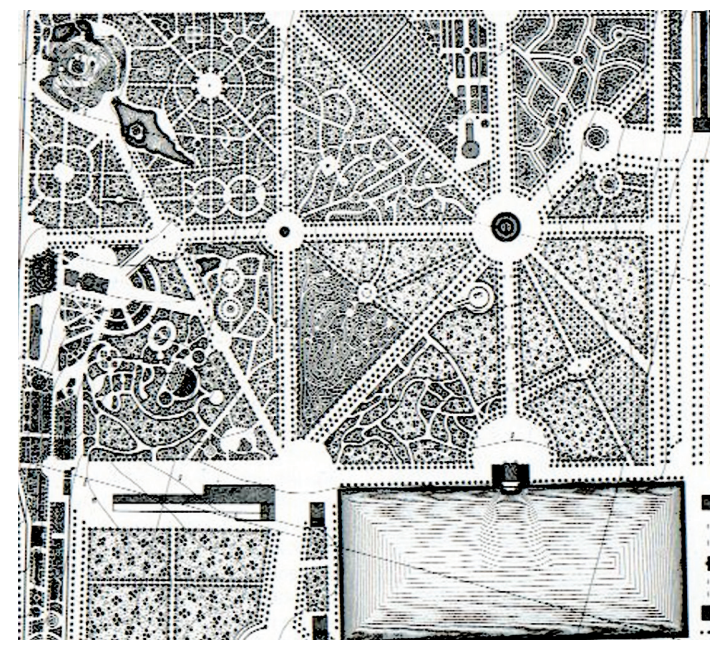

La zona del Apartado creada por Fernando VII tras la Guerra de la Independencia 
vacío producido por la muerte de los grandes olmos atacados por la enfermedad conocida entonces como "el escoillo".

Durante la primera fase del reinado de Isabel II, gobernando Narváez, la zona del reservado recibió especiales atenciones y sabemos a través de los informes de Fernando Boutelou, jardinero mayor del lugar, que en esta parte existían, además de las plantas traídas de otros jardines del Real Patrimonio, otras procedentes de Francia, Alemania y América septentrional lo que explicaría la presencia aún hoy de la gran variedad de árboles y arbustos del jardín.

Hacia el final del reinado de la soberana, empiezan a sustituirse los frutales, viñedos y otras plantaciones de flor cortada por árboles de sombra y plantas de adorno con el objeto de ahorrar los jornales de los empleados que trabajaban en dicho lugar. Lo mismo se realizó con el resto de la posesión donde las nuevas intervenciones siempre siguieron los trazados sinuosos de las nuevas corrientes jardineras.

Todas estas intervenciones, más las obras y añadidos históricos que el jardín poseía hicieron decir a Gustavo Adolfo Bécquer que el jardín tenía el carácter de un jardín "omnibus", es decir, para todos, por la gran variedad de escenarios diversos que mostraba en su superficie (38).

Con la revolución de 1868 que destrona a Isabel II, el Retiro pasa a ser propiedad del Ayuntamiento y se convierte en el primer parque de la ciudad "cedido para recreo, higiene, instrucción y moralidad de la población”. Hay que añadir que una parte del jardín había sido vendido por la reina Isabel. Tal parte es la que corresponde desde la actual calle de Alfonso XII hasta el paseo del Prado. Pertenece a este período (1877-78) la transformación del Campo Grande en jardines de trazado paisajista realizada por Eugenio de Garagarza, lugar donde posteriormente se instalarán los pabellones de Velázquez y de Cristal, acentuándose de nuevo las trazas irregulares tan de moda en la jardinería de la Europa del momento.

El Ayuntamiento consiguió poco a poco incrementar el arbolado a través de nuevas plantaciones y evitando la tala de los ejemplares existentes que con cualquier pretexto se realizaba, utilizando como excusa los nuevos usos recreativos que el jardín iba recogiendo. Disponemos de referencias por las que conocemos el estado del parque en este período. En la Guía de Madrid de Fernández de los Ríos nombra alguna de las especies más abundantes en el lugar. Igualmente en el libro de Celedonio Rodrigañez El arbolado de Madrid de 1888 encontramos una relación numérica de las especies más importantes, destacando en primer lugar los casi 130.000 olmos, hoy prácticamente desaparecidos por la grafiosis que padecieron estos árboles a finales del siglo XX (39).

(38) ARIZA MUÑOZ, Carmen. Obra citada, página 130.

(39) Otros árboles que se citan en esta obra son: acacias: 3.138: ahylantos, 1.852; áceres, 1.337; álamos, 1; amores, 382; almeces, 570; alcornoques, 6; algarrobos, 1; almendros, 5.310; abedules, 7; amyris, 7; avellanos, 4; Castaños de Indias, 435; catalpas, 109; cedros, 59; carpes, 20; cipreses, 743; cinamomos, 2; chopos, 169; eucaliptus, 1; encinas, 1.546; fresnos, 1.066; gleditseas, 1.653; guayacanas, 18.811; laureles, 8; moreras, 1.437; nogales, 132; olmos, 129.393; olivos, 79; pinos, 2.557; plátanos, 477; paulonias, 7; paraísos, 34; pacanos, 87; pinsapos, 88; quejipo, 1; raigón de Canadá, 228; robles, 2.844; saucos, 173; tilos, 245; tuyas, 1.607; tulipanes, 2; y welingtonias, 184. 
Tras la Guerra Civil, se hace un inventario de la vegetación existente en el jardín dando el siguiente resultado: 31.909 arbustos y 49.609 árboles. Cifras sorprendentes si las comparamos con las de finales del siglo anterior y todavía más sorprendentes si las volvemos a comparar con las de hoy día: unos 20.000 arbustos y cerca de 30.000 árboles. Es decir, se ha pasado de los 177.197 ejemplares arbóreos de 1888 a los arriba mencionados. Como se puede apreciar ha habido en un siglo una disminución enorme en lo que respecta al número de ejemplares.

El siglo XX por otra parte, va a ver la continuidad de esa moda de añadir estatuas y demás construcciones artísticas o recreativas al jardín. En 1915 se crea la Rosaleda, influenciada por las existentes en Europa, a cargo de Cecilio Rodríguez que tendrá que ser rehecha tras la Guerra Civil. Esta contienda tendrá consecuencias negativas sobre el parque que conocerá la tala de árboles y el abandono de los cuidados más básicos debido a la situación que se vive en aquellos momentos en la ciudad.

Este notable descenso cuantitativo de la masa vegetal del jardín se debe, al margen de las enfermedades sufridas por el arbolado, fundamentalmente, al cambio de criterios en lo que respecta al diseño de los diferentes espacios del jardín ocurrido a partir de los años sesenta del siglo XX. Tal cambio perdura en la actualidad y ha consistido en la supresión de las masas de arbustos y árboles dentro de los cuadros a favor de las praderas de césped con la excepción de algunos arreglos puntuales como los del Parterre. Incluso los nuevos ajardinamientos de la zona sur, lo que eran los antiguos eriales, han visto como se realizaba la sorprendente combinación de almendros rodeados de praderas de césped.

A la degradación del parque contribuyeron además otras causas. El antiguo Real Sitio, en los años 80 del siglo XX, siendo alcalde Enrique Tierno Galván, es abierto por la noche lo que conduce a una veloz destrucción de algunas de las zonas del jardín por su utilización abusiva al margen de las normas más elementales del respeto y la urbanidad. Igualmente, el jardín pasa a ser un lugar comodín para la celebración de actividades multitudinarias tales como la Feria del Libro, marco de fiestas patronales, etc., que producen un deterioro real de las zonas ajardinadas por la desbordante masificación de esta clase de actos.

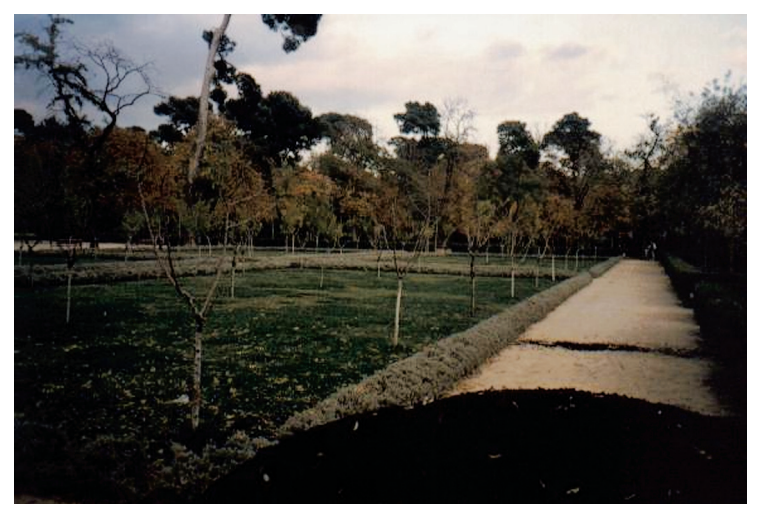

Recientes plantaciones: almendros con praderas de césped. (Foto del autor) 
Esta degradación causó en el Ayuntamiento la lógica preocupación y ello condujo a la elaboración de un plan de rehabilitación que originó una profunda polémica entre diversos colectivos sociales acusando algunos de ellos al Ayuntamiento de malgastar el dinero público con los estudios previos en la elaboración del mismo. Igualmente se dijo que dicho plan contribuiría a la degradación del parque más que a su recuperación ya que se fomentaba la implantación de praderas y riegos por aspersión a costa del riego tradicional a manta así como por la eliminación de las densas plantaciones de árboles y arbustos en el interior de los cuadros.

Como ejemplo de esta polémica y por la importancia de los datos que aporta de cómo era el jardín antes de la llegada de las reformas de Arias Navarro, veremos una carta al director aparecida en el periódico El País de fecha 24 de agosto de 1989 firmada por Víctor J. Puente que reproduciremos por su valor testimonial. La letra negrita es añadido nuestro" Leo en el periódico (día 18 de agosto) de su dirección, un reportaje sobre la alarmante situación del Retiro por la falta de atención y sobre todo de riego, y me viene al recuerdo otro informe sobre el mismo tema que lei en otro diario hace aproximadamente un mes.

Si el motivo de la demora en el tratamiento del tema fuese el intento de hacer más responsable de la situación al nuevo gobierno municipal, como en algún fragmento del artículo parece, quisiera modestamente tratar de señalar el momento en que para mí se produjo la causa del actual deterioro. Quisiera recordar aquí a sus lectores la antigua concepción del parque, estructurado en polígonos delimitados por aligustre en cuyo interior se encontraban los árboles y arbustos. El suelo de estos polígonos estaba labrado y el riego tenía lugar mediante un sistema de canales que cubrían todo el área del parque. Estos polígonos delimitaban una red de paseos de tierra (hoy muchos de asfalto) y eran prácticamente inexistentes las praderas de césped.

La densidad del arbolado era bastante mayor que ahora, por lo que, salvo en los grandes espacios abiertos como el estanque o el Palacio de Cristal, una gran parte de la superficie del parque permanecía en umbría, con la consiguiente menor pérdida de humedad por efecto del sol.

Fue en el año 1968 -lo presencié en directo -, siendo alcalde de Madrid el señor Arias Navarro, cuando se transformó radicalmente nuestro Retiro. Se taló un gran número de árboles para hacer las actuales praderas, inspirándose sin duda en los parques londinenses. Esta transformación fue aplaudida en la época, como otras realizaciones del citado alcalde, al que se dio fama de modernizador de Madrid (supresión de tranvías y bulevares, demolición de palacetes de la Castellana, scalextric, etcétera). Sin ser un técnico en la materia, pienso que en Londres es la humedad ambiente la que mantiene las praderas de césped, mientras que en Madrid es preciso aportar grandes cantidades de agua que por suerte o por desgracia no tenemos.

¿Tendrá que ver esa transformación, sin duda poco estudiada y apoyada en el esnobismo de la época, con la actual degradación de nuestro querido parque? Cuesta creer que haya sobrevivido varios siglos, con sequías posiblemente más graves que las actuales y sin los cuidados y conocimientos técnicos de nuestra época. 
¿No esteremos pagando ahora la factura de la metedura de pata de 1968? Si así fuese, debería actuarse como se ha hecho ante otras modernidades del señor Arias (scalextric de Atocha, conservación de antiguas fachadas y los escasos bulevares supervivientes). ¿Sería más costoso devolver el Retiro a su estado original que desmontar el paso de Atocha? Al menos reflexionemos sobre el tema”.

A pesar de la polémica existente, el plan de rehabilitación siguió su curso y los resultados del mismo se pueden observar en las fotos tomadas recientemente que muestran la transformación de un jardín decimonónico de densa vegetación en otro con superficies de limpias praderas despejadas de la antigua vegetación compacta, abandonándose además el sistema antiguo de riego a favor de la aspersión.
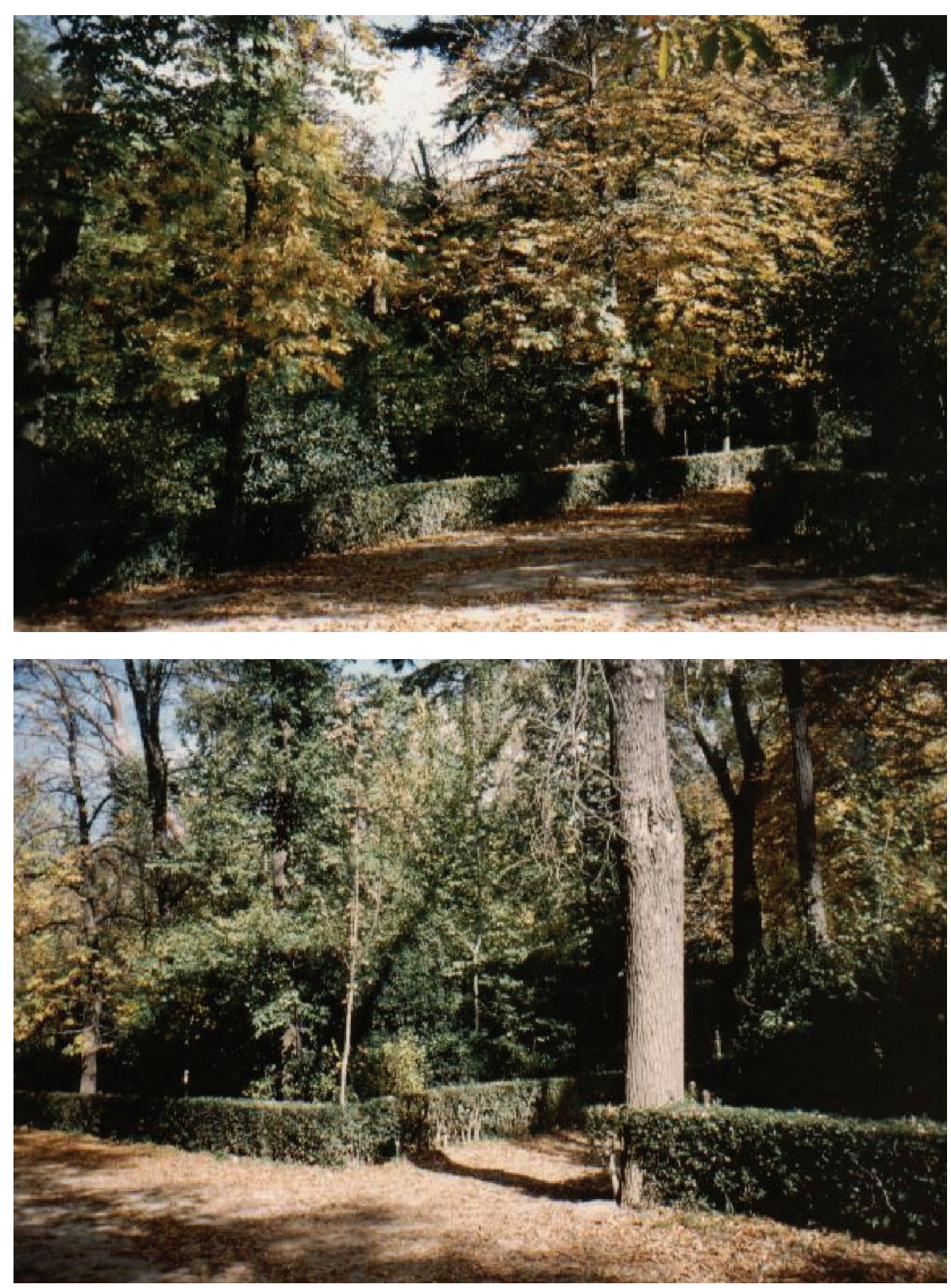

Imágenes de zonas del Retiro sin haber sido restauradas. (Fotos del autor). Año 2000 
Si el tema de fondo es evitar que el Retiro se convierta en un refugio de elementos variopintos que acuden al lugar a hacer lo que no se atreven a realizar en su casa o calle, la solución no es arrasar el jardín, sino volver a cerrarlo por la noche como estuvo durante siglos. Al fin y al cabo, el Retiro no es un parque urbano convencional, sino un parque que tiene la clasificación de Jardín HistóricoArtístico desde 1935 y resultado de haber sido el parque de los reyes de España

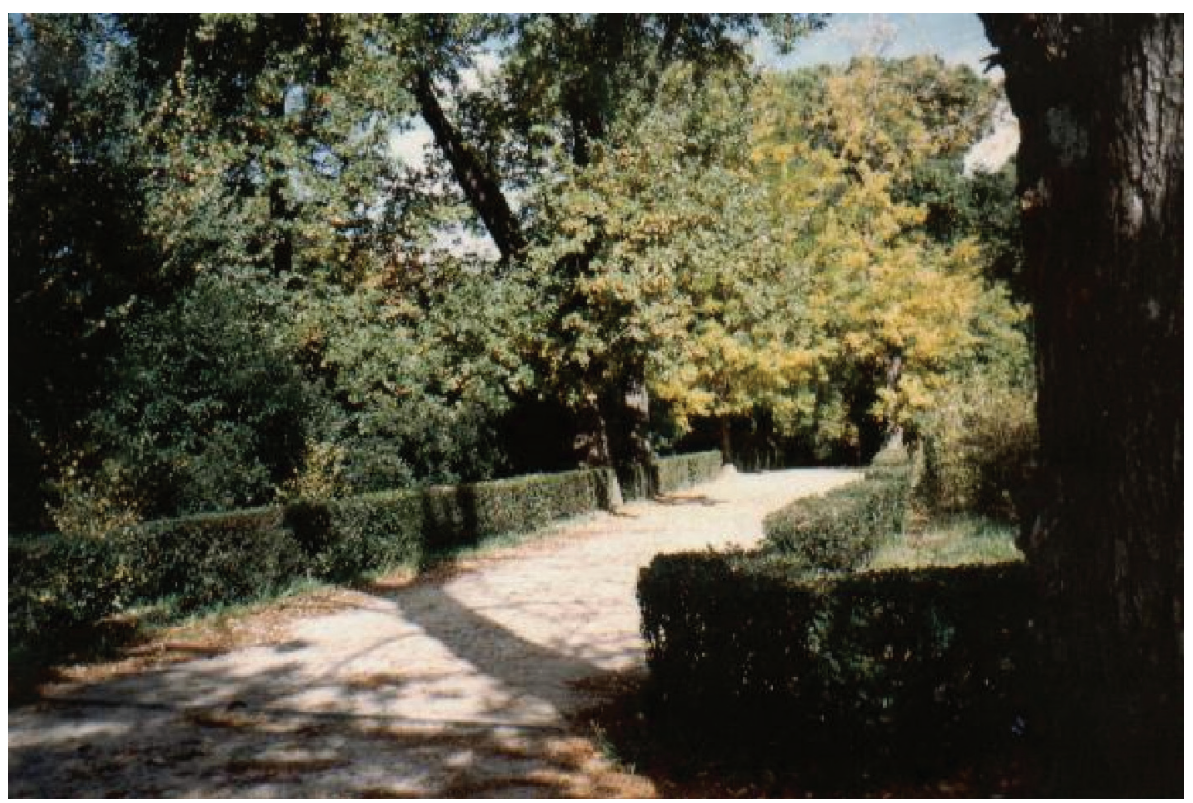

Otra de las zonas sin restaurar. Otoño del 2000. (Fotos del autor)

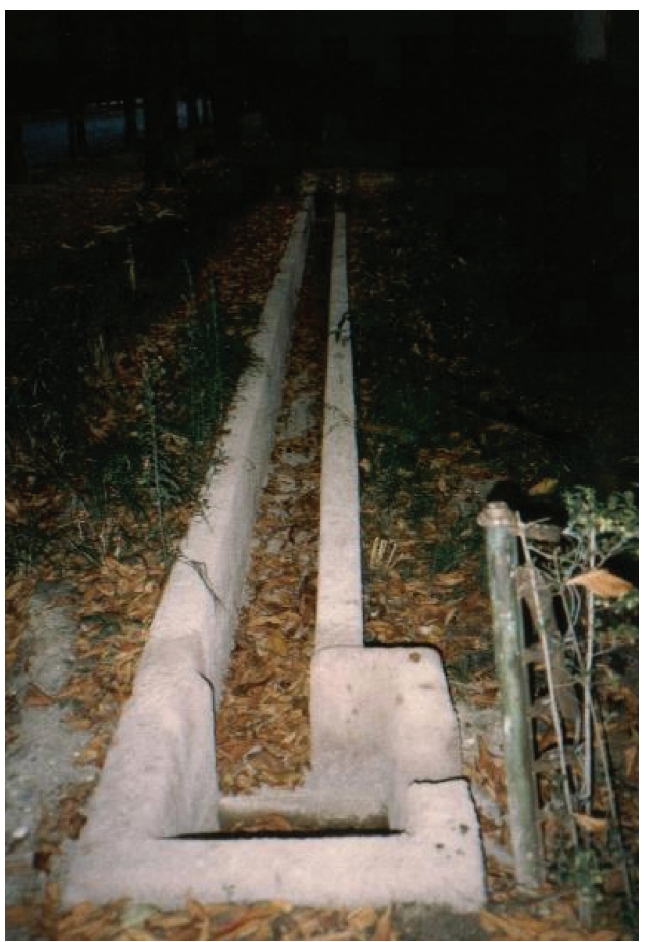

Una de las acequias del sistema antiguo de riego. (Fotos del autor) 
durante varios siglos donde se han ido acumulando testimonios históricos y artísticos de enorme valor. Tras todo lo expuesto, queda un tanto esperpéntica la declaración de Criterios de Actuación del citado plan municipal el cual reproducimos para compararlo con los resultados obtenidos: El objetivo de los trabajos emprendidos en el Plan de Rehabilitación de los Jardines del Buen Retiro es recuperar la identidad del jardín consolidando la estructura básica de paseos y plazas. El estudio de la evolución histórica es el punto de referencia para definir el diseño a realizar. La decisión final será el resultado de sopesar lo existente, la historia y el uso de la unidad ambiental.

Una vez analizado el carácter de cada zona se elabora el proyecto cuya ejecución material se hará con materiales existentes ya en el jardín o bien con las innovaciones que ayuden a reducir los costos de mantenimiento. La instalación del riego automático facilitará sin duda el mantenimiento de praderas y arbolado.

El arbolado es principalmente caduco y muy denso produciendo umbría en verano y soleamiento en invierno.

Durante los últimos años el arbolado de los jardines ha sufrido grandes pérdidas debido a la desaparición de casi la totalidad de los Olmos a causa de la Grafiosis y a los daños acaecidos por el vendaval del año 1991. En consecuencia se están incrementando las plantaciones que se venían realizando.

Existen en los jardines 19.813 árboles y 3.355 grandes arbustos. La especie predominante en la actualidad es el Castaño de Indias (Aesculus hippocastanum) con 7.033 árboles.

En combinación con los trabajos y proyectos de recuperación de las zonas, se ha desarrollado un programa para la mejora de la masa vegetal con los siguientes objetivos:

- Conocer las características y estado fitosanitario de la masa arbórea y arbustiva.

- Desarrollar un programa de gestión para la recuperación del arbolado. Con las conclusiones y los datos de este estudio se ha puesto en marcha un programa de gestión del mismo basado en el análisis del estado de cada uno de los árboles y una propuesta de los trabajos que son necesarios para su recuperación.

Si tuviéramos que hacer un resumen de lo que está sucediendo en el Retiro, tendríamos que decir que es una lamentable actuación que está produciendo la transformación/destrucción de un jardín típico de la jardinería clásica española en un conjunto de praderas monótonas, una vez más síntoma de la aculturación proveniente del mundo anglosajón que sufrimos en tantos aspectos de nuestro entorno social, económico, político y sobre todo, cultural. 


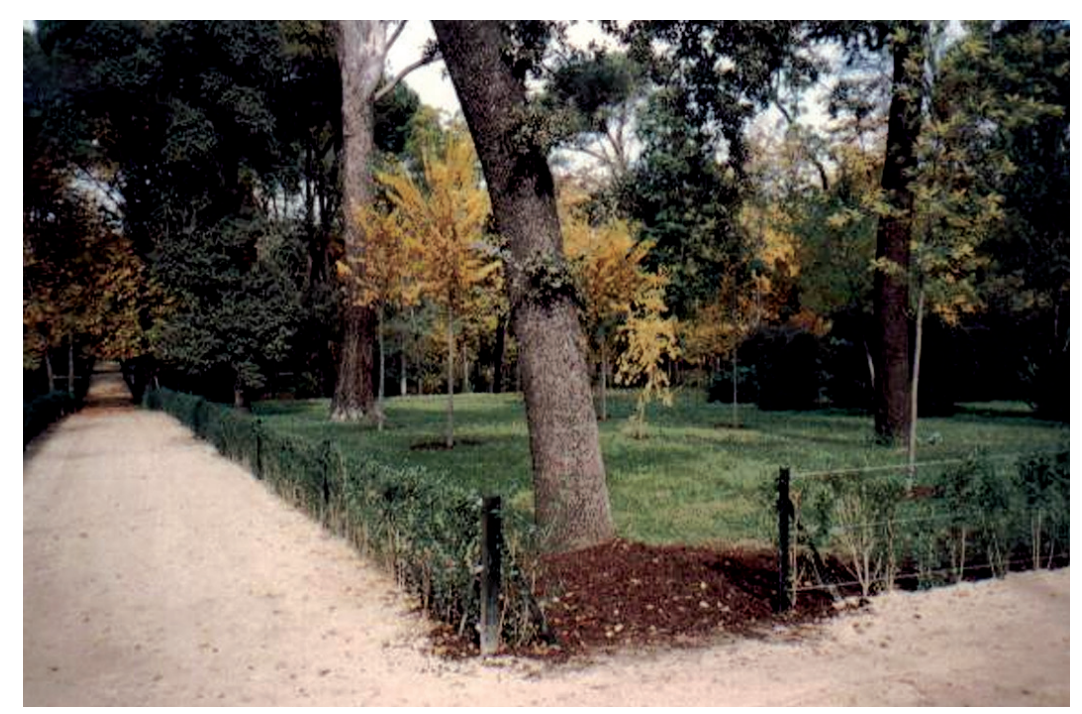

Aspecto de los cuadros tras la reciente restauración. (Fotos del autor)
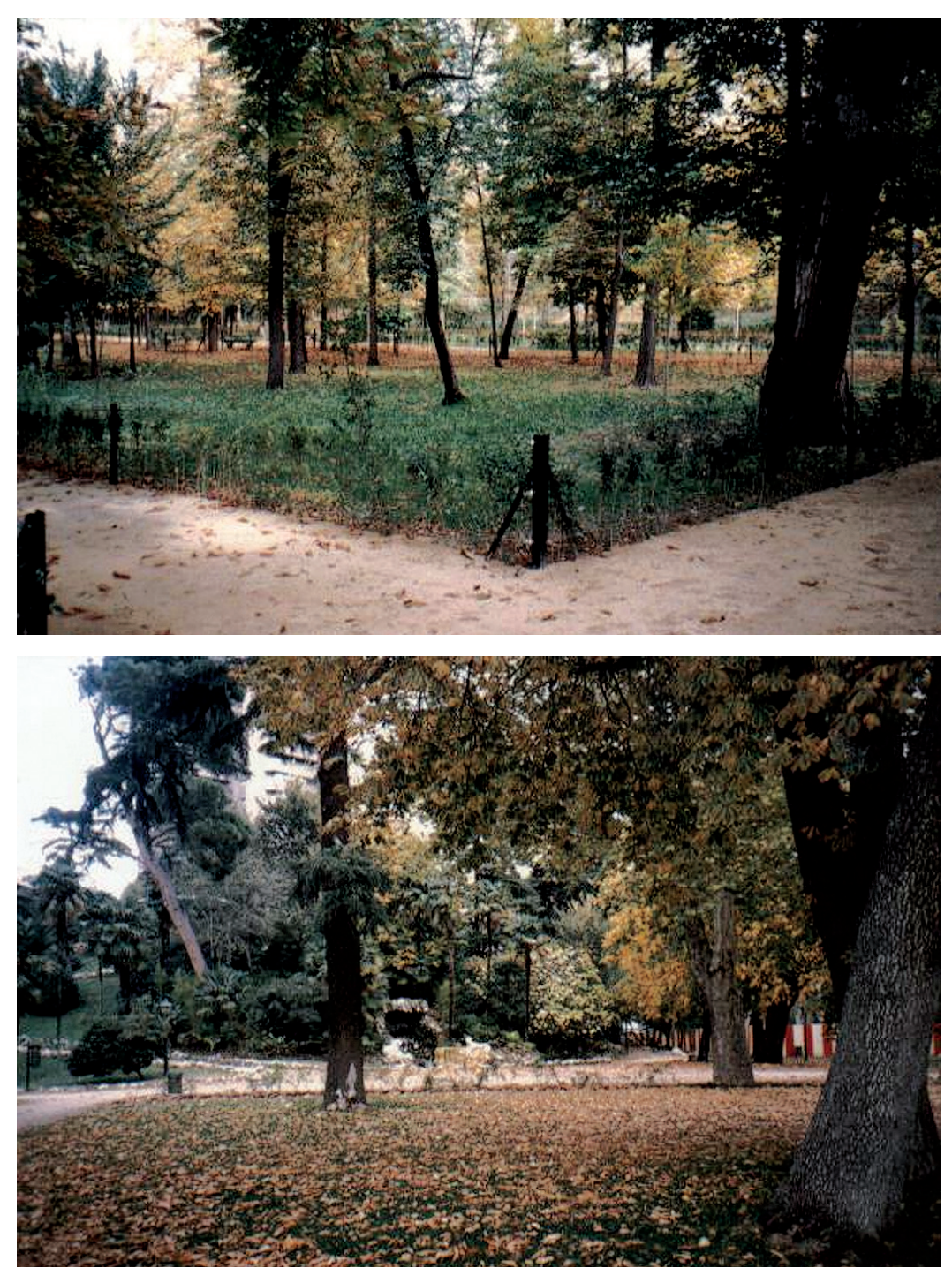

Otras imagenes de los resultados de la última intervención. (Fotos del autor) 


\section{Bibliografía sobre el Parque del Retiro de Madrid}

ARIZA NUÑOZ, Carmen. Los Jardines del Buen Retiro, dos tomos. Ed. Lunwerg. Madrid, 1990. Ayuntamiento de Madrid.

La mejor monografía sobre el lugar hasta la fecha sobre la historia del jardín y de los cambios sucedidos en el mismo hasta la Guerra Civil. La degradación sufrida por el parque en la segunda mitad del siglo XX no es tratada.

ARIZA MUÑOZ, Carmen. El Buen Retiro en la serie Parques y Jardines de Madrid, edición a cargo de Carmen Añón. Ed. El Avapiés. Madrid, 1994.

Es un resumen del libro anterior y no aporta nada nuevo. Aunque se cita ya el Plan de Recuperación Integral, no se para a analizarlo.

BROWN, Jonathan y ELLIOTT, John H. Un Palacio para el Rey. El Buen Retiro y la corte de Felipe IV. Ed. Alianza Forma. Madrid, 1981, 1985.

Contexto histórico en que se analiza el cómo el jardín es creado junto al casi desaparecido palacio. Se tratan los artistas, políticos y escritores que tuvieron algo que ver con el lugar que adquiere en aquellos momentos el carácter de símbolo de la monarquía

GUERRA DE LA VEGA, Ramón. Jardines de Madrid. I. El Retiro. Edición a cargo del autor. Madrid, 1983.

Encomiable y valioso trabajo que fue hasta la aparición del libro de Carmen Ariza el mejor documento de síntesis de la historia del jardín.

MARTIN MARTIN, Luis. Arboles del Retiro. Edición del Ayuntamiento de Madrid. 1. Colección Cuadernos. Tercera Tenencia de Alcaldía. $1^{\mathrm{a}}$ ed. enero de 1985. $2^{\mathrm{a}}$ ed. abril de 1990. Madrid. Relación de los principales árboles del jardín. 


\section{D.2.3.3. Jardines restaurados en la Comunidad Valenciana}

\section{a) El Jardín Botánico de Valencia}

En primer lugar, haremos un breve resumen de la historia del Jardín desde su creación en 1802 hasta la inauguración del nuevo edificio de investigación en el año 2000. La historia del mismo se puede estudiar de un modo más extenso en las publicaciones existentes sobre el tema (40).

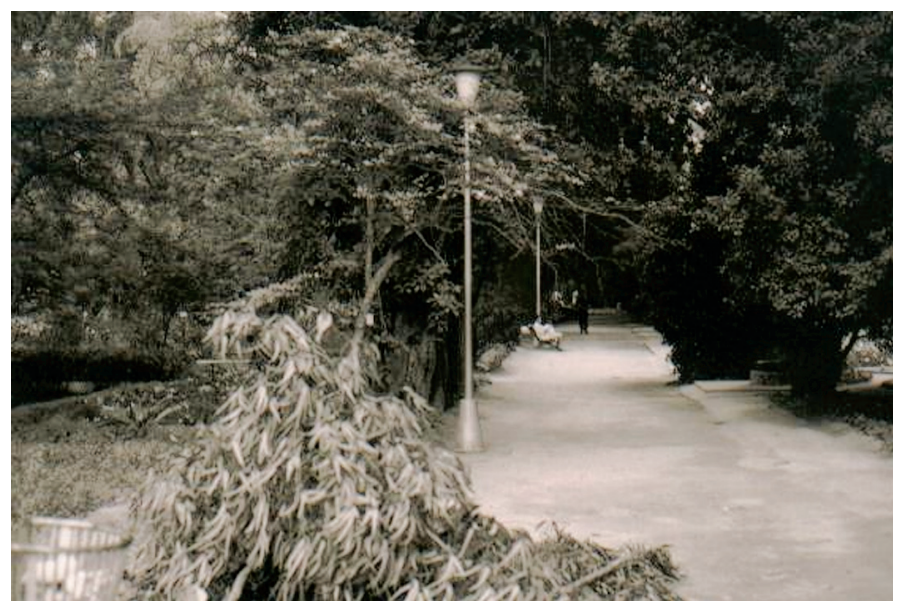

El Jardín Botánico por los años 80 del pasado siglo. (Foto del autor)

Los orígenes del actual Jardín Botánico se remontan a 1802, siendo rector de la Universidad Vicente Blasco. En 1805 es nombrado director Vicente Alfonso Lorente.

Los objetivos que el Jardín se marca son el conocimiento de las plantas, de sus utilidades y propiedades por lo que se dedicará a la aclimatación de cualquier especie que tenga interés económico y medicinal. Intereses relacionados con los impulsos de renovación científica fomentados por la monarquía ilustrada de los Borbones.

Como consecuencia de la invasión francesa de 1811 el Jardín queda completamente arrasado, estado del que no se recuperó hasta 1829 en que José Pizcueta Donday fue nombrado director. Pizcueta, botánico de formación, se propuso levantar el Jardín, hecho que consiguió en su largo gobierno (1829-1863) a lo que sin duda contribuyó su nombramiento de rector en 1859.

El Jardín vio el incremento de las colecciones, la nueva ordenación de la Escuela Botánica según el método de Endlicher, la construcción de estufas e inver-

(40) DOCAVO ALBERTI, Ignacio. Guía del Jardín Botánico de Valencia. Institución Alfonso el Magnánimo. Diputación Provincial de Valencia. 1977. VV AA El Jardín Botánico de la Universidad de Valencia. Edición a cargo de Manuel Costa y Jaime Güemes. Publicaciones de la Universidad de Valencia. Valencia, 2001. 
naderos para el cultivo de nuevas especies así como la publicación del primer catálogo de semillas de las plantas existentes en el Jardín en 1862.

Durante la segunda mitad del siglo XIX, el Jardín va a ser dirigido por los responsables de la novedosa cátedra de Historia Natural, ninguno de ellos botánico sino zoólogos: Rafael Cisternas (1867-1876); José Arévalo Baca (1876-1888) y Eduardo Boscà (1888-1913).

En el período de dirección de este último se hacen nuevas construcciones como la estufa de la balsa y el gran umbráculo frente al edificio de la antigua dirección. Hay que señalar que durante parte de ese siglo, el Jardín se dedicó a experimentar nuevos cultivos agrícolas para su posterior introducción en los campos que rodeaban la ciudad con fines comerciales. La relación de plantas que el Diccionario de Madoz recoge es una muestra de la importancia de dicha actividad en ese momento.

Durante la primera mitad del siglo XX, el Jardín es dirigido por Francisco Beltrán, botánico, cuyos esfuerzos y trabajos se vieron destruidos con la riada del 57.

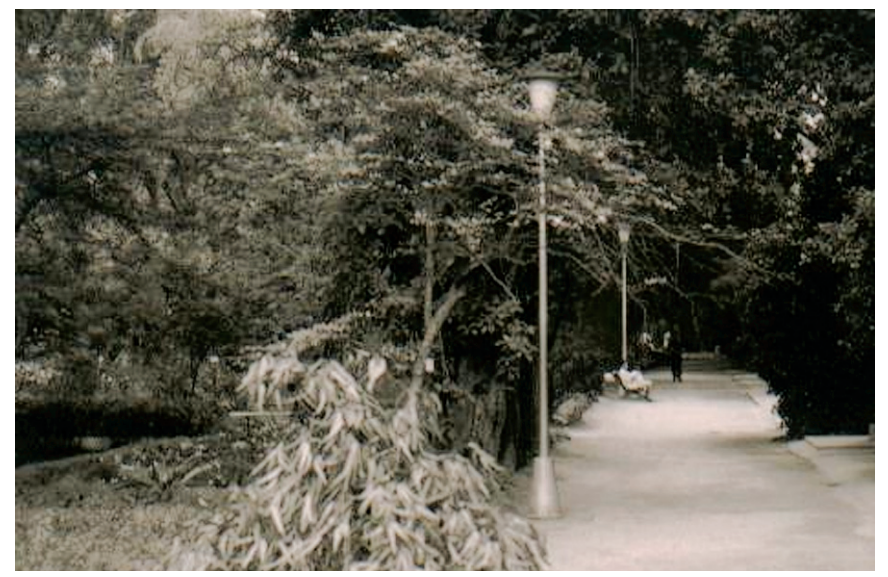

El Jardín Botánico antes de la riada del 57. (Foto procedente de la obra de Sarthou Carreres "Jardines de España: Valencia")

A su muerte en 1962, el Jardín vuelve a las manos de otro zoólogo: Ignacio Docavo. Este lo dirigirá hasta la década de los ochenta. Durante este período, el Jardín, recuperándose de la riada, siguió manifestándose como la inmensa selva monumental a la que con el tiempo había devenido. Desde la entrada por beato Gaspar Bono hasta llegar a la zona de los cactus al fondo del Jardín, el sol no llegaba al suelo. El tamaño gigantesco de aquellos ejemplares originaba una luz, tamizante, de efecto maravilloso a la que se habían adaptado los arbustos y herbáceas sobrevivientes a ese aparente abandono - no del todo cierto- pues una brigada de cinco trabajadores se hacía cargo del mantenimiento y cuidados imprescindibles del lugar. Las plantas supervivientes, beneficiadas con esa situación, mostraban su contento con un crecimiento libre adaptado a esas circunstancias y por ello constituían, sin lugar a dudas, el mejor arboreto de España y uno de los mejores de Europa. 

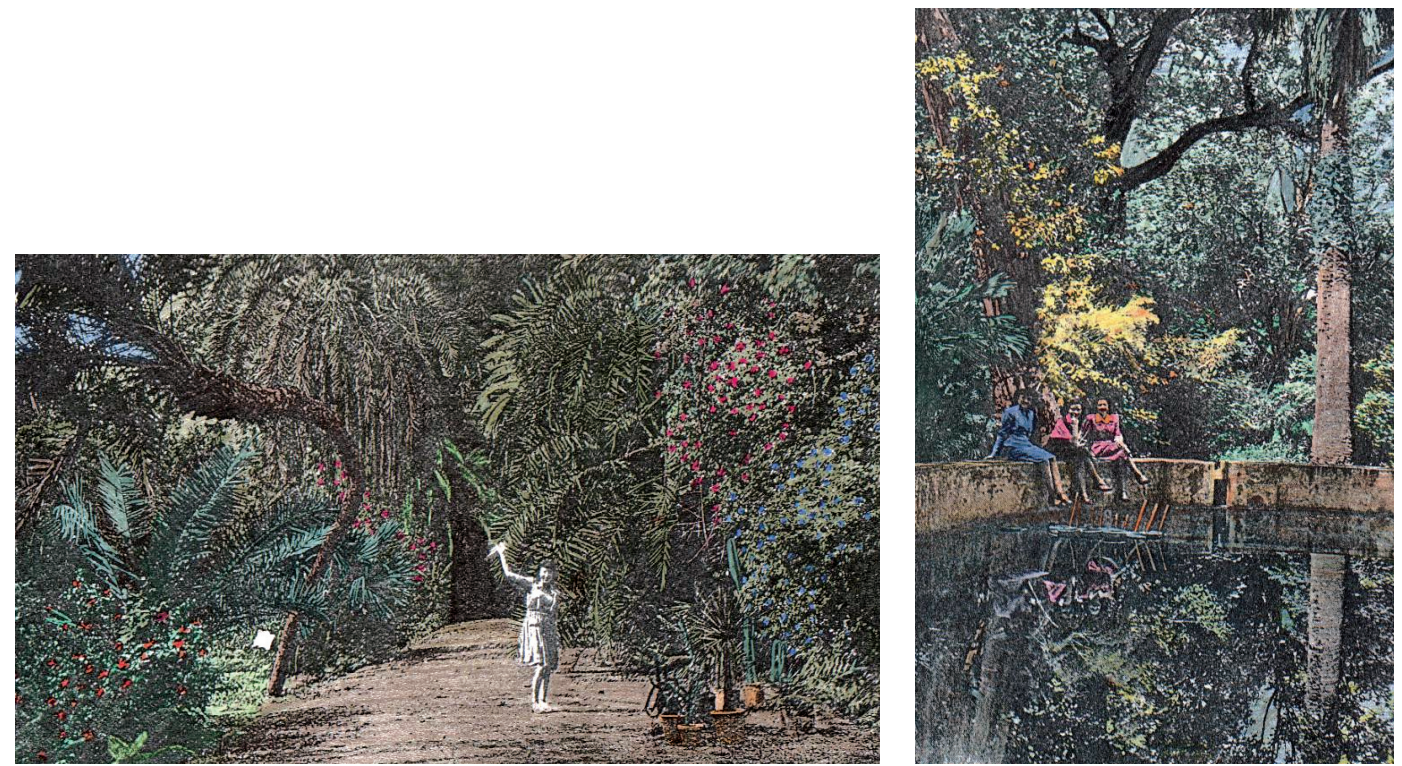

Imágenes del Jardín Botánico antes de la riada de 1957. (Del libro de Sarthou Carreres: "Jardines de España: Valencia")

Como jardín histórico, testimonio de la herencia botánica de dos siglos, tenía un valor extraordinario a pesar de la situación ruinosa de sus edificios, del estado sanitario de los árboles, de los peces y aves introducidos por Docavo en uno de los cuadros de la escuela botánica y de los cachivaches y trastos que se amontonaban en las estufas vacías en lugar de las colecciones de plantas. A pesar de las críticas recibidas durante su gestión por diversos colectivos sociales, -algunas de ellas con mucha razón-, el balance de la era Docavo hoy no nos parece tan negativo. Considerando las circunstancias de cómo estaba la universidad bajo el franquismo, casi parece milagroso que el Jardín se conservara, que se editara una guía del mismo (41) y que se volviera a instaurar la docencia en su recinto para los estudiantes de biológicas.

Al final de la dirección de Docavo, un huracán -el Hortensia-, arrasa el Jardín. Algunos árboles caen. En un artículo en la prensa local (42) Docavo volvía a repetir las causas del deterioro del Jardín y los remedios a esta situación ya expuestos en la Guía anteriormente mencionada y en otros artículos (43): "Las causas de la catástrofe originadas por el vendaval en el valiosísimo arboreto del Jardín, cada día más deteriorado, son las siguientes:

- Falta de aireación del Jardín, al estar rodeado de casas por todas partes y de un murallón carcelario por el único lugar que podría ventilarse.

- Ataque masivo de hongos y bacterias por la gran humedad existente debido a la causa anterior.

(41) DOCAVO ALBERTI, Ignacio. Obra citada.

(42) Levante, 11 de octubre de 1984

(43) Levante, 6, 7, 8 y 9 de septiembre de 1984 
- Podredumbre de troncos y ramas originadas por tales ataques, que disminuyen la resistencia del árbol y ponen en peligro su vida, la que corta drásticamente cualquier soplo fuerte de viento.

- Demasiada densidad arbórea para la superficie del recinto y en relación con la muralla de casas que lo rodean y la mucha edad de los árboles más valiosos.

Tales agresiones se pueden evitar o paliar con los siguientes remedios:

a) Derribo del muro y sustitución del mismo por una verja artística que cierre el recinto, como sucede en todos los botánicos del mundo. Con el derribo anterior, aumentaría la ventilación, disminuiría la humedad y con ella el ataque de hongos y bacterias.

b) Compra de la maquinaria necesaria para el tratamiento de árboles de gran altura, de la que ahora se carece totalmente, con fungicidas e insecticidas, en evitación de las graves enfermedades y plagas que afectan al jardín, pues actualmente no se dispone en absoluto de tales medios.

c) Necesidad de disponer de personal preciso para el saneamiento de los árboles, práctico en cirugía arbórea, que realicen podas racionales, traten las heridas, desgarraduras y podredumbres con productos apropiados para evitar así las infecciones que son la causa de los derribos. De tal personal se carece totalmente pese a su petición constante."

A pesar de todo lo expuesto, el abandono en que la Universidad tenía sumido al Jardín continuó.

Los últimos años de Docavo vieron -frente a la petición de cese de su cargo cada día más insistentemente reclamada desde diversos ámbitos sociales- un hecho sorprendente. El Ayuntamiento de Valencia, entonces gobernado por una coalición de socialistas y comunistas, llega a un acuerdo con la Universidad. A cambio de ser barrido diariamente el Jardín, el Botánico elimina la cuota simbólica de entrada (25 ptas.) y así pasa a ser un jardín de barrio y sus metros cuadrados contribuyen a engrosar el patrimonio verde logrado por la gestión municipal.

Aquello supuso un paso más en la degradación del Jardín ya que este uso público no se vio compensado con un aumento de servicios de vigilancia y así aparecieron pelotas, bicicletas, balones, perros, indigentes, vandalismo, heroinómanos, etc., etc.

En la primavera de 1987 asume Manuel Costa la dirección del Botánico. La situación de mal uso del espacio es cortada de raíz y vuelve a ponerse vigilancia y control al Jardín. Sin embargo, una extraña política de disminuir el riego del lugar para evitar las plagas de hongos, favorece el incendio del gran umbráculo, perdiéndose -entre otras especies- los extraordinarios ejemplares de buganvilea y glicinia que lo cubrían. 


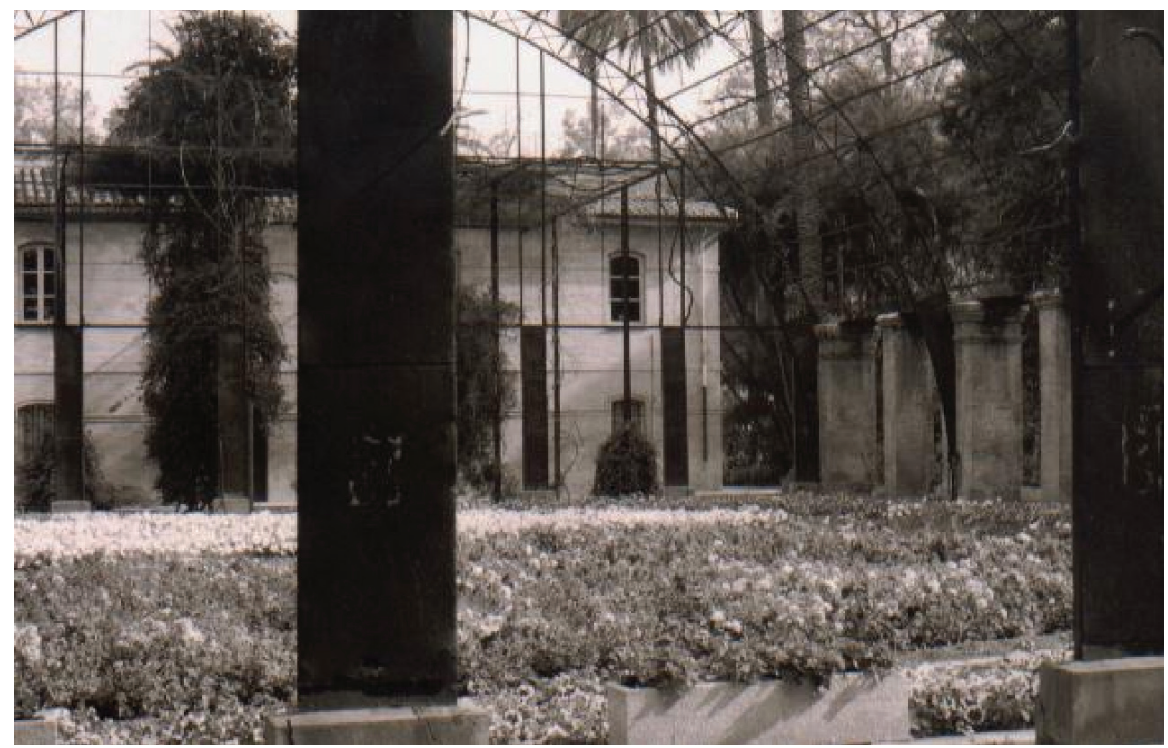

El gran umbráculo después del incendio. (Foto del autor)

También surge entonces la colaboración entre el Servicio Municipal de Jardinería y la dirección del Jardín. Los criterios que emplean ambas instituciones son los imperantes para la jardinería urbana con lo que comienza a producirse, por un lado, un proceso de eutanasia arbórea que conlleva la eliminación de grandes ejemplares enfermos o viejos con la excusa siempre de conseguir la seguridad para los visitantes del lugar y, por otro, se evita que las plantas crezcan en libertad, manifestando sus formas naturales. Así, por ejemplo, son eliminados todos los hijuelos de los troncos de las grandes cicas o se suprimen los brotes del ginkgo macho de un tamaño considerable como atestiguan los tocones todavía existentes. Y mejor olvidar la utilización de herbicidas para combatir las plantas no deseadas en el recinto del Jardín.

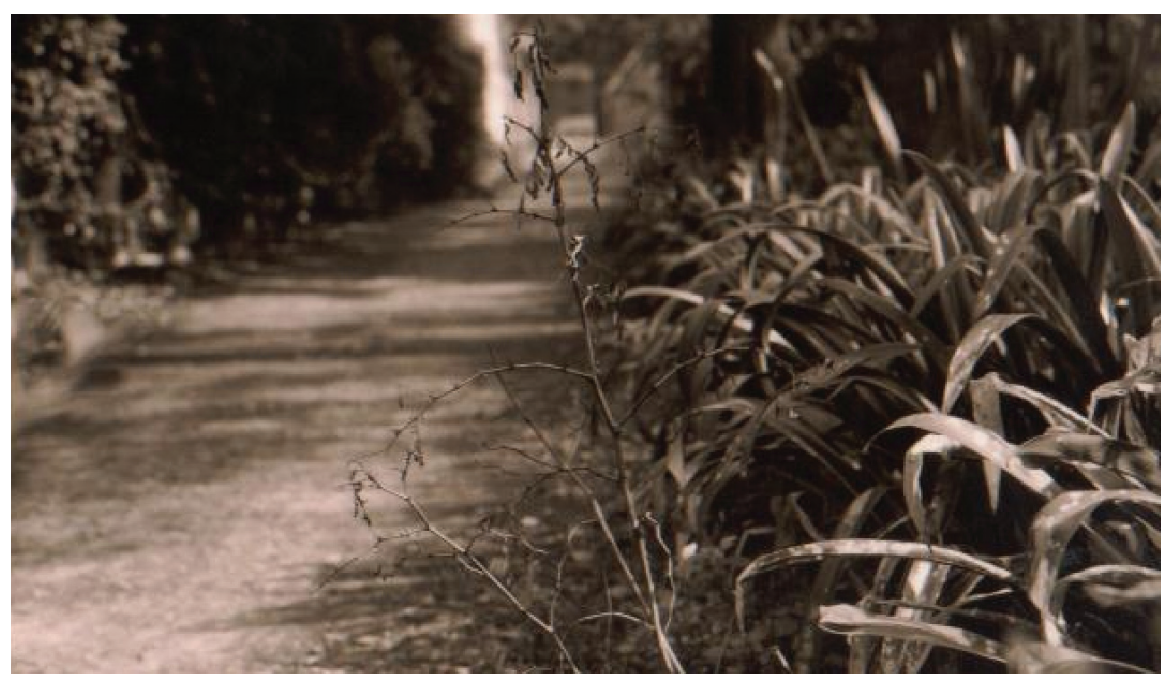

Seto de agapantos quemado por los herbicidas en el Jardin. (Foto del autor) 
Esta destrucción de los grandes ejemplares viejos o enfermos del Jardín va a prolongarse durante los años 87 y parte del 88 no sin originar cierta polémica entre los sectores naturalistas y conservacionistas, reflejada en la prensa (44) como una crítica al recién presentado proyecto de restauración del Jardín. Todas estas críticas fueron desoídas y se siguió adelante con el plan de limpieza y eliminación del viejo arbolado reforzados sus responsables por la caída de una gran rama en junio de ese año (45)y la descalificación de las críticas por parte de Jesús Sánchez Carrascosa desde Las Provincias acusando a sus autores de tener intereses "más nacionalistas y políticos que científicos" al realizar las mismas (46).

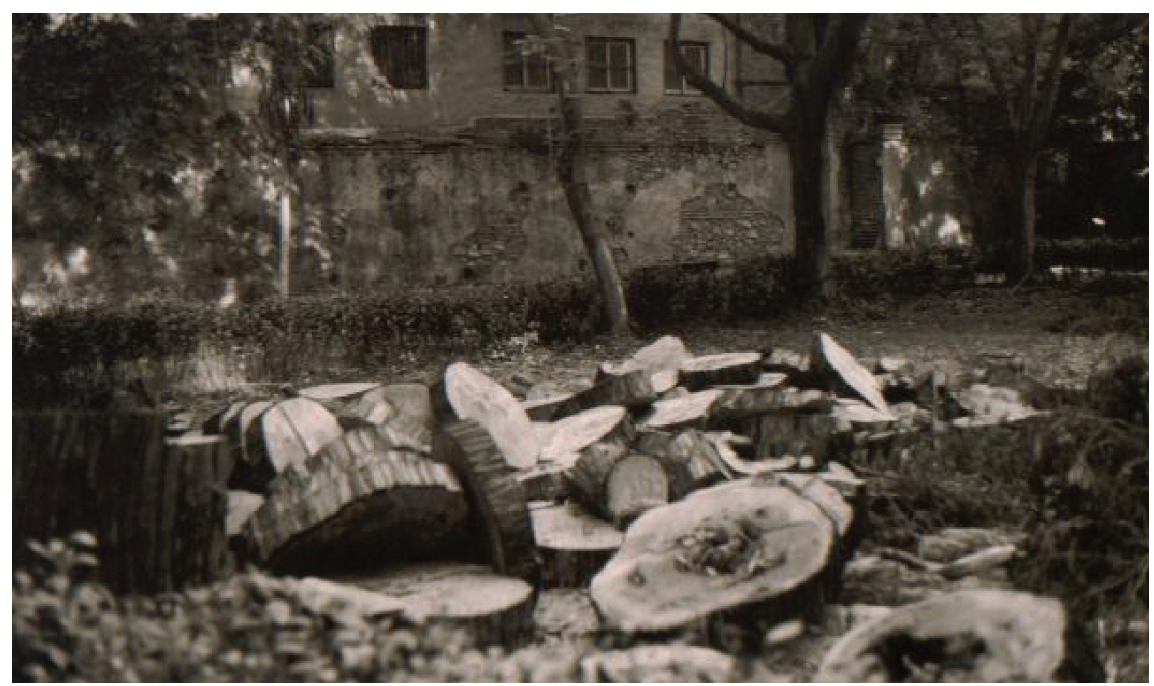

Eliminación del arbolado "enfermo" del Jardín. (Foto del autor)

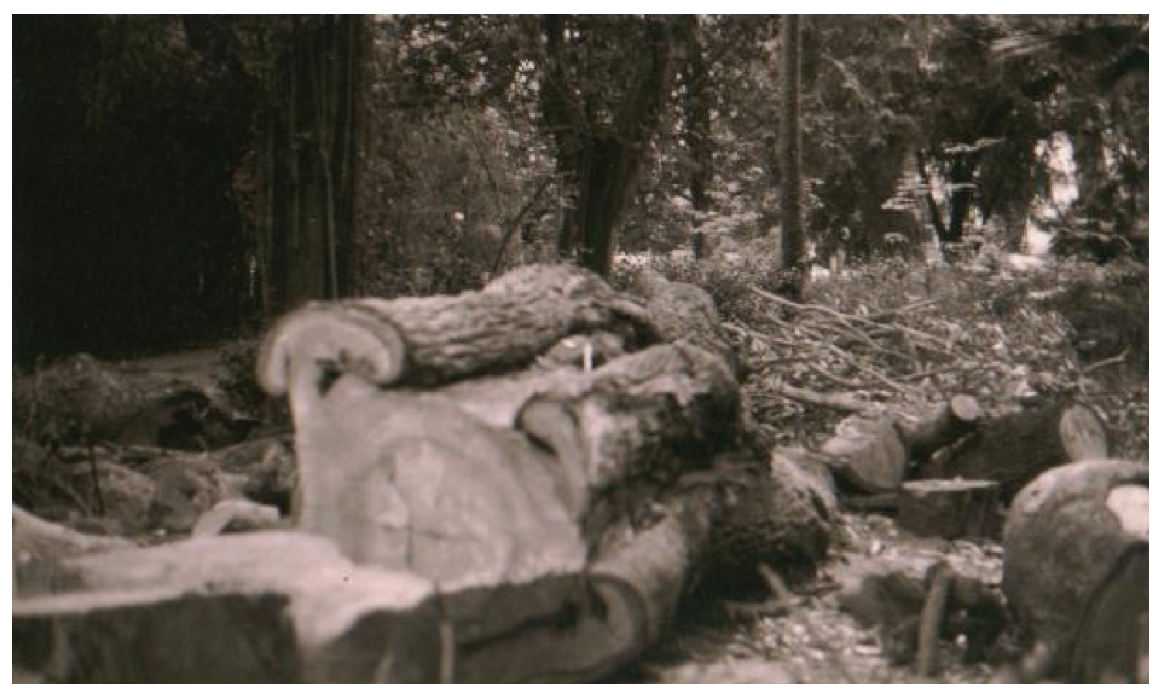

Otro ejemplo de eutanasia arbórea como el anterior. (Foto del autor)

(44) El País, 31 de mayo de 1988

(45) El País y Las Provincias, 21 de julio de 1988

(46) Las Provincias, 2 de junio de 1988 


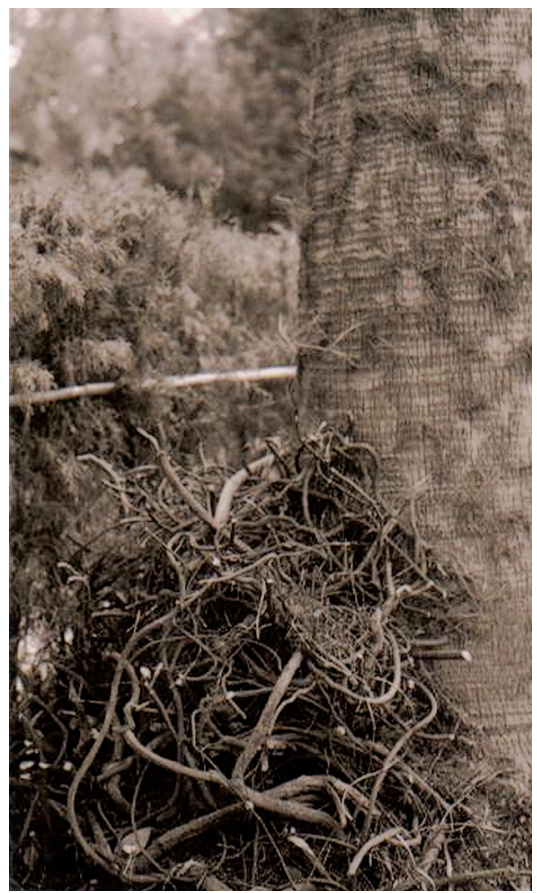

Eliminación de la excepcional Muehlenbeckia complexa o enredadera del alambre que trepaba por una washingtonia. (Foto del autor)

Coincidiendo con lo anteriormente expuesto se estaba realizando una exposición sobre el proyecto de restauración del Jardín en el Ateneo Mercantil de Valencia en mayo de ese mismo año. Esta exposición era la consecuencia de recoger el mandato que el rector

La piedra había encargado a Manuel Costa para conseguir convertir el Jardín en un nuevo espacio dedicado a la investigación, conservación y difusión del patrimonio botánico valenciano según la situación surgida en la Universidad tras la aprobación de los nuevos Estatutos. Pero dejemos que sean los autores de la reciente publicación sobre el Jardín ya citados anteriormente los que nos expliquen los objetivos y logros de la primera fase de la restauración del Botánico antes de hacer nuestra crítica a la misma.

"Los Estatutos de la Universidad de 1985 abrieron una nueva perspectiva para el Jardín Botánico, que dejó de depender de la Facultad de Ciencias al ser considerado un "centro universitario de investigación, docencia y cultura", dependiente directamente del rectorado. En 1987 el rector Ramón Lapiedra nombró director a Manuel Costa, catedrático de botánica de la Facultad de Farmacia, y le encargó la redacción de un proyecto de restauración integral del Jardín para recuperar el uso de todas sus instalaciones y darle el contenido que le atribuían los Estatutos. El proyecto incluyó la restauración de los invernaderos y del umbráculo, la transformación de los cuadros de plantación, del sistema de riego, la remodelación de la Escuela Botánica, el desarrollo de nuevas colecciones de plantas, la implantación de un sistema adecuado de información y la construcción de un edificio de investigación. 


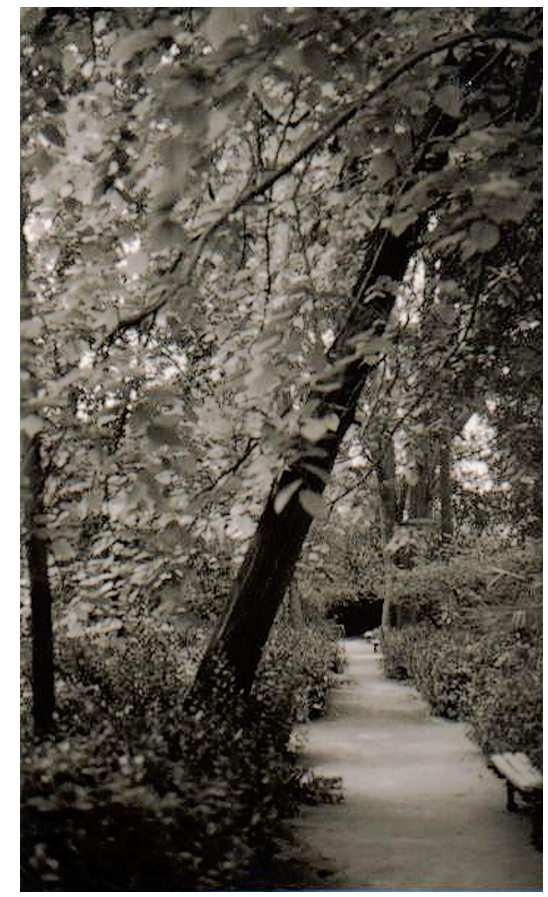

Tilo eliminado por no crecer recto. (Foto del autor)

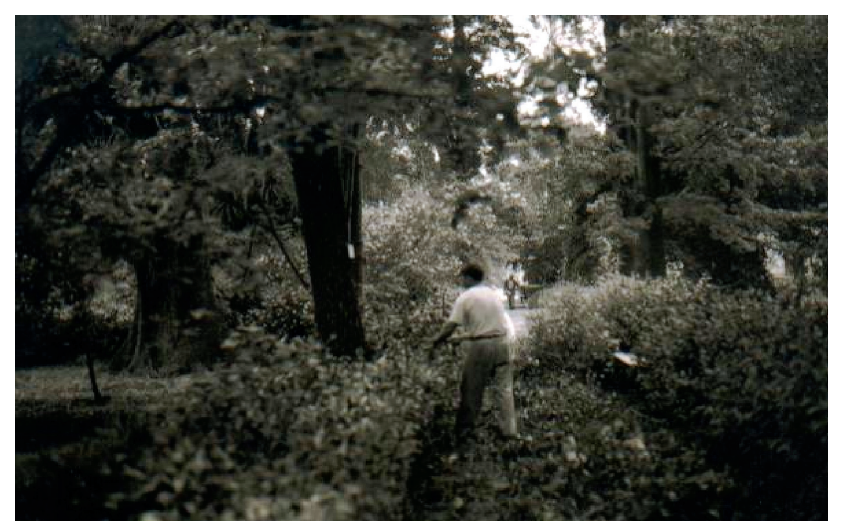

Limpieza del seto del laurel de Alejandría. (Foto del autor)

La primera fase, la recuperación del espacio ajardinado, se realizó entre 1989 y 1991. La segunda fase, la construcción del edificio de investigación, no pudo completarse, por distintas dificultades administrativas y económicas, hasta 1999.

La restauración del Jardín permitió recuperar los antiguos y deteriorados edificios. El umbráculo fue demolido y construido de nuevo. Se renovó la estructura metálica y la cristalera de los invernaderos, sólo se conservó la estructura de la estufa tropical con un perfil muy singular que aún estaba en buen estado, y se instaló en ellos calefacción, riego y sistemas de humectación. La antigua estufa fría de grandes ventanales en el muro de mampostería, ocupada por el acuario, fue restaurada y dedicada a exposiciones y actividades culturales. En los invernaderos, que estaban deteriorados y vacios, se instalaron colecciones nuevas de palmeras, orquídeas, bromeliáceas, plantas suculentas, tropicales y carnívoras. Todos se abrieron al público. Se crearon la rocalla y nuevas colecciones de plantas útiles para el hombre: frutales, plantas medicinales, plantas de interés económico, colecciones todas ellas que volvieron al Jardín después de años de haber desaparecido y que recuerdan las distintas épocas y orientaciones por las que pasó. Se reordenó la Escuela Botánica, adecuándola a los modernos conceptos de la sistemática, y se volvió a plantar.

El 12 de junio de 1991, tras permanecer dos años cerrado por las obras realizadas, el Jardín se abrió de nuevo al público una vez concluida la primera fase de la restauración. Desde esa fecha ha dedicado una especial atención a la divulgación científica, manteniendo una incesante oferta de acogida para los colegios y potenciando el desarrollo de actividades educativas sobre temas de naturaleza y medio ambiente, a la investigación, centrada en la línea de la biología de la con- 
servación y participando en proyectos de estudio de la diversidad vegetal, y a la cultura, acogiendo actividades de todo tipo como exposiciones de artes plásticas, conciertos o representaciones de teatro".

La inauguración de esta primera fase fue un éxito de crítica y público. En los folletos entregados en los días posteriores en la taquilla del Jardín se señalaba que el número de plantas se había incrementado de una manera importante ya que:

"Antes de la restauración: 1.100 ejemplares

300 especies

después de la restauración: 43.000 ejemplares

3.000 especies"

Esto es considerado un gran logro al igual que:

“- la restauración de edificios: umbráculo, invernadero, etc.

- la viabilidad de los cuadros

- las nuevas colecciones: crasas, medicinales, céspedes, etc.

- la nueva red de riego automatizada: $15 \mathrm{~km}$. de tubería y 6.000 bocas de riego

- las nuevas plantaciones"

Para evaluar los resultados de las intervenciones habidas en esta primera fase continuaremos con la metodología seguida en los trabajos anteriores y aplicaremos la división brandiana de aspecto y estructura como componentes de la materia de la obra de arte para analizar la restauración del Jardín Botánico.

El diseño del jardín -el aspecto brandiano- fue alterado al introducir nuevas sendas y caminos en el interior de los cuadros con la finalidad anteriormente señalada de favorecer el estudio de las plantas al facilitar su contemplación más de cerca. Esto es lo que se denomina "viabilidad" por los autores de los folletos.

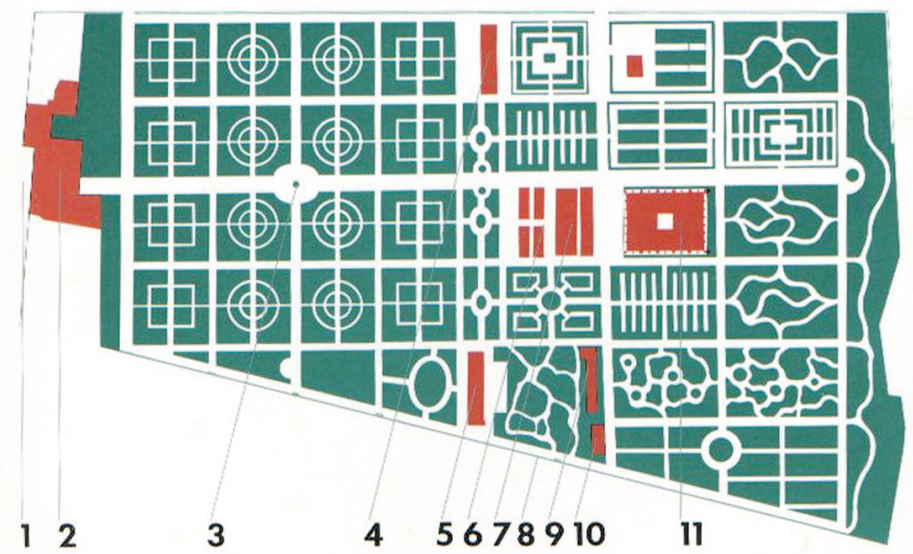

Proyecto de la nueva traza para los cuadros del Jardín Botánico. Catálogo de la exposición sobre el proyecto de restauración en el Ateneo Mercantil de Valencia. Primavera de 1987 
Ello obligó a realizar algunos transplantes y en otros casos se dejaron las plantas en los caminos por la imposibilidad de realizar con éxito éstos debido al tamaño de las mismas.

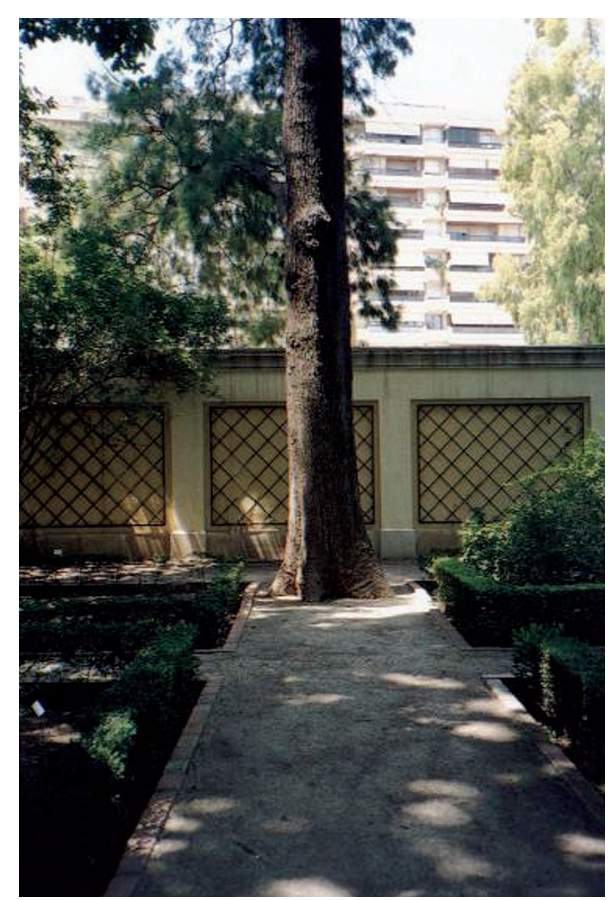

Casuarina en medio de un camino tras el nuevo diseño. (Foto del autor)

Teniendo en cuenta el estado en que se encontraba el estrato de herbáceas y arbustos del Jardín, muy escaso por la falta de sol debido al tamaño del arbolado como hemos comentado en las líneas anteriores, este nuevo trazado no supuso una importante pérdida de vegetación arbustiva aunque si podemos decir que se perdieron algunos ejemplares curiosos de vivaces como las crocosmias, los lirios de Rodas, las dragonteas, la colección de aquilegias, las peonías vivaces, los heléboros y todos los laureles de Alejandría (Ruscus hypoglossum) que tan eficazmente formaban los setos de los cuadros en la penumbra del lugar como se ha visto posteriormente al no haber vegetado todos los setos de arrayán de un modo óptimo por la ausencia de luz y haberse tenido recientemente que recurrir a otro tipo de plantas para reponerlos.

En lo que respecta a la estructura -es decir, todos los elementos materiales que componen el Jardín - vamos a realizar tres apartados: a) edificios y estatuaria; b) sistema de riego y c) vegetación.

A) Edificios.

El proceso de reconstrucción en un caso -el gran umbráculo- o de restauración -resto de los invernaderos- ha sido un logro indudable. No existe nadie que pueda objetar lo más mínimo frente a la calidad de los trabajos realizados. Todo el pro- 
ceso de recuperación de las antiguas estructuras de hierro, su acondicionamiento para volver a ser funcionales, la incorporación de todos los adelantos que la técnica actual conoce para preservar esas estructuras decimonónicas es ejemplar. Los resultados espléndidos. Aquellos invernaderos siempre cerrados y que acumulaban trastos y cochambre se han convertido en lugares donde las colecciones de plantas se muestran en todo su esplendor aunque en algún caso como el del invernadero de la balsa la elección de las palmeras tropicales no sea la más conveniente para ese espacio por el tamaño de las mismas.

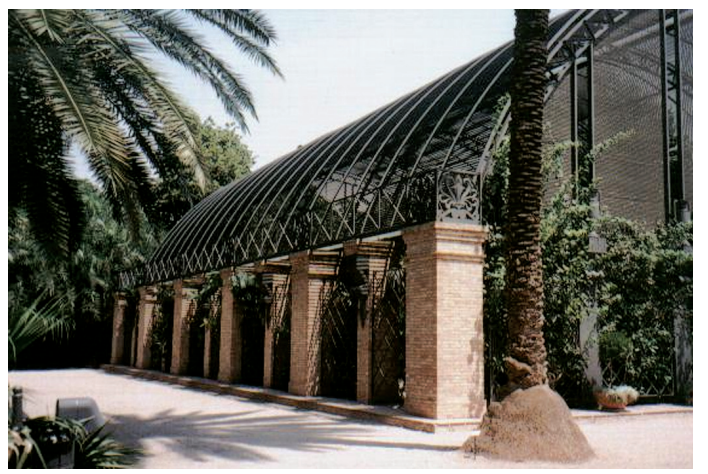

El umbráculo tras su reconstrucción. (Foto del autor)

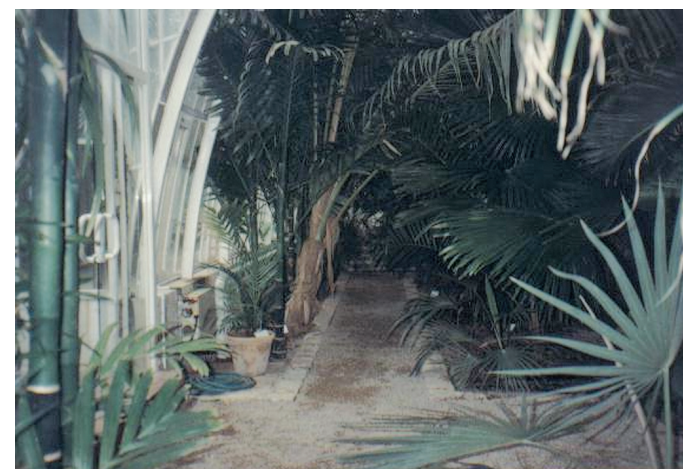

El invernadero de la balsa tras su restauración. (Foto del autor)

Lo mismo hay que decir de la recuperación de la antigua estufa fría, transformada en un inmenso acuario en la era Docavo y hoy reconvertida en sala de exposiciones. Una reconstrucción dignísima, habiéndose conseguido la recuperación del espacio cubista y diáfano de los orígenes del Jardín de gran valor arquitectónico y proyectual

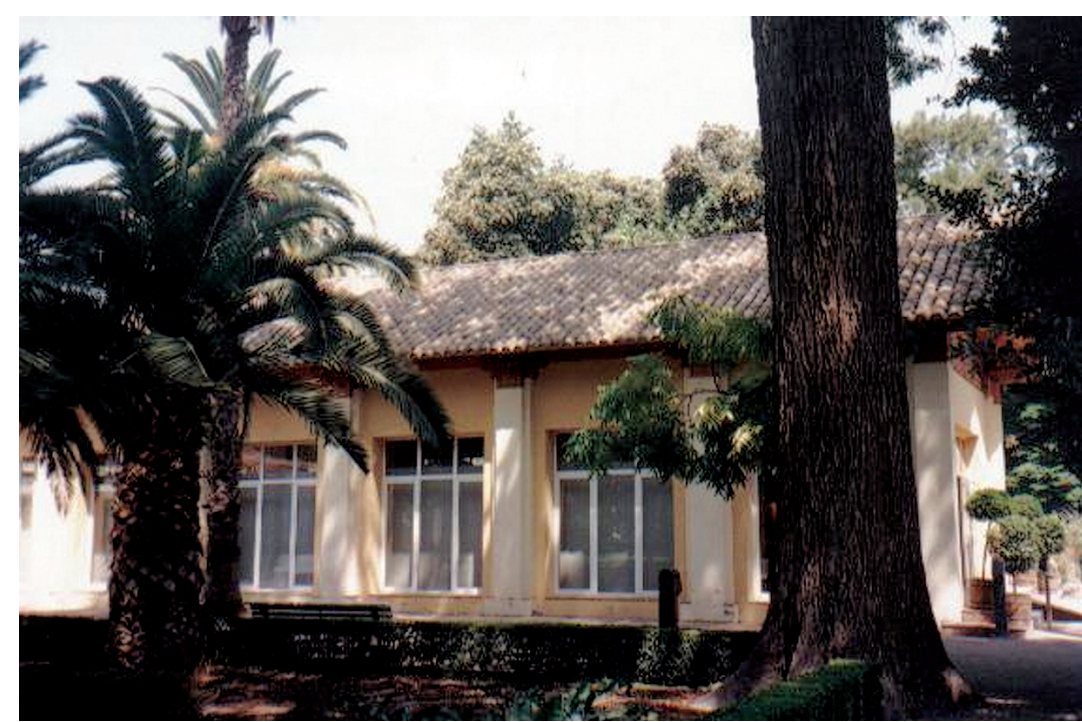

Antigua estufa fría (acuario de la era Docavo) recuperada para Sala de Exposiciones. (Foto del autor) 
Respecto a la estatuaria existente en el Jardín, es del todo incomprensible que la única existente en el lugar fuese trasladada desde el centro del Jardín -plaza de los magnolios- al fondo del mismo cuando se trata además de uno de los más grandes botánicos valencianos de todos los tiempos: Simón de Rojas Clemente y Rubio.

B) Sistema de riego.

El Jardín Botánico se crea en un antiguo huerto, el huerto de Tramojeres, que disponía de unos recursos hídricos asegurados por estar cruzado por la acequia de $\mathrm{Na}$ Rovella. Tal acequia es la que regó al Jardín hasta hace diez años utilizando el sistema tradicional de riego a manta o pie.

El nuevo proyecto cambió el sistema de riego tradicional instalándose en su lugar riegos de aspersión. Pensar que este cambio no alteraría la vegetación era de una ingenuidad alarmante El tamaño de la mayoría de los árboles del Jardín presupone que las raíces están hondamente ancladas. El riego a manta hidrata los suelos en profundidad y así permite que los nutrientes (fertilidad) originados en los veinte $\mathrm{cm}$. de la superficie vayan bajando a alimentar los árboles a la vez que origina que los seres vivientes que habitan en la tierra (lombrices principalmente y otras formas de vida) suban a la superficie tras los riegos con lo que producen la aireación de los suelos a través de los innumerables túneles que originan con sus movimientos.

Por el contrario, el riego por aspersión es un riego superficial. Es útil para mantener esas extensiones de césped que nos empeñamos en cultivar contra natura en estos climas influenciados por las formas jardineras de la aculturación anglosajona. Su otra variante, el riego por goteo, hay que recordar que es una invención de un pueblo que disponía sólo de tierras estériles y agua escasa con lo que se vio en la necesidad de introducir en el agua los nutrientes necesarios para que las plantas cultivadas en esos suelos estériles vegetaran y pudieran alimentar a aquellos descendientes de David. Como técnica de agricultura industrial es aceptable para esas condiciones o parecidas (caso Almería en nuestro país). Pero en un jardín, la visión de esas innumerables gomas de plástico ofende al gusto además de producir desconcierto en los sentidos y sobre todo, aparte de consideraciones estéticas, el goteo no profundiza la humedad y fuerza a los árboles regados desde sus orígenes con esta técnica a concentrar sus raíces alrededor del lugar donde el líquido con los nutrientes es recibido. La ventaja aparente es su rápido crecimiento y alta productividad. El inconveniente es que si fallan los recursos hídricos como sucedió en la zona de Godelleta, Turís y Chiva en el verano del 2000, los primeros que perdieron la fruta y el follaje fueron los naranjos cultivados con la técnica señalada mientras que los árboles regados con el sistema tradicional de riegos a manta aguantaron mucho más las condiciones adversas de ese momento de sequía al tener su sistema radicular más anclado en el terreno.

Toda esta parafernalia expositiva sobre técnicas de regadío viene en relación al disparate que supuso para el arbolado del Jardín Botánico el cambio de sistema de riego. Los resultados se vieron rápidamente, produciéndose la mortandad de 


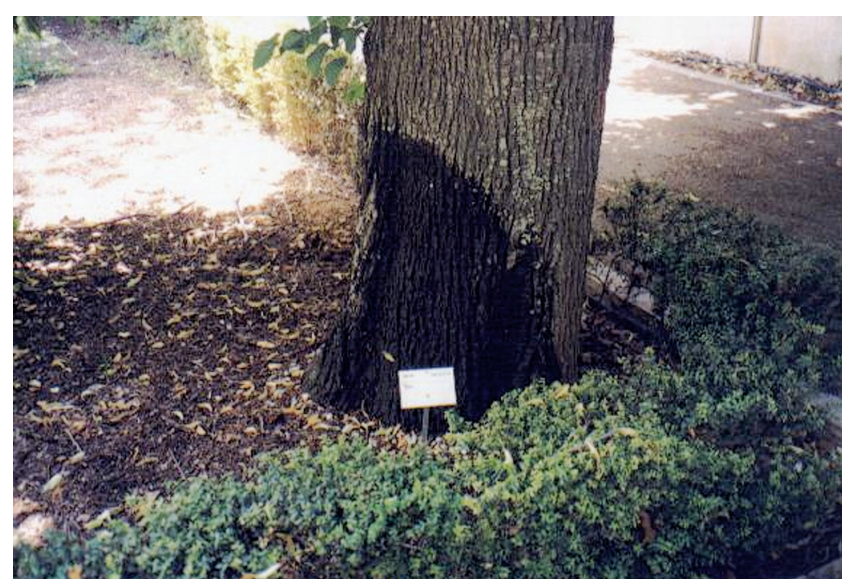

Tronco humedecido por los aspersores. (Foto del autor)

importantes ejemplares del arboreto. Y el asunto no es una cuestión de cantidad sino de calidad. Y esto se trae a colación por los datos ofrecidos tras la restauración sobre el importante aumento del número de plantas en el Jardín. Se escribió que eran casi 50.000 las plantas introducidas tras la restauración frente a las tres mil existentes del anterior período. Si se realiza una comparación basada únicamente en las cantidades, por supuesto que ganan las begonias, claveles chinos, petunias, alegrías de la casa, coleos, liliums y demás plantas de temporada frente a la pérdida de los ejemplares que a continuación enumeraremos y eso teniendo en cuenta que se realizaron muchos taladros en el suelo del jardín hace unos cuantos años para airear el mismo y se cavó alrededor de numerosos árboles añadiendo gravas junto a sus troncos para facilitar la aireación, faenas un tanto absurdas puesto que cada año se vuelve a introducir plantas de flor de temporada regadas por la dichosa aspersión diariamente cuando no se mantiene la colección de los céspedes a pesar de las muertes constantes de los grandes ejemplares que no pueden soportar las condiciones de encharcamiento superficial que tal cultivo genera.

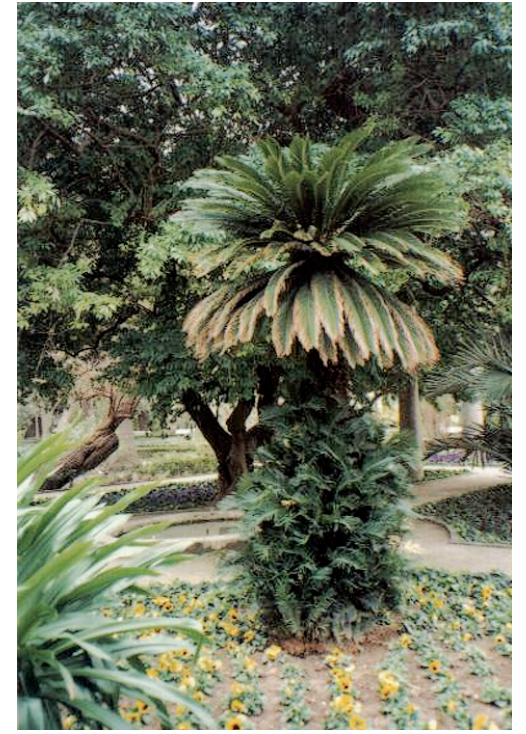

Plantaciones de temporada a los pies de la cica. (Foto del autor)

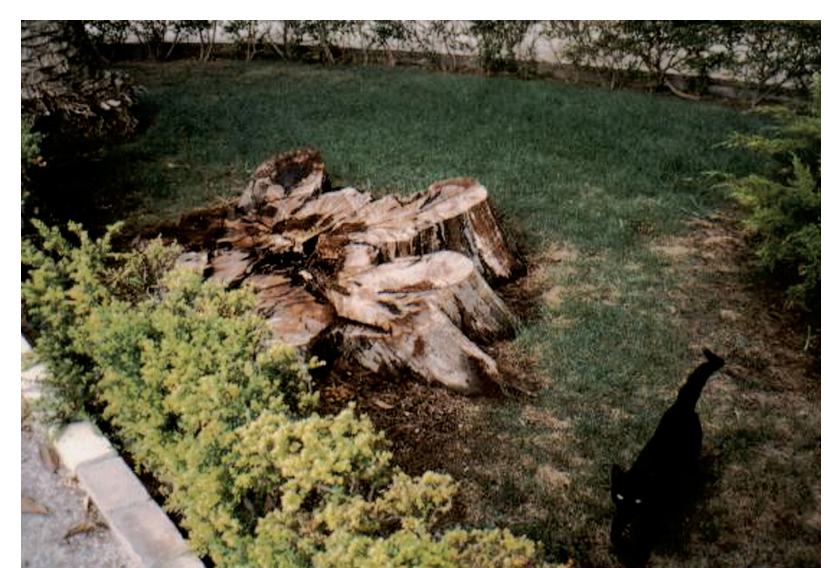

Plantaciones de césped rodean el tocón de una casuarina muerta. (Foto del autor) 


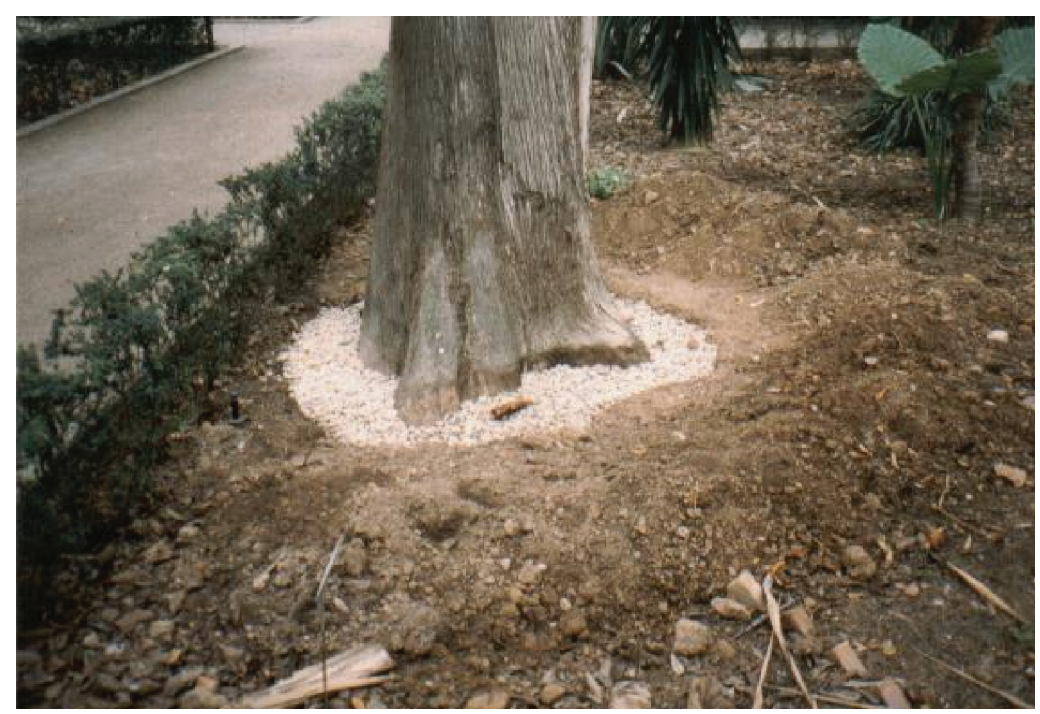

Gravas alrededor de los troncos para evitar la asfixia producida por los riegos de aspersión. Noviembre de 1998. (Foto del autor)

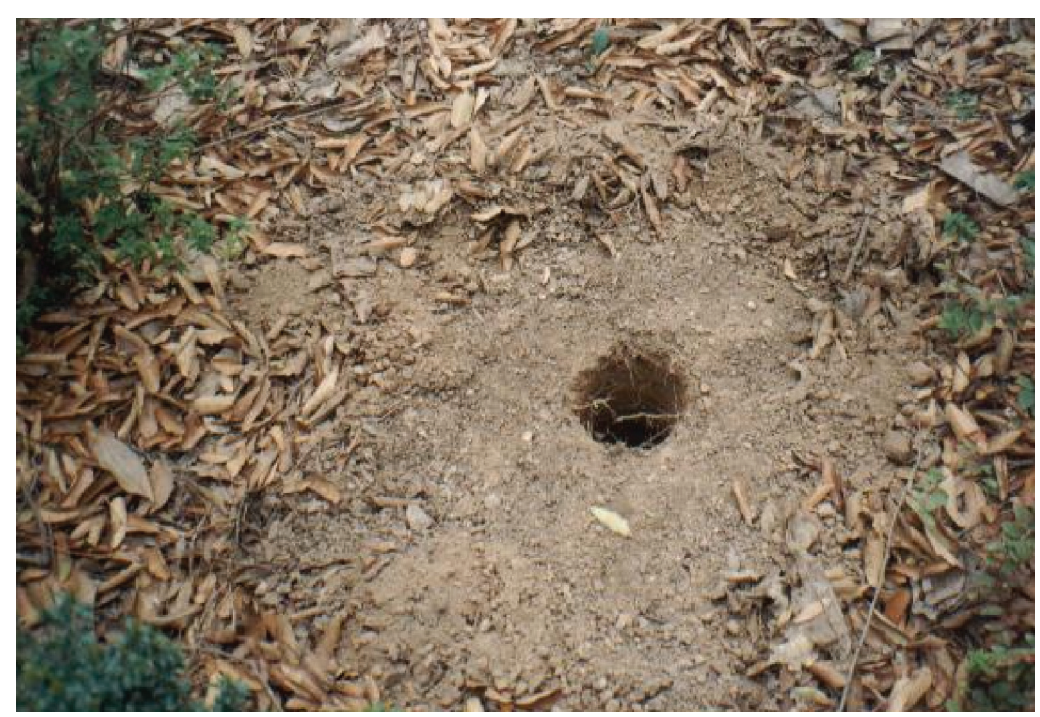

Agujeros realizados para airear los suelos. Primavera de 1996. (Foto del autor)

\section{C) Vegetación}

La relación de los ejemplares perdidos desde 1989 al 2001 es importante sobre todo por la calidad, tamaño y rareza de los mismos como señalábamos en líneas anteriores. La relación de la vegetación desaparecida que a continuación se inserta está obtenida de Guía del Jardín Botánico de Docavo, de nuestras propias notas de campo y fotografías en el período de 1980-2001.

La relación abarcará la vegetación siguiendo este orden: árboles, arbustos, vivaces y trepadoras. Las que figuran con un número y Docavo entre paréntesis señalan el orden en que aparecen en la mencionada Guía. Las otras son el resultado del inventario realizado por nosotros de la vegetación de algunos cuadros del jardín antes de la restauración y su posterior comparación tras la finalización de aquella. 
Plantas desaparecidas del Jardín Botánico desde la restauración de 1989.

\section{Arboles:}

- Cupressus funebris (Docavo $\mathrm{n}^{\mathrm{o}} 2$ ).Edificado.

- Podocarpus neriifolia (Docavo $\mathrm{n}^{\mathrm{o}} 3$ ). Edificado.

- Erythea edulis (Docavo n ${ }^{\circ}$ 5). Edificado.

- Erythea armata (Docavo $\mathrm{n}^{\mathrm{o}}$ 6). Edificado.

- Yucca aloifolia (Docavo 8). Edificado.

- Erythrina crista-galli (Docavo ${ }^{\circ} 22$ )

- Fagus sylvatica (Docavo n 23)

- Eucalyptus camaldulensis (Docavo 26)

- Araucaria bidwilii (Docavo $\mathrm{n}^{\circ} 31$ )

- Diospyros lotus (Docavo 32)

- Sterculia platanifolia (Docavo $\mathrm{n}^{\circ} 36$ )

- Fraxinus americana (Docavo 38)

- Tilia tomentosa (Docavo $\mathrm{n}^{\mathrm{o}} 43$ )

- Feijoa sellowiana (Docavo 44)

- Asimina triloba (Docavo 48)

- Liriodendron tulipifera (Docavo $\mathrm{n}^{\circ} 50$ )

- Arbutus unedo (Docavo no 52)

- Pinus pinea (Docavo no 54)

- Maclura pomifera (Docavo 57)

- Brachychiton populneum (Docavo 59)

- Brachychiton acerifolium (Docavo 60)

- Arbutus andrachne (Docavo ${ }^{\circ} 63$ )

- Aesculus hippocastanum (Docavo 65)

- Criptomeria japonica (Docavo $\mathrm{n}^{\mathrm{0}} 66$ )

- Hibiscus rosa-sinensis (Docavo $\mathrm{n}^{0} 74$ )

- Catalpa bignonioides (Docavo 79)

- Persea americana (Docavo 81)

- Tetraclinis articulata (Docavo ${ }^{0}$ 84)

- Schinus terebinthifolius (Docavo $\mathrm{n}^{\mathrm{o}} 85$ )

- Acer platanoides (Docavo $\mathrm{n}^{\circ} 88$ )

- Musa paradisiaca (Docavo $\mathrm{n}^{\circ} 89$ )

- Taxodium mucronatum (Docavo $\mathrm{n}^{\circ}$ 90)

- Sequoia sempervirens (Docavo 91)

- Elaeodendron capense (Docavo 93)

- Juglans nigra (Docavo 95)

- Phytolacca dioica (Docavo 97)

- Cercis siliquastrum (Docavo no 99)

- Ailanthus altissima (Docavo n ${ }^{\circ} 100$ )

- Taxus baccata (Docavo 102)

- Quercus serrata (Docavo no 105)sp 
Arbustos, trepadoras y vivaces:

- Paeonia suffruticosa

- Periploca graeca

- Bignonia sp.

- Alaedendron capense

- Centrathus macrosphon

- Daxylirium texanum

- Philadelfus levesii

- Philadelfus polyanthus

- Philadelfus falconeri

- Philadelfus sericanthus

- Philadelfus coronarius

- Seto en la zona de la actual huerta de Nerium oleander

- Cordiline indivisa

- Prunus domestica

- Locuma deliciosa

- Symphytum officinale

- Ugnandia speciosa

- Paeonia officinalis

- Crocosmia sp.

- Dracunculus vulgaris

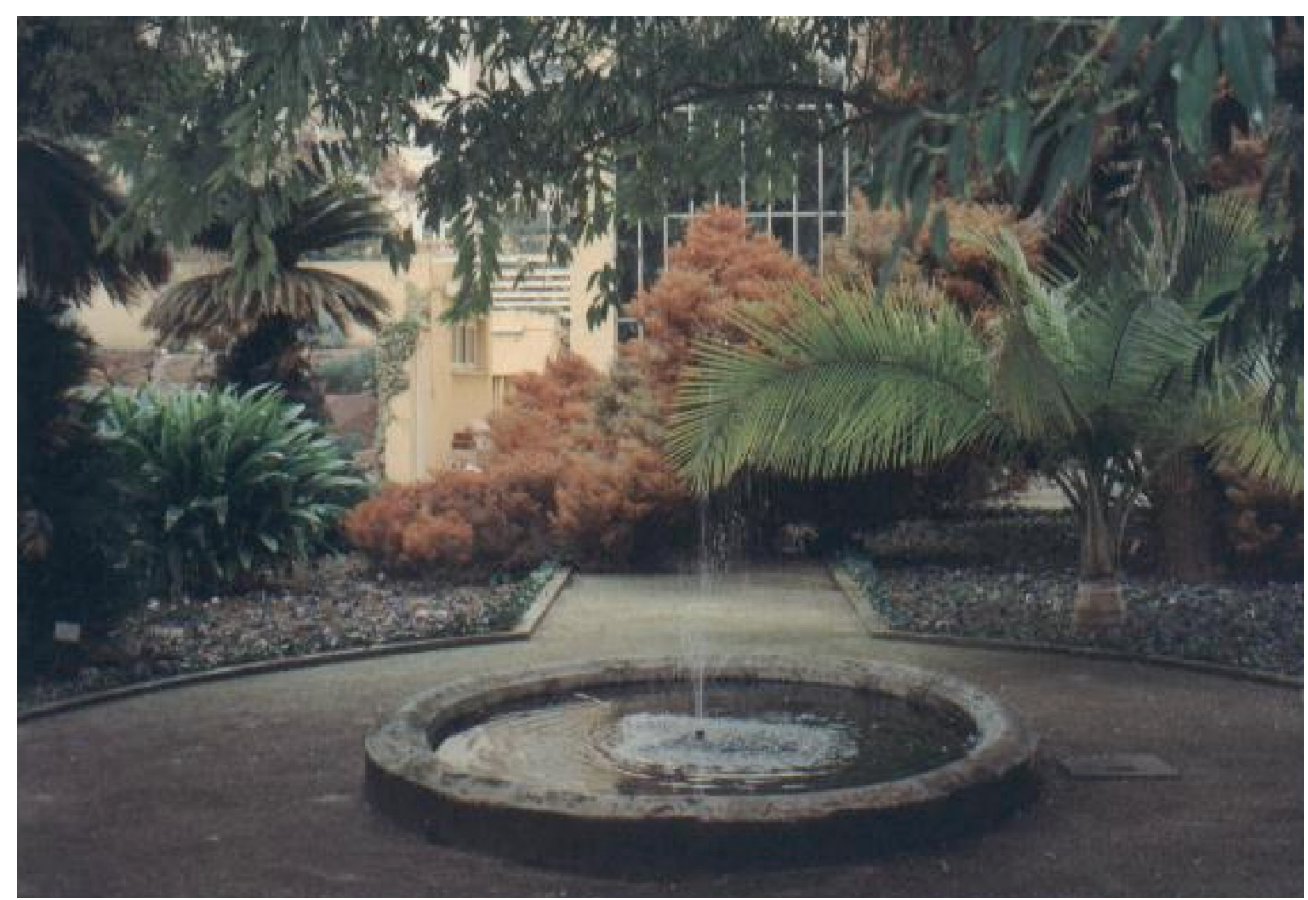

Al fondo de la foto se ve el color cobrizo invernal de la Cryptomeria japonica, una de las grandes pérdidas del arboreto del Jardín. (Foto del autor) 


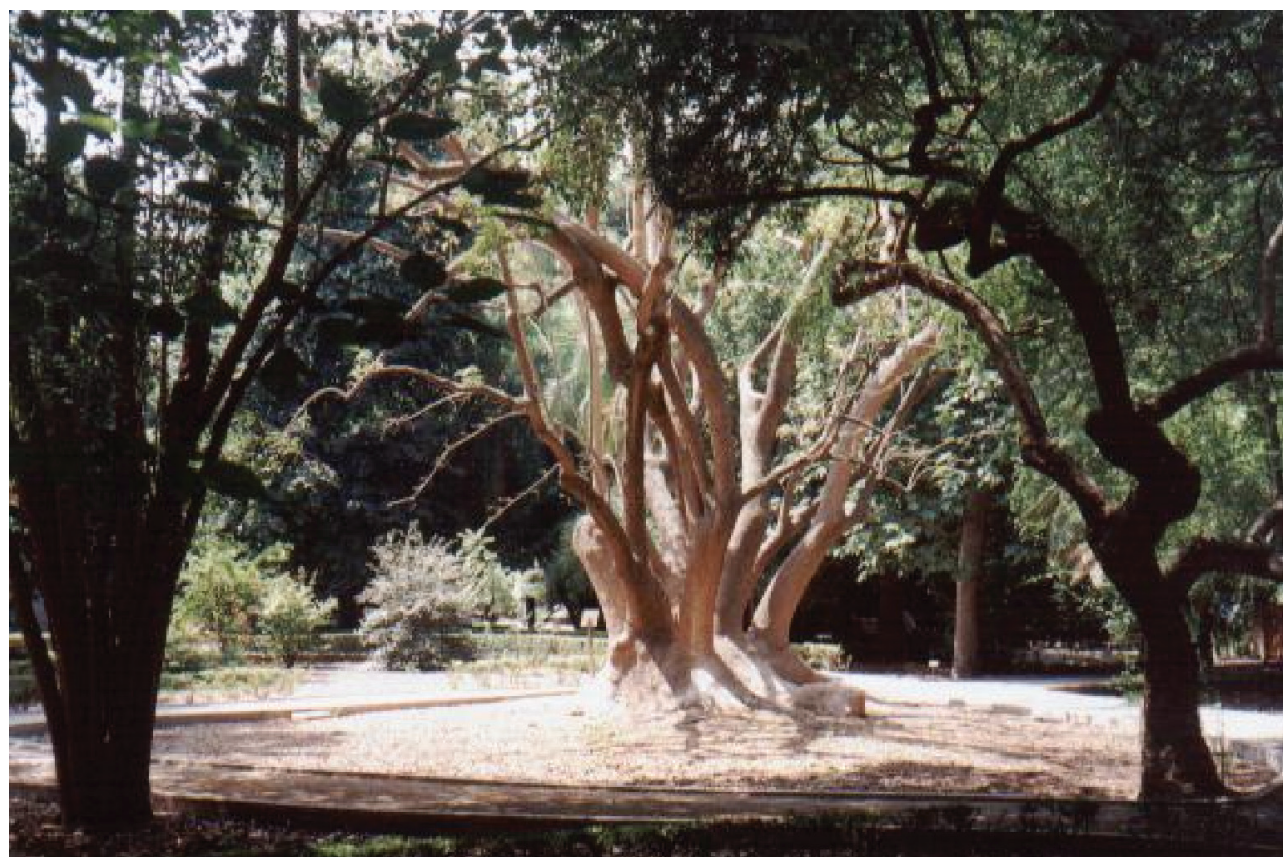

Gran ejemplar de ombú (Phytolacca dioica) desaparecido tras las obras. (Foto del autor)

Para aquellos que no conocían el Jardín, los cambios realizados constituyeron la prueba inequívoca de que empezaba una nueva fase de esplendor en el lugar. Para los que conocíamos el lugar, los cambios eran la prueba irrefutable de que el Jardín histórico se sacrificaba sin ningún miramiento para realizar otro botánico nuevo.

La creación de los jardines botánicos siempre refleja el momento político, cultural y científico de la sociedad que los genera. La destrucción del viejo Jardín para hacer uno nuevo igualmente es el resultado de la situación que vivía la Comunidad Valenciana en esos momentos.

En el otoño de 1988 aparecen publicadas en la prensa las intenciones que tenían el Ayuntamiento y la Universidad para ampliar el Jardín en el cauce del río Túria. Se afirma que será el Jardín Botánico más grande de España pues ocuparía el tramo que va desde el puente de San José al de las Glorias Valencianas o Ademuz.

La Delegación de Urbanismo del Ayuntamiento (entonces a cargo de Fernando Puente) encargó a Manuel Costa la redacción de un estudio sobre esta ampliación el cual conocemos por su aparición en la prensa local (47). Veamos lo que se dice en este artículo:

“Costa manifestó a Hoja del Lunes que el estudio ya está en marcha, y que será concluido en breve para poder agilizar los trámites.

En el proyecto global de futuro para el Jardín Botánico existen dos partes bien diferenciadas. Por un lado, la restauración del jardín clásico, y, por otra, la 
ampliación al cauce. En la práctica ello significará que Valencia tendrá dos jardines botánicos con personalidad bien diferenciada. El botánico clásico, en el que predominan las especies exóticas como reflejo del ideal del siglo XIX, y el nuevo botánico, en el que su director pretende darle un carácter mucho más mediterráneo, con predominio de las especies autóctonas, y con una función didáctica bien clara destinada a la toma de contacto de los valencianos con el mundo vegetal".

En enero de 1989 se anuncia la reunión de la alcaldesa de la ciudad. Clementina Ródenas y el conseller Lluís Font de Mora para discutir el proyecto mencionado (48) y firmar un convenio a tres bandas entre el Ayuntamiento, la Generalitad y la Universidad con el fin de llevarlo a buen puerto. Estas conversaciones no conducen a nada provechoso. Los políticos (Ayuntamiento y Generalidad) aterrados por la pérdida galopante de su electorado, deciden hacer un "bosque mediterráneo" en lo que iba a ser la zona de ampliación del Jardín Botánico y de los $150.000 \mathrm{~m}^{2}$ disponibles en un principio se pasa a una oferta de $10.000 \mathrm{~m} 2$ para el nuevo jardín y con la condición de que esté abierto al público sin ningún tipo de vallas o rejas protectoras.

Manuel Costa intenta convencer a los responsables políticos de la ocasión histórica que se pierde y llega hasta a criticar en la prensa (49) la idea de este parque electoral de la Generalidad y el Ayuntamiento. Al final el proyecto de ampliación del Jardín Botánico es desechado y Valencia pierde esta ocasión única de haberse dotado con el jardín botánico de más amplia superficie de España.

Pero no acaba aquí la relación entre el Botánico y los poderes políticos. Si por su lado norte se le impide crecer, condicionada la ampliación al río como hemos visto; si por el lado oeste se le amenaza con edificaciones que han originado uno de los grandes movimientos ciudadanos de protesta (Torres de los Jesuitas), por el lado sur (calle Quart) se actúa de una manera sorprendente como a continuación veremos.

El proyecto original de construcción de los edificios de investigación expuesto en el Ateneo de Valencia recogía la compra de varias casas colindantes para su derribo, la conservación de la vieja alquería (ya presente en el mapa del Padre Tosca y con nivel de protección 1 en el Plan General) aunque se sacrificaba la ventana sur que el Jardín tenía a la calle Quart para realizar en ella y en los nuevos terrenos adquiridos la construcción del nuevo edificio.

En este proyecto, cuyo autor era Luis Gay Llácer, la construcción del nuevo edificio se acompañaba con la recuperación de la alquería y la peatonalización de ese tramo de la calle Quart con la finalidad de realzar el conjunto del Botánicocalle Quart-plaza de San Sebastián. Pero como todos los políticos llevan coche y ninguno es peatón, a pesar de contar este proyecto con el visto bueno de la Consellería de Cultura de la Generalidad, fue desestimado y se decidió derribar la 


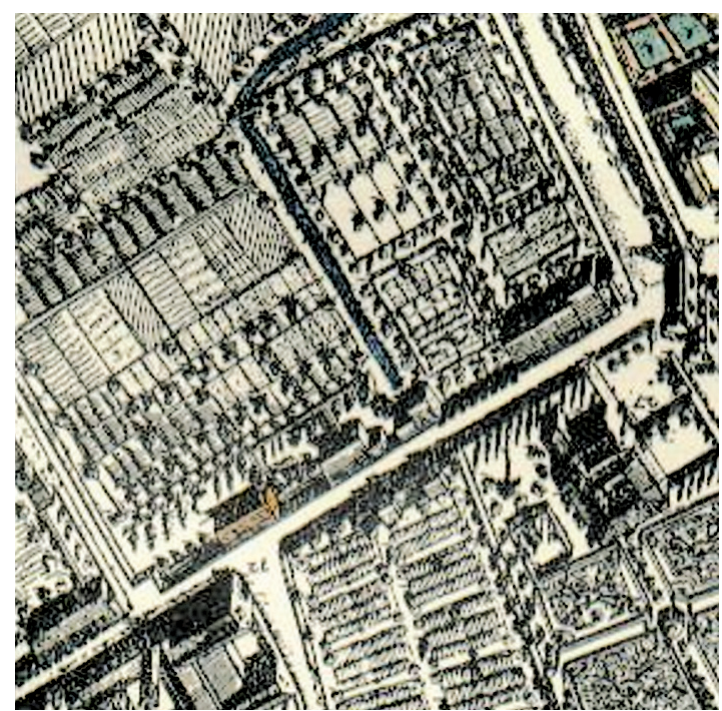

Fragmento del mapa del Padre Tosca de los huertos que formarán el futuro Jardín Botánico La alquería está coloreada en marrón y la acequia en azul

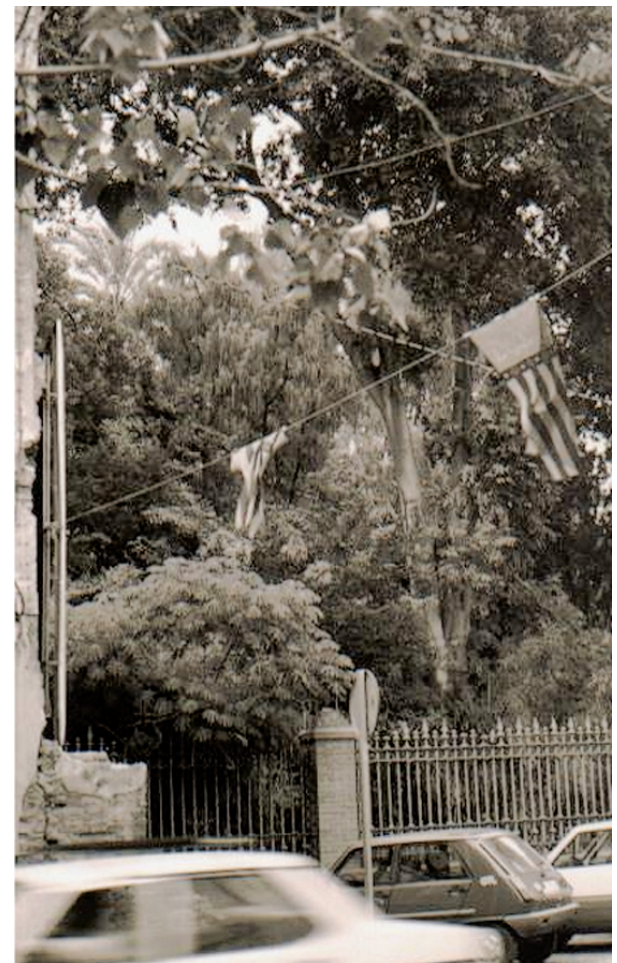

La ventana sur del Jardín (calle Quart) antes de ser eliminada con la edificación del nuevo edificio. (Foto del autor)

alquería para evitar el estrangulamiento que originaba en el tráfico rodado de la ciudad. Y así se hizo con el silencio de todas las asociaciones y colectivos proteccionistas, salvadores o conservacionistas. Tras esto, se proyectó el nuevo edificio el cual se retranqueó hacia el Jardín con lo que éste perdió superficie como veremos a continuación y los coches pudieron ir más rápidos (50).

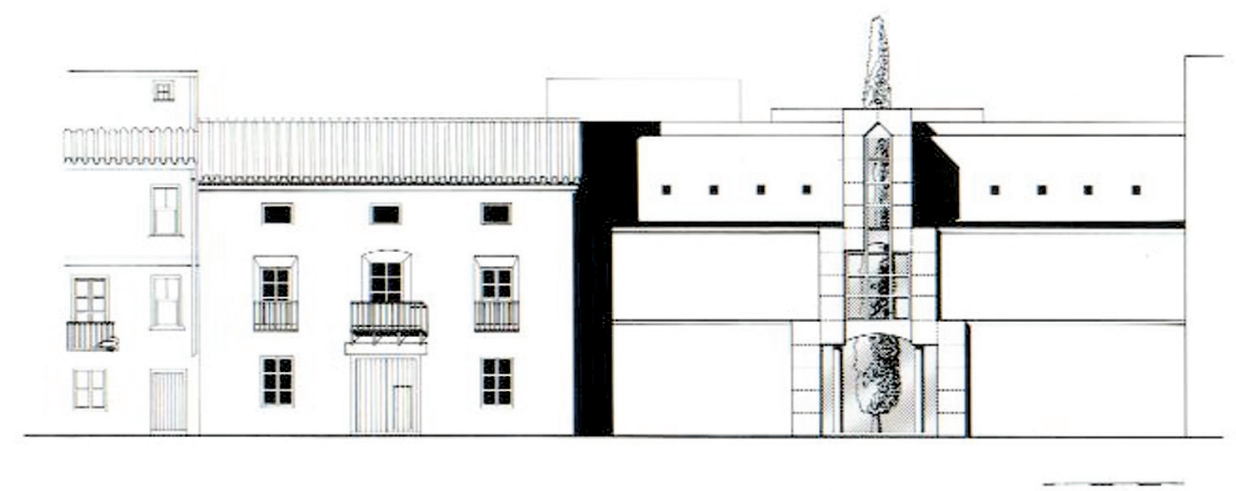

Primer proyecto de construcción con la alquería y el nuevo edificio de Luis Gay. Folleto de la Exposición en el Ateneo Mercantil de Valencia en mayo de 1988 


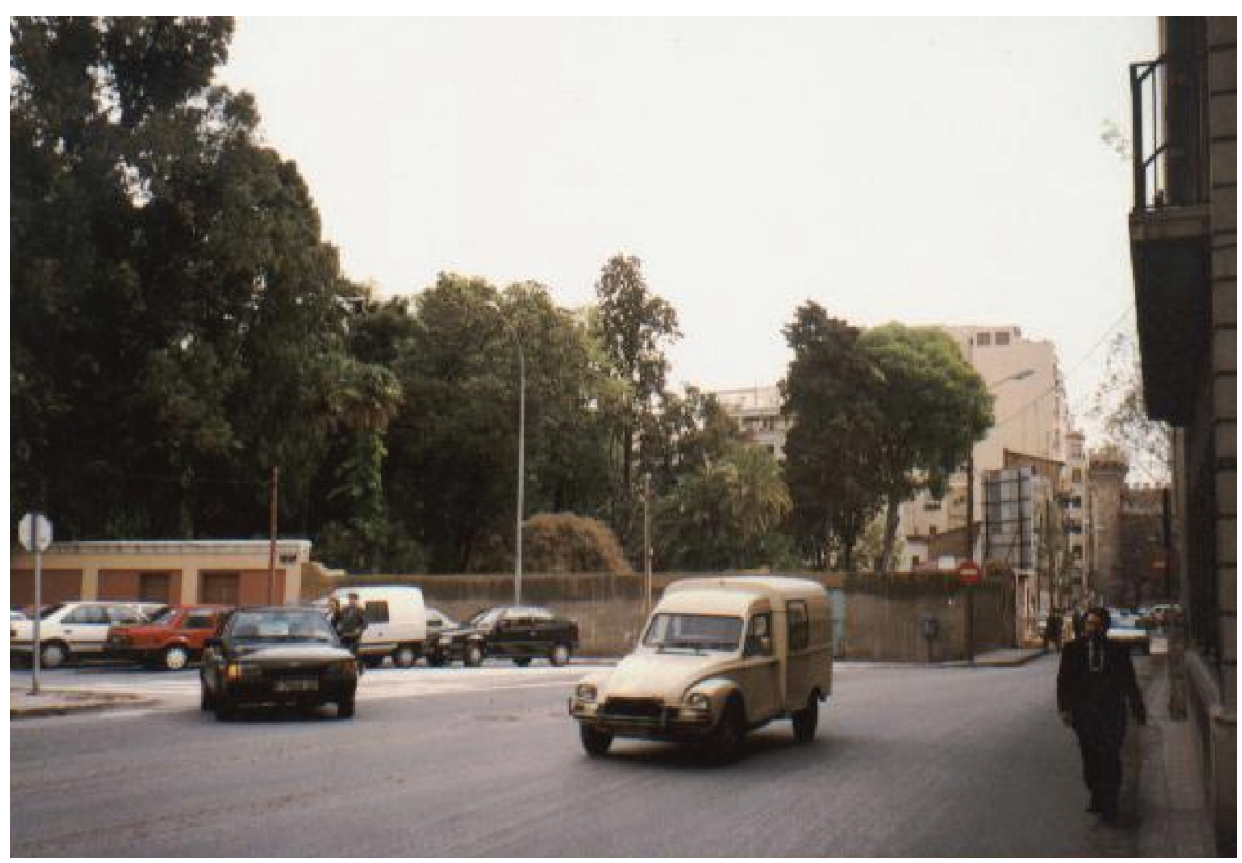

Vista del Jardín sin la alquería y las casas ya derruidas pero sin haberse realizado la eliminación del "cuello de botella " que tanto dificultaba el Tráfico”. (Foto del autor)

Y con esto entramos en la segunda fase del proyecto de restauración del Jardín Botánico. Volvemos a citar a los autores antes mencionados para que definan los trabajos realizados:

"La segunda fase de la restauración proyectada, la construcción del edificio de investigación, sufrió algún retraso, pero, finalmente, se pudo llevar a buen término con la aportación económica de los Fondos Europeos de Desarrollo Regional. El nuevo edificio se inauguró el 18 de mayo del año 2000. Su construcción ha sido de gran importancia para la consolidación de la actividad científica, docente y cultural que el Jardín Botánico venía desarrollando. En él está instalado el herbario de la Universidad de Valencia y el banco de germoplasma de flora valenciana amenazada, que empezó a desarrollarse en 1990 en colaboración con la Consellería de Medio Ambiente y que conserva las semillas y esporas de las plantas valencianas en peligro de extinción. Una biblioteca especializada en botánica ha encontrado, también, su ubicación en el nuevo edificio, abierta al público, reúne un importante fondo de revistas, artículos y libros para los aficionados y estudiosos de las plantas. El edificio está dotado de aulas y laboratorios, para poder explicar a los estudiantes cómo es el mundo de las plantas y cuál es su importancia para el hombre. Los laboratorios de investigación, el salón de actos y la sala de exposiciones son algunas de las nuevas dependencias del Jardín que completan la oferta científica y cultural de este centro ubicado en el corazón de la ciudad de Valencia.

Todo ello hace que el Jardín Botánico de la Universidad de Valencia se encuentre actualmente en una situación inmejorable para atender, desde el ámbito universitario, las exigencias de la sociedad valenciana en temas de medio ambiente". 
Nadie puede discutir la importancia que significan para la Universidad las actividades y finalidad de ese edificio. Lo que se discutía y cuestionó era la idoneidad del lugar elegido para levantarlo pues estaba claro que el edificio se iba a construir en parte del Jardín. Algo parecido a lo sucedido con el teatro romano de Sagunto.

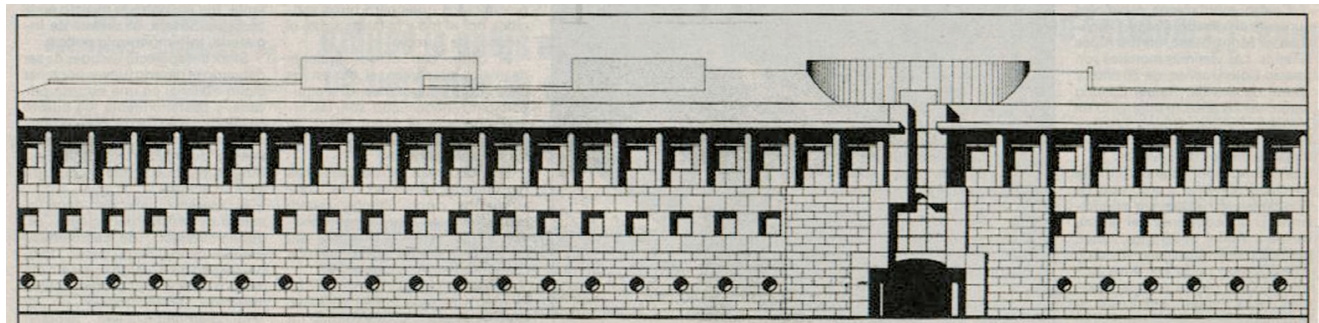

Nuevo proyecto del edificio de investigación en el Jardín Botánico

En febrero de 1997 aparece el primer artículo de una larga serie de la periodista Concha Raga (51) en el que acusaba de hipocresía a la coordinadora Salvem el Botànic y a la Universidad por su oposición a la construcción de las torres de los Jesuitas en el solar cercano al Jardín por su parte oeste mientras que se silenciaba las consecuencias que tendría la construcción del nuevo edificio sobre el Jardín en su parte sur.

La polémica fue subiendo de tono a lo largo de la primavera como muestras las páginas de la prensa de esos meses. Els Verds se oponen a que se construya en el interior del Jardín (52) y se eleva la temperatura cuando el Consell Valencià de Cultura, tras visitar el lugar, muestra su oposición al proyecto de construir el edificio nuevo en ese lugar (53) y aconseja que se construya en el Campus de Burjasot alegando la proximidad de los departamentos de genética, botánica y farmacia ya existentes y de los cuales los nuevos estudios científicos de la Botánica no deberían de distanciarse.

Al final, el 20 de enero de 1998, solucionado el problema de la cesión de unos viales, el Ayuntamiento otorga la licencia de construcción a la Universidad. Las obras comienzan en junio de ese año y solamente se oyen críticas a esta intervención desde el diario Las Provincias (54). En ese mismo diario se publica a los pocos días del comienzo de las obras una carta del vicerrector de investigación de la Universidad, Juli Peretó, que reproducimos integramente por su interés para nuestro trabajo, en la que se afirma "La Universitat de Valencia no destroza el Jardín Botánico como por error, se informó en la edición de Las Provincias del día 20 de junio de 1998. El edificio de investigación que se construye actualmente no invade el Jardín. Por el contrario, se levanta en el espacio que siempre ocuparon unas viviendas recayentes a la calle Quart... El solar que ocupará el edificio siempre estuvo construido desde el siglo XVIII".

(51) Las Provincias, 23 de febrero de 1997

(52) Las Provincias, 2 de marzo de 1997

(53) Las Provincias, 4 de agosto de 1997

(54) Las Provincias, 20 de junio de 1998 
Es inexacto que la Universitat reduzca la superficie de plantación, como erróneamente se afirmaba en la mencionada noticia. La demolición de las viviendas recayentes a la calle Quart permite levantar en ese espacio el edificio de investigación y, además, ampliar la superficie de plantación en unos 400 metros cuadrados. Esto es posible porque la Universitat no construirá en todo el espacio que permite el ordenamiento municipal. El espacio que queda libre permitirá aumentar la superficie de plantación.

Los antiguos edificios de la calle Quart llegaban a alcanzar una altura de hasta 16 metros. En cambio, el edificio de la Universitat sólo se elevará 11 metros.

El edificio cuenta con licencia municipal del Ayuntamiento de Valencia, con autorización de la Unitat Tècnica d'Arquitectura del Servei de Patrimoni Cultural, Belles Arts y Museus de la Conselleria de Cultura, y con la financiación de la Unión Europea.

En la noticia se afirma que el edificio de investigación "es para uso del director del Jardín, Manuel Costa, y los cuatro investigadores de su equipo”. Esta aseveración es inexacta. El edificio que construye la Universitat dispondrá de laboratorios, un herbario, el banco de semillas y una biblioteca, instalaciones abiertas a toda la comunidad científica, tanto valenciana como de otros centros. También permitirá que el personal de apoyo, como jardineros y administrativos, dispongan de unas condiciones de trabajo más dignas que las actuales.

Es también inexacto que se haya desoído un informe del Consell Valencià de Cultura sobre el edificio de investigación. El mencionado informe señala como muy conveniente la apuesta de la Universitat por reforzar el carácter investigador y científico del jardín.

Sólo se han eliminado los árboles y arbustos que fueron creciendo como consecuencia de las diásporas originadas por el propio jardín y que fueron creciendo en los viejos corrales y en el propio solar, todo ello abandonado desde 1990-91 a la espera de la construcción. Al inicio de las obras, el 19 de junio, se trasladó con todas las precauciones sanitarias la "Strelitzia reginae", que se ha situado a la entrada del nuevo acceso del Jardí desde el edificio. La "Yuca elephantipes", que

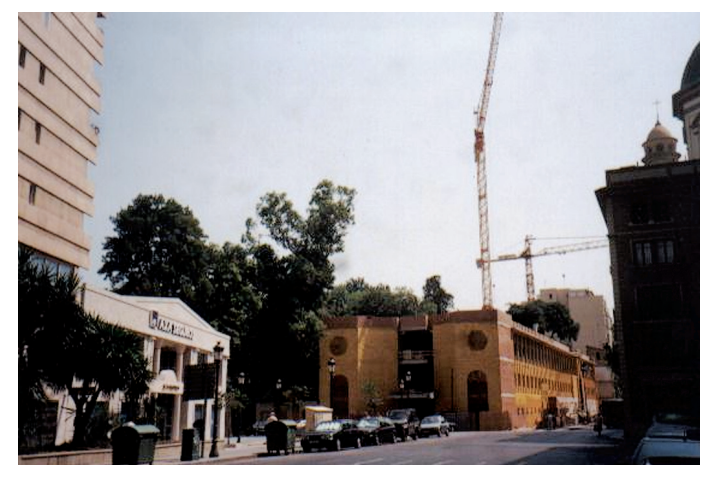

Edificio de investigación durante la fase de construcción. (Foto del autor) 
linda con el edificio, se encuentra en mal estado sanitario y se saneó hace algunos años, cuando se eliminó uno de sus brazos. En una de las fotografías que acompañaban la noticia objeto de rectificación figura este árbol, con el corte del brazo indicando que se ha cortado para construir el edificio, lo que no es cierto. Dicho brazo se eliminó hace dos años debido al ataque de xilófagos que lo habían debilitado y con ello salvar el resto de la planta. De hecho, el edifico se ha adecuado arquitectónicamente para proteger el "Celtis australis" y el "Osteomeles", ambos centenarios" (55).

La contrarréplica a estas noticias así como la afirmación de que no se va a construir en la superficie del Jardín, todo ello expuesto por el vicerrector Juli Peretó y que como hoy puede verse no es del todo exacto, la hace Manuel Loris en una columna en la que alega motivos estéticos por encima de los técnicos en contra de las nuevas construcciones: "...Pero aquí, en el caso del Botánico, hay un dato que todo el mundo entiende: los expertos no podrán decirnos que el edificio dentro del jardín favorece y hace prosperar las plantas. A lo sumo, dirá un sector de ellos, que no las daña.

Pues ya está. Tenemos razón. Ese edificio que está construyendo la universidad es un descomunal atropello. Dañe o no dañe los árboles, lo cierto es que les resta lugar posible y que a mayor abundamiento constituye una herida estética absolutamente imperdonable.

El Botánico es joya en su género, por su gran cantidad de especies exóticas. Pero no dejemos de tenerlo en cuenta: era y es una joya pequeña. Para adquirir verdadero rango internacional le falta espacio. Que la universidad construya sobre una zona arbolada o no arbolada anteriormente, sólo añade al desaguisado. Alegar que el nuevo edificio se construye sobre casas viejas, es inaceptable. Todo el espacio recuperable, absolutamente todo, debería dedicarse a la ampliación de

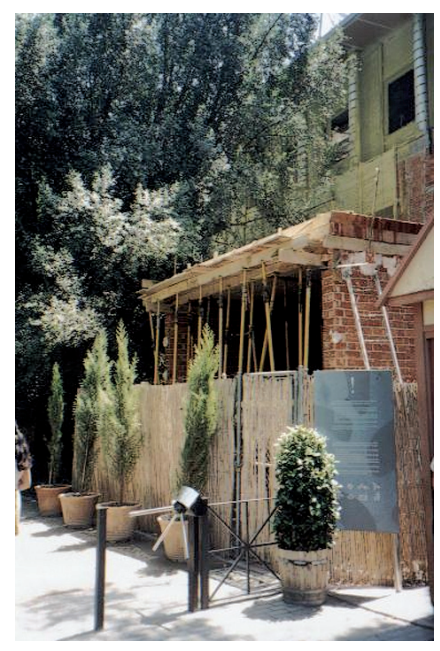

Construcción del nuevo edificio en la superficie del Jardín. Este "grano" del edificio se hizo a costa de arrancar el centenario podocarpo (Podocarpus neriifolia). (Foto del autor) 
la superficie arbolada. Sólo en los grandes parques, cabe la armonía entre la naturaleza y la mano del hombre. En un jardín como el Botánico, el cemento se carga, estéticamente, la majestuosidad y el encanto de la naturaleza"(56).

El nuevo edifico es inaugurado el 18 de mayo del 2000. El evento es ampliamente recogido en la prensa y uno de los grandes periódicos nacionales (57) en las páginas dedicadas a nuestra Comunidad afirma que: "El profesor y director del Jardín Botánico desde 1987 Manuel Costa ha visto culminado un proyecto de rehabilitación concebido en los estatutos fundacionales de la Universidad de Valencia, que ha sufrido en la última década severas embestidas por parte de los sectores más derechistas de la ciudad de Valencia y que, finalmente, se presenta mañana con la inauguración del edificio de investigación dedicado a la Biología de la Conservación y la Biodiversidad, en pleno centro de la capital, en la confluencia de las calles de Quart, Gran Vía y Paseo de la Pechina".

Las palabras señaladas en negrita son nuestras y es por señalar como se estableció entre un amplio sector de la opinión pública que cualquier crítica al proyecto y a las obras realizadas en el recinto del Jardín tenían que poseer un carácter derechista. Y aunque se nos acuse de tal cosa -a estas alturas estamos curados de espanto- expondremos aquí las críticas propias al proyecto y ejecución de unas obras denominadas unas veces rehabilitación y otras restauración del Jardín Botánico de Valencia. Y ello aún con el riesgo de repetir lo ya señalado en las páginas anteriores pero debido a la importancia y polémica generada con este Jardín, sostenemos:

$\mathbf{1}^{\mathbf{a}}$ que la restauración de los invernaderos, recuperación de los edificios y recreación del umbráculo han constituido trabajos de una calidad excepcional;

$\mathbf{2}^{\mathbf{a}}$ que la nueva traza para hacer "viables" los cuadros alteró el carácter histórico de los mismos de una manera importante e innecesaria;

$3^{\text {a }}$ que las repetidas plantaciones de flor de temporada, aunque obtengan el aplauso del gran público, son una agresión al Jardín tanto por falsear su historia como por ser las causantes de enfermedades en los grandes ejemplares del arboreto como hemos explicado más extensamente en anteriores líneas;

$4^{\mathrm{a}}$ que la supresión del riego a manta, sustituyéndolo por los sistemas de aspersión o goteo, supuso romper una de las estructuras básicas del Jardín como era el sistema de acequias históricas y esto ha producido la gran mortandad de los grandes ejemplares del recinto, ya fuese por sequía al no hidratarse en profundidad los suelos donde tenían ancladas sus raíces desde hace doscientos años estos personajes, ya fuese por asfixia al apelmazarse los mismos.

(56) Las Provincias, 10 de agosto de 1998

(57) El País, 17 de mayo del 2000 
$\mathbf{5}^{\mathbf{a}}$ que los criterios importados de la jardinería practicada en la ciudad de Valencia son dañinos para la misma existencia del Jardín ya que dichos criterios incluyen prácticas absurdas de poda, el uso de herbicidas y sobre todo la aplicación de la eutanasia arbórea para los viejos ejemplares del Jardín, algo incomprensible en un centro que pretende dedicarse a la Biología de la Conservación.

$\mathbf{6}^{\mathbf{a}}$ que la construcción del nuevo edificio ocupó suelo del jardín histórico como lo demuestran las fotos obligando en unos casos al transplante y en otros a la tala de ejemplares de ese lugar, además de cerrar la única ventilación que el Jardín tenía por su cara sur.

$7^{a}$ que es incomprensible, indignante y todo el resto de adjetivos que puedan surgir del enfado, que el busto de uno de los más grandes botánicos valencianos de todos los tiempos, Simón de Rojas Clemente y Rubio haya sido desplazado desde la posición central del Jardín que es la plaza de los magnolios hasta el fondo del recinto.

En resumen, se ha llamado restauración de un jardín una vez más a la destrucción de todo un patrimonio histórico para crear otro jardín nuevo: todo un ejemplo de lo que nunca debería de volver a repetirse y muchos menos impulsado por una universidad y además subvencionado con fondos públicos -y para más inri- europeos.

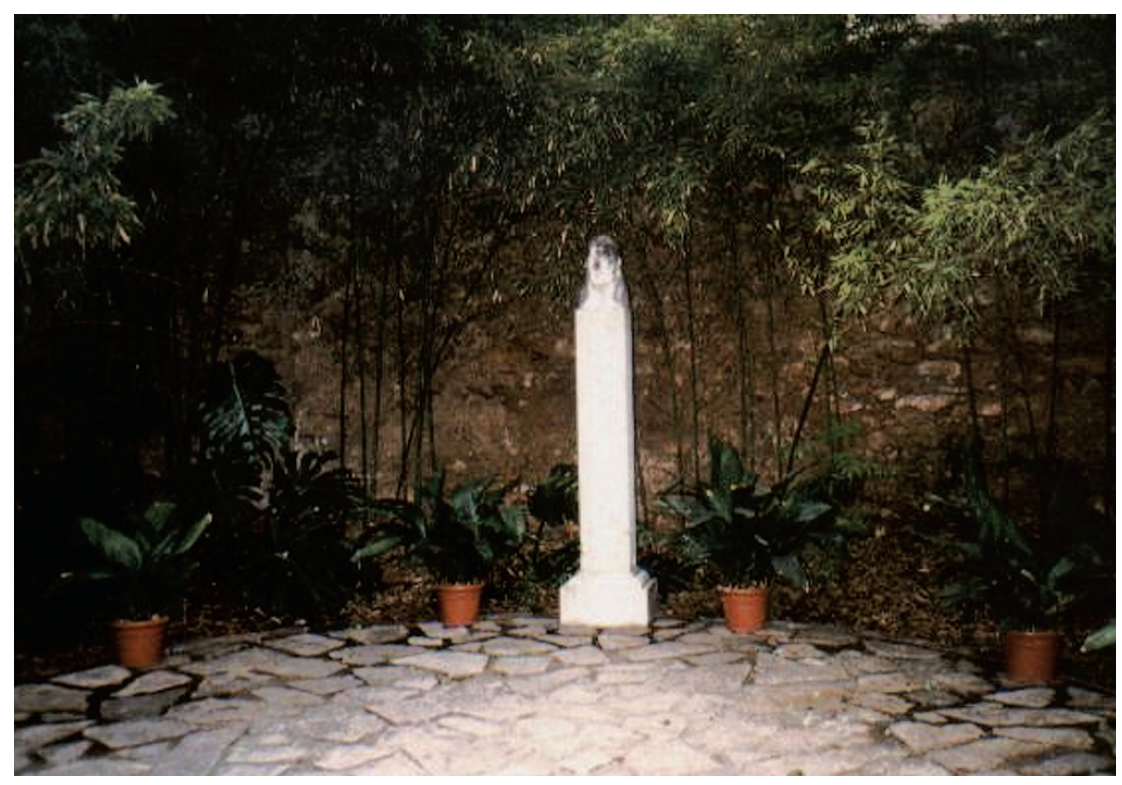

Emplazamiento actual del busto de Simón de Rojas Clemente. (Foto del autor) 


\section{Bibliografía sobre el Jardín Botánico de Valencia}

AGUILELLA, Antoni y CARRAU, Ma José. Guía para educadores del Jardí Botànic de Valencia. Universitat de València. Edita: Jardí Botànic de València. 1989.

ALMELA Y VIVES, Francisco. “Jardines Valencianos”. Monografías de "Valencia Atracción". Arte y Turismo. Valencia, 1945.

Trata del Jardín Botánico en el capitulo VII. Hay referencias a plantas del lugar y a las andanzas literarias de la condesa Gasparín así como los trabajos de los los pintores Rusiñol y Llorens en el Jardín. La estatua - mejor dicho busto- de Simón de Rojas Clemente es obra del "laureado escultor Carmelo Vicent".

BERCHEZ, J. "Jardín Botánico de Valencia” en la obra colectiva Catálogo de monumentos y Conjuntos de la Comunidad Valenciana, págs. 619-637, editado por la Consellería de Cultura, Educación y Ciencia. Valencia, 1983.

Hace una breve historia de los otros jardines botánicos existentes en Valencia hasta la fundación del actual. Avatares de su fundación y división de criterios entre la Universidad y la Real Sociedad de Amigos del País sobre los fines del mismo. Para la Universidad, era básico el estudio de la Botánica. Para la Real Sociedad era primordial el impulso a la investigación agrícola. Construcciones de la época de Pizcueta en el XIX. Señala que el busto de Simón de Rojas Clemente se erigió en 1927 en conmemoración del centenario de su muerte. Sobre las plantas dice: "El Jardín Botánico contiene actualmente una densa arboleda compuesta por unos trescientos ejemplares de arbustos, árboles y palmeras que repartidos por toda la superficie del Jardín constituyen un auténtico "arboretum" residiendo en ellos el principal mérito del Jardín".

CASA VALDES, Marquesa de. Jardines de España. Ed. Aguilar. Madrid, 1973.

En la página 172 del capítulo XI dedicado a la historia de los jardines botánicos en España, la Marquesa trata de este Jardín. Hace un breve resumen de los anteriores jardines y una descripción ligera del mismo. Acaba afirmando: "Indiscutiblemente es el mejor jardín botánico que posee hoy día España."

GINES, Eugenio. “El Jardín Botánico de Valencia” Artículo de la revista Arte y Cemento, no 1.677, abril-mayo de 1992. Páginas 78-85.

Se elogian las obras realizadas. Aparece la ficha técnica de las obras de restauración de la primera fase del Jardín.

MADOZ, Pascual. Diccionario geográfico-estadístico-histórico de Alicante, Castellón y Valencia. Tomos I y II. Edicions Alfons el Magnànim. Valencia, 1982.

Ofrece una extensa relación de las plantas cultivadas en el jardín a mediados del siglo XIX.

RODRIGUEZ GARCIA, Aurora. Historia de los jardines valencianos. Ed. Marí Montañana. Valencia, 1996.

Trata del Jardín Botánico en el capítulo XII del libro. Resumen de anteriores jardines botánicos. Fundación por la Universidad en 1802 siendo rector Blasco. Unión de las cátedras de Agricultura y Botánica en 1834. Descripción de Madoz. Evolución en el siglo pasado. Ejemplares desaparecidos.

VV.AA. El Jardín Botánico de la Universidad de Valencia. Editado por Manuel Costa y Jaime Güemes. Universidad de Valencia. Cinc Segles. Valencia, 2001.

Publicación en la que se trata de la historia del Jardín, sus colecciones de plantas, la arquitectura del nuevo edificio y el proceso de restauración llevado a cabo a finales del siglo XX, las colecciones culturales, los objetivos de la investigación y conservación de la biodiversidad y las actividades de educación y extensión cultural realizadas en el lugar. 


\section{Hemeroteca}

En estos últimos años los artículos que hacen referencia al Jardín y su entorno han sido numerosísimos. Aquí recogemos algunos de ellos por haber servido los mismos como documentos para la elaboración de este trabajo.

\section{4}

- Levante, 11 de octubre: "El Hortensia arrasa el Jardín"

\section{8}

- Las Provincias, 18 de mayo: "En el J. B. se creará un centro de investigación"

- El País, 11 de mayo: "Un grupo de biólogos y naturalistas critica el proyecto de restauración del J. B. de V."

- Las Provincias, 2 de junio: "El Botánico de Costa".

- El País, 21 de julio: "La dirección del J. B. de V. intenta atajar el grave deterioro que sufre el arbolado".

- Las Provincias, 21 de julio: "El Botánico necesita 600 millones".

- Hoja del Lunes, 17 de octubre: "El J. B. de V. se convertirá en el más grande de España".

\section{9}

- El País, 28 de enero: "El Ayuntamiento quiere acondicionar como bosque mediterráneo el tramo del Túria cercano al Botánico."

- Las Provincias, 31 de enero: "Esta es la trasera del Jardín Botánico".

- Las Provincias, 14 de febrero: "Sería un grave error no ampliar el Botánico en el río".

- Las Provincias, 19 de octubre: "Comienzan las obras de rehabilitación del J. B."

- Levante, 8 de noviembre: "El J. B. de V. ha logrado reunir 20.000 ejemplares en su herbario".

\section{0}

- El País, 24 de enero: "Reforma en el Jardín Botánico".

- Las Provincias, 25 de abril: "El J.B. en pleno proceso de rehabilitación".

- Las Provincias, 27 de mayo: "La manzana de los Jesuitas". Publicidad.

\section{1}

- Las Provincias, 12 de junio: "La renovación del Botánico" por César Simón.

- El País, 13 de junio: "El J. B. de V. vuelve a abrir sus puertas tras la reforma".

- Levante, 13 de junio: "El J. B. reabre sus puertas".

- Las Provincias, 13 de junio: "Apertura oficial del botánico".

- Hoja del Lunes, 17 de junio: "Valencia recuperó su Jardín Botánico".

\section{3}

- Levante, 27 de febrero: "Las fincas del solar de jesuitas sufrirán un recorte de alturas para proteger el Botánico".

- Las Provincias, 7 de septiembre: "Nueva entrada principal y más edificaciones para el Botánico". 
- Levante, 21 de julio: "Cultura estudia si el nuevo proyecto para jesuitas no daña el Botánico".

\section{5}

- Levante, 3 de enero: "Arte para el Botánico".

- El País, 8 de febrero: "Urbanistas y vecinos se movilizan contra las tres torres de 20 pisos proyectadas en el solar de Jesuitas".

- Levante, 10 de marzo: "El movimiento contra las torres se convierte en una coordinadora".

- El País, 13 de abril: "Salvem el Botànic pide al Consell que vete el proyecto del solar de Jesuitas".

- 8 de mayo: Presentación pública de la Coordinadora: "Salvem el Botànic, Recuperem ciutat".

- El País, 24 de abril: "El Botánico, un error enmendado".

- El País, 7 de junio: "La Academia de San Carlos rechaza las torres del solar de Jesuitas".

- Levante, 26 de julio: “Cinco jardines botánicos europeos protestan contra las torres de Jesuitas".

- El País, 28 de julio: "El Consell Valencià de Cultura se opone a la construcción de las Torres de Jesuitas".

- El País, 10 de septiembre: "Inminente "luz verde" para levantar tres torres en el solar de Jesuitas".

- Levante, 15 de septiembre: "Cultura autoriza la construcción de tres torres de 20 pisos en Jesuitas".

- El País, 15 de septiembre: "Villalonga da luz verde para construir las tres torres junto al Botánico".

- El País, 19 de septiembre: "El PSPV se desdice y boicotea ahora las torres del Solar de Jesuitas".

- El País, 21 de septiembre: "La empresa anuncia la construcción inminente de las torres de 20 pisos del solar de Jesuitas".

- Las Provincias, 6 de octubre: "El edificio que la Universidad va a construir en el B. dará más sombra que las torres de Jesuitas".

- El País, 3 de noviembre: "Salvem el Botànic" anuncia diversos actos contra las torres de los Jesuitas".

- Levante, 15 de noviembre: "Salvem el Botànic cree que se ha anulado la licencia de Jesuitas".

- Levante, 19 de noviembre: "Salvem el Botànic" intentó confundir a la opinión pública: Cultura no ha suspendido el acuerdo de Jesuitas".

- Levante, 19 de noviembre: "Protesta contra las Torres de Jesuitas".

- Las Provincias, 19 de noviembre: "Entreavenidas envía a Carmen Arborch toda la información sobre Jesuitas".

- Levante, 14 de diciembre: "Barberá: "La rebaja de alturas en jesuitas conviene a Valencia".

- El País, 14 de diciembre: "El PSPV muestra una alegría contenida por la reducción de las Torres de Jesuitas".

- Levante, 7 de diciembre: "Botànic".

- Levante, 15 de diciembre: "Salvem el Botànic mantiene su campaña contra las torres de los Jesuitas". 
- Levante, 12 de diciembre: "Calatrava suspende su viaje a Valencia tras el "disgusto" por la anulación de su proyecto".

- Levante, 13 de diciembre: "Entreavenidas acepta recortar a la mitad la altura de sus dos torres en el solar de los jesuitas de V.".

\section{6}

- Levante, 12 de enero: "Rita firma con los dueños de jesuitas el preacuerdo para reducir las Torres".

- El País, 19 de enero: "El B. de V. acerca al público "El arte de un naturalista".

- Las Provincias, 18 de enero: "Muestra sobre arte y ciencia en el J. B. de V.".

- El País, 23 de enero: "Ginkgo biloba".

- El País, 8 de febrero: “Un grupo entregará mañana a Barberá 53.844 firmas contra las Torres de Jesuitas".

- El País, 10 de julio: "El Ayuntamiento anuncia que en el solar de Jesuitas sólo habrá un hotel".

- La Cartelera, julio: "Salvem el Botànic" en video.

- Levante, 30 de noviembre: "Salvem el Botànic" pide la ampliación del jardín con un mural".

\section{7}

- Las Provincias, 23 de febrero: "La Universidad quiere construir un gran edificio en el Jardín Botánico".

- Las Provincias, 28 de febrero: "El Jardín Botánico".

- Las Provincias, 28 de febrero. "Vecinos del Botánico se sienten utilizados en el caso de jesuitas".

- Las Provincias, 12 de marzo: "Els Verds" rechaza el edificio que la Universidad pretende construir en el interior del J. B.".

- Levante, 2 de marzo: "Los enemigos del Botánico".

- Levante,2 de marzo: "El derribo de fincas ruinosas aumentará las zonas ajardinadas en el Botánico".

- Levante, 9 de marzo: "Una cesión de viales bloquea el centro científico del B."

- Levante, 26 de marzo: "Els dos Jardins Botànics de la Universitat".

- El País, 9 de marzo: "Un Botánico incompleto".

- Las Provincias, 2 de mayo: "Declaraciones de Santiago Grisolía".

- Levante, 12 de abril: "El Consell Valenciá de Cultura hará un informe sobre el nuevo edificio del Jardín Botánico".

- Las Provincias, 4 de agosto: "El Consell V. de C. se opone a que la Universidad construya dentro del Jardín Botánico".

- Levante, 20 de junio: "Nueva protesta de la coordinadora "Salvem el Botànic".

- Levante, 21 de junio: "Salvem el Botànic" encinta un hotel”.

- Levante, 31 de julio "Botánico y otros cultivos".

- Levante, 29 de noviembre: "Salvem el Botànic" busca en Córdoba apoyo europeo para ampliar el Jardín".

- El País, 1 de diciembre: "Salvem el Botànic" ya tiene banda sonora".

\section{8}

- El País, 20 de enero: "Valencia da vía libre para construir el centro de investigación del Botánico". 
- Levante, 10 de enero: "El Ayuntamiento da la licencia de obras a la Universitat para el centro del Botánico."

- El País, 29 de abril: "Cantores botánicos".

- Las Provincias, 20 de junio: "Empieza la destroza del Botánico: el cemento arrasará una parte del bicentenario jardín".

- Las Provincias, 20 de junio: "La sombra de las Torres del solar de Jesuitas".

- Las Provincias, 20 de junio: "Los gritos del silencio".

- Las Provincias, 20 de junio: "Que pena, profesor Costa".

- Las Provincias, 27 de junio: "Botánico".

- El País, 25 de junio: "Bajo el espíritu de la Ilustración”.

- Las Provincias, 2 de julio: "Nuevo desafío: el equipo rectoral de la Universidad tomó posesión en el Botánico".

- Las Provincias, 10 de agosto: "El Botánico".

- El País, 17 de noviembre: "La cuestión inacabada del Botánico".

\section{9}

- El País, 28 de marzo: "Arte para salvar el Botànic".

- El País, 10 de julio: "Una palmera de 253 millones".

- El País, 22 de julio: Publicidad de Grand Hotel Crystal Palace S.A.”.

- Levante, 14 de diciembre: "Salvem el Botànic y la Universitat proponen hacer de Jesuitas un conjunto monográfico".

\section{0}

- El País, 10 de enero: "Sin investigación, el Botánico moriría".

- Levante, 28 de marzo: "La Universitat concluye las obras del edificio del J. B."

- El País, 17 de mayo; "Nace el primer instituto de investigación dedicado a la Biología de la Diversidad".

- El País, 19 de mayo: "Costa recibe la medalla de la Universidad por su tarea al frente del Botánico".

- Las Provincias, 19 de mayo: "Costa recibe la medalla de la Universidad el día de apertura del edificio de investigación del B.".

- El País, 25 de mayo: "Llidoner".

- El País, 4 de junio: "Salvem el Botànic" pinta la valla del solar de jesuitas para pedir la ampliación del jardín".

- Levante, 20 dejunio: "Exposición de cactus en el J. B."

- Levante, 4 de junio: "Científicos internacionales analizan en Valencia la importancia de los jardines botánicos".

- Levante, 27 de noviembre: "El Botánico y jesuitas".

\section{1}

- Levante, 22 de junio: "EL Botánico y la Ley del Patrimonio".

- Levante, 23 de diciembre: "Salvem el Botànic exige a Cultura que se defina y proteja el solar de Jesuitas". 


\section{b) Jardín de Monforte}

Habíamos dejado en páginas anteriores el Jardín de Monforte después de que Javier de Winthuysen lo restaurara tras la Guerra Civil. Durante la riada del 57 sabemos que el jardín sufrió el aporte indeseado de lodos y gravas. Además la alta humedad presente en el lugar hizo que muchos de los setos de boj se pudrieran siendo sustituidos por los aún visibles de evónimo en algunos sectores del jardín.

Durante la década de los setenta sufre en jardín una pérdida irreparable. Todo el conjunto del castillo de Ripalda desaparece para construirse en su lugar el nuevo edificio de la Pagoda. Poco a poco el Jardín irá viendo su perímetro cercado por otros edificios que aunque no tan cercanos como el señalado anteriormente, lograrán cerrar el jardín por todos sus lados.

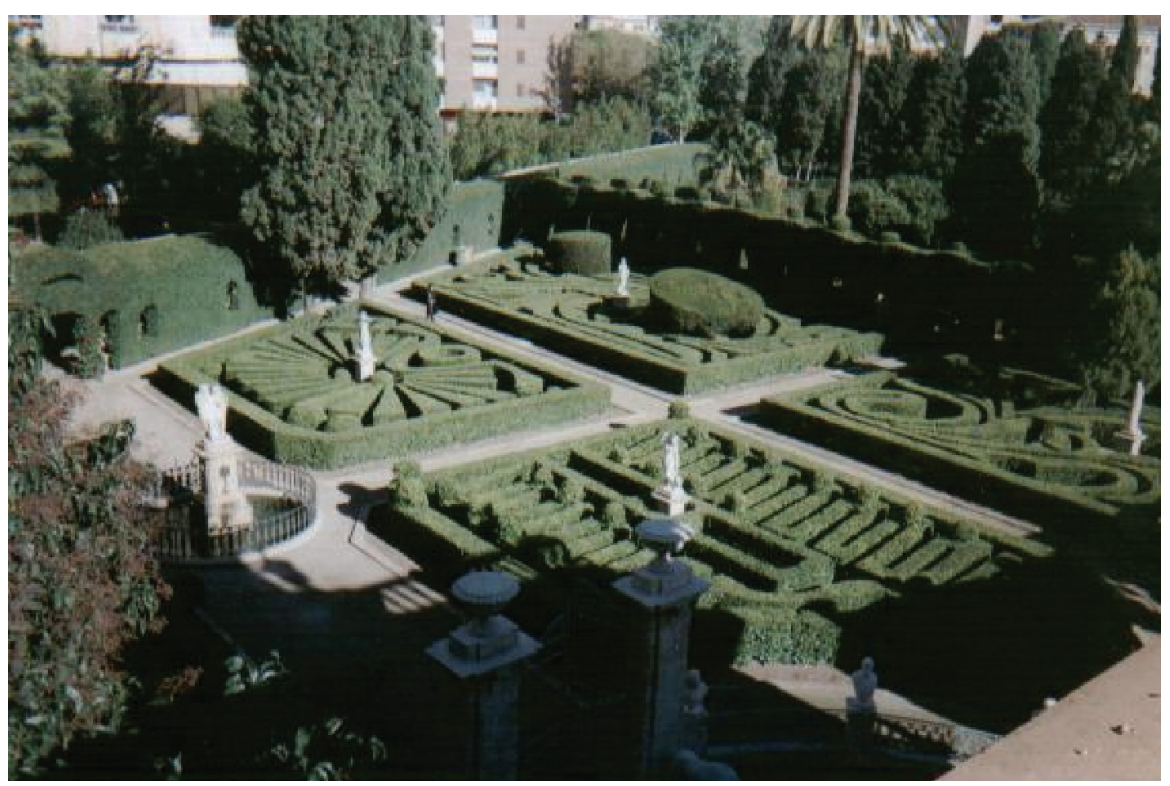

Las casas se han ido acercando al Jardín. (Foto del autor con autorización del Excmo. Ayuntamiento de Valencia)

Tras realizar una permuta de Terrenos, los propietarios cedieron la propiedad del Jardín al Ayuntamiento de la ciudad, el cual siguió cuidando de él como había hecho desde los años cuarenta tras la restauración de Winthuysen.

Por los años ochenta del pasado siglo, el Ayuntamiento crea la Fundación de Parques y Jardines Singulares que se hace cargo de los cuidados de conservación del jardín hasta el día de hoy.

Durante este período vamos a presenciar diversas intervenciones, algunas afortunadas y otras lamentables.

Entre las afortunadas destacan la recuperación de los suelos y pavimentos antiguos del jardín; la restauración del sistema hidráulico para permitir el funcionamiento de las bromas de agua; el cambio de los setos de evónimo por otros nuevos 
de arrayán; la conservación del costoso diseño de figuras y dibujos en la parte formal del Jardín mediante frecuentes podas; el mantenimiento de la estructura histórica de los cuadros y el cultivo en el interior de los mismos de plantas de temporada o tradicionales (agapantos y crinos como ejemplo) evitando de esta manera la presencia del césped.

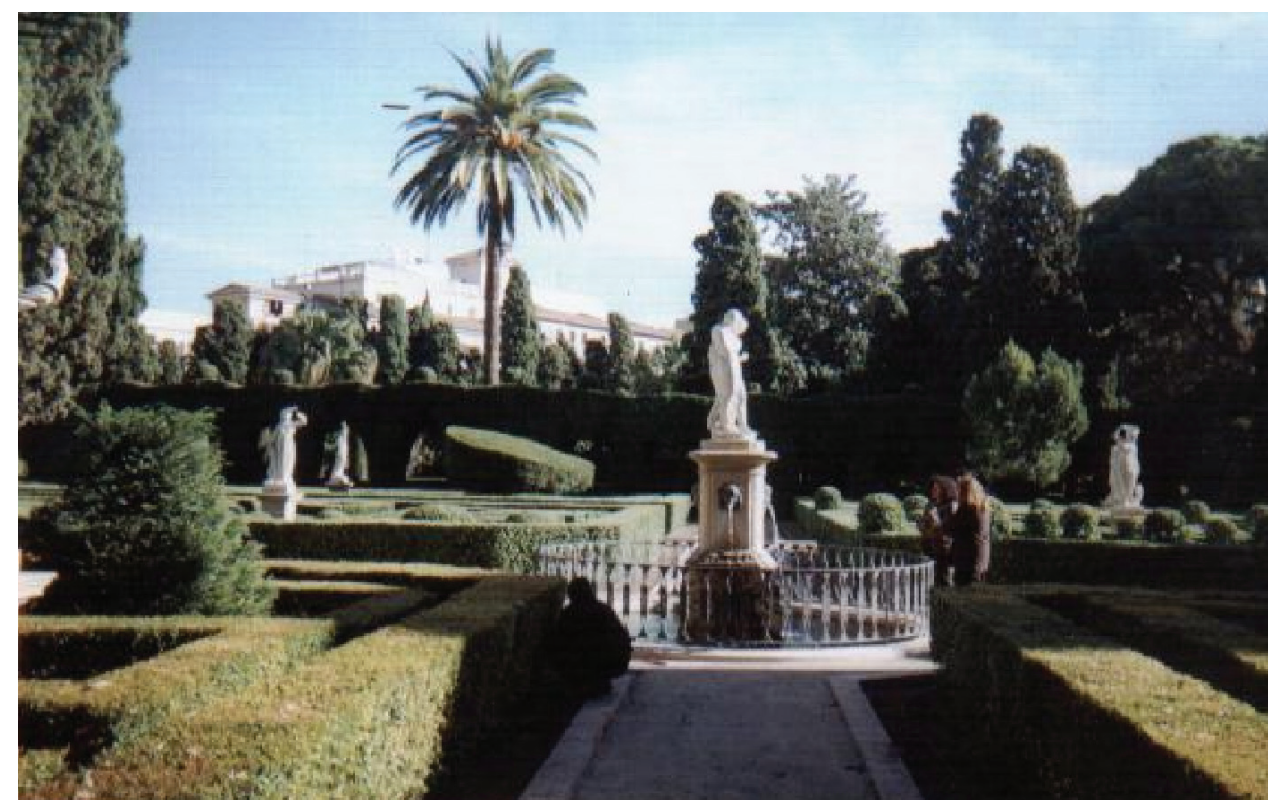

El mantenimiento de los setos y topiaria del Jardín exige grandes cuidados y atenciones. (Foto del autor)

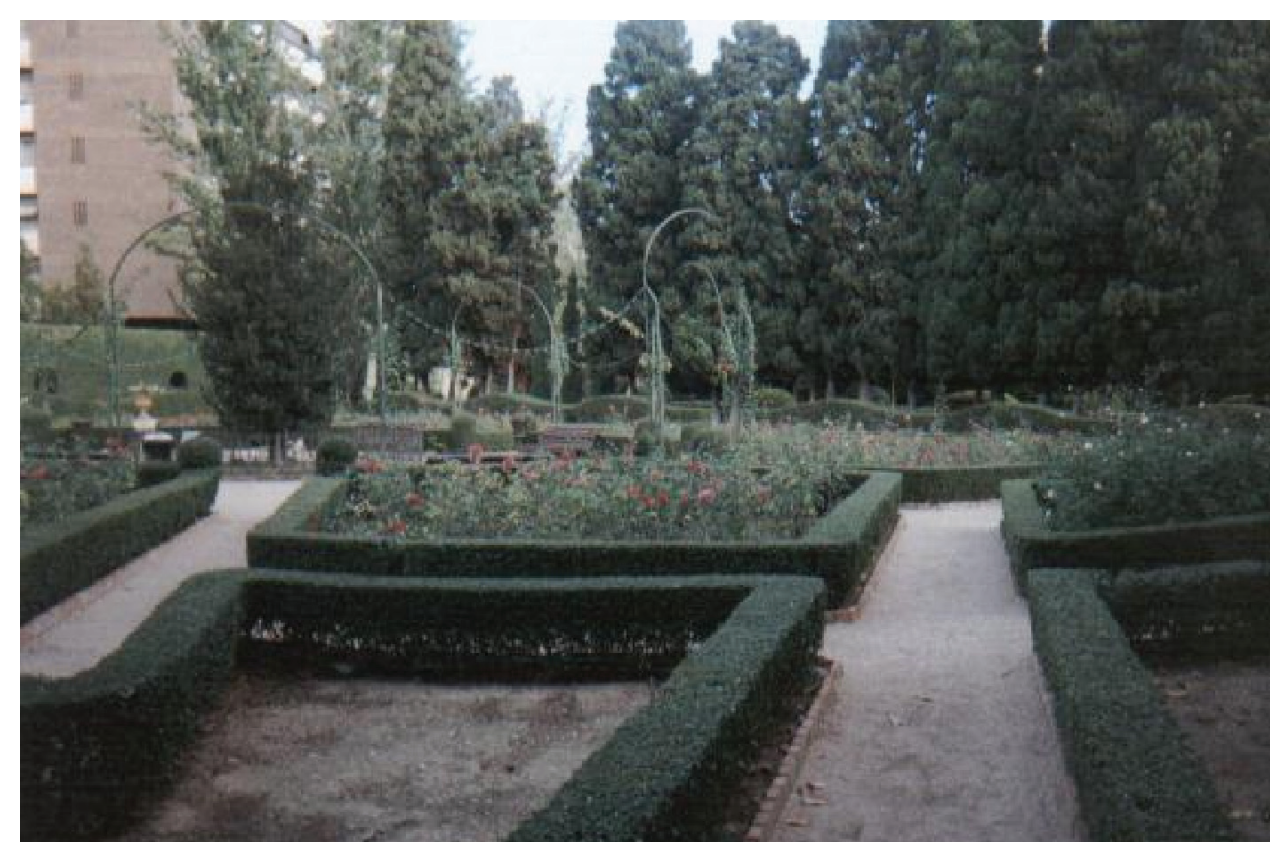

Otro de los logros elogiables de Monforte es la conservación de los cuadros del jardín para plantas de temporada o vivaces sin haber recurrido al césped. (Foto del autor) 
Como aspectos negativos hay que destacar la extensión del sistema de riego a goteo que ha llenado el jardín de gomas; la introducción de plantas demasiado modernas que desentonan con el carácter del lugar como son las lenguas de suegra (Sansevieras) y flores del Paraíso (Strelitzia reginae), la "restauración" del pabellón o Palacete con la pérdida de toda la colección de azulejos y mármoles para ser reutilizado como lugar para las bodas municipales; la desaparición del diseño y la vegetación del jardín de la entrada tras las obras del palacete que atribuimos a Javier de Winthuysen así como la limpieza de tipo "scotch brite" de la estatuaria; el importante cambio de entrada por la parte de atrás - una puerta de servicio- en vez de utilizar la histórica con lo que se pierde la simbología del acceso al jardín y la ampliación de la montaña con piedras de rodeno para conservar la absurda colección de bonsais cuando toda la montaña está construida con piedra caliza.

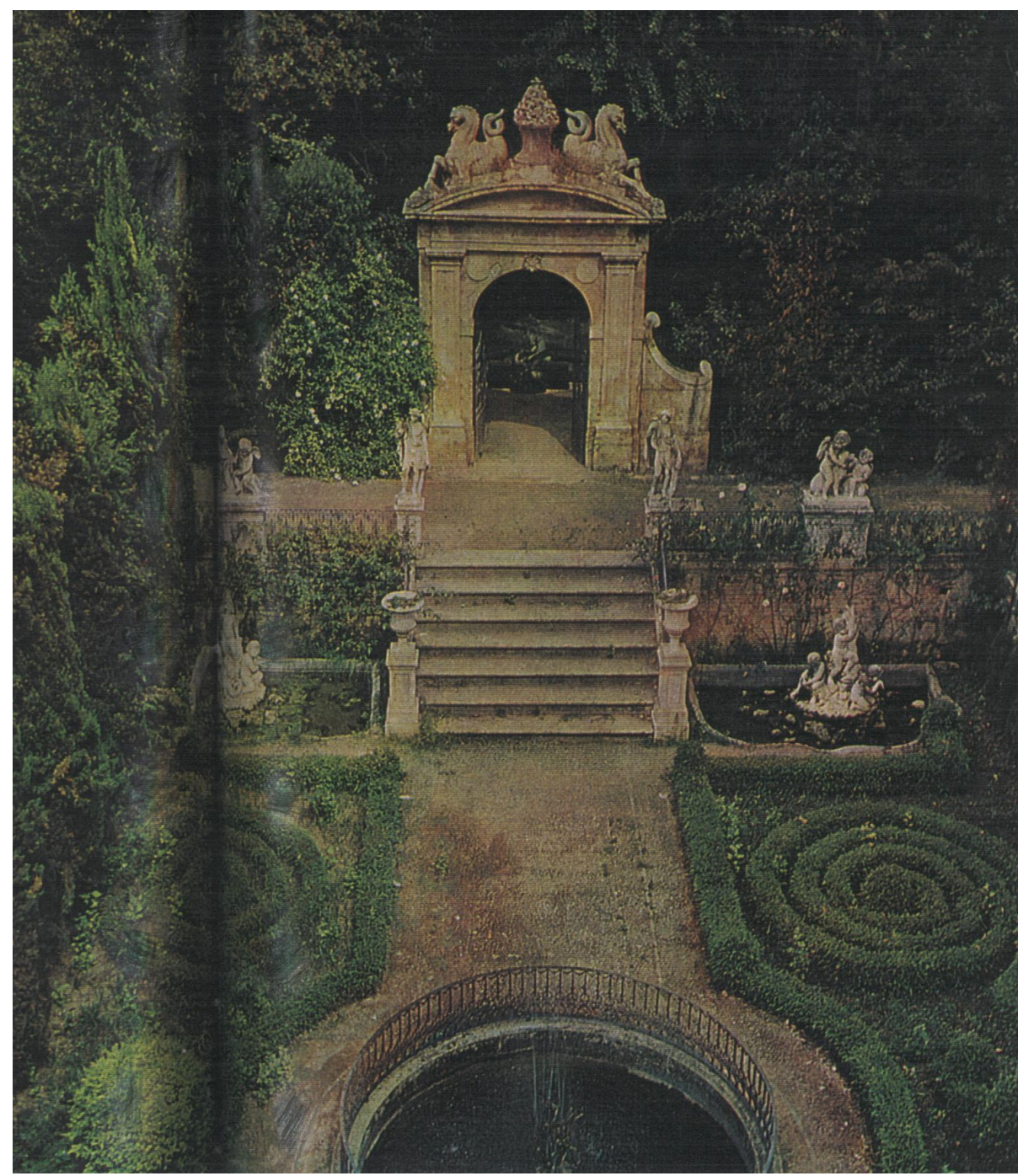

Jardín del pabellón de Monforte en los años sesenta del pasado siglo. Fascículos “Jardines de España” de la revista Blanco y Negro. (Foto de Alvaro García-Pelayo) 


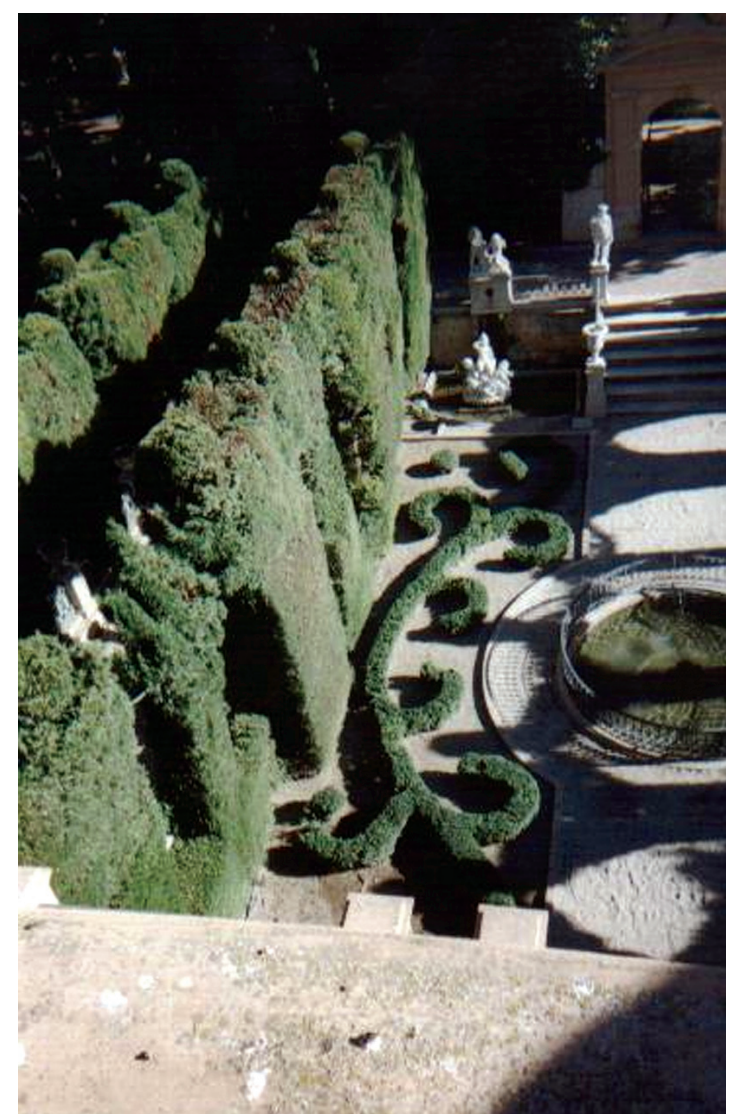

Jardín del pabellón tras la reciente restauración. (Foto del autor con autorización del Excmo.

Ayuntamiento de Valencia)

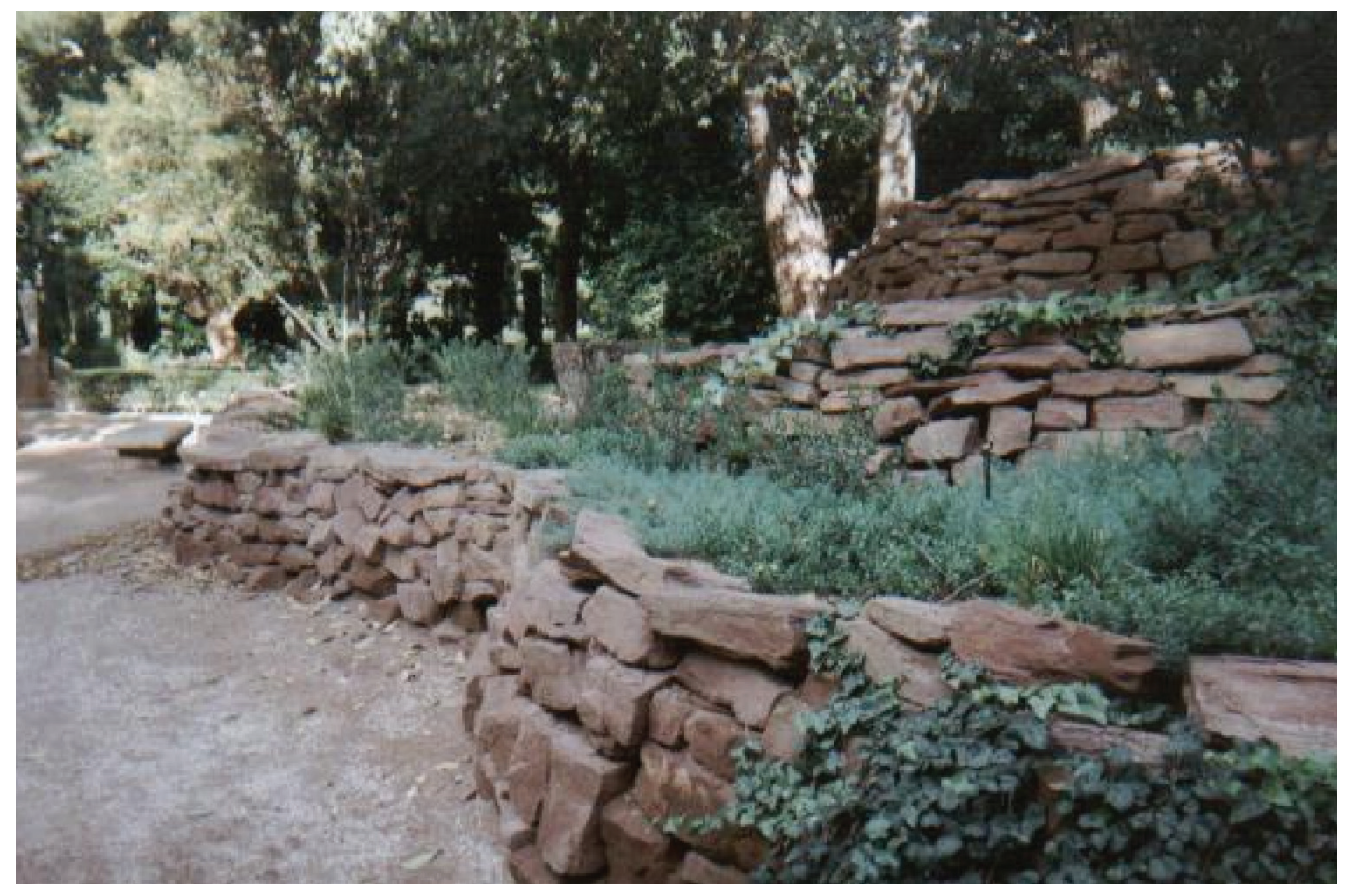

Añadidos de rodeno a la montaña para conservar la colección de bonsais. (Foto del autor) 
Las últimas obras realizadas (2001) han consistido en fijar con cemento todos los elementos de la rocalla de la montaña tal vez con la pretensión de evitar que crezcan las plantas entre las piedras que constituyen la estructura de la misma. Otra intervención sorprendente y que nos hace pensar que no se actúa según unos criterios de mantenimiento acordes con el carácter de jardín histórico del lugar sino con la improvisación tan característica con que funcionan los ayuntamientos en general con sus bienes culturales. Y nos sirve de ejemplo la montaña mencionada, símbolo máximo en el jardín del lugar agreste y salvaje, de la expresión de la naturaleza libre y sin intervención humana. Cementadas sus paredes de piedra para evitar las brozas ¿qué espacio queda para que se exprese la natura naturans en el jardín?

Todo lo anterior muestra la falta de criterios imperante en el mantenimiento del considerado mejor jardín histórico de Valencia.

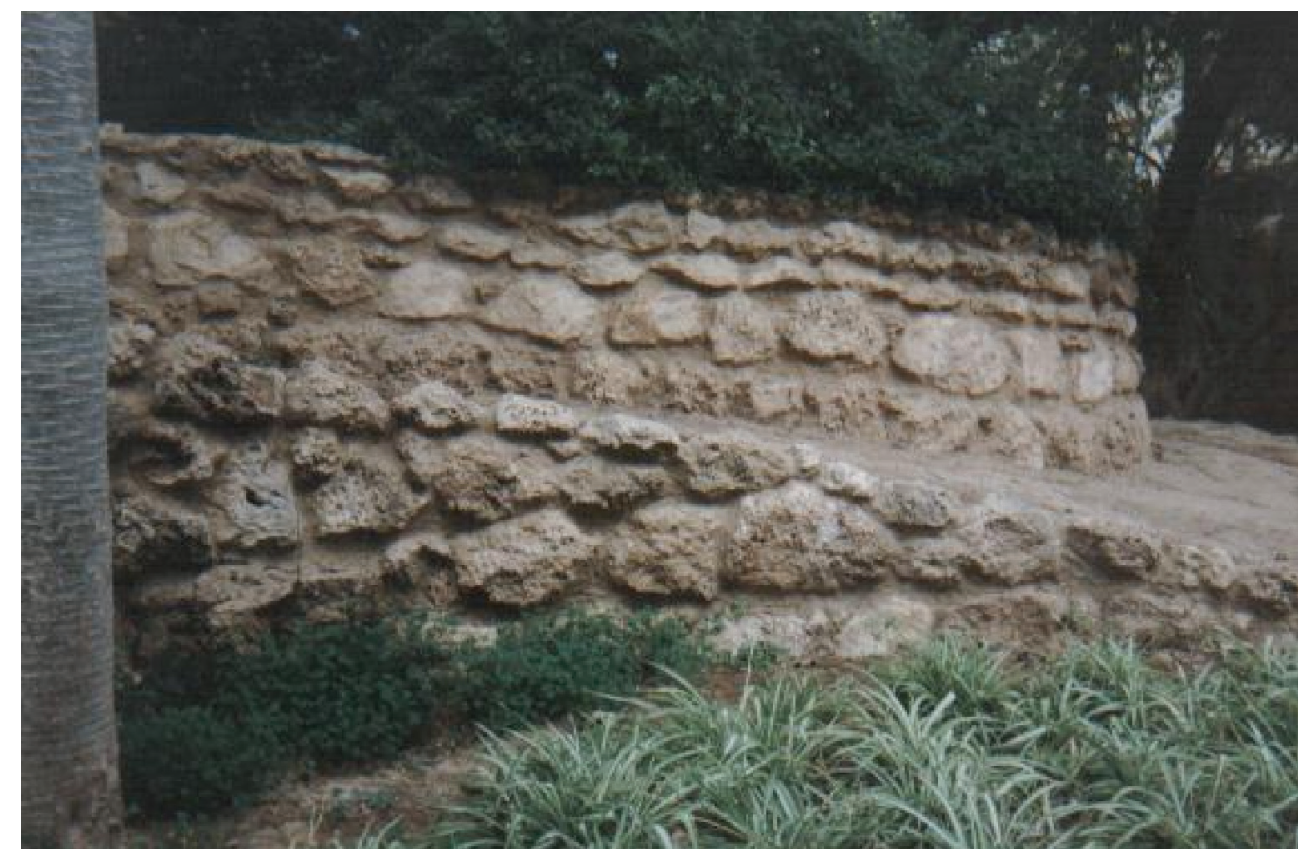

Obras recientes en la antigua montaña obradas con cemento. (Foto del autor) 


\section{c) Jardín del Beso de Xàtiva}

\section{Antecedentes históricos}

La ciudad de Xàtiva se halla situada en la falda del monte Bernisa, prolongación de Serragrosa y lugar donde el acuífero de la citada sierra descarga. Desde siempre ha sido un lugar famoso por la abundancia de agua y el uso lúdico y ornamental de ésta en casas, palacios y fuentes públicas para pasar después a dar vida a las acequias de riego de sus huertas.

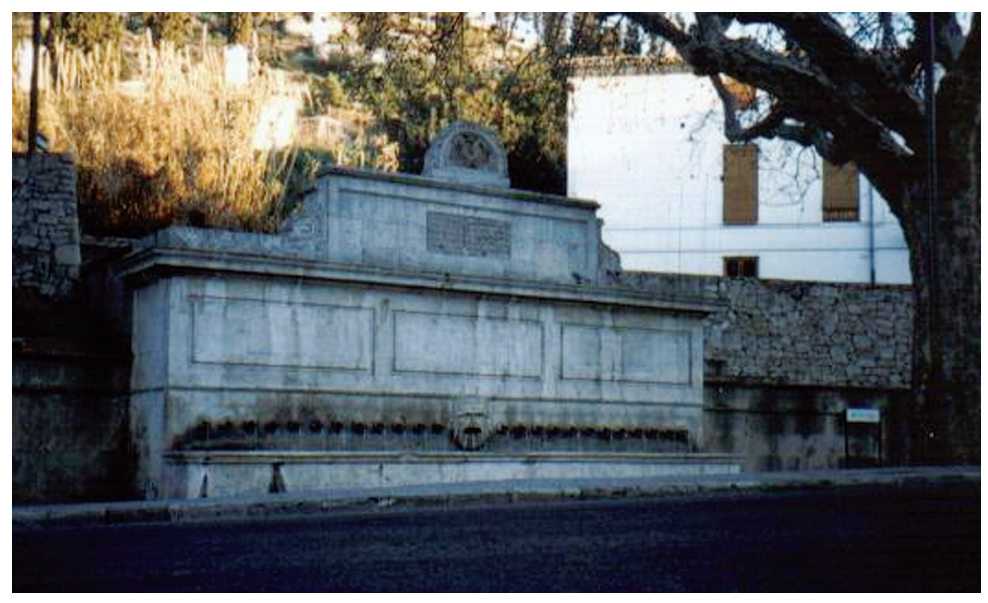

Fuente de los 25 caños en Xàtiva. (Foto del autor)

El jardín que nos ocupa, situado al NE del centro histórico, tiene su origen en la famosa fuente de los 25 caños. El caudal de agua potable más importante, procedente del "estret de les aigues" cercano a la población, ofrece en esta fuente su primera manifestación. Dicha fuente ya está citada por Cavanilles en el siglo XVIII. El agua, antes de la construcción del jardín, se utilizaba para baños, molienda y riego.

A principios del siglo XX (1914) dos benefactores de Xàtiva llamados Carmen Pérez Pascual y Attilio Bruschetti Mariotti ofrecen al Ayuntamiento restaurar la fuente de los 25 caños y hacer un lavadero. A petición de la Federación Obrera se realiza también la cubierta del mismo. Las obras del lavadero se acaban en 1915 y fue utilizado hasta los años 60 del pasado siglo XX. Se continúa haciendo el jardín que es inagurado en 1924, llamándolo el Ayuntamiento Parque Infantil de Carmen Pérez en honor de la ya difunta benefactora. También se denominó oficialmente Parque Bruschetti en época posterior. Pero el pueblo de Xàtiva lo bautizó como Jardín del Beso y como tal es en la actualidad conocido.

\section{Características e importancia del Jardín}

Los elementos de la obra del jardín corresponden a la tradición jardinera valenciana: bancos y fuentes de azulejos, un curioso templete neoárabe, escalinata con 
adornos de leones de cerámica de reflejos dorados y una delicadísima red de acequias cubierta con rejas que permite sentir el sonido del agua evitando los tropezones, las caídas y la acumulación de basuras.

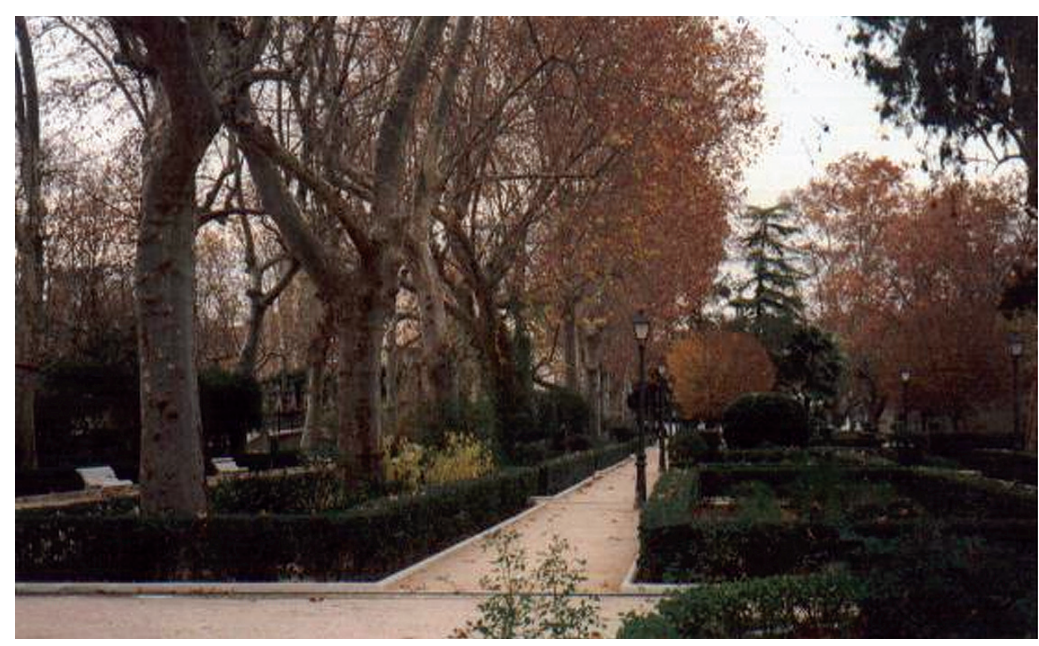

Aspecto del Jardín del Beso en Xàtiva. (Foto del autor)

El diseño está compuesto por un rectángulo imperfecto al que se acopla una trama geométrica de parterres rectangulares con un gran paseo de plátanos en su centro. Dichos parterres encierran las plantaciones y, según se desciende, éstos van en disminución debido al estrechamiento del espacio.

\section{La importancia del jardín reside en tres aspectos fundamentales:}

El primero de todos es el del riego. El agua procedente de la ya citada fuente de los 25 caños hace su aparición en el jardín -tras cruzar oculta la carretera XàtivaBenigànim- en la cumbre de una pequeña montaña de piedras cubierta de musgos y helechos. Su simbología se remonta a los orígenes de nuestra civilización: la montaña sagrada de la que surgen los cuatro ríos del mítico Edén.

Elemento originario del Próximo Oriente, se recreará en numerosos jardines de la cuenca mediterránea. En la Comunidad Valenciana, que sepamos, solamente es en este lugar donde se muestra en todo su esplendor a pesar de la humildad de sus elementos constructivos. Desde ella el agua llena el lavadero y tras cumplir ese servicio social hoy sustituido por las máquinas, riega a la manera tradicional (a manta o pie) los cuadros del jardín.

El segundo reside en la pervivencia del trazado original. El diseño original del jardín se mantiene hoy. Los añadidos posteriores han consistido en pequeñas obras que no han alterado en lo sustancial su primer trazado.

El tercer aspecto lo constituye la permanencia de numerosas plantas que corresponden al momento de los orígenes del jardín junto a algunos añadidos actuales de carácter menor que desvirtúan la materia original. 


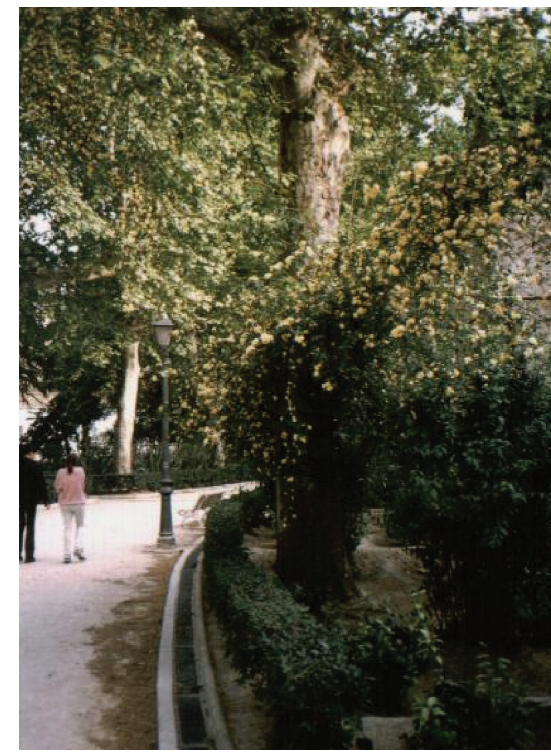

Floración del rosal banksi amarillo, una de las plantas del origen del Jardin. (Foto del autor)

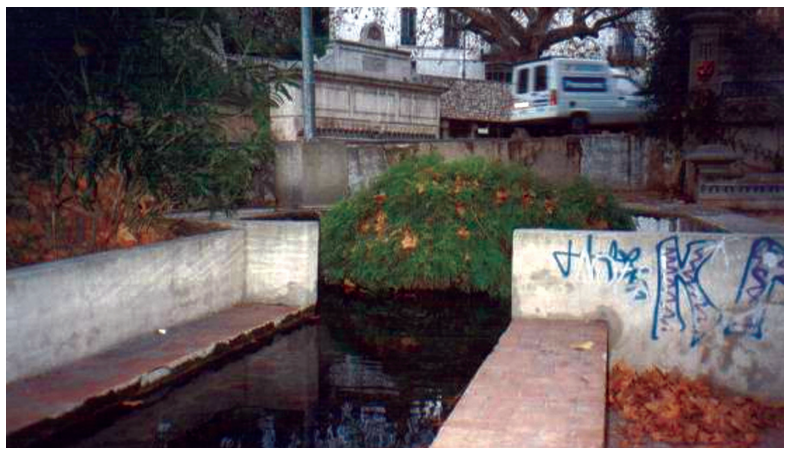

Montaña de helechos desde la que surge el agua en el Jardin. (Foto del autor)

\section{La restauración de 1999}

Esta intervención se centró solamente en los elementos arquitectónicos y abarcó dos aspectos: uno de restauración propiamente dicha y otro de recreación de elementos nuevos.

En lo que respecta al punto primero fueron restaurados el templete neoárabe, suprimiéndose las pintadas y reponiéndose los elementos cerámicos que faltaban; la fuente de las tortugas a la que se le reparó el sistema hidráulico, dotándola otra vez con agua y, finalmente, la pared superior de la terraza adornada con los leones. Aquí, se debería de hablar más de recreación que de restauración. Es cierto que entero sólo quedaba uno de los leones presentando el resto un estado de destrucción casi total. El criterio de sustituir todos ellos por piezas de factura moderna nos ha privado de contemplar el único original superviviente, ejemplo de una manera de hacer los objetos en un momento histórico concreto -la cerámica de reflejo dorado- hoy casi desaparecida en nuestra Comunidad.

El segundo aspecto de la intervención se centró en la recreación de nuevos elementos consistiendo éstos en la reconstrucción del antiguo lavadero, la creación de una nueva acequia escalonada paralela a la carretera y en el cierre de la parte baja del jardín.

Las obras de 1999, como decíamos anteriormente, se han centrado en la restauración y recreación de la parte arquitectónica del jardín siendo los resultados -a nuestro parecer- de carácter variado.

Empecemos por la restauración. En el caso de los leones de cerámica de reflejo metálico, es lamentable lo sucedido. Sin embargo, es digno de alabanza la recupe- 


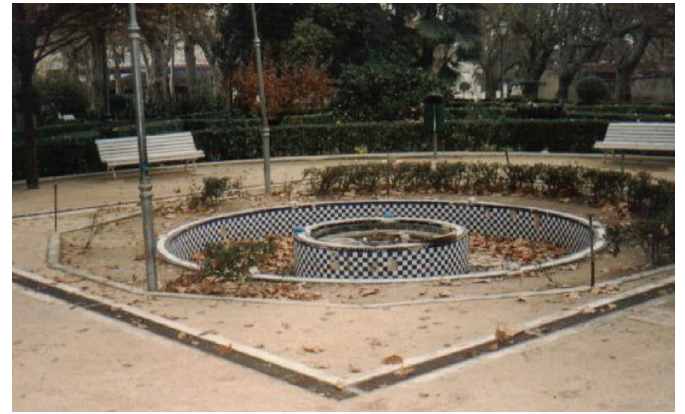

Fuente de las tortugas antes de su restauración. (Foto del autor)

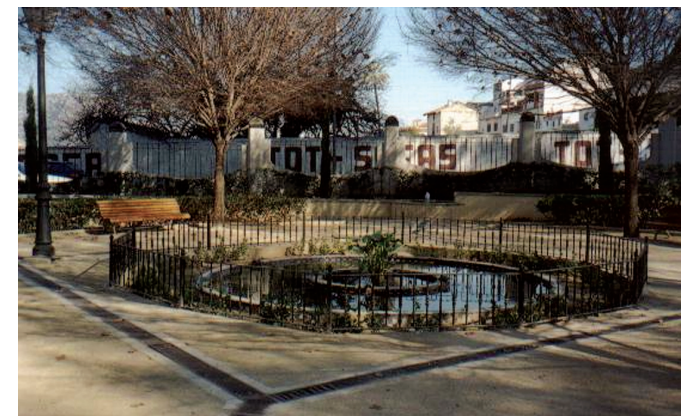

La fuente de las tortugas tras la intervención. (Foto del autor)

ración del sistema hidráulico de la fuente de las tortugas y la intervención realizada en el templete neoárabe.

Las obras nuevas en el jardín han consistido en el cierre de la parte baja del mismo, imitando el estilo de la parte superior con el resultado de producir un pastiche y en la construcción de una acequia, perpendicular a la carretera escalonada donde el agua se recrea alegremente para finalizar en una espiral. La creación de esta acequia escalonada es todo un acierto ya que realza la sonoridad y presencia del agua ayudando a amortiguar el fuerte tráfico de la carretera de BisquertBenigànim Una intervención atrevida y polémica en el contexto histórico del jardín.

$\mathrm{Y}$, finalmente, no deja de ser sorprendente que a finales del siglo XX se realice la recreación del lavadero y su cubierta en la línea del restauro archeologico o tal vez mejor en la del restauro storico de Luca Beltrami según los planos originales del arquitecto municipal Emilio Ferrer Gisbert existentes en el Archivo Municipal de Xàtiva.

Sin embargo, lo más relevante de toda esta restauración es que el elemento más significativo de la estructura del jardín - lo vegetal - no se haya tocado en absoluto. Eso nos permite ver claramente la otra historia del jardín a través de sus plantas. Y digo lo mejor porque suele suceder frecuentemente en este campo de la restauración que sean talados los árboles, arrancados los arbustos y completamente transformados los setos o parterres, privándonos así de la información y del placer de su presencia ya que por lo general las variedades antiguas suelen ser más perfumadas aunque menos espectaculares que las modernas. Pienso, por ejemplo, en las rosas, peonías, claveles, crisantemos, narcisos, nardos, lirios, madreselvas, guisantes o azucenas - entre otras- por no hacer la lista demasiado larga

Y señalar por su importancia, la conservación del sistema de riego tradicional a manta, una de las principales características de los jardines valencianos y cada vez con más frecuencia hecha desaparecer de los mismos para ser sustituido por sistemas de riego a goteo o aspersión, riegos que son la muestra más palpable de la perdida de los principales rasgos formales y valores históricos de la jardinería valenciana inmersa en un proceso de aculturación galopante plasmado en la copia ciega del modelo estéril del jardín anglosajón. 


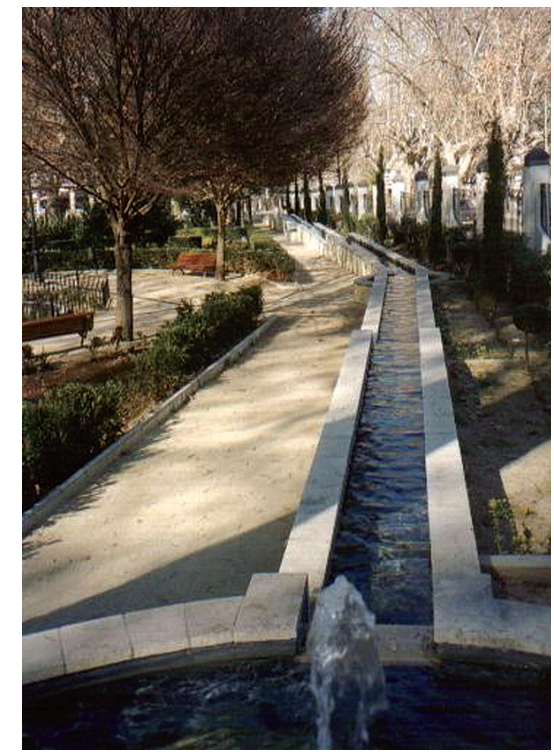

Aspecto de la nueva acequia añadida al Jardín tras la reciente intervención. (Foto del autor)

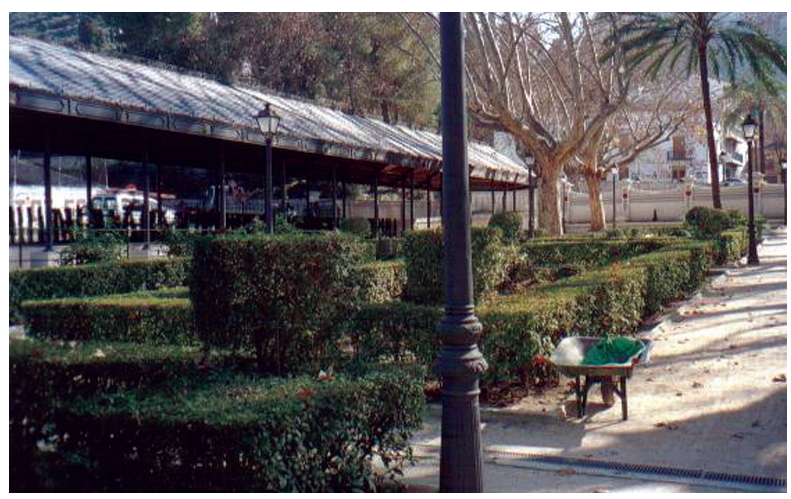

A la izquierda de la foto se puede observar parte del lavadero reconstruido según los planos originales del mismo. (Foto del autor)

Y queda pendiente para otra fase de restauración del jardín, la recuperación de los componentes vegetales originales que muestran hoy una mezcla sorprendente de especies recién importadas de la horticultura holandesa junto con las tradicionales del jardín valenciano, heredero de esa pervivencia agrícola y jardinera de honda raíz musulmana.

Acabemos diciendo que lo hecho constituye una intervención notable es su conjunto sobre todo porque no impide la realización de futuras actuaciones.

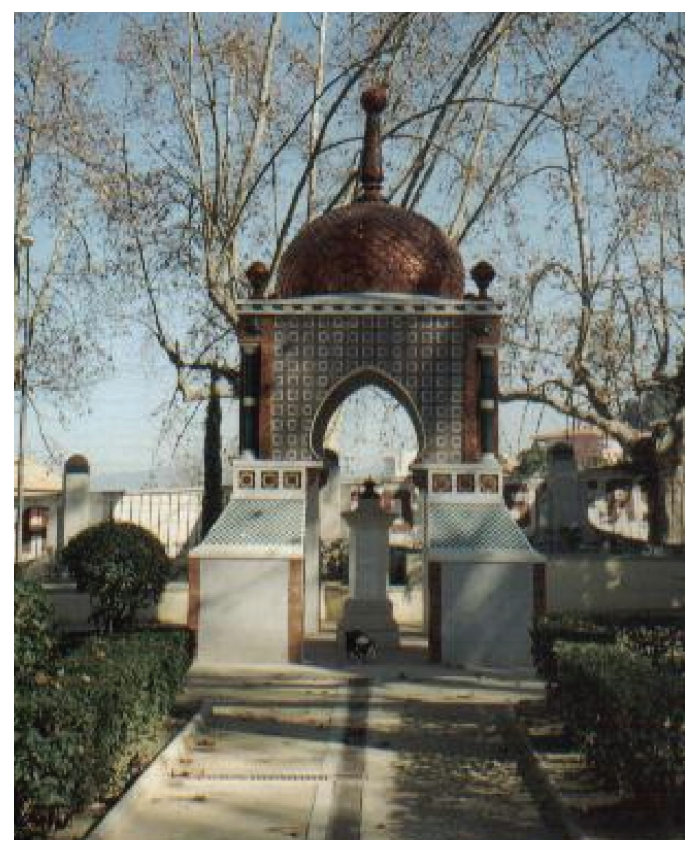

El templete tras la restauración. (Foto del autor) 


\section{Bibliografía:}

CARRASCOSA CRIADO, Josep. Elementos para el estudio histórico de la Jardinería Valenciana.Valencia.1932.

SARTHOU CARRERES, Carlos. Jardines setabenses. Imprenta Semana Gráfica. S.A.

En esta obra, Sarthou lo llama Jardín de Bruschetti. Exactamente en la página 11 dice: "El Parque Infantil de Attilio Bruschetti aparece en el extremo opuesto de la alameda recayente a Levante. Es, como la Glorieta, de puro estilo valenciano, y lo vimos construir hace un cuarto de siglo a expensas del malogrado benemérito hijo adoptivo de nuestra ciudad, en la cual puso todos sus amores. En este parque dejó un lindo palomar (ya desaparecido), fuentes, mayólicas, un templete árabe de azulejería, bancos, escalinatas y una plétora de flores bajo frondoso arbolado. Sus andenes o paseos los llenó el fundador de máximas de bondad, decálogo moral y buenos consejos de Santa Teresa y clásicos escritores de la ortodoxia cristiana.

El Parque de Bruschetti se hizo pronto tan popular, que la fantasía lo ha bautizado con el sobrenombre de "Jardín del Beso", porque realmente parece un remanso de paz para románticos enamorados",

Levante, 12 del XII de 1997. "El Ayuntamiento recuperará el lavadero del Jardín del Beso siguiendo los planos de 1929”.

Levante, 16 del XII del 2001. "Reinventar antes que restaurar". 


\section{d) La Casa de las Marquesas de Gandia}

El Palau dels Marquesos de González-Quirós, actual Casa de la Cultura de la capital de la Safor y conocido popularmente como Casa de las Marquesas es todo un ejemplo claro de reconstrucción de un jardín. Al haber participado personalmente en el desarrollo de estos trabajos por ser la empresa en la que trabajo responsable de los mismos, será utilizado para terminar los ejemplos de esta tesis como caso de reconstrucción de un jardín moderno junto a un edificio histórico aunque el edificio no fuera restaurado sino vaciado su interior y completamente rehecho para darle nuevos usos dejando en pie solamente las fachadas exteriores y aún estas modificadas.

La construcción del edificio es de finales del siglo XIX (1884). Posteriormente a principios del siglo XX (1902) se vuelve a edificar, hecho que conocemos por la existencia de un permiso de obra para tal fin existente en el Archivo Municipal de Gandia.

El jardín primitivo ocupaba toda la manzana actual. Los herederos de los marqueses fueron vendiendo fragmentos de su superficie hasta quedar reducido a lo que hoy podemos apreciar. Esta es la causa de que el jardín se haya quedado casi completamente cercado por edificios alguno de catorce alturas.

En la Guerra Civil el palacio fue ocupado por los sindicatos obreros que le dieron un uso público. El arbolado del jardín fue cortado, volviéndose a plantar tras la contienda gran cantidad de pinos y cinamomos en su parte central sin ningún tipo de diseño.

Tras el fallecimiento de la última de las marquesas a finales del siglo XX, sus herederos iniciaron los trámites para ceder el edificio a Gandia para uso cultural. Tal vez por cierta desconfianza hacia la gestión de las instituciones públicas la cesión fue un tanto sorprendente. La propiedad pasó a la Fundación Cultural de Bancaixa -con lo que se aseguraban su conservación para el futuro-mientras que el usufructo pasaba al Ayuntamiento el cual decidió ubicar allí la nueva Casa de Cultura.

Cuando fuimos llamados por la Fundación Bancaixa para ocuparnos del jardín en 1998, tras visitar el sitio propusimos un plan de actuación con las siguientes fases:

- Informe sobre la situación en que se encontraba el lugar;

- Limpieza, poda y eliminación de los ejemplares muertos o con riesgo para las personas y edificios;

- Transplante de lo recuperable y protección de las especies de las obras;

- Proyecto de reconstrucción del nuevo jardín donde se recogían los criterios de actuación, los objetivos, el calendario y el presupuesto económico. 
Veamos con más detalle alguno de los apartados anteriores. El informe de actuación recogía en primer lugar las diferentes partes del jardín. Este constaba de tres unidades: una próxima a la casa, ubicada entre las dos alas del edificio, sin vegetación arbórea importante y que cumplía la función de lugar de estancia y encuentro dependiente de la casa. Sus perímetros estaban ocupados por grandes trepadoras de perfume y de color como los jazmines, buganvillas y plumbagos.

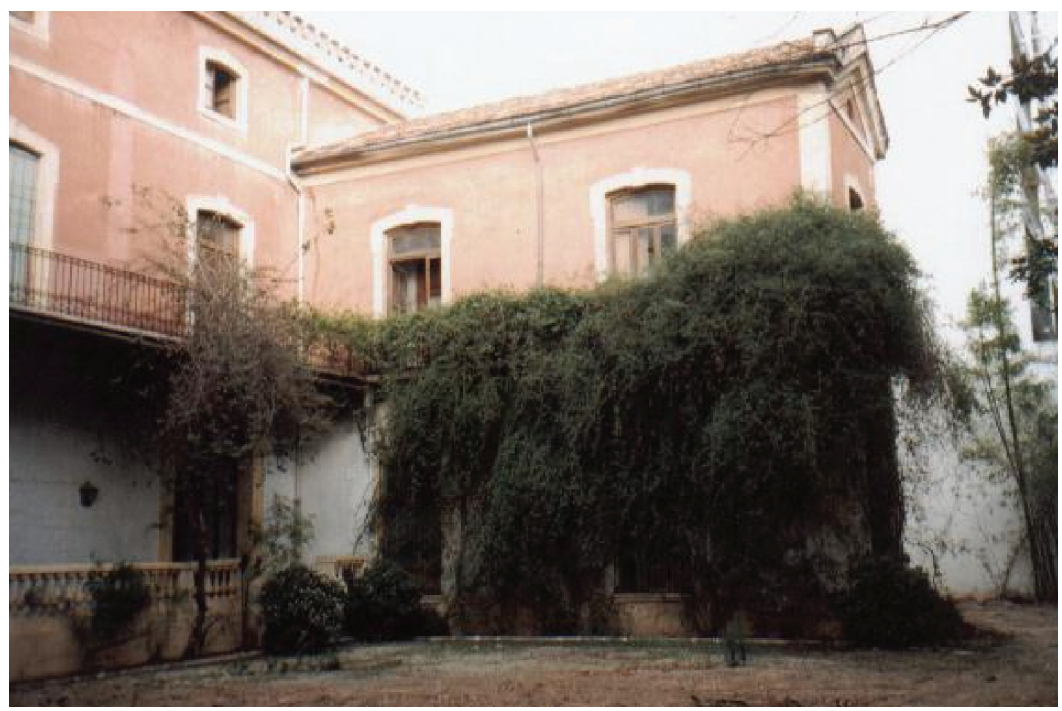

Patio interior del caserón antes de las obras. (Foto del autor)

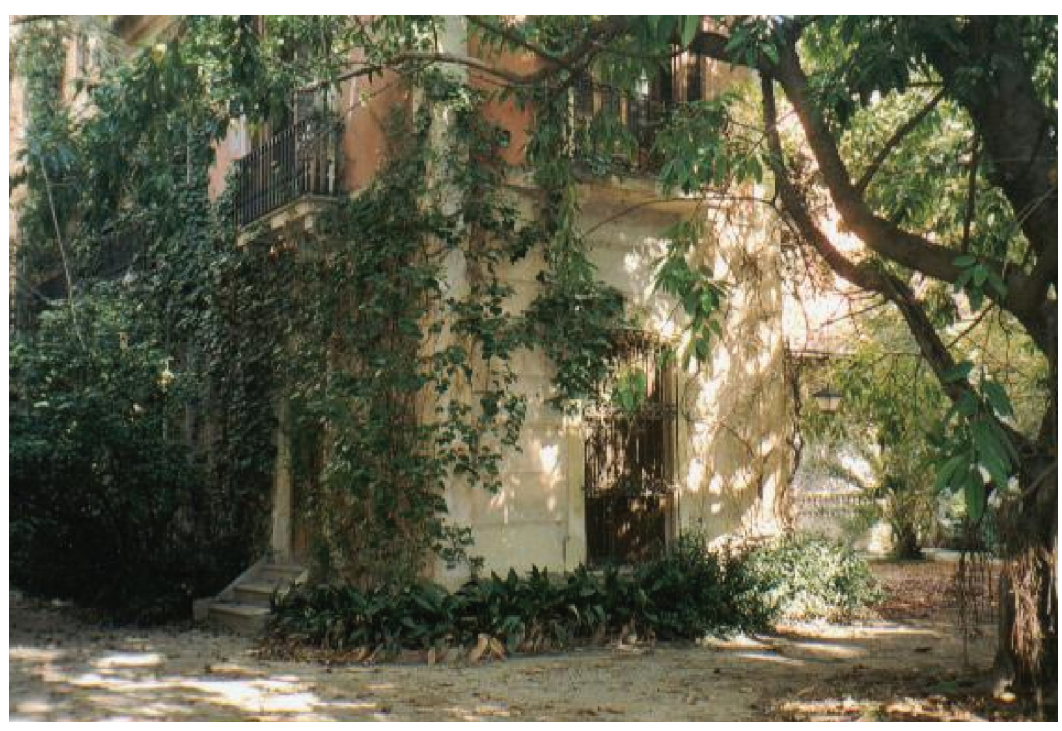

Otro aspecto del caserón antes de las obras. (Foto del autor)

A continuación de ésta se encuentra la zona que cumplía las mismas funciones que la anterior pero más para el verano ya que poseía alineaciones de árboles de hoja perenne y flor perfumada como son los magnolios junto a caducifolios de abundante fronda estival como los tilos. Este espacio se vio alterado con la posterior introducción de kentias y setos de aspidistras. 
La tercera zona, que es la de mayor superficie, estaba constituida por una plataforma de tierra elevada unos $60 \mathrm{~cm}$. sobre el nivel del suelo del jardín. Contenida por un murete de piedra estaba densamente plantada de pinos y jacarandas. También había invasión de aligustres, hiedras y cinamomos como consecuencia del abandono de los últimos tiempos.

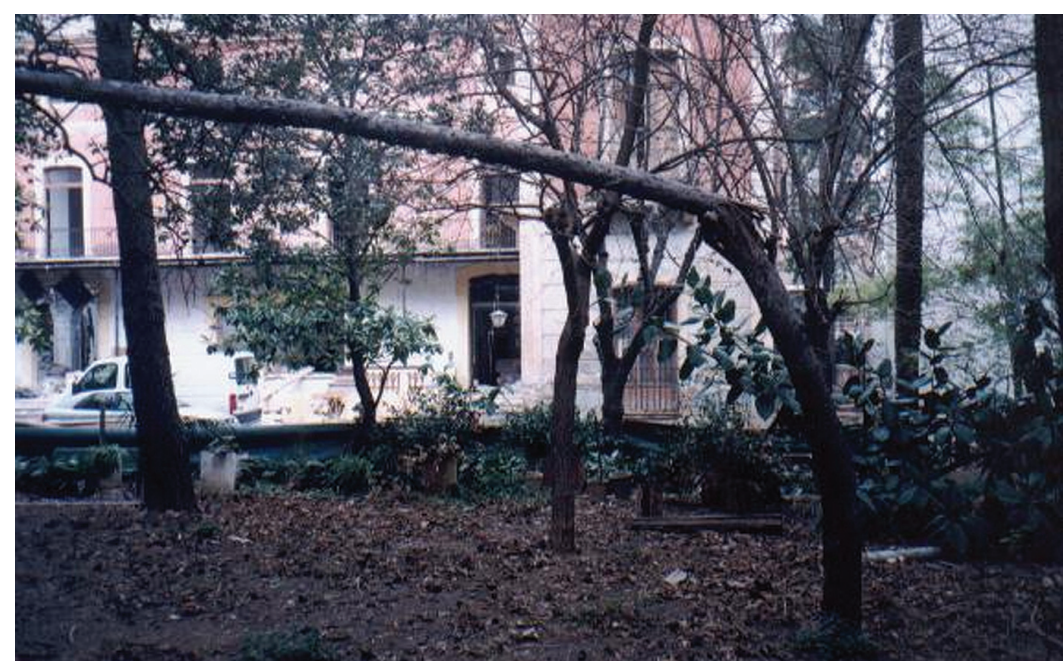

Estado de la plantación de pinos y cinamomos junto a la casa. (Foto del autor)

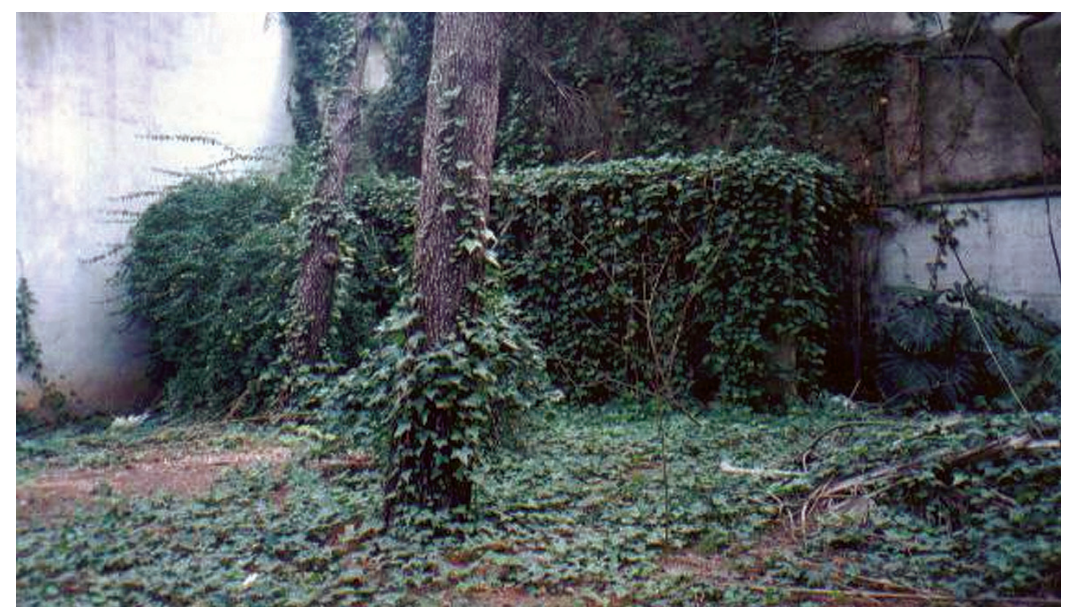

Invasión de hiedra en algunas partes del jardín. (Foto del autor)

El segundo punto que recogía el mencionado informe era el estado en que se encontraban los elementos vegetales existentes en el jardín.

El abandono de unos cuantos años por un lado, el denso marco de vegetación por otro unido a la falta de luz por la altitud de los edificios circundantes habían producido un crecimiento desmesurado de los ejemplares buscando la luz con el resultado del debilitamiento de los más bajos, putrefacción de heridas en los más 
viejos por la falta de aireación y sobre todo acumulación de ramaje seco por donde subían trepadoras oportunistas e invasoras como las hiedras y los convolvulus. En otros casos, como el de los ficus, el crecimiento incontrolado de sus ramas ya había producido daños importantes en la casa rompiendo partes del tejado con la consiguiente aparición de goteras.

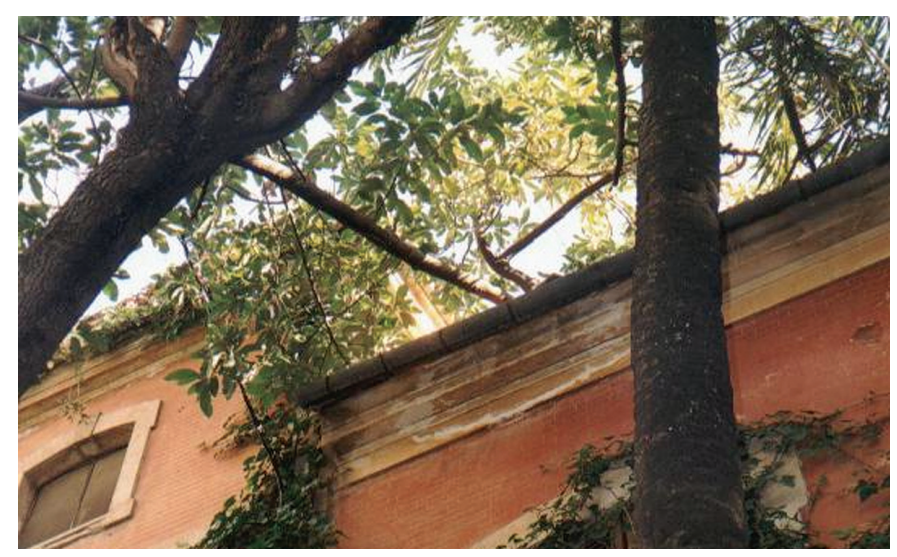

El crecimiento incontrolado de la vegetación dañaba los tejados. (Foto del autor)

Todos los muros estaban cubiertos de diversas trepadoras alguna de las cuales también había alcanzado el tejado como la viña virgen. Igualmente, pegado a la casa existían plantaciones de aspidistras y laurel de Alejandría (Ruscus hypoglossum) colocados como setos.

La vegetación existente en el lugar era la siguiente:

Arboles: Casuarina (Casuarina equisetifolia)

Magnolia (Magnolia grandiflora)

Tilo (Tilia platyphyllos)

Cinamomo (Melia azederach)

Aguacate (Persea gratissima)

Palmeras: Washintonia (Washingtonia filifera)

Palmito de la suerte (Trachicarpus fortunei)

Palmera datilera (Phoenix dactylifera)

Kentia (Howea forsteriana)

Arbustos: Naranjo de Méjico (Choisya ternata)

Durillo (Viburnum davidii)

Arbol de Júpiter(Lagerstroemia indica)

Paraísos (Hibiscus rosa-sinensis)

Trepadoras: Plumbago (Plumbago capensis)

Buganvilla (Bougainvillea sp.)

Jazmín (Jasminum grandiflora)

Viña virgen (Parthenocissus quinquefolia) 
Setos: $\quad$ Laurel de Alejandría (Ruscus hypoglossum)

Aspidistra: (Aspidistra elatior)

Jazmín amarillo (Jasminum primulinum)

Macetas: Clivia (Clivia miniata)

Cintas (Clorophitum sp.)

Arbol del Jade (Crassula argentea)

Dentro del grupo conocido como vegetación espontánea e invasora se consideró un aspecto importante. Mucha de la planta considerada invasora podía proceder de ejemplares presentes en el jardín y, en otros casos, no. Su consideración de invasor se fundamenta en la distinta función que cumple en el diseño del lugar y éste fue el criterio elegido para suprimirlas o dejarlas estar.

Las germinaciones de invasoras presentes en el mencionado jardín se suprimieron en gran número aunque se dejaron algunos ejemplares adultos de las mismas. Estos son de las siguientes:

- Aligustre (Ligustrum japonicum)

- Cinamomo (Melia azederach)

- Palmera canaria (Phoenix canariensis)

- Jacaranda (Jacaranda mimosifolia)

- Níspero (Eriobotrya japonica)

Del mobiliario sólo habían sobrevivido dos bancos de madera en mal estado y algunas macetas de barro con maceteros de hierro.

En el centro de la zona del jardín se encontraba un jaulón destartalado sin ningún valor histórico o artístico el cual albergó alguna vez pavos reales y se consideró su eliminación. Por otra parte, todo el sistema de riego tradicional había desaparecido de la superficie quedando únicamente una arqueta que servía para drenar la superficie en los casos de grandes lluvias. Es decir, las antiguas acequias habían sido transformadas en albañales con lo que fue descartada la posibilidad de recuperar los sistemas antiguos de riego.

La fase siguiente consistió en la limpieza, poda y eliminación de los ejemplares muertos, así como los que suponían serio riesgo para el edificio y las personas ya fuese por su estado fitosanitario o por su crecimiento incontrolado.

Entre éstos se cuentan las ramas de los grandes ficus que tocaban el tejado, los pinos torcidos que se acercaban a las casas próximas o los estrangulados por la instalación de alambres para el antiguo tendido eléctrico en el jardín, los árboles invasores traídos por las aves o el viento como los aligustres y acebuches, las trepadoras invasoras, los tocones de los ejemplares muertos, etc.

El apartado de protección de la vegetación obligó a cubrir los troncos de los árboles más cercanos a los caminos y edificio con fibra de coco, cubrir las raíces del gran ficus con tierra y crear barreras tanto visuales como físicas (telas de plás- 
tico o caballón con los residuos de las podas) para proteger la superficie del jardín y los árboles de los riesgos del proceso de construcción (grúas, camiones, almacenaje de materiales, etc.).

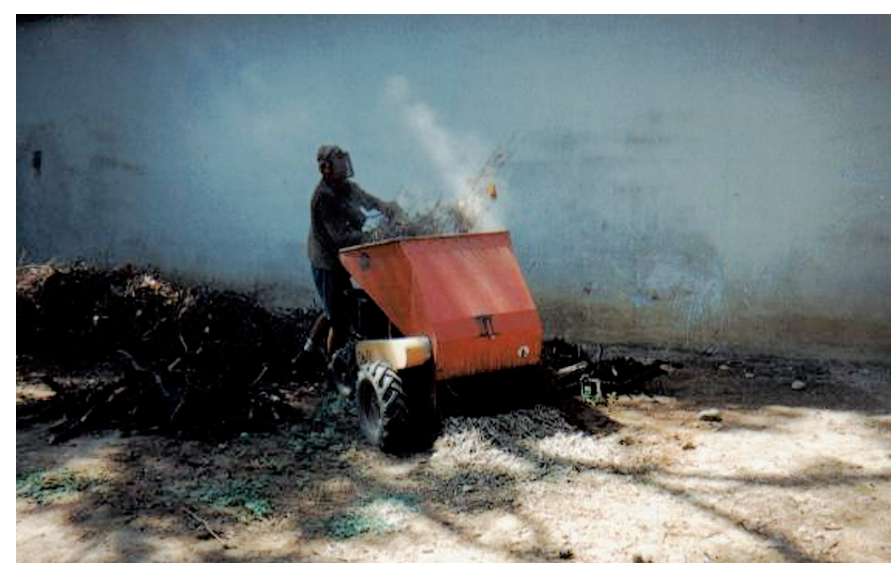

Triturado de los restos del ramaje para ser posteriormente reintegrado al jardin. (Foto del autor)

Posteriormente todos los setos de laurel de Alejandría y aspidistra cercanos a la casa fueron transplantados a un rincón del jardín pensando en su posterior reutilización. Igualmente todas las macetas se trasladaron de sitio con el mismo fin valorando en la mayoría de los casos más su valor testimonial que el propio de las macetas y plantas.

Las grandes trepadoras cercanas a la casa no pudieron recuperarse ya que las obras de consolidación de los muros exigían hacer profundas zanjas para cimentar la nueva construcción con lo que fueron sacrificadas al comienzo de las obras.

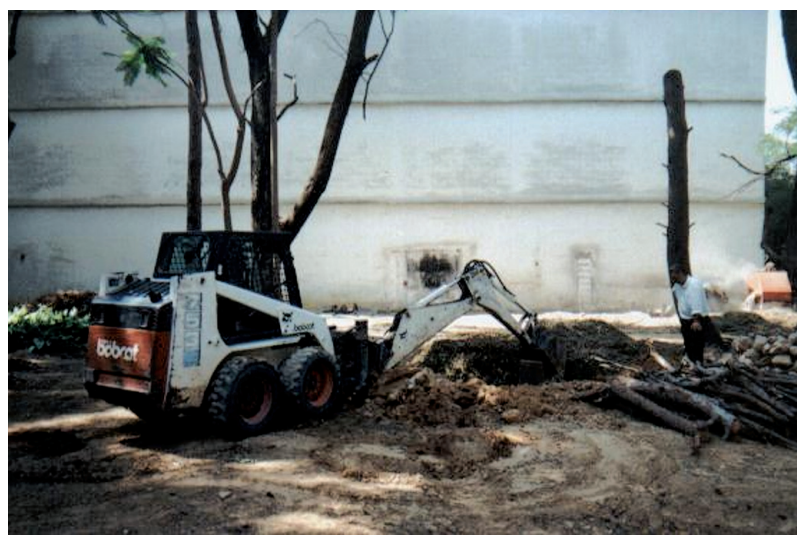

Eliminación de los tocones de los árboles muertos. (Foto del autor)

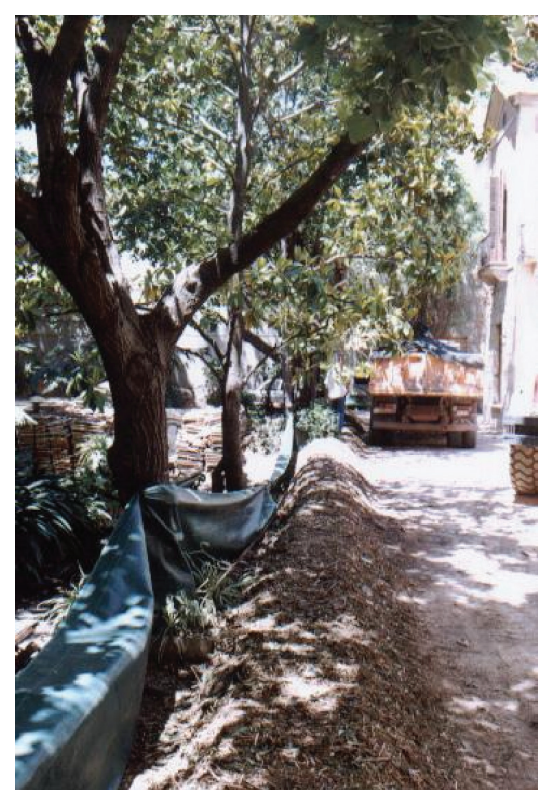

Protección de los ejemplares frente a las obras del caserón. (Foto del autor) 
Una vez acabada la limpieza del espacio se presentó el proyecto de reconstrucción del nuevo jardín donde se recogían los criterios de actuación, objetivos de la misma, calendario y presupuesto económico.

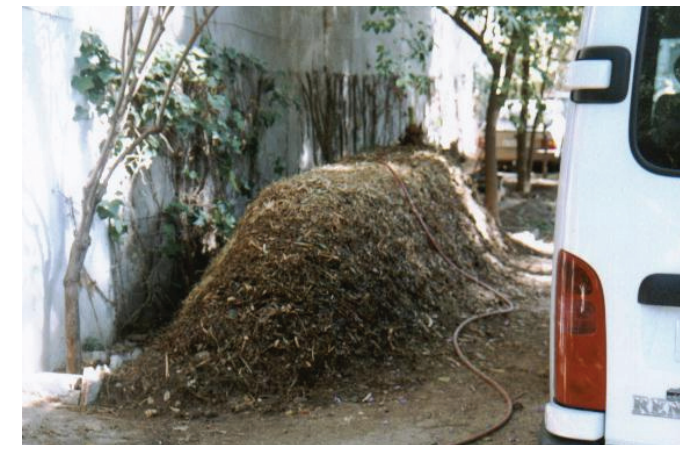

Restos de las podas en espera de ser reintegrados al jardín. (Foto del autor)

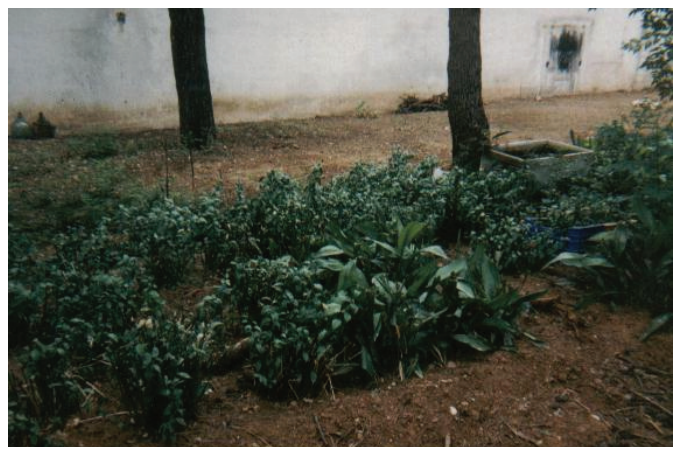

Recuperación de los setos de aspidistra y laurel de Alejandría. (Foto del autor)

Respecto a los criterios se establecía la definición conceptual y lingüística de la dualidad restauración/recreación evitando el no llamar a las cosas por su nombre. Los trabajos de restauración propiamente dichos se centraban sólo en algunas partes del jardín tales como el pasillo antiguo de la entrada mientras que la intervención principal era definida como una reconstrucción.

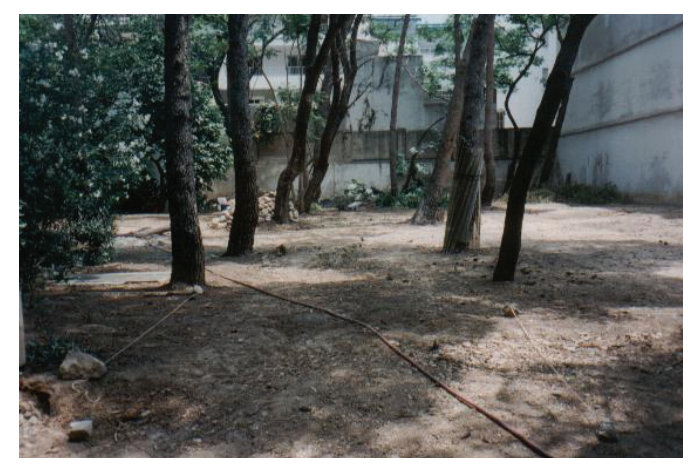

El espacio de recreación del jardín tras su limpieza. (Foto del autor)

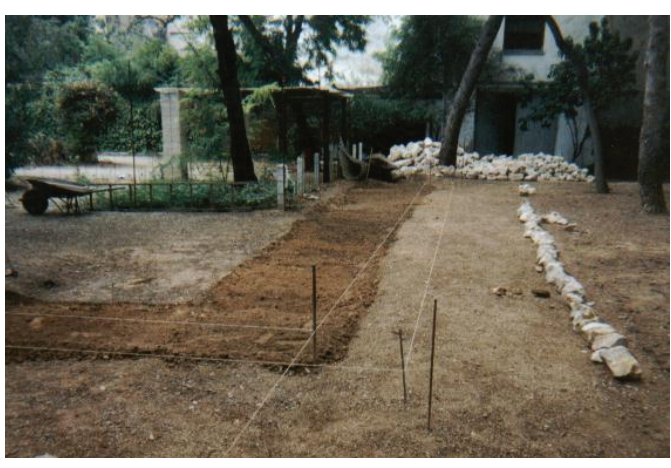

Trazado del jardín nuevo. (Foto del autor)

Para realizar la recreación se partía de la información dada por el propio lugar reutilizándo por una parte los elementos existentes en el jardín que fueron transplantados para salvarlos de las obras y por otra se introducían especies características de la jardinería valenciana del XIX seleccionados por existir en otros jardines de la zona y de la documentación gráfica y literaria del momento. En este apartado es donde tenemos que situar la introducción de peonías, agapantos, crinos o el resto de las especies presentes en los jardines con bosquetes de vegetación mediterránea. 


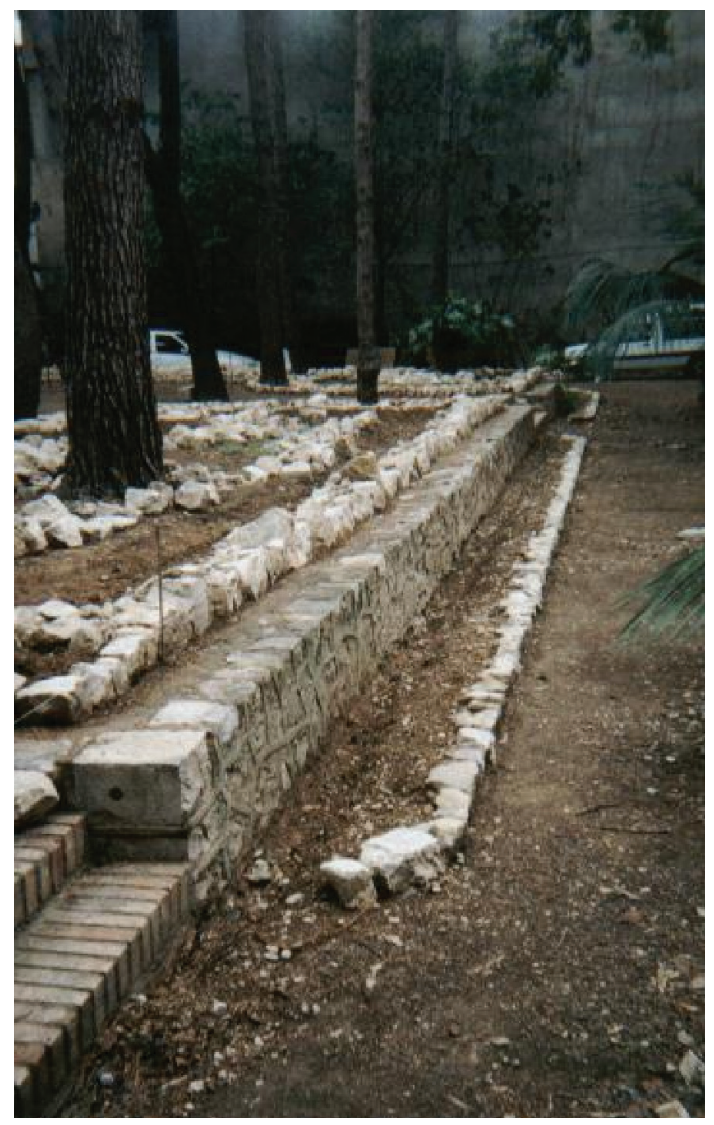

Aquí podemos ver el muro antiguo y los nuevos juntos. (Foto del autor)

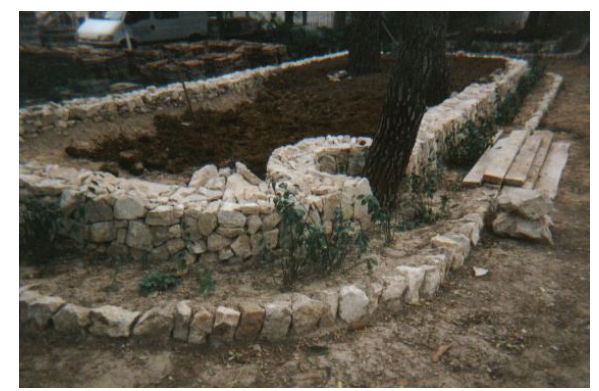

Construcción y relleno de las grandes jardineras. (Foto del autor)

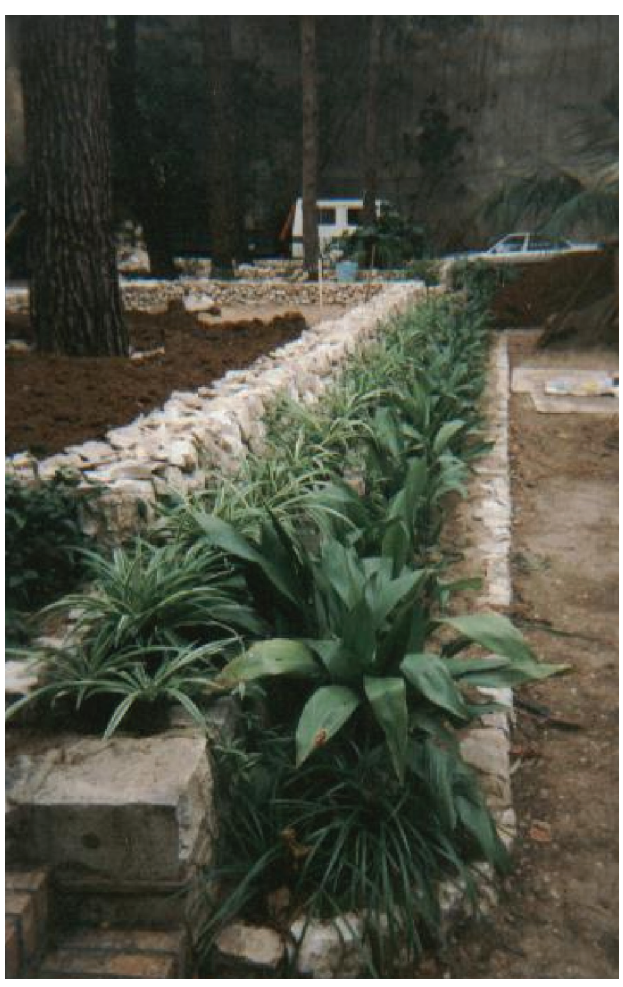

Utilización de las plantas recicladas en la nueva obra. (Foto del autor)

Orejas de oso y crinos se utilizaron en las
partes más cercanas a la casa. (Foto del autor) 


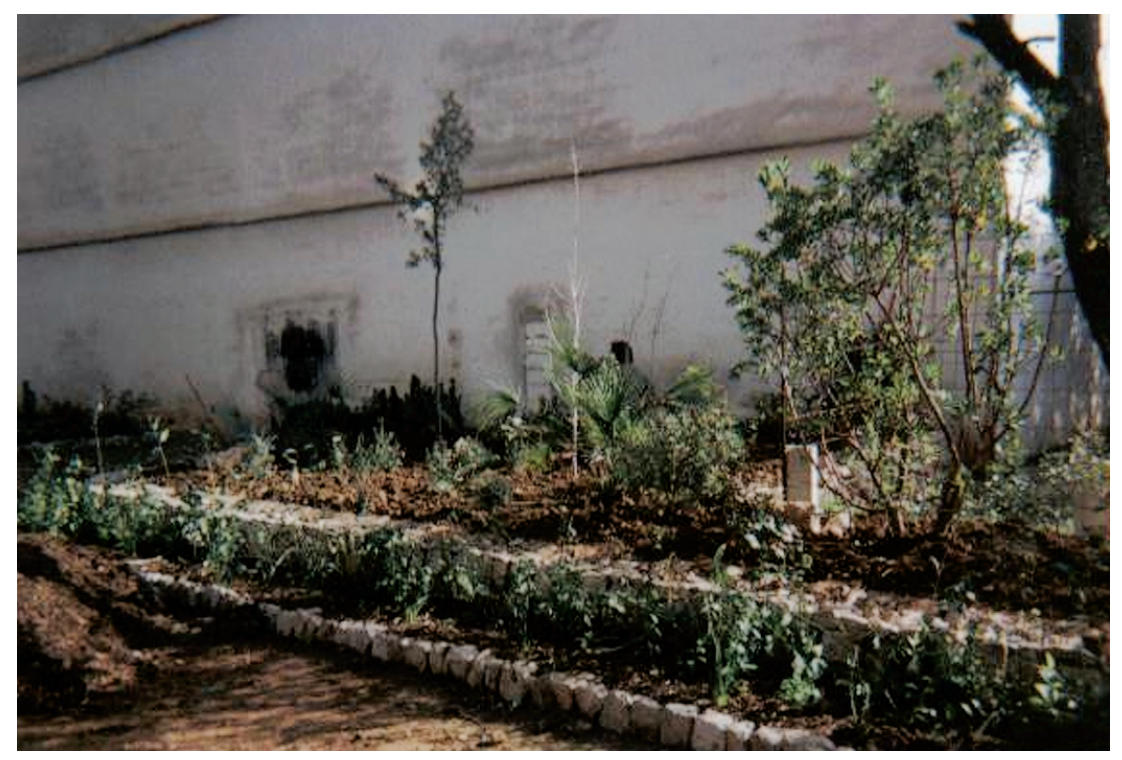

En las partes más alejadas se utilizó vegetación mediterránea. (Foto del autor)

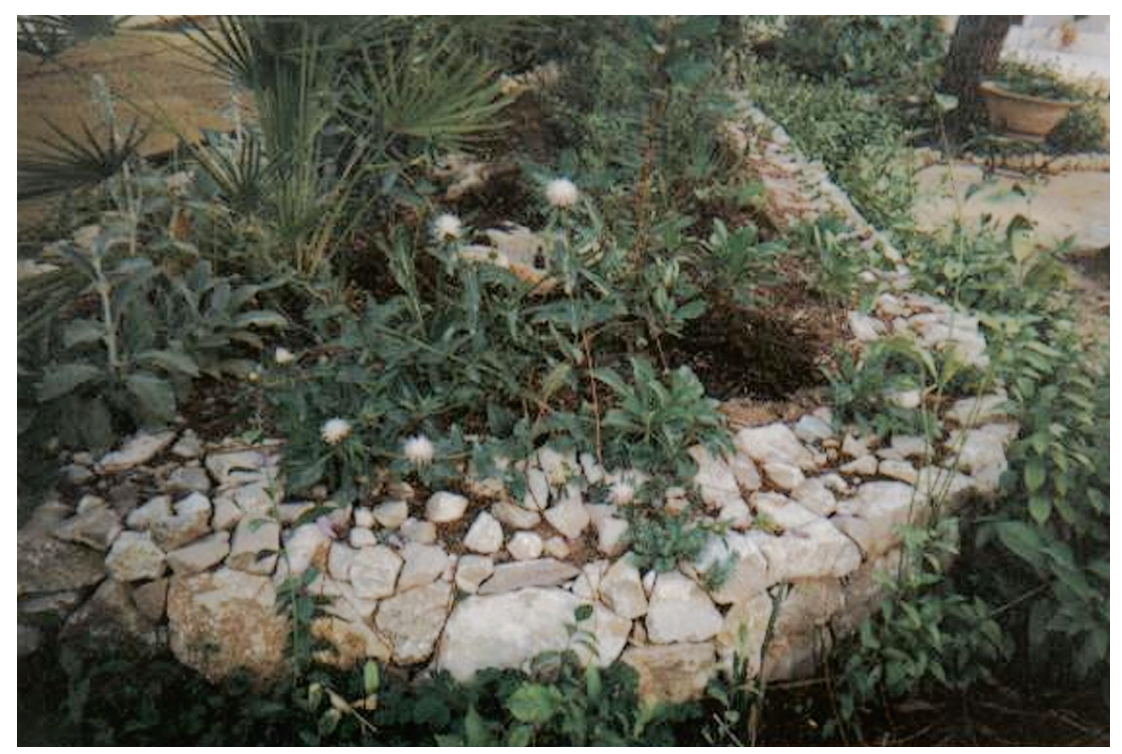

Floración del cardo del Montgó, uno de los endemismos utilizados en el jardin. (Foto del autor)

En los grandes macetones que tendrían que sustituir a los setos transplantados próximos a la casa se introducían, aparte de todas las plantas de maceta sobrevivientes del jardín, una colección de las plantas endémicas, raras y amenazadas de la Comunidad Valenciana debido al compromiso ético que tiene hoy la Jardinería con la salvaguarda de la biodiversidad. Tales plantas fueron cedidas por la Generalitad Valenciana al tratarse del jardín de un edificio con fines culturales. 
Por otra parte, los maceteros de hierro que habían llegado hasta nuestros días fueron utilizados como modelos para realizar copias y en ellos se colocaron toda las macetas nuevas con muchas de las plantas recuperadas del antiguo jardín.

En la antigua pinada tuvo lugar la más importante fase de la intervención. Allí se recreó un patio de carácter romántico. Como todo el suelo estaba ocupado por las raíces de los grandes pinos, hubo que hacer enormes jardineras de piedra seca, rellenarlas de tierra y plantar en ellas la vegetación con el criterio de plantar las de carácter más ornamental más próximas a la casa mientras que las más rústicas se introducían en las zonas alejadas de aquella. Algunas de estas son:

Arboles: Carrasca (Quercus ilex)

Fresno de flor (Fraxinus ornus)

Olivo (Olea europaea)

Algarrobo (Ceratonia siliqua)

Higuera (Ficus carica)

Arbustos: Madroño (Arbutus unedo)

Durillo (Viburnum tinus)

Lentisco (Pistacea lentisco)

Mirto (Myrtus communis)

Palmito (Chamaerops humilis)

Brezo (Erica multiflora)

Lilo (Syringa vulgaris)

Celinda (Philadelphus coronarius)

Espirea (Spiraraea japonica)

Trepadoras: Madreselva (Lonicera implexa)

Jazmín común (Jasminum grandiflorum)

Planta de la cera (Hoya carnosa)

Jazmín de Madagascar (Stephanotis floribunda)

Herbáceas: Violeta (Viola odorata)

Agapanto (Agapanthum africanus)

Vara de Fuego (Crocosmia sp.)

Cintas (Ophiopogon japonicus)

Azucena del Brasil (Crinum x powelli)

Peonía (Paeonia lactiflora)

Aguileña (Aquilegia vulgaris)

Amarilis (Amarillis belladona)

Frisia (Frisia x kewensis)

Lirio de Rodas (Iris monnieri)

Lirio hediondo (Iris phoetida)

Acanto (Acanthus mollis)

Vincapervinca (Vinca minor)

Rusco (Ruscus aculeatus)

Laurel de Alejandría (Ruscus hypoglossum) 
En uno de los lados del jardín se construyó una pequeña fuente para dotar al lugar de un punto de agua. Y finalmente, mirando a la casa, se colocó un busto del Marqués de González-Quirós, creador de la casa.

Los trabajos duraron año y medio, finalizando en la primavera del 2000.

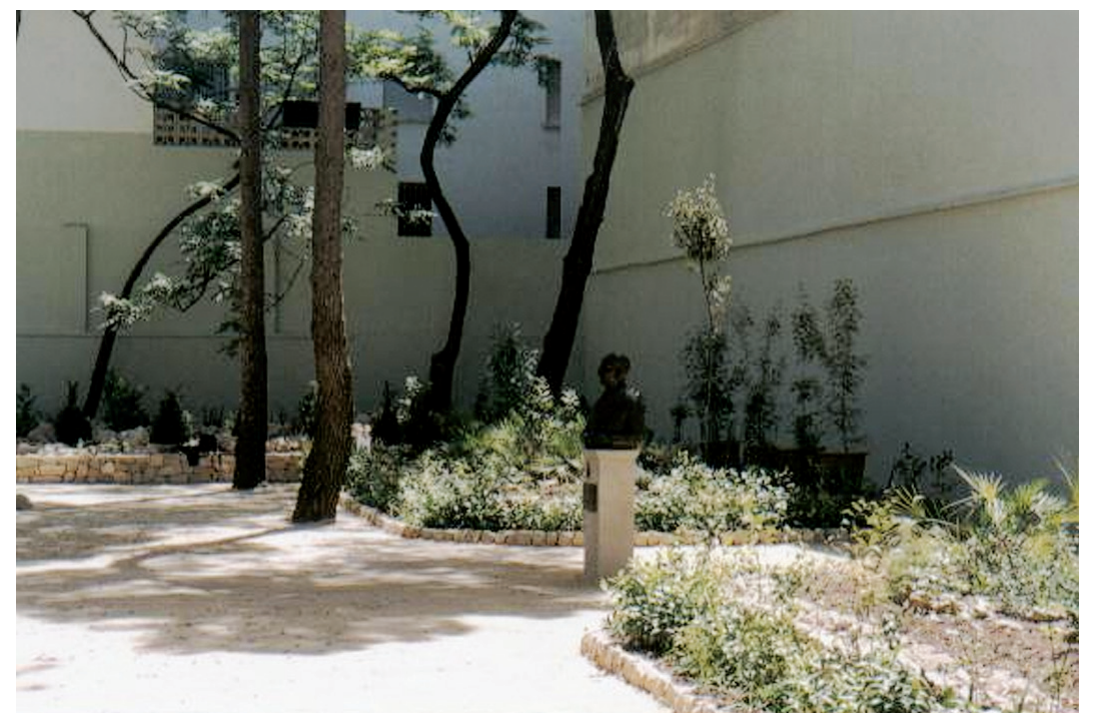

El jardín acabado con el busto del marqués. (Foto del autor) 


\title{
E. DISCIPLINAS AUXILIARES Y FUENTES DOCUMENTALES DE UTILIDAD PARA LA RESTAURACIÓN DE LOS JARDINES
}

\author{
E.1. La pintura
}

E.2. El grabado

E.3. La fotografía

E.4. La arqueología

E.5. La iconología

E.6. Fuentes literarias diversas:

E.6.1. Narrativa y poesía

E.6.2. Tratados de Agronomía, Agricultura, Botánica y Jardinería 
Para realizar la restauración de los dos componentes del jardín (aspecto o trazado y estructura o componentes materiales del mismo) nos van a ser de gran utilidad tanto las fuentes gráficas (pintura, grabado, fotografía) como las literarias (cartas, tratados de jardinería y agricultura, novelas, etc. ) siempre utilizadas con un sentido crítico ya que excepto la fotografía, las demás manifestaciones están sometidas a la posible imaginación del autor. Como insistía Isa Belli Barsali en el coloquio posterior de la Carta de Florencia (1), antes de reconstruir un jardín según el diseño de una pintura o un grabado hay que realizar en primer lugar excavaciones arqueológicas para asegurarse si tal trazado existió realmente pues a menudo podemos contemplar bocetos y cuadros de jardines que sólo existieron en la imaginación de los artistas.

Esto nos exige antes de recurrir a las diversas fuentes documentales citadas, contrastarlas y someterlas a una rigurosa crítica histórica previa a su utilización como norma general 


\section{E.1. La pintura}

Comenzaremos nuestro recorrido con ejemplos de pinturas del mundo romano que han llegado hasta nuestros días en las que se pueden apreciar de forma clara las especies utilizadas. Estas pinturas tenían la finalidad de llenar las paredes de los jardines creando efectos de falsas perspectivas produciendo el agrandamiento óptico del lugar. Los mejores ejemplos son los encontrados en Pompeya y Herculano y las de la casa de Livia en Roma.

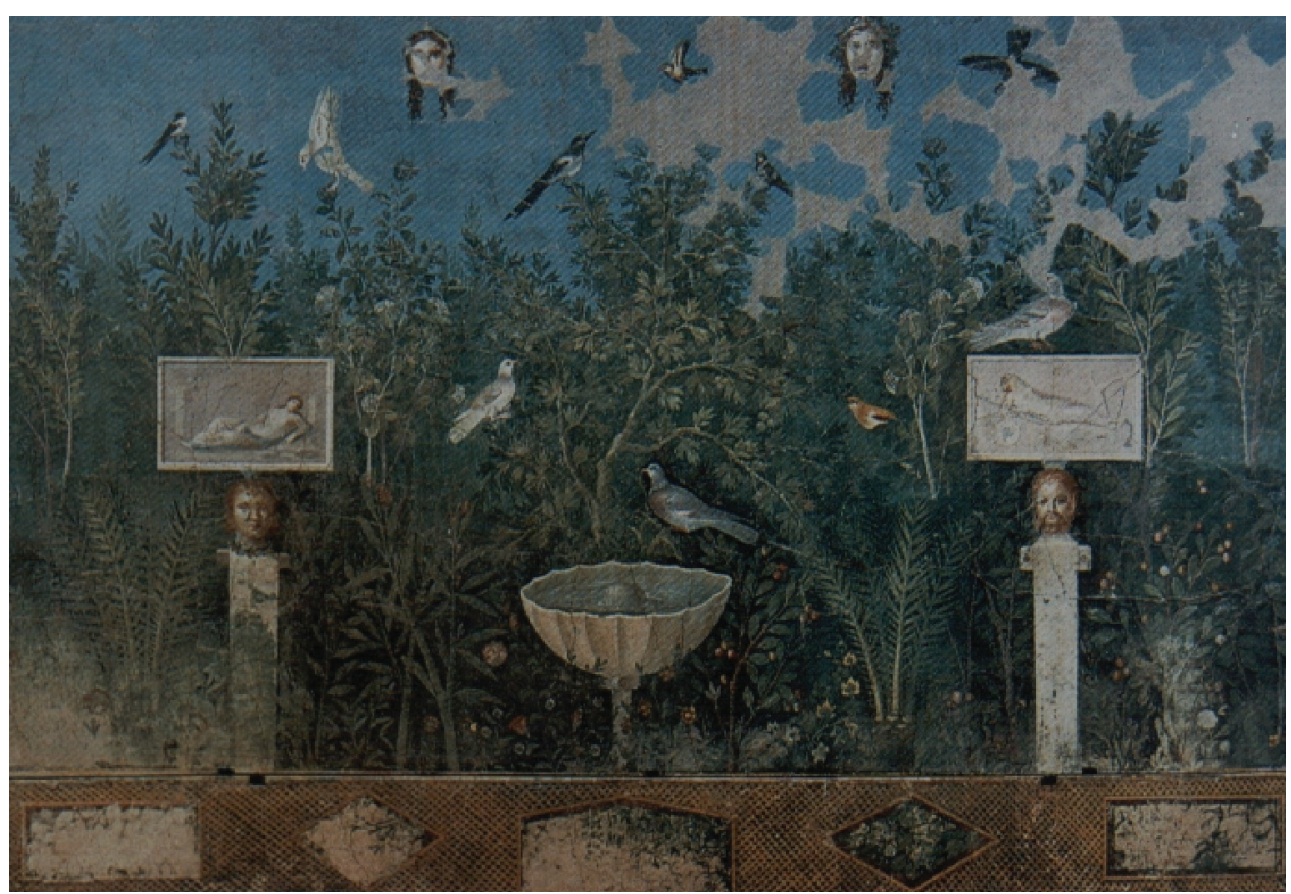

Pompeya. Casa del Bracciale d'Oro

En el fresco reproducido sobre estas líneas podemos apreciar claramente el laurel, el durillo, el madroño, la palmera datilera, la hiedra, la adelfa, el plátano oriental junto a crisantemos y rosas. Toda la relación de las plantas encontradas en estos frescos así como en los textos literarios se reproduce en el Anexo Documental $\mathrm{n}^{\circ}$ 6. Tal apéndice se ha compuesto con las especies citadas por el ya clásico Jardins romains de P. Grimal (2) y del aparecido más recientemente de Annamaria Ciarallo (3). Otro de los clásicos sobre el tema de jardines romanos, el de Jaruselski, nos ha sido imposible encontrarlo y consultarlo.

Uniendo a estas representaciones los testimonios arqueológicos y literarios que posteriormente citaremos ha sido posible realizar algunas reconstrucciones bastante fieles de aquellos jardines como el reproducido en la foto, de la página siguiente en la Villa Casalle de Piazza Armerina en Sicilia. 


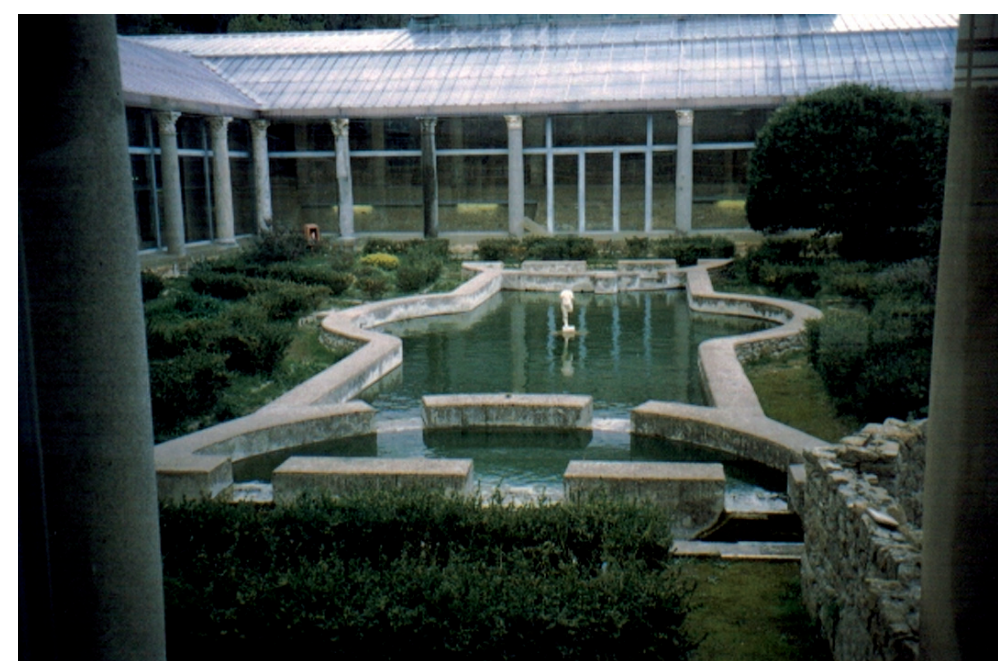

Jardín de la Villa Casalle en Piazza Armerina. Sicilia. (Foto del autor)

Igualmente todo este conocimiento es el que nos permite juzgar como incoherentes algunas intervenciones vistas en ciudades romanas como son los geranios utilizados en Volúbilis (Meknes, Marruecos) o la introducción de piteras en una de las casas de Pompeya.

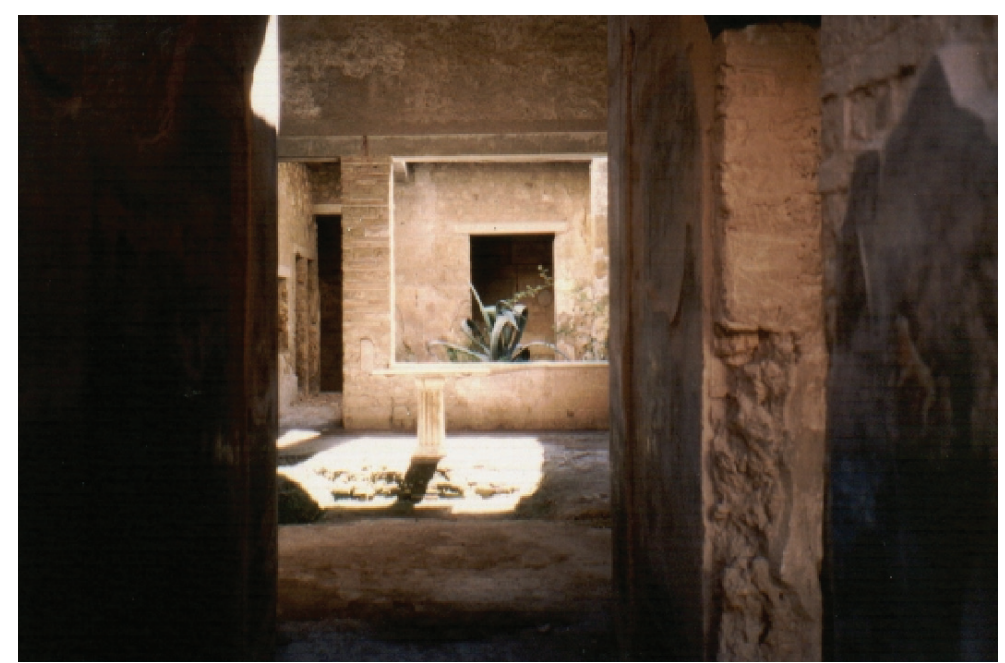

Patio de Pompeya con una pitera. (Foto del autor)

En el largo período de la Baja Edad Media encontraremos únicamente referencias escritas sobre la utilización de las plantas ornamentales pues el arte abandona la mimesis a favor de la abstracción.

No nos servirán las obras artísticas de ese momento hasta que la pintura occidental abandone los convencionalismos y estereotipos medievales para comenzar a captar y reproducir el mundo real (Giotto y Massaccio en el sur y los van Eyck en el norte de Europa) hasta la ruptura cubista. La pintura y el grabado nos ofrecerán a menudo imágenes de jardines o plantas de uso corriente en el momento en 
que ésta se realiza. En unos casos, los mencionados grabados y pinturas nos servirán para tener un reflejo fiel de las formas (el diseño) imperantes en una época. En otros, la representación de las plantas es tan minuciosa y real que nos permite el conocimiento botánico de numerosas especies, por lo que es una base segura para la restauración o recreación de los jardines del momento. Y como anteriormente hemos señalado, cuando la pintura ahonda en la abstracción, la fotografía cubre el hueco que aquella dejaba.

Tomaremos como primer ejemplo una de las obras más emblemáticas de la pintura europea: la Adoración del Cordero Místico, realizada por los hermanos van Eyck (Hubert, 1370-1426 y Jan, 1390-1441) pintado hacia 1430 y que se encuentra en la iglesia de San Bavón de Gante.

En esta obra han sido identificadas más de 42 especies distintas de plantas (4). Descartando algunas que aparecen al fondo del paisaje que fueron tomadas durante el viaje a Portugal en 1428 y difíciles de vivir en el clima de Gante (pino piñonero, palmera datilera y ciprés) el resto son ejemplos de las plantas utilizadas en los jardines de la época ya sean por su fragancia, belleza o simbología. Así, el cortejo de los confesores, muchos de ellos con la palma del martirio, lo enmarcan rosas rojas, granados y parras, plantas todas ellas asociadas al sufrimiento y dolor de la Pasión de Jesús. Bajo ellas y tapizando el suelo se reconocen claramente el sello de Salomón, las fresas silvestres, el diente de león y el geum entre otras.

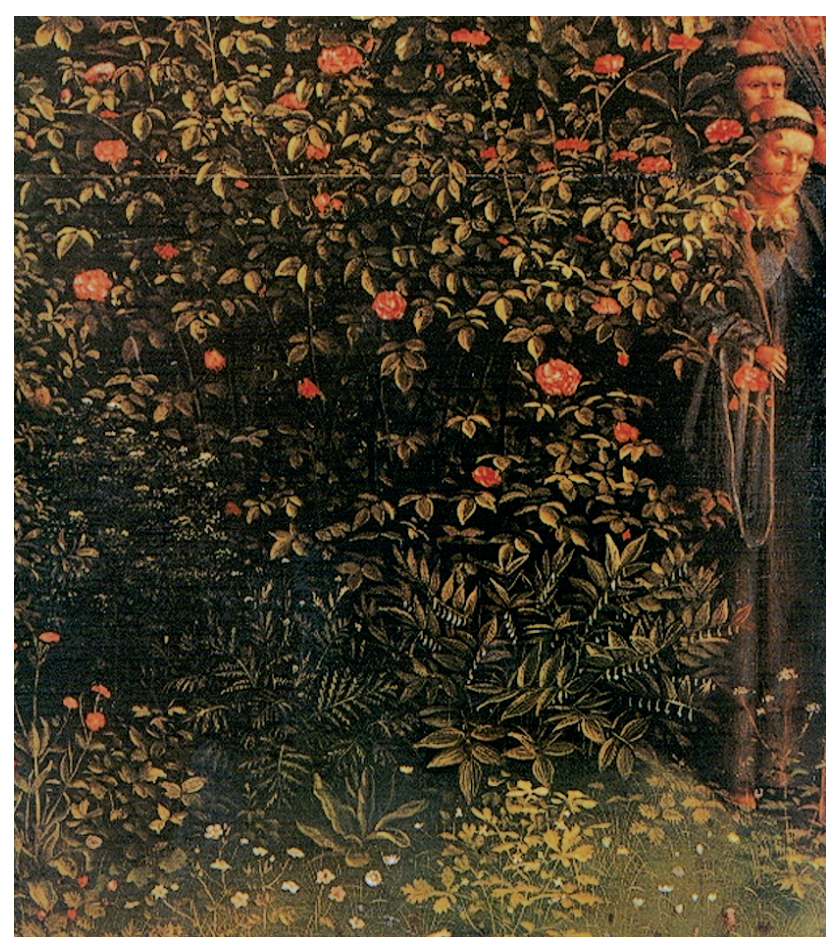

Adoración del Cordero Místico de los van Eyck. 


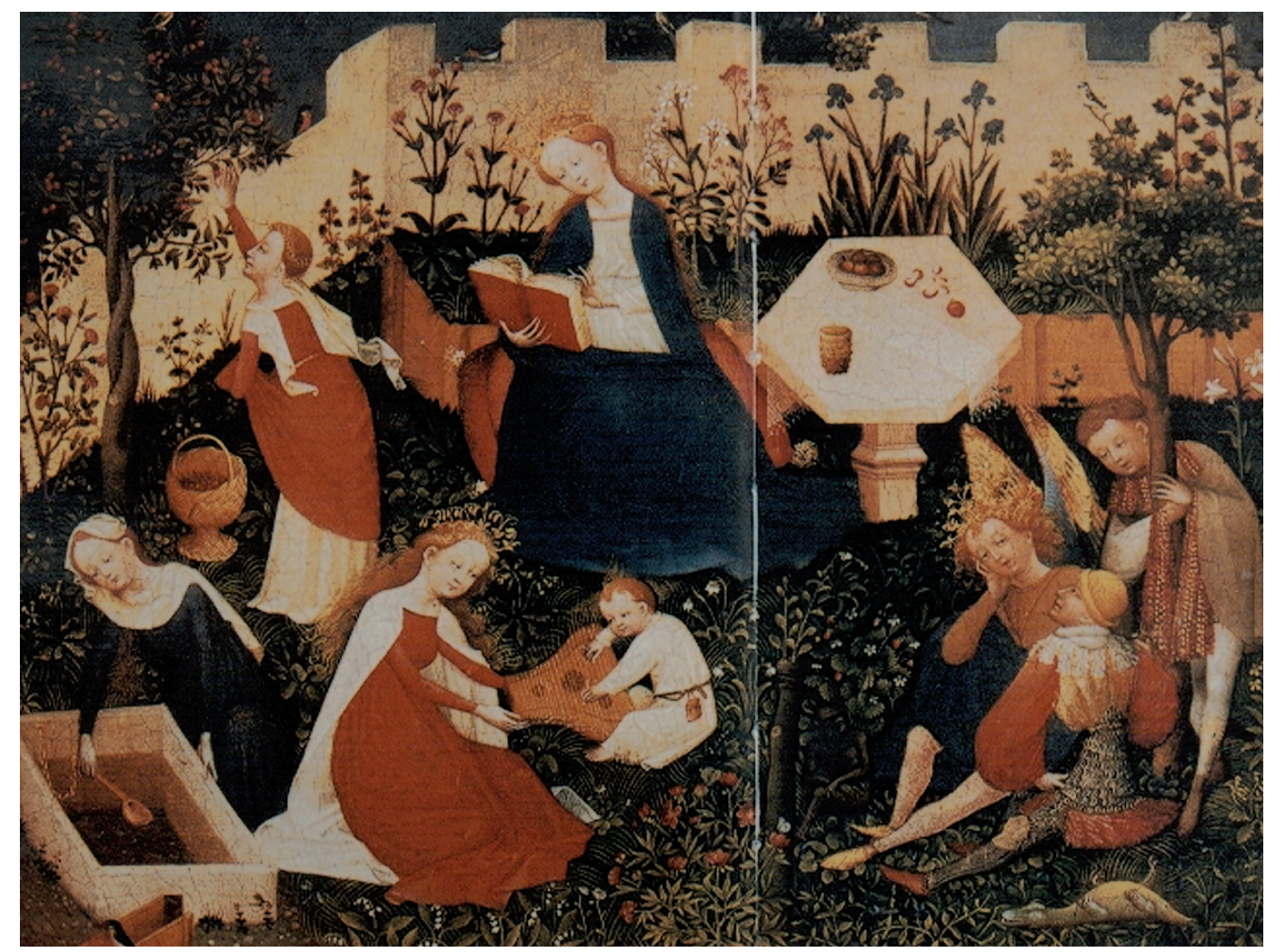

La Virgen María con santos en el hortus conclusus. Maestro del Paraíso de Frankfurt.

No deja de ser sorprendente que en una de las obras de la misma época que el cuadro de los van Eyck, se representen muchas de las mismas plantas siguiendo el mismo significado alegórico. La obra que a continuación tratamos es anónima. Atribuida al Maestro del Paraíso de Frankfurt, se pintó hacia 1410 y refleja la visión del "Hortus conclusus" medieval (5) La Virgen pasa el rato leyendo mientras los santos hacen una tertulia y las santas unas faenas en un prado donde se pueden distinguir hasta veinte clases diferentes de plantas: azucenas, lirios, prímulas, sellos de Salomón, fresas, peonías y rosas son algunas de ellas (6).

La voluntad artística de reflejar fielmente -o mágicamente como prefieren algunos señalar- la naturaleza es una constante en la pintura flamenca. En el florero de Menling (1433-1494) de la colección Thyssen-Bonermisza de Madrid las plantas son el soporte para transmitir una profunda alegoría sobre la divinidad.

(5) VAN ZUYLEN, Gabrielle. Tous les jardins del monde. 1994. Ed. Gallimard.

(6) HAGEN, Rose-Marie y Rainer. Los secretos de las obras de arte. 2001. Colonia. Ed. Taschen 


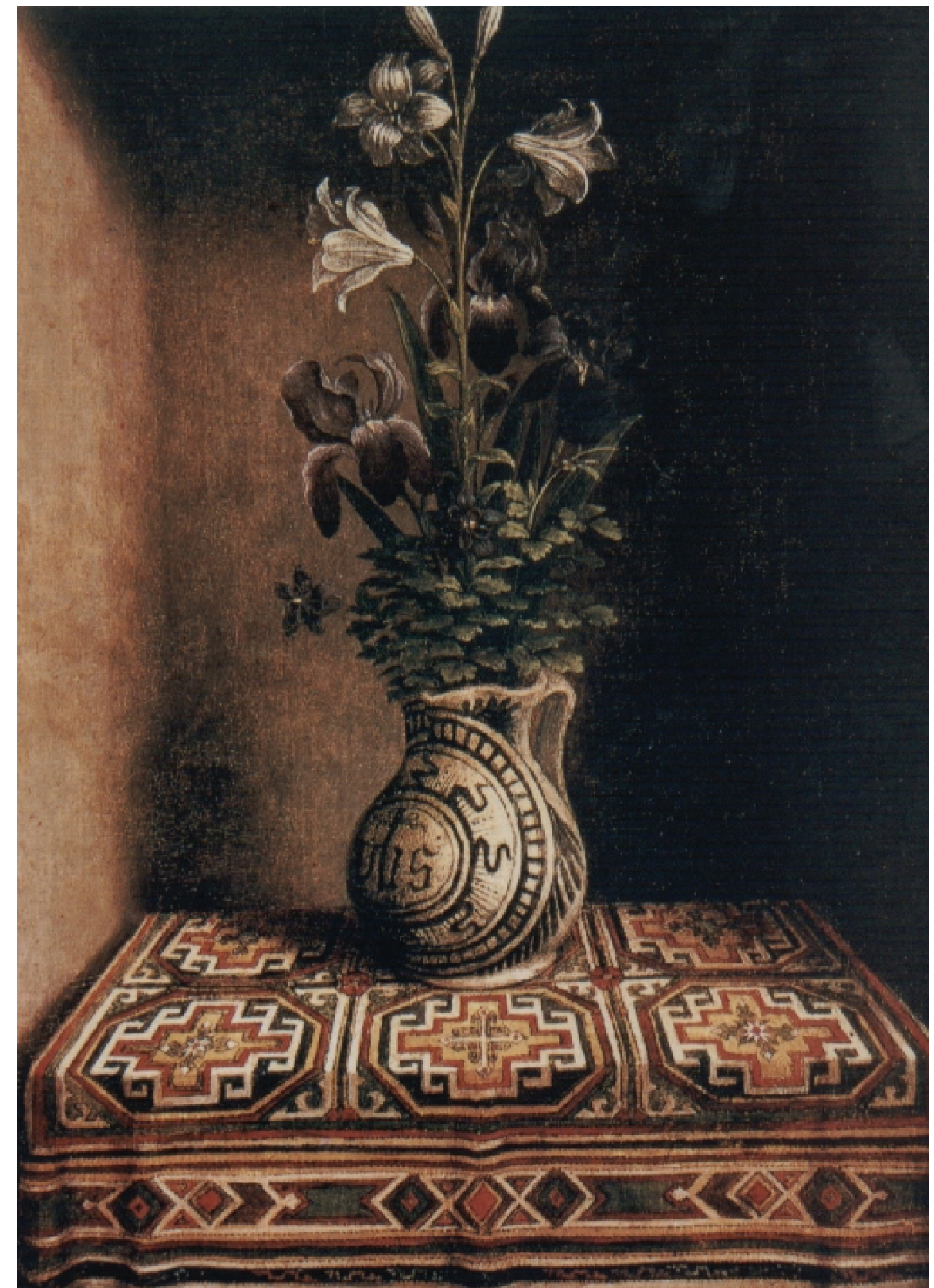

Menling. Bodegón. Colección Thyssen-Bonermisza de Madrid.

El centro de una alfombra persa, cuyos motivos podrían ser los cuadros de un jardín, está ocupado por una jarra que contiene agua -símbolo de la vida-y que en su decoración muestra un anagrama de Jesús. De esta jarra-montaña sagradafuente de la vida surgen tres especies con un claro contenido alegórico: la azucena, el lirio y la aquilegia (7). Vemos que el antiguo mito de la montaña sagrada como fuente de la vida se nos muestra con una nueva fuerza poética al reinterpretar el pintor los viejos arquetipos bajo el prisma de un cristianismo primigenio que conducirá a la Reforma.

(7) LOPEZ TERRADA, María José. Tradición y cambio en la pintura valenciana de flores 1600 - 1850. Ayuntamiento de Valencia. Colección "La Valencia del siglo XIX". Valencia, 2001 


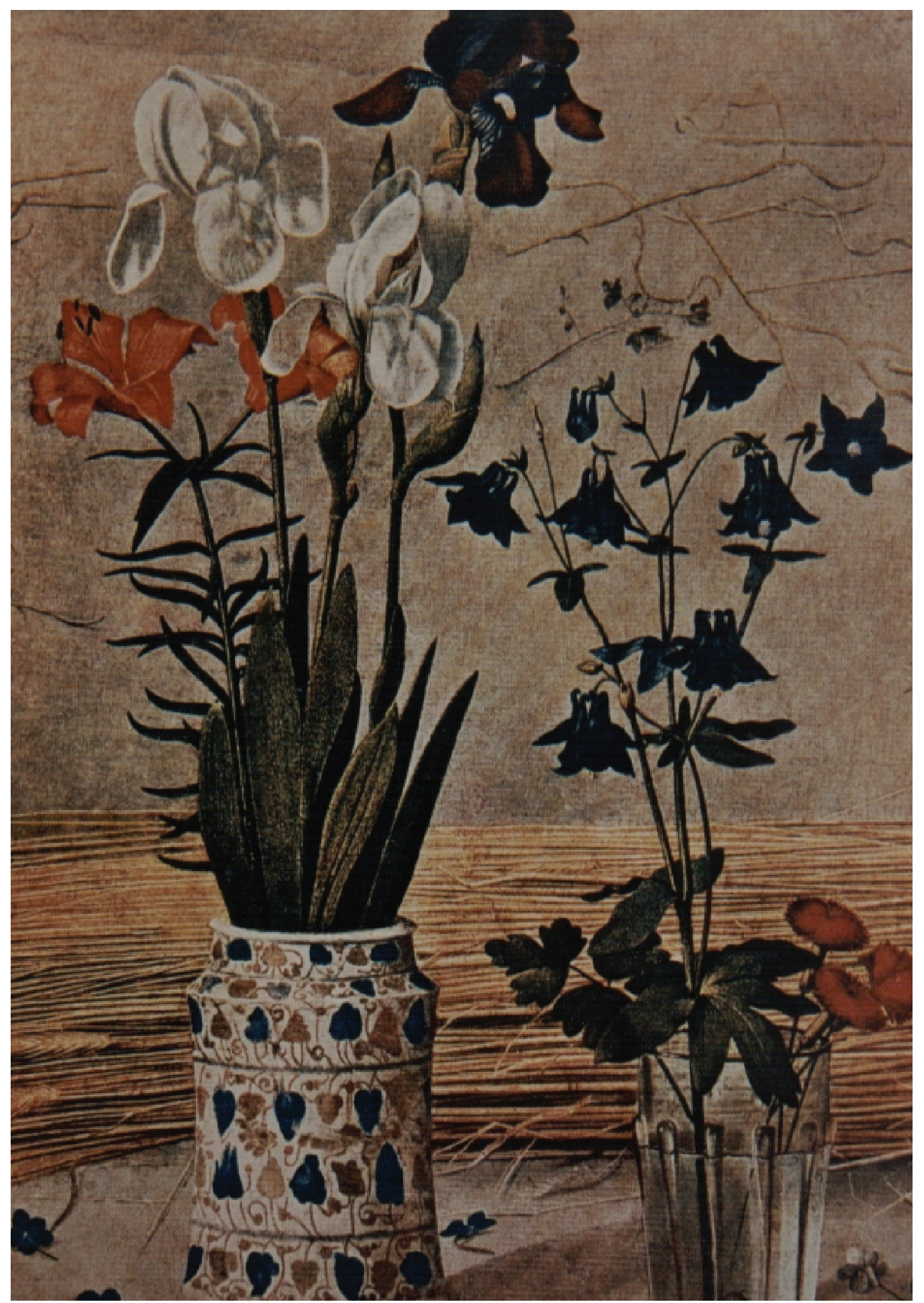

Fragmento del Tríptico de Portinari de Hugo van der Goes (1435-1482)

Unas veces como tema central del cuadro como hemos visto con Menling y otras como elemento secundario que se introduce en la composición con profundos significados alegóricos como es este ejemplo, las plantas siguen apareciendo en las obras de arte ofreciéndonos una información de gran utilidad para nuestro trabajo.

Aquí sobre el fondo de un haz de espigas y esta vez en un florero de reflejo metálico, aparecen lirios de tres clases diferentes (martagón, florentina y germánica) junto a las aquilegias y tres claveles rojos. Recuérdese que clavel viene de clavo y el color elegido por el pintor -rojo sangre- se convierte en una premonición de lo que le espera a ese niño recién nacido. 

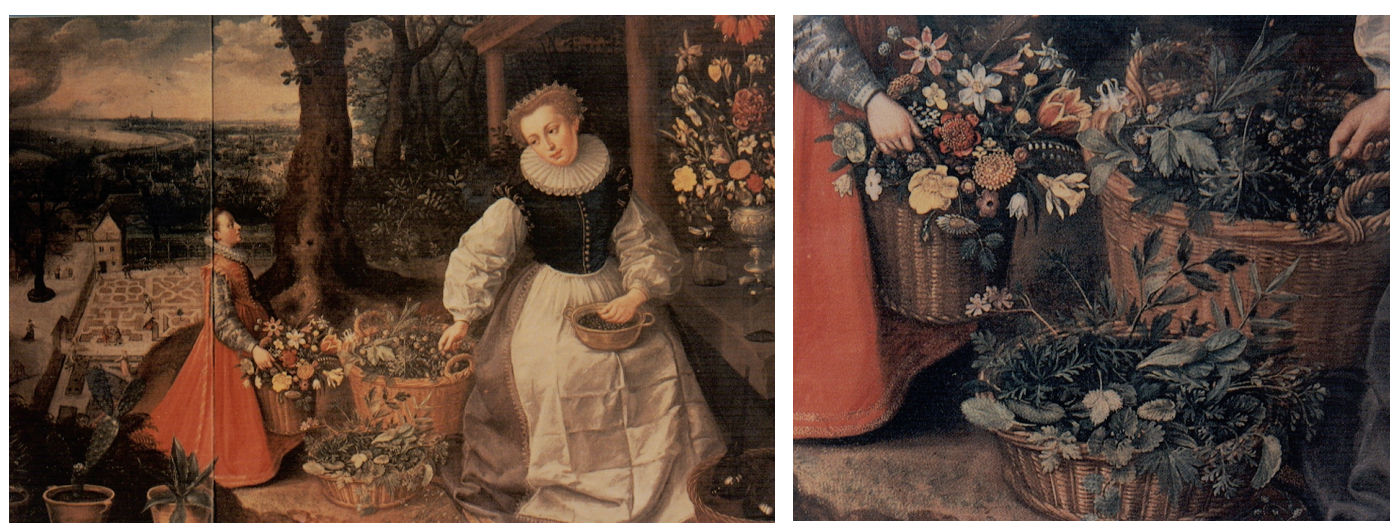

Primavera de Lucas van Valkenbosch. A la derecha detalle del mismo cuadro.

En el siglo siguiente, otro flamenco, Lucas van Valkenbosch (1530-1579) en su obra "Primavera", utilizando la forma arcaica de la pintura-relato de tradición medieval, nos ofrece la representación de la forma de un jardín flamenco de la época y de las plantas que en el mismo se cultivan (8). Podemos apreciar igualmente en esta secuencia de espacio-tiempo los diversos usos de las plantas: secado de las medicinales y culinarias y elaboración de esencias a partir de las mismas con la figuración de los alambiques y de los frascos etiquetados y llenos de las aguas recién hechas.

En esta obra, además de la presencia de las numerosas plantas ornamentales y medicinales que comentaremos posteriormente, destacan dos macetas a la izquierda del cuadro que contienen una chumbera y una pitera. Las plantas de América hacen ya acto de presencia en un lugar destacado, papel que irá en constante aumento hasta nuestros días (9).

En este detalle del cuadro antes reproducido podemos apreciar otra gran variedad de plantas de uso culinario y ornamental.

En el cesto de la izquierda podemos ver aguileñas, lirio de los valles, tulipanes, narcisos, anémonas, centaureas, gladiolos, alhelíes, rosas, margaritas, geums, ranúnculos y violetas.

En los otros dos cestos, los de la derecha, se entremezclan plantas medicinales y culinarias: manzanillas, ajenjo, saponaria, apio y consuelda entre otras irreconocibles.

(8) VEREY, Rosemary. 1984. El Jardín aromático. Ed. Folio. Barcelona.

(9) Sobre la llegada a Europa de las plantas de América y sus diversos usos hay que citar los trabajos del Instituto de Estudios Documentales e Históricos sobre la Ciencia de la Universidad de Valencia de los siguientes autores:

PARDO TOMAS, José y LOPEZ TERRADA, María Luz. 1993. Las primeras noticias sobre plantas americanas en las relaciones de viajes y crónicas de Indias (1493-1553).

LOPEZ PIÑERO, José María y PARDO TOMAS, José. 1994. Nuevos materiales y noticias sobre la Historia de las plantas de Nueva España, de Francisco Hernández.

LOPEZ PIÑERO, José María y PARDO TOMAS, José. 1996. La influencia de Francisco Hernández (1512-1587) en la Constitución de la Botánica y la Materia Médica Modernas. 
En la parte derecha de la misma obra que estamos comentando aparece un jarrón. Este tema del jarrón con flores se desarrollará de tal manera que adquirirá el rango de género propio en la pintura occidental. La utilidad que tiene para nuestra labor es inmensa ya que es una manera segura de ir inventariando todo el material vegetal según va apareciendo en Europa tras los descubrimientos botánicos con la ventaja de que la mayoría de las obras al estar firmadas y fechadas por el autor nos ofrecen fechas de datación fidedignas.

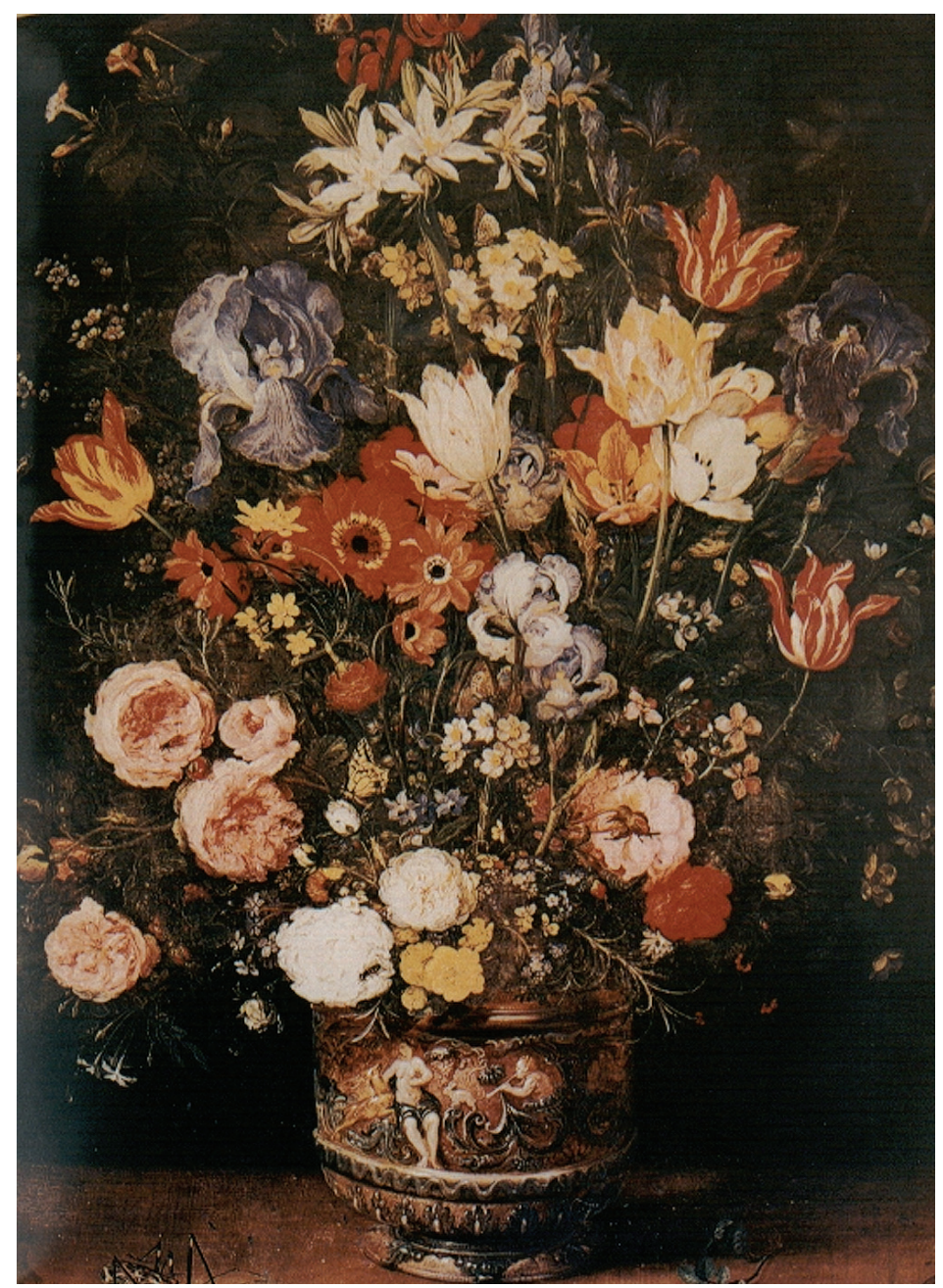

Jarrón con flores de Brueghel de Velours

La pintura de género de flores tuvo un éxito inmenso en la Europa barroca del XVII. En esta obra de Brueghel de Velours (1568-1625) podemos ver una amplia representación de plantas de bulbos, mostrando a la vez este cuadro la importancia que tuvo aquel comercio floreciente hasta convertirse en locura colectiva

La obra recoge varias clases de lirio germánica, anémonas, peonías, narcisos, talictro y lirio martagón entre otras. 


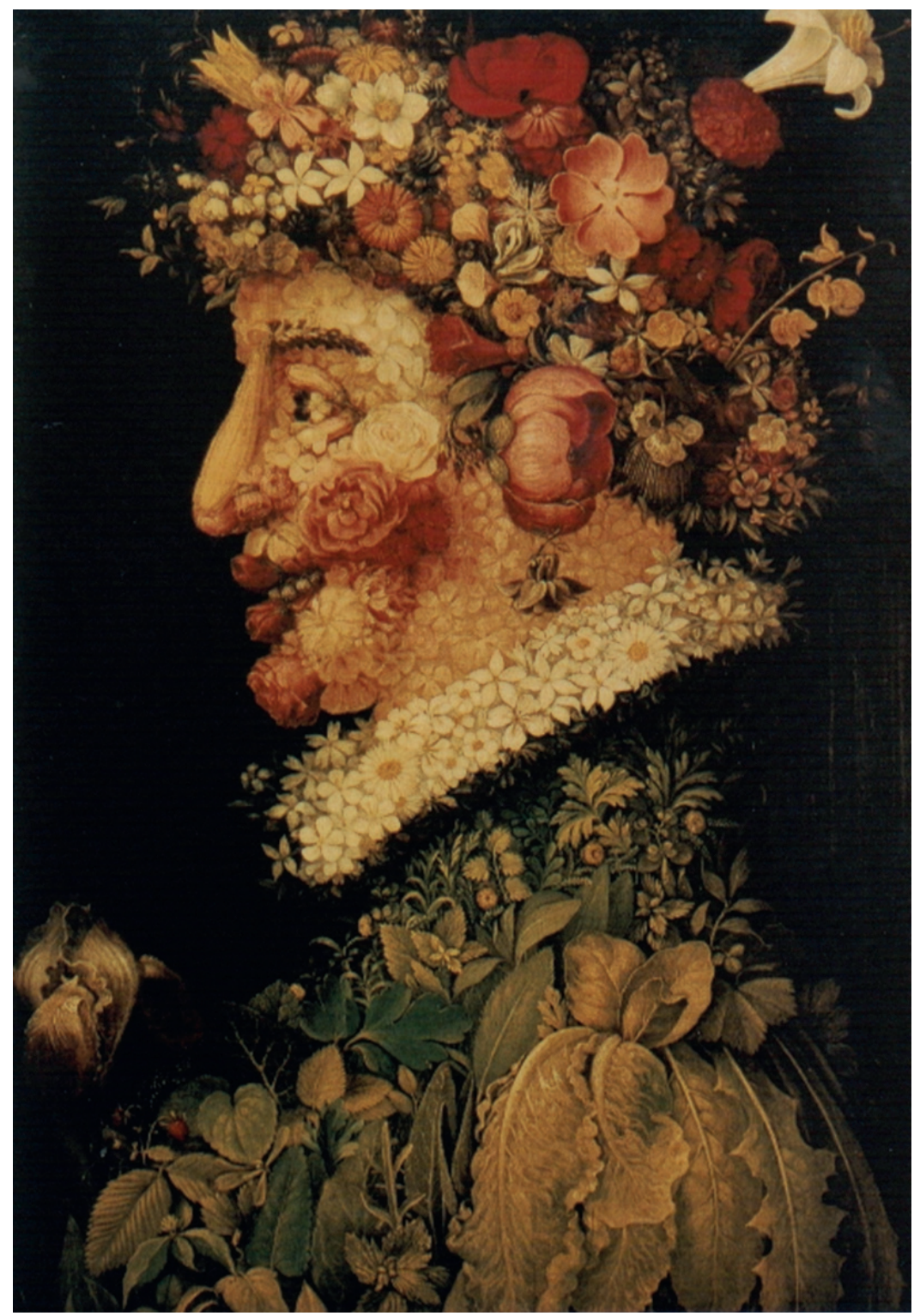

Giuseppe Arcimboldo: Primavera

Citamos aquí a otro de los grandes pintores de la naturaleza en la Europa del XVI: el sorprendente Arcimboldo (1527-1593).

Muchos de sus cuadros son un reflejo de las plantas existentes en los jardines de la Viena de Fernando I. (10) Sirva de ejemplo una de sus primaveras, la que se encuentra en la Real Academia de Bellas Artes de San Fernando de Madrid. La representación realista de los elementos vegetales nos permite conocer con todo certeza las especies utilizadas en la composición de la obra. 


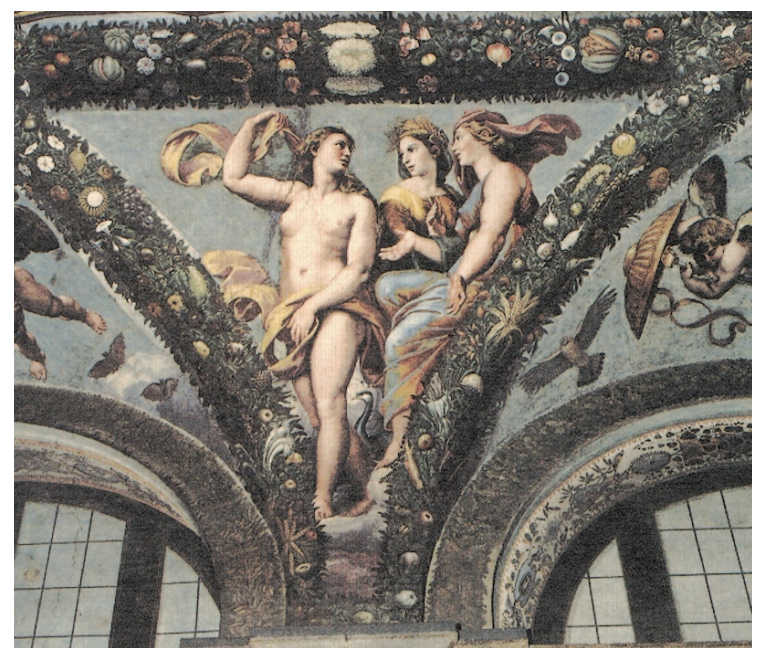

Venus, Ceres y Juno. Frescos de la Villa Farnesina de Roma de Rafael y Giovanni da Udine

A principios del siglo XVI el banquero Agostino Chigi (1466-1520) encarga a Rafael la ejecución de los frescos de la loggia de su villa junto al Tíber. Este realizará las figuras mientras que su colega Giovanni da Udine se hará cargo de las guirnaldas que enmarcan aquellas. Las pinturas debían de reflejar el proceso del mito de Eros y Psique según el relato de Apuleyo. Hoy sabemos que la recreación de tal mito estaba relacionada con la corriente neoplatónica que conocieron los círculos ilustrados renacentistas hasta el hundimiento cultural y crisis existencial que produjo la ocupación de Roma por las tropas del emperador Carlos V en 1527.

Las guirnaldas que ejecutó Giovanni da Udine recogen elementos variados de una riquísima flora que incluye flores de jardín y silvestres, frutos de ambas, hojas, raíces, bulbos y hongos tanto del viejo mundo como de las novedades recién llegadas de América.

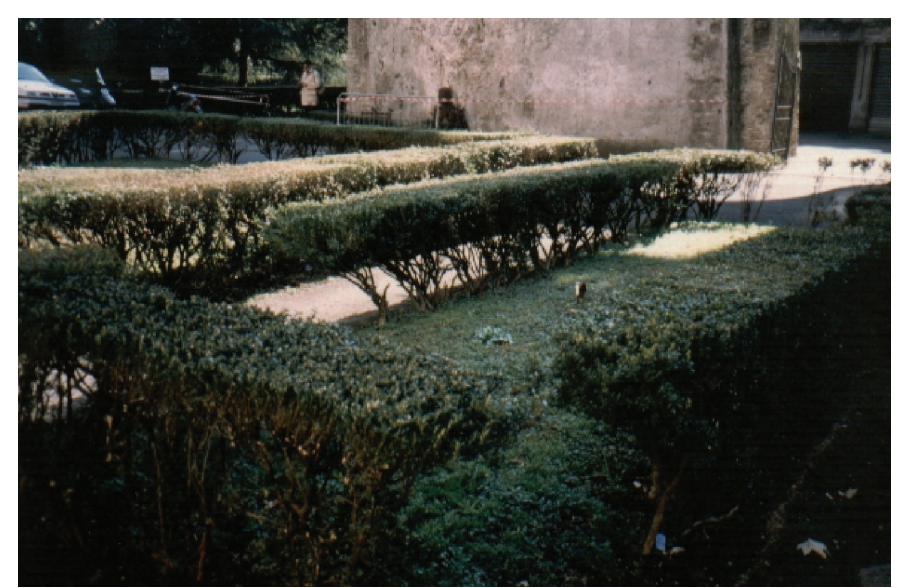

El jardín de la Villa Farnesina en 1999. (Foto del autor)

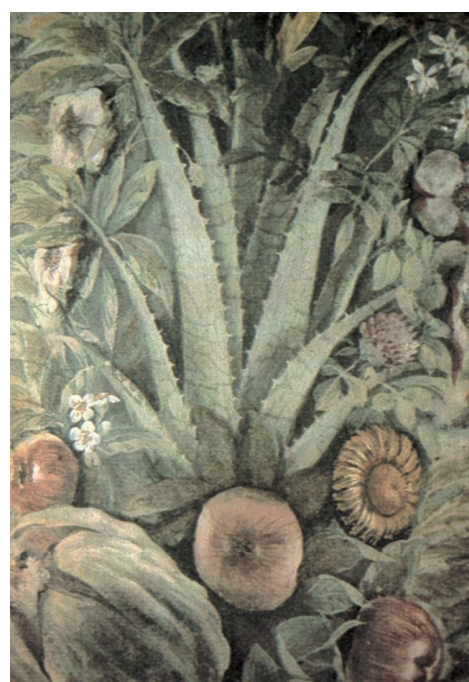

Giovanni da Udine. Detalle de una guirnalda con Aloe vera 
La presencia de todas estas especies ha sido estudiada por Giulia Caneva (11) con lo que podemos hacernos una idea de la gran variedad de plantas existentes en aquellos jardines ya que esta estudiosa llega a clasificar 165 especies diferentes frente a la monotonía de las praderas de césped en el jardín actual.

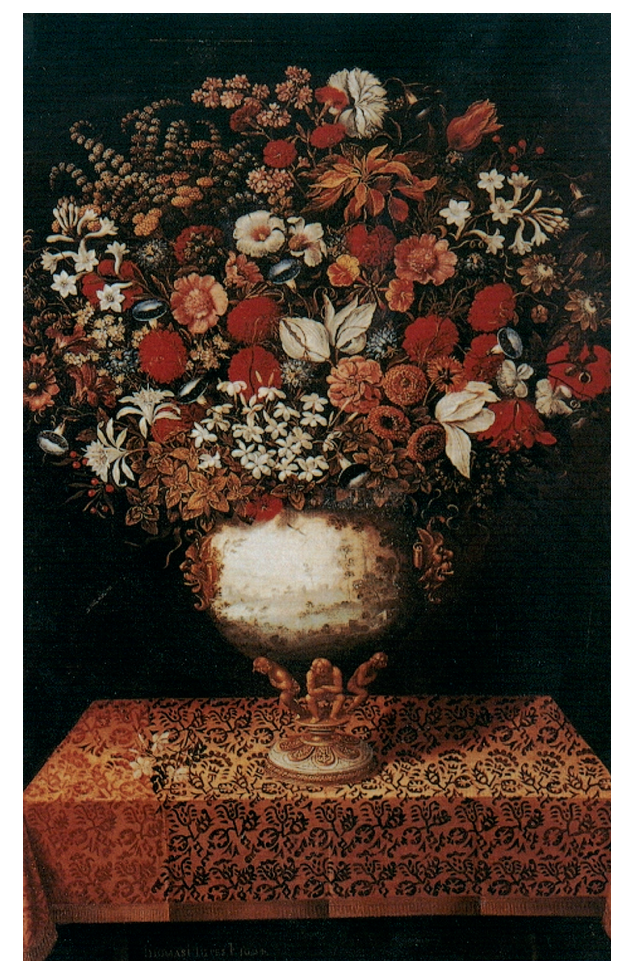

Tomás Yepes. Jarrón con flores

Dejando los pintores europeos por cuestiones metodológicas con el fin de centrar el trabajo en España, debemos de señalar la importancia de la obra del valenciano Tomás Yepes (1600-1674) para nuestros fines. Su obra, cada día se encuentra más revalorizada desde la antológica de 1995 de la Fundación Bancaja de Valencia (12).

Pero han sido los trabajos de otra estudiosa del mundo del arte, María José López Terrada, los que nos han facilitado una información exhaustiva sobre las plantas representadas por este pintor valenciano así como los pintores que posteriormente desarrollaron este genero en los siglos siguientes. Esta estudiosa no descarta que Yepes tuviera contactos con la cátedra de Botánica de la Universidad de Valencia por la gran variedad de plantas registradas en sus cuadros (13). La relación de las especies que López Terrada reúne en su obra obtenidas de las pinturas del siglo XVII se reproduce en el anexo documental $n^{\circ} 6$.

(11) CANEVA, Giulia. I/ Mondo di Cerere nella Loggia di Psique. Edición a cargo de la Academia Nazionale dei Lincei y de la Fundación Ippolito Nievo. Roma, 1992

(12) Catálogo de la exposición de Tomás Yepes. Fundación Bancaja. 1995. Valencia.

(13) LOPEZ TERRADA, María José. "El mon vegetal en la pintura espanyola del Renaixemente al segle XIX" en la obra Les plantes del món en la historia. Fundación Bancaja, 1996. Y especialmente útil es para nuestros fines la obra Tradición y cambio en la pintura valenciana de flores 1600-1850.Ajuntament de València. Colección "La Valencia del Siglo XIX. Valencia, 2001. 


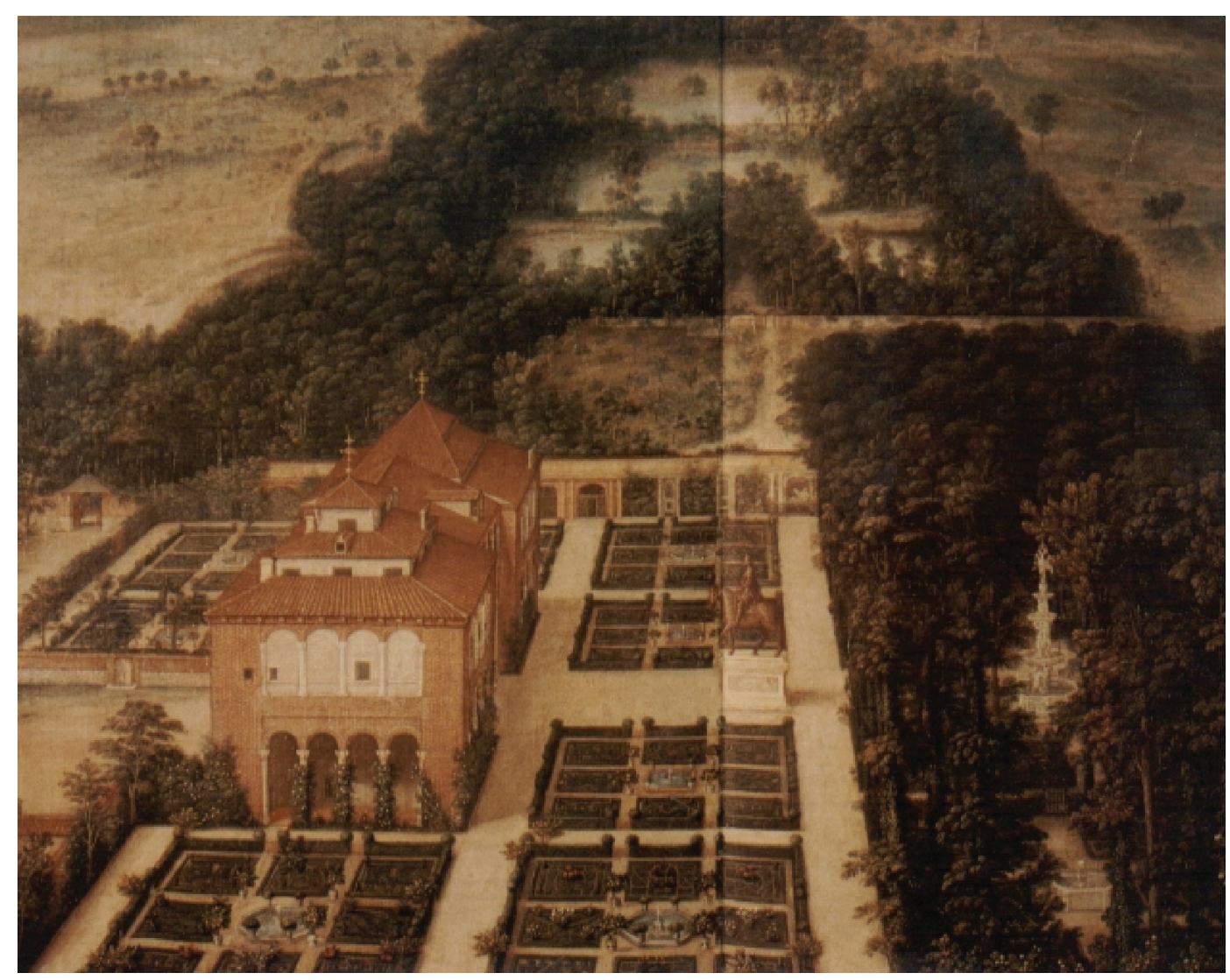

Félix Castello: La Casa de Campo de Madrid

Citamos como otro ejemplo de este apartado, el cuadro de Félix Castello que recoge una vista de la Casa de Campo en tiempos de Felipe II y que se conserva en el Museo Municipal de Madrid. Tal cuadro, junto con la obra de Gregorio de los Ríos Agricultura de Jardines, (14) hizo fraguar uno de los proyectos de recreación-restauración de jardinería más importante de los últimos años movido por el Ayuntamiento de la capital y el Real Jardín Botánico de la misma.

Del jardín representado por el pintor apenas queda hoy algún fragmento de las paredes del cierre, las que se ven al fondo del cuadro con hornacinas y estatuas. El proyecto se basó en recuperar la traza geométrica a partir del cuadro y los componentes vegetales según las especies citadas por Gregorio de los Ríos. Surgido con un fuerte componente político por parte del Ayuntamiento (PP) como oposición a las obras del nuevo trazado del metro por parte del Gobierno de la Comunidad Autónoma (PSOE) que no respetaba los restos existentes al hacer las vías al aire, sufrió el mencionado proyecto un parón al ganar el PP los gobiernos central y autonómico y no existir ninguna oposición que impulsara su realización (15).

(14) DE LOS RIOS, Gregorio. Agricultura de jardines.1 $1^{\text {a }}$ edición en 1620. Existe una reproducción facsímil y con artículos de varios autores titulada $A$ propósito de la Arquitectura de Jardines de Gregorio de los Ríos. La edición está a cargo de J. Fernández Pérez y Z. González Tascón junto con el Real Jardín Botánico de Madrid (CSIC) y el Ayuntamiento de la capital. Madrid, 1991.

(15) $A B C .17$ de julio de 1993 y El Mundo, 30 de julio de 1993. 


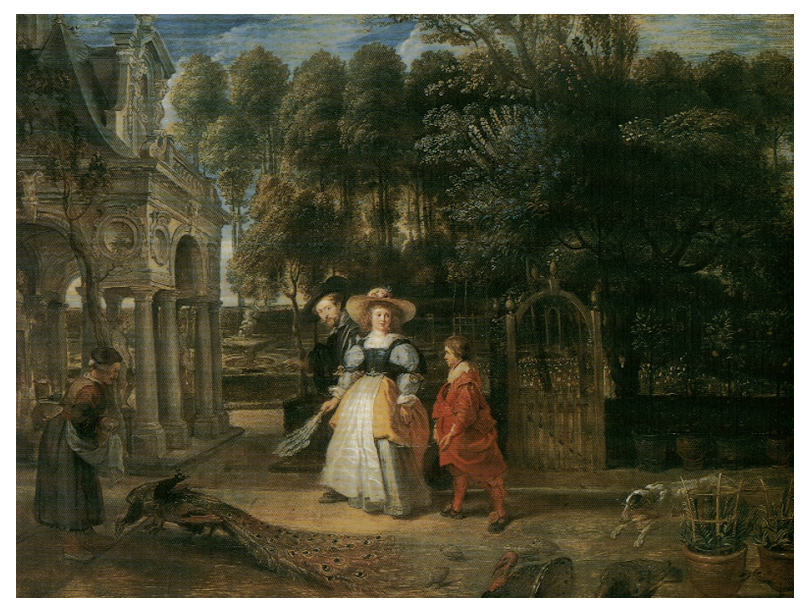

Pedro Pablo Rubens. El pintor, su hijo y su segunda esposa en el jardín de su casa de Amberes (1630/31)

Este cuadro de Rubens ha servido de base para la reconstrucción del jardín de la casa del pintor pero solamente se tomaron los motivos arquitectónicos. La importante variedad de flores que Rubens refleja ha sido ignorada, habiéndose optado por uno de los modelos franceses de Dezallier d'Argenville: el del parterre de césped ribeteado con herbáceas de flor.

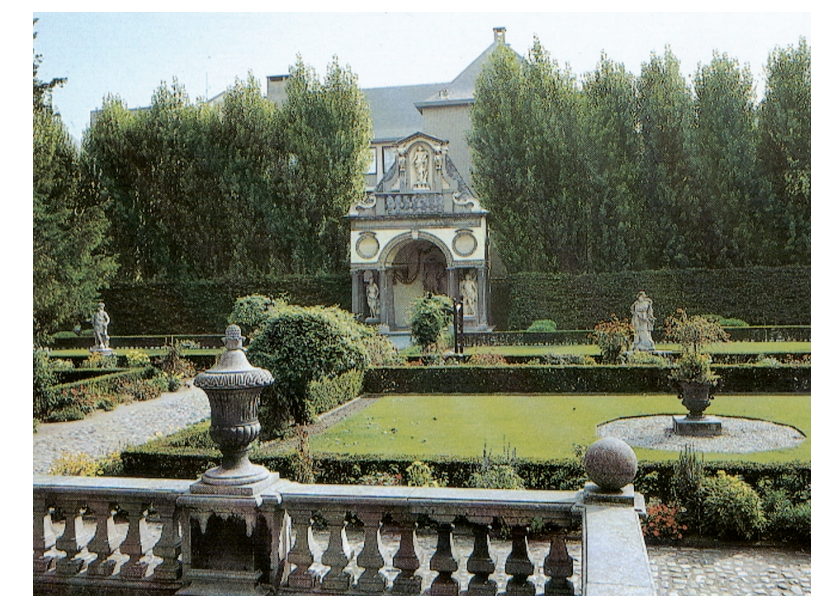

Reconstrucción del jardín de la casa de Rubens en Amberes. (Foto D. Ogrin)

Otra recreación de un jardín a partir de un cuadro es el de la casa de Erasmo (1469-1536) en Anderlecht, cerca de Bruxelas (16) René Pechère recreó un jardín inspirado en uno de los paneles de la obra de Dirk Bouts (1414-1475) La Justicia del emperador Otón. Los elementos vegetales se obtuvieron de la obra de Rembert Dodoens (Dodoneus), de las que el humanista utilizó para su salud y de las bordadas en la serie de tapices de La Dama del unicornio (siglos XV y XVI) conservados en el Museo de la Edad Media de Cluny en Francia. 


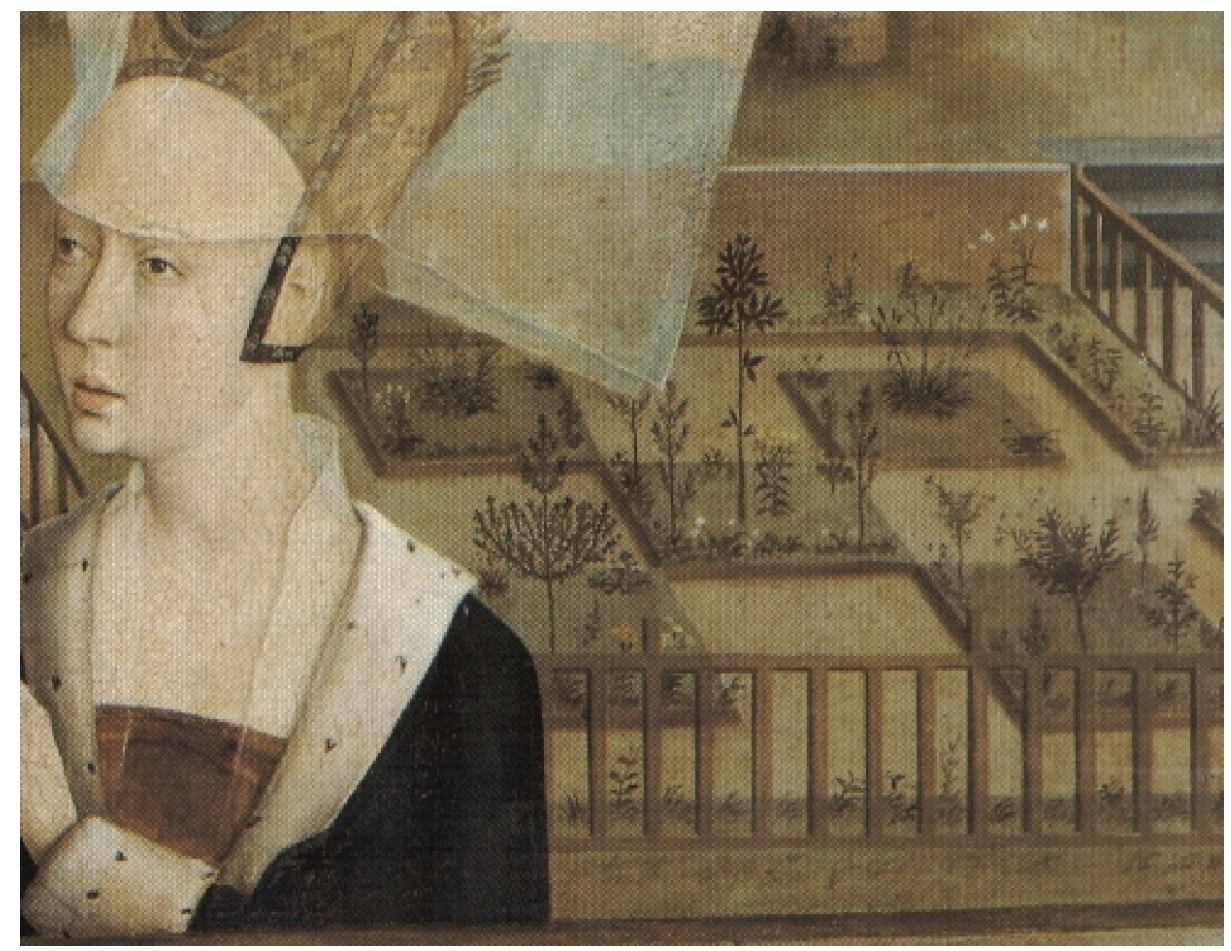

Fragmento del cuadro de Dirk Bouts La Justicia del emperador Otón

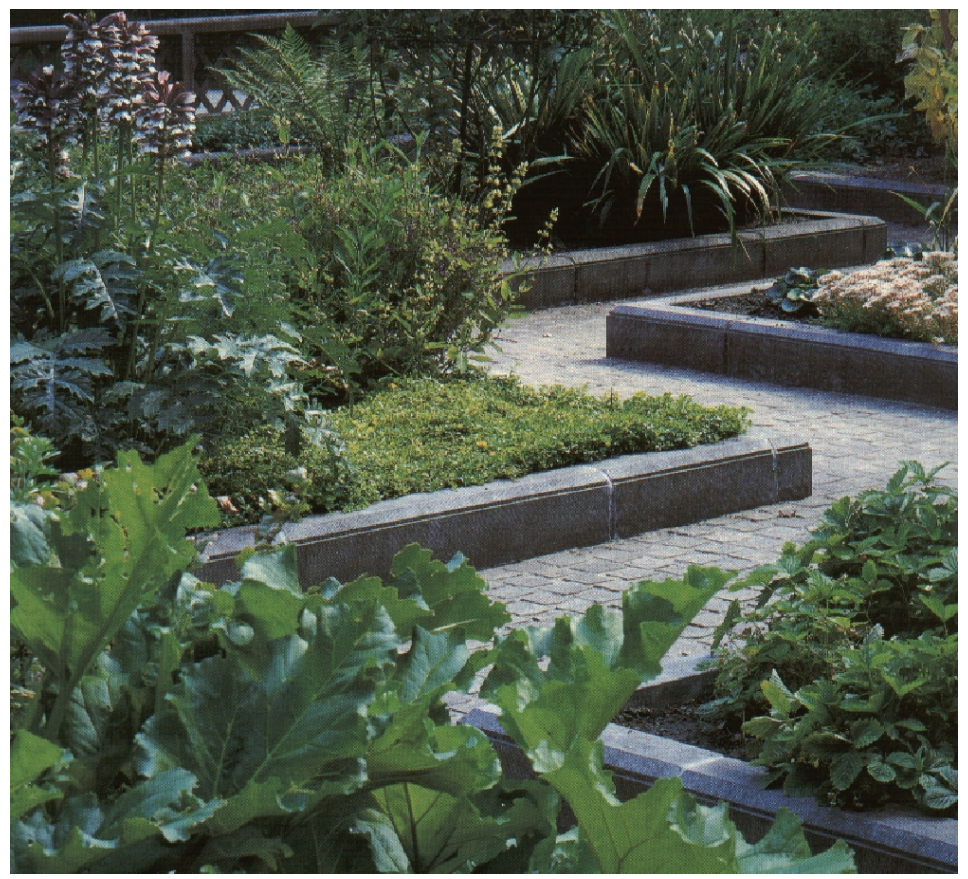

Jardín de la casa de Erasmo en Anderlecht. (Foto de Alain Le Toquin) 


\section{E.2. El grabado}

Gracias al grabado que multiplicó las reproducciones, nos han llegado innumerables testimonios de jardines. Unos son fantásticos, puras ensoñaciones como es el caso del Sueño de Polifilo de inmensa influencia en el renacimiento italiano y europeo. Otros son proyectos en los que domina la abstracción pero también existen algunos que han reflejado fielmente el aspecto del jardín como es el caso del Laberinto de la Granja que vimos anteriormente o fueron creados en un intento de ser recordatorios, algo así como nuestras postales y revistas. Ahí podemos apreciar la vida cotidiana de esos espacios, cómo se utilizaban y las faenas necesarias de mantenimiento. Echamos, sin embargo, de menos en estas reproducciones, los elementos materiales que constituyen el jardín, especialmente lo vegetal. En estos dibujos es muy difícil que se representen las especies de modo individual. Sólo son formas, elementos vivos de un gran escenario donde aquellas minorías realizaban sus actuaciones regidas por absurdos protocolos. Podríamos afirmar para resumir que los grabados por regla general muestran el aspecto quedando la materia relegada a un plano secundario cuando no inexistente.

Pero a pesar de estos inconvenientes, tenemos la ventaja por otra parte de disponer por primera vez de planos de conjuntos, de dibujos de parterres y de otros testimonios formales de las jardinerías renacentista y barroca hechos con gran minuciosidad por lo que es el único modo de conocer algunos jardines hoy desaparecidos por desidia, desastres o transformados por el cambio de gusto y moda que supuso la revolución paisajista inglesa en el continente. De estos aspectos es de lo que este apartado tratará más extensamente.

Citaremos en primer lugar un jardín hoy desaparecido de los muchos que rodeaban la ciudad de Valencia: el Hort de Julià. Gracias al grabado que hizo Carrascosa Criado en su obra sobre los jardines valencianos, hoy nos podemos hacer una idea de su trazado.

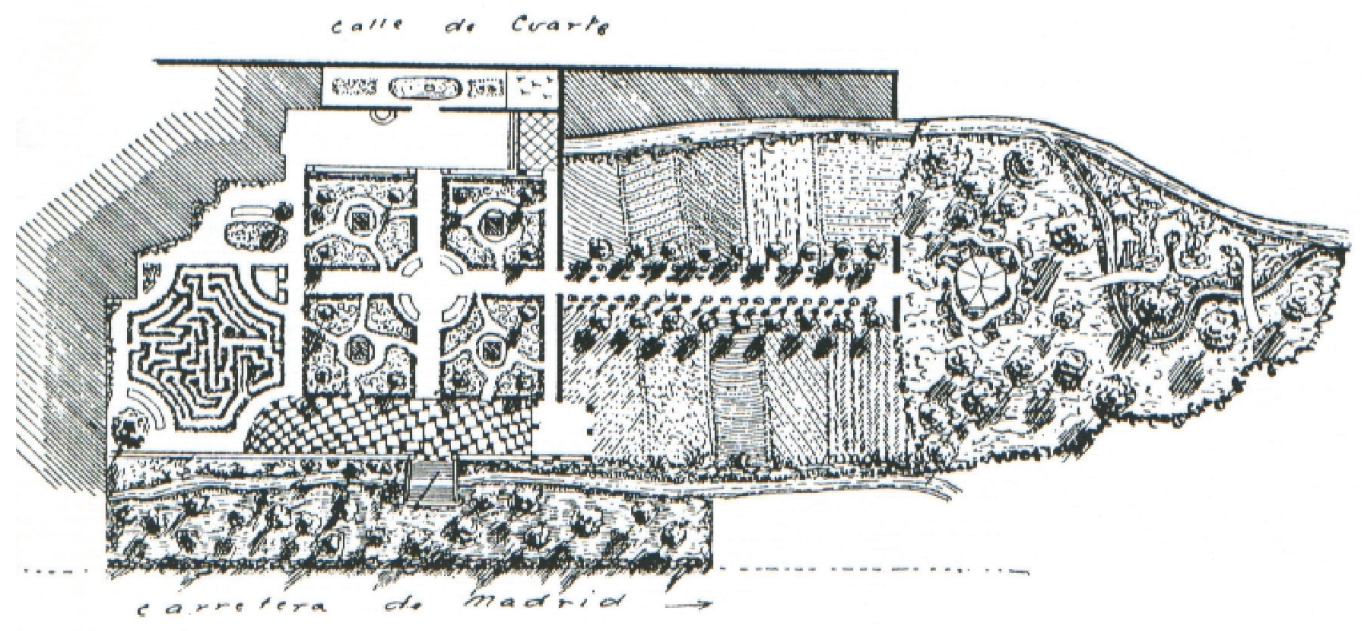

Plano del desaparecido Hort de Juliá, según Carrascosa Criado 
Gracias también al grabado, podemos hacernos una idea del aspecto de una de las obras que más influyeron en la evolución de la jardinería occidental. Se trata del Belvedere de Bramante en el Vaticano. La utilización de las tres dimensiones en este espacio, recogiendo la tradición de Babilonia, la Roma clásica y el mundo islámico, nos llega pálidamente a través de los grabados. Por ellos, podemos conocer lo que fue este jardín, desaparecido poco tiempo después al ampliarse el palacio papal para nuevos usos: biblioteca, museos y más recientemente aparcamiento (17).

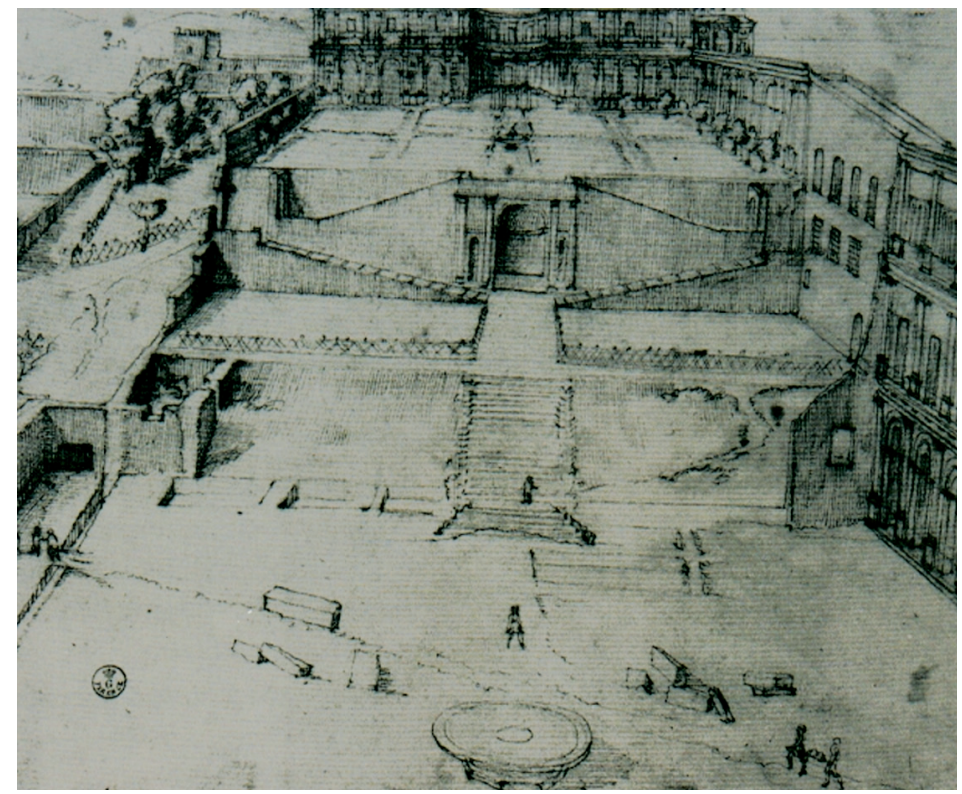

Grabado de G. A. Dosio con el Belvedere en construcción

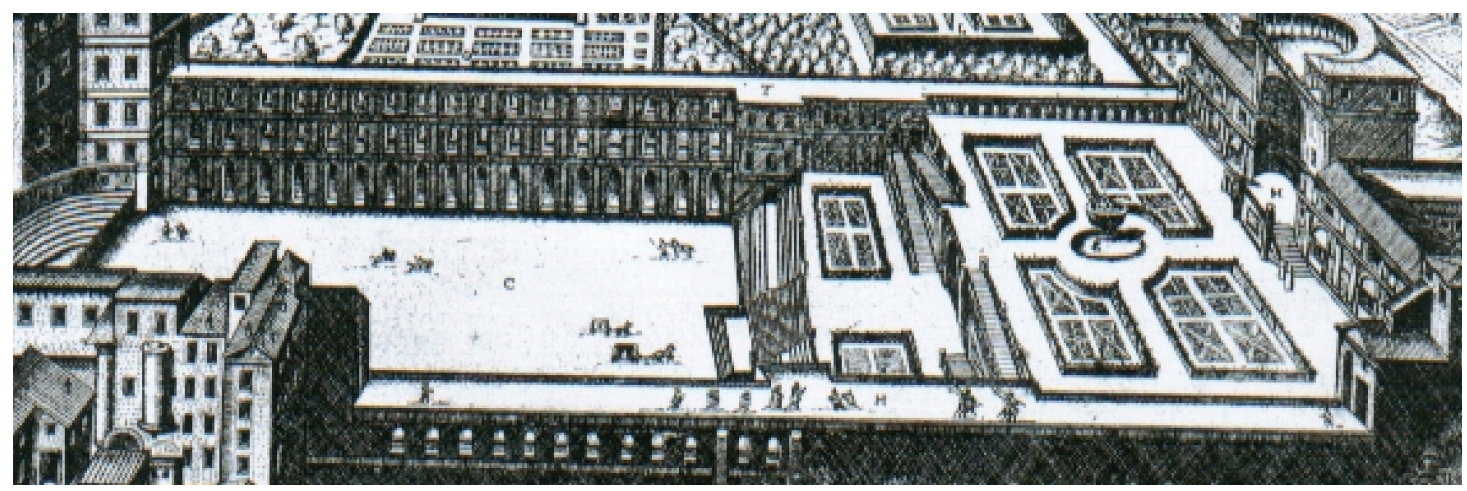

Fragmento de un grabado de Hendrick van Schoel de 1579 donde podemos apreciar el resultado final del Belvedere antes de su desaparición 


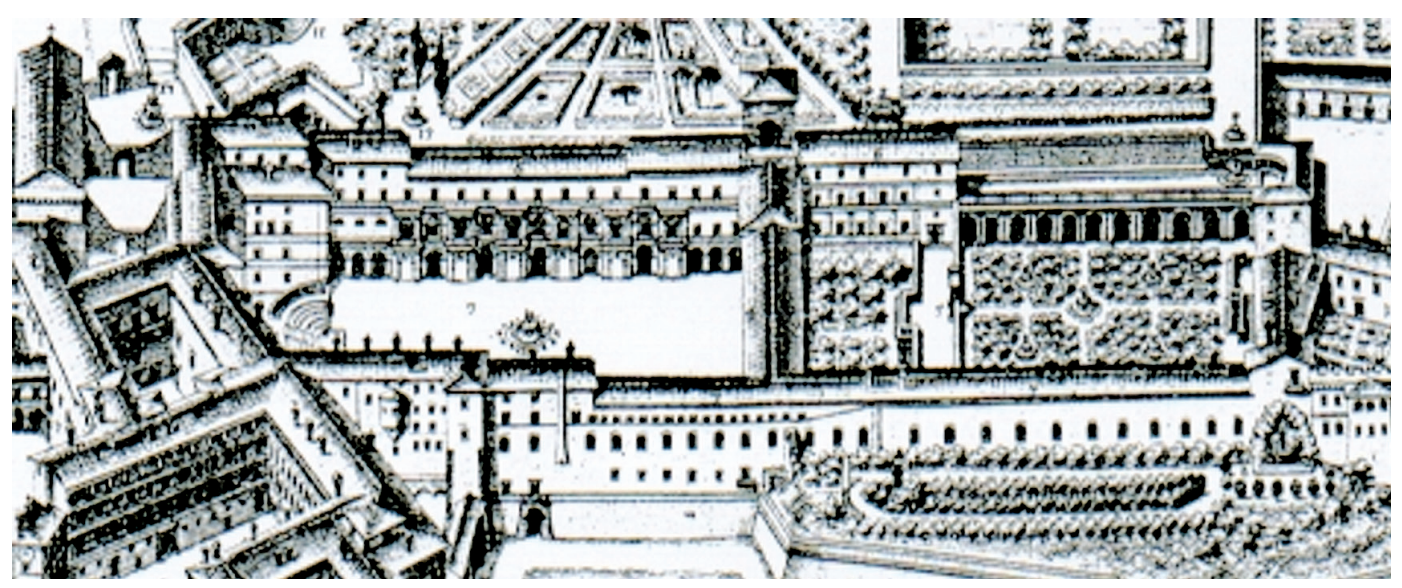

En este otro fragmento del grabado de G. B. Falda apreciamos los cambios habidos en el patio tras la construcción de la biblioteca vaticana que hizo desaparecer las escaleras y los jardines trazados por Bramante

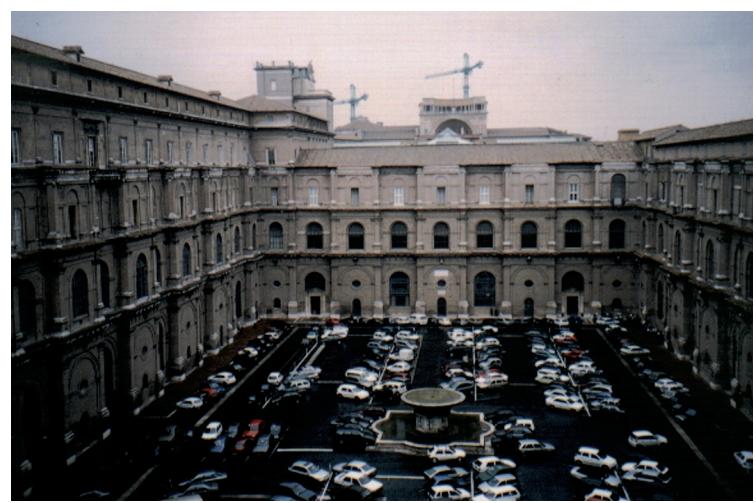

Estado actual del patio de Bramante. (Foto del autor)

La utilización de los grabados en la reconstrucción de los jardines la vimos en anteriores capítulos. Uno fue el caso de Het Loo en Holanda donde los grabados de R. de Hooghe y de Marot fueron los modelos seguidos para la reconstrucción del conjunto, en particular la parte del Jardín de la Reina (ver página siguiente). Otro caso ha sido el del Jardín Botánico de Madrid donde la existencia de grabados de la época de su inauguración se utilizó de guía para rehacer el antiguo diseño a partir de los restos existentes del jardín original. Igualmente los trabajos realizados en el Laberinto de la Granja de San Ildefonso estuvieron guiados por los numerosos ejemplos de grabados del mismo pertenecientes a épocas diversas.

Y por último, para acabar este apartado, vamos a reproducir dos grabados de Salomón Kleiner. Este arquitecto hizo numerosos grabados de los jardines de la Viena barroca. En ellos podemos apreciar además de los aspectos formales, los trabajos que exigía su mantenimiento así como los usos de estos espacios (18). 


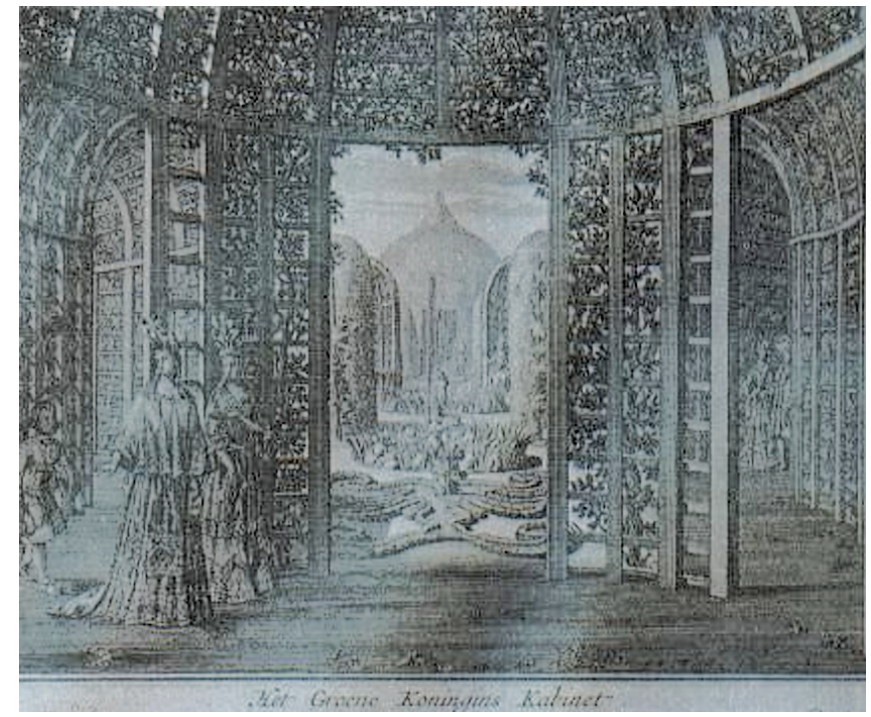

Grabado de las pérgolas del Jardín de la Reina en Het Loo

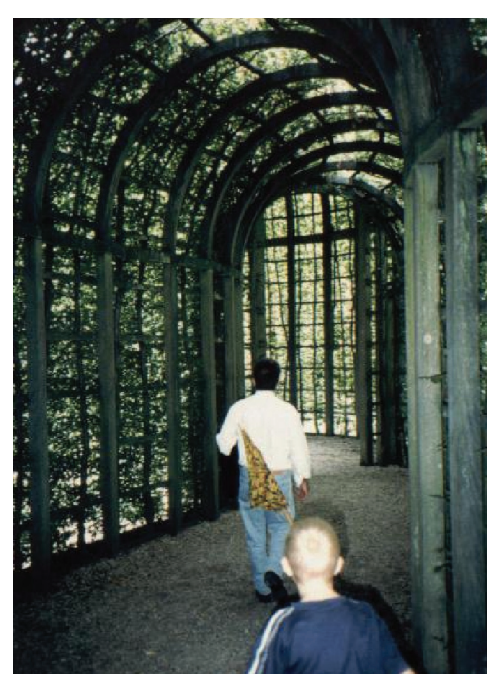

Estado actual de las pérgolas del Jardín de la Reina en Het Loo tras su reconstrucción según el grabado de la izquierda. (Foto del autor)

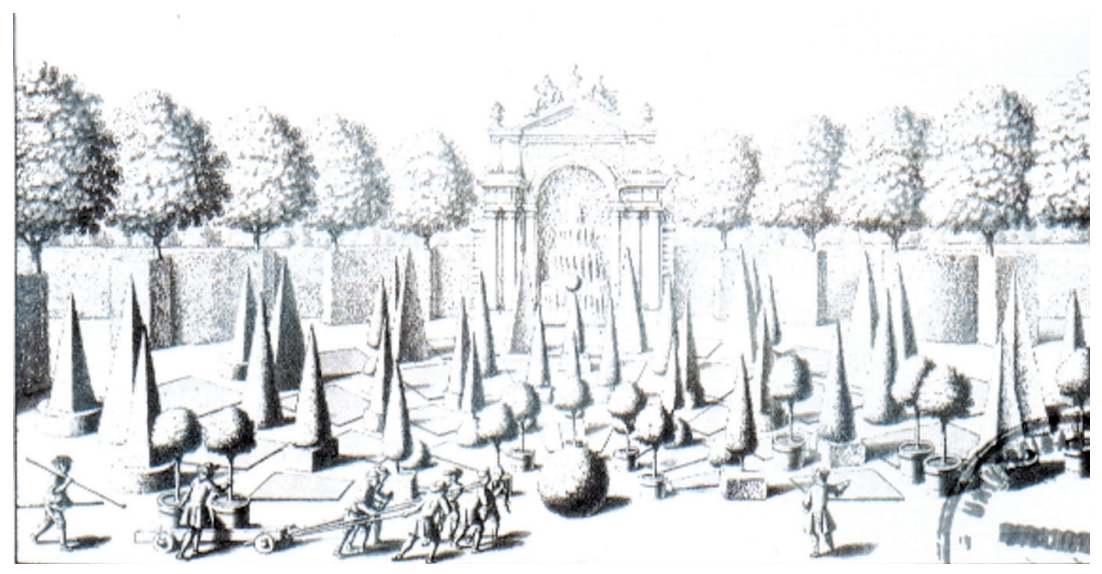

Salomon Kleiner. Trabajos en el jardín

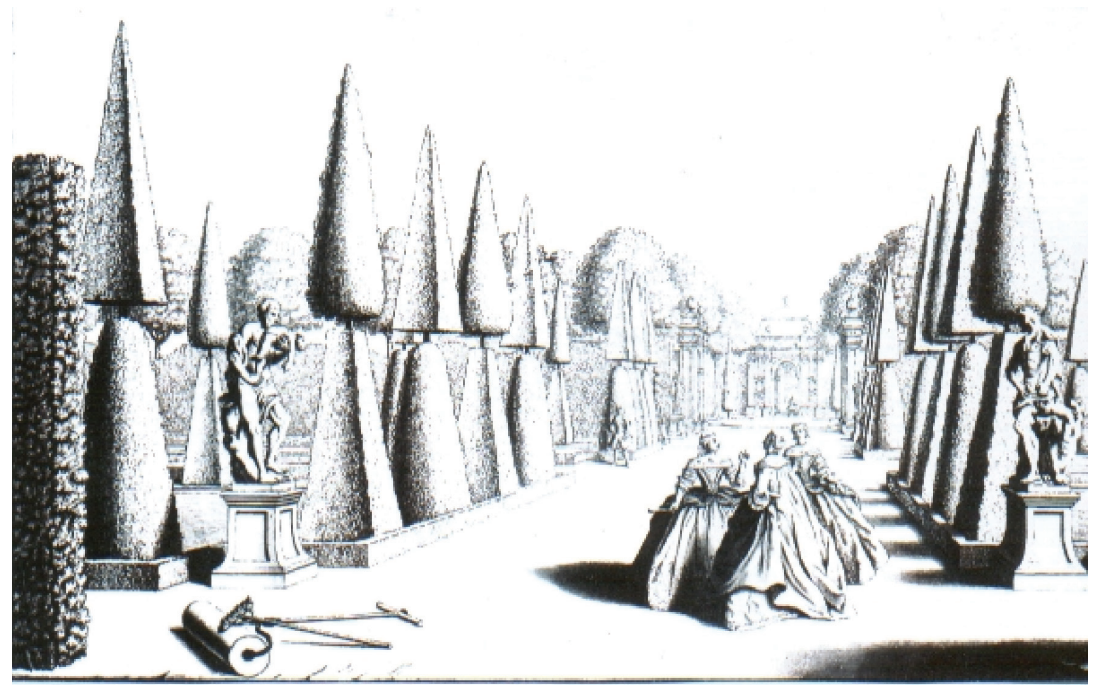

Salomon Kleiner. Usos del jardín 


\section{E.3. La fotografía}

El contar con fotos de jardines a la hora de restaurarlos es de tan gran utilidad que no tiene sentido comentar más el tema por obvio.

Como primer ejemplo vamos a utilizar una de las fotografías que realizó Javier de Winthuysen de la Exedra de la Alameda de Osuna para su libro (19) y que sería años después de gran interés para iniciar su recuperación

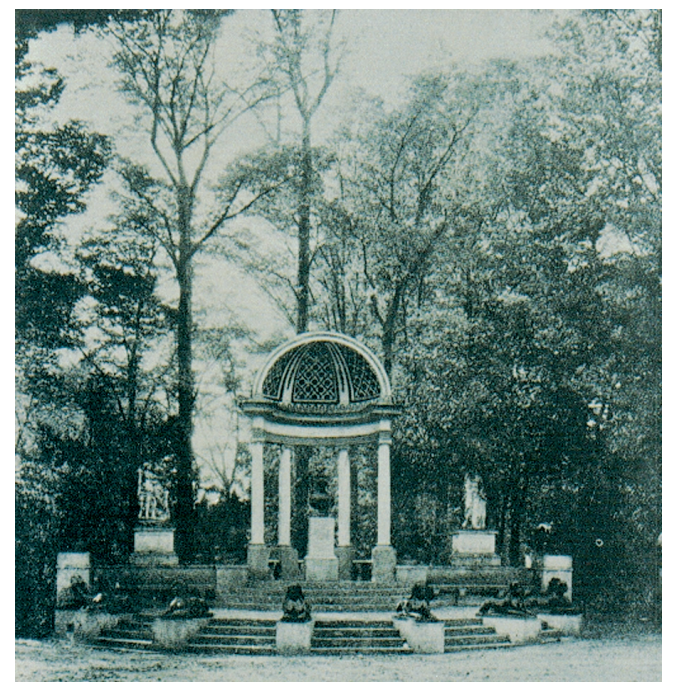

Exedra de la Alameda de Osuna de la obra de Winthuysen

Igualmente, en otra foto del archivo Vernacci de principios del siglo XX, publicada en el cuaderno donde se explica el proceso de restauración de este jardín histórico, podemos apreciar que el entorno que rodeaba al monumento reproducía un fragmento de bosque según las ideas románticas imperantes en el momento de la construcción de esta obra.

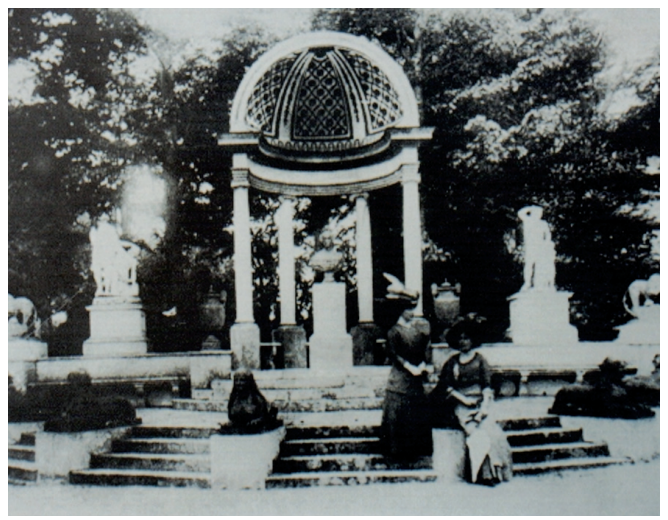

La Exedra hacia 1900-1910. Archivo Vernacci

(19) AA.VV. Escuela Taller Alameda de Osuna. Obra citada. 
La foto que a continuación reproducimos es de 1971. Ella muestra por sí misma el abandono sufrido por el jardín con los actos de vandalismo y expolio de los elementos más valiosos del lugar.

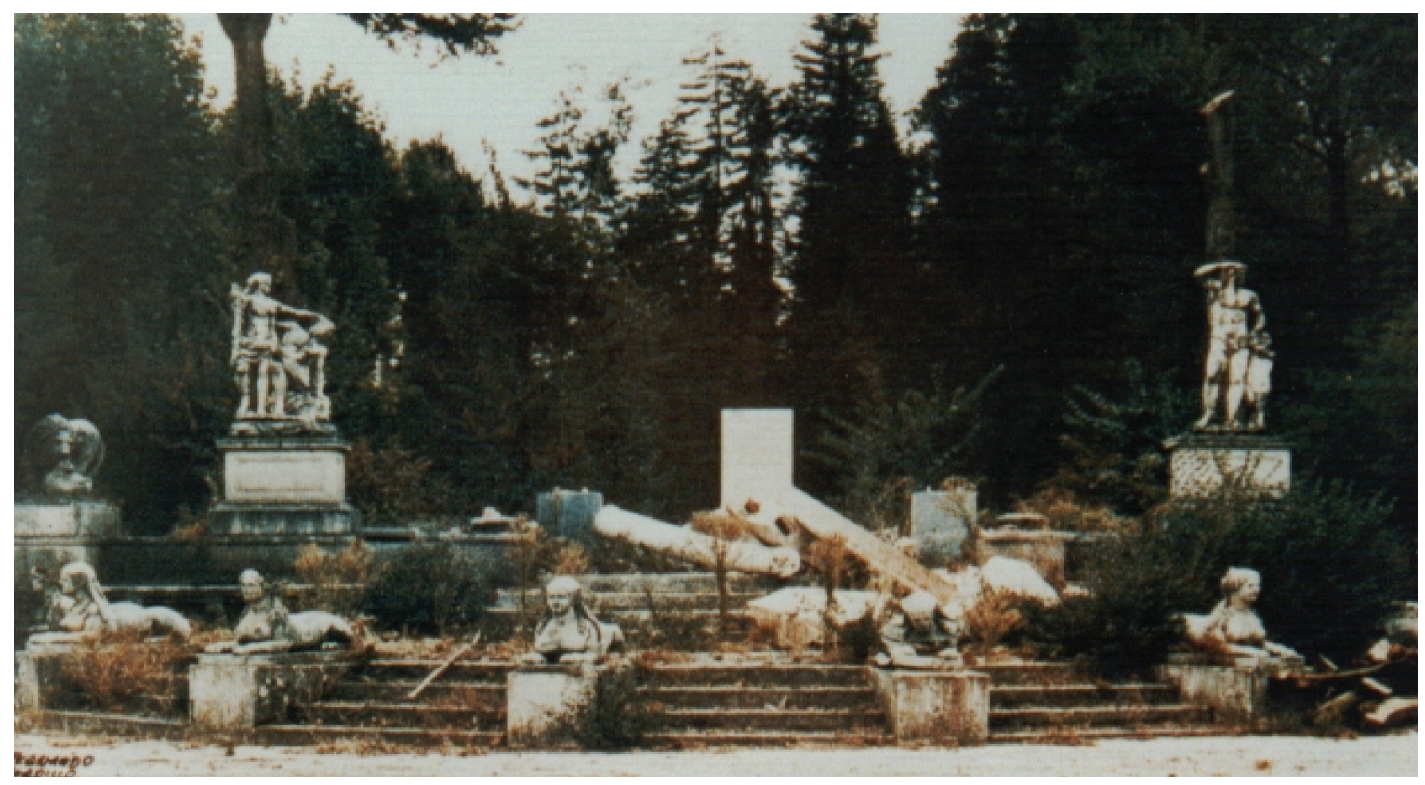

Estado de la exedra en 1971. Foto procedente de la publicación anteriormente citada

En las imágenes siguientes veremos como ese espíritu de insertar la obra en un entorno lo más natural posible no fue respetado cuando se realizó la restauración del monumento ya que le fue añadido una pared de ciprés recortado que desvirtúa completamente la voluntad artística de sus creadores.

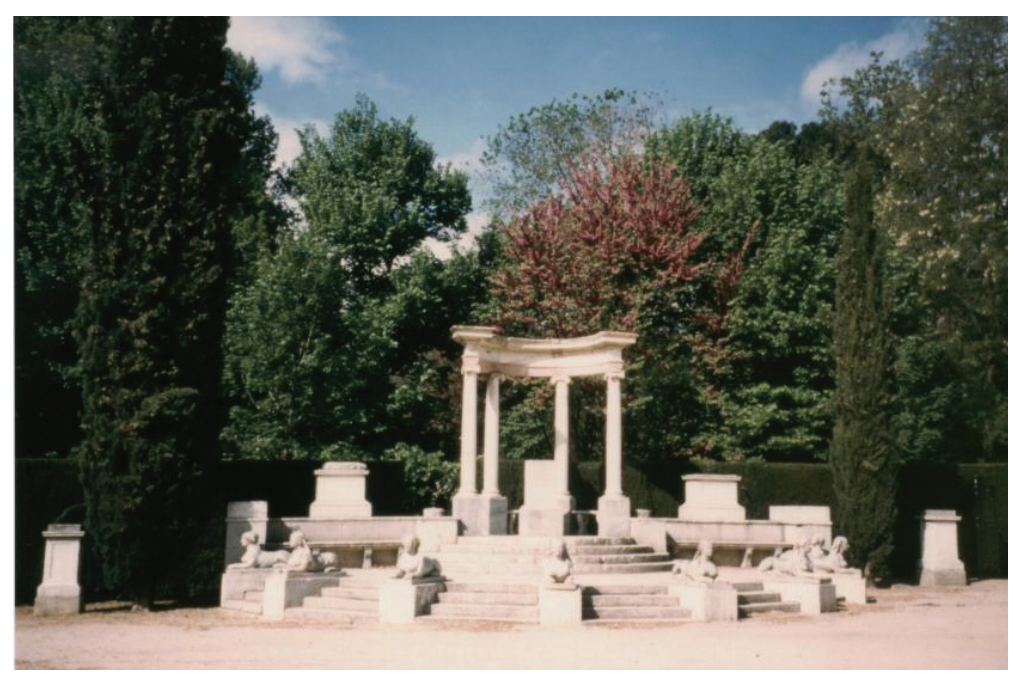

Exedra de la Alameda tras su restauración. (Foto del autor) 


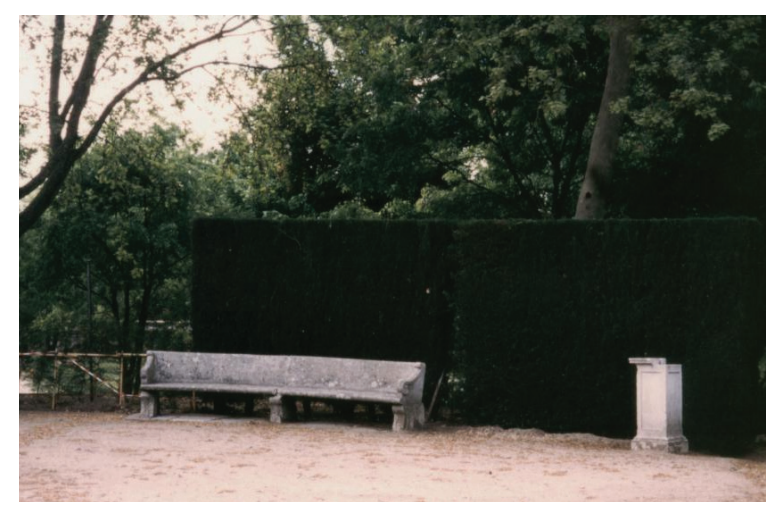

Plaza de la exedra tras su restauración. (Foto del autor)

Otro ejemplo de la ayuda de la fotografía para nuestros fines lo constituyen las tarjetas. Esta que aquí se reproduce forma parte de un bloc temático sobre el Colegio del Sagrado Corazón de Godella el cual conserva todavía uno de los mejores jardines de la zona (20).

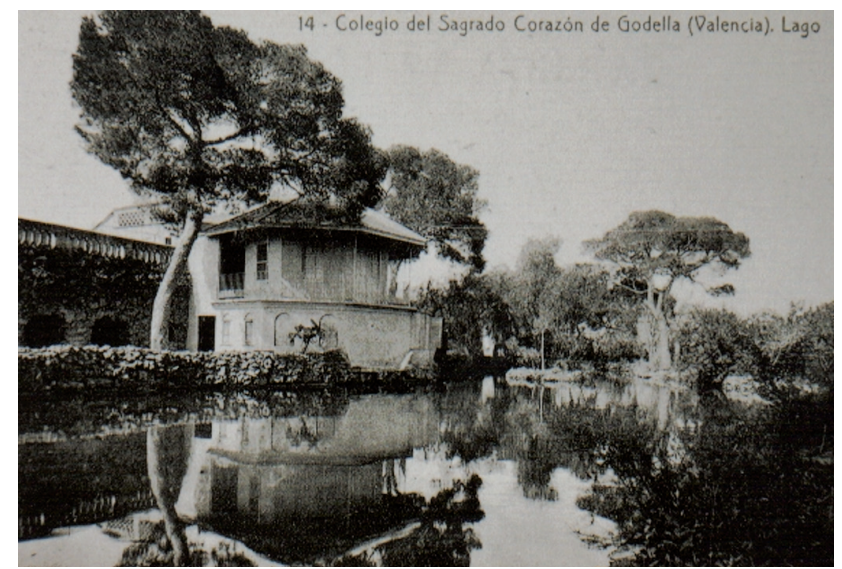

Lago del Bosque del Sagrado Corazón por los años 1950

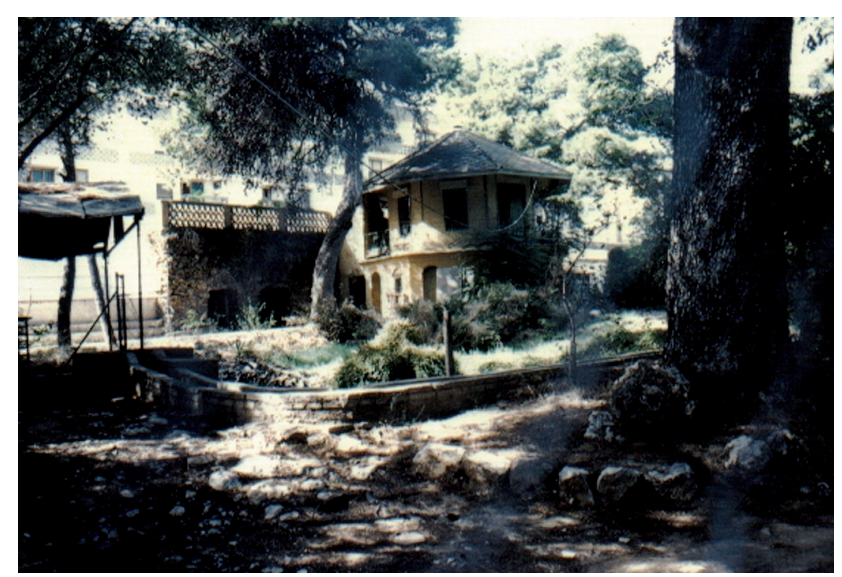

El mismo lugar tras su desecación y relleno por los años 1970. (Foto del autor) 
El Jardín poseía un lago en su parte alta el cual fue desecado y rellenado de escombros y basura por la década de los setenta del pasado siglo. La desaparición de este componente influye poderosamente en la percepción del lugar tanto por haber sido eliminada la lámina de agua -espejo del sol- como por la sensación de frescor que causaba la misma.

También las fotos nos sirven para notificar el cambio de gustos y diseño ocurrido en uno de los jardines más emblemáticos de la Toscana: el de Villa Gamberaia en Setignano, cerca de Florencia. El jardín, fue completamente rehecho tras la Segunda Guerra Mundial. Los testimonios gráficos recogidos por Inigo Triggs en su obra (21) nos permiten hacernos idea de la riqueza botánica de los setos alrededor de los parterres de agua a principios del siglo XX frente a la pobreza ornamental que muestra la reconstrucción llevada a cabo tras la contienda.

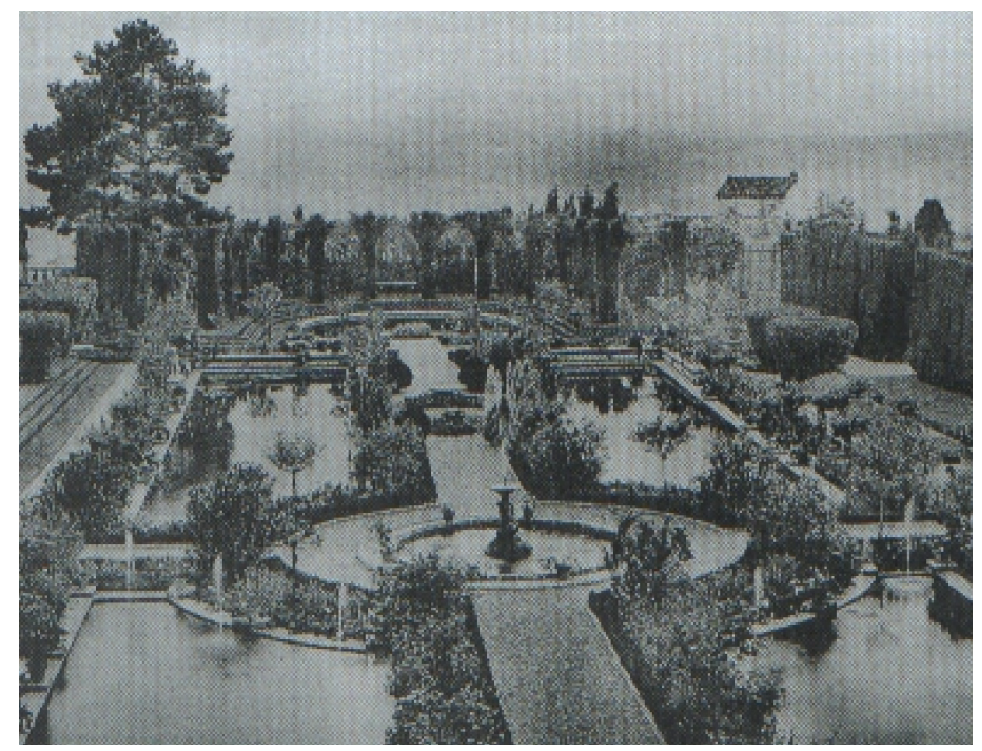

Villa Gamberaia a principios del siglo XX. (Foto de Inigo Triggs)

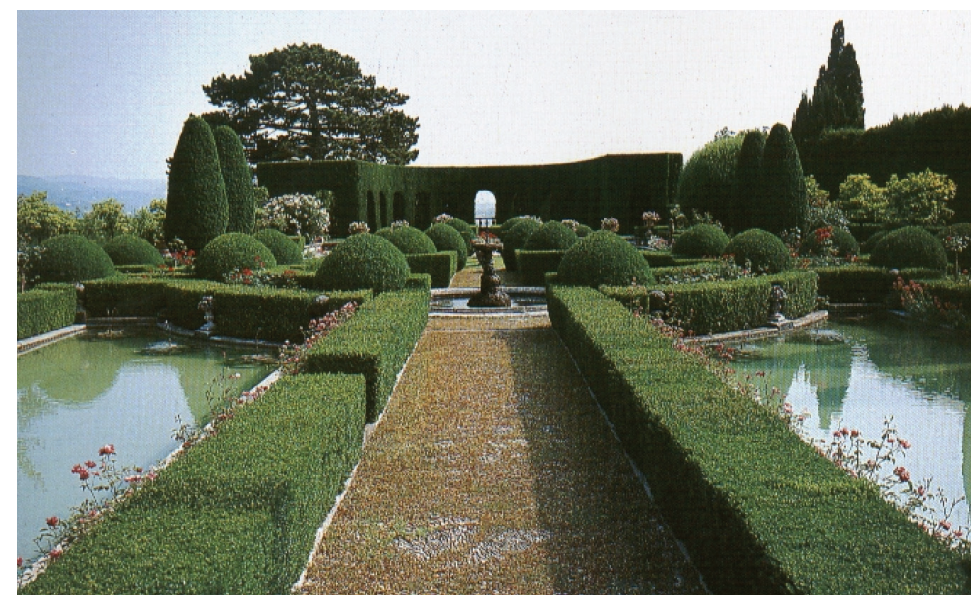

Villa Gamberaia tras su reconstrucción tras la Guerra Mundial (Foto de Aubrey le Blond)

(21) TRIGGS, Inigo. The Art of Garden Design in Italy. 1906. 
Estas dos imágenes que vemos en esta página corresponden al mismo espacio. El "jardín secreto" de villa Farnese en Gamberaia. Una es de principios del siglo XX (22). La otra de su final. En la primera podemos ver que los parterres están llenos de plantas según la tradición del jardín latino. La otra refleja el momento en que los monumentos cumbre de la historia del arte se han convertido en meros objetos de consumo de ese fenómeno turbulento de finales de ese siglo al cual se le denominó indulgentemente "turismo cultural".

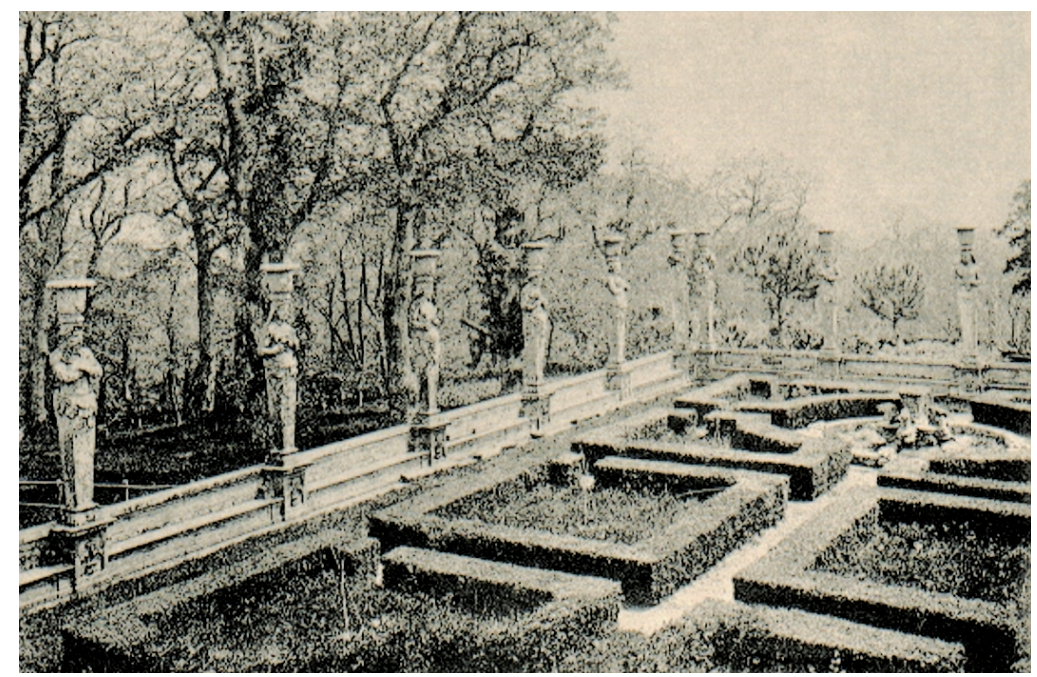

Foto de Villa Farnese de la obra de A. Duchâne y M. Fouquier. en 1914

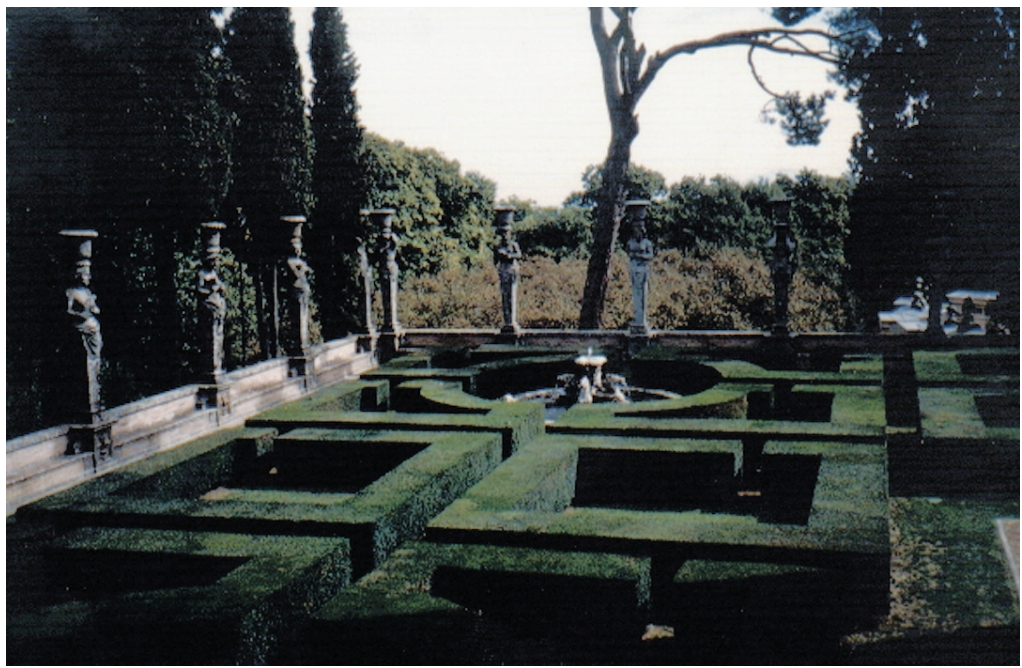

El mismo lugar en 1999. (Foto del autor) 


\section{E.4. La arqueología}

Se inserta aquí esta disciplina por ser una de las más útiles para la restauración y recreación del jardín tanto por la información que se obtiene sobre las plantas como sobre la estructura y materiales de los edificios. Con su ayuda podemos reconstruir los trazados de desaparecidos jardines de los que hoy sólo quedan cascotes y ruinas. Para la reconstrucción de la materia vegetal, tenemos que ayudarnos de la palinología (estudio de los polenes). Al tener cada especie vegetal un polen diferente, si las excavaciones se hacen con cuidado, podemos saber las plantas presentes en ese lugar aunque tiene el inconveniente de que no sólo encontraremos el polen de las plantas ornamentales del jardín sino también de todas las de los alrededores. En ese caso hay que recurrir a otras fuentes (artísticas y literarias) para seleccionar las ornamentales de las silvestres (23).

En Pompeya, con la ayuda de estas disciplinas más los restos de los tocones y otros fragmentos de vegetales, ha sido posible reconstruir alguno de los jardines de aquella época. Por fotos conocemos la reconstrucción del jardín de la casa de los Amorini Dorati a principios del siglo XX y de la cual no podemos saber su estado actual por encontrarse siempre cerrada los últimos años.

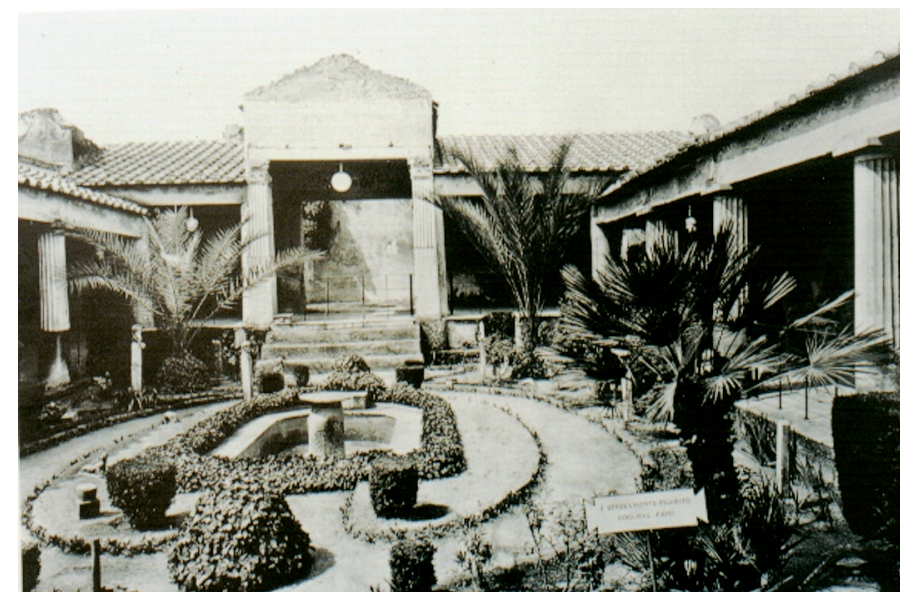

Casa de los Amorini Dorati a principios del siglo XX

Una de las casas más célebres y visitable con facilidad es la del Lorio Tiburtinus o de Octavius Quartius más recientemente. Provista de un largo canal, se han reconstruido las pérgolas con parras y la plantación de frutales (almendros, membrillos, perales, cerezos y olivos). Solamente se han sustituido los cipreses por los plátanos debido al peligro que supondría para las ruinas el crecimiento de estos últimos. En el jardín de inferior tamaño más cercano a la casa se ha recurrido al arrayán para los setos y al granado y al boj recortado como vegetación para el interior del parterre. Tal vez sea una de las recuperaciones más cuidadas realizadas en la antigua ciudad destruida por el Vesubio. 


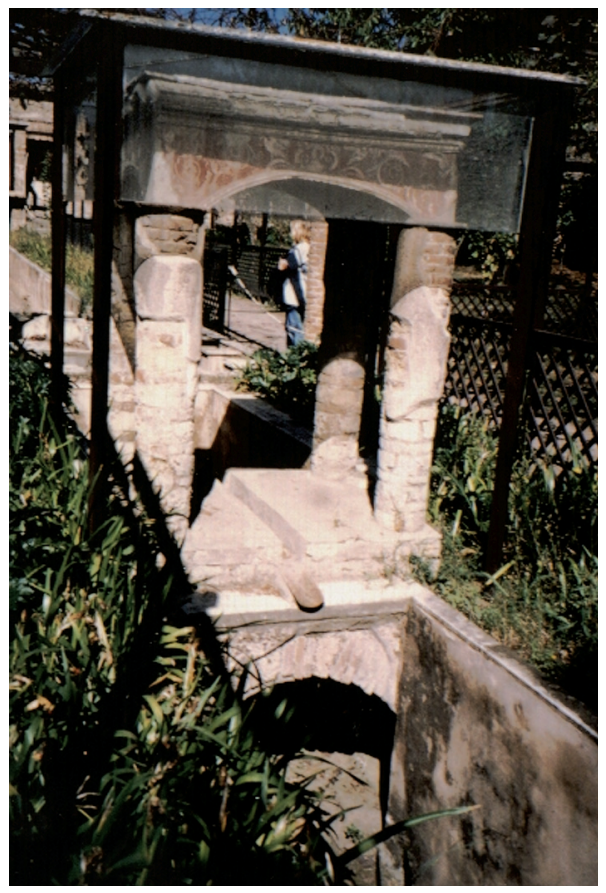

Canal de la casa de Lorio Tiburtinus en Pompeya. La vegetación junto al canal está formada exclusivamente por ejemplares de Iris foetida y acantos. (Foto del autor)

Otra de las casas cuyo patio ha sido reconstruido con la vegetación de época romana es la de los Vettii. Aunque faltan las macetas y jarrones que cita G. Mason (24) como características de este tipo de patios, al menos la vegetación corresponde al momento histórico de la edificación: setos de laurel de Alejandría (Ruscus hypoglossum), romero, hiedra y septiembres (Aster sp.) entre otras.

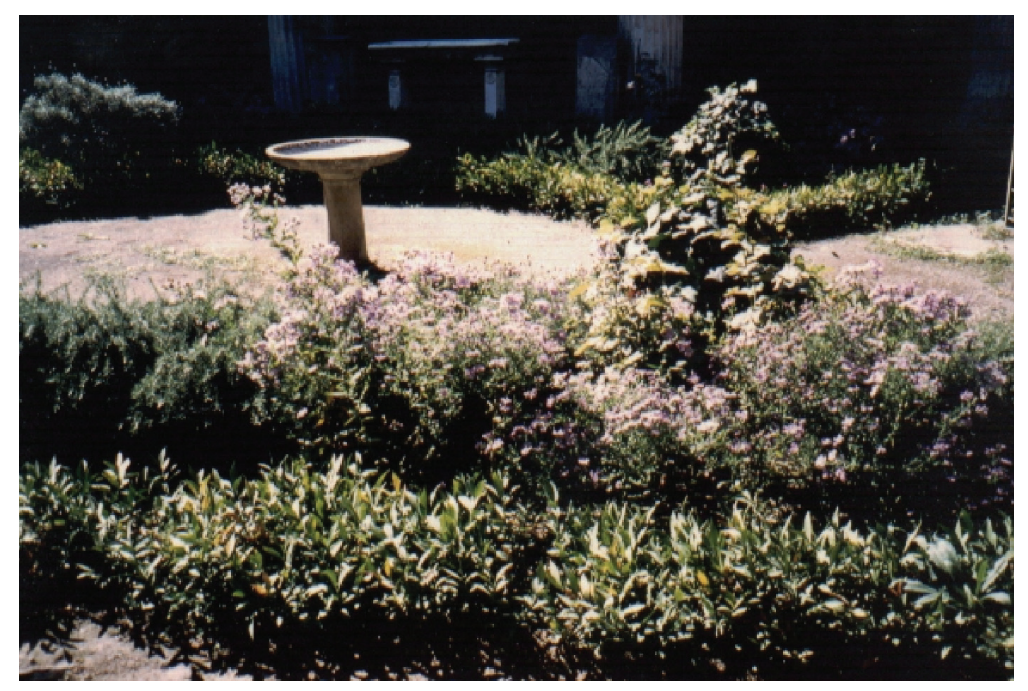

Jardín de la casa de los Vettii en Pompeya. (Foto del autor) 
En su conjunto podemos decir que las reconstrucciones llevadas a cabo en Pompeya han sido irregulares. Tras el impulso que significó el trabajo de W. Jhashenski por los años setenta del pasado siglo con la construcción de pequeños huertos y viñedos (zona SE de la ciudad) dedicados a plantas para perfumes como los lirios y las violetas, viveros de frutales, ajardinamientos de zonas públicas como los plátanos de la Gran Palestra y la reutilización de las antiguas huertas de hortalizas para proteger la flora vesubiana, también se contempla una tendencia a utilizar una jardinería de batalla cuya base son el césped, los arbustos recortados y hasta algún atrevimiento como las piteras. En fin, es sorprendente que el monumento más visitado de toda Italia (y con la entrada más cara) muestre esa jardinería de relleno sin que podamos conocer y apreciar la riquísima variedad vegetal que tenían estos jardines tal como muestran los frescos y los testimonios escritos. (Ver Anexo Documental n ${ }^{\circ} 6$ donde están recogidas las plantas de la obra de P. Grimal.)

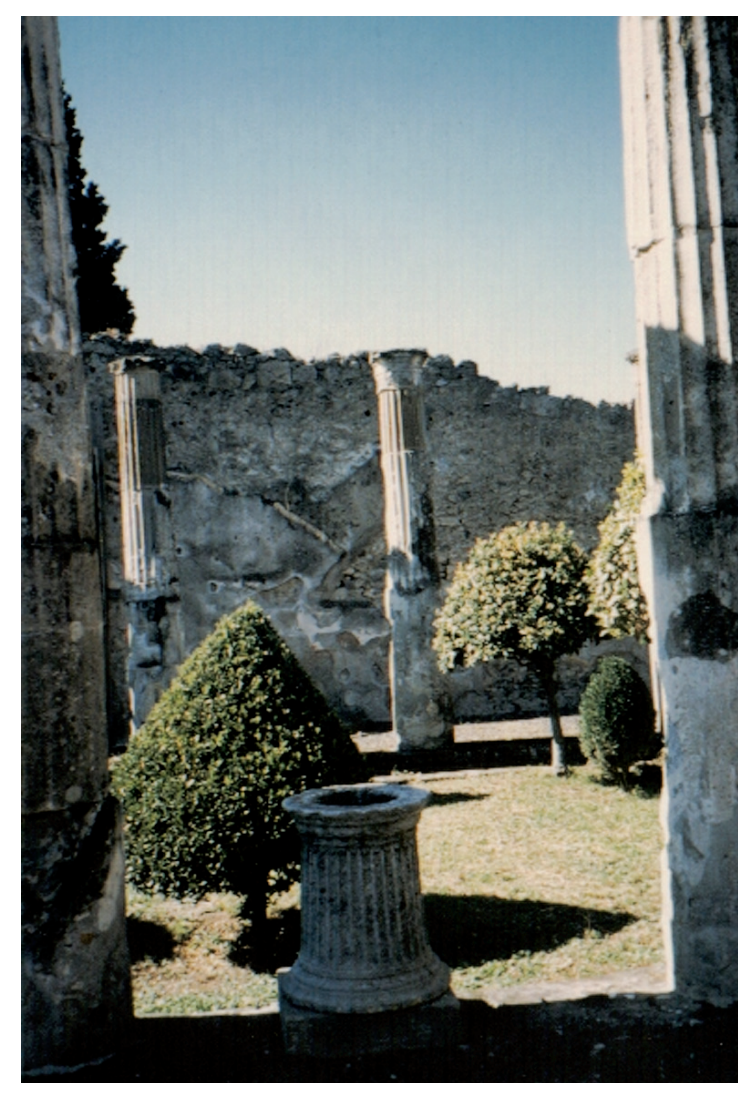

Ajardinamientos nuevos en las ruinas de Pompeya. (Foto del autor)

Gracias igualmente a las excavaciones podemos conocer la riqueza de las formas de los patios de la arquitectura islámica, aparentemente similares pero con una gran variabilidad sobre el mismo tema (25). 
Uno de los primeros ejemplos de patio en cruz es el que el arqueólogo Herzfeld encontró en Samarra por el 1911, breve capital del califa Mutasim (836-892), el cual abandonó Bagdad debido a que su trazado circular dificultaba su crecimiento. La nueva capital recuperó los trazados rectilíneos que tan bien se amoldaban al cubismo arquitectónico tradicional del paleomediterráneo.

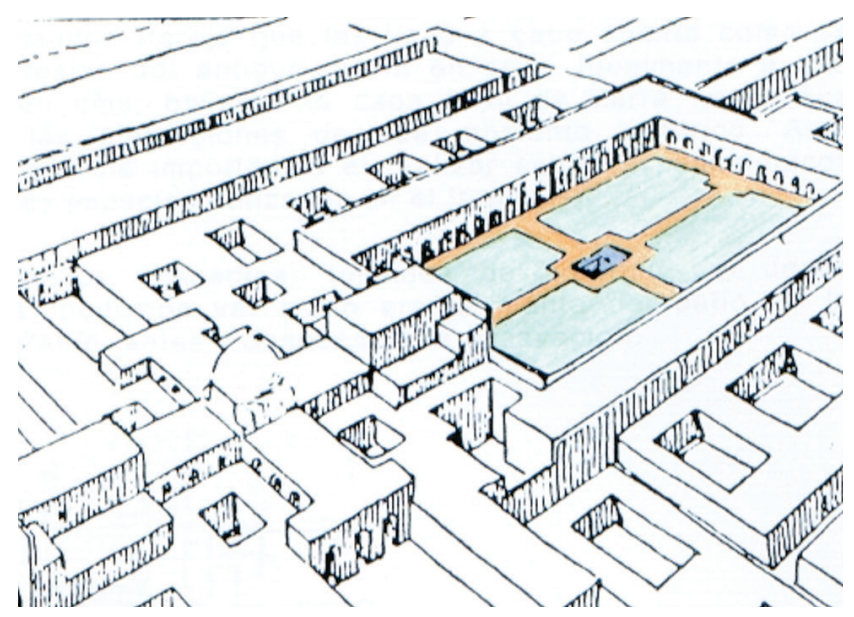

Reconstrucción del arqueólogo Herzfeld de la ciudad de Samarra

De la misma manera que a Herzfeld, debemos a Leopoldo Torres Balbás el conocimiento de la planta del jardín almohade más antiguo de la península. Nos referimos al del Castillejo de Monteagudo (26) en Murcia, excavado por los años 1930-34. Como resultado de esas excavaciones se publicó el trazado de la planta, precedente de los que volveremos a encontrar en Granada en el patio de los leones o en Fez en la mezquita Karaouin siglos más tarde. Tras la Guerra Civil el lugar fue sometido a importantes transformaciones para explotarlo agrícolamente. Toda la ladera se plantó de cítricos. El recinto del patio se acondicionó para balsa de riego con lo que desaparecieron todos los restos en los que nuestro arquitecto se basó para levantar su planta. Hoy resultaría imposible acometer tal trabajo debido a la importancia de la transformación acaecida en el lugar. Gracias por tanto a aquellas excavaciones conocemos este antiguo trazado.

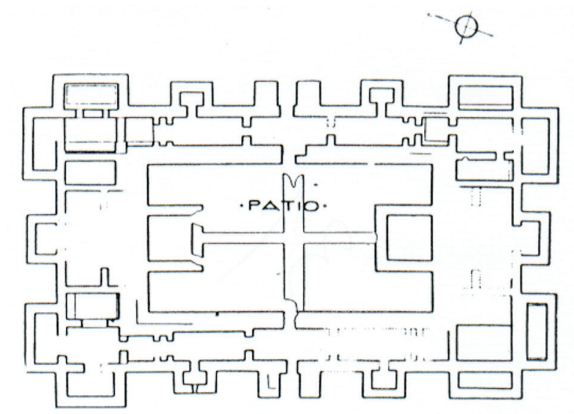

Planta de las ruinas del Castillejo de Monteagudo (Murcia) según Torres Balbás tras realizar las excavaciones por los años 1920-23

(26) NAVARRO PALAZÓN, Julio y JIMENEZ CASTILLO, Pedro. "El Castillejo de Monteagudo: Qasr ibn Sad" artículo de la obra Casas y Palacios de al-Andalus. Siglos XII y XIII de AAVV. Ed. Lunwerg. Barcelona, 1995. 
Los resultados de las excavaciones llevadas a cabo por Jesús Bermúdez Pareja en el Generalife tras el incendio de 1958 son otro ejemplo de la utilidad de esta disciplina (27).

Jesús Bermúdez cuenta como se encontraron los restos del antiguo jardín en cruz, en lo que se conoce como Patio de la Acequia.

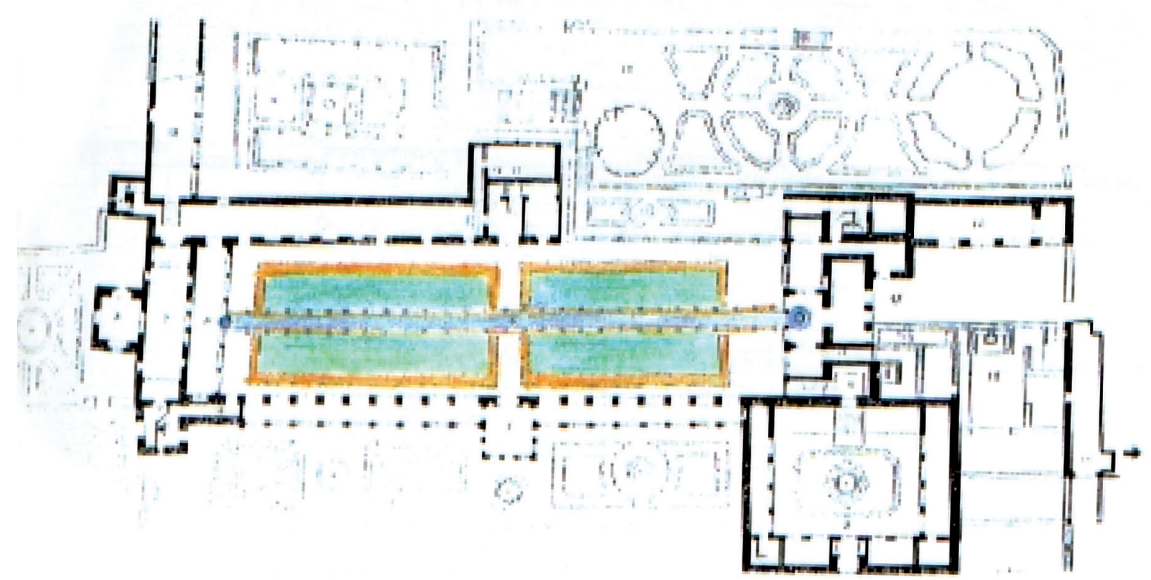

Planta del Patio de la Acequia antes de la excavación. Plano de J. Bermúdez

Igualmente se encontraron los restos de la tierra negra vegetal del antiguo jardín a una profundidad de $80 \mathrm{~cm}$. como es corriente en los jardines de este tipo. Desgraciadamente no se realizó ningún tipo de estudio palinológico (28).

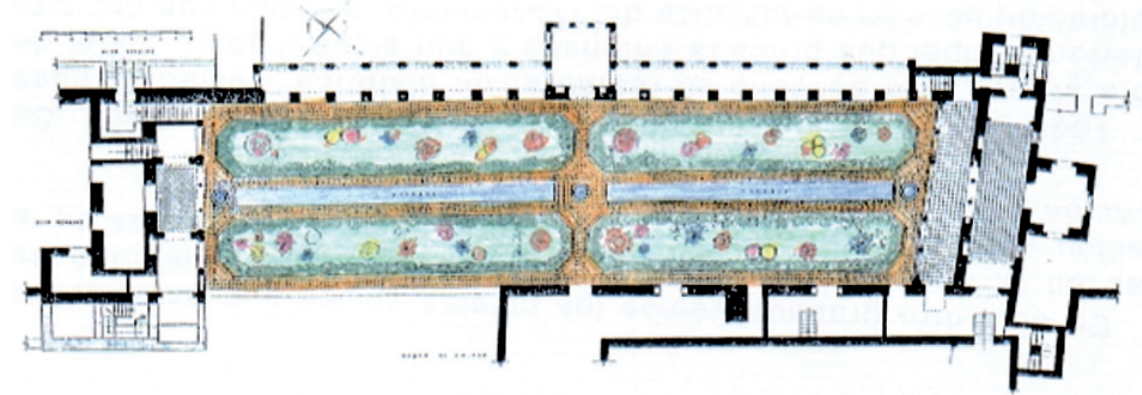

Planta en cruz del Patio de la Acequia del Generalife según la excavación. Plano de J. Bermúdez

(27) BERMUDEZ PAREJA, Jesús. "El Generalife después del incendio de 1958" Revista Al-Andalus. Tomo XXIII, año 1958.

(28) MENENDEZ, AMOR, J. " Aplicaciones de modernas técnicas de la ciencia paleobotánica a la restauración de los antiguos jardines mediante la recogida de muestras de tierra". Actas del Congreso del ICOMOS de 1973 en Granada. 
En el grabado inferior vemos el perfil del jardín con las capas de escombro y rellenos realizadas en época cristiana.

Lo asombroso de todo esto es que la información obtenida fue desechada por los responsables del monumento en ese momento. El jardín fue vuelto a rellenar y no se respetó su antiguo nivel de época andalusí. Primó el criterio de mantener una imagen consolidada o tal vez el de anteponer su explotación económico-turística a la de recuperar el trazado original cuando lo uno no está en ningún momento reñido con lo otro.

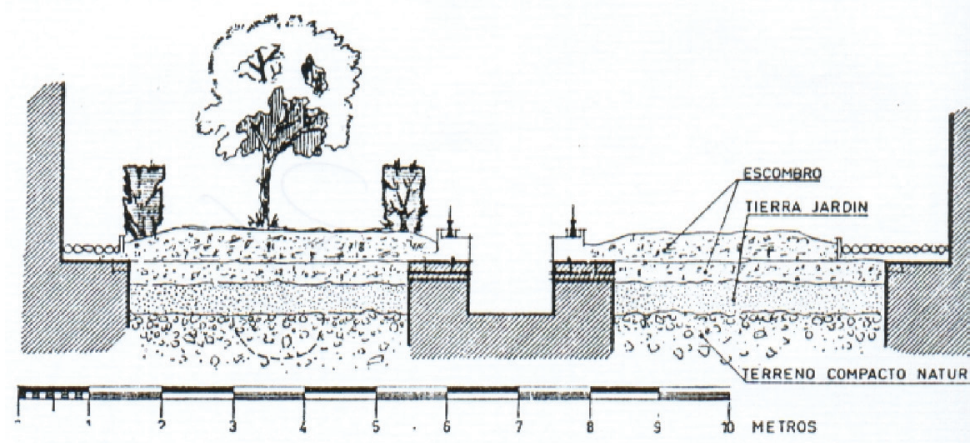

Perfil de las excavaciones del Patio de la Acequia en el Generalife

También existen casos en los que las excavaciones arqueológicas, la utilización de las fuentes literarias y otra actitud de respeto hacia la historia del monumento han originado reconstrucciones aceptables como es el caso del Patio de la Contratación en los Reales Alcazares de Sevilla (29) el cual vimos más detalladamente en uno de los capítulos anteriores de este trabajo.

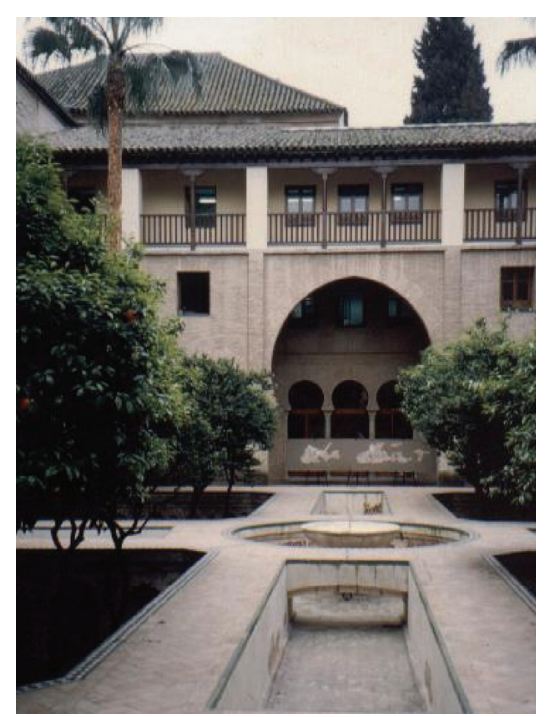

Jardín de la Casa de Contratación en los Reales Alcázares. (Foto del autor)

(29) MANZANO MARTOS, Rafael. «Casas y palacios en la Sevilla almohade. Sus antecedentes hispánicos» en Casas y Palacios de al-Andalus. Edición a cargo de Julio Navarro Palazón. Editorial Lunwerg. Granada, 1995. Para otra bibliografía sobre este jardín acudir al capítulo anterior donde analizamos la recreación realizada en este lugar. 


\section{E. 5. La iconología}

Desde sus orígenes la jardinería ha sido un arte unido a la simbología en todas las culturas. Por ejemplo en el Mediterráneo cristiano el jardín es el símbolo del paraíso perdido mientras que para el mundo musulmán es el de la anticipación del paraíso prometido en este mundo.

Toda la jardinería del Renacimiento, del Manierismo y el Barroco así como la del Paisajismo europeo del XIX y XIX son incomprensibles sin entender los mensajes en clave iconográfica que desarrollan jardines tan diversos en tiempo y espacio como Pratolino, Vila de Este, Bomarzo, Versalles, La Granja o Stowe.

Toda la jardinería occidental desde los patios medievales al minimal de ayer mismo es una sucesión de significados diferentes utilizando a menudo las mismas formas. Tal vez sean el laberinto y el patio en cruz los ejemplos más claros. Y cuando estas formas acaban repitiéndose sin poseer ningún contenido ideológico y simbólico, podemos afirmar que es la prueba cierta de que ese momento cultural ha entrado en decadencia.

En la Edad Media, la Iglesia que es la fuerza social y cultural dominante, impone sus programas ideológicos obligando al artista a adoptar todo un universo de símbolos. Sin embargo, esto no quita para que a veces los artistas utilicen el lenguaje más convencional para expresar otros mensajes. Es aquí donde iconografía e iconología desarrollan sus campos analíticos para facilitar la comprensión de la obra y su significado cultural completo.

Así podemos ver que las plantas utilizadas en el patio en cruz del mundo cristiano tienen una relación directa con el simbolismo religioso de la época: el iris siempre aparece asociado a la Virgen ya que era el símbolo de la estirpe real de David a la que ésta pertenecía; las azucenas simbolizan la pureza, las rosas rojas el amor divino y la Pasión, las fresas recuerdan a la Trinidad por la forma de sus hojas, la viña recuerda a Noé y la nueva alianza a través del sacrificio de la sangre -vino- de Jesucristo. El manzano va unido a la tentación de Eva junto con la higuera que se asocia igualmente a la caída y expulsión del Paraíso (30).

También podemos observar que desaparece el uso de numerosas plantas que estaban consagradas a los dioses paganos como por ejemplo el laurel, planta dedicada a Apolo de la que se pensaba en el mundo clásico que estaba protegida contra la caída de los rayos, motivo por el que se plantaba cerca de las casas. Y la disminución en la utilización del mirto, planta dedicada a Afrodita y cuyo uso, sin embargo, recogerá el mundo islámico.

(30) PAEZ DE LA CADENA, Francisco. Historia de los estilos en Jardinería. Ediciones Istmo. Madrid, 1982. A partir esa fecha han sido abundantes las publicaciones que han tratado este tema de la simbología de las plantas, especialmente en los últimos años como recogemos en la bibliografía general. 
Cuando venga el Renacimiento, los temas paganos volverán a ser tomados para expresar las preocupaciones del momento y las fantasías. Algunas de las grandes villas de esta época desarrollan complejísimos programas iconográficos para intentar demostrar cosas tan imposibles como la descendencia de su propietario del mismo Hércules. Estamos hablando del cardenal Hipólito d'Este y de su famosa villa de Tívoli (31).

En otros casos, la complejidad del mensaje es tal que resulta difícil su compresión para los no iniciados en el mundo de la mitología, la alquimia, la literatura y la filosofía hermética anteriores a la Contrarreforma. Bomarzo constituye el ejemplo más claro de lo anterior (32). La estatuaria del jardín se realiza sobre grandes piedras existentes en el lugar que es un robledal. Este está atravesado por un arroyo cuyo agua es utilizada para formar un gran complejo hidráulico hoy completamente perdido. Cuando sus actuales propietarios realizaron los trabajos de "restauración" con la finalidad de ponerlo en los circuitos turísticos de Italia, los estanques y fuentes no se recuperaron y sin embargo se atrevieron a limpiar el sotobosque de los robles y a talar algunos de ellos, olvidando que son árboles consagrados a Júpiter cuyo fruto es el mismísimo glande del dios y a plantar en los espacios vacíos resultantes ciruelos rojos (Prunus pisardii), planta de extenso uso en la jardinería europea actual, pero que es una muestra palpable de cómo se puede conseguir desvirtuar la estructura de uno de los grandes jardines de Europa que vivía felizmente su abandono.

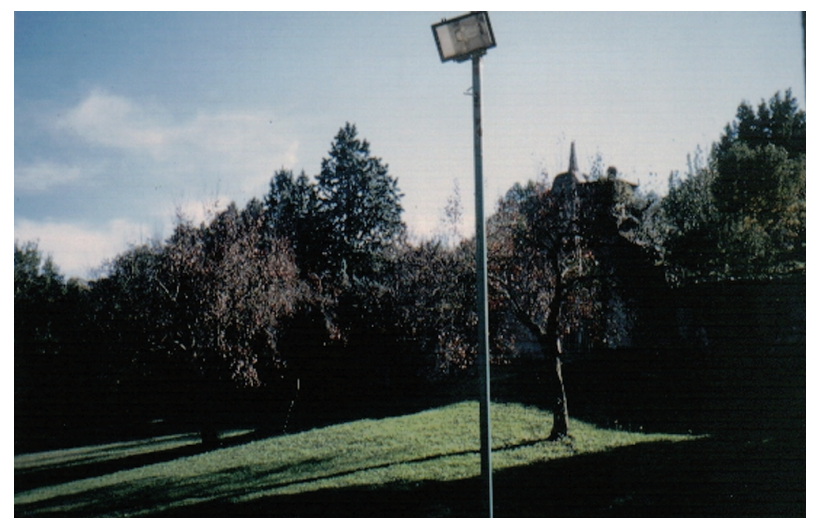

Aunque no lo parezca, esta imagen pertenece al Jardín de Bomarzo en 1999. (Foto del autor)

Este discurso iconográfico-iconológico seguirá in crescendo a lo largo del período barroco llegando a ser Versalles su ejemplo más claro. Luis XIV, el Rey Sol, elige a Apolo como motivo de sus jardines y se dedica a exaltarlo -a la vez que se exalta el mismo- hasta unos límites tan excesivos que son la confirmación de que te has convertido irremediablemente en carne de psicoanalista. 
Igualmente su nieto Felipe V, cuando realice La Granja, utilizará el ya agotado discurso mitológico para hacer una demostración del poder conseguido por su victoria sobre sus enemigos, quedando todo ello plasmado en la estatuaria del jardín.

Y no deja de ser aún más sorprendente que cuando triunfe la revolución paisajista inglesa y los jardines se llenen de templos clásicos, ruinas góticas y estanques alimentados por tranquilos arroyos, la simbología siga teniendo la misma importancia como en los jardines de los siglos anteriores y el jardín se convierta en una obra de arte -en Inglaterra la que más- que sólo muestra sus significados a los entendidos siendo a veces el mismo jardín el escenario marco para aquellas ceremonias de iniciación a sociedades secretas que tanto gustaban a nuestros antepasados ilustrados (33).

Uno de los jardines más emblemáticos de este movimiento, el de Stowe, hecho construir por Lord Cobham (1699-1749) contiene todo un programa político en desacuerdo con las acciones de los reyes Jorge I y Jorge II. Por este jardín pasaron Charles Bridgeman, William Kent y Capability Brown. Ellos fueron los encargados de edificar templos griegos, construcciones medievales, recrear Campos Elíseos y transformar un sencillo arroyo en nada menos que la Laguna Estigia, abandonándose deliberadamente los Hércules, Apolos, Venus y Dianas para ser

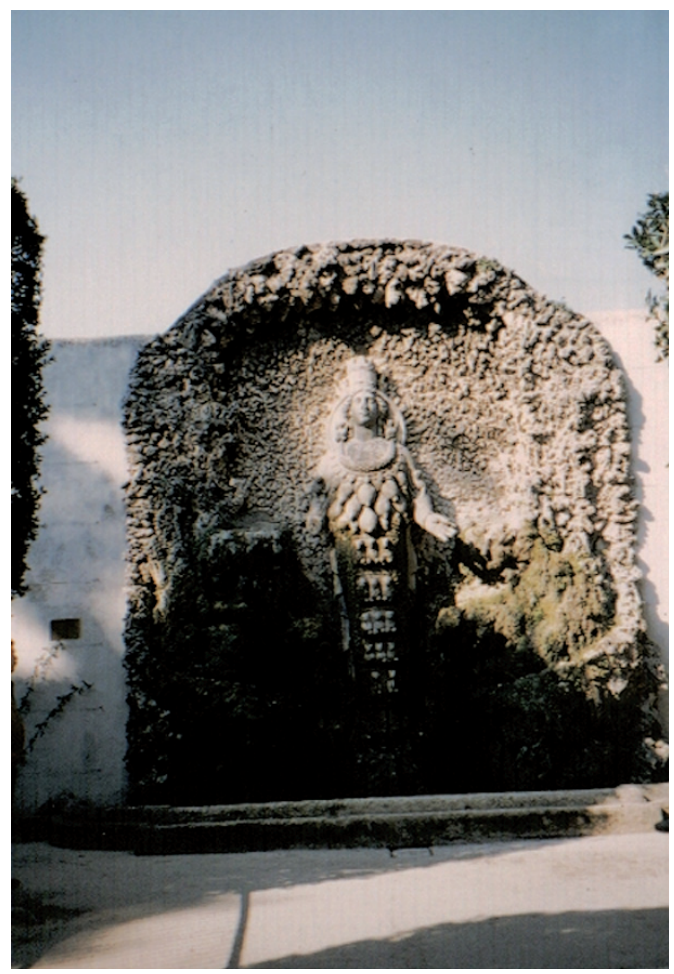

La Diana de Villa d'Este, en un tiempo centro del jardín y hoy desplazada a un rincón marginal del mismo. (Foto del autor) 
sustituidos por los grandes personajes de la Inglaterra de aquel momento como fueron Isabel I, Isaac Newton, William Shakespeare, John Milton, Francis Bacon y John Locke cuyas estatuas adornaron aquellos jardines aparentemente "naturales" en una voluntad deliberada de hacer resaltar los grandes valores de aquellos políticos, científicos, artistas y filósofos tan diferentes de los existentes en ese momento de decadencia.

Este tema de la iconografía y la iconología de los jardines es de tal complejidad que aquí sólo podemos esbozarlo pues desborda los límites de este proyecto de investigación. El sólo merecería otra tesis. Nos basta para finalizar volver a insistir en la importancia que tiene para la restauración contar con estas disciplinas tanto en lo que respecta a la estructura (estatuaria, vegetación, elementos ornamentales, etc.) como al aspecto (recuperación y mantenimiento de los trazados originales). 


\section{E.6. Fuentes literarias diversas}

Hemos visto en las páginas anteriores las ciencias y técnicas que ayudaban a recuperar la forma del jardín (aspecto) y su contenido (estructura). Para completar aún más ese armazón son necesarios los datos de otras manifestaciones culturales, artísticas y científicas del ser humano.

Por un lado, tenemos las referencias literarias sean poemas, cuentos, relatos históricos o biográficos, que nos ofrecen preciosa información sobre los elementos vegetales que llenaban aquellos espacios y que nos han llegado hoy desnudos o transformados. Igualmente conocemos por esas narraciones su utilización como lugar de encuentro social o bien de estricta y sagrada intimidad.

Por otro lado se conservan tratados de botánica y agricultura del mundo clásico y medieval, y que según avanzamos hacia la Edad Moderna se hacen más abundantes, separándose la jardinería como actividad independiente de los tratados de agronomía y agricultura a partir del siglo XVI.

Un breve repaso a estas fuentes de tanta utilidad para la restauración del jardín es lo que vamos a ver a continuación. 


\section{E.6.1. Narrativa, poesía, libros de viajes, biografías, etc.}

No deja de ser sorprendente que para el diseño del Jardín de las Tres Culturas en Madrid (34), la jardinera Myriam Silber Brodsky tomara como fuente documental y de inspiración la descripción del huerto de granados del profeta Zacarías.

Este es un ejemplo más de como una fuente literaria puede servir de tema para la creación de un jardín.

Otro ejemplo es el de la reconstrucción de los jardines romanos (Coimbra, Pompeya). Para ello, han sido fundamentales los Tratados de Agricultura que luego veremos, el análisis de los restos arqueológicos (que ya vimos en el capítulo anterior) y las referencias literarias que nos han llegado.

Las más famosas de todas son las Cartas de Plinio el Joven. En ellas describe sus villas con los jardines existentes junto con la utilización de las diversas plantas según sus fines: sombra, perfume, estructura ornamental, religiosa, etc. (35)

Del mundo islámico - heredero de la antigüedad clásica- conservamos numerosos tratados agrícolas que contienen referencias a plantas ornamentales como veremos a continuación cuando se desarrolle ese capítulo pero aquí trataremos de los poemas que nos han llegado. En ellos la referencia al mundo vegetal es una constante, ya sea como metáfora o como descripción pura o abstracta del mismo.

Esta relación con las plantas va adquiriendo tal desarrollo que originará un género propio conocido como nawriyyat o poesía floral. Tal género alcanzará su apogeo en el período de los taifas con la figura de Ben Jafacha y su escuela a comienzos del siglo XII (36). Aquí, como ejemplo, citaremos los poemas de Ar-Rusafi de Valencia (37):

\section{Un pino en el jardín}

Muestra el jardín la herrumbre de la fuente cuyas aguas compiten con la brisa; y junto a la corriente alza su tronco un pino que penetra en sus entrañas.

Parecen, él y sus raices, por donde el agua se derrama en ondas, una sierpe enroscada con sus crías.

(34) AA V. Parque Juan Carlos I. Jardín de las Tres Culturas. 1994. Fundación Caja-Madrid. Edición a cargo de Carmen Añón.

(35) MASSON, Giorgina. Italian Gardens. Ed. Thames and Hudson.Londres. 1966

(36) GARCíA GÓMEZ, Emilio. 1944. Cinco poetas musulmanes. Colección Austral.

(37) AR-RUSAFI de Valencia. Poemas. 1980. Traducción de Teresa Garulo. Ed.Hiperión. 


\title{
El viento en el río
}

\author{
Vuelve a llenar las copas, aunque agucen \\ sus oídos las hojas de los mirtos; \\ sólo son nubes risueñas \\ que juegan con la antorcha del relámpago \\ y el tropel de los vientos en el río \\ como caballos galopando \\ sobre una cota de mallas.
}

\author{
El néctar de su boca \\ El néctar de su boca \\ se escancia en copas de perlas. \\ El Can ladra envidioso y, deslumbrado, \\ acusa al sol cuando amanece: \\ con la saliva aún brillan más las perlas \\ y su fulgor aumenta las tinieblas. \\ El que no entiende ignora que su rostro \\ es un jardín con arrayanes y amapolas; \\ con estas flores, se diría, lo apedreo \\ y me sonríe apartando las mejillas.
}

Dando un salto temporal y geográfico y situándonos en Italia, allí podemos encontrar una amplia gama de descripciones literarias de jardines. La más famosa de todas es el Sueño de Polifilo (38) cuyos grabados sirvieron de inspiración a numerosos jardineros de la Europa del manierismo y del barroco. Igualmente en la literatura de esos siglos abundan las referencias a jardines y fue una italiana, Antonella Pietrogrande (39) quien ha reconstruido esos espacios imaginarios a partir de las descripciones de los poetas de su patria.

Igualmente reconstruyó el jardín que Giovanni Boccaccio (1313-1375) describe en la introducción de la tercera jornada del Decamerón (1335) y que vamos a citar aquí como uno de los mejores ejemplos pues podemos sentir que el escritor se estaba refiriendo a alguno de los jardines que conociera en su vida. Luego reproduciremos la reconstrucción del mismo realizada por la estudiosa italiana:

Desearon descansar a la sombra de un pórtico que dominaba el patio y cuyas columnas estaban cubiertas de flores y de arbustos, pero apenas se habían sentado, cuando apareció el mayordomo trayéndoles confituras deliciosas y exquisitos vinos. Luego pasaron a un jardín situado detrás del palatraducción y edición en castellano a cargo de Pilar Pedraza, publicada por El Acantilado en Barcelona en 1999.

(39) PIETROGRANDE, Antonella."El jardín imaginado", capítulo dentro de la obra Paisaje mediterráneo. Edición a cargo de Electa. Sevilla. Exposición Universal 1992. 
cio, totalmente rodeado por un alto muro, y pareciéndoles en su conjunto de extraordinaria belleza, quisieron examinarlo detenidamente. El jardín estaba rodeado y cruzado de espaciosos senderos, rectos como saetas, y cubiertos de emparrados que daban señales inequívocas de que aquel año darían uvas en abundancia; y como a la sazón estaban todos en flor, difundían un olor tan vivo, que, mezclado al aroma de millares de flores, parecíales hallarse entre cuantos perfumes ha habido jamas en Oriente. Los senderos estaban flanqueados por rosales blancos y encarnados y jazmines, por lo cual, no ya en las primeras horas de la mañana, sino también cuando más alto estaba el sol, se podía pasear bajo una aromática y fresca sombra sin experimentar el más leve contacto de sus rayos.

Largo sería explicar cuales y cuantas plantas había en aquel jardín y el orden con que estaban colocadas; baste decir que ninguna de las más bellas que puedan soportar nuestro clima no se encontraran alli en abundancia.

En el centro del jardín, cosa no menos hermosa, había un prado de hierba menudísima, de un color verde muy oscuro, matizado todo él de mil clases de flores, y encerrado en un círculo de cedros y naranjos, los cuales, unos ostentando frutos y otros flores, no sólo daban agradable sombra, sino que halagaban el olfato con su aroma.

En el centro de este prado surgía una fuente de mármol blanquísimo, con bellas figuras maravillosamente talladas, y, del interior de una de ellas, no sé si a causa de una veta natural o artificial, oíase de continuo el murmullo de un manantial poderoso que, saliendo primero de dentro de una columnita central, arrojaba en gran cantidad y elevación el agua hacia el cielo, para caer con agradable susurro en aquella clarísima fuente donde había agua más que suficiente para mover un molino.

El agua sobrante salía del prado por un canal oculto, y después se repartía por pequeños caños, artificiosamente hechos siendo recogida por un arroyo que la llevaba hacia el llano, dando en su camino movimiento y vida a dos molinos, con no poca utilidad para su afortunado dueño.

La vista de este jardín con su hermoso orden, las pérgolas y senderos, la fuente con los arroyuelos que de ella procedían, tanto agradó a las siete damas y a los tres jóvenes que expresaron entusiasmados su asombro, diciendo que si en la tierra pudiera formarse un Paraíso, no cabría dársele mejor forma ni orden de los que alli se veían". 


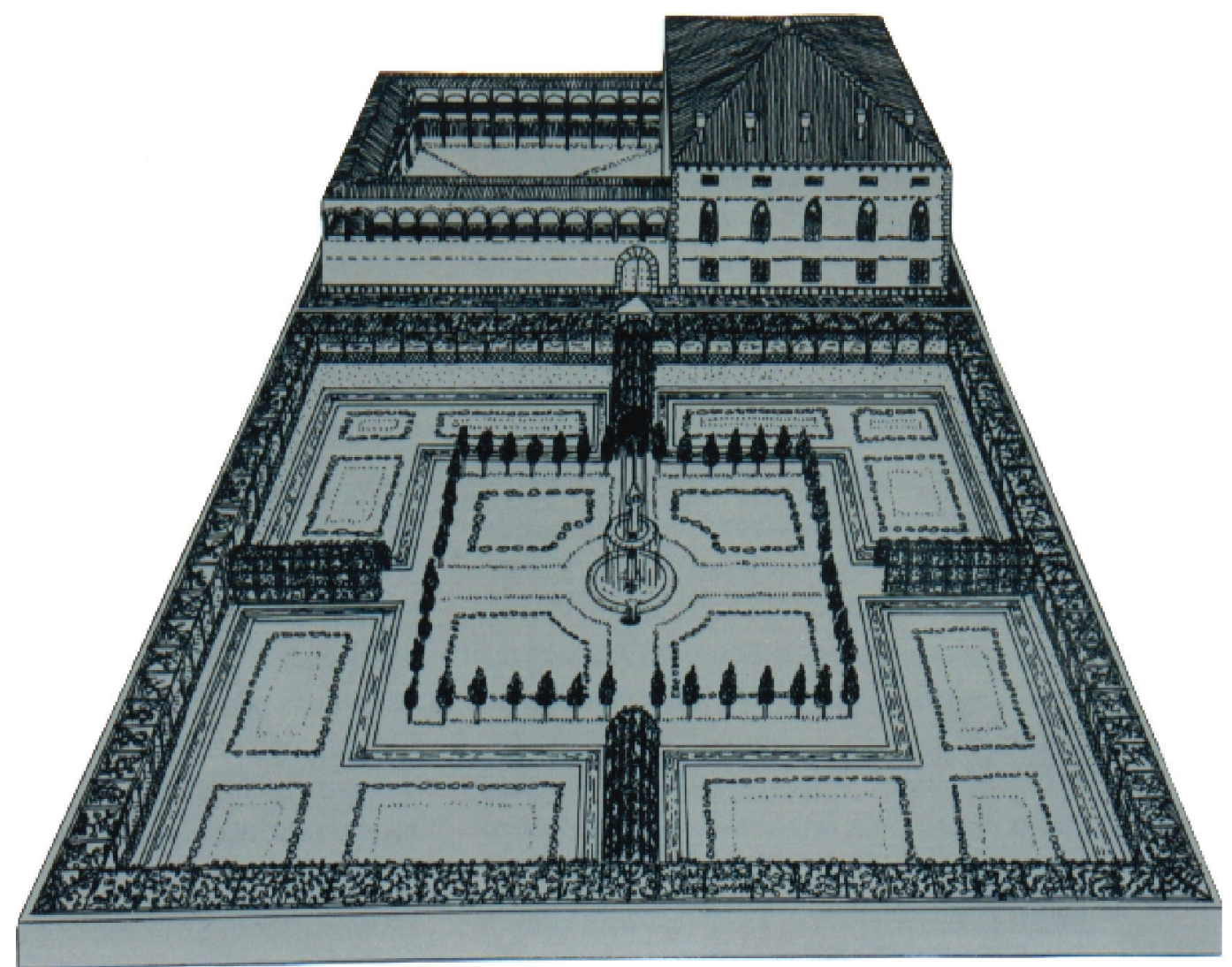

Reconstrucción del jardín de la tercera jornada del Decamerón por A. Pietrogrande 


\section{E.62. Tratados de Agronomía, Agricultura, Botánica y Jardinería}

La Botánica, como ciencia del estudio de las plantas, tiene su desarrollo en las primeras civilizaciones agrícolas urbanas del Creciente Fértil. Desde el principio se centró en el estudio de conocer las propiedades curativas y alimenticias de los vegetales y así no es casualidad que la primera lista de plantas existentes -el papiro de Ebers- sea de utilidad médica.

Igualmente medicinales son los listados de plantas que nos han llegado del mundo clásico (Teofrasto y Dioscórides) siendo bastante escasas las referencias a plantas ornamentales por parte de los autores griegos. Más conocimientos tenemos del mundo romano donde la jardinería se desarrolló de una manera más extensa que en Grecia. De todas formas, cualquier referencia pertenece al mundo de lo utilitario lo cual no es excluyente ya que en el ciclo cultural del paleomediterráneo clásico y sus sucesores medieval cristiano y musulmán, la vegetación de los jardines es una mezcla de ornamentales, productivas (frutales) y simbólicas.

No será hasta la Edad Moderna que podamos de disponer de obras dedicadas exclusivamente a las plantas ornamentales como veremos a continuación. Nosotros, por razones metodológicas dividiremos este capítulo en tres apartados. En el primero trataremos a los autores del mundo clásico grecolatino. En el segundo veremos los trabajos de los herederos de ese mundo clásico en sus versiones cristiana y musulmana. Y por fin, el último punto lo dedicaremos a repasar algunos de los grandes tratados de jardinería que empiezan a aparecer desde el siglo XVI a nuestros días cada vez con más abundancia y especialización.

\section{El mundo clásico: Grecia y Roma.}

Los griegos no destacaron por la construcción de jardines. Ellos, indoeuropeos, tenían un concepto sagrado de algunos lugares de su entorno natural. En estos sitios se edificaron templetes, se erigieron estatuas y fueron considerados lugares de las divinidades. Igualmente en lugares públicos se practicó la plantación de plátanos sobre todo y no fue hasta que entraron en contacto con la superior civilización persa que empezaron a plantarse recintos en imitación de los parques aqueménidas.

Sin embargo, ese espíritu curioso común entre las potencias marítimas les llevo a la investigación del mundo circundante por lo que son de autores griegos los primeros tratados de plantas que conocemos: Teofrasto y Dioscórides. La obra de este último constituye uno de los logros de la historia de la botánica y es significativo que haya sido actualizada tanto en el Renacimiento en Italia por Mattioli como en España por Laguna en el siglo XVI y por el gran botánico Pío Font i Quer en el XX.

Debido a la importancia que alcanzó en Roma la explotación agrícola de la tierra, conservamos varios tratados sobre este tema. Tenemos de M. Porcio Catón, el Censor, uno titulado De re rustica, escrito un siglo antes de C. En el no se nom- 
bra para nada la jardinería. Un siglo más tarde, a comienzos de nuestra era, aparece la obra de Columela titulada de igual manera que la anterior. En ella lo predominante es el cultivo de las plantas con fines utilitarios y solamente en el capítulo 30 que denomina "De arboribus" hace mención de la rosa y la violeta sin especificar uso o finalidad concreta (40).

Conocemos el cambio de mentalidad que hubo en Roma tras la conquista del Oriente en el siglo primero de nuestra era por la obra de Terencio Barrón también titulada De re rustica. En ella hay referencias a las villas construidas por los grandes personajes del momento en las que los jardines ocupaban un lugar importante. Debemos de suponer que serían del tipo de las encontradas en Pompeya que reflejan claramente la influencia de las nuevas tierras incorporadas al imperio y cuyos constructores tenían otra mentalidad distinta a la de los primeros patricios de la República tan bien retratados por Catón.

La obra más importante sobre el tema que nos ocupa que conservamos del mundo romano es la de Plinio el Viejo. Nos referimos a su Historia Natural (41). Este autor pertenece al siglo primero después de Cristo ya que falleció en la erupción del Vesubio que arrasó Pompeya y Herculano. Aunque su trabajo es mayormente una recopilación de otros autores tiene la ventaja de servir de antología por citar numerosas plantas aunque siguen siendo la mayoría traídas a colación por sus usos medicinales o alimenticios. Las ornamentales como tal aparecen poco y van unidas a la confección de guirnaldas y coronas para loa ofrendas de las ceremonias civiles o religiosas.

De más utilidad son para nuestros fines las informaciones que nos ofrecen otras fuentes vistas en anteriores páginas que las que nos pueden ofrecer estos tratados.

\section{La Edad Media: el mundo cristiano.}

Tras la caída del imperio romano, las referencias más antiguas que tenemos sobre la utilización de plantas corresponde a la relación que San Isidoro de Sevilla inserta en sus Etimologías (42). Tal obra es un reflejo de aquella sociedad heredera de la tradición tardo romana con un mismo parecido marco político y cultural. Por lo tanto la jardinería no es nombrada en las Etimologías. Para San Isidoro, el mundo vegetal se reduce a una relación de plantas útiles por su valor alimenticio, aromático o industrial. No existe ninguna prueba de que existieran estímulos para crear belleza y placer a los sentidos una vez cubiertas las necesidades básicas.

(40) COLUMELA, Lucio Junio Moderato. De los trabajos del campo. Edición de A. Holgado. Ministerio de Agricultura, Pesca y Alimentación. Ed. Siglo XXI de España Editores. Madrid, 1988.

(41) PLINIO SEGUND0, Cayo. Historia natural. Facsímil de la traducción de Francisco Hernández y Jerónimo de Huerta. Editada por VISOR Libros. Universidad Nacional de Mexico en la serie Biblioteca Filológica Hispana $n^{\circ} 38$.

(42) SAN ISIDORO DE SEVILLA. Etimologías. Edición bilingüe de José Oroz Reta y Manuel-A. Marcos Casquero. Biblioteca de Autores Cristianos. Madrid, 1993. 
En el Apéndice Documental $n^{\circ} 6$ se inserta un listado de las plantas citadas por San Isidoro que comprende árboles, arbustos, hortalizas y aromáticas, plantas que suponemos que estarían presentes en los escasos jardines de aquella turbulenta época.

Conocemos otras relaciones de plantas pertenecientes a ese período que cita Francisco Páez de la Cadena en su obra (43). Así, Carlomagno (768-814) en su Capitulare de villis hace una relación de plantas que debían ser cultivadas en sus dominios, unas por su interés alimenticio y otras medicinal. Entre éstas cita la rosa. También de estos tiempos se conserva el plano de la abadía suiza de San Gall en el que además de la división de la superficie en distintas zonas según sus usos, aparece un listado de plantas entre las que vuelven a predominar las medicinales.

Este autor nombra otros trabajos de este período como son el Liber de cultura hortorum del monje Walafrid Strabo (809-849); el de San Alberto Magno De vegetabilibus, fechable hacia el 1260 aproximadamente y el importante Opus ruralium commodorum (hacia el 1300) de Petrius Crescentius (44). A esta misma línea de investigación pero más actualizado y centrado sobre todo en Francia pertenece la obra de Marie-Françoise Valéry (45) donde ahonda en las fuentes documentales históricas, artísticas y literarias del jardín medieval y ofrece una relación de jardines franceses (y algunos de otros países de Europa) reconstruidos recientemente siguiendo la inspiración de ese momento histórico.

Así sabemos que en Tusson se reconstruyó hace unos años el jardín de una abadía medieval desmantelada en los tiempos de la Revolución según los planos de San Gall. En Melle se reconstruyeron otros jardines inspirándose en las plantas mencionadas en las Capitulaciones de Carlomagno y así hasta alcanzar la cifra de una treintena de ejemplos.

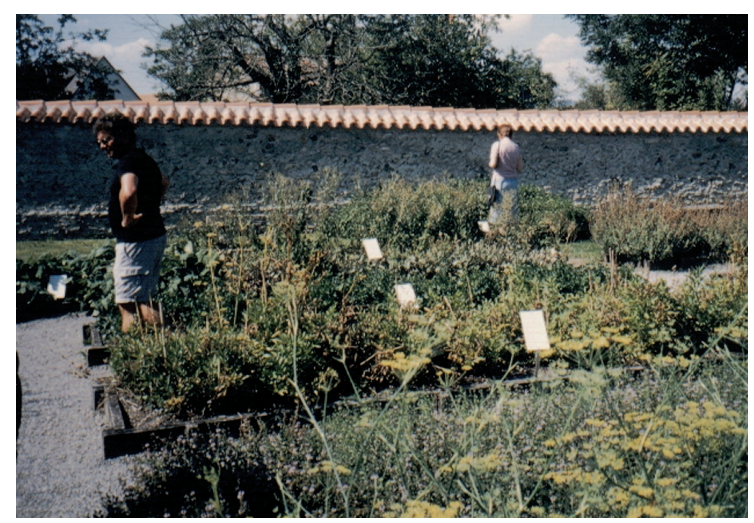

Reconstrucción de un jardín monacal en la isla de Reichenau (Lago de Costanza) según las plantas citadas por Petrus Crescentius. (Foto del autor)

(43) PAEZ DE LA CADENA, Francisco. Obra citada.

(44) La importancia de la obra de Petrus Crescentius es señalada igualmente por Filippo Pizzoni en The Garden. A History in Landscape and Art. Ed. Aurum Press. Londres, 1999.

(45) VALERY, Marie-Françoise. Jardins du Moyen Age. Ed. La Renaissance du Livre. París, 2001. 


\section{El mundo medieval islámico}

La herencia de los mundos clásico y persa es recogida por el Islam y aquí veremos que los estudios de agricultura, botánica y jardinería son más abundantes por varias razones. Una es producto de la revolución agrícola musulmana que instaura la libertad del individuo que trabaja la tierra en régimen de minifundio, con un cultivo intensivo de la misma y con la ampliación del sistema de regadíos constituyendo ambas la base de su sistema social y político. Otra causa es la especial sensibilidad mostrada por unas gentes venidas de zonas de climas áridos ante la vegetación tanto la natural como la cultivada. Y la última tiene que ver con el concepto del Paraíso prometido cuya anticipación en este mundo la constituye un jardín cargado de simbolismo y que encuentra su forma arquitectónica en el patio en cruz de la Persia sasánida, heredera de toda la tradición aquémenida, y en un componente vegetal que se basaba en hacer una selección de la vegetación de su entorno más inmediato acrecentada por las novedades que el comercio y los viajes iban aportando a esas sociedades.

De los numerosos trabajos existentes en el mundo islámico sobre temas agronómicos, nosotros nos limitaremos al estudio de los más representativos de la zona del Islam conocida como al-Andalus. El primero de nuestros autores es Ibn Al-Awwan conocido como Abu Zacaria cuya obra Libro de Agricultura (46) traducida a principios del siglo XIX aún conserva interés.

Abu Zacaria cita en su obra más de cuatrocientas especies y todavía no habían llegado las plantas americanas que hoy constituyen el $40 \%$ de las especies de la producción agrícola de nuestros campos. Igualmente dedica alguno de los capítulos de su obra (el IV, el XXVII y el XXVIII) a las plantas de jardín detallando su cultivo, siembra, cuidados así como la mejor manera de distribuirlas en el espacio. Plantas de uso hoy común son tratadas tales como el alhelí, la azucena, los nenúfares, las peonías, narcisos, violetas, malvas, rosales, etc. y otras que han caído en desuso como la amapola cornuda o la dragontea

El segundo de nuestros autores es el almeriense Ibn Luyn (47) en cuya obra encontramos abundantes referencias a las plantas ornamentales aparte de las de uso estrictamente utilitario. El tercero lo constituye un tratado anónimo, el conocido como Kitab fi Tartib (48) traducido y estudiado por Angel C. López y López.

Y de gran utilidad para nuestros fines son los dos trabajos de Esteban Hernández Bermejo, director del Jardín Botánico de Córdoba, que amablemente nos faci-

(46) BN AL-AWWAN o ABU ZACARIA. Libro de Agricultura Traducción de J. A. Banqueri de 1802. Facsímil editado por el Ministerio de Agricultura en 1988 en Clásicos Agrarios con notas de J. Esteban Hernández Bermejo y un estudio preliminar de Expiración García Sánchez. Existe otra edición de 1878, no bilingüe como la anterior, pero que está prologada por Esteban Boutelou y "arreglada" la traducción de José Banqueri por Claudio Boutelou.

(47) IBN LUYN. Tratado de Agricultura. Traducido por Joaquina EGUARAS IBAÑEZ. Patronato de la Alhambra. Granada, 1975.

(48) LOPEZ Y LOPEZ, ANGEL C. Un tratado agrícola andalusí anónimo (Kitab fi tartib awqat al-girasa wa-l-magrusat). CSIC. Escuela de Estudios Arabes. Granada, 1990. 
litó en nuestra visita a ese lugar. Uno de ellos es (49) una relación exhaustiva de plantas a introducir y a eliminar de los jardines de Madinat al-Zahra basándose en estudios botánicos, históricos y literarios del momento. El otro trabajo se centra en los problemas de la restauración de los jardines de al-Andalus y trata de los estudios botánicos previos que sentarán los criterios bajo las que debe llevarse a cabo tales acometidos (50). Por haber sido el origen de la limpieza de la vegetación alóctona en el recinto arqueológico de Medina Zahara al haber apoyado esta acción los responsables culturales y políticos del monumento tras conocer estos informes, los añadiremos al Apéndice Documental anexo a esta tesis por su interés.

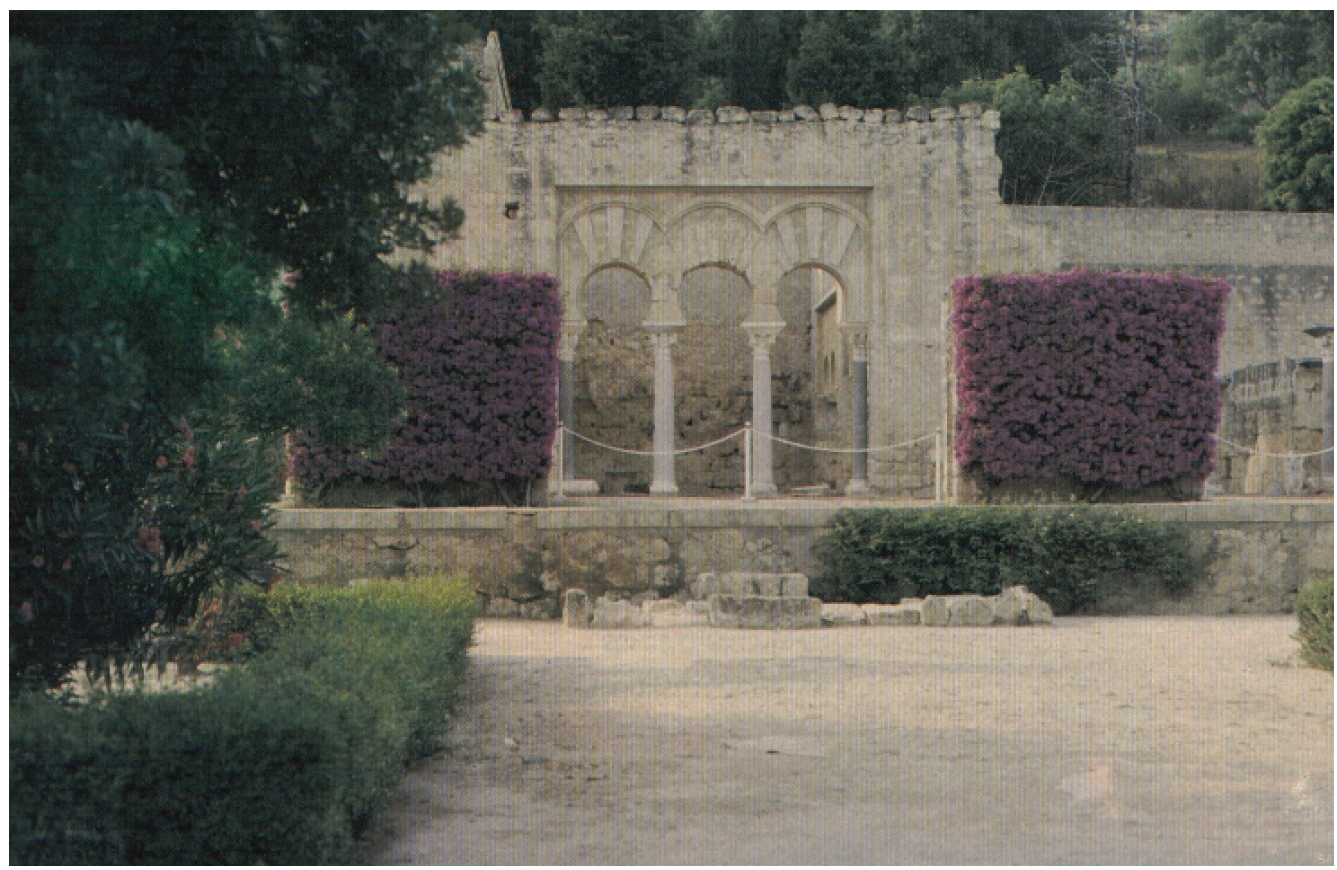

Medina Zahara con la vegetación eliminada (buganvillas) tras el establecimiento de unos criterios respetuosos con la historia del monumento. (Foto de Arte y Cemento)

(49) HERNANDEZ BERMEJO, J. ESTEBAN. "Aproximación al estudio de las especies botánicas originariamente existentes en los jardines de Madinat al-Zahra" artículo de los Cuadernos de Madinat al.Zahra, nº 1.

(50) HERNANDEZ BERMEJ0, J. Esteban. "Botanical foundations for the restoration of Spanish-Arabic gardens: study of the plants species used and their introduction during the Andalusi period" comunicación al simposium sobre jardines de la Fundación Clusius titulado The Authentic Garden. Edición a cargo de L. Tjon Sie Fat y de E. de Jong. 


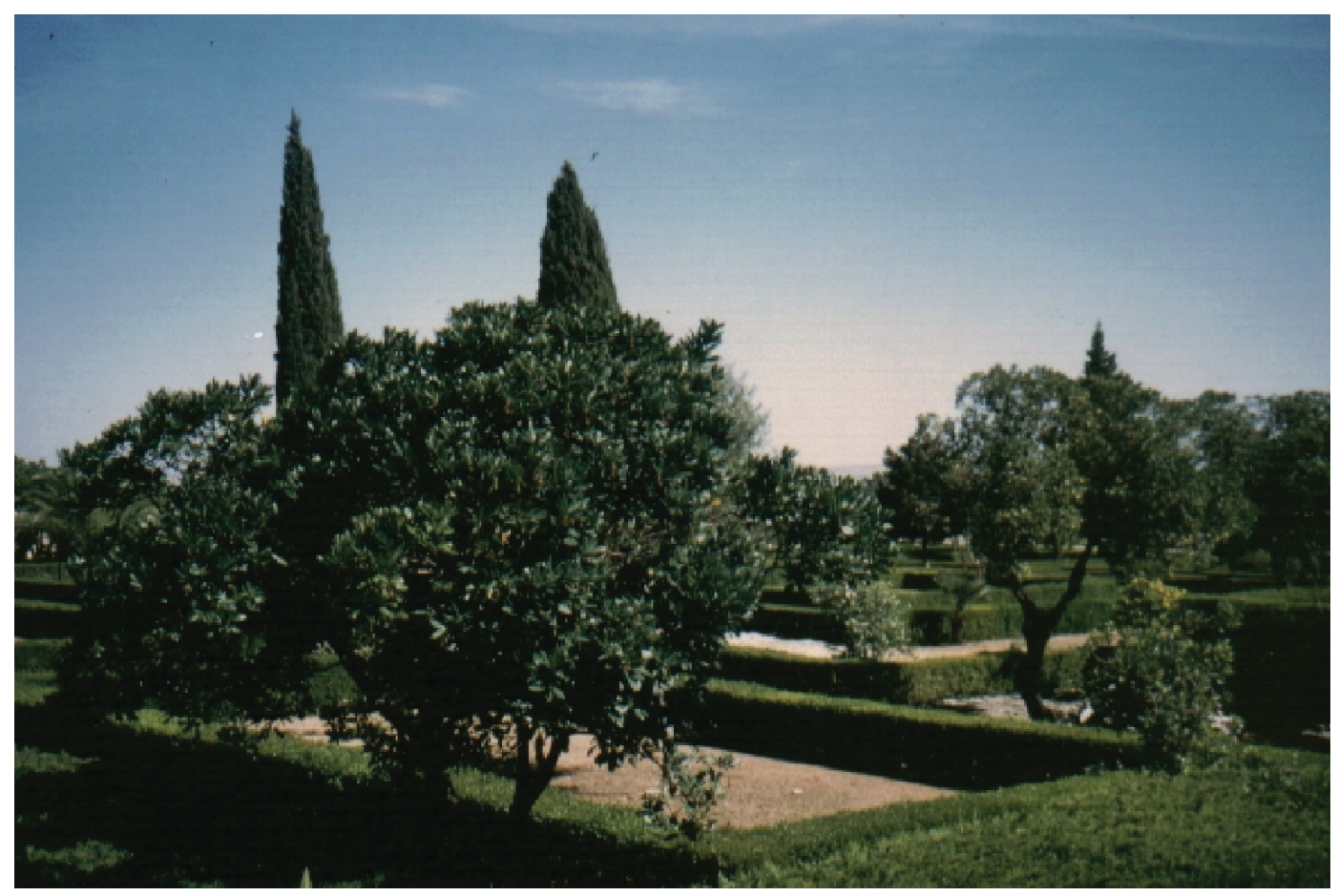

Medina Zahara. Ajardinamiento actual. (Foto del autor)

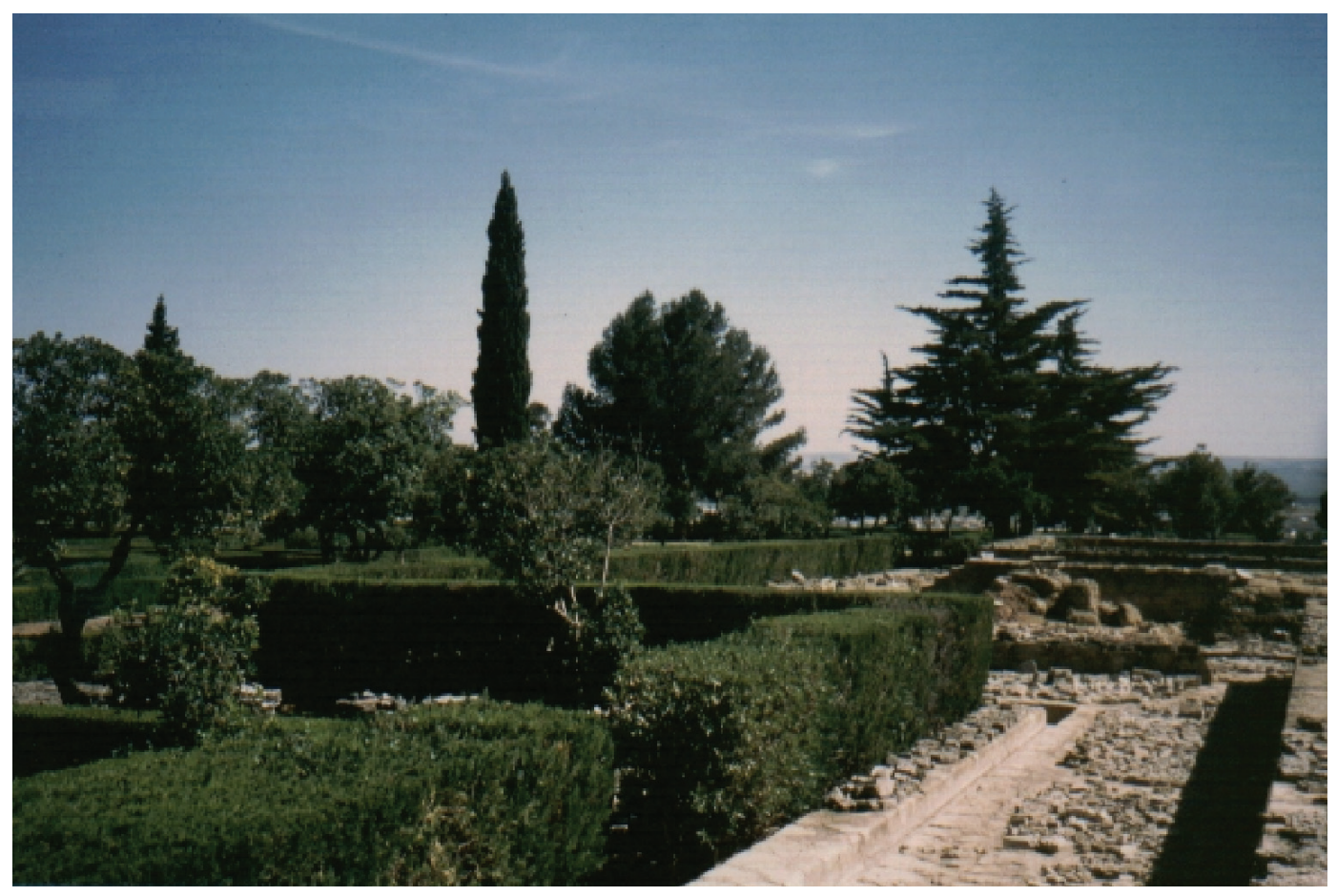

La jardinería del recinto de Medina Zahara en la actualidad, a pesar de contar con el inconveniente de la falta de agua, ha suprimido las especies que no corresponden a aquel momento histórico, ha recuperado un probable diseño y ha introducido las plantas utilizadas en los jardines de al-Andalus. Todo un ejemplo a seguir. (Foto del autor) 


\section{Las Edades Moderna y Contemporánea.}

El resurgimiento de la Botánica como ciencia en el siglo XVI se va a plasmar en tres aspectos. El primero será la actualización del tratado clásico de Dioscórides por los botánicos de la época: Mattioli en Italia (1548) y Andrés Laguna en España (1555).

El segundo aspecto es el del estudio de la flora local y nacional (Clusius) y el tercero es la catalogación de las nuevas especies como consecuencia de los descubrimientos geográficos a partir del siglo XVI.

La llegada de la flora americana a la Península ha sido estudiada ampliamente por los miembros del Instituto de Estudios Documentales e Históricos sobre la Ciencia de la Facultad de Farmacia de Valencia (51).

La expansión de las potencias europeas sobre los nuevos territorios y la consiguiente constitución de las colonias irá produciendo el estudio de las especies exóticas, estudios fomentados desde la metrópolis con fines fundamentalmente económicos. De esta corriente de curiosidad científica surgirá la creación de los primeros jardines botánicos de aclimatación y desde ellos se producirá la difusión de las nuevas especies.

El desarrollo de este tema que por sí mismo produciría varias tesis, lo mencionamos brevemente y citaremos algunas obras significativas de los estudios científicos de la flora no europea en la bibliografía como puntos de referencia temporales de la aparición en Europa de numerosas plantas de uso común hoy en día en la jardinería actual por lo que significan para nuestro trabajo tales referencias.

Por lo que respecta a obras de jardinería en España tenemos la suerte de disponer de una de las primeras obras sobre este tema en Europa. Nos referimos a la "Agricultura de jardines" (1592) de Gregorio de los Ríos (52).

Gregorio de los Ríos fue nombrado por Felipe II capellán de la Casa de Campo y jardinero del mismo sitio. Y pocos datos biográficos se saben más de su vida. El valor de su obra reside en que describe casi doscientas plantas de utilización jardinera a pesar del título del libro pues él indica que su selección se basa en plantas de olor y color gratas a los sentidos descartando las productivas que deja para los huertos o las medicinales que deia a los botánicos.

(51) PARDO TOMAS, José y LOPEZ TERRADA, María Luz. Las primeras noticias sobre plantas americanas en las relaciones de viajes y crónicas de Indias (1493-1553). Instituto de Estudios Documentales e Históricos sobre la Ciencia. 1993. Valencia. LOPEZ PIÑERO, José María y PARDO TOMAS, José. Nuevos materiales y noticias sobre la historia de las plantas de Nueva España de Francisco Hernández. Instituto de Estudios Documentales e Históricos sobre la Ciencia. Valencia, 1994. LOPEZ PIÑERO, José María y PARDO TOMAS, José. La influencia de Francisco Hernández (1515-1587) en la constitución de la Botánica y la Materia Médica Modernas. Instituto de Estudios Documentales e Históricos sobre la Ciencia. Valencia, 1996.

(52) DE LOS RIOS, Gregorio. Agricultura de jardines, que trata de la manera que se han de criar, governar, y conservar las plantas, $y$ todas las demas cosas que para ello se requieren. Edición facsímil a cargo de Joaquín Fernández Pérez e Ignacio González Tascón. Real Jardín Botánico de Madrid CSIC y Area de Medio Ambiente del Ayuntamiento de Madrid. Madrid, 1991. 
Los nombres utilizados son los comunes del momento. El trabajo de identificación y correspondencia con los nombres actuales que figura en la edición facsímil de la obra de Gregorio de los Ríos fue realizado por Juan Armada e Inmaculada Porras para el Simposium Internacional de Leiden con motivo de la restauración del jardín botánico de Clusius, contemporáneo del jardinero de Felipe II. Dicha identificación está basada en la comparación entre la edición de Gregorio de los Ríos, el Dioscórides de Andrés Laguna (1555) y el de Font i Quer (1961) además de la revisión de las descripciones e índices de Quer, Palau, Boutelou y Colmeiro. Ambos estudiosos señalan que "a partir de este punto en que la parte principal del trabajo estaba ya encauzada, se revisó la nomenclatura moderna por Flora Europea (53) y Hortus Third (54), comprobando igualmente las descripciones. Otras plantas hubo que buscarlas en variados libros, pues el texto de Gregorio de los Ríos era muy poco concreto o no se ajustaba con claridad a las descripciones que se encontraban.

La relación de plantas que se incluye, un año más tarde, corresponde a la edición de 1620. En ella se indican los nombres de plantas y los sinónimos, conforme el orden que figura en el libro y numeradas en la columna "NUM:", repitiendo el mismo número para las plantas que agrupa el autor, se relacionan sin numeración las plantas citadas fuera del orden alfabético del texto, figuran a continuación el nombre científico, el autor o autores, familia a la que pertenece, origen de la plantas y un nombre vernáculo".

Como se puede apreciar el trabajo es exhaustivo. Por su importancia, está incluido en el Apéndice Documental número 6.

Otro de los grandes libros de la jardinería europea es el aparecido en la Francia barroca en 1709 y que sirvió de inspiración a numerosos jardines de ese siglo. Nos referimos a la obra de Antoine Joseph Dezallier d'Argenville La Théorie et la Practique du Jardinage.

Volviendo a España, a principios del siglo XIX aparece otra de las joyas de tratados de jardinería. Nos referimos al "Tratado de las flores" de Claudio y Esteban Boutelou. (55) La obra tiene la ventaja de reflejar las principales plantas ornamentales cultivadas en los mejores jardines de España ya que uno era jardinero mayor del Jardín Botánico de Madrid y el otro de los jardines de Aranjuez

En esta obra se recogen casi 200 especies con numerosas variedades de algunas de ellas. Aunque su nombre de referencia es el común, todas ya tiene la catalogación lineana. Y otra particularidad a señalar es que muchas de ellas todavía siguen cultivándose en la jardinería tradicional. Destaca igualmente la incorporación al tratado de numerosas plantas de origen americano, en la actualidad completamente integradas en el jardín español.

(53) TUTIN, T. G. Et al.: Flora Europea. Cambridge University Press, Cambridge, 1964-1972.

(54) BAILEY, L. H. Y BAILEY, E. Z.: Hortus Third. Macmillan Publishing Company, Nueva York, 1976.

(55) BOUTELOU, Claudio y BOUTELOU, Esteban. Tratado de las flores. Facsímil de las librerías París-Valencia del original de 1804. Valencia, 1993. 
A veces la información sobre los componentes de la estructura del jardín nos puede venir por vías que no son las convencionales como es una obra botánica sino por encargos principescos.

Uno de estos casos es el libro titulado "Hortus Eystettensis" o Libro de las plantas de Basilius Besler aparecido en 1613 (56).

El origen de esta publicación es la siguiente. En el siglo XIV se funda el casti1lo-fortaleza de Willibaldburg que era la residencia del obispo y príncipe elector de Eichstätt. El castillo se va ampliando a lo largo de los siglos. A finales del siglo XVI, los alrededores del castillo son transformados en jardines en el marco de una escenografía paisajista que abarcaba los campos de cultivo circundantes, el pueblo y los bosques más lejanos. A principios del XVII, el obispo Joseph Konrad von Gemmingen encarga la elaboración de una recopilación florística - un florilogiuma Basilius Besler. El trabajo fue lento y el resultado fue una obra muy costosa pero de calidad extraordinaria y que nos permite hacernos una idea de las plantas presentes en el jardín del palacio así como de algunas plantas silvestres de los alrededores de la residencia.

Estos jardines se perdieron completamente en la Guerra de los Treinta Años. A finales del pasado siglo, se decidió la reconstrucción de parte de ellos basándose en el libro citado. Tal reconstrucción que no conocemos directamente, la citamos siguiendo los datos de la obra referida de la editorial Taschen.

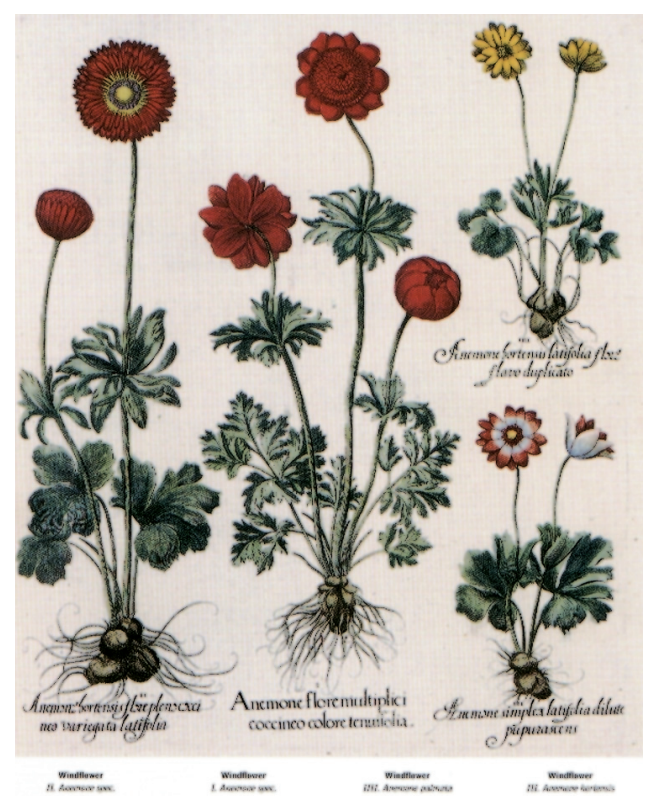

Reproducción de las variedades de anémonas en el Hortus Eystettensis

(56) BESLER, Basilius. The Garden at Eichstätt. Edición facsímil de la obra a cargo de la editorial Taschen. La introducción histórica es de Klaus Walter LITTGER; el estudio botánico es de Werner DRESSENDÖRFER y las notas sobre la recreación del jardín actual corren a cargo de Bernd RINGHOLZ. Colonia, 2000. 
Y acabaremos este capítulo con otro libro también de la editorial Taschen. Se trata del Jardín del Edén de Walter Lack (57) es cual es una antología de los libros de Botánica que contienen ilustraciones que como decíamos al principio según nos acercamos a nuestros días son cada vez más numerosos y los dibujos son sustituidos por las fotografías aunque hay que señalar que en los grandes trabajos de botánica el papel del dibujo sigue siendo fundamental como muestran los volúmenes publicados de la todavía inacabada Flora Ibérica o esa maravilla que es El Dioscórides renovado de D. Pío Font i Quer.

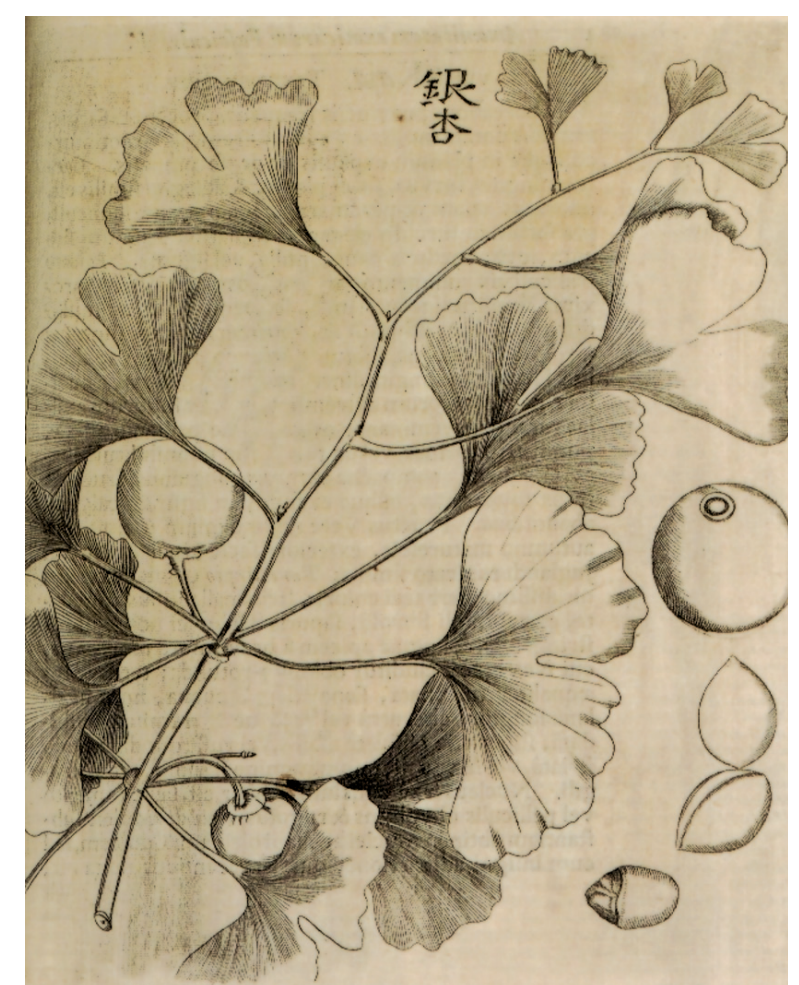

Grabado del árbol de los cuarenta escudos (Ginkgo biloba) realizado por el doctor Engelbert Kaempfer durante su viaje a Japón (1691-1692) gracias al cual el árbol se conoció en Europa por primera vez. Imagen del libro de H. Walter Lack 


\section{F. CONCLUSIONES}


Nuestro trabajo comenzó haciendo una breve exposición de las diversas corrientes existentes entre los distintos profesionales del mundo de la restauración los siglos pasados exponiendo la imposibilidad de establecer criterios comunes y como tal divergencia de opiniones llega hasta hoy mismo.

El siglo XIX conocerá la coexistencia, - unas veces pacífica y otras de enfrentamiento virulento- entre las dos corrientes representada una por los seguidores de la restauración en estilo de Violet-le Duc y la otra por los que aceptaron las teorías conservadoras personalizadas en la obra de Ruskin.

La jardinería durante ese período sigue las posturas de la restauración en estilo en las principales intervenciones como consecuencia del contexto político y social de ese momento caracterizado por la restauración de las monarquías y el conservadurismo de las repúblicas. Estas actitudes están representadas fundamentalmente por las obras de los Duchâne (Achiles, el padre y Henry, el hijo) que se dedicarán a reconstruir los grandes jardines de la Francia del antiguo régimen, arrasados la mayoría de ellos por la Revolución, extendiéndose los trabajos de Henry hasta la mitad del siglo $\mathrm{XX}$.

Este siglo va a ver en sus comienzos el cuestionamiento de la corriente violetiana que se plasmará en la Carta de Atenas (1931).

Esta Carta producirá en España la consolidación de las actitudes conservadoras representadas por la figura de Leopoldo Torres Balbás y en lo que respecta a la jardinería tendrá como consecuencia la catalogación del patrimonio verde histórico a cargo de Javier de Winthuysen quien realizará además la primera restauración conocida y documentada de ese siglo. Nos referimos a los jardines del palacete de La Moncloa destruidos durante la Guerra Civil.

Tras esta contienda, la dictadura producirá el renacimiento de las posturas restauradoras en todos los monumentos intervenidos y en lo que respecta a los jardines las actividades de restauración son casi inexistentes con la excepción de las obras realizadas por Winthuysen en Madrid (Alameda de Osuna) y Valencia (Jardín de Monforte) hasta los años 80 del pasado siglo según podemos comprobar en los datos del Archivo General de la Administración.

En Europa, la II Guerra Mundial produce igualmente una crisis de la practica restauradora ya que se rehacen casi todos los monumentos repitiendo los modelos destruidos. En jardinería, este dominio de los criterios de la reconstrucción histórica conduce a que numerosos jardines se rehagan según su diseño original, suprimiéndose las aportaciones de los períodos posteriores Estos excesos producirán nuevas reflexiones sobre la actividad restauradora que conducirán a la promulgación de la Carta de Venecia en 1964.

Pero esta Carta no va a producir la desaparición de aquella antigua dualidad que escindió la práxis restauradora durante los siglos XIX y XX. Las dos posturas, corrientes o escuelas o como se prefiera llamar, siguieron coexistiendo paralela- 
mente hasta hoy mismo. Destacan en este período las aportaciones teóricas de Cesare Brandi.

1981 es un año crucial en lo que compete a la restauración de los jardines. El grupo franco-belga del ICOMOS-IFLA encabezado por René Pechêre consigue que se apruebe la Carta de Florencia en esa misma ciudad constituyendo el triunfo más espectacular de Violet-le-Duc post mortem ya que supone la aceptación de las anquilosadas teorías del restauro estilístico más de un siglo después. Ello implica que vuelve a predominar como criterio la "reconstrucción del jardín tal como debió de haber sido" al igual que había ocurrido en la restauración de las obras arquitectónicas.

Frente a estos criterios y al peligro que significaban para la conservación del patrimonio verde histórico existente, surgió en la misma reunión de Florencia, otro punto de vista, incluido hoy en lo que se denomina conservación integral que abogó por conservar todo lo que había llegado hasta nosotros a través de los siglos por su valor histórico y documental. Su portavoz fue Isa Belli Barsalli. El grupo italiano consiguió que la Carta fuera modificada en el ámbito de Italia eliminándose de la misma la mención al repristino de los jardines en su versión italiana mientras que en los otros idiomas se mantenía la propuesta.

Sin embargo, los hechos van a demostrar el gran peso de los seguidores de la Carta de Florencia en las recientes restauraciones tanto en Italia (Convento de Santa Clara), en Inglaterra (Hampton Court) como en España (Jardín del Rey en Aranjuez; Claustro del Monasterio de Guadalupe; El Retiro de Madrid y el Jardín Botánico de Valencia).

De todas formas, en nuestro país, la herencia de la tradición conservadora de Torres Balbás y Winthuysen hace que también se acometan restauraciones alejadas de los repristinos decimonónicos (Casitas de Arriba y Abajo de El Escorial, Laberinto de la Granja, Jardín Botánico de Madrid, Jardín del Beso de Xàtiva) junto a recreaciones respetuosas con el carácter del lugar (Jardín de las Marquesas de Gandia).

Hoy, en los comienzos del siglo XXI, las posturas divergentes ante el hecho de la restauración continúan como en los siglos XIX y XX y la elección de un criterio o de otro depende al final de los planteamientos éticos y culturales de respeto ante la obra del profesional que tiene que resolver ese trabajo en concreto.

Tras esta exposición de las diversas corrientes teóricas existentes en el mundo de la restauración, se establecen los objetivos de la tesis tras una aclaración lingüística de los conceptos de restauración y reconstrucción. Tales objetivos son establecer unos criterios de validez general para afrontar la restauración de cualquier jardín.

Los fundamentos para la elaboración de dichos criterios se basan a nivel teórico, en tomar de la teoría brandiana de la restauración el punto de la bipolaridad de la materia de la obra de arte (aspecto y estructura) junto con los principios del 
restauro integral de conservar todo lo existente con valor cultural llegado hasta nosotros. A nivel práctico, se basan en el estudio de las restauraciones y reconstrucciones de algunos de los jardines de nuestro entorno más cercano.

Veamos estos fundamentos teóricos de una manera más extensa:

El jardín se constituye en obra de arte al separarse de la naturaleza circundante gracias a su diseño independientemente del estilo que éste adopte. A este diseño, lo llamaremos aspecto siguiendo la terminología de la teoría de la restauración de Cesare Brandi.

Al resto de los elementos materiales que conforman el jardín -fuentes, acequias, estanques, mobiliario, estatuaria y vegetación- los denominaremos estructura siguiendo igualmente los términos de la teoría brandiana.

En el jardín se restauran tanto los elementos de la estructura anteriormente mencionados como el aspecto ya que éste puede llegar a ocultarse o llegar a perderse por la expansión invasora de la vegetación. La recuperación del aspecto, por regla general, no ofrece grandes dificultades en los jardines formales por la abundancia de restos que ayudan a su reconstrucción/recuperación mientras que se vuelve más dificultoso en los de tipo paisajístico.

La restauración de los elementos no vivos de la estructura -mobiliario, fuentes, estatuaria, acequias o estanques- tampoco presenta grandes dificultades pues existe gran experiencia y abundantes soportes técnicos para su ejecución. Sin embargo, es en la vegetación donde reside el reto pues, a diferencia de los otros componentes de la estructura, la vegetación está constituida por seres vivos cuyos ciclos vitales exigen un mantenimiento constante y costoso. Por ejemplo, hay especies que se plantan pensando en que al cabo de 200 o 300 años alcanzarán su estado óptimo. Otras, como los setos, exigen esfuerzos constantes para mantenerlos en los límites que se hayan marcado para poder cumplir su función. Y existen otras, sin embargo, como las de temporada que alegran los cuadros y parterres que obligan a su reposición continua debido a lo breve de sus ciclos vitales. Imaginémonos que todo esto se abandona y además añadamos la presencia de las plantas no deseadas, es decir, las invasoras, que pueden llegar a ocultar el diseño original del jardín y hasta matar con su sombra a las plantas elegidas para la composición de la estructura vegetal del mismo.

También nos podemos encontrar con casos en que los nuevos gustos y modas jardineras han originado importantes cambios tanto en los diseños originales como en la vegetación perteneciente a los primeros momentos del jardín.

Todo esto hace que en un jardín abandonado o deteriorado que se quiere recuperar encontremos gran cantidad de plantas presentes en el espacio. ¿Qué conservamos y qué eliminamos?

Como criterio elegiremos el siguiente: todo lo que en principio fue plantado intencionadamente en cualquier momento de la historia del lugar, se debe de conservar así como debe de ser eliminada toda la vegetación invasora traída por el 
viento, los animales o la propia expansión vegetativa de los ejemplares presentes en el jardín. Y respecto al diseño actuaremos de igual manera. Se tenderá a recuperar todo lo existente aunque sea de épocas diversas. Al fin y al cabo, el jardín es muchas veces una sucesión de aportes de diferentes épocas y no tenemos el derecho a suprimir ninguna de ellas por muy contrarias que sean a nuestros gustos o a las modas imperantes en el momento en que se realiza la intervención. Quizá el ejemplo más claro de esta actitud lo constituyan la presencia de las grandes wellingtonias en la Casita del Príncipe de El Escorial, en la Quinta del Duque de Arco o los grandes ejemplares del Jardín Botánico de Madrid que se alzan en medio de los caminos recuperados por el nuevo diseño.

Es en esta selección donde se plasman los conocimientos del restaurador, surgidos de una metodología interdisciplinar, de los estudios previos y del establecimiento de los criterios respecto a la decisión de que se elimina, se deja o se introduce.

La conclusión final es que tras ver las diversas posturas ante la restauración de los dos últimos siglos, su práctica y resultados hoy se puede decir que resulta insostenible recurrir al uso frecuentemente utilizado de hacer desaparecer todo lo existente en el jardín para volver a recrear lo que pudo haber existido ya que por una parte nunca podremos conocer con certeza absoluta como fue pues pertenece al pasado, mientras que hacemos desaparecer con tales practicas los componentes del jardín existentes de ayer y de hoy de indiscutible valor histórico y a veces artístico y que en definitiva constituyen ellos y solamente ellos, los testimonios reales de nuestra historia.

Por lo tanto, la Carta de Florencia, no puede continuar teniendo validez como documento guía a seguir para afrontar la restauración del jardín. Sus principios, anquilosados y obsoletos, no aseguran ni la permanencia de los componentes del jardín ni su transmisión al futuro. 
G. BIBLIOGRAFÍA

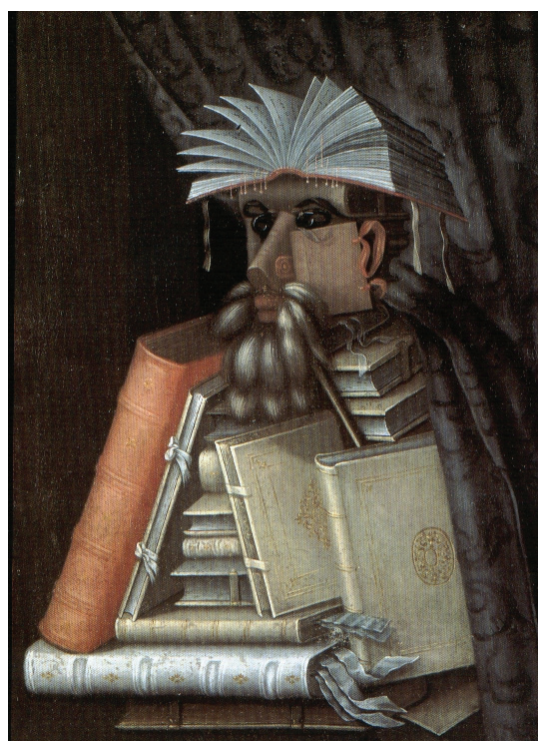




\begin{tabular}{|c|c|c|c|c|}
\hline AUTOR & TITULO & EDITORIAL & AÑO & LUGAR \\
\hline AA VV & $\begin{array}{l}\text { Fuentes Documentales para el Estudio de } \\
\text { la Restauración de Monumentos en España }\end{array}$ & Ministerio de Cultura & 1989 & Madrid \\
\hline AA VV & $\begin{array}{l}\text { El lenguaje oculto del jardín: jardín y } \\
\text { metáfora }\end{array}$ & Complutense & 1996 & Madrid \\
\hline AA VV & $\begin{array}{l}\text { The King's Privy Garden at Hampton } \\
\text { Court }\end{array}$ & Apollo Magazine & 1995 & Londres \\
\hline AA VV & $\begin{array}{l}\text { Mecenazgo y Conservación del Patrimonio } \\
\text { Artístico: reflexiones sobre el caso español }\end{array}$ & $\begin{array}{l}\text { Fundación Argentaria } \\
\& \text { Visor }\end{array}$ & 1995 & Madrid \\
\hline$A A V$ & The History of Garden Design & Thames \& Hudson & 1991 & London \\
\hline AA VV & Neoclasicismo y Romanticismo & Könemann & 2000 & Colonia \\
\hline AA VV & $\begin{array}{l}\text { Historic Gardens: Safeguarding a } \\
\text { European Heritage }\end{array}$ & European Comission & 1996 & Luxemburgo \\
\hline AA VV & Jardins et Sites Historiques & $\begin{array}{l}\text { ICOMOS } \\
\text { Fundación Banesto }\end{array}$ & 1993 & Aranjuez \\
\hline AA VV & $\begin{array}{l}\text { Master de Restauración y Rehabilitación } \\
\text { del Patrimonio: Teoría e historia de la } \\
\text { restauración }\end{array}$ & Munilla-Lería & $\begin{array}{l}1997 \\
\text { Univer } \\
\text { Alcalá }\end{array}$ & $\begin{array}{l}\text { Madrid, } \\
\text { rsidad de } \\
\text { de Henares }\end{array}$ \\
\hline AA VV & $\begin{array}{l}\text { Felipe II. El rey íntimo. Jardín y Naturaleza } \\
\text { en el reinado de Felipe II }\end{array}$ & $\begin{array}{l}\text { Sociedad Estatal para la } \\
\text { Conmemoración de los } \\
\text { Centenarios de Felipe II y } \\
\text { Carlos V }\end{array}$ & 1998 & Aranjuez \\
\hline AA VV & Les plantes del món en la història & Fundación Bancaja & 1996 & Valencia \\
\hline AA VV & $\begin{array}{l}\text { El Jardín Botánico de la Universidad de } \\
\text { Valencia }\end{array}$ & Universitat de València & 2001 & Valencia \\
\hline AA VV & L'Empire de Flore & La renaissance du Livre & 1996 & Bruxelles \\
\hline AA VV & Restauración Arquitectónica II & Universidad de Valladolid & 1998 & Valladolid \\
\hline AA VV & Arquitecturas restauradas 1986-1995 & $\begin{array}{l}\text { Consellería de Educación } \\
\text { y Cultura de la Comunidad } \\
\text { de Madrid }\end{array}$ & 1995 & Madrid \\
\hline AA VV & $\begin{array}{l}\text { Intervenciones en el Patrimonio } \\
\text { Arquitectónico (1980-1985) }\end{array}$ & Ministerio de Cultura & 1990 & Madrid \\
\hline AA VV & $\begin{array}{l}\text { Il giardino sacro. Chiostri e giardini della } \\
\text { Campania }\end{array}$ & Electa Napoli & 2000 & Napoli \\
\hline $\begin{array}{l}\text { AA VV Catálogo } \\
\text { de la exposición: }\end{array}$ & Paisaje Mediterráneo & Electa & 1992 & Sevilla \\
\hline $\begin{array}{l}\text { AA V Catálogo } \\
\text { de la exposición: }\end{array}$ & Juan de Arellano 1614-1676 & Caja Madrid & 1998 & Madrid \\
\hline $\begin{array}{l}\text { AA VV Catálogo } \\
\text { de la exposición: }\end{array}$ & $\begin{array}{l}\text { La belleza de lo real. Floreros y } \\
\text { bodegones en el Museo del Prado } \\
\text { 1600-1800. }\end{array}$ & Publyco S.A. & 1995 & Madrid \\
\hline $\begin{array}{l}\text { AA V Catálogo } \\
\text { de la exposición: }\end{array}$ & Jardines de España & Fundación Mapfre Vida & 1999 & Madrid \\
\hline AA VV & $\begin{array}{l}\text { Intervenciones en el Patrimonio } \\
\text { (1980-1985) Arquitectónico }\end{array}$ & ICRBC & 1990 & Madrid \\
\hline AA VV & $\begin{array}{l}\text { Catálogo de Monumentos y Conjuntos } \\
\text { de la Comunidad Valenciana }\end{array}$ & $\begin{array}{l}\text { Consellería de Educación } \\
\text { y Ciencia. Generalitad } \\
\text { Valenciana. }\end{array}$ & 1983 & Valencia \\
\hline
\end{tabular}




\begin{tabular}{|c|c|c|c|c|}
\hline AA VV & $\begin{array}{l}\text { Journal of Garden History, Vol. } 8 \text {, } \\
n^{\circ} 2 \text { y } 3\end{array}$ & $\begin{array}{l}\text { John Dixon Hunt } \\
\text { y Erik de Jong }\end{array}$ & 1988 & London \\
\hline AA WV & $\begin{array}{l}\text { Jardines y Paisaje en el Arte y en } \\
\text { la Historia }\end{array}$ & Complutense & 1994 & Madrid \\
\hline AA VV & Escuela Taller Alameda de Osuna & $\begin{array}{l}\text { Ayuntamiento de Madrid, } \\
\text { INEM y Fondo Social } \\
\text { Europeo }\end{array}$ & 1986 & Madrid \\
\hline $\begin{array}{l}\text { AA V Catálogo } \\
\text { de la exposición: }\end{array}$ & Jardines clásicos madrileños. & Ayuntamiento de Madrid & 1981 & Madrid \\
\hline $\begin{array}{l}\text { Aguilella, Antoni y Carrau, } \\
\text { Ma José }\end{array}$ & $\begin{array}{l}\text { Guía para educadores del } \\
\text { Jardí Botànic de Valencia }\end{array}$ & Universitat de València & 1989 & Valencia \\
\hline Almela y Vives, Francisco & Jardines valencianos & Valencia Atracción & 1945 & Valencia \\
\hline Alvarez, Arturo & Guadalupe & Studium & 1964 & Madrid \\
\hline Añón, Carmen & $\begin{array}{l}\text { "El Capricho" de la Alameda de } \\
\text { Osuna }\end{array}$ & Avapiés & 1998 & Madrid \\
\hline Añón, Carmen & $\begin{array}{l}\text { Real Jardín Botánico de Madrid. } \\
\text { Sus orígenes 1755-1781 }\end{array}$ & $\begin{array}{l}\text { Real Jardín } \\
\text { Botánico/CSIC }\end{array}$ & 1987 & Madrid \\
\hline $\begin{array}{l}\text { Añón, Carmen; Castroviejo, } \\
\text { Santiago;Fernández Alba, } \\
\text { Antonio }\end{array}$ & $\begin{array}{l}\text { Real Jardín Botánico de Madrid. } \\
\text { Pabellón de Invernáculos }\end{array}$ & CSIC & 1983 & Madrid \\
\hline $\begin{array}{l}\text { Añón, Carmen; Luengo, } \\
\text { Mónica y Luengo, Ana }\end{array}$ & Jardines artísticos de España & Espasa Calpe & 1995 & Madrid \\
\hline Ariza Muñoz, Carmen & Los Jardines del Buen Retiro & $\begin{array}{l}\text { Lunwerg. } \\
\text { Ayuntamiento de Madrid }\end{array}$ & 1990 & Madrid \\
\hline Ariza Muñoz, Carmen & El Buen Retiro & Avapiés & 1994 & Madrid \\
\hline Ariza Muñoz, Carmen & $\begin{array}{l}\text { Los jardines de Madrid en } \\
\text { el siglo XIX }\end{array}$ & Avapiés & 1998 & Madrid \\
\hline $\begin{array}{l}\text { Armada, Juan y } \\
\text { Castroviejo, Santiago }\end{array}$ & $\begin{array}{l}H^{a} \text { del Jardín Botánico, actual } \\
\text { estado tras la restauración y } \\
\text { situación actual }\end{array}$ & Avapiés & 1994 & Madrid \\
\hline Assunto, Rosario & Ontología y teleología del jardín & Tecnós & 1991 & Madrid \\
\hline $\begin{array}{l}\text { Ballester-Olmos y Anguís, } \\
\text { José Francisco }\end{array}$ & Diseño y Construcción de Jardines & El autor & 1999 & Valencia \\
\hline $\begin{array}{l}\text { Ballester-Olmos y } \\
\text { Anguís, José Francisco }\end{array}$ & El Jardín Valenciano & UPV & 1998 & Valencia \\
\hline $\begin{array}{l}\text { Battistini, Matilde; } \\
\text { Impelluso, Lucía y Zuffi, } \\
\text { Stefano }\end{array}$ & La naturaleza muerta & Electa & 1999 & Milán \\
\hline Bazin, Germain & Paradeisos: Historia del Jardín & Plaza \& Janés & 1988 & Barcelona \\
\hline Beck. J. & $\begin{array}{l}\text { La restauración de obras de arte. } \\
\text { Negocio, cultura, controversia, } \\
\text { escándalo }\end{array}$ & Serbal & 1997 & Barcelona \\
\hline Blair Macdougall, Elizabeth & $\begin{array}{l}\text { Viaggio nei Giardini di Napoli } \\
\text { e di Salerno }\end{array}$ & M. T. Train/Scala Books & 1995 & New York \\
\hline $\begin{array}{l}\text { Boutelou, Claudio y } \\
\text { Boutelou, Esteban }\end{array}$ & Tratado de las Flores & $\begin{array}{l}\text { Facsímil de } \\
\text { "París-Valencia" }\end{array}$ & $\begin{array}{l}1804 \Lambda \\
(1993)\end{array}$ & $\begin{array}{l}\text { Madrid } \\
\text { (Valencia) }\end{array}$ \\
\hline Brandi, Cesare. & Teoría de la restauración. & Alianza Forma. & 1988 & Madrid \\
\hline $\begin{array}{l}\text { Brown, Jonathan y } \\
\text { J. H. Elliott }\end{array}$ & $\begin{array}{l}\text { Un palacio para el rey.El Buen } \\
\text { Retiro y la corte de Felipe IV }\end{array}$ & Alianza Forma & 1981 & Madrid \\
\hline
\end{tabular}




\begin{tabular}{|c|c|c|c|c|}
\hline Callejo, Carlos & El monasterio de Guadalupe & Plus-ultra & 1958 & Madrid \\
\hline Campanelli, Daniela & Il Monastero di Santa Chiara & Electa Napoli & 1995 & Napoli \\
\hline Caneva, Caterina & The Boboli Gardens & Becocci Editore & 1982 & Florencia \\
\hline Capitel, Antón & $\begin{array}{l}\text { Metamorfosis de monumentos } \\
\text { y teorías de la restauración }\end{array}$ & Alianza Forma & 1988 & Madrid \\
\hline Carabasa Bravo, Julia María & $\begin{array}{l}\text { Monografías del Jardín Botánico } \\
\text { de Córdoba: "Plantas en } \\
\text { Al-Andalus en el siglo Xl" }\end{array}$ & Volumen I & 1964 & \\
\hline Carrascosa Criado, Josep & $\begin{array}{l}\text { "De Jardines Valencianos". } \\
\text { Elementos para el estudio histórico } \\
\text { de la Jardinería Valenciana }\end{array}$ & Lo Rat Penat & 1932 & Valencia \\
\hline Catálogo de la Exposición: & Javier de Winthuysen, jardinero & CSIC & 1986 & Madrid \\
\hline Ciarallo, Annamaria & Verde Pompeiano & “L’Erma” & 2000 & Roma \\
\hline Clifford, Derek & Los jardines. Historia, trazado, arte & $\begin{array}{l}\text { Instituto de Estudios de } \\
\text { la Administración Local }\end{array}$ & 1970 & Madrid \\
\hline Colmeiro, Miguel & $\begin{array}{l}\text { Bosquejo Histórico y Estadístico } \\
\text { del Real Jardín Botánico de Madrid }\end{array}$ & Facsímil de París-Valencia & 1995 & Valencia \\
\hline Columela, L. J. M. & De los trabajos de campo & Siglo XXI & 1988 & Madrid \\
\hline Dezzi Bardeschi, Marco & $\begin{array}{l}\text { Restauro: punto e da capo. } \\
\text { Frammenti per una (impossibile) } \\
\text { teoria. }\end{array}$ & Franco Angeli & 1991 & Milano \\
\hline Docavo Alberti, Ignacio & $\begin{array}{l}\text { Guía del Jardín Botánico de } \\
\text { Valencia }\end{array}$ & Diputación Provincial & 1977 & Valencia \\
\hline Du Cerceau, Androuet & $\begin{array}{l}\text { Les plus excellents bastiments } \\
\text { de France }\end{array}$ & $\begin{array}{l}\text { Facsímil a cargo } \\
\text { de Sand \& Conti }\end{array}$ & 1988 & Paris \\
\hline Eco, Umberto & Cómo se hace una tesis & Gedisa & 1997 & Barcelona \\
\hline Eguaras Ibáñez, Joaquina & Ibn Luyn. Tratado de agricultura & $\begin{array}{l}\text { Patronato de la } \\
\text { Alhambra }\end{array}$ & 1975 & Granada \\
\hline Fariello, Francesco & La arquitectura de los Jardines & Mairea/Celeste & 2000 & Madrid \\
\hline Fisher, John & The origins of garden plants & Constable & & London \\
\hline Font Quer, Pío & $\begin{array}{l}\text { Plantas medicinales. } \\
\text { El Dioscórides renovado }\end{array}$ & Labor & 1961 & Barcelona \\
\hline $\begin{array}{l}\text { Forestier, Jean-Claude } \\
\text { Nicolas }\end{array}$ & $\begin{array}{l}\text { Jardines. Cuaderno de dibujo } \\
\text { y planos }\end{array}$ & Stylos & 1985 & Barcelona \\
\hline Fouquier, M. y Duchêne, A. & Des Divers Styles de Jardins & Emile Paul & 1914 & París \\
\hline Fuchs, Leonhart & The New Herbal of 1543 & Taschen Facsímil & 2001 & Colonia \\
\hline Gómez Anuarbe, Manuel & Jardines de España & Revista GE0, No 171 & 2001 & Madrid \\
\hline Gómez-Centurión, Pilar & $\begin{array}{l}\text { Real Jardín Botánico de Madrid. } \\
\text { Un Jardín Ilustrado }\end{array}$ & CSIC. Lunwerg & 1999 & Madrid \\
\hline $\begin{array}{l}\text { González-Moreno } \\
\text { Navarro, Antoni }\end{array}$ & "La restauración objetiva” & ICOMOS XII Asamblea & 1999 & Mexico \\
\hline $\begin{array}{l}\text { González-Varas Ibañez, } \\
\text { Ignacio }\end{array}$ & $\begin{array}{l}\text { Restauración monumental en } \\
\text { España durante el siglo XIX }\end{array}$ & Ambito & 1996 & Valladolid \\
\hline González-Varas, Ignacio & Conservación de Bienes Culturales & Manuales Arte Cátedra & 1999 & Madrid \\
\hline Gracia, Carmen & Arte valenciano & Cátedra. Cuadernos Arte & 1998 & Madrid \\
\hline Guerra de la Vega, Ramón & $\begin{array}{l}\text { Juan de Villanueva, arquitecto } \\
\text { del rey Carlos III }\end{array}$ & A cargo del autor & 1987 & Madrid \\
\hline
\end{tabular}




\begin{tabular}{|c|c|c|c|c|}
\hline Guerra de la Vega, Ramón & Jardines de Madrid I. El Retiro & El autor & 1983 & Madrid \\
\hline $\begin{array}{l}\text { Hagen, Rose-Marie } \\
\text { \& Rainer }\end{array}$ & Los secretos de las obras de arte & Taschen & 2001 & Colonia \\
\hline Hansmann, Wilfried & $\begin{array}{l}\text { Jardines del Renacimiento } \\
\text { y el Barroco }\end{array}$ & Nerea & 1983 & Madrid \\
\hline Hauser, Arnold & $\begin{array}{l}\text { Historia Social de la Literatura } \\
\text { y el Arte }\end{array}$ & Guadarrama & 1962 & Madrid \\
\hline Heilmeyer, Marina & $\begin{array}{l}\text { The Language of flowers. } \\
\text { Symbols and Myths }\end{array}$ & Prestel & 2001 & Munich \\
\hline Insausti, Pilar de & El Jardín dibujado & UPV & 1997 & Valencia \\
\hline Insausti, Pilar de & $\begin{array}{l}\text { Jardinería y Paisaje aplicados a } \\
\text { la Arquitectura. Bibliografía }\end{array}$ & Univ. Politec. de Valencia & 1991 & Valencia \\
\hline Jellicoe, Geoffrey y Susan & El Paisaje del Hombre & GG & 1995 & Barcelona \\
\hline Kluckert, Ehrenfried & Grandes Jardines de Europa & $\begin{array}{l}\text { Köneman } \\
\text { Ed. Por Rolf Toman }\end{array}$ & 2000 & Colonia \\
\hline Lazzaro, Claudia & The Italian Renaissance Garden & Yale University Press & $\begin{array}{l}1990 \\
\text { and } L\end{array}$ & $\begin{array}{l}\text { New Haven } \\
\text { ondon }\end{array}$ \\
\hline López Terrada, María José & $\begin{array}{l}\text { Tradición y cambio en la pintura } \\
\text { valenciana de flores 1600-1850 }\end{array}$ & Ayuntamiento de Valencia & 2001 & Valencia \\
\hline López López, Angel C. & $\begin{array}{l}\text { Un tratado agrícola andalusí } \\
\text { anónimo }\end{array}$ & $\begin{array}{l}\text { CSIC. Escuela de } \\
\text { Estudios Arabes }\end{array}$ & 1990 & Granada \\
\hline $\begin{array}{l}\text { López Piñero, José María } \\
\text { Pardo Tomás, José }\end{array}$ & $\begin{array}{l}\text { Nuevos materiales y noticias sobre } \\
\text { la historia de las plantas de Nueva } \\
\text { España de Francisco Hernández }\end{array}$ & $\begin{array}{l}\text { Instituto de Estudios } \\
\text { Documentales e } \\
\text { Históricos sobre la Ciencia }\end{array}$ & 1994 & Valencia \\
\hline $\begin{array}{l}\text { López Piñero, José María } \\
\text { Pardo Tomás, José }\end{array}$ & $\begin{array}{l}\text { La influencia de Francisco } \\
\text { Hernández (1515-1587) en la } \\
\text { constitución de la Botánica y } \\
\text { la Materia Médica Modernas }\end{array}$ & $\begin{array}{l}\text { Instituto de Estudios } \\
\text { Documentales e } \\
\text { Históricos sobre la Ciencia }\end{array}$ & 1996 & Valencia \\
\hline $\begin{array}{l}\text { Macarrón Miguel, Ana Ma } \\
\text { González Mozo, Ana }\end{array}$ & $\begin{array}{l}\text { La conservación y la Restauración } \\
\text { en el siglo XX }\end{array}$ & Tecnos & 1998 & Madrid \\
\hline Macarrón Miguel, Ana Mª. & $\begin{array}{l}\text { Historia de la Conservación y la } \\
\text { Restauración }\end{array}$ & Tecnos & 1995 & Madrid \\
\hline Madoz, Pascual & $\begin{array}{l}\text { Diccionario Geográfico-Estadístico- } \\
\text { Histórico de Alicante, Castellón y } \\
\text { Valencia. }\end{array}$ & $\begin{array}{l}\text { Alfons el Magnànim. } \\
\text { Institució Valenciana } \\
\text { d'Estudis i Investigació. }\end{array}$ & 1982 & Valencia \\
\hline Margiotta, Maria Luisa & $\begin{array}{l}\text { /l giardino sacro. Chiostri e } \\
\text { giardini della Campania }\end{array}$ & Electa Napoli & 2000 & Napoli \\
\hline Marqués de Lozoya & Los jardines españoles & Cigüeña & 1951 & \\
\hline Marquesa de Casa Valdés & Jardines de España & Aguilar & 1973 & Madrid \\
\hline Martín Martín, Luis & Arboles del Retiro & Ayuntamiento de Madrid & 1985 & Madrid \\
\hline Martínez Justicia, Ma José & $\begin{array}{l}\text { Historia y teoría de la conservación } \\
\text { y restauración artística }\end{array}$ & Tecnos & 2000 & Madrid \\
\hline $\begin{array}{l}\text { Martínez Justicia, } \\
\text { María José. }\end{array}$ & $\begin{array}{l}\text { Antología de textos sobre. } \\
\text { restauración }\end{array}$ & Universidad de Jaén & 1996 & Jaén \\
\hline Mason, Georgina & Italian Gardens & Antique Collector's Club & 1987 & Suffolk \\
\hline Molinier, Jean-Christophe & $\begin{array}{l}\text { Catálogo de la exposición: } \\
\text { Jardins de Villes Privés 1890-1930 }\end{array}$ & Ramsay de Cortanze & $\begin{array}{l}1991 \\
\text { Seine }\end{array}$ & Hauts-de- \\
\hline
\end{tabular}




\begin{tabular}{|c|c|c|c|c|}
\hline Muñoz Cosme, Alfonso & $\begin{array}{l}\text { Fuentes Documentales de la } \\
\text { Restauración de Monumentos } \\
\text { en España }\end{array}$ & Ministerio de Cultura & 1989 & Madrid \\
\hline Ogrin, Dusan & The World Heritage of Gardens & Thames \& Hudson & 1993 & London \\
\hline $\begin{array}{l}\text { Olaf Enge, Torsten y } \\
\text { Schröer, Carl Friedrich }\end{array}$ & Arquitectura de jardines en Europa & Taschen & 1992 & Colonia \\
\hline Ordieres, Isabel & $\begin{array}{l}\text { Historia de la restauración } \\
\text { monumental en España (1835-1936) }\end{array}$ & Ministerio de Cultura & 1995 & Madrid \\
\hline $\begin{array}{l}\text { Páez de la Cadena, } \\
\text { Francisco }\end{array}$ & Historia de los Estilos en Jardinería & Ediciones Istmo & 1982 & Madrid \\
\hline $\begin{array}{l}\text { Pardo Tomás, José. } \\
\text { López Terrada, María Luz }\end{array}$ & $\begin{array}{l}\text { Las primeras noticias sobre } \\
\text { plantas americanas en las } \\
\text { relaciones de viajes y crónicas } \\
\text { de Indias (1493-1553) }\end{array}$ & $\begin{array}{l}\text { Instituto de Estudios } \\
\text { Documentales e Históricos } \\
\text { sobre la Ciencia. }\end{array}$ & 1993 & Valencia \\
\hline Panofsky, Erwin & Estudios sobre iconología & Alianza Universidad & 1972 & Madrid \\
\hline Péris y Pérez, Pascual & El jardinero valenciano & Terraza, Aliena y Cía & 1898 & Valencia \\
\hline Pizzoni, Filippo & $\begin{array}{l}\text { The Garden: a History in } \\
\text { Landscape and Art }\end{array}$ & Aurum Press & 1999 & London \\
\hline Redouté, Pierre-Joseph & The Lilies & Taschen & 2000 & Colonia \\
\hline Redouté, Pierre-Joseph & Romantic Roses & Taschen & 2002 & Colonia \\
\hline Ríos, Gregorio de los & Agricultura de Jardines & $\begin{array}{l}\text { Tabapress } \\
\text { Facsímil }\end{array}$ & 1991 & Madrid \\
\hline Rodríguez García, Aurora & Historia de los jardines valencianos & Mari Montañana & 1996 & Valencia \\
\hline Roquero, Luisa & Bomarzo & Celeste & 1999 & Madrid \\
\hline $\begin{array}{l}\text { Rubió i Tudurí, } \\
\text { Nicolás María }\end{array}$ & El Jardín Meridional & Salvat Editores & 1934 & Barcelona \\
\hline $\begin{array}{l}\text { Rubió i Tudurí, } \\
\text { Nicolás María }\end{array}$ & Del Paraíso al jardín latino & Tusquets Editores & 1981 & Barcelona \\
\hline $\begin{array}{l}\text { Ruiz de Lacanal, } \\
\text { M }^{\mathrm{a}} \text { Dolores }\end{array}$ & $\begin{array}{l}\text { El conservador-restaurador de } \\
\text { bienes culturales. Historia de la } \\
\text { profesión }\end{array}$ & Síntesis & 1999 & Madrid \\
\hline Ruskin, John & $\begin{array}{l}\text { Las siete lámparas de } \\
\text { la arquitectura }\end{array}$ & Alta Fulla & 1997 & Barcelona \\
\hline San Isidoro de Sevilla & Etimologías & B.A.C. & 1993 & Madrid \\
\hline Sancho Gaspar, José Luis & La Arquitectura de los Reales Sitios & Patrimonio Nacional & 1995 & Madrid \\
\hline Sancho Gaspar, José Luis & $\begin{array}{l}\text { "Notas sobre la vida y escritos de } \\
\text { Xavier de Winthuysen" En la edición } \\
\text { facsímil de "Jardines clásicos de } \\
\text { España" de J. de Winthuysen }\end{array}$ & Doce Calles & 1990 & Aranjuez \\
\hline Sancho, José Luis & La Arquitectura de los Sitios Reales & Patrimonio Nacional & 1995 & Madrid \\
\hline Sancho, José Luis & $\begin{array}{l}\text { Guía de Visita del Real Sitio de } \\
\text { Aranjuez }\end{array}$ & Patrimonio Nacional & 1997 & Madrid \\
\hline $\begin{array}{l}\text { Santa-Ana y } \\
\text { Alvarez-Osorio, Florencio }\end{array}$ & Guía del Museo Sorolla & Mº de Educación y Cultura & 1999 & Madrid \\
\hline Santamaría, María Teresa & El Jardín de Monforte & Ayuntamiento de Valencia & 1993 & Valencia \\
\hline Sarthou Carreres, Carlos & $\begin{array}{l}\text { Palacios monumentales y palacios } \\
\text { reales de España }\end{array}$ & Semana Gráfica & 1953 & Valencia \\
\hline
\end{tabular}




\begin{tabular}{|c|c|c|c|}
\hline Sarthou Carreres, Carlos & $\begin{array}{l}\text { Monasterios monumentales } \\
\text { de España }\end{array}$ & Semana Gráfica & 1951 Valencia \\
\hline Sarthou Carreres, Carlos & Jardines de España Valencia & Semana Gráfica & 1948 Valencia \\
\hline Sarthou Carreres, Carlos & Jardines setabenses & $\begin{array}{l}\text { Imprenta Semana } \\
\text { Gráfica. S.A. }\end{array}$ & 1951 Valencia \\
\hline Schneider, Norbert & Naturaleza muerta & Taschen & 1999 Colonia \\
\hline Tapié, Alain & $\begin{array}{l}\text { Le sens caché des fleurs. } \\
\text { Simbolique \& botanique dans la } \\
\text { peinture du XVII siècle. }\end{array}$ & Adam Biro & 1997 Paris \\
\hline Thacker, C. & The History of gardens & $\begin{array}{l}\text { University of California } \\
\text { Press }\end{array}$ & 1979 Berkeley \\
\hline $\begin{array}{l}\text { Tito Rojo, José } \\
\text { \& Casares Porcel, Manuel }\end{array}$ & El Carmen de la Victoria & Universidad de Granada & 2000 Granada \\
\hline Tovar Martín, Virginia & El Pardo & Avapiés & 1994 Madrid \\
\hline Triggs, Inigo H. & $\begin{array}{l}\text { Formal Gardens in England and } \\
\text { Scotland }\end{array}$ & $\begin{array}{l}\text { Antique } \\
\text { Collector's Club }\end{array}$ & $\begin{array}{l}1^{\mathrm{a} e d .} 1902 \text { London } \\
2^{\mathrm{a}} \text { ed. } 1998\end{array}$ \\
\hline Valéry, Marie-Françoise & Jardins du Moyen Âge & La Renaissance du Livre & 2001 Bruxelles \\
\hline Van de Perre, Harold & Van Eyck. El Cordero Místico & Electa & 1996 \\
\hline Vigil Escalera, Manuel & $\begin{array}{l}\text { El Jardín musulmán de la Antigua } \\
\text { Casa de Contratación de Sevilla }\end{array}$ & Junta de Andalucia & 1992 Sevilla \\
\hline von Buttlar, Adrian & $\begin{array}{l}\text { Jardines del Clasicismo } \\
\text { y el Romanticismo }\end{array}$ & Nerea & 1993 Madrid \\
\hline Walter Lack, H. & $\begin{array}{l}\text { Garden Eden. Mastepieces of } \\
\text { Botanical Illustration }\end{array}$ & Taschen & 2001 Colonia \\
\hline Winthuysen, Xavier de & Jardines Clásicos de España & $\begin{array}{l}\text { Edición facsímil de } \\
\text { Doce Calles }\end{array}$ & 1990 Aranjuez \\
\hline Winthuysen, Xavier de & Jardines Clásicos de España & $\begin{array}{l}\text { Compañía Ibero-Americana } \\
\text { de Publicaciones }\end{array}$ & 1930 Madrid \\
\hline
\end{tabular}

